

\section{Agrarian change in tropical landscapes}

Editors

Liz Deakin

Mrigesh Kshatriya

Terry Sunderland 
(c) 2016 by the Center for International Forestry Research.

All rights reserved.

Content in this publication is licensed under a Creative Commons Attribution

4.0 International (CC BY 4.0), http://creativecommons.org/licenses/by/4.0/

ISBN 978-602-387-022-6

DOI: $10.17528 /$ cifor/005867

Deakin L, Kshatriya M and Sunderland T. 2016. Agrarian Change in Tropical Landscapes.

Bogor, Indonesia: CIFOR.

Photo credits:

Cover $\odot$ Terry Sunderland

Aerial view of mosaic landscape, Gunung Halimun National Park, West Java, Indonesia.

Designed by CIFOR's Multimedia Team

CIFOR

Jl. CIFOR, Situ Cede

Bogor Barat 16115

Indonesia

$T+62(251) 8622-622$

$\mathrm{F}+62(251) 8622-100$

E cifor@cgiar.org

cifor.org

We would like to thank all funding partners who supported this research through their contributions to the CCIAR Fund. For a full list of the 'CCIAR Fund' funding partners please see: http://www.cgiar.org/who-we-are/cgiar-fund/fund-donors-2/

Any views expressed in this publication are those of the authors. They do not necessarily represent the views of CIFOR, the editors, the authors' institutions, the financial sponsors or the reviewers. 


\section{Contents}

List of authors viii

Foreword $\quad x$

Christine Padoch

Executive summary $\quad$ xii

Acknowledgments $\quad$ xiv

1 Introduction: Agrarian change in tropical landscapes $\quad 1$

Liz Deakin, Mrigesh Kshatriya and Terry Sunderland

2 Understanding people and forest interrelations along an intensification gradient in Arsi-Negele, Ethiopia

Jean-Yves Duriaux and Frédéric Baudron

3 Land-use change and its influence on rural livelihoods, food security and biodiversity conservation in the Southwest Region of Cameroon

Stella Asaha and Liz Deakin

4 Drivers and effects of agrarian change in Kapuas Hulu Regency,

West Kalimantan, Indonesia

91

Laurio Leonald and Dominic Rowland

5 Historical drivers of landscape and dietary change in an agricultural frontier:

Bosawas Biosphere Reserve, Siuna, Nicaragua

139

Lisa Hansen, John Innes, Bronwen Powell, Janette Bulkan, Sarah Gergel and Ian Eddy

6 Forest and agrarian change in the Chittagong Hill Tracts region of Bangladesh

Ronju Ahammad and Natasha Stacey

7 Agrarian changes in the Nyimba District of Zambia

Davison J Gumbo, Kondwani Y Mumba, Moka M Kaliwile, Kaala B Moombe and

Tiza I Mfuni

8 Drivers and outcomes of changing land use in parkland agroforestry systems of central Burkina Faso

Samson Foli and Rabdo Abdoulaye

9 Conclusion: Agrarian change-A change for the better?

Terry Sunderland, Liz Deakin and Mrigesh Kshatriya 


\section{List of figures and tables}

\section{Figures}

1.1 Map showing the location of the seven landscapes used as case studies for the Agrarian Change Project.

$\begin{array}{lll}1.2 & \text { The project's landscape-level hierarchical research design. } & 7\end{array}$

$\begin{array}{lll}1.3 & \text { Forest transition curve. } & 7\end{array}$

2.1 Location of Munessa Forest and the study area, which can be described as
an intensification gradient.

2.2 Mean annual rainfall and mean temperature. $\quad 17$

2.3 Map displaying the study area, and the three zones along an intensification
gradient from Munessa Forest to Arsi-Negele.

2.4 Rainfall and agricultural calendar in the study area. 23

2.5 Household types and their proportions in the three settlements of the study area. 25

2.6 Modalities of land-use access in the study area. 28

2.7 Diagram representing access to forest products in the study area. 30

2.8 Fuelwood value chain in the study area. 34

2.9 Maize value chain in the study area. 36

2.10 Wheat value chain in the study area.

2.11 Potato value chain in the study area. 37

2.12 Livestock (live animals) value chain in the study area. 38

2.13 Probable vegetation loss between 1987 and 2011 . 42

2.14 Historical diagram of land-use change in the landscape as perceived by elders of Zone 2. 43

2.15 Historical trend lines and important events between 1970 and 2014 in the study area. $\quad 44$

3.1 Map of Cameroon. $\quad 56$

3.2 Map of villages in Nguti study area, Southwest Region, Cameroon. 58

3.3 Map highlighting different land-use types in Nguti study area. 66

3.4 Mean annual buying prices of cocoa in Cameroon in Central African Franc (XAF)
per kilogram.

3.5 Mean annual buying prices of palm oil from Cameroon producers in Central African $\begin{array}{ll}\text { Franc (XAF) per ton. } & 70\end{array}$

3.6 Map of the extent of the study area and the boundaries of the selected protected areas of interest.

3.7 Historical land-use trends in the Nguti study area. $\quad 73$

3.8 Summary of the scores from the land-use valuation by men and women
in the three focal villages.

3.9 Summary of the scores from the forest-use valuation by men and women
in the three focal villages.

$\begin{array}{ll}3.10 & \text { Location map of SG-SOC plantation. }\end{array}$

$\begin{array}{lll}3.11 & \text { New SG-SOC allocated land. } & 78\end{array}$

3.12 Main farm products in the study area. $\quad 80$

4.1 Map of Kapuas Hulu. $\quad 93$

4.2 Historical land use in Kapuas Hulu. $\quad 97$ 
4.3 Forest loss in Kapuas Hulu 2000-13. 98

4.4 Forest loss by year in Kapuas Hulu 2000-13. 98

4.5 Location of Kapuas Hulu Regency in Indonesia. 100

4.6 Map of national parks in Kapuas Hulu. 102

4.7 Contribution to regional GDP of economic sectors. 106

4.8 Proposed biodiversity corridor in Kapuas Hulu. 107

4.9 Oil palm plantations in Kapuas Hulu. 109

4.10 Location of study zones. 114

4.11 Map of Zone 1 settlements. 115

4.12 Map of Zone 2 settlements. 118

4.13 Map of Zone 3 settlements and oil palm plantations. 123

4.14 Common agrarian transitions in Kapuas Hulu. $\quad 127$

5.1 Bosawas Biosphere Reserve and Siuna Municipality with comarcas, Nicaragua. $\quad 141$

5.2 Departments, municipalities and population of Nicaragua in 2005.

5.3 Bosawas with indigenous territories and zones. 143

5.4 Siuna municipality in Bosawas with zones and comarcas. 144

5.5 Map of the study communities, highways and Bosawas zones in Siuna. 145

5.6 Spatial analysis study limits (Landsat scene path 16, row 51). 148

5.7 Forest cover change in the study landscape. 150

6.1 Map of the Chittagong Hill Tracts region, Bangladesh. 193

6.2 Percentages of local ethnic population (not including Bangalees). 195

6.3 Trend in population growth in Chittagong Hill Tracts. 196

6.4 Institutional framework related to forest and land management in
the Chittagong Hill Tracts region of Bangladesh.

6.5 Different economic activities in Chittagong Hill Tracts. 204

6.6 Forest cover map of Bangladesh and encircled forest areas in Chittagong Hill Tracts. 208

6.7 Map of potential land-use Zone 1 in the Chittagong Hill Tracts region of Bangladesh. 218

6.8 Map of potential land-use Zone 2 in the Chittagong Hill Tract region of Bangladesh. 220

6.9 Map of potential land-use Zone 3 in the Chittagong Hill Tracts region of Bangladesh. 223

7.1 Districts considered for the Agrarian Change Project. 239

7.2 Mpika District showing Lwitikila National Forest No. 291.

7.3 Eastern Province elevation. 243

7.4 Historical trend lines and important events in the Eastern Province. 247

7.5 Location of Nyimba District in Eastern Province, Zambia. 248

7.6 Eastern Province elevation. 249

7.7 Vegetation of Nyimba District. 250

7.8 Wood biomass change in Nyimba District from 1990 to 2013.

7.9 Nyimba District map showing the selected landscape and location of the settlements. $\quad 254$

8.1 Ziro Province, which includes Cassou, Gao and Bakata districts located in Centre-Ouest Region of Burkina Faso. $\quad 274$

8.2 Climate data showing monthly rainfall (1980-2013) and minimum-maximum $\begin{array}{ll}\text { temperature ranges. } & 277\end{array}$

8.3. Timeline of forest cover change, and the drivers and outcomes in Ziro Province. $\quad 278$

8.4 Map of Ziro Province showing the 12 management units under the CAF demarcation. 281 
8.5 Vegetation cover change visualized between 1999 and 2013 in the $30 \mathrm{~km}$ radius of our study site in Ziro Province.

8.6 Land modification gradients in Cassou, Bakata and Gao districts classified into zones. 288

8.7 Proportion of Mossi, Gourounsi, Fulani and Walla in the local population in Ziro Province.

8.8 Average seasonal percentage of food sourced from markets, forests and own farms in Ziro Province.

8.9 Seasonal food availability in Ziro Province overlaid with average annual rainfall.

\section{Tables}

1.1 Example criteria used to help distinguish characteristics of different zones within a focal landscape.

2.1 General characteristics of the three zones characterizing the study area, which form an intensification gradient from Munessa Forest to Arsi-Negele.

2.2 Price range for fuelwood in Arsi-Negele market. 35

2.3 Price range for maize in Arsi-Negele market. 36

2.4 Price range for wheat in Arsi-Negele market.

2.5 Price range for potato in Arsi-Negele market. 38

2.6 Price range for male adult cattle for meat in Arsi-Negele market. 39

2.7 Maximum attainable income from the three main crops in the study area. 39

3.1 Number and percentage of interviewed households in each village. 59

3.2 Landownership in the Nguti study area. 63

3.3 Average number of people per household and estimated population of the three focal villages.

3.4 Education levels of the adult population in the Nguti study area. 65

3.5 List of protected areas in the Southwest Region of Cameroon $\begin{array}{ll}\text { (not including forest reserves). } & 76\end{array}$

3.6 Interventions within the Nguti research area. $\quad 79$

3.7 Income summary for the most common income-producing products. 81

3.8 Wealth ranking characteristics from key informant interviews. $\quad 82$

3.9 Typical food and food-related items, their accessibility, and access constraints in the Nguti study area. 83

4.1 Slope class in Kapuas Hulu. 100

4.2 Education certificates obtained by the population of Kapuas Hulu. 101

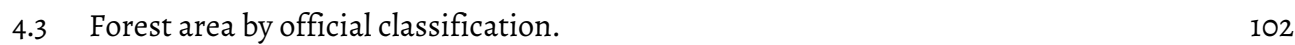

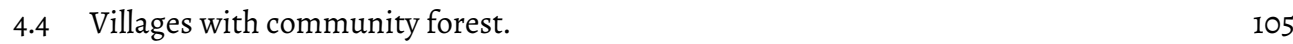

$\begin{array}{ll}\text { 4.5 Percentage of population by occupation. } & 106\end{array}$

4.6 Palm oil companies in Kapuas Hulu. 108

4.7 Area of community-owned oil palm, 2009-12. 109

4.8 Mining operations in Kapuas Hulu. 110

$\begin{array}{ll}4.9 & \text { Summary of Zone i settlements. } \\ 4.10 & \end{array}$

4.10 Summary of Zone 2 settlements. 121

4.11 Summary of Zone 3 settlements. $\quad 125$

5.1 Location of study communities (comarcas) within Bosawas and Saslaya. 146

5.2 Estimated population change of study communities from 1950 to 2014
as indicated by estimated number of households. 
5.3 Percentage land-cover change from 1940 to 2014 as estimated by study communities. 151

5.4 Social farming classes and landholding sizes. 152

5.5 Summary of key historical drivers/events of land-use change in Siuna (1904-34). 155

5.6 Summary of key historical drivers/events of land-use change in Siuna (1935-79). 162

5.7 Summary of key historical drivers/events of land-use change in Siuna (1981-90). 166

5.8 Summary of key historical drivers/events of land-use change in Siuna (1991-2000). 172

5.9 Summary of key historical drivers/events of land-use change in Siuna (2001-14). 175

5.10 Wildlife historically consumed on a regular basis in Siuna, Nicaragua. 179

$\begin{array}{ll}5.11 & \text { Fruits grown on Siuna farms (indigenous and imported). } \\ 6.182\end{array}$

6.1 Key institutions related to land and forest management in the Chittagong Hill Tracts of Bangladesh. 199

6.2 Major seasonal land-use practices in Chittagong Hill Tracts. 210

6.3 Historical trends of forest and agriculture land-use changes, their causes and effects in Chittagong Hill Tracts. 213

$\begin{array}{ll}6.4 & \text { Salient features of Zone 1. } \\ 6.5 & \text { Salient features of Zone 2. }\end{array}$

6.5 Salient features of Zone 2. 221

6.6 Main features of Zone 3. 223

7.1 Strengths, weaknesses, opportunities and threats (SWOT) analysis used to
compare Mpika and Nyimba.

7.2 Crop productivity figures for Nyimba District for 2012 . 251

7.3 Key aspects of the revised land-use zone selection criteria. 255

8.1 Criteria for classification of land modification gradients in Ziro Province. 276

8.2 Important trees and shrubs of the Sudan-Sahelian savannah and their local uses
specific to the research site.

8.3 Sources of household income in Cassou district in Ziro Province compared
to neighboring districts.

8.4 Example of a typical cropping calendar in the study sites. 286 


\section{List of authors}

Ronju Ahammad, PhD student, Research Institute for the Environment and Livelihoods, Charles Darwin University, Australia - ronju.ahammad@cdu.edu.au

Stella Asaha, Co-founder and Co-ordinator, Forests, Resources and People; Master's student Pan African Institute for Development-West Africa, Cameroon - stellaasaha@yahoo.com

Frédéric Baudron, Senior Scientist, International Center for Maize and Wheat Improvement Center, Ethiopia - f.baudron@cgiar.org

Janette Bulkan, Assistant Professor, Department of Forest Resource Management, Faculty of Forestry, University of British Columbia, Canada - janette.bulkan@ubc.ca

Liz Deakin, Research Fellow, Center for International Forestry Research, Indonesia -1.deakin@cgiar.org

Jean-Yves Duriaux, Research Consultant, International Center for Maize and Wheat Improvement Center, Ethiopia-jy.duriaux@gmail.com

Ian Eddy, Master's student, Department of Forest and Conservation Sciences, Faculty of Forestry, University of British Columbia, Canada - Ianmseddy@gmail.com

Samson Foli, Associate Professional Officer, Center for International Forestry Research, Indonesia-s.foli@cgiar.org

Sarah Gergel, Assistant Dean, Department of Forest and Conservation Sciences, Faculty of Forestry, University of British Columbia, Canada - sarah.gergel@ubc.ca

Davison Gumbo, Scientist, Center for International Forestry Research, Zambia

-d.gumbo@cgiar.org

Lisa Hansen, PhD student, Department of Forest Resource Management, University of British Columbia, Canada - hansen.lisa.c@gmail.com

John Innes, Dean, Faculty of Forestry, University of British Columbia, Canada -john.innes@ubc.ca

Mrigesh Kshatriya, Scientist, Center for International Forestry Research, Indonesia -m.kshatriya@cgiar.org

Laurio Leonald, Research Consultant, Center for International Forestry Research, Indonesia -1.leonald@cgiar.org

Bronwen Powell, Research Fellow, Center for International Forestry Research, Indonesia - b.powell@cgiar.org

Abdoulay Rabdo, Research Consultant, Center for International Forestry Research, Burkina Faso-r.abdoulay@cgiar.org

Dominic Rowland, Research Consultant, Center for International Forestry Research, Indonesia - dominicrowland@gmail.com 
Natasha Stacey, Associate Professor, Research Institute for the Environment and Livelihoods, Charles Darwin University, Australia - natasha.stacey@cdu.edu.au

Terry Sunderland, Principal Scientist, Center for International Forestry Research, Indonesia - t.sunderland@cgiar.org

Kondwani Yoba, Research Consultant, Center for International Forestry Research, Zambia - kondwani.yobe@gmail.com 


\section{Foreword}

We live in a time of rapid change and perplexing choices. The conversion of forests and other natural habitats to farmland continues to transform the planet. But while we bemoan the loss of forests, the world's population continues to grow. Many believe that to feed the 9 billion people who will be on the earth by 2050 , we will need to produce $75 \%$ more food than we do now. The need to grow more food has historically resulted in forest clearance. Yet, is it true that agricultural production must rise drastically just to keep hunger at bay? And must forests disappear if we are to feed our children?

Fifty years after the Green Revolution there remain about 800 million people in the world who are undernourished. Changing dietary habits, including an increase in meat consumption, are putting additional burdens on existing production systems. But while hunger still affects almost a million people, an almost equivalent number are obese. The need to improve food security and nutrition is not simply a problem of production. Inequities in who has access to food, to what kind of food, and when, is the source of much of the problem; waste and loss are others.

Recent evidence has shown that we need to move beyond the alluring linear thinking that equates the need to better feed a burgeoning world with the need for more food; we need a more nuanced understanding of how agriculture and the environment can and do interact. More food security need not mean more production, nor does it require less forest.

Sustainable intensification of agriculture is advocated as the best way to advance and reconcile the need to protect ever-decreasing forest lands and the imperative to feed the growing human population. The sustainable intensification paradigm appears attractive indeed and has come to dominate the discourse of many institutions devoted to economic and agricultural development.

Yet this model often overlooks broader social, environmental and economic contexts and goals. The disaggregation of agriculture from other land uses is symptomatic of a 'siloed' approach that characterizes much of the official discourse on food production today. Over $40 \%$ of the world's food is actually grown by smallholders, many of whom produce their crops within diverse landscapes and in close association and integration with forests and other 'natural' vegetation. Such diverse systems often tend to be more resilient both economically and environmentally, serve the needs of rural households, and benefit from a broad range of ecosystem services provided by nearby forests and trees. But such systems are rarely promoted by governments and development organizations - or by conservationists.

As many of the landscapes of the tropics experience increasing levels of agrarian change - primarily shifting from extensive, diverse systems, to more intensive simplified ones - there are significant benefits that accrue to some sectors of society. But what of the livelihoods, nutritional status and environmental security of those directly experiencing such drastic changes on their own lands? 
This Agrarian Change Project, led by CIFOR, has been designed to help us understand just what occurs in forested landscapes in the tropics when significant environmental change, driven by agricultural development, occurs. Working in seven countries, in diverse social and ecological contexts, we are finding that the 'one size fits all' and the 'black and white' approaches and scenarios offered as solutions to global food security - including sustainable intensification and the land sharing/sparing debates - are, at best, only part of the answer; the issues are considerably more complex in reality. Here we present the initial findings of the project. Over the coming months, further analysis will enable us to flesh out this initial framework. We will challenge some of the current thinking about integrated landscape approaches that link agriculture with forestry and other land uses. But will we be able to provide evidence that will compel the development and conservation communities to expand their thinking about future needs and local realities? The initial findings presented in this book suggest that perhaps we will.

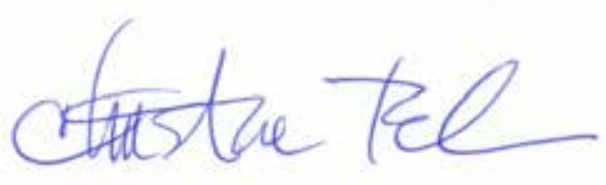

Christine Padoch

Research Director

Forests and Livelihoods 


\section{Executive summary}

Agricultural expansion has transformed and fragmented forest habitats at alarming rates across the world, but especially so in tropical landscapes. This has resulted in mosaics of land use encompassing varying levels of tree cover, human settlements and agricultural land units. Meanwhile, as a result of our expanding human population, global demands for agricultural commodities have never been as high as they are today. The imperative to feed 9 billion people by 2050 is causing further agricultural intensification and market-orientated production systems are now increasingly replacing traditional farming practices, but at what cost?

CIFOR's Agrarian Change Project uses an integrated landscape approach to explore the livelihood and food security implications of land-use change and agrarian change processes in multi-functional landscapes in seven tropical countries. The content of this book draws from experiences in field sites identified for the project: Cameroon, Burkina Faso, Ethiopia, Zambia, Bangladesh, Indonesia and Nicaragua. Each chapter gives a comprehensive background to how tropical forest landscapes have undergone (and are still undergoing) considerable agrarian change as a result of global and local food supply pressures. The chapters document the historical and political drivers of land-use change in the focal landscapes, and outline the potential social, biological and economic outcomes for these areas.

This book also provides comprehensive contextual background to the wider empirical study that is ongoing in the focal landscapes. The main aim of the project is to examine socioeconomic outcomes, and conservation, livelihood and food security implications of land-use change and agrarian change processes in multi-functional landscapes. The research focuses on landscapes in multiple tropical countries, each exhibiting various combinations of agricultural modification, productivity, changing forest cover and integration with global commodity markets. Relationships between agricultural production and trade-offs/synergies with landscape components such as local food security, dietary diversity and nutrition levels, market access, tenure, local poverty, and biodiversity conservation are currently being investigated.

There is a distinct lack of information on the human impacts of agrarian change in forested areas, particularly with regards to socioeconomic effects of agricultural intensification, long-term dietary diversity and market integration processes. Previous research within the land sharing versus land sparing debate has focused heavily on the trade-offs between food security (nominally production and yield metrics) and biodiversity at a macro level, while local-scale effects upon livelihoods, poverty, food security and nutrition have tended to be overlooked.

The case studies in this book highlight landscapes of varying scales, forest dependency and farming practices. Although the landscapes are very different in some respects (i.e. differing forest types, levels of biodiversity, agricultural practices and market influence), the main characteristic comparable across all seven landscapes is that 
they exemplify clear gradients of agricultural expansion and intensification. Each is characterized by a continuum of land use from best available forest cover and high dependency on forest products with subsistence agriculture, to agroforestry systems (a mix of forest cover and crops), and monoculture/intensive cash cropping systems. For example, this transition is demonstrated in Indonesia where a subsistence farming scenario (with high dependency of communities on forest products) transitions into a rubber agroforestry and swidden agriculture system, which then transitions into a commercial oil palm system. Similarly in Cameroon, the focal landscape exemplifies an agrarian transition from a cash cropping system, to cocoa agroforestry regimes, and to a commercial oil palm system. In Ethiopia, subsistence agriculture transitions to a local market-orientated cash-cropping system and then to an extensive commercially-driven wheat arrangement.

The continuums of changing land use evident in each landscape collectively represent a gradient of agrarian change across the tree cover transition. An agricultural modification gradient often mirrors the forest transition curve, where it is anticipated that as agricultural modification increases, forest cover and dependency on forest resources decreases. The land-use gradients in each focal landscape also often mimic historical land-use trajectories of the countries they are located in.

Each of the seven case study chapters provides a comprehensive description of the physical and socioeconomic context of the focal landscape chosen to conduct the wider Agrarian Change study, and a structured account of the historical and political drivers of land-use change occurring in the area. The chapters draw on information obtained from key informant interviews, focus group discussions and preliminary data collection regarding key topics of interest. These include: changes in forest cover and dependency on forest products, farming practices, tenure institutions, conservation projects, and major economic activities. The case studies give first-hand insights into how and why land use has occurred in the focal regions, give a preliminary insight into the social, economic and environmental effects of these changes, and provide comprehensive background information to the study areas should further research be conducted in these regions in the future. 


\section{Acknowledgments}

The editors would like to express heartfelt thanks to the villagers and other national stakeholders who took park in numerous focus group discussions and key informant interviews in each of the seven case study landscapes (Ethiopia, Cameroon, Indonesia, Nicaragua, Bangladesh, Zambia and Burkina Faso). We are also grateful to the national, regional and local governments who embraced our research objectives, authorized us to conduct research in their jurisdictions and gave consent for us to obtain research permits. The support of numerous host organizations in the seven countries is also acknowledged in each of the case study chapters of this book.

We thank CIFOR's Information and Communications Group for editorial and publication support. Special thanks to John Colmey, Gideon Suharyanto, Joanne Walker, Vidya Fitrian, Perdana Maulansyah Putra, Erisa, Erin O'Connell and Wiwit Siswarini. Christine Padoch, Director of CIFOR's Forests and Livelihoods Portfolio, provided invaluable reviews and feedback on the original manuscript.

Funding for this project has been provided by the United States Agency for International Development (USAID) and the UK's Department for International Development (DFID) KnowFor grant to CIFOR. This publication is an output of the CGIAR Research Program on Forests, Trees and Agroforestry. 


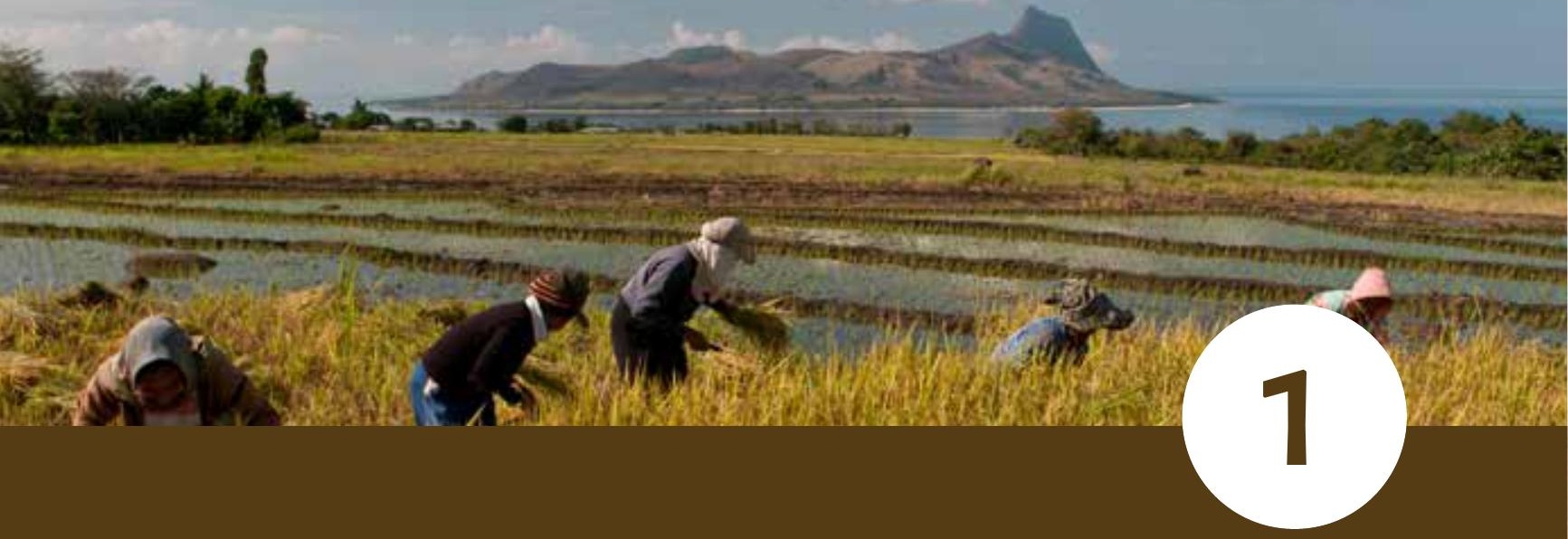

\section{Introduction}

\section{Agrarian change in tropical landscapes}

Liz Deakin, Mrigesh Kshatriya and Terry Sunderland

Agricultural expansion has transformed forest habitats at alarming rates across the globe, but especially so in tropical landscapes (Laurance et al. 2014; Shackelford et al. 2014) due to increasing global demands for food, fiber and biofuels (Tilman and Clark, 2014). This has resulted in mosaic landscapes encompassing varying levels of tree cover, human settlement and agricultural production units. The expansion of agriculture has resulted in large-scale habitat loss, fragmentation of forests and simplification of natural ecosystems, causing increases in the probability of extinction in small and isolated populations of both flora and fauna (Tilman et al. 1994), significant losses in biological diversity (Fahrig 2003; Ewers and Didham 2006; Krauss et al. 2010) and negative impacts on many ecosystem services (Hooper et al. 2005; Tscharntke et al. 2008).

Between 1700 and 1980, the total area of cultivated land in the world increased by $466 \%$ (Meyer and Turner 1992); croplands and pastures have now become one of the largest terrestrial biomes on the planet, exceeding the amounts of forest cover and occupying $\sim 40 \%$ of the land surface (Foley et al. 2005; Ellis et al. 2010). Between 1980 and 2000, more than half of new agricultural land across the tropics was established at the expense of intact forests, while a further $28 \%$ was opened up to the detriment of disturbed or secondary forests (Gibbs et al. 2010). This habitat loss is further compounded by land degradation and competition from other land uses such as urbanization (Ellis et al. 2010). 
Although the rate of expansion of agricultural land has slowed considerably over the last three decades (and even decreased in some areas), the focus on food production has ensured a rapid rate of increase in yield per unit area and has overtaken the rate of global human population growth (Naylor 1996; Matson et al. 1997). Technological and scientific advancements have provided access to cheaper chemical fertilizers and pesticides, high-yielding crop varieties, advanced irrigation technologies and more efficient mechanization (Matson et al. 1997), which have all contributed to elevated crop yields. Unsurprisingly, given the dependency of this model on fossil fuels, concerns have been raised over the long-term sustainability of the intensification of agriculture, particularly as food demands are expected to more than double by 2050 (Tilman et al. 2001; Green et al. 2005; Fischer et al. 2008; Godfray et al. 2010). Pressures on biodiversity and ecosystem services are also increasing due to the growing impacts of human activities across many landscapes (Tylianakis et al. 2008; Defries and Rosenzweig 2010; Tscharntke et al. 2012). Consequently, hard choices need to be made about how tropical landscapes should be managed to optimize multiple outcomes.

The competing global demands for agricultural commodities and vital environmental services provided by forests are now attracting significant attention and investment, for example through calls for "sustainable intensification" of farming and a second Green Revolution (Nature 2010). Meanwhile multiple objectives are increasingly sought from mosaic landscapes such as biodiversity conservation, maintenance of ecosystem services, food production, sustainable livelihood provision and climate change mitigation (Sayer et al. 2013; Reed et al. 2015). However, land scarcity results in trade-offs and synergies between many of these components, particularly between the provision of food and conserving biodiversity (Law and Wilson 2015). As such, global food security is increasingly trading off food for nature (Lambin 2012).

Despite significant progress toward meeting the Millennium Development Goal of halving the prevalence of hunger worldwide by 2015 , levels of global food insecurity are still unacceptably high. Approximately 842 million people worldwide do not have sufficient quantities of food to eat and undernutrition is linked to one-third of child deaths in developing countries (UNICEF 2011; Black et al. 2013; FAO et al. 2013). This situation is exacerbated by global population growth and changing dietary patterns resulting in a predicated $50 \%$ increase in the demand for agricultural products by 2030 (Bruinsma 2003). Historically, the trade-off between food security and the environment led to a perception that biodiversity conservation and food security were considered mutually exclusive (Tscharntke et al. 2005; Brussaard et al. 2010). This perspective may be misplaced as it fails to account for biodiversity within agricultural landscapes and the multiple contributions to food security that biodiversity already provide to food production systems (Perrings et al. 2006; Bharucha and Pretty 2010; Sunderland 2011).

Managing and negotiating trade-offs between conservation and agricultural production involves maximizing food security benefits while minimizing damage to the wider environment. Two contrasting approaches: 'land sparing' and 'land sharing' have been proposed to minimize the negative consequences of agriculture on biodiversity; they aim to consider land-use change in such a way that competing demands for food, commodities and forest services can be reconciled (Phalan et al. 2011a, 2014) 
'Land sparing' aims at intensifying production and maximizing agricultural yields by trading-off its negative consequences on the environment by 'sparing' areas of natural capital (often in the form of protected areas) and therefore reducing the need for agricultural expansion into forest areas (Pirard and Treyer 2010). ' 'Land sharing' is based on a land-use model that integrates production and conservation within the same land units. It proposes to minimize the use of external inputs and to retain patches of natural habitat within farmlands in a form of extensive agriculture. Under this land management regime, landscapes consisting of low-intensity productive areas are combined with areas of natural biodiversity (Wright et al. 2012). Such strategies include agroforestry systems and traditional swidden farming practices (Ziegler et al. 2009; Clough et al. 2011).

Recent studies suggest that efforts to emulate land sparing through the application of incentives, regulations and land-use planning could lead to the best outcomes for food production, climate change mitigation and biodiversity conservation (Balmford et al. 2005; Green et al. 2005; Phalan et al. 2011b). This perspective has had considerable influence on policy makers and donors and provides some of the underpinning logic for a range of high-profile interventions underway around the world (e.g. Alliance for the Green Revolution in Africa, ${ }^{2}$ USAID's Africa Rising Initiative ${ }^{3}$ and the Commission on Sustainable Agriculture and Climate Change $e^{4}$. In recent studies, land sparing was regarded as a more promising strategy than land sharing for securing crop production with minimum negative impact on the abundance and diversity of birds and trees in southwest Ghana, northern India and southern Uganda (Phalan et al. 2011a, 2011b; Hulme et al. 2013). Consequently, the notion of securing forest conservation and food security through land sparing offers a convincing narrative for achieving desirable agrarian change, particularly in the developing world. However, the approach has also attracted sharp criticism as it has been shown that this strategy rarely occurs 'naturally,' because increased productivity can also increase incentives to further clear forests.

Land sharing is supported by the fact that many species are dependent on farmland and other habitats maintained by humans (Wright et al. 2012) and that farmlands that are structurally similar to the original native vegetation, such as tropical agroforests, often support biodiversity as effectively as native vegetation (Clough et al. 2011). This land sparing versus land sharing debate has consequently become somewhat polarized in the scientific literature (Law and Wilson 2015) and there is increasing opinion that a "black and white" dichotomy has been formed that oversimplifies issues that in practice are highly complex (Gutiérrez-Vélez et al. 2011; Adams 2012; Sunderland 2012; Fischer et al. 2014).

1 Agricultural intensification does not always mean increases in inputs such as fertilizer and capital (e.g. through mechanization), but it can also include changes to the use of labor and environmental services. See discussion in Pirard and Treyer $(2010,6)$. More often however, intensification is understood as additional inputs to increase productivity.

2 http://www.agra.org/

3 http://africa-rising.net/

4 See recent article by Commission on Sustainable Agriculture and Climate Change (CSACC) member Mohammed Asaduzzaman: http://climate-l.iisd.org/guest-articles/now-is-the-time-to-make-agriculture-part-ofthe-climate-change-solution/ 
Baudron and Giller (2014) suggest that both options are equally important and can be complementary strategies under different circumstances. Land sparing and land sharing land management regimes are not necessarily mutually exclusive and some landscapes may exhibit elements of both strategies (Scariot 2013). Smallholder farmers for example, who form the backbone of global food security, provide up to $40 \%$ of the world's food; most of them fall somewhere on the continuum between land sharing and land sparing (Tscharntke et al. 2012). Baudron and Giller (2014) also identify a number of general principles that should be considered, beyond the land sparing/land sharing debate, for example: managing spillover effects from intensive production systems; maintaining resilience and ecosystem services; accounting for landscape structure and configuration of land units, reducing losses and wastes; improving access to agricultural products in developing countries; changing consumption patterns in developed countries; and developing supportive markets and policies.

It has also recently been recognized that land-use strategies aimed at balancing agriculture and biodiversity conservation must also consider socioeconomic outcomes and trade-offs (Grau et al. 2013; Fischer et al. 2014; Loos et al. 2014). Landscapes should be viewed as complex socioecological systems that consist of mosaics of natural and/ or human-modified ecosystems (Bennett et al. 2006). While the physical configuration of topography, soils, vegetation and geology greatly influences land use, forests and settlements, these components are also subject to ecological, historical, economic and cultural processes of an area (Sayer et al. 2013). However, there is a distinct lack of information on the human impacts of agrarian change in forested areas, particularly on the socioeconomic effects of agricultural intensification, long-term dietary diversity and market integration processes. Previous research within the land-sharing versus land sparing debate has focused on the trade-offs between food security and biodiversity at a macro level (Balmford et al. 2005; Clough et al. 2011; Ben Phalan et al. 2011a), while local-scale effects upon livelihoods, poverty, food security and nutrition have been overlooked. More food production does not automatically lead to better local food security and better livelihoods for rural communities (Powell et al. 2015).

The consequences of land-use strategies can only be fully understood within the wider context of local histories, culture, politics and market dynamics. For example, land-use decisions at the household level often influence what happens at the landscape scale, yet in the majority of cases, such decisions are driven by strong externalities such as government policies, labor, extension and markets. A myriad of land uses will fragment and parcel out the landscape, meaning that some landscape configurations may not even lend themselves to a contrasting land sparing or land sharing land-use regime. Therefore, we need to advance our understanding of agricultural landscapes as integral socioecological systems and to move the land sharing/land sparing debate forward from solely examining trade-offs between food production and biodiversity.

The CIFOR-led Agrarian Change Project aims to address this research gap by working directly with communities within multifunctional tropical landscapes to understand the social, economic and ecological consequences of land use and agrarian change processes. 


\section{The Agrarian Change Project}

\section{Overview}

The Agrarian Change Project is a multidisciplinary research project led by CIFOR. It examines socioeconomic outcomes and conservation, livelihood and food security implications of land-use change and agrarian change processes in multifunctional landscapes. The research focuses on landscapes in a number of tropical countries around the world, each exhibiting various combinations of agricultural modification, productivity, changing forest cover and integration with global commodity markets. The relationships between agricultural production and trade-offs/synergies with landscape components (such as local food security, dietary diversity and nutrition levels, market access, tenure, local poverty, as well as biodiversity conservation) are currently being investigated. A common set of qualitative and quantitative research methods have been applied in each landscape to enable a global comparative analysis. The effects of landscape configuration (including forest fragmentation and levels of patchiness), land sharing/sparing scenarios and synergies and trade-offs between different land uses (e.g. agroforestry, crops, livestock rearing, swidden agriculture) with forests and tree-based systems are being examined.

The focal landscapes chosen for the Agrarian Change Project were selected based on extensive background information obtained by conducting scoping studies in the field, primarily by a team of graduate students and their academic supervisors. The case study chapters in this book document the findings of these scoping surveys for seven different landscapes in seven different countries: Bangladesh, Burkina Faso, Cameroon, Ethiopia, Indonesia, Nicaragua and Zambia (Figure 1.1). The purpose of the scoping surveys was to ensure that the landscape selected in each country fulfilled the experimental design criteria devised for the project and to provide detailed background information on land management practices, both historically and more contemporarily for the regions selected.

The first section of this introductory chapter provides contextual background information to the Agrarian Change Project. In the following section, we give a brief overview of the project objectives and experimental design to provide further context for the following case study chapters.

\section{Research objectives}

1. How is land use changing over time and what are the underlying drivers behind these changes? Are there consistencies/differences between the different landscapes/countries?

2. What are local people's perceptions of the outcomes of land-use change in each landscape in terms of their livelihoods, access to natural resources, land tenure and food security?

3. What is the relationship between land use and local livelihoods and food security (i.e. food production, food access, market integration, nutrition, wealth) under different land-use scenarios along an agricultural modification gradient?

4. What is the relationship between local food production and local food security along an agricultural modification gradient and does this differ between different countries? 


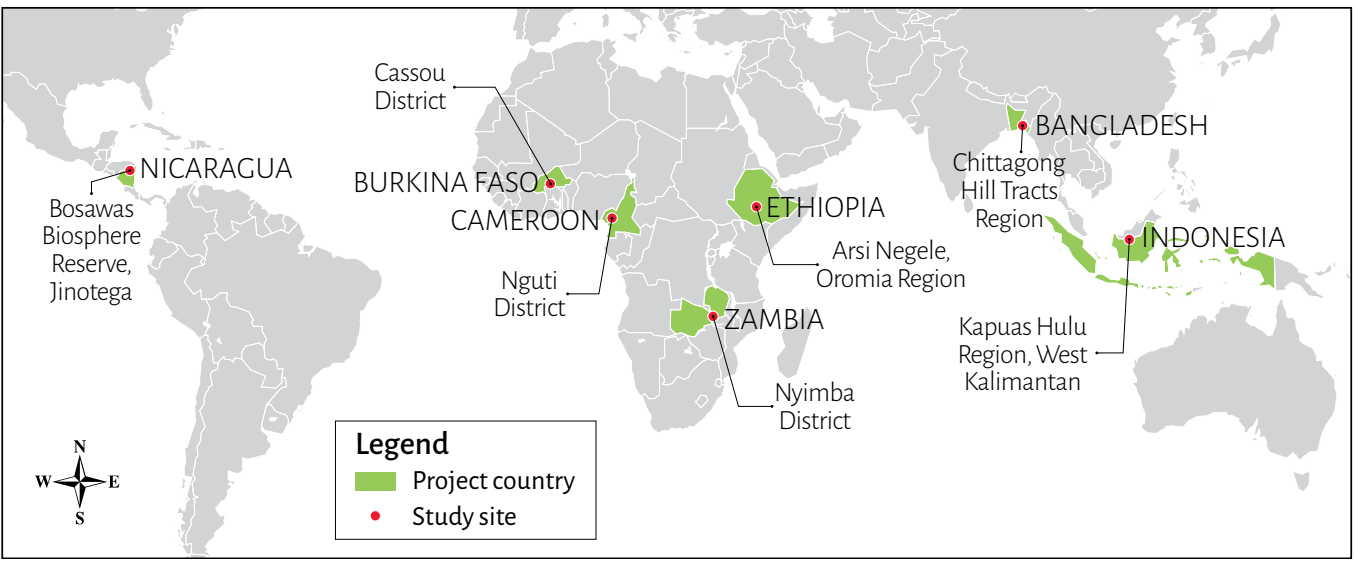

Figure 1.1 Map showing the location of the seven landscapes used as case studies for the Agrarian Change Project.

\section{Research design}

Using a landscape-level approach, a nested hierarchical experimental design was devised incorporating three levels (Figure 1.2):

- a landscape in each focal country that exhibits changing land-use practices (agricultural modification and forest loss)

- three land-use 'zones' in each landscape, collectively representing a gradient/continuum of agricultural modification and decreasing tree cover

- village/s or settlement/s within or in close proximity to the dominant zone of land use.

\section{Selection of landscapes, zones and villages}

The selection of landscapes in the project was based on prior knowledge by field teams in the focal countries, followed by scoping surveys to ensure that the chosen landscapes met project criteria. Attempts were also made to collate these landscapes where there were already research initiatives in place, such as the Sentinel Landscapes framework of the CGIAR's Forests Trees and Agroforestry Research Program. ${ }^{5}$ A continuum of changing land-use practices needed to be present within each landscape; often these mimic historical land-use trajectories. Three land-use 'zones' were clearly identified based on dominant ${ }^{6}$ land-use practices representative of the landscape, collectively representing a gradient of agrarian change across the tree cover transition. An agricultural modification gradient often mirrors the forest transition curve (Figure 1.3), where it is anticipated that as agricultural modification increases, forest cover and dependency on forest resources decreases.

5 http://www1.cifor.org/sentinel-landscapes/home.html

6 We acknowledge that multiple land uses will occur in each zone but each zone was identified based on the presence of a most prevalent land use. 


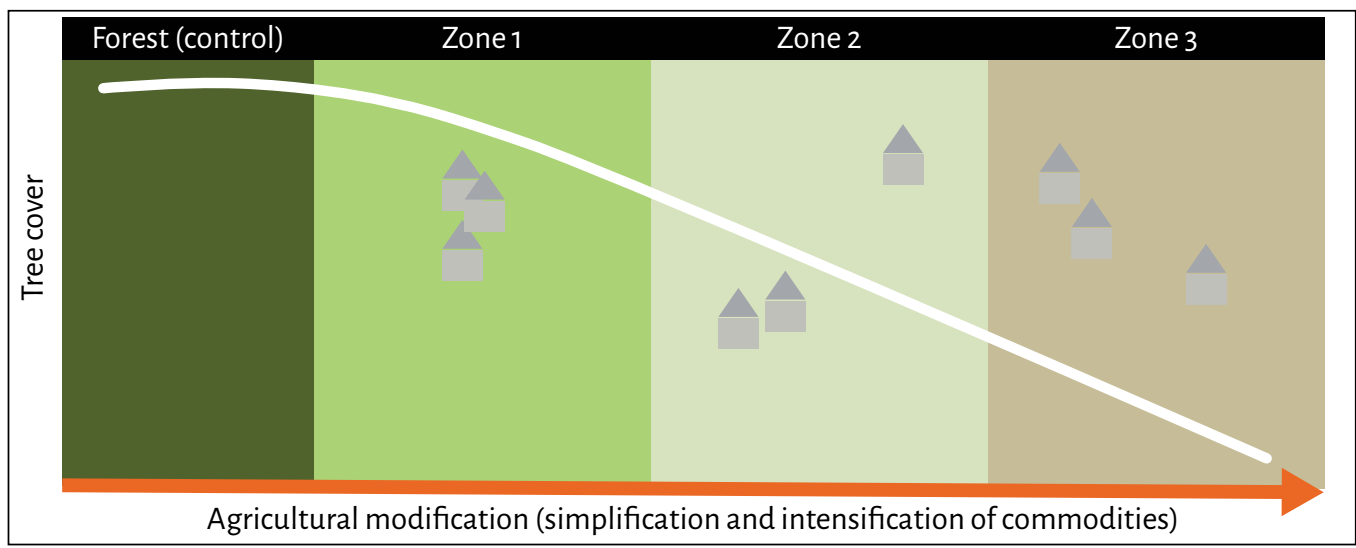

Figure 1.2 The project's landscape-level hierarchical research design.

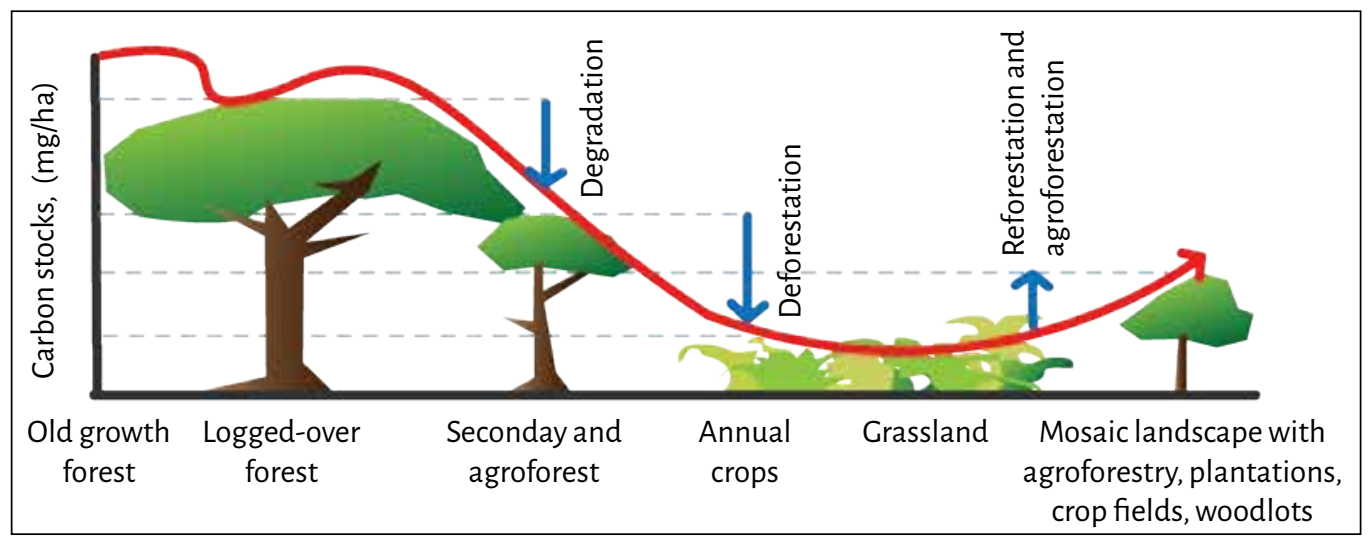

\section{Figure 1.3 Forest transition curve.}

Source: CGIAR Research Program on Forests, Trees and Agroforestry, CIFOR

For example:

- Zone 1: an area with 'best' available forest cover and high dependency on forest products, coupled with subsistence agriculture

- Zone 2: an agroforestry system (a mix of forest cover and crops)

- Zone 3: a monoculture/intensive cash crop system (e.g. wheat, maize or palm oil).

There were no constraints to the size of the landscapes or zones within a landscape. However, for each landscape, we ensured that there was limited variability in terms of rainfall/climatic characteristics and elevation and zones within a landscape were of the same biome or agro-ecological zone. Within each zone, there was at least one village (with a minimum number of 100 households, as this was the minimum number of households needed to conduct household surveys later on); ideally each zone should contain several villages, with a minimum number of 100 households combined. 
Table 1.1 Example criteria used to help distinguish characteristics of different zones within a focal landscape.

\begin{tabular}{|l|l|l|l|l|}
\hline & Criteria & Zone 1 & Zone 2 & Zone 3 \\
\hline $\mathbf{1}$ & Population density & Sparse & Medium & Dense \\
\hline $\mathbf{2}$ & Land tenure & State/customary & Customary & Customary/title deeds \\
\hline $\mathbf{3}$ & Proximity to major towns & Distant & Far & Near \\
\hline $\mathbf{4}$ & Level of dependence on forest resources & High & High-medium & Medium-low \\
\hline $\mathbf{5}$ & $\begin{array}{l}\text { Proximity to protected areas (forest } \\
\text { reserves, game management areas, } \\
\text { national parks) }\end{array}$ & Near & Far & Distant \\
\hline 6 & Level of in-migration & High-medium & Medium-low & Low \\
\hline 7 & $\begin{array}{l}\text { Level of agricultural inputs } \\
\text { (fertilizers) }\end{array}$ & None-low & Medium & High \\
\hline 8 & $\begin{array}{l}\text { Market oriented crop production/ } \\
\text { presence of cash crops: tobacco, } \\
\text { maize, groundnuts and cotton }\end{array}$ & Rare & Occasional & Common \\
\hline 9 & Presence of subsistence farming & High & Medium & Low \\
\hline 10 & Level of infrastructural development & Low & Moderate & High \\
\hline & & & \\
\hline
\end{tabular}

We aimed to capture as much variation along a modification gradient in each focal landscape with regard to the following characteristics:

- agricultural modification (from low inputs - diversified, extensive, subsistence orientated practices through to high input - market orientated, intensive, simplified practices)

- forest/tree cover

- community dependency on forest products

- market access and infrastructure.

To help with the process of distinguishing three zones, a list of criteria was developed for each focal landscape to help discriminate the different practices and relative differences between the key characteristics of each zone (Table 1.1). This was modified for each landscape; it helped to clarify whether the landscapes selected exhibited a gradient of agrarian change/agricultural modification. The type of criteria/variables and number of criteria/variables differed between focal landscapes.

\section{Structure and content of this book}

This book uses insights and preliminary data from scoping studies undertaken in seven focal landscapes identified to conduct further data collection for the project. The purpose of this introductory chapter is to provide the background information to help contextualize the research aims and objectives of the project and provide a brief overview of the experimental design and criteria required of the focal landscapes. The case study chapters of this book provide detailed background information on the seven 
landscapes (in seven different countries) that were chosen to conduct the in-depth global comparative study: Bangladesh, Burkina Faso, Cameroon, Ethiopia, Indonesia, Nicaragua and Zambia. The focal landscapes exhibit various scenarios of changing forest cover and transition, agricultural modification and integration with local and global commodity markets.

Each of the seven case study chapters gives a comprehensive description of the physical and socioeconomic context of each focal landscape and a structured account of the historical and political drivers of land-use change occurring in the area; it draws on information obtained from key informant interviews, FGDs and preliminary data collection about key topics of interest such as changes in forest cover and dependency on forest products, farming practices, tenure institutions, conservation projects and major economic activities. The case studies give first-hand insights into how and why land use has occurred in the focal regions; they give a preliminary insight into the social, economic and environmental effects of these changes and provide comprehensive background information to the study areas that can be drawn upon if further research is conducted in these regions in the future. 


\section{References}

Adams WM. 2012. Feeding the next billion: hunger and conservation. Oryx 46:157-58. http://journals.cambridge.org/abstract_So030605312000397

Balmford A, Green RE and Scharlemann JPW. 2005. Sparing land for nature: Exploring the potential impact of changes in agricultural yield on the area needed for crop production. Global Change Biology 11:1594-1605.

Baudron F and Giller KE. 2014. Agriculture and nature: Trouble and strife? Biological Conservation 170:232-45.

Bennett AF, Radford JQ and Haslem A. 2006. Properties of land mosaics: Implications for nature conservation in agricultural environments. Biological Conservation 133(2):250-64.

Bharucha $\mathrm{Z}$ and Pretty J. 2010. The roles and values of wild foods in agricultural systems. Philosophical Transactions of the Royal Society B: Biological Sciences, 365(1554):2913-26. http://rstb.royalsocietypublishing.org/content/365/1554/2913.abstract

Black RE, Victora CG, Walker SP, Bhutta ZA, Christian P, de Onis M, Ezzati M, Grantham-McGregor S, Katz J, Martorell R et al. 2013. Maternal and child undernutrition and overweight in low-income and middle-income countries. Lancet 382(9890):427-51.

Bruinsma J, ed. 2003. World agriculture: Towards 2015/2030. An FAO perspective. London: Earthscan Publications.

Brussaard L, Caron P, Campbell B, Lipper L, Mainka S, Rabbinge R, Babin D and Pulleman M. 2010. Reconciling biodiversity conservation and food security: Scientific challenges for a new agriculture. Current Opinion in Environmental Sustainability 2(1-2):34-42. http://www.sciencedirect.com/science/article/pii/ S1877343510000151

Clough Y, Barkmann J, Juhrbandt J, Kessler M, Wanger TC, Anshary A, Buchori D, Cicuzza D, Darras K, Putra DD, et al. 2011. Combining high biodiversity with high yields in tropical agroforests. Proceedings of the National Academy of Sciences of the United States of America 108(20):8311-16

DeFries R and Rosenzweig C. 2010. Toward a whole-landscape approach for sustainable land use in the tropics. Proceedings of the National Academy of Sciences of the United States of America 107(46):19627-32.

Ellis EC, Goldewijk KK, Siebert S, Lightman D and Ramankutty N. 2010. Anthropogenic transformation of the biomes, 1700 to 2000. Global Ecology and Biogeography 19(5):589-606.

Ewers RM and Didham RK. 2006. Confounding factors in the detection of species responses to habitat fragmentation. Biological Reviews 81:117-42.

Fahrig L. 2003. Effects of habitat fragmentation on biodiversity. Annual Review of Ecology and Systematics 34:487-515.

[FAO] Food and Agriculture Organization of the United Nations, [IFAD] International Fund for Agricultural Development and [WFP] World Food Programme. 2013. 
The state of food insecurity in the world, 2013. The multiple dimensions of food security. Rome: FAO.

Fischer J, Abson DJ, Butsic V, Chappell MJ, Ekroos J, Hanspach J, Kuemmerle T, Smith HG and von Wehrden H. 2014. Land sparing versus land sharing: Moving forward. Conservation Letters 7(3):149-57. doi:10.1111/conl.12084

Fischer J, Brosi B, Daily GC, Ehrlich PR, Goldman R, Goldstein J, Lindenmayer DB, Manning AD, Mooney HA, Pejchar L, et al. 2008. Should agricultural policies encourage land sparing or wildlife-friendly farming? Frontiers in Ecology and the Environment 6(7):380-5.

Foley JA, DeFries R, Asner GP, Barford C, Bonan G, Carpenter SR, Chapin FS, Coe MT, Daily GC, Gibbs HK, et al. 2005. Global consequences of land use. Science 309(5734):570-4.

Gibbs HK, Ruesch AS, Achard F, Clayton MK, Holmgren P, Ramankutty N, and Foley JA. 2010. Tropical forests were the primary sources of new agricultural land in the 1980s and 1990s. Proceedings of the National Academy of Sciences of the United States of America 107(38):16732-7. http://www.pnas.org/content/107/38/16732.abstract

Godfray HCJ, Crute IR, Haddad L, Lawrence D, Muir JF, Nisbett N, Pretty J, Robinson S, Toulmin C and Whiteley R. 2010. The future of the global food system. Philosophical Transactions of the Royal Society B-Biological Sciences 365(1554):2769-77.

Grau R, Kuemmerle T and Macchi L. 2013. Beyond "land sparing versus land sharing": Environmental heterogeneity, globalization and the balance between agricultural production and nature conservation. Current Opinion in Environmental Sustainability 5(5):477-83. http://www.sciencedirect.com/science/article/pii/S1877343513000687

Green RE, Cornell SJ, Scharlemann JPW and Balmford A. 2005. Farming and the fate of wild nature. Science 307(5709):550-5.

Gutiérrez-Vélez VH, DeFries R, Pinedo-Vásquez M, Uriarte M, Padoch C, Baethgen W, Fernandes K and Lim Y. 2011. High-yield oil palm expansion spares land at the expense of forests in the Peruvian Amazon. Environmental Research Letters 6(4):044029. http://iopscience.iop.org/article/10.1088/1748-9326/6/4/044029

Hooper DU, Chapin FS, Ewel JJ, Hector A, Inchausti P, Lavorel S, Lawton JH, Lodge DM, Loreau M, Naeem S, et al. 2005. Effects of biodiversity on ecosystem functioning: A consensus of current knowledge. Ecological Monographs 75(1):3-35.

Hulme MF, Vickery JA, Green RE, Phalan B, Chamberlain DE, Pomeroy DE, Nalwanga D, Mushabe D, Katebaka R, Bolwig S, et al. 2013. Conserving the birds of Uganda's banana-coffee arc: Land sparing and land sharing compared. PLoS One 8(2):e54597.

Krauss J, Bommarco R, Guardiola M, Heikkinen RK, Helm A, Kuussaari M, Lindborg R, Ockinger E, Partel M, Pino J, et al. 2010. Habitat fragmentation causes immediate and time-delayed biodiversity loss at different trophic levels. Ecology Letters 13(5):597-605.

Lambin EF. 2012. Global land availability: Malthus versus Ricardo. Global Food Security 1(2):83-7. http://www.scopus.com/inward/record.url?eid=2-s2.0$84872268512 \&$ partnerID=tZOtx3y1 
Laurance WF, Sayer J and Cassman KG. 2014. Agricultural expansion and its impacts on tropical nature. Trends in Ecology and Evolution 29:107-16.

Law EA and Wilson KA. 2015. Providing context for the land-sharing and land-sparing debate. Conservation Letters. doi:10.1111/conl.12168

Loos J, Abson DJ, Chappell MJ, Hanspach J, Mikulcak F, Tichit M, Fischer J. 2014. Putting meaning back into "sustainable intensification." Frontiers in Ecology and the Environment 12(6):356-61. http://www.esajournals.org/doi/abs/10.1890/130157

Matson PA, Parton WJ, Power AG, Swift MJ. 1997. Agricultural intensification and ecosystem properties. Science 277(5325):504-9

Meyer WB, Turner BL. 1992. Human-population growth and global land-use cover change. Annual Review of Ecology and Systematics 23:39-61.

Nature 2010. How to feed a hungry world. Nature 466:531-2.

Naylor RL. 1996. Energy and resource constraints on intensive agricultural production. Annual Review of Energy and the Environment 21:99-123.

Perrings C, Jackson L, Bawa K, Brussaard L, Brush S, Gavin T, Papa R, Pascual U and De Ruiter P. 2006. Biodiversity in agricultural landscapes: Saving natural capital without losing interest. Conservation Biology 20(2):263-4. http://doi.wiley.com/10.1111/ j.1523-1739.2006.00390.x

Phalan B, Balmford A, Green RE, Scharlemann JPW. 2011a. Minimising the harm to biodiversity of producing more food globally. Food Policy 36:S62-S71.

Phalan B, Green R, Balmford A. 2014. Closing yield gaps: perils and possibilities for biodiversity conservation. Philos Trans R Soc L. B Biol Sci 369:20120285.

Phalan B, Onial M, Balmford A, Green RE. 2011b. Reconciling food production and biodiversity conservation: Land sharing and land sparing compared. Science 333(6047):1289-91.

Pirard R and Treyer S. 2010. Agriculture and deforestation: What role should REDD+ and public support policies play? Paris: Institut du Developpment durable et des relations internationles (IDDRI) No.10/2010 December.

Powell B, Thilsted SH, Ickowitz A, Termote C, Sunderland T and Herforth A. 2015. I mproving diets with wild and cultivated biodiversity from across the landscape. Food Security 7(3):535-54.

Reed J, Deakin L and Sunderland T. 2015. What are "integrated landscape approaches" and how effectively have they been implemented in the tropics: A systematic map protocol. Environmental Evidence 4(1):2.

Sayer J, Sunderland T, Ghazoul J, Pfund JL, Sheil D, Meijaard E, Venter M, Boedhihartono AK, Day M, Garcia C, et al. 2013. Ten principles for a landscape approach to reconciling agriculture, conservation and other competing land uses. Proceedings of the National Academy of Sciences of the United States of America $110(21): 8349-56$.

Scariot A. 2013. Land sparing or land sharing: The missing link. Frontiers in Ecology and the Environment 11(4):177-8. http://www.researchgate.net/publication/260162546_ Land_sparing_or_land_sharing_the_missing_link 
Shackelford GE, Steward PR, German RN, Sait SM and Benton TG. 2014. Conservation planning in agricultural landscapes: Hotspots of conflict between agriculture and nature. Diversity and Distributions. 21(3):357-67. doi:10.1111/ddi.12291

Sunderland T. 2012. Land sharing or land sparing? Reconciling agriculture and biodiversity conservation. Bogor, Indonesia: Center for International Forestry Research. Accessed November 2015. http://blog.cifor.org/8110/land-sharing-or-land-sparing-reconcilingagriculture-and-biodiversity-conservation?fnl=en

Sunderland TCH. 2011. Food security: Why is biodiversity important? International Forestry Review 13(3, SI):265-74.

Tilman D and Clark M. 2014. Global diets link environmental sustainability and human health. Nature 515:518-22.

Tilman D, Fargione J, Wolff B, D'Antonio C, Dobson A, Howarth R, Schindler D, Schlesinger WH, Simberloff D and Swackhamer D. 2001. Forecasting agriculturally driven global environmental change. Science 292(5515):281-84.

Tilman D, May RM, Lehman CL and Nowak MA. 1994. abitat destruction and the extinction debt. Nature 371:65-66.

Tilman D and Clark M. 2014. Global diets link environmental sustainability and human health. Nature 515(7528):518-22.

Tscharntke T, Clough Y, Wanger TC, Jackson L, Motzke I, Perfecto I, Vandermeer J and Whitbread A. 2012. Global food security, biodiversity conservation and the future of agricultural intensification. Biological Conservation 151(1):53-59.

Tscharntke T, Klein AM, Kruess A, Steffan-Dewenter I and Thies C. 2005. Landscape perspectives on agricultural intensification and biodiversity-ecosystem service management. Ecology Letters 8(8):857-74.

Tscharntke T, Sekercioglu CH, Dietsch T V, Sodhi NS, Hoehn P, Tylianakis JM. 2008. Landscape constraints on functional diversity of birds and insects in a tropical agroecosystem. Ecology 89(6):944.

Tylianakis JM, Didham RK, Bascompte J, Wardle DA. 2008. Global change and species interactions in terrestrial ecosystems. Ecology Letters 11:1351-63.

[UNICEF] United Nations Children's Fund. 2011. Levels and trends in child mortality. 2011. Estimates developed by the UN Inter-agency Group for Child Mortality Estimation. New York, NY: United Nations Children's Fund.

Wright HL, Lake IR and Dolman PM. 2012. Agriculture - a key element for conservation in the developing world. Conservation Letters 5(1):11-19. http://doi.wiley.com/10.1111/ j.1755-263X.2011.00208.X

Ziegler AD, Fox JM and Xu J. 2009. Agriculture: The rubber juggernaut. Science 324(5930):1024-5. http://www.sciencemag.org/content/324/5930/1024.short 


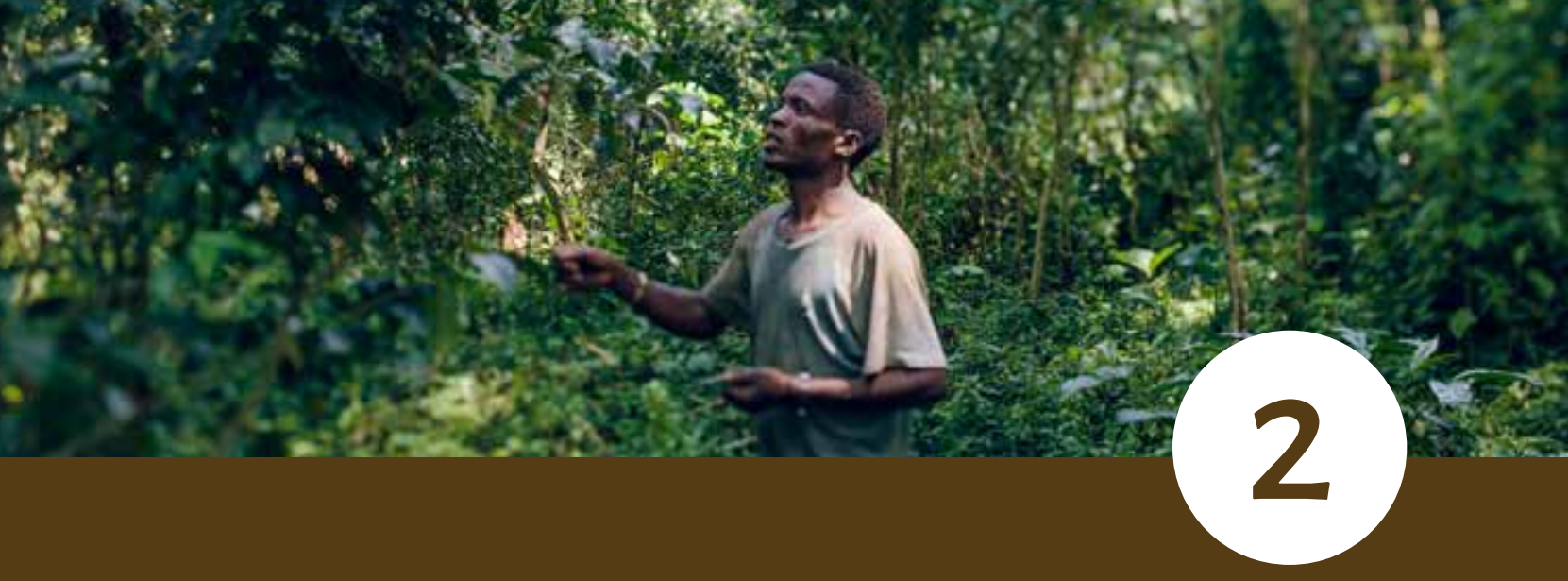

\section{Understanding people and forest interrelations along an intensification gradient in Arsi-Negele, Ethiopia}

\section{Summary}

This chapter presents the results of a scoping study conducted along an agricultural intensification and forest cover gradient from Arsi-Negele town to Munessa Forest in southern Ethiopia. It summarizes preliminary research in the study area led by the International Maize and Wheat Improvement Center (Centro Internacional de Mejoramiento de Maíz y Trigo, CIMMYT) as part of the Agrarian Change Project, a multi-country comparative research project led by CIFOR. The objective was to gather information that will guide further research in the area including: characterization of the intensification gradient (context), access to resources, livelihood strategies, market access and value chains, institutional support, and perceptions of change (land-cover change and historical trends).

\subsection{Introduction}

In Ethiopia, 82.22\% of the population is rural and relies mainly on agriculture for its living (FAO 2014). Ethiopian (and most sub-Saharan African) farmers often experience low productivity due to low input access and use, lack of market access, and government or institutional failures, among other reasons (Ehui and Pender 2005). Although Ethiopia 
is very diverse agro-ecologically and socioeconomically, mixed crop-livestock systems dominate. Livestock generate a number of benefits (nutritional animal products, income, manure, traction, saving, insurance, display of status, etc) but generally require more feed and fodder than available on-farm. Similarly, rural households are generally not selfsufficient in household fuel material (fuelwood, crop residue, dung and other materials). Therefore, farming households rely on communal resources, including pastures and natural areas, for their provision of fodder, fuel, construction materials and wild food.

In 2005 it was estimated that $11.9 \%$ of the Ethiopian territory was covered by forest $\left(0.13\right.$ million $\left.\mathrm{km}^{2}\right)$ and that these forest areas had been declining at a rate of $1.1 \%$ annually between 2000 and 2005 (FAO 2005 as cited by Garedew 2010). It is assumed that the rate of forest loss was similar for the period 2005-10 (FAO 2010). Although there is a lack of reliable data about forest cover before the 1980s, it is believed that in the late 1960 s forest covered around $40 \%$ of the country (personal communication from Kedir Nino, head of Oromia Forest and Wildlife Enterprise - OFWE - Arsi-Negele Branch, September 2014). Various drivers have been identified in different regions, but changes in property and use rights, and the role of the State have been recognized as the most important (Bekele 2003). In addition to lack of governance during repeated periods of violent political, social and economic changes, uncertainty in the land tenure system and the introduction of new profitable crops have contributed to the decline in forest cover in the south Central Rift Valley of Ethiopia (Dessie and Christansson 2007). Sassen et al. (2012) demonstrated in Kenya that the context (e.g. law enforcement, collaborative management, political interference) is more important than the drivers (population, wealth, market access, prices) that operate under this context in explaining deforestation. Conservation and development policies and interventions need to address local factors within the context and conditions generated by larger-scale external influences (Sassen et al. 2012).

Most farmers in Ethiopia and sub-Saharan Africa have to achieve production with scarce resources (Rufino et al. 2009). Forest and other communal resources help farmers who are facing a shortage of resources at times of low agricultural productivity. Although communal resources provide fuel, food, feed and income, their buffering effect is decreasing fast as areas shrink or degrade (Tittonel 2013). It is thus urgent to understand what drives forest loss and its impact on rural livelihoods, and be able to identify compromises - in terms of landscape composition and configuration - that provide the best outcomes for rural households and the environment. Such analysis, however, should be context-specific.

This chapter provides a first overview of the selected study area, local value chains of important products and local perceptions of livelihoods, historical trends, land-use change and access to resources.

\subsection{Methodology}

\subsubsection{Site selection}

Suitable sites for the Agrarian Change Project - characterized by changing land-use practices, the presence of an intensification gradient/chronosequence and similar altitude, soil type and weather - were prospected. Interviews with Ethiopian forestry 
experts Dr. Habtemariam Kassa (CIFOR; 19 September 2014) and Dr. Menfese Tadesse (Wondo Genet Forestry College; 23 September 2014) were held to obtain recommendations of possible study areas. Following their suggestions, exploratory visits took place until an adequate intensification gradient was found. Three settlements along the intensification gradient were selected. Each settlement was chosen as representative of distinct zones along the intensification gradient. Settlement leaders and local administration offices were invited to collaborate.

\subsubsection{Selected landscape: Munessa Forest area}

The selected landscape is located in the Oromia region, Arsi-Negele woreda (district) and includes three kebeles (subdistricts): Gambelto, Bombaso Regi and Ashooka. Munessa Forest is a protected forest that is owned by the State and controlled by OFWE. It has an estimated area of 23,000 ha and is subdivided into three management blocks: Degaga, Sole and Gambo (Figure 2.1; Halle-Wittenberg University 2002). Only the latter block is part of the selected landscape.

According to the Ethiopian classification of climatic zones, Munessa Forest and its surroundings can be classified as Woyna Dega (1500-2300 masl) and Dega (2300-3200 masl) zones (Teshome 1996). The selected landscape is found in the Woyna Dega zone since the elevation ranges from 1970 to 2200 masl. According to Lemenih (2004) the forest can be classified as tropical dry evergreen montane forest. Soils are mainly andosols (Lemenih 2004). The Halle-Wittenberg University website (2002) describes the area as presenting bimodal rainfall pattern with a short rainy season from March to May and a long rainy season from July to September. In Degaga station ( $20 \mathrm{~km}$ north of the selected landscape) the mean annual rainfall is $1075 \mathrm{~mm}$ (18 year average) and the mean annual temperature is $15^{\circ} \mathrm{C}$ (16 year average) (Figure 2.2 ).

\subsubsection{Understanding the context}

A first set of interviews was conducted with the settlement leaders and administration officers in order to obtain general information about history, economic activities, agricultural seasons and presence of infrastructure in the area. In addition, two interviews were conducted with the head of OFWE to obtain background information about the forest history and the current situation.

A participatory rural appraisal (PRA) was held in each settlement with a subgroup of 50-60 community members that was representative in terms of gender, age and wealth. To obtain an initial but complete understanding of the settlement situation and its history, six participatory activities were carried out leading to the six following outputs: a timeline of historical events, a settlement map (displaying major resources and land uses), a representation of the modalities of access to major resources (forest products, land, water and grazing lands), a Venn diagram (representation of the institutional and organizational support in the area), value-chain representations for the main commodities, and a household typology based on self-categorization (Geilfus 2008). 


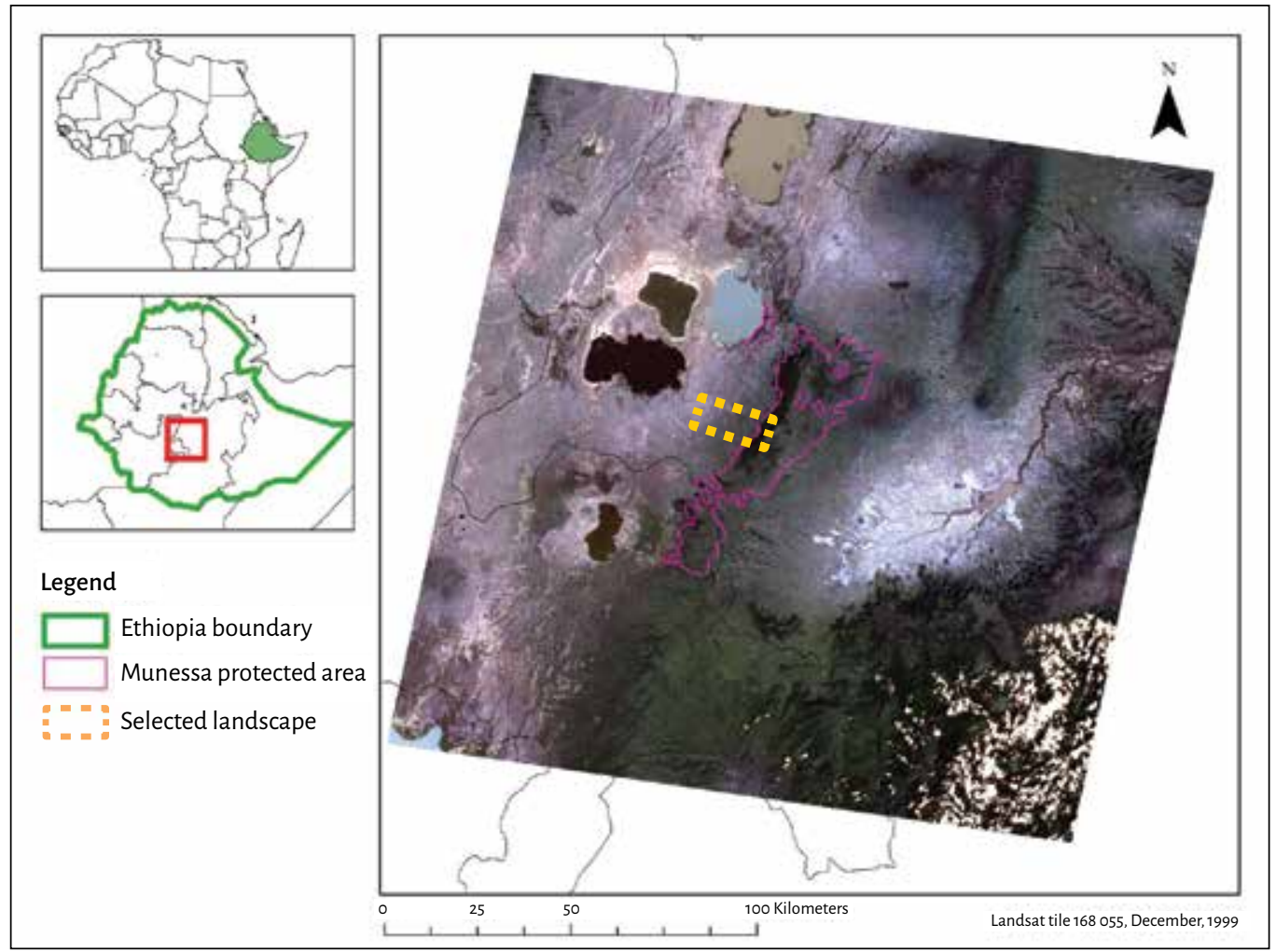

Figure 2.1 Location of Munessa Forest and the study area, which can be described as an intensification gradient.

Source: John Arnet and Ian Eddy (2015), Remote Sensing Department, University of British Columbia

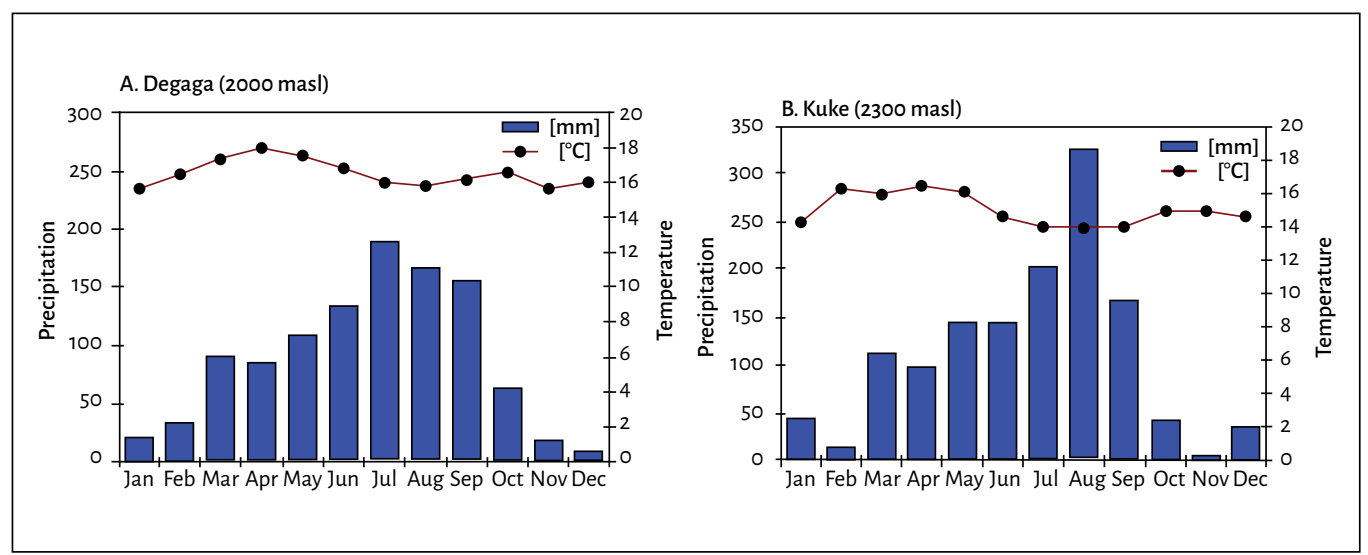

Figure 2.2 Mean annual rainfall and mean temperature $(A)$ in Degaga (18 year average and 16 year average, respectively) and (B) Kuke (rainfall and temperature data for 2002). The two sites are about $\mathbf{2 0} \mathbf{~ k m}$ north from the studied landscape.

Source: Halle-Wittenberg University (2002) 


\subsubsection{Focus group discussions}

An FGD was held in each settlement $(n=3)$ to analyze land-use/land-cover changes as well as trends of historical changes (Geilfus 2008). A group of 14 elders and settlement leaders were invited to participate. First, trend lines were drawn and discussed by participants, describing changes over the last 40 years in population, forest cover, crop productivity, food security, farm size and livestock number. The second part of the activity consisted of creating historical diagrams of land-use/land-cover change for five points in time during the last 40 years. Participants selected four land-use types: forest, cropland, grazing land and eucalyptus woodlots (most important land uses in the area), and their change over time was analyzed.

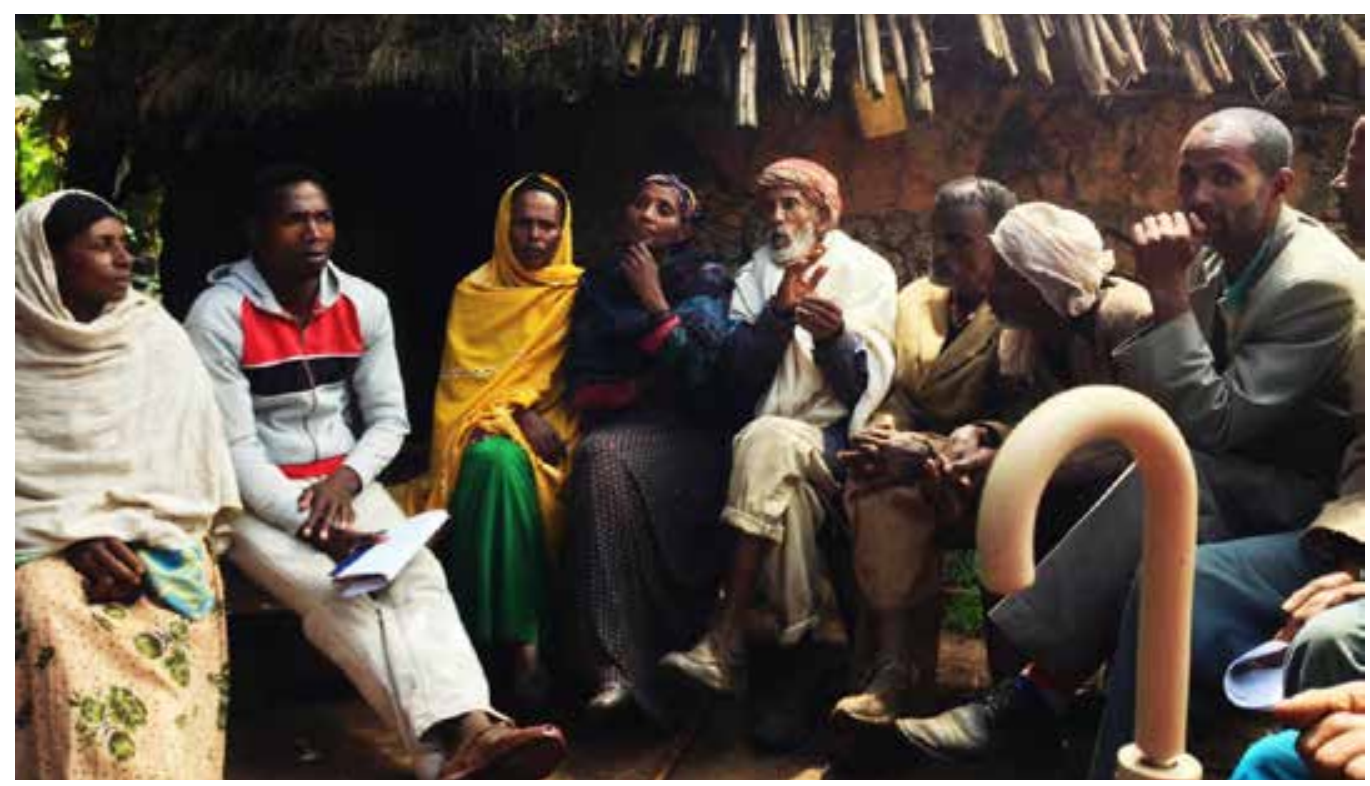

An FCD with elders and settlement leaders in one of the selected settlements. (lean-Yves Duriaux/CIMMYT)

\subsubsection{Key informant interviews}

Based on preliminary information obtained through the PRA, actors of the following value chains were interviewed: fuelwood, maize, wheat, potato, milk and livestock. The urban market of Arsi-Negele and rural market of Lephis were visited several times to conduct interviews. A total of 23 interviews were held in order to complete the value-chain diagram for the different commodities. A list of interviews can be found in Appendix 2A.

An interview with the community-based organization ( $\mathrm{CBO}$ ) managing the forest around Ashooka kebele was conducted with three members of the managing committee in order to understand the functioning of the organization as well as the actual situation concerning the forest access and use in the area (method based on personal 
communication from Annemiek Pas, 29 September 2014). The head of the local office of OFWE working in the area was interviewed to examine the institution's position and the legal situation related to access and use of the forest. Representatives from Lephis Ecotourism Cooperative were interviewed (locally based) to examine its functioning and importance in the area. Finally, two meetings were held with health officers working in the area (one health extensionist and one health service provider) to get an understanding of the general health situation, the biggest problems and the most susceptible groups in the area.

\subsubsection{Remote sensing}

A preliminary analysis of land-cover change in the study area was performed by John Arnet, Ian Eddy and Sarah Gergel from the Remote Sensing Department of the University of British Columbia. The remote sensing study explored possible vegetation loss from 1987 to 2011 .

\subsubsection{Gray literature and literature review}

Different literature sources were consulted, chiefly MSc and PhD theses from Wondo Genet Forestry and Agriculture College library.

\subsection{General information of the study area}

\subsubsection{Selected zones and settlements}

The study area is represented in Figure 2.3. It can be divided into three zones along an intensification gradient from Arsi-Negele to Munessa Forest (Gambo block) near Lephis village. The zone closest to the forest (Zone 1) has access to the forest, has a high tree density on its farmland and has species-diverse home gardens. In the intermediate zone (Zone 2), residents have no access to the forest but the density of indigenous trees is high both in the farmland and the home gardens. In Zone 3 (furthest from the forest) annual crops dominate, native tree species are almost absent from the farmland and home gardens are almost absent (only few eucalyptus trees can be found around the homestead).

As seen in Table 2.1, the tree density decreases with increasing distance from the forest. Indigenous trees are almost absent from Zone 3. Elevation varies less than $200 \mathrm{~m}$ and
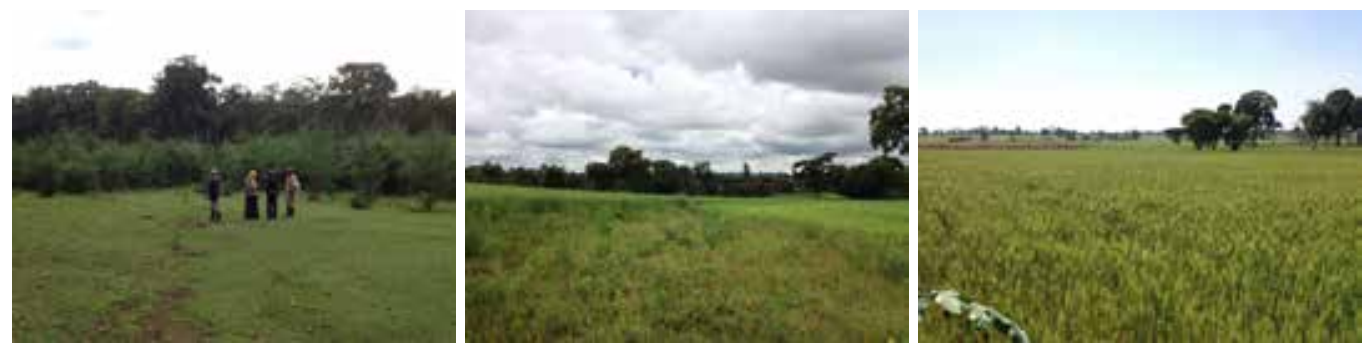

Intensification gradient starting from a settlement next to Munessa Forest (left), to a high tree density zone (center) and ending in a low tree density zone (right). (Jean-Yves Duriaux/CIMMYT) 


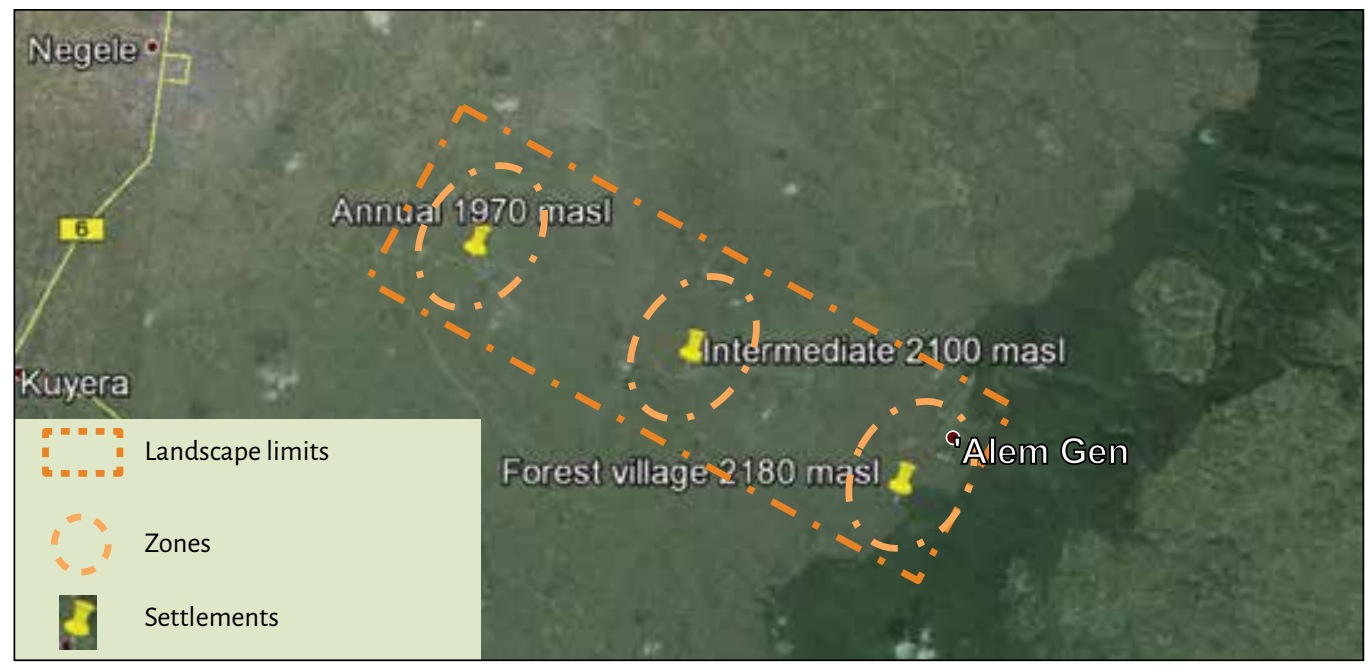

\section{Figure 2.3 Map displaying the study area, and the three zones along an intensification gradient from Munessa Forest to Arsi-Negele.}

Source: Modified by the author from Google Earth: Images $\odot 2015$ CNES/Astrium, Landsat, Digital Globe; Map data @2015 Google

soil type does not change significantly (andosols) along the gradient. The most important market of the area (Arsi-Negele) is found at the extreme of the intensification gradient (away from Zone 1 and close to Zone 3), where farms are more market oriented and dedicate a significant area to vegetables (cabbages, carrots, onions and leaf beets). Zone 1 has access to a rural market (Lephis village) were traders buy products from the farmers and resell them in the Arsi-Negele market.

Common lands are of high importance for the residents of the study area, particularly as a source of feed for livestock. The settlement in Zone 1 is the only one with recognized access to the forest, but lacks common grazing land. Zone 2 and Zone 3 have access to communal grazing areas. The settlements near the forest have a smaller area of farmland than the ones in the other zones, therefore forest is used as an extension of the settlement and plays a vital role in providing a diversity of products: fuelwood, feed, construction materials and fruits.

Although men are usually considered the head of the household in Ethiopia, the proportion of female-headed households is very high in the region, ranging from $26 \%$ to $39 \%$. This might be explained by the fact that in the 1970 s, men generally married several wives, some of whom became the head of their household. Men with several wives usually have a main home, and their other wives and houses are considered separate households. Each household typically has its own agricultural land and animals. The man seems to have the strongest decision power in all households related to him. Almost all of the population is of Islamic faith. 
Table 2.1 General characteristics of the three zones characterizing the study area, which form an intensification gradient from Munessa Forest to Arsi-Negele.

\begin{tabular}{|c|c|c|c|c|}
\hline & \multicolumn{3}{|c|}{ Zones } & \multirow[b]{2}{*}{ Source } \\
\hline & Forest & Intermediate & Annual & \\
\hline Settlement (kebele) & $\begin{array}{l}\text { Sida Malkatuka } \\
\text { (Ashooka) }\end{array}$ & $\begin{array}{l}\text { Gurgure Lako } 1 \\
\text { (Ashooka) }\end{array}$ & Shona (Gambelto) & - \\
\hline Tree density & High & High & Low & Observation \\
\hline Number of households & 42 & 46 & 31 & \multirow[t]{2}{*}{ Settlement leaders } \\
\hline $\begin{array}{l}\text { Percentage female- } \\
\text { headed households }\end{array}$ & $36 \%$ & $39 \%$ & $26 \%$ & \\
\hline Elevation (masl) & 2,180 & 2,110 & 1,970 & \multirow{4}{*}{$\begin{array}{c}\text { GPS } \\
\text { measurements }\end{array}$} \\
\hline Area (ha) & 38.8 & 89.5 & 61.5 & \\
\hline Distance to forest & 0 & $5-6 \mathrm{~km}$ & $10-12 \mathrm{~km}$ & \\
\hline $\begin{array}{l}\text { Distance to Arsi- } \\
\text { Negele market }\end{array}$ & $17 \mathrm{~km}$ & $9 \mathrm{~km}$ & $6 \mathrm{~km}$ & \\
\hline Soil type & \multicolumn{3}{|c|}{ Andosols } & Lemenih (2004) \\
\hline Access to forest & Yes & No & No & \multirow{2}{*}{$\begin{array}{c}\text { Group interview } \\
\text { with settlement } \\
\text { leaders }\end{array}$} \\
\hline Common grazing land & No & Yes & Yes & \\
\hline
\end{tabular}

\subsubsection{Major agricultural enterprises and other economic activities}

Agricultural production is the most important economic activity in the area. Most farms are mixed crop-livestock systems; therefore, livestock rearing is also common though it comes after crop production in perceived socioeconomic importance (note that this conclusion is drawn based on the great decline of grazing areas and livestock numbers due to cropping area expansion, and the perception of higher food security due to crop production as mentioned during the PRA and FGDs). Trading and transport services for agricultural products are other agriculture-related activities in the study area. Fuelwood extraction/production is also common in the area, being most important close to the forest where illegal trading remains common.

The four major crops (by planted area and perceived importance) are: maize (Zea mays), wheat (Triticum aestivum), potato (Solanum tuberosum) and teff (Eragrostis tef). Other crops vary in importance across the zones and include: barley (Hordeum vulgaris), vegetables and enset (Ensete ventricosum). Enset is mostly found in Zone 1 and Zone 2, usually planted in home gardens. It is sometimes planted with or next to a small number of coffee (Coffea arabica), avocado (Persea americana) or banana (Musa spp.) plants. 


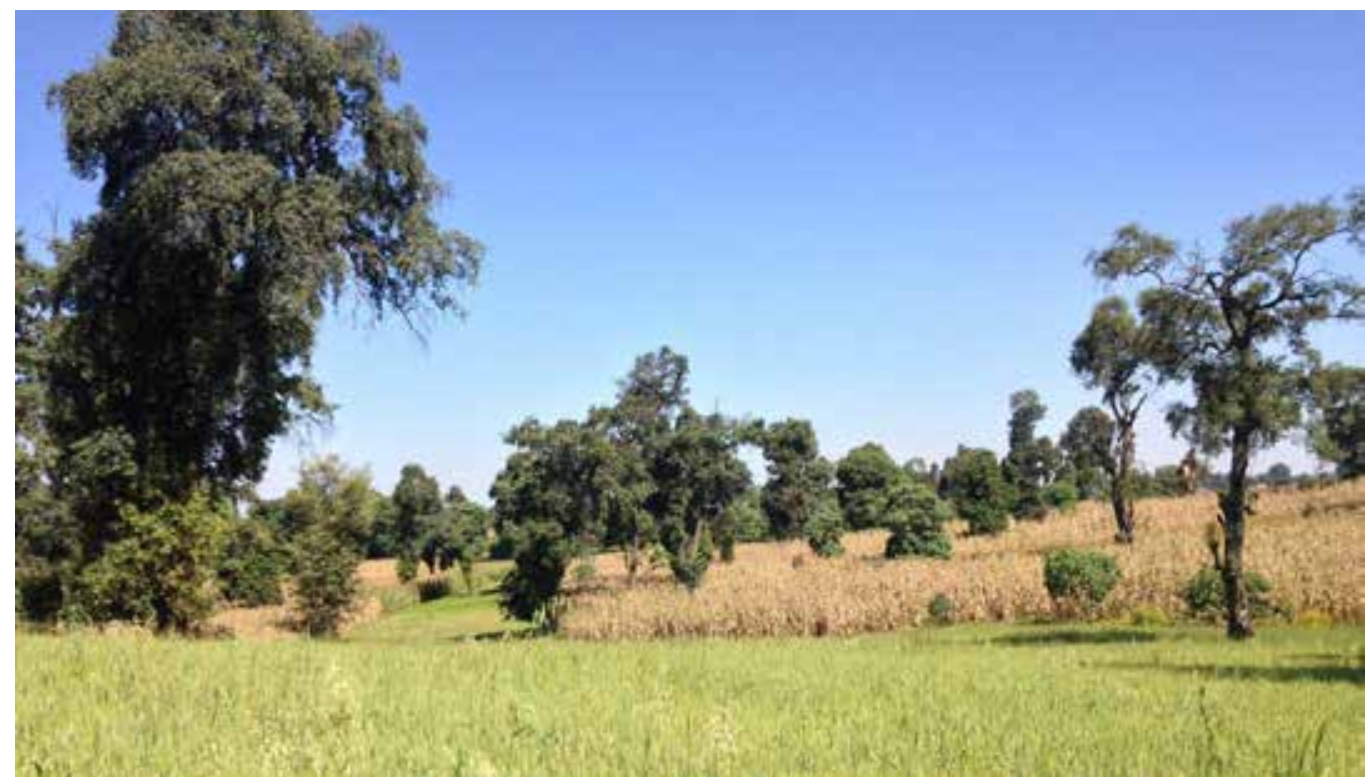

Wheat and maize with scattered trees (remnants of the original forest) in Zone 2. (Jean-Yves Duriaux/CIMMYT)

Maize is considered the most important crop in terms of food self-sufficiency. Part of the maize is consumed as green cobs ( 3 months before harvesting), while the dry grain is stored for consumption over the year. Potato and teff are considered cash crops in the area. Potato has a low selling price (ETB 100-200/100 kg or USD 5-10/100 kg) compared to all the other crops, but is characterized by high productivity (up to 20 tons/ha). On the other hand, teff has very low productivity ( $\sim$ ton/ha) but fetches high market prices (> ETB 1200/ha or USD 60/ha). Vegetables, if planted across large areas (i.e. not solely for household consumption), can also be a cash crop. Vegetable market prices are very volatile and vegetable production can be highly profitable at times, while one can hardly find a buyer at other times. Finally, wheat was one of the last crops introduced in the area and is characterized by high productivity compared to other regions in the country ( 3 tons/ha) and a price that is considered adequate even when the market is saturated. This is due to the constant demand from the milling industry year round.

Eucalyptus trees have become the most common tree species in the landscape, especially in Zone 3 where native trees have almost disappeared. Eucalyptus is present in all zones but can be found as woodlot in Zone 2 and especially in Zone 3. Eucalyptus is used as construction material and fuelwood, and is sold on the market. A study in Arsi-Negele area showed that $90 \%$ of the farmers interviewed planted eucalyptus trees and $52 \%$ had planted them since 1990 (Jenbere et al. 2012).

\subsubsection{Agricultural seasons}

Agricultural cycles and management in the area are mostly dependent on the rainfall pattern. Two cropping seasons are possible in the area starting with a short-cycle crop (potato, beans or vegetables) followed by long-cycle crop (wheat, maize) or another short-cycle crop. Although two cropping seasons are possible, not all land is 


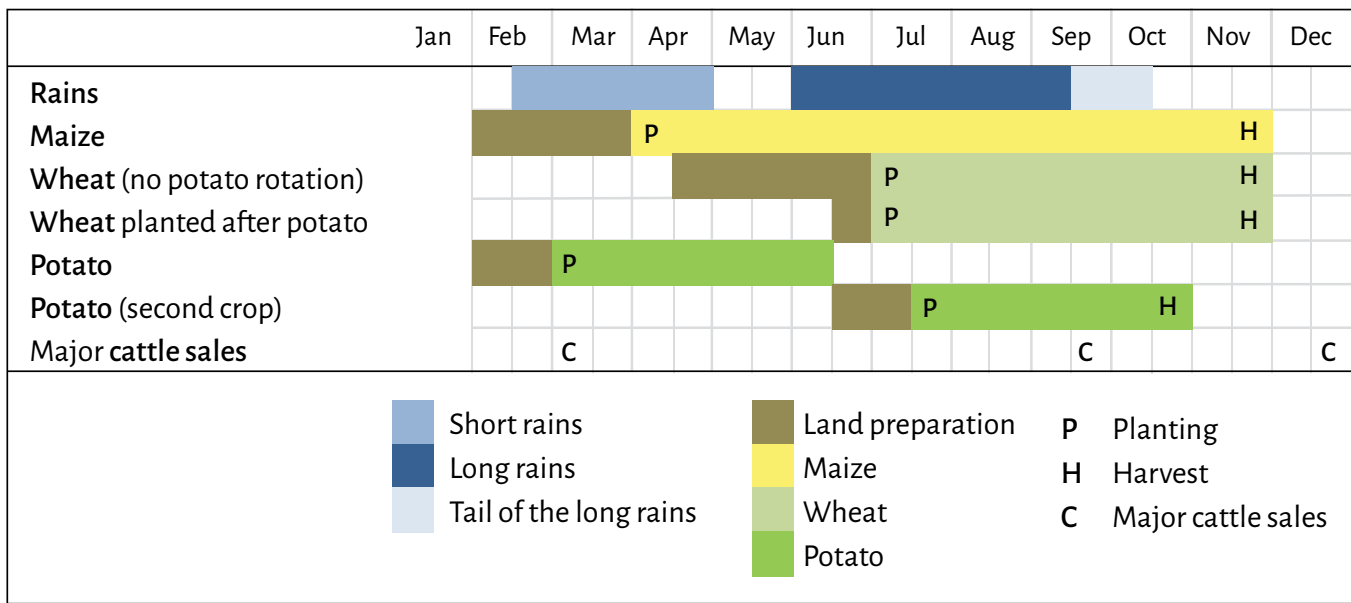

\section{Figure 2.4 Rainfall and agricultural calendar in the study area.}

planted during the short rains (Figure 2.4) since potato and vegetables require a large investment and most farmers do not have the resources available to plant the entire area they have available. Figure 2.4 represents schematically the different agricultural seasons, with a focus on the three most important crops. Land preparation starts with the first rains (February) and is mostly done using animal traction (oxen and plow). Potato can be planted twice in a year, but maize and wheat only once. Wheat can be planted after potato or in a field fallowed during the short rains, whereas maize (which requires a longer period of time) is planted in a field were no previous crop had been grown in that year. The major cattle sales are during March, September and December. The first major sale arises from farmers' need to obtain cash for the purchase of seeds and fertilizers. The other two major sales coincide with festivities during which the demand for (and thus the market price of) meat is high.

\subsubsection{Munessa Forest}

\section{Ownership and management}

Munessa Forest is a state-owned forest managed by OFWE. It is degraded due to constant grazing and extraction of fuelwood. In Zone 1 there is a forest plantation surrounding the natural forest, which demarcates the state land and is used for timber production. There is one local office for each of the blocks: Degaga, Sole and Gambo. Next to each office is a timber processing facility. OFWE employs guards (from the nearby communities) that patrol the forest and plantations to ensure that no illegal activities take place. Guards are empowered to detain illegal users if found in the plantations but not if found in the forest. In the latter situation, guards identify the illegal user and inform the CBO managing the forest.

A CBO was created in 2012 with the support of OFWE, following the assumption that forest conservation would only succeed if local communities were involved in its management (based on previous experience). The $\mathrm{CBO}$ consists of $\sim 150$ members, all residents of settlements that border the forest in Ashooka kebele. Its objectives are: (1) to conserve 

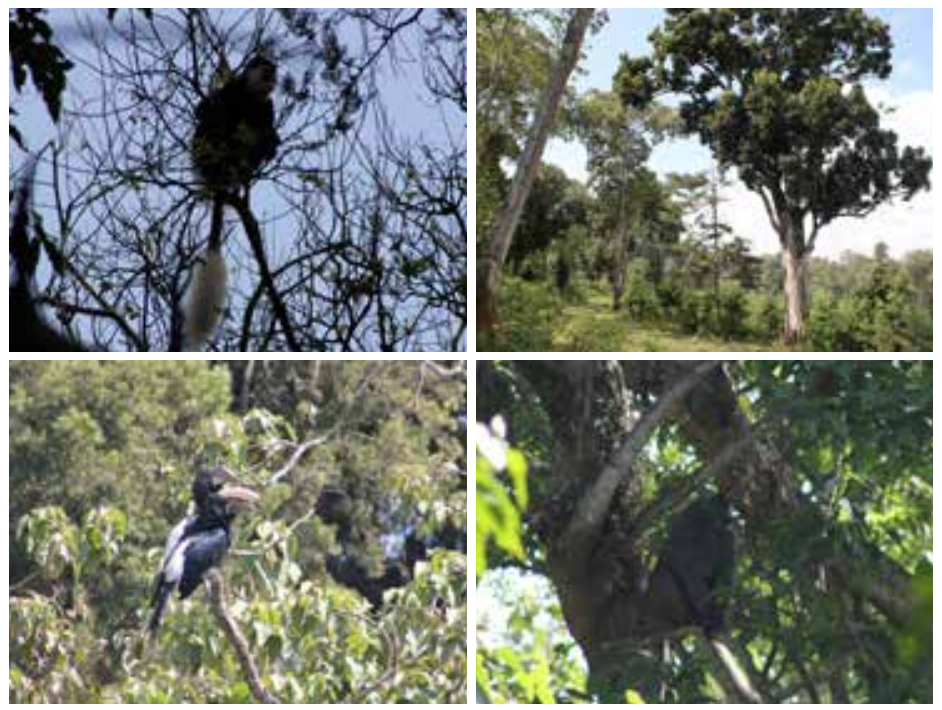

A representation of the biodiversity found in Munessa Forest: colobus monkey (Colobus guereza, top left), Podocarpus falcatus tree in the border of the forest (top right), silvery-cheeked hornbills (Bycanistes brevis, bottom left) and olive baboon (Papio anubis, bottom right). (Frédéric Baudron/CIMMYT)

the forest and wildlife; (2) to share the benefits with the CBO members; (3) to protect the springs that provide water to the communities; and (4) to restore the forest back to its original state. A committee of 30 members including a leader, a vice-leader, a secretary, a cashier and managers makes decisions. Leaders are in charge of activity planning, and managers execute these activities and supervise the work of other members. If any member of this $\mathrm{CBO}$ encounters financial problems, the cashier can provide credit and will guarantee repayment. The cashier is also responsible for fund-raising. Membership is not open to all: "only the ones that show potential and interest in conserving the forest can join." The leaders of each settlement make a pre-selection and the committee makes the final decision. Details about forest access rights are discussed in Section 2.5.

A local ecotourism cooperative provides guided tours and promotes sustainable use of the forest. They return $10 \%$ of their income to the communities through support for development projects promoted by the settlement leaders.

\section{Biodiversity (trees, birds)}

According to the bird list created by the Lephis Ecotourism Cooperative, there are more than 270 bird species in the area. Some key species found in the forest include: silvery-cheeked hornbill (Bycanistes brevis), Hemprich's hornbill (Tockus hemprichii), Abyssinian oriole (Oriolus monacha), white-cheeked turaco (Tauraco leucotis), black-winged lovebird (Agapornis taranta) and banded barbet (Lybius undatus).

According to the head of the Gambo office of OFWE there are four key tree species in the forest. These are protected by Ethiopian law due to their importance and endangered status, and include: Hagenia abyssinica, Podocarpus falcatus, Cordia africana and Juniperus procera. 


\subsection{Diversity of livelihood strategies}

\subsubsection{Household types as perceived by community members}

The types of households delineated and described by the community members for the settlements of Zone 1 and Zone 2 were similar. The following types were common to both: (1) cereal producers, (2) livestock producers and (3) diversified farmers. An additional category was identified in Zone 1: landless households. The types identified in Zone 3 were: (1) renters, (2) model farmers, (3) traders and (4) vegetable producers (see Figure 2.5).

Although the self-categorization led to similar types in Zone 1 and Zone 2, the proportion of the total settlement population that each type represents was significantly different (Figure 2.5). Diversified farmers were the most common in Zone 1 while in Zone 2 cereal producers were the most common. Livestock producers represented a fifth of the households in Zone 1 but a small minority ( $2 \%$ in Zone 2 . In Zone 2, cereal producer was the most important type of household.

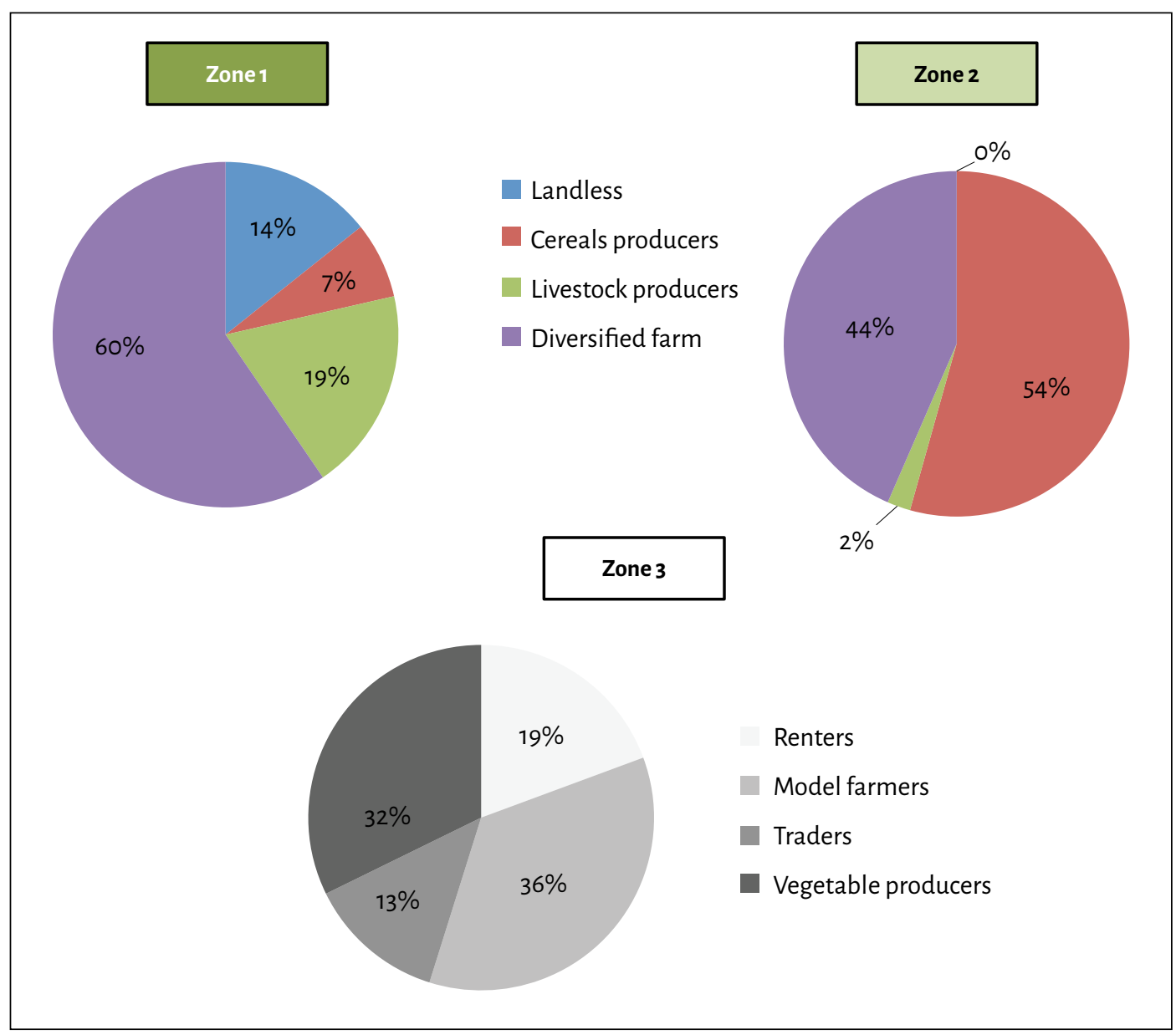

Figure 2.5 Household types and their proportions in the three settlements of the study area. 


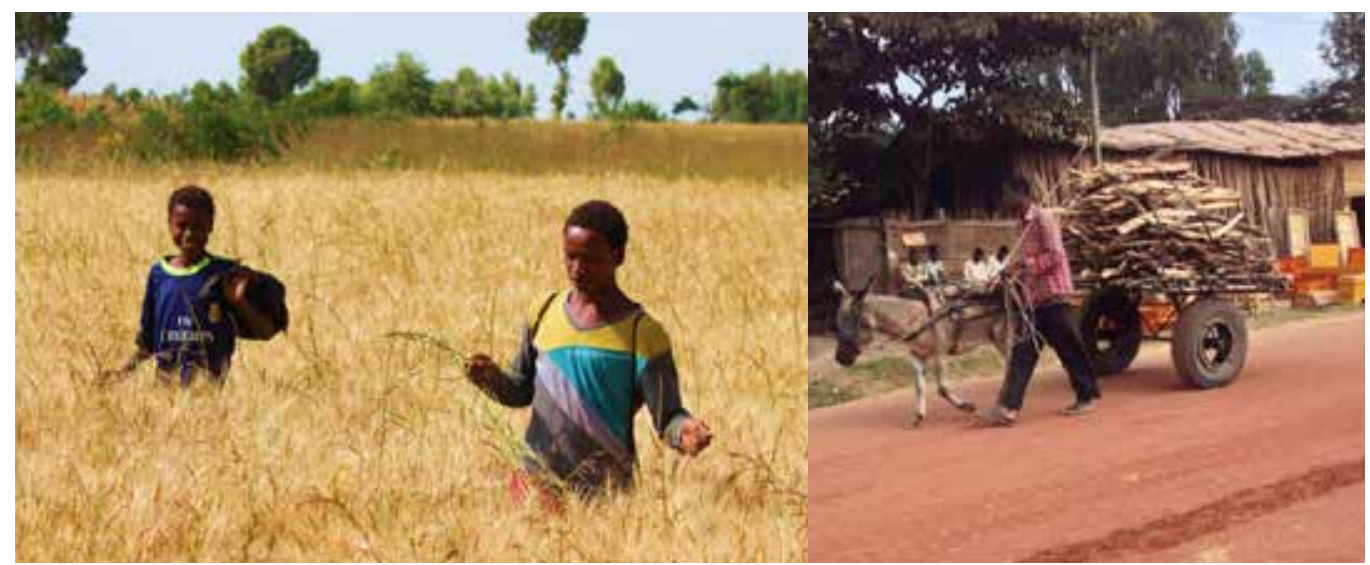

Weeding wheat fields in Zone 3 before mechanical harvest and transporting fuelwood to Arsi-Negele market. (Frédéric Baudron/CIMMYT)

In Zone 3, households were classified as renters (who cannot produce for lack of resources), model farmers (similar to diversified farmers but with an emphasis on being able to plant on time and having high productivity), traders (which besides farming also buy/sell agricultural products on the closest urban market) and vegetable producers (whose main income is generated by the sale of vegetables on the urban market).

The different household types identified during the self-categorization activity relate to different livelihood strategies. Farming is obviously the main activity in the study area, though different strategies exist. All farmers produce some maize and wheat, but some also produce other crops (diversified farmers and vegetable producers) and engage in other activities (e.g. trading). Livestock rearing, although decreasing for a number of reasons (e.g. decrease in communal and private grazing area due to the expansion of cropland and smaller farm sizes), is still recognized as an important strategy. Finally, the two household types that struggle the most to make a living include households that do not own land and those that are forced to rent their land due to lack of resources (labor or money to purchase agricultural inputs).

A problem that was identified as common for some household types was the difficulty of sourcing input on time (due to cash constraints), resulting in late planting and poor crop nutrition and protection. This in turn leads to a severe yield penalty, locking these households in a 'poverty trap'.

\subsubsection{Criteria for self-categorization}

Although the household types identified in Zone 3 were different from the ones identified in Zone 1 and Zone 2, there were similarities in the criteria used for the delineation of the types and the characteristics of the different types. The main criteria used were:

- the activity which generated most of the income (farming, trading, renting land, employment)

- the diversity of farming enterprises (livestock, cereal, vegetables, diversified) 
- land and livestock ownership

- hiring or selling labor.

Two other characteristics of lower importance were also used when describing the household types:

- wealth (wealthy being described as being "better off" or always having cash available to buy agricultural inputs on time)

- the performance of the farms ("model," "good," "facing difficulties," etc.).

By using the criteria considered as important by the community, a statistical typology can be generated that would be representative of the situation in the study area. Tables with the typology and group characteristics for each settlement can be found in Appendix 2B.

\subsection{Access to resources}

\subsubsection{Land}

As most households are dependent on farming in the study area, land is a fundamental resource for local livelihoods. During Haile Selassie's era from 1930 to 1974, land was owned by landlords who did not live in the area (i.e. feudalism). Local communities used the land (mostly forest and grassland) to rear cattle, and a small portion of land was cultivated for subsistence agriculture. The communities had to pay a tribute to the landlords. With the fall of Haile Selassie and the beginning of the socialist regime in 1974, landlords were expropriated and land was redistributed among the community members under the famous slogan "land to the tillers." Land rights were transferred to land users. Adult males received land rights from the government according to their number of wives (indicator of household size). The area that adult males received at the time ranged from 3 to 8 ha. Farmers did not own their land but received use rights for a period of 100 years.

Nowadays, land can only be accessed through four modalities: (1) inheritance, (2) sale, (3) shared cropping and (4) renting. Traditionally, men inherit land from their fathers at the time of their marriage, or by arranging an early inheritance from their father. Although the government was said to promote women empowerment, most (if not all) inherited land is passed from father to sons. There were a large number of female-headed households in the study area (26\%-39\%) who probably inherited land at the death of their husband (more interviews are needed to confirm this supposition). Figure 2.6 represents the different modalities for accessing land.

Land rights can be sold legally. More frequently than selling, two short-term arrangements are made: shared cropping and renting. Shared cropping refers to the arrangement where two parties pool resources together to produce a crop and share the harvest equally. Usually in the area, one party contributes land and seeds, while the other party contributes labor and fertilizer; harvest is a joint responsibility. Farmers can also rent their land out and earn an income from it. This generally takes place when a household does not have enough cash to purchase seeds and fertilizers, or does not have adequate labor to work their land. 


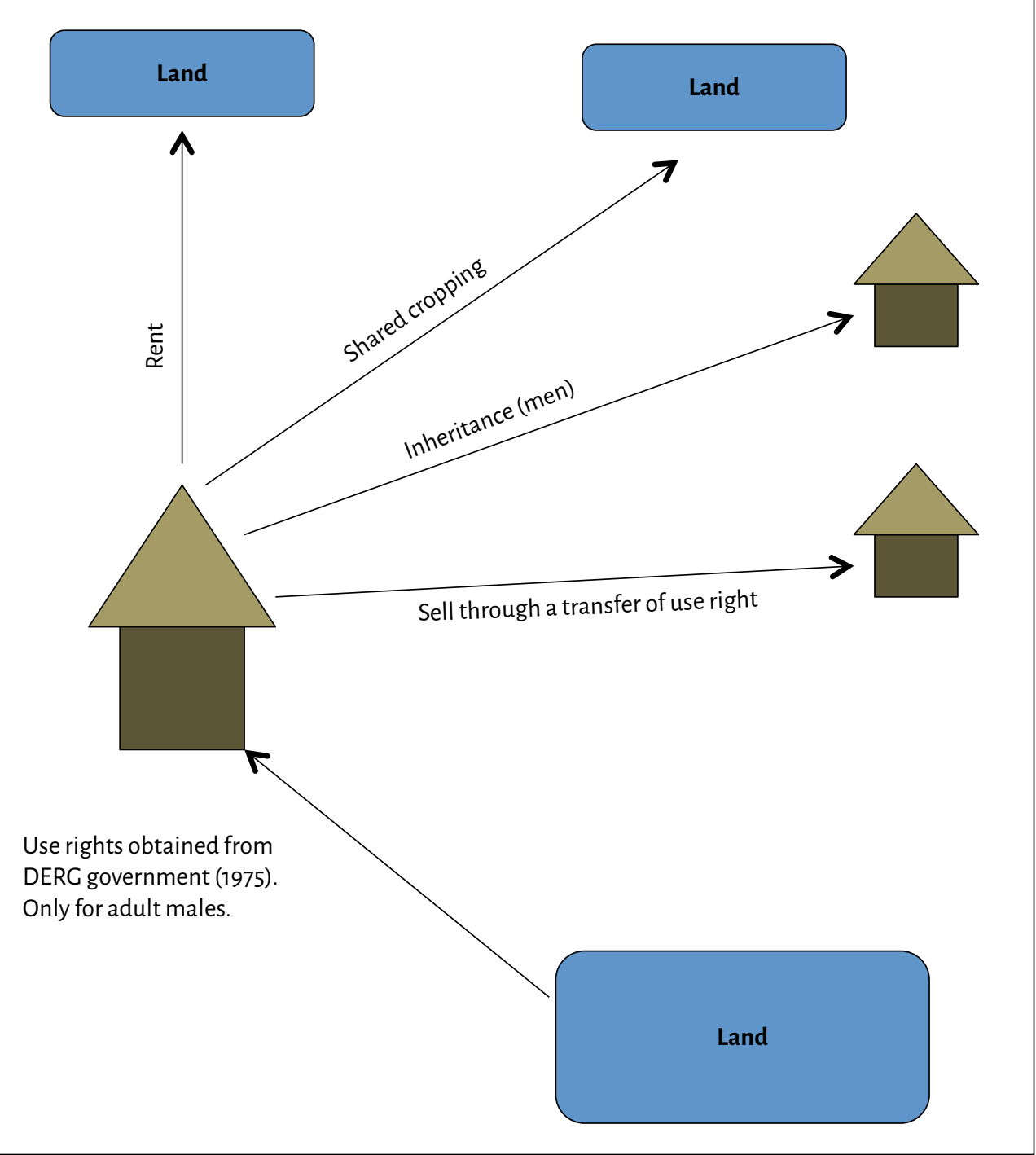

Figure 2.6 Modalities of land-use access in the study area.

\subsubsection{Water}

There is free access to rivers for different uses: watering livestock, obtaining water for household consumption, washing and irrigation (to a lesser extent). Some of the rivers and streams dry out during the dry season, in which case communities can use rivers and streams in other settlements without any restriction. The term 'free access' means that not only people from communities bordering the rivers and streams, but any traveler and members of other communities can use the water without limitation related to quantity or use (this was clearly stated during the PRA). For example, when the stream next to Zone 3 dries out during the dry season, community members will take their animals to the river in Zone 2. 


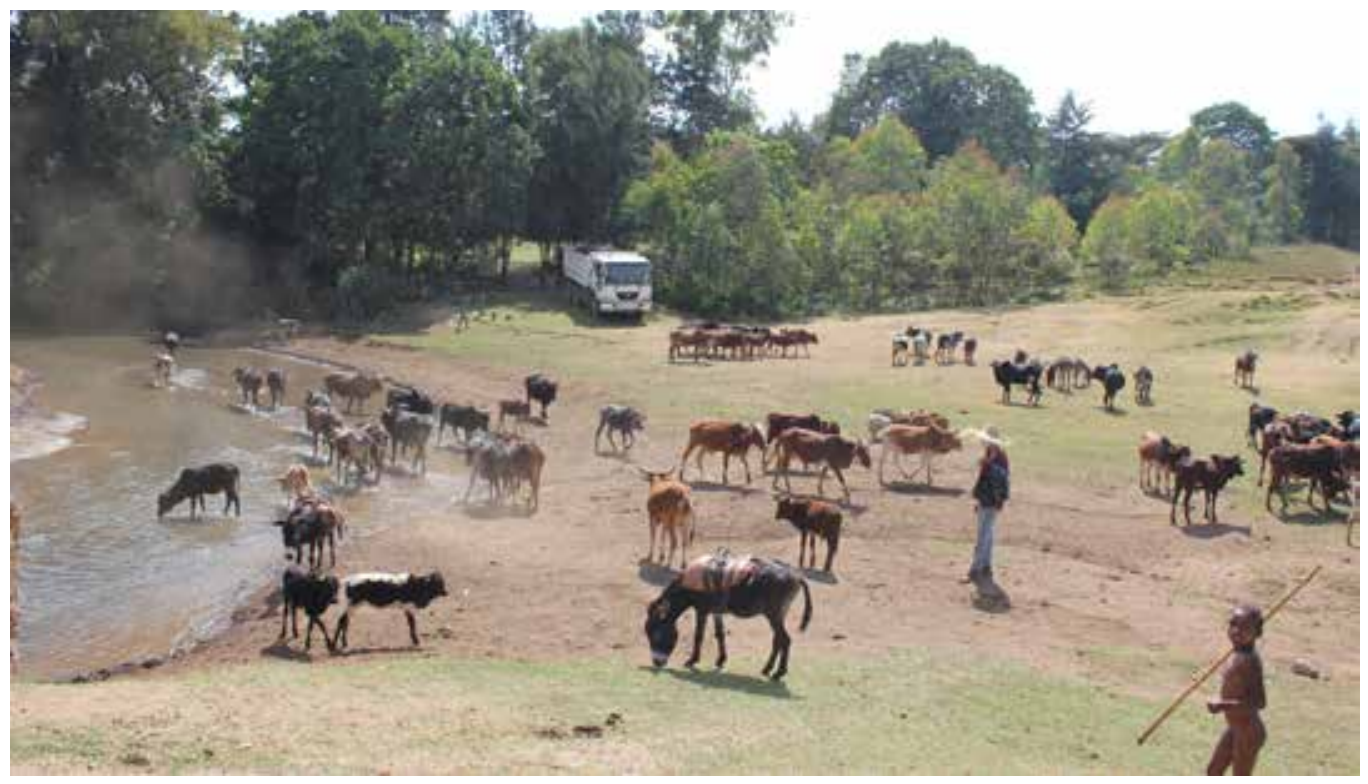

Livestock drinking water in the river next to Cogorri settlement in Zone 2. (Frédéric Baudron/CIMMYT)

Drinking water is considered a highly important resource. It was made available by the government after installation of infrastructure (pipelines, filters, pumps and distribution points). Distribution points are the only available sources of drinking water and are located at a walking distance of o-2 km (in Zone 2 and Zone 3) depending on the settlement. A cashier controls the water point and collects payment for the water taken. The cost of the drinking water is ETB 1 (USD 0.05) for $100 \mathrm{~L}$ of drinking water. Infrastructure for drinking water is present in Zones 2 and Zone 3, but not in the zone next to the forest (Zone 1 ). Therefore, settlements next to forest have no access to 'clean' water (mentioned as a critical problem) and use the river as a source of drinking water (which has been reported by the health officers to cause diarrhea, a common problem in the area).

\subsubsection{Communal grazing lands}

Communal grazing lands are important sources of feed for livestock. The use of some communal grazing land is restricted to one settlement (when the communal grazing land is within the settlement borders); others are shared between different settlements (all the settlements that share a border with the communal grazing land). Members of a settlement with rights to use the communal grazing land have unrestricted use and may graze as many animals as they wish for as long as desired.

Travelers with cattle from other settlements are allowed to graze in the communal grazing land and stay overnight there. Then they will continue their journey. Apparently, this is a traditional practice.

\subsubsection{Munessa Forest}

Munessa Forest is said to be used exclusively by the settlements bordering it (Figure 2.7). The $\mathrm{CBO}$ managing the forest has an exclusive right to extract wood for sale. 


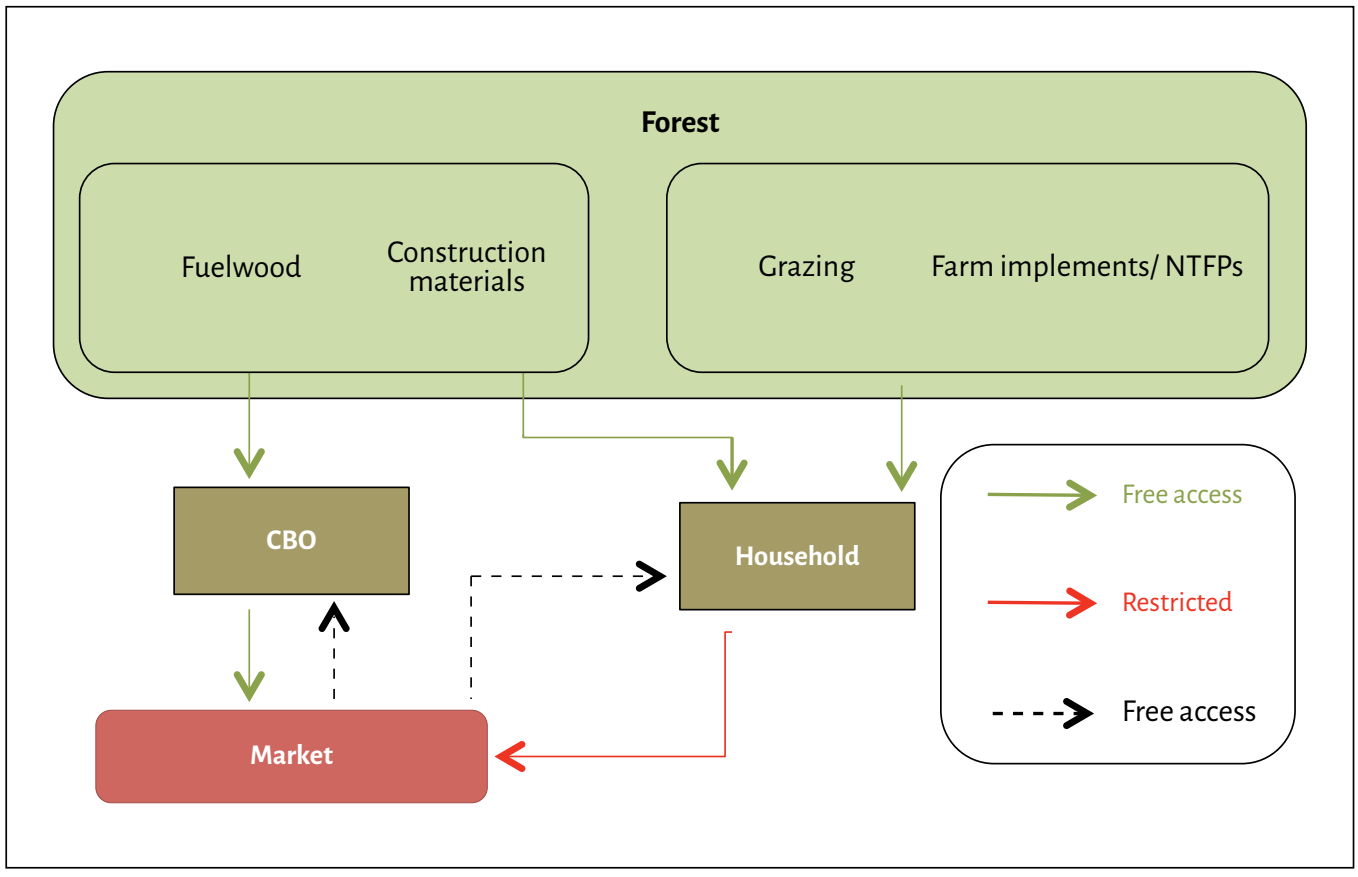

Figure 2.7 Diagram representing access to forest products in the study area.

The proceedings of the sale are distributed among the $\mathrm{CBO}$ members. Any community member (including non-CBO members) has the right to extract fuelwood and other forest products for household consumption, but only dead wood can be harvested.

There is no limit to the amount of products that can be extracted. All members of the $\mathrm{CBO}$ are responsible for monitoring the use of the forest. If rules are broken (illegal extraction for sale occurs), the $\mathrm{CBO}$ will first gather the community in a council that will make a decision. The decision is usually to exert public pressure on the culprit's settlement and give a warning. If the culprit repeats the illegal action, the committee will inform OFWE and the police, and the culprit will face legal prosecution and up to 5 years of imprisonment if found guilty.

\subsection{Institutional support}

\subsubsection{Governmental institutions}

The institution responsible for all administrative affairs is the Arsi-Negele woreda bureau. This institution has little direct contact with the population but provides any legal documents or permits. Under the supervision of this bureau is the kebele administration bureau. Kebeles are the smallest administrative subdivision in the country. Each kebele is composed of $\sim 30$ settlements. The study area covers parts of three different kebeles, each with a bureau: Gambelto, Bombaso Regi and Ashooka. The kebele administration bureaus are the direct link between the government and 
the communities. They are in charge of resolving any administrative issues, keeping registers of population and land, organizing any project/activity planned by the government or other organizations and holding regular meetings with settlement leaders and local organizations.

The agricultural bureau of Arsi-Negele woreda is responsible for technical assistance in three domains: crop, livestock and environment. This office supplies assistance to all kebeles of the woreda. Each kebele has three development agents providing technical assistance to all farmers (one for each topic). According to community members, development agents are the most important government support they receive. There are supervisors that will visit the areas occasionally to control the quality of the development agents' work, and a veterinarian that will occasionally visit the area. The agricultural bureau also supervises one farmer-training center in each kebele, and one animal health center shared between 3-5 kebeles. The farmer-training centers host meetings with farmers and exhibit best practices in demonstration plots. The animal health centers are used to provide veterinary assistance to farmers. Both are run by development agents. Development agents interact closely with the kebele administration bureau.

A health center provides service to four kebeles: Gambelto, Ashooka, Bombaso Regi and Aga. They monitor target groups every 3 months including children under 5 years old, and pregnant and breast-feeding women. They also have a health extension agent in each kebele who teaches community members about hygiene, nutrition and health issues. The officers of the health center provide health care to all people in need. It was clearly stated that children, pregnant and breast-feeding woman do not pay for any received health service and that health extension has no cost. Based on the interviews, we cannot clearly define if other services to other groups require payment.

The OFWE is responsible for the forest plantations and indirectly for Munessa Forest. It has a central office in Arsi-Negele responsible for Munessa Forest and a sub-center near Zone 1 responsible for the Gambo sub-zone of Munessa Forest. Guards are hired to patrol the forest and control movement of fuelwood from the forest.

\subsubsection{Religious institutions}

Most (practically all) residents are Islamic. Therefore, the mosques are of great importance in the community. They provide spiritual guidance, but also promote union between the community members.

A Catholic mission is established close to Zone 1 . It runs different development projects in the area. Its main achievement is the creation of a hospital that provides intervention for difficult medical cases in the area.

\subsubsection{Local institutions}

Settlement leaders' councils are the oldest institutions (except possibly for religious institutions) in the area and aim to maintain the peace in the community, promote its well-being and deal with other settlements. They comprise two leaders, one secretary, one cashier and two or three council members. They are in direct contact 
with the kebele administration bureau. They help to solve conflict within the settlement and may gather the community to make a joint decision. They are also the ones that give permission for development or research activity (governmental or otherwise) in the settlement.

A general council of all settlements' leaders' councils in the area ( $>50$ settlements) is held occasionally to build a joint vision of development and social cohesion for the communities. It prevents conflict between bordering settlements or kebeles.

The decisions made by the local institutions will always prevail over the government's decisions on conflicts. Community meetings are held in order to solve conflicts regarding, for example, land, trade, illegal use of the forest and theft. If the conflict cannot be solved by the council or if the mediation proposed is not followed, the problem will be communicated to the kebele administration office or the police for legal action. There is an ancient tradition of solving conflicts through community meetings, the settlement leaders or the council.

Other local institutions have been created in recent times ( $<15$ years). A youth group (at kebele level) tries to create activities to reunite all young members as well as to find opportunities for them (university admission processes, scholarships and jobs). A women's group (at kebele level) controls a credit scheme and provide loans to its members.

There is a CBO managing the forest. It was created 2 years ago with the help of OFWE. It includes about 150 members from different settlements next to the forest from Ashooka kebele (Zone 1). They are responsible for the supervision of the use of the forest products (making sure, in particular, that they are used for household purposes and not sold, and that only dead wood is being extracted).

The Lephis Ecotourism Cooperative has worked in the area since 2011. It is composed of nearly 20 members from four different kebeles bordering the forest near Zone 1. Its objective is to promote the sustainable use of the forest and development of the community. It has received support from Ethiopian NGOs for its establishment. Ten percent of the Cooperative's income is saved in a bank account and used to support local development projects (e.g. water systems).

\subsubsection{Non-profit/nongovernmental organizations}

The Ethiopian Sustainable Tourism Association promoted the creation of the Ecotourism Cooperative by raising funds from USAID and building the capacity of the cooperative.

\subsection{Market and value chains}

\subsubsection{Market places}

The most important market in the area is the urban market of Arsi-Negele, where products from the rural surroundings (including the study area) are traded. Most agricultural products and livestock are transported to other areas of the country, while fuelwood and maize are mainly used within the city. The market is located at 16, 11 and 6 $\mathrm{km}$ from the center of Zone 1, Zone 2 and Zone 3, respectively. The highest selling prices 


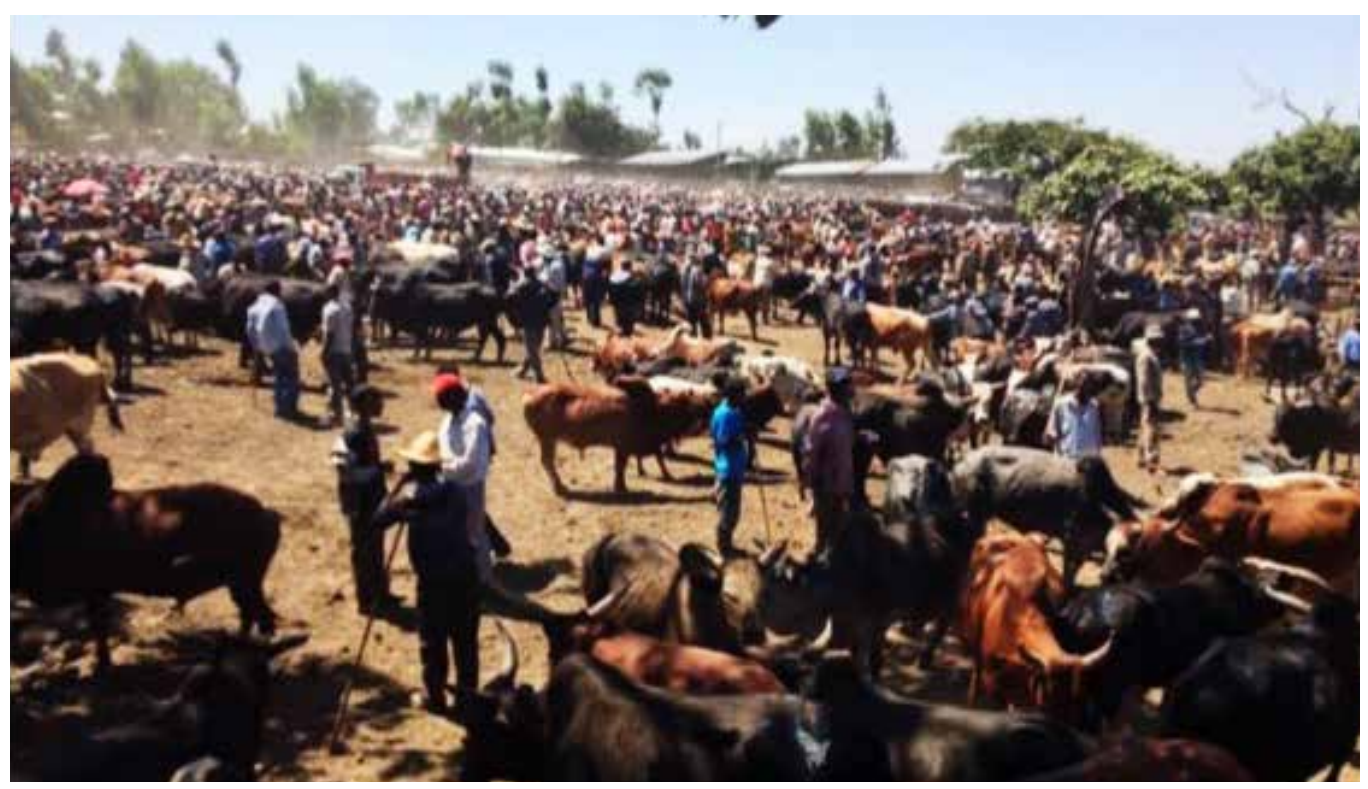

Livestock market in Arsi-Negele. (Jean-Yves Duriaux/CIMMYT)

in the area are fetched at this market. Market days are three times per week, on Mondays, Wednesdays and Fridays. The livestock market only takes place on Fridays. There are different market places in Arsi-Negele that specialize in different products. There is one livestock marketplace, one potatoes marketplace, three fuelwood marketplaces and one central market where many types of products are traded, including cereal and pulses.

Two rural markets are found in Zone 1 and Zone 2. Lephis market in Zone 1 is an important node in the value chains of fuelwood and potatoes, since farmers sell products to rural traders who then resell the products in Arsi-Negele's market. In Zone 2, Gogorri market is small and most buyers are local residents. In these rural markets, community members buy foodstuffs for the household and sell small quantities of agricultural products. Women are the most common sellers in rural markets. According to community members of Zone 3, there is little interest in a rural market in their settlements since Arsi-Negele market is relatively close and fetches better prices. Rural markets are always 1 day earlier than Arsi-Negele market so that traders can transport products the next day (from rural to urban markets).

\subsubsection{Fuelwood}

Most actors in the fuelwood chain are women, who take on the role of harvesters, traders and sellers in the market (Figure 2.8). Although it is illegal to sell fuelwood from the forest, most fuelwood marketed from Zone 1 originates from there. Zone 2 and Zone 3 do not have access to the forest for fuelwood. Farmers are allowed to sell fuelwood from non-protected species found on their farm (woodlots or scattered trees). The most common planted species on farms are eucalyptus species. 


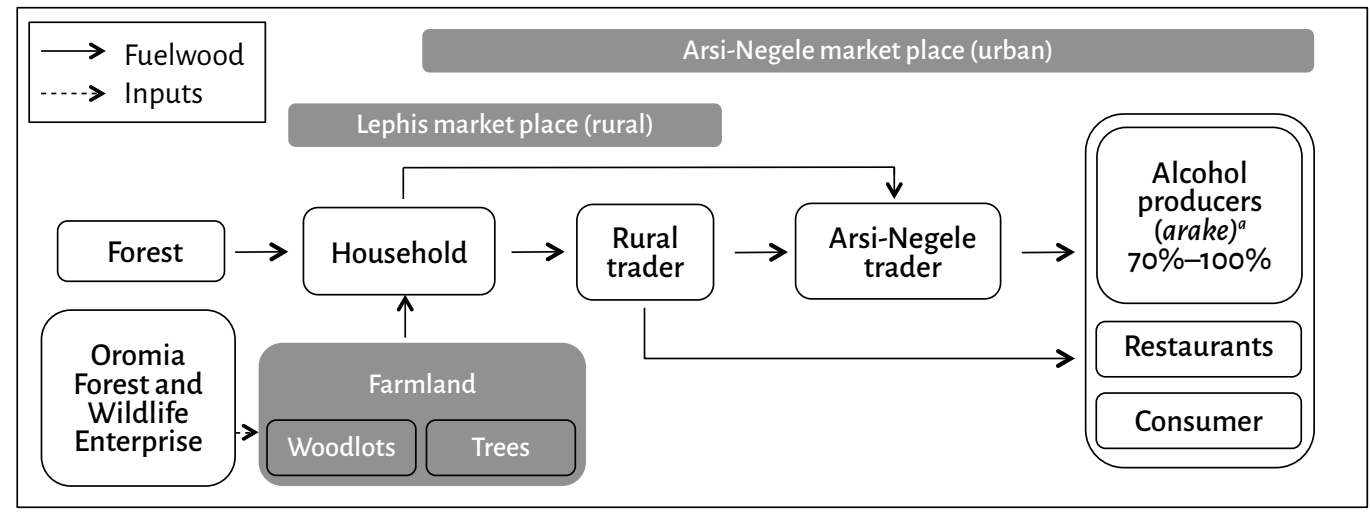

\section{Figure 2.8 Fuelwood value chain in the study area.}

Note: The main transportation methods are donkeys and donkey carts. These are also the measurements to pay the farmers.

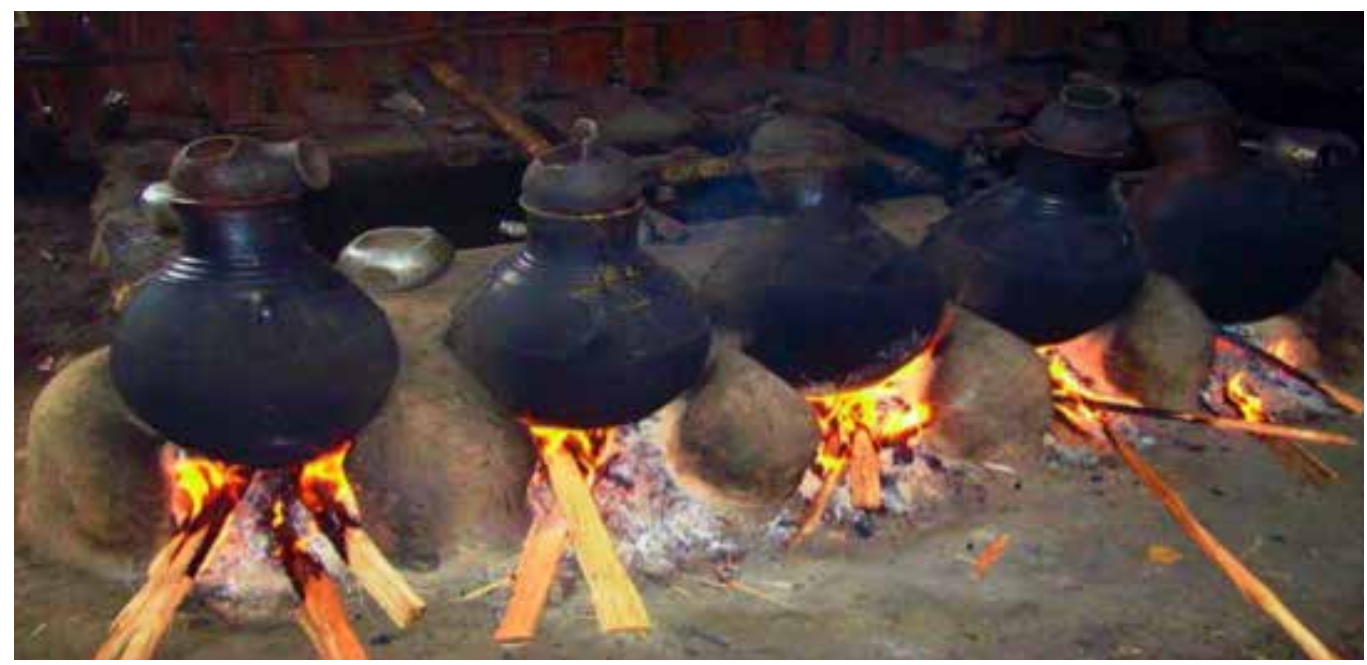

Arake (traditional alcohol) production in Arsi-Negele. (Addis, 2008)

The only input used for eucalyptus was reported to be the seedlings sold at a low price by OFWE (or for free if received from a project). The forest is the most important source of fuelwood traded at Arsi-Negele and Zone 1 the most important production area in the study landscape (as reported by fuelwood traders in Arsi-Negele). This means that most fuelwood traded in the study area has an illegal origin.

Fuelwood is transported by backload for short distances, by donkey cart for longer distances, and by donkey for both short and long distances. Rural traders tend to buy fuelwood from the rural areas (where established exchange places exist) a day before Arsi-Negele's market. Farmers can also bring their fuelwood directly to Arsi-Negele. In Arsi-Negele, traders buy fuelwood from rural traders and farmers, 
Table 2.2 Price range for fuelwood in Arsi-Negele market.

Fuelwood

Highest price

Lowest price
Time of the year

Dry season

Rainy season
Price per donkey (ETB)

$60-80$

$35-40$
Price per cart (ETB)

$500-800$

$350-450$

Note: USD $1=\sim$ ETB 20 . No estimation of the weight of fuelwood that a donkey or cart represents at this stage of the study; measurements will be done in the next phase.

and resell to buyers. This step is sometimes avoided when consumers come and buy directly, or when a periodical arrangement exists. The largest buyers of fuelwood in the study area and in all area surrounding Arsi-Negele are the local producers of arake. Arake is a strong alcohol that requires several distillations (low combustion efficiency). All sellers interviewed in Arsi-Negele stated that they sell between $70 \%$ and $100 \%$ of their fuelwood to arake producers. The rest is sold to restaurants and a small proportion to households.

Highest prices are attained during the dry season as fewer people sell (Table 2.2). Most farmers have alternative income from their recent harvest. Conversely, farmers have little alternative sources of income to fuelwood during the months before harvest time (wet season) and often face food shortages. Fuelwood supply therefore increases during the wet season, and prices reach their lowest levels as farmers look for this alternative source of income. Prices are $\sim$ ETB 20 higher per donkey load in Arsi-Negele compared with prices in the rural areas. Selling fuelwood is a coping strategy for vulnerable households that face shortages of cash, land or food.

\subsubsection{Maize and wheat}

Maize and wheat are the most common crops in the study area. Maize is harvested both as green cobs and dry grain. Wheat is generally harvested by combine harvesters through hire services. For both crops, part of the harvest is stored for self-consumption and another part is sold in Arsi-Negele's market (Figures 2.9 and 2.10). If they do not need the cash immediately and have room for storage, farmers will store the grain and only sell when prices are high. Little maize and wheat is sold on rural markets.

In Arsi-Negele market, grain traders first buy maize, later beans and finally wheat. Farmers bring their grain by donkey carts and sell to traders. Traders will subsequently sell maize and beans to Arsi-Negele retailers and consumers but also to traders from other regions of the country. In the case of wheat, traders sell mostly to milling factories located in other regions of the country. If grain is sold for use outside Arsi-Negele, it is transported by trucks provided by the buyers.

Maize and wheat prices vary with the season (Tables 2.3 and 2.4). For both crops, prices are the lowest at harvest time and the highest a month before harvest time. 


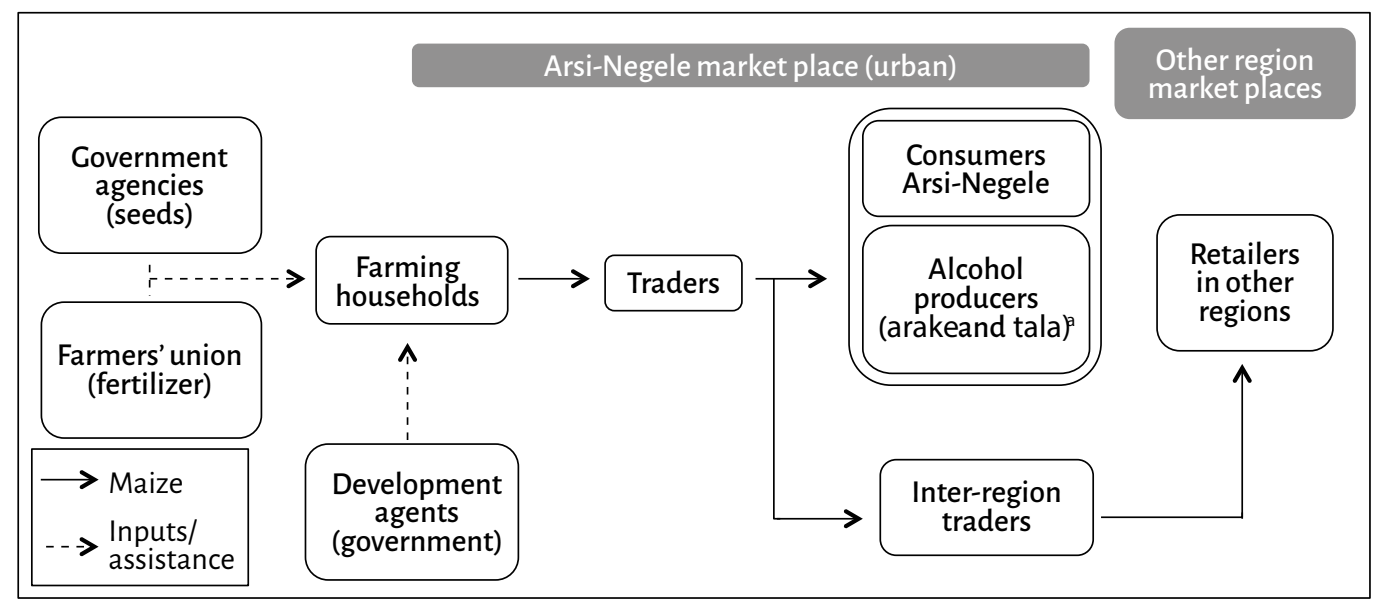

Figure 2.9 Maize value chain in the study area.

a Tala is a locally brewed beer.

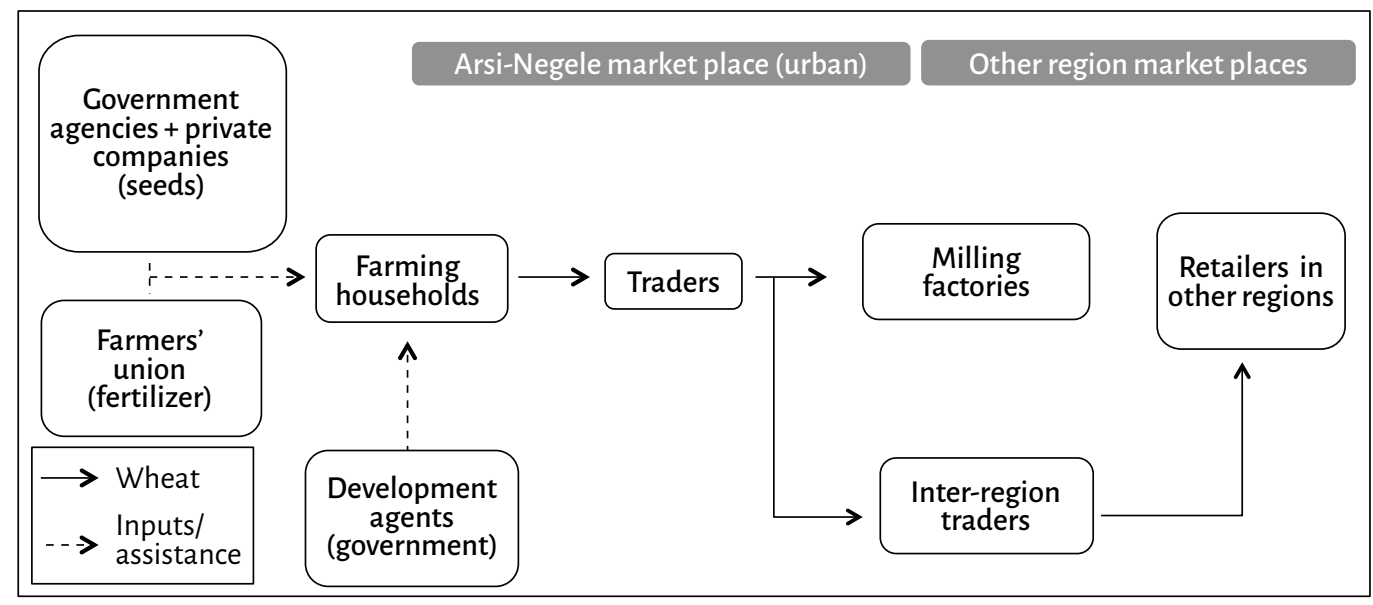

Figure 2.10 Wheat value chain in the study area.

Table 2.3 Price range for maize in Arsi-Negele market.

\begin{tabular}{|c|c|c|}
\hline Maize & Time of the year & Price per 100 kg (ETB) \\
\hline Highest price & April-October & 600 \\
\hline Lowest price & November-December & 400 \\
\hline
\end{tabular}

Note: USD $1=\sim$ ETB 20. 
Table 2.4 Price range for wheat in Arsi-Negele market.

\begin{tabular}{|c|c|c|}
\hline Wheat & Time of the year & Price per 100 kg (ETB) \\
\hline Highest price & April-November & 900 \\
\hline Lowest price & November-January & 750 \\
\hline
\end{tabular}

Note: USD $1=\sim$ ETB 20.

\subsubsection{Potatoes}

Potatoes are an important cash crop, characterized by a short growing period. They can be planted before wheat or maize. Farmers cannot plant all their land with potatoes at this time because potato seed is expensive and potatoes are a high-input demanding crop.

Most commonly, potatoes are sold at harvest time through intermediaries (Figure 2.11). Intermediaries are contacted by farmers using cellphones and link up with the regional traders who arrange for transport and for cash to pay for the harvest. Intermediaries receive a prearranged payment for each bag of $100 \mathrm{~kg}$. Sometimes farmers can also store a part (or more rarely the totality) of their harvest to wait for higher prices in the market. In this case, they bring their potato harvest by donkey cart to Arsi-Negele's market.

In Arsi-Negele's market, there are intermediaries year round that buy potato from farmers until they collect enough potato to fill a truck. A trader will then come and buy the potato from them and bring it to other regions of the country.

Farmers can also sell directly in the market to other buyers such as retailers that will resell in the city, restaurants and consumers.

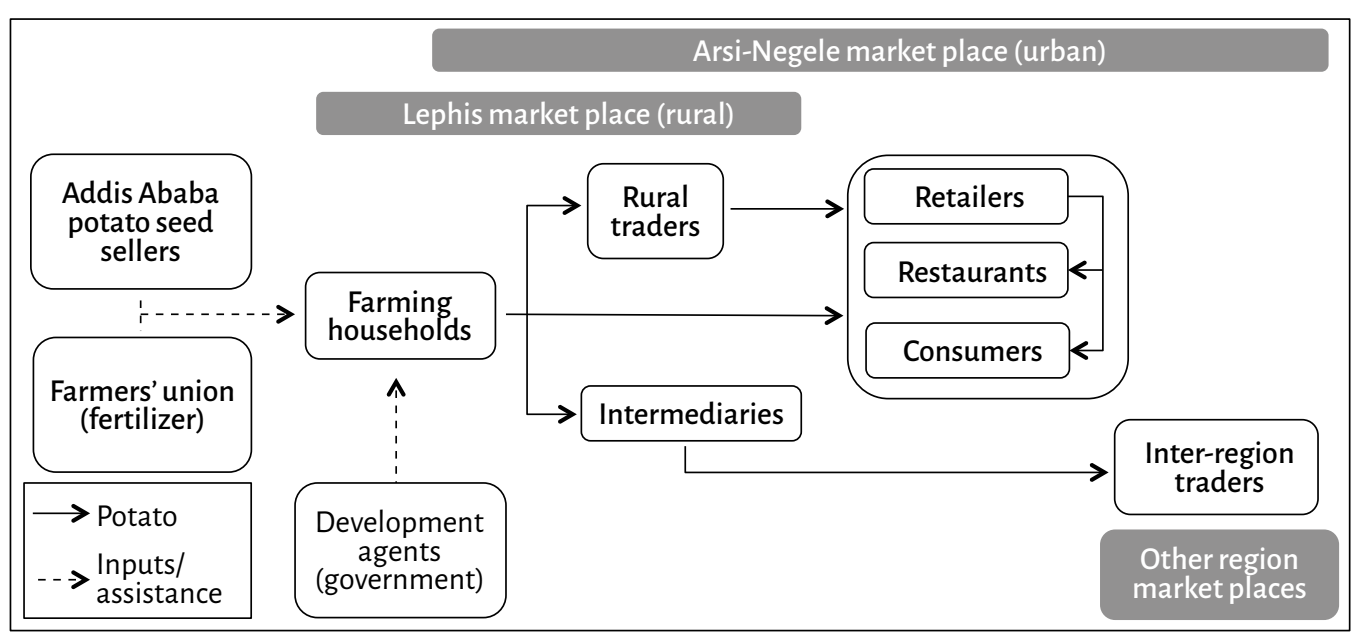

Figure 2.11 Potato value chain in the study area. 
Table 2.5 Price range for potato in Arsi-Negele market.

\begin{tabular}{|c|c|c|}
\hline Potato & Time of the year & Price per $100 \mathrm{~kg}$ (ETB) \\
\hline Highest price & December-May & 220 \\
\hline Lowest price & June-August & 100 \\
\hline
\end{tabular}

Note: USD $1=\sim$ ETB 20.

Potato price varies during the year and is lowest during harvest time (Table 2.5).

There are two potato harvest times in the area. The first is the most important and is in June/July. During the second period, much less area is planted. The second harvest is around October/November.

\subsubsection{Livestock}

Cattle are an important asset for farmers in the study area. They provide draft, milk and income through the sale of live animals. Cattle are also an inflation-proof asset used for banking and sold during times of hardship. Traditionally, milk and butter are women's property, while live animals are men's property.

Milk and butter are mostly consumed at home but can also be sold in Arsi-Negele's market or locally within the community.

Live animals (including cattle, sheep and goats) are only sold on Arsi-Negele's market, where traders buy animals, mostly transport them to other regions of the country and also sell them to restaurants in town (Figure 2.12). Restaurants are most often also butcheries that sell raw meat to urban households. Sometimes a fattener will buy lean or cheap animals on Arsi-Negele's market, fatten them near the city over 3 months and sell the finished animals back on the market. Oxen (castrated males used specifically for traction) are sold during the 3 months preceding the start of the planting season to other farmers.

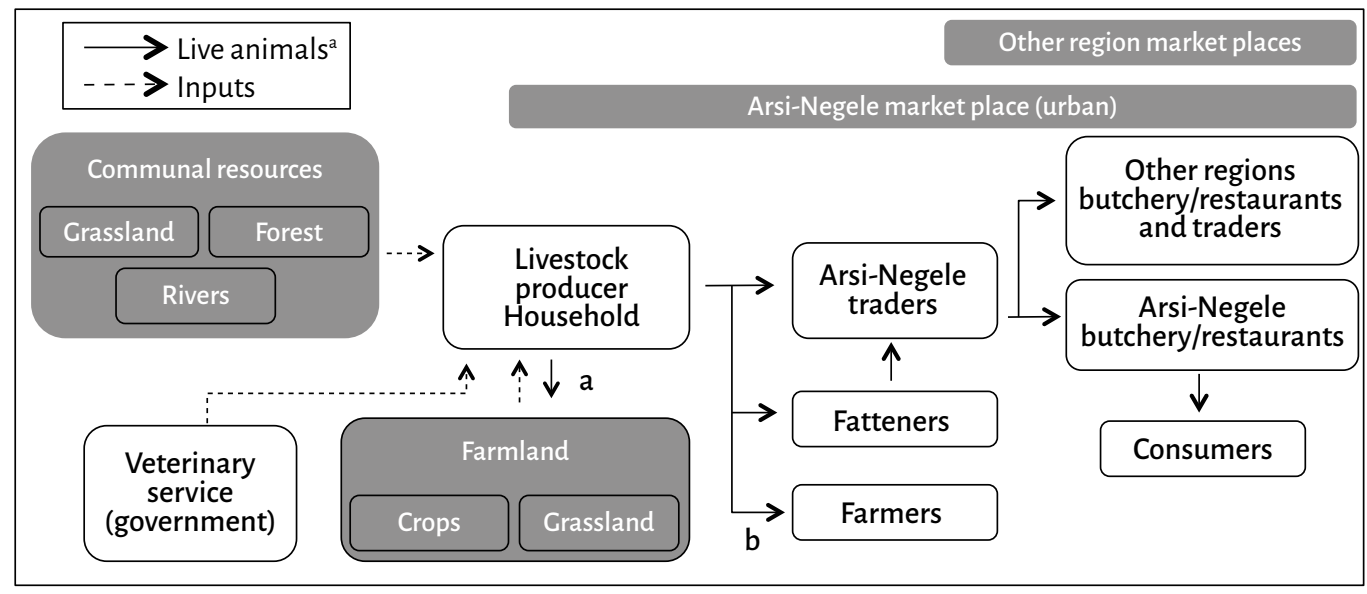

Figure 2.12 Livestock (live animals) value chain in the study area.

a All dark arrows represent live animals to be used for meat, except for ' $a$ ' which represents oxen and donkeys, and ' $b$ ' which represents animals to be used for work. 
Table 2.6 Price range for male adult cattle for meat in Arsi-Negele market.

\begin{tabular}{|c|c|c|}
\hline Cattle for meat & Time of the year & Price per animal (ETB) \\
\hline Highest price & April/September/December & 25,000 \\
\hline Lowest price & January-March & 12,000 \\
\hline
\end{tabular}

Note: USD $1=\sim$ ETB 20 .

Donkeys are of extreme importance for transport. Young donkeys can be sold to other farmers in the same livestock market in Arsi-Negele.

The market price of cattle sold for meat is marked by three peaks during the year (Table 2.6) related to religious or national celebrations: Easter (after 2 months of fasting), Ethiopian new year (September) and Christmas time (Orthodox tradition). The lowest prices occur during the dry season when there is little feed for the animals and farmers need cash for the preparation of the planting season. At this time, supply is high, demand low and this is a buyer's market (farmers are in need of cash). The price for a working ox is around ETB 12,000 and their sale occurs from January to March (before planting, since they are needed for land preparation).

\subsubsection{Highest possible income from a hectare of cropland}

Based on the information gathered during interviews (highest market price) and FGD (highest yield), we estimated the maximum income that 1 ha can generate for the most important crops (see Table 2.7). These calculated incomes are theoretical and presented only for comparison between crops as farmers are unlikely to obtain both the highest yield and the highest market price.

Potato produces much higher income than cereals but also requires a much greater investment in input and cannot be stored as long. Wheat produces much lower income than potato but almost twice as much as maize.

Table 2.7 Maximum attainable income from the three main crops in the study area.

\begin{tabular}{|c|c|c|c|}
\hline & Zone 1 & Zone 2 & Zone 3 \\
\hline Maize & - & ETB 12,000 & ETB 15,000 \\
\hline Potato & - & - & ETB 40,000 \\
\hline Wheat & - & ETB 25,600 & - \\
\hline
\end{tabular}

Note: Max income $=$ max yields $\mathrm{x}$ highest price at Arsi-Negele's Market. USD $1=\sim$ ETB 20 . 


\subsection{Food security, nutrition and health}

\subsubsection{Interviews with health officers}

The groups most susceptible to nutritional deficiencies are children younger than 5 years old, pregnant women and breast-feeding women (not an extensive list). The cereal-based diet of the area results in deficiencies in vitamin A among other micronutrients. Every 3 months, regular checkups (with special focus on children) take place in the settlements. For each kebele ( $\sim 30$ settlements) there is one health officer who is responsible for medical checkups of the community members, providing vitamin A and deworming for children, and advising sick patients to visit the health center. There is one health center for the four kebeles. All settlements in the study area share the same health center. The health center is located between Zone 2 and Zone 3 .

Vitamin A is provided to children from 6 months to 5 years old. For children from 2 to 5 years it is provided together with deworming tablets. In cases of acute malnutrition, every 3 months, children are provided with ready-to-use therapeutic food (Plumpy Nut), which has a high caloric content and contains different vitamins.

Pregnant women are at risk of anemia and are provided with folic acid by the health center. Breast-feeding women should attend the health center regularly to get vitamins and other nutritional supplements.

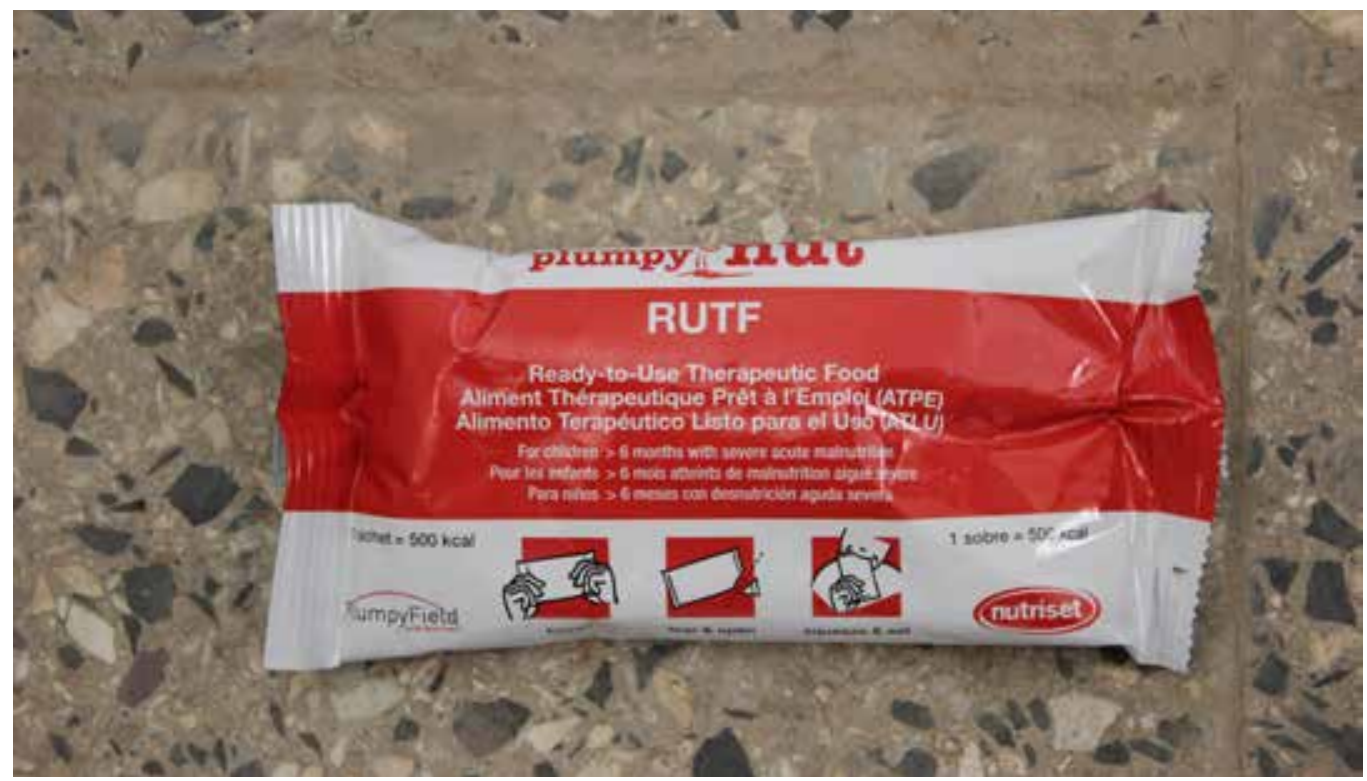

Ready to use therapeutic food provided to children under 5 years of age presenting with malnutrition symptoms. (Frédéric Baudron/CIMMYT) 
Residents from Zone 1 were reported to be commonly affected by diarrhea as a result of lack of clean water. During the PRA residents of Zone 1 identified the lack of clean water as one of their most important problems.

A hospital is located in Zone 1 , built and managed by a Catholic mission (Consolata). Community members only go to this hospital in the case of extreme illness or serious accident. A small private clinic is located in Zone 2, which provides a faster service for community members who have the resources to access it. Any important matter has to be treated in the Catholic hospital.

\subsubsection{Food security}

From the information collected during FGDs, community members in the three zones appear to be food secure. A food secure household was defined as one that does not struggle to feed the family. Community members indicated that food security was achieved between the years 1980 to 1990 because of the following:

- access to fertilizer, improved seeds and agricultural technical assistance leading to improved yields

- education resulting in better planning of the food production and consumption throughout the year

- introduction of potato into cropping cycle.

The change in food security over the past 50 years is discussed in Section 2.10.

\subsection{Land-cover change: remote sensing}

A preliminary analysis of land-use change around Munessa Forest area was conducted (Figure 2.13). The study spanned the period 1988-2011 and covered a much larger area than the study area discussed in this chapter. It yielded interesting insights regarding land-cover change around Munessa Forest.

During the period analyzed, the greatest vegetation changes in Munessa Forest occurred between 1987 and 1995. It can be hypothesized that this was the result of farmers returning to the forest border and clearing it, after they had been displaced from it in the late 1970s by the Derg regime. Bekele (2003) mentions an official government report presented to the vice minister of Agriculture by the Ethiopian Wildlife Conservation and Development Organization, listing extensive damage to the national parks by farmers and stating that the destruction was an expression of resentment toward the former government (i.e. the Derg regime).

Between 1995 and 2011, vegetation was lost mainly from scattered forest patches on the eastern side of the forest, where agricultural expansion was still possible through forest clearance. On the west side of the forest (where the study area is located), most forest was cleared before 1987 and such vegetation loss was thus not captured by the remote-sensing analysis. 


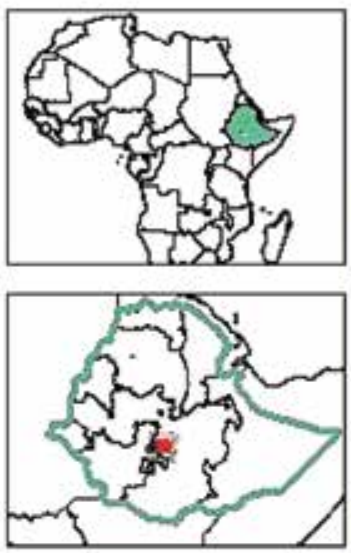

Probable vegetation loss

1987-95

1995-99

$1999-2000$

2000-2011

2009-11

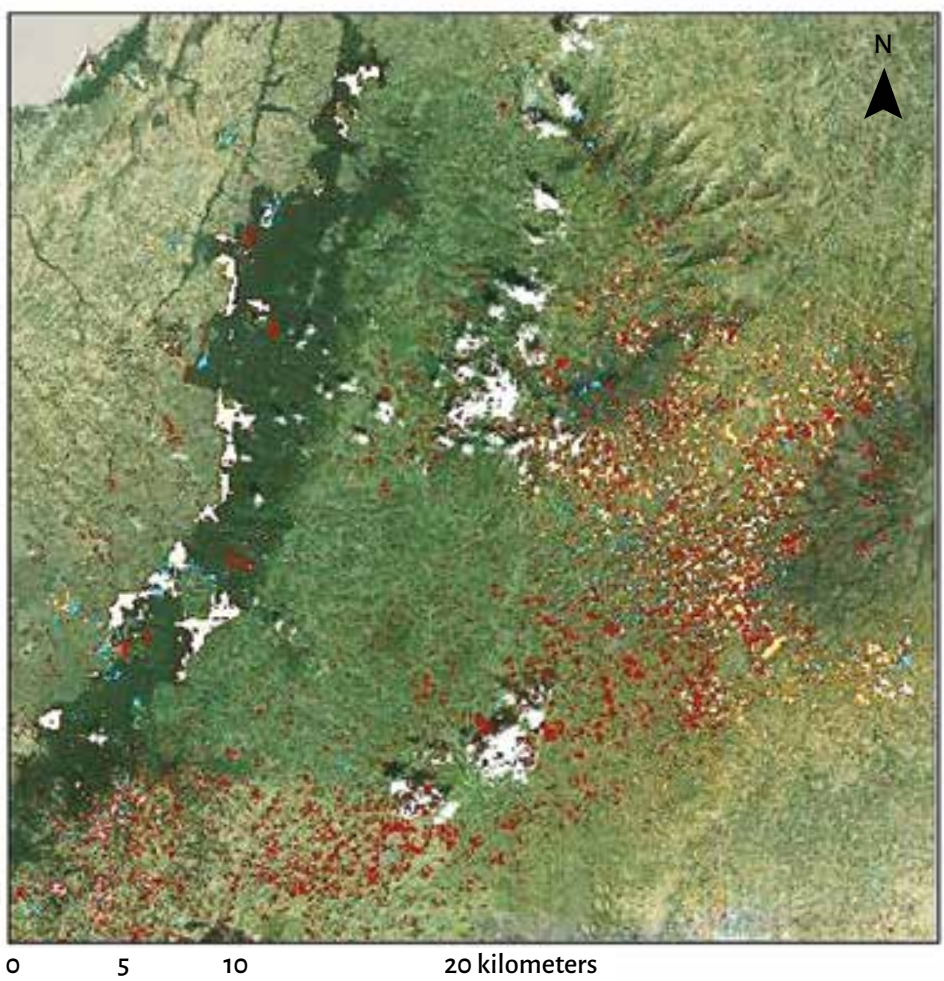

20 kilometers

Figure 2.13 Probable vegetation loss between 1987 and 2011.

Source: John Arnet and Ian Eddy (2015), Remote Sensing Department, University of British Columbia

\subsection{Perceptions of changes during the past 40 years}

\subsubsection{Historical diagrams of land-use change}

Figure 2.14 represents diagrammatically the perception of land-use change over time in Zone 2 (settlement Gogorri Lako Toko). Perceptions were very similar in all zones (see Appendix 2C). Four major land uses were identified during the first FGD (Zone 1) and then used for the next two zones: forest, cropland, grazing land and woodlots. Woodlots are plots planted with eucalyptus for the production of construction materials and fuelwood.

The general trends observed were a sharp decrease in forest cover as it was converted to agricultural land resulting in the total disappearance of the forest. Grazing land has decreased constantly since 1975, and can only be found today in smaller area. Grazing land was mainly converted to cropping land, with some converted to eucalyptus woodlots. (Note: 'grazing land' includes all private grazing land and all communal grazing land within the settlement boundaries and excludes communal grazing land that is shared with other settlements and therefore not considered part of the settlement.) 


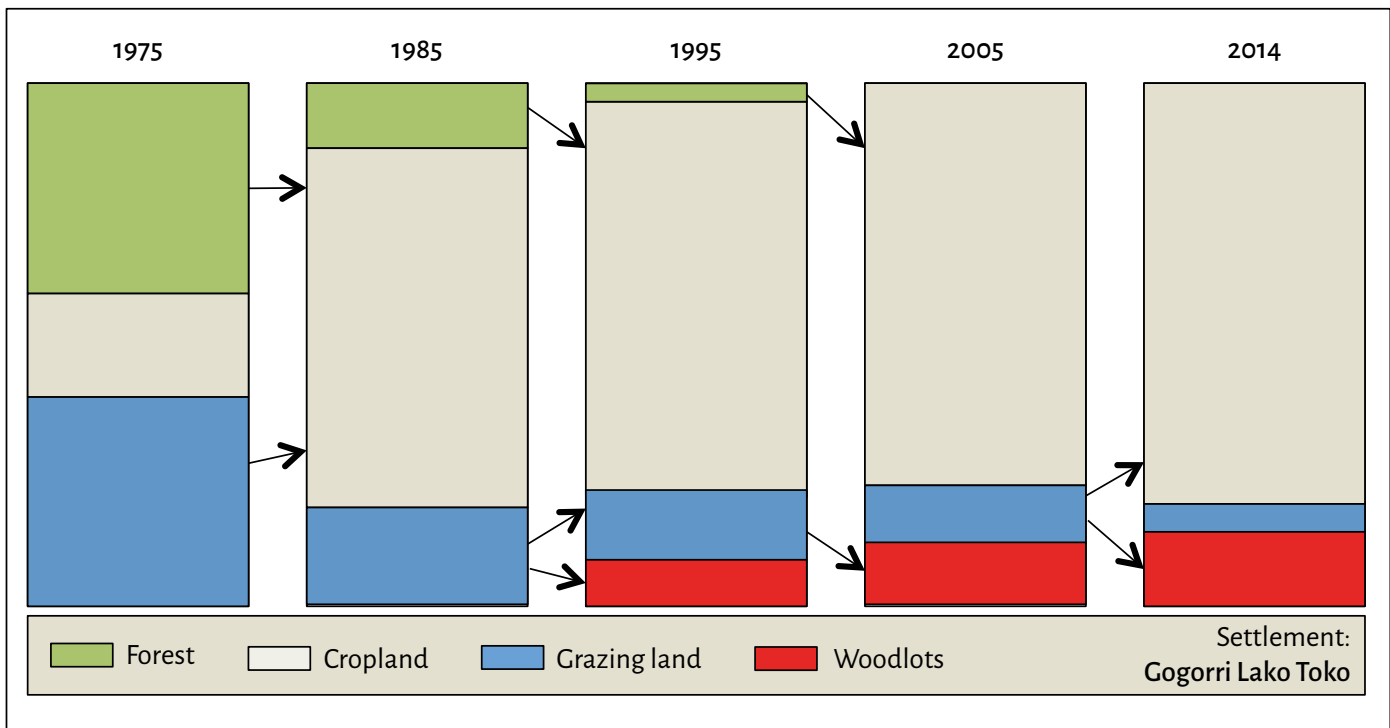

Figure 2.14 Historical diagram of land-use change in the landscape as perceived by elders of Zone 2.

The area dedicated to eucalyptus woodlots increased as a result of the growing scarcity of fuelwood and construction materials (resulting from deforestation). Eucalyptus was introduced to the area by the government in the 1970s. It grows fast and requires little management. Today, it is the dominant tree on-farm (as in many other rural areas of Ethiopia).

The conversion of grazing land to cropland was said to have led to an increase in food security, but also had important consequences for gender dynamics. Indeed, women traditionally control milk and butter, while men control crop harvest. Such a drastic decrease in grazing land has reduced cattle numbers and the associated dairy production per household and has disempowered women.

Similar trends were found in a land-use/land-cover change study using remote-sensing techniques and conducted in a landscape bordering the study area (Mekonen 1998). The study focused on changes between 1965 and 1994. Cropland increased sharply between 1965 and 1988 at the expense of grassland and forest. The extent of the different land uses differed from that perceived by the farmers, but this could be a result of the fact that Mekonen's study included the protected forest owned by the government, whereas the perceived changes were limited to the settlements boundaries. In Mekonen's study, cropland increased from $24.1 \%$ in 1965 to $54.2 \%$ in 1994 , whereas grassland declined from $14.3 \%$ to $2.1 \%$.

\subsubsection{Historical trend lines}

Population has grown constantly since 1970. At that time, the total population in each settlement was said to be between 20 and 30 people, compared to 200-600 today. These numbers are estimations made by settlement elders and leaders, and not official figures. Although people were said to have died during the 1984-85 famine and during conflict that punctuated the 40 years of study, these events were not visible on the trend line drawn by the participants of the FGDs. 
Forest was the most important land-cover class before 1970. The trend line presented in Figure 2.15 does not take into account the state-owned forest (Munessa Forest). According to the elders of Zone 1 and Zone 3, most (if not all) of the forest was cleared by 1982. In Zone 2, the last remaining forest patches were cleared by 1995. During the regime of Haile Selassie, all land was owned by a few landlords (nobles).

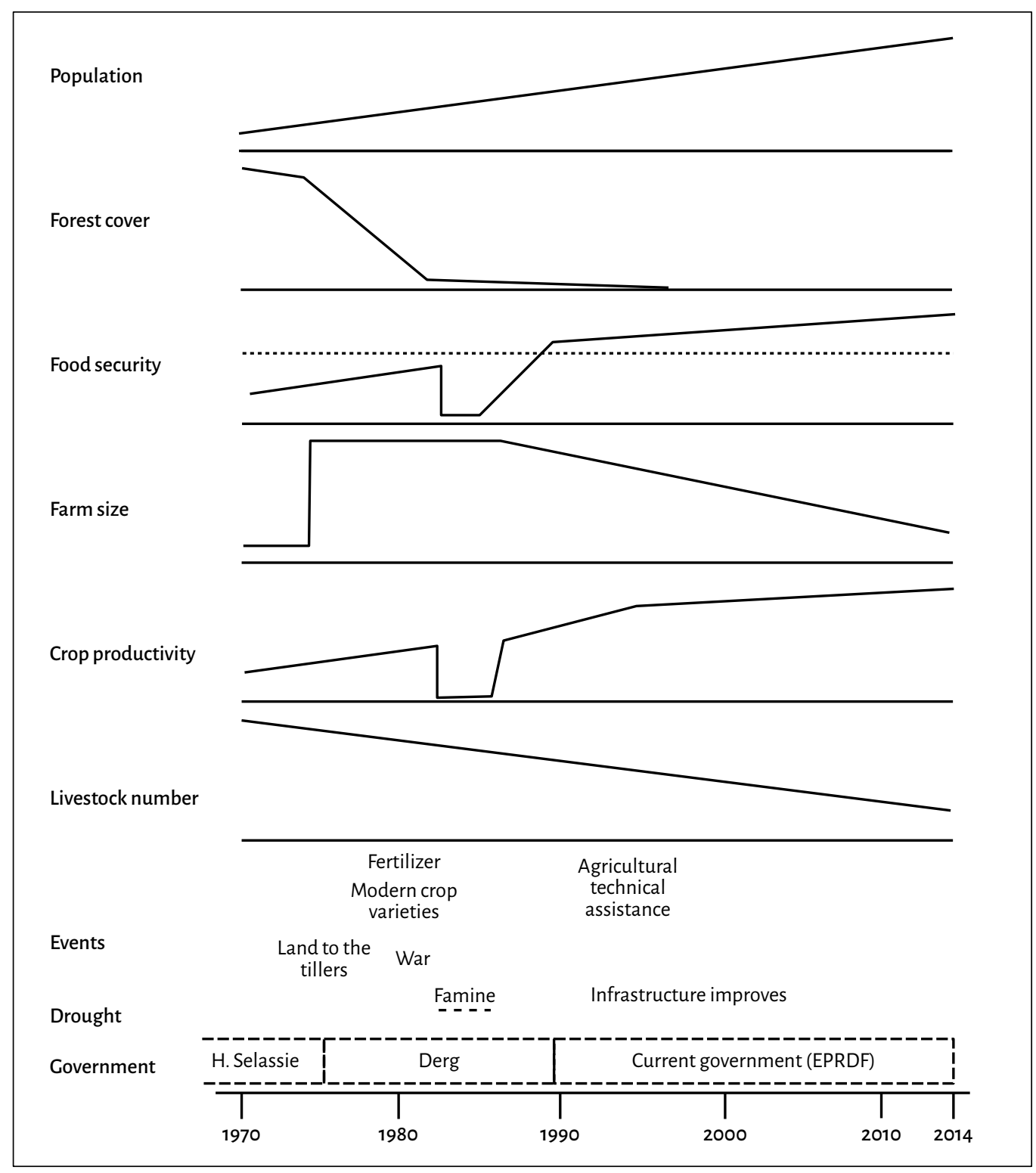

Figure 2.15 Historical trend lines and important events between 1970 and 2014 in the study area.

Note: The lines represent an average for the three zones where information was collected. 
People of the Oromo ethnic group (all the population on the studied landscape) were discriminated against and considered servants of the landlords, and were unable to access land. Landlords initiated deforestation and forest degradation by extracting wood for timber. The sharp decline in the forest cover during the Derg regime was a result of the agrarian land reform that gave "land to the tillers." Forest clearance was the dominant strategy to access farmland during that time. The forest remained state land and access was forbidden. Anyone who entered the forest and/or used its products risked imprisonment (Bekele 2003).

Food security (defined as having enough food - or cash to purchase food - to feed the family) has increased from 1970, when most households struggled to produce or purchase enough food, to today, when most household produce enough for self-consumption and market surpluses. At the time of Haile Selassie, farmers had very limited cropland (around 0.5 ha for 20 people) and were mainly allowed to use the land for grazing. The diet was based on milk and honey (from the forest). With the land reform, farmers could use land for cropping, increasing agricultural yield. Food security was achieved at the end of the 1980s. The years 1984-85 were marked by a major famine resulting from two consecutive years of drought. Access to fertilizer and improved seeds, together with better planning of food production and consumption, were the main reasons given for the improvement in food security.

The average farm size was negligible before 1975, since all land was owned by landlords. With the land reform, farmers gained rights to use the land they cultivated. The area of land received from the government depended on the total area available and the household size (or in the case of the study area, the number of wives in the polygamous households). Land was accessed by men only. At this time (1977), the average farm size was the highest in the period considered. Farm size plateaued after this, and started to decline as farms were subdivided through inheritance.

Crop yield (kg/ha) has increased since the 1970s. Crop yield was very low, since there was little knowledge about crop management and no external input was used. Crop yield increased with access to fertilizers and improved seeds (during the Derg regime), and to agricultural technical assistance (with the current government). During the drought of 1984-85, most crops failed. After that, the productivity kept increasing. Comparing the trend line for the yield of different crops (see Appendix 2D) reveals that maize yield peaked in 1995 and declined until 2008 because of weather conditions (too wet). From 2008 to today, maize yield increased until it reached maximum yields (achieved in the study area). Wheat productivity also reached its peak around the same time as maize but since then has decreased due to the increased occurrence of fungal diseases. Maximum yields mentioned by farmers are 3 tons per ha for maize, 3.2 tons per ha for wheat and 20 tons per ha for potato.

Both total livestock number and livestock number per household have decreased steadily since 1970. The reason for this is the reduction of grasslands and forest, which used to be the major sources of feed. Today, most feed comes from crop residues, but the feed quantity produced by crops is lower than that produced by grazing land. 


\section{Acknowledgments}

Jean-Yves Duriaux and Frédéric Baudron based this chapter on data collected from September to December 2014. Support was received from CIFOR personnel: Liz Deakin, Mrigesh Kshatriya, Habtemariam Kassa and Terry Sunderland. The remote-sensing preliminary analysis was undertaken by John Arnet, Ian Eddy and Sarah Gergel from the University of British Columbia. Advice was also received from Dr. Menfese Tadesse from Wondo Genet College of Forestry and Agriculture. 


\section{References}

Addis E. 2008. Socioeconomic Analysis of 'Katikala' Production and Consumption in ArsiNegele Woreda of Oromia Region, Ethiopia,[MSc thesis]. Addis Ababa: University of Addis Ababa.

Bekele M. 2003. Forest Property Rights, The Role of the State and Institutional Exigency: The Ethiopian Experience. Uppsala, Sweden: Swedish University of Agricultural Sciences.

Dessie G. and Christiansson, C. 2007. Forest Decline and its Causes in the South Central Rift Valley of Ethiopia. Human Impact over a One Hundred Year Perspective, Ambio.

Ehui S and Pender J. 2005. Resource degradation, low agricultural productivity, and poverty in sub-Saharan Africa: pathways out of the spiral. Agricultural Economics 32(1):225-42.

[FAO] Food and Agriculture Organization of the United Nations. 2010. Global Forest Resources Assessment 2010 - Country Report Ethiopia. Rome: FAO.

[FAO] Food and Agriculture Organization of the United Nations. 2014. FAOSTATCountry Profile for Ethiopia. Rome: FAO. Accessed 24 January 2014. http://faostat.fao. org/site/550/default.aspx\#ancor

Garedew E. 2010. Land-use and land-cover dynamics and rural livelihood perspectives, in the semi-arid areas of Central Rift Valley of Ethiopia [Doctoral thesis]. Umeå University, Sweden: Umeå University, Department of Forest Resource Management.

Geilfus F. 2008. 80 Tools for Participatory Development. San José, Costa Rica: Instituto Interamericano de Cooperación para la Agricultura.

Halle-Wittenberg University 2002. Munessa Forest. Accessed 20 December 2014. http:// www.munessa-forest.uni-halle.de/location/

Jenbere D, Lemenih M and Kassa H. 2012. Expansion of eucalypt farm forestry and its determinants in Arsi Negelle District, South Central Ethiopia. Small-scale Forestry 11(3):389-405.

Lemenih M. 2004. Effects of Land-Use Changes on Soil Quality and Native Flora Degradation and Restoration in the Highlands of Ethiopia. Uppsala, Sweden: Swedish University of Agricultural Sciences.

Mekonen K. 1998. Estimating land cover/land use change in Munessa Forest area using remote sensing techniques [MSc thesis]. Uppsala, Sweden: Swedish University of Agricultural Sciences.

Rufino M, Tittonell P, Reidsma P, López-Ridaura S, Hengsdijk H, Giller K and Verhagen A. 2009. Network analysis of $\mathrm{N}$ flows and food self-sufficiency: A comparative study of crop-livestock systems of the highlands of East and southern Africa. Nutrient Cycling in Agroecosystems 85:169-86.

Sassen M, Sheil D, Giller K and ter Braak C. 2012. Complex contexts and dynamic drivers: Understanding four decades of forest loss and recovery in an East African protected area, Biological Conservation 159:257-68.

Teshome T. 1996. A Growth and Yield Model for Cupressus lusitanica in Munessa Shashemene State Forest Project (MSSFP), Southwest Ethiopia, University of Aberdeen.

Tittonell P. 2013. Livelihood strategies, resilience and transformability in African agroecosystems, Agricultural Systems 126:3-14. 


\section{Appendices}

Appendix 2A Interviews with value chain actors

Table 2A.1 Number of interviews with value chain actors.

\begin{tabular}{|c|c|}
\hline Value chain & No. of interviews \\
\hline Fuelwood & 8 \\
\hline Maize and wheat & 5 \\
\hline Potato & 5 \\
\hline Livestock & 5 \\
\hline
\end{tabular}




\section{Appendix 2B Typologies based on self-categorization for three settlements}

\section{Table 2B.1 Typologies for Zone 1, Sida Malkatuka settlement, based on self-categorization activities.}

\begin{tabular}{|l|l|l|}
\hline Category & Criteria & Proportion of the households \\
\hline Landless & $\begin{array}{l}\text { - No farming land } \\
\text { - Employed (agriculture or forest guard) } \\
\text { - Can rent land or do sharecropping sometimes }\end{array}$ & $\begin{array}{l}14 \% \\
16 \text { out of } 42\end{array}$ \\
\hline Cereals producers & $\begin{array}{l}\text { - Most land is covered with maize and wheat } \\
\text { - Livestock (4 oxen for cultivation and 1-3 cows) }\end{array}$ & $\begin{array}{l}7 \% \\
3 \text { out of } 42\end{array}$ \\
\hline $\begin{array}{l}\text { Livestock } \\
\text { producers }\end{array}$ & $\begin{array}{l}\text { - More than 5 animals, but normally 8-10 } \\
\text { - Grazing land in the farm }\end{array}$ & $\begin{array}{l}19 \% \\
8 \text { out of } 42\end{array}$ \\
\hline $\begin{array}{l}\text { - Cropland, mostly maize followed by wheat } \\
\text { - Enset is important as a feed during dry season }\end{array}$ & \\
\hline Diversified farm & $\begin{array}{l}\text { - Enset and coffee } \\
\text { - Vegetables } \\
\text { - Grazing land } \\
\text { - Maize and wheat } \\
\text { - Livestock (less than five) }\end{array}$ & $\begin{array}{l}60 \% \\
25 \text { out of } 42\end{array}$ \\
\hline
\end{tabular}

Table 2B.2 Typologies for Zone 2, Gogorri Lako Toko settlement, based on self-categorization.

\begin{tabular}{|c|c|c|}
\hline Category & Criteria & Proportion of households \\
\hline Cereals producers & $\begin{array}{l}\text { Most land is covered with maize and wheat } \\
\text { and some with barley } \\
\text { - Livestock ( } 2 \text { oxen for cultivation and } 2-3 \\
\text { other animals) } \\
\text { - Very little false banana in home garden }\end{array}$ & $\begin{array}{l}54 \% \\
25 \text { out of } 46\end{array}$ \\
\hline Livestock producers & $\begin{array}{l}\text { - Donkeys, sheep and 8-10 cattle } \\
\text { - Grazing land in the farm } \\
\text { - Cropland, mostly maize followed by wheat } \\
\text { and barley } \\
\text { - Very little sorgum and sometimes potato }\end{array}$ & $\begin{array}{l}2 \% \\
1 \text { out of } 46\end{array}$ \\
\hline Diversified farm & $\begin{array}{l}\text { - Maize and wheat, barley, sorgum, cabbage, } \\
\text { potato, teff } \\
\text { - Enset and coffee; some farms have avocado } \\
\text { trees } \\
\text { - Eucalyptus planted in woodlots } \\
\text { - Grazing land (little) } \\
\text { - Livestock ( } 2 \text { cows }-2 \text { oxen) }\end{array}$ & $\begin{array}{l}44 \% \\
20 \text { out of } 46\end{array}$ \\
\hline
\end{tabular}


Table 2B.3 Typologies for Zone 3, Shona, based on self-categorization.

\begin{tabular}{|c|c|c|}
\hline Category & Criteria & Proportion of the households \\
\hline Renters & $\begin{array}{l}\text { Rent their land because they do not have } \\
\text { enough money to obtain fertilizer or seeds, or } \\
\text { because of illness } \\
\text { - Lack oxen and have no animals }\end{array}$ & $\begin{array}{l}19 \% \\
6 \text { out of } 31\end{array}$ \\
\hline Model farmers & $\begin{array}{l}\text { - Can produce two times per year (first } \\
\text { vegetables and then cereals) } \\
\text { - Can prepare all inputs before the rain so they } \\
\text { can plant on time } \\
\text { - Own 2-4 oxen and 2-3 cows } \\
\text { - Own their own donkey cart to bring their } \\
\text { product to the market } \\
\text { - Hire labor } \\
\text { - A model for other farmers } \\
\text { - Own or are building a house in Arsi-Negele } \\
\text { (closest town) } \\
\text { - Plan all their activities } \\
\text { - Have capital, so provide credit to poorer } \\
\text { farmers } \\
\text { - Are better-off economically (e.g. have house, } \\
\text { chairs, etc.) }\end{array}$ & $\begin{array}{l}36 \% \\
11 \text { out of } 31\end{array}$ \\
\hline Traders & $\begin{array}{l}\text { - Practice agriculture and trading } \\
\text { - Own 2-3 animals (cattle) only because of lack } \\
\text { of grazing land } \\
\text { - Store their product and wait for higher prices } \\
\text { to then sell to the market } \\
\text { - Rent their cart services to people (10-15 } \\
\text { people, ETB } 2 \text { to go and ETB } 5 \text { to come back) } \\
\text { and for product (ETB 10/QQ } \text { to go and } \\
\text { ETB } 20-30 \text { to come back) }\end{array}$ & $\begin{array}{l}13 \% \\
4 \text { out of } 31\end{array}$ \\
\hline $\begin{array}{l}\text { Vegetable } \\
\text { producers }\end{array}$ & $\begin{array}{l}\text { - Plant on time when the rain starts (and can } \\
\text { get all the inputs on time) } \\
\text { - Own 3-4 cattle } \\
\text { - Do two plantings of vegetables per year } \\
\text { - Start with cabbage nursery before the rain } \\
\text { starts and irrigate with water from the river } \\
\text { - If many people plant, the prices go down; } \\
\text { prices are very variable }\end{array}$ & $\begin{array}{l}32 \% \\
10 \text { out of } 31\end{array}$ \\
\hline
\end{tabular}

a QQ stands for quintal and represents $100 \mathrm{~kg}$. 
Appendix 2C Perception of land-use change in two settlements

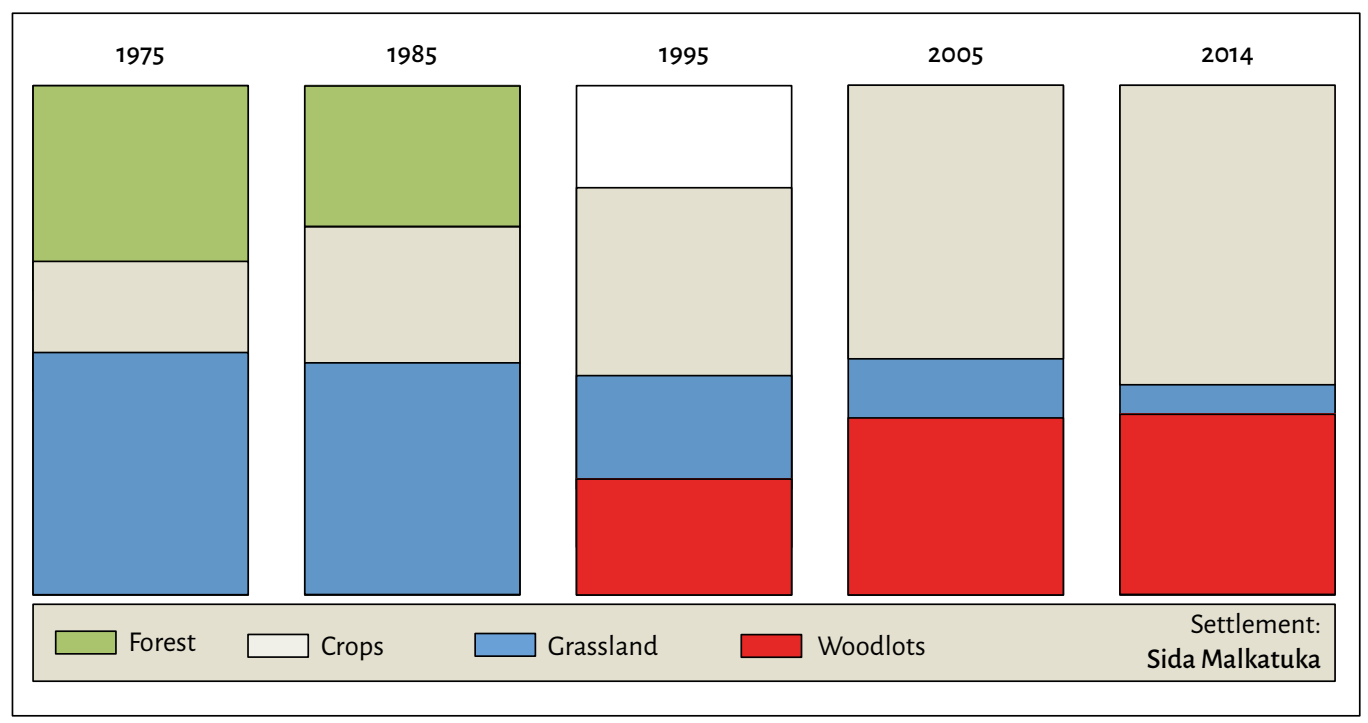

Figure 2C.1 Perceptions of land-use change in Zone 1, Sida Malkatuka.

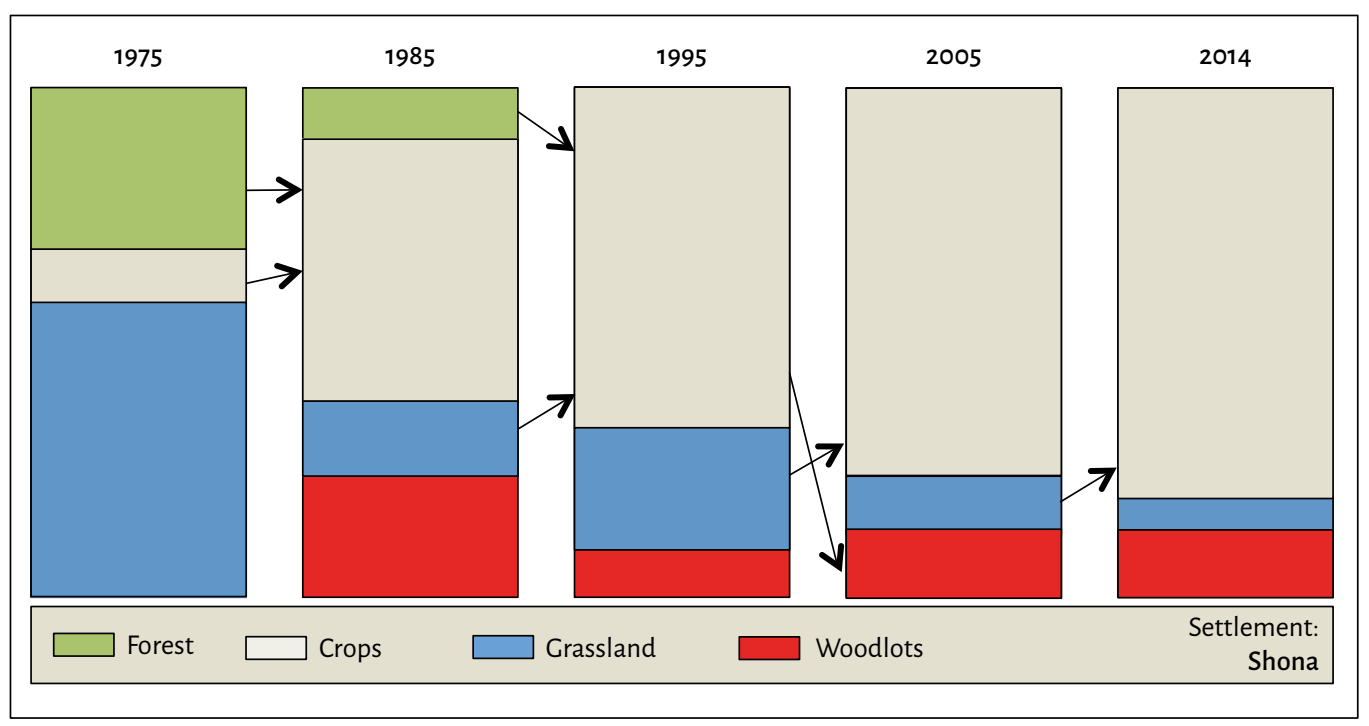

Figure 2C.2 Perceptions of land-use change in Zone 3, Shona. 


\section{Appendix 2D Trend lines of historical changes in three settlements}
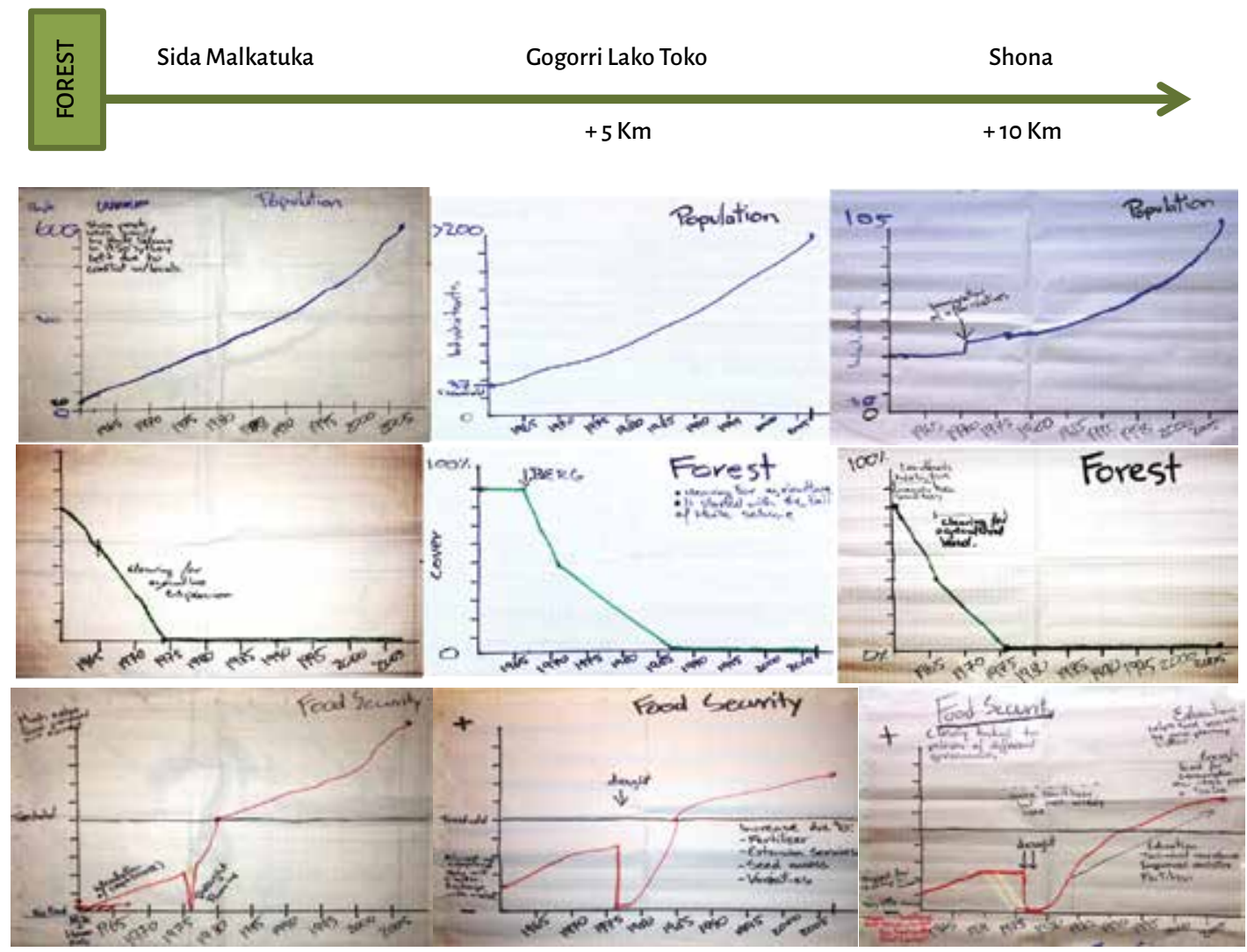

Figure 2D.1 Trend lines for population, forest cover and food security changes over time.

Note: Years on the graphs are on the Ethiopian calendar, which is 8 years behind the Gregorian calendar (e.g. 2007 in Ethiopian calendar is 2015 in Gregorian calendar). 


\begin{tabular}{|ccc}
\hline $\begin{array}{c}\text { 㟧 } \\
\text { 它 }\end{array}$ & Sida Malkatuka & Shona \\
\hline
\end{tabular}
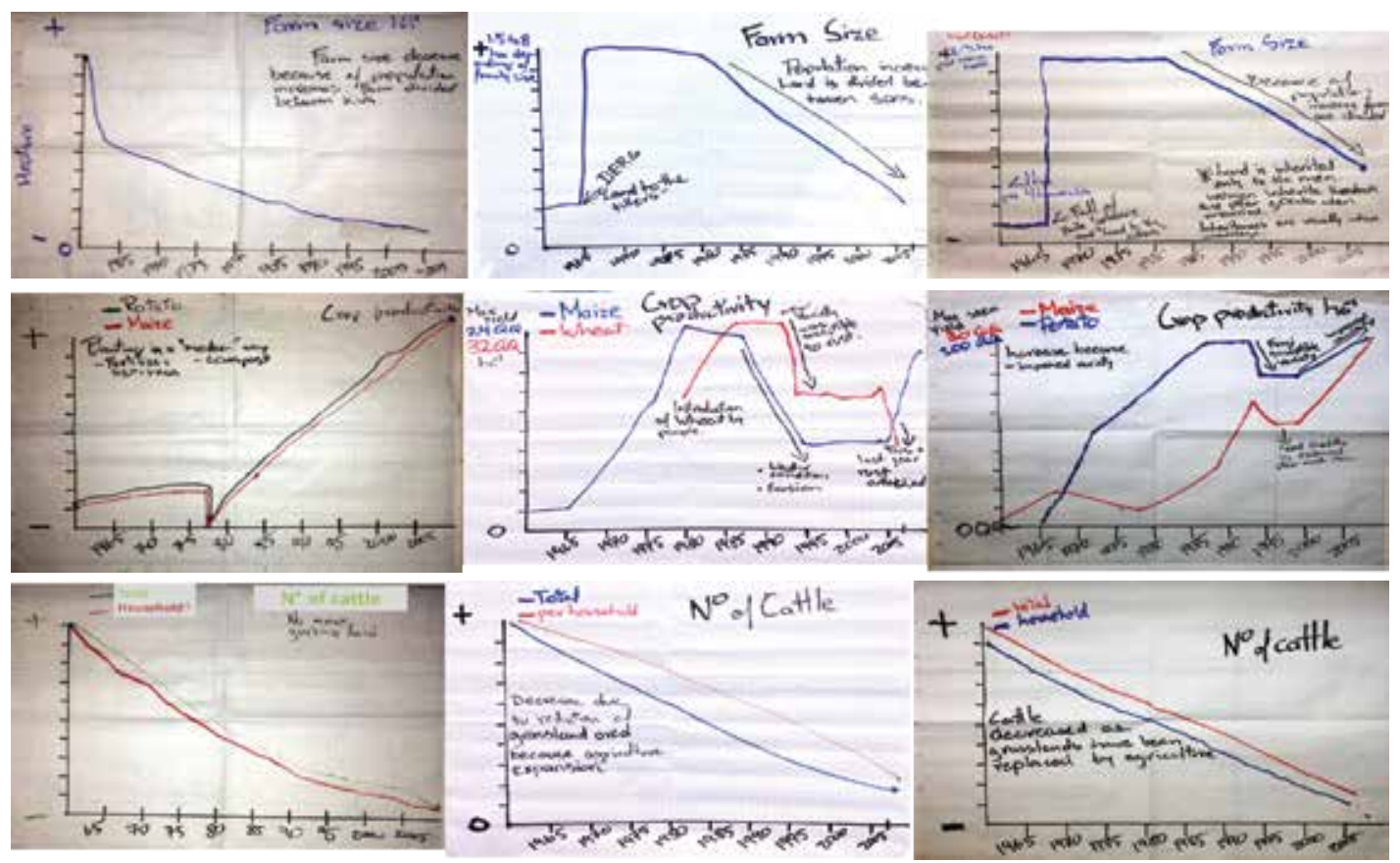

Figure 2D.2 Trend lines for farm size, crop productivity (the two crops considered the most important in the settlement) and livestock number (per settlement and per farm) changes over time.

Note: Years on the graphs are on the Ethiopian calendar, which is 8 years behind the Gregorian calendar (e.g. 2007 in Ethiopian calendar is 2015 in Gregorian calendar). 
Land-use change and its influence on rural livelihoods, food security and biodiversity conservation in the Southwest Region of Cameroon

\section{Summary}

This scoping study aims to give a preliminary overview of historical land uses, the underlying drivers of land-use change and the impacts on rural communities in the Nguti area of Southwest Cameroon. The information presented in this report was gathered through a literature review, collection of secondary data and scoping field visits. A reconnaissance survey, community meetings and participatory rural appraisals were undertaken in three focal villages in the Nguti district.

This area has experienced a number of changes in land use over the last 100 years and is currently experiencing a new wave of change in the form of large-scale agro-industrial oil palm development. Until recently, the land use has been small-scale household swidden agriculture with traditional shifting cultivation and fallowing, secondary forest of different stages, food crop farmlands, and cocoa agroforestry.

\subsection{Introduction}

Cameroon is located in West Africa and shares borders with Nigeria, Chad, Equatorial Guinea, Gabon, Central African Republic and Republic of Congo (Figure 3.1). It has a mix in vegetation ranging from the tropical rainforests typical of the Congo Basin 
countries, to the savanna/Sahel grasslands typical of West African countries such as Burkina Faso. Cameroon offers a rare diversity of ecosystems, mountains, littoral and marine coastlines, and has a great diversity of people and cultures. The total land area of Cameroon is about 47 million ha and some type of forest (including both dense and mixed forests) covers $59 \%$ of the land (WRI, 2013). The overall landuse figures in Cameroon are classified as: forest area (19.48 million ha), arable land (6.2 million ha), permanent crops (1400 million ha), others including permanent meadows and pasture land (20.04 million ha) (FAO 2013).

Between 2000 and 2005, the rate of forest change in Cameroon was estimated at 9.9\% per annum. This was primarily due to timber exploitation (legal and illegal) and land clearing for agricultural activities and mining (WRI 2013).

Cameroon has an estimated population of about 20 million (UN 2014). It is estimated that about $85 \%$ of the population are employed in the agricultural sector and the majority of people live in rural areas where there is a significantly higher rate of population increase. The economic crisis that hit Cameroon in the late $1980 \mathrm{~s}$ and 1990 s left many young people jobless, with no option but to settle on farming as a means of fighting poverty, (personal communication from S Abia, 2013). In the early 2000s, an increase in cocoa prices gave farmers a strong motivation for expansion of their income from cocoa. These factors greatly contributed to the expansion of the agricultural sector and simultaneously increased forest degradation and deforestation. Cameroon has also become the breadbasket of its neighbors, especially Gabon and Equatorial Guinea, which have a high demand for Cameroonian food crops such as cassava, cocoyams, plantains and banana. According to Sneyd (2014), the cross-border trade in Cameroonian banana, manioc and plantains engaged in by Gabonese and other "buyam-sellam" traders is seen by many to be an additional source of price pressure on traditional staples. This crossborder trade seems to be on the rise (Sneyd 2013). These lucrative external markets have encouraged high levels of food crop cultivation in all regions of the country.

The establishment of large-scale agro-industrial palm oil plantations has recently taken place in Cameroon as a result of the government's quest to become an emerging economy by 2035 (MINEPAT 2009). The Southwest Region of Cameroon in particular has undergone significant changes in land-use patterns and practices, from primary forest, foraging for NTFPs, and swidden agricultural practices for coffee (Coffea arabica and C. robusta) and cocoa (Theobroma cacao) to timber exploitation and more recently, establishment of agro-industrial plantations. The fertile soils, available land and high prices of cocoa have greatly contributed to the changes in land-use patterns by local farmers. It is now becoming increasingly common for farmers to alter their agricultural practices and begin growing oil palm (Elaeis guineensis). Planting a few stands of oil palm on the farm has been a common practice on farms to provide palm oil and palm wine for domestic consumption.

During the last 7 years however, farmers have begun to establish oil palm plantations on a medium scale, producing palm oil for the local Cameroonian market. In addition to the smallholder oil palm farmers, two main agro-industries have been operating within the region for almost 100 years: CDC (Cameroon Development 


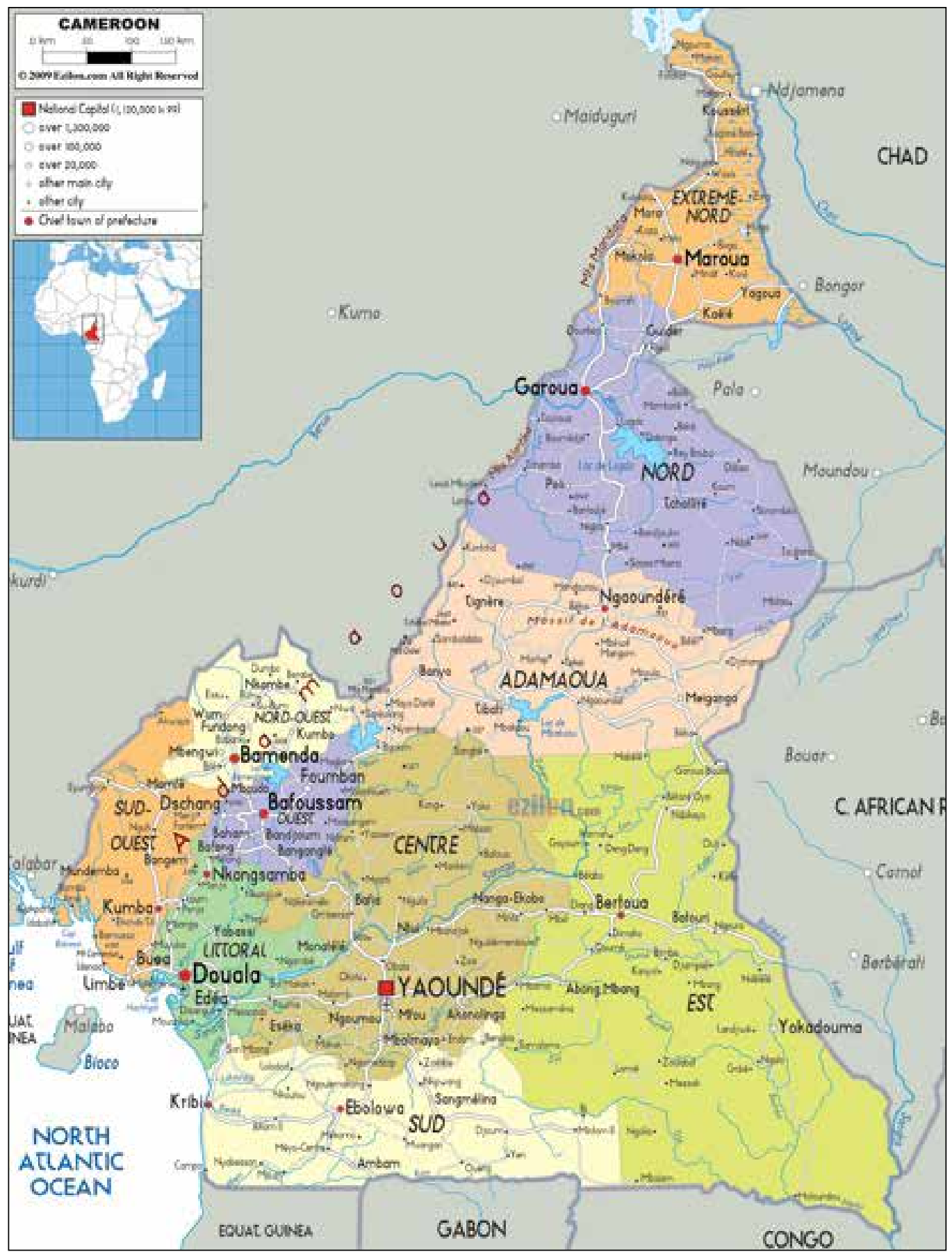

Figure 3.1 Map of Cameroon.

Source: Ezilon (2013) 
Corporation) and PAMOL. There is now a new multinational palm oil company in the southwest area of Cameroon; SG-SOC (Sithe Global Sustainable Oils Cameroon Ltd.) in partnership with Herakles Farm, a US company. Their initial negotiation with the government gave them access to about 70,000 ha of land, which covered two divisions of the Southwest Region. While there is no question that oil palm is a highly lucrative crop that can contribute to economic development, the conversion of native forests for plantations places a heavy toll on the environment (Hance and Butler 2011). These plantations bring ecological, sociocultural, economic and demographic changes as well as other related issues linked to human settlement and livelihoods.

\subsection{Background}

The purpose of this scoping study is to provide background information on a selected study area (Nguti) in the Southwest Region of Cameroon in order to understand the processes and impacts related to land-use change in the region. Research was focused on four main areas of interest, each following specific objectives:

1. Description of the study area

- What is the geographical, social, cultural, political, economic and ecological context of the study area?

2. Land use: Changes, drivers and impacts

- What are the current types of land use in the landscape?

- What are the local and external historical events/drivers that have influenced land cover, land use and land management in the study area?

3. Interventions affecting land use in the study area

- What interventions have influenced land use/land cover in the landscape?

- What are the motivations/expected outcomes of the intervention in terms of participation, food security, livelihoods and biodiversity in the landscape?

4. Livelihoods, food security and nutrition

- What is the current livelihood, food security and nutrition situation in the study area?

\subsection{Research methods}

Information presented in this report is based on:

- secondary data sources and the wider literature, which was consulted to gather background information on the Southwest Region of Cameroon and the Nguti study area

- a scoping field research study carried out in the Nguti-Manyemen region during November/December 2013. A grounded theory approach (Glaser 2013) was implemented in settlements in the study area to gather information on land-use practices, food security issues and livelihoods. A reconnaissance survey, community meetings and participatory rural appraisals (Liswanti and Basuki 2009) were undertaken in three focal villages. 


\subsubsection{Reconnaissance survey and site selection}

The reconnaissance survey involved a 5-day trip to the study area where previously identified villages were visited. During this time, all of the villages within the project area were visited and three focal villages were selected for the purpose of the scoping study: Ayong, Babensi I and Babensi II (Figure 3.2). These villages were selected based on their easy accessibility compared to others in the study area. GPS coordinates were taken for each village.

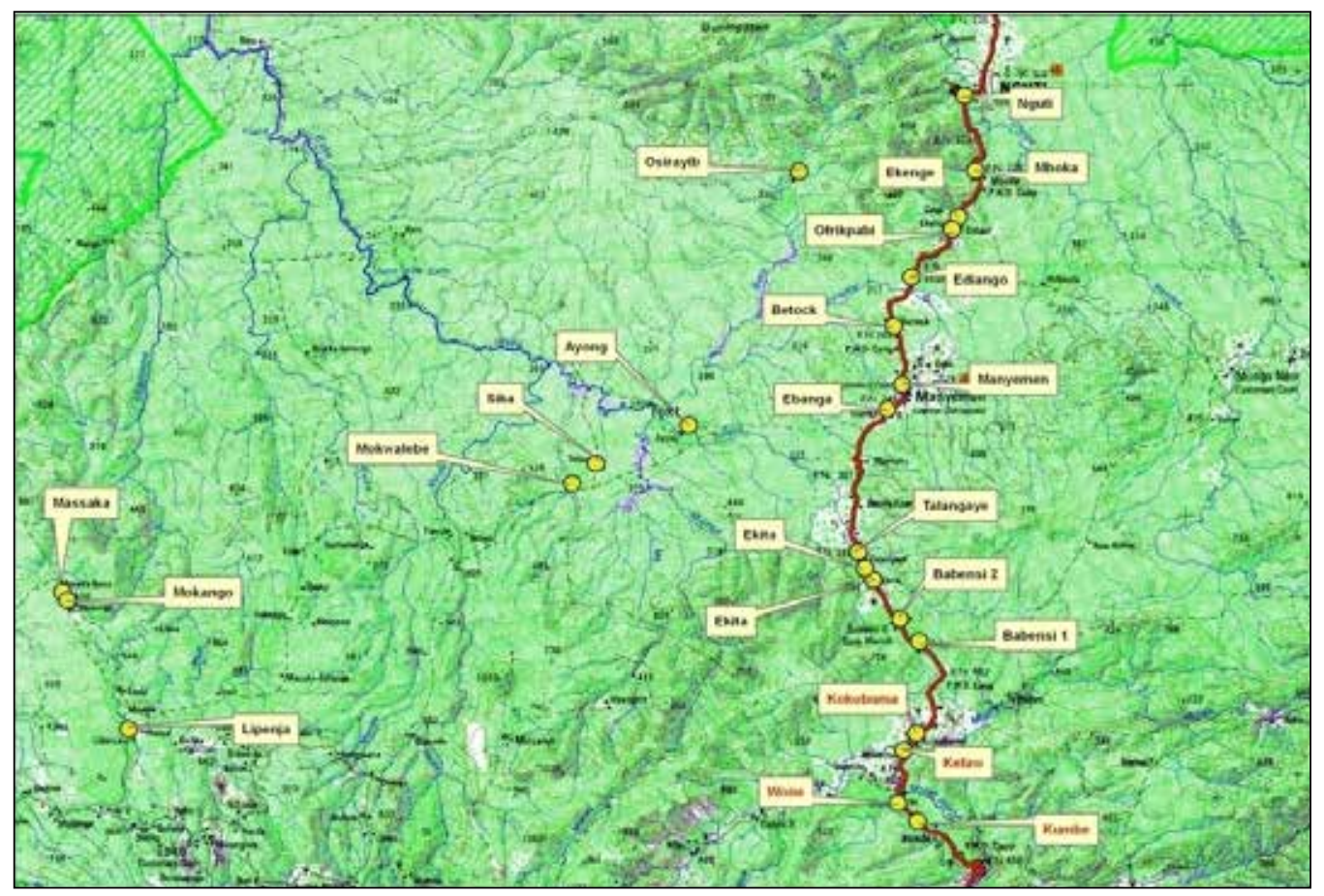

Figure 3.2 Map of villages in Nguti study area, Southwest Region, Cameroon.

Source: Map produced by E Kuchambi, Independent GIS Expert, October 2014

\subsubsection{Methods undertaken in each village}

\section{Initial community meetings}

In each of the three villages, a meeting was held with the chief, council and other elders of the village to introduce the research team to them. A subsequent meeting was held with the entire community to provide a detailed explanation of the research objectives and program.

\section{Administration of structured questionnaires}

Structured questionnaires were administered to a sample of the households. The number of households interviewed in each village is shown in Table 3.1. 
Table 3.1 Number and percentage of interviewed households in each village.

\begin{tabular}{|l|c|c|c|}
\hline Settlement name & $\begin{array}{c}\text { Total no. of } \\
\text { households }\end{array}$ & $\begin{array}{c}\text { No. of households } \\
\text { interviewed }\end{array}$ & $\begin{array}{c}\text { Percentage } \\
\text { interviewed (\%) }\end{array}$ \\
\hline Ayong & 111 & 41 & 36.9 \\
\hline Babensi I & 107 & 41 & 38.3 \\
\hline Babensi II & 60 & 41 & 68.3 \\
\hline
\end{tabular}

\section{Participatory rural appraisal tools}

The participatory tools used to gather information in each village included general observations, household mapping and wealth ranking exercises, FGDs, a historical trends exercise, and the pebble distribution method. For the FGDs, historical trends exercise and pebble distribution games, two separate meetings were held in each village: one with men and the other with women. A discussion was also had with the village council members of each community using guiding questions (Appendix $3 \mathrm{~A}$ ).

\section{Household mapping and household wealth ranking exercises}

The household mapping and wealth ranking exercises were conducted to establish a list of all households in the settlements and to gather information on the socioeconomic characteristics and wellbeing of the households. These exercises were carried out with key informants from each community. The card game method (Mukherjee 1992) was used for the wealth ranking exercise. Using household lists from the household mapping exercise, cards were prepared to represent each household. Each card had the house number, name, age and gender of one household head. The key informants were guided to independently rank or group the household heads according to their individual perceptions of wealth and wellbeing, alongside the common characteristics of each wealth group.

\section{Focus group discussions}

Group discussions and exercises were conducted with the village head and elders on the village's historical and cultural background, land tenure and ownership, collection and sale of forest products, and the regulations and taboos concerning land and forest use.

\section{Habitat type and forest use scoring exercises}

Scoring exercises were undertaken to assess the relative importance of different land-use types and practices in the landscape. These took place during FGDs with men and women separately. The pebble distribution method (Liswanti and Basuki 2009) was used such that the groups distributed 20 pebbles, beans, maize or other small objects over illustrations of land and forest types (Appendix 3B and $3 \mathrm{C}$ ) according to their perceived relative importance. Explanations were asked for each choice.

\section{Historical trends exercise}

Working with the two groups (men and women) separately, the villagers from a number of different households took part in an historical trends exercise to determine events that took 


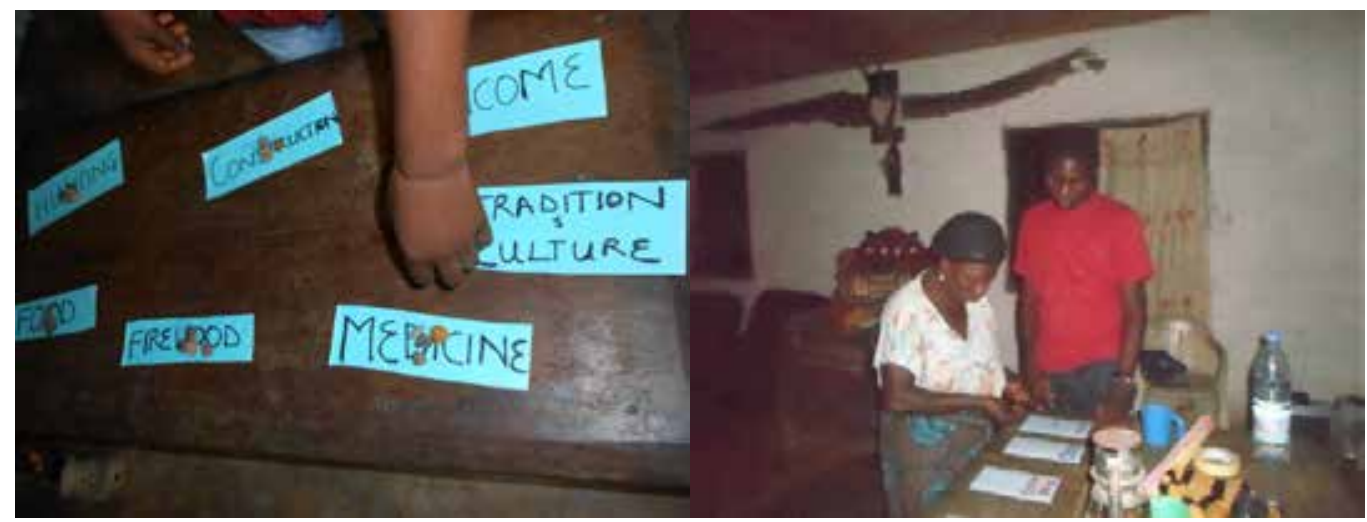

Scoring exercise on primary forest use using the pebble distribution method. (Stella Asaha/Forests, Resources and People, FOREP)

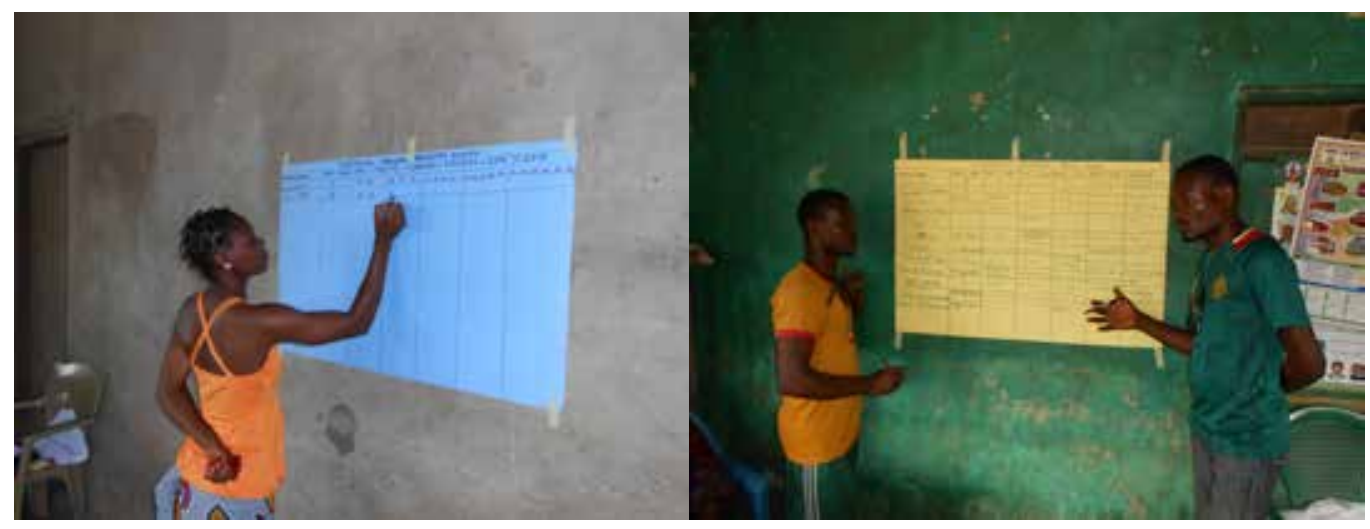

Historical trends exercises with women and men. (Stella Asaha/FOREP)

place in the study area over the past 30 years. They were encouraged to brainstorm and discuss parameters or specific events and how they had evolved over time. The parameters included social, economic, infrastructure, health, cultural, administrative and other issues that had been noticed to change. A template of the historical trends exercise and parameters used for discussion is shown in Appendix 3D.

\subsection{Scoping study results}

\subsubsection{Study area description}

\section{Geographical context}

Cameroon's Southwest Region is bounded to the north by the Northwest Region, to the east by the Littoral and West Regions and to the west by Nigeria. It is made up of six divisions: Fako, Meme, Manyu, Ndian Kupe Muanenguba and Lebialem. The regional capital, Buea, is situated at an altitude of 1000 masl on the southern flank 
of Mount Cameroon. The natural vegetation of most of the Southwest Region is dense, humid, evergreen forest characterized as Atlantic Biafran forest rich in Caesalpiniaceae. Extensive areas of this forest formation have been lost through agricultural expansion. Agriculture based on shifting cultivation practices is the main cause of forest loss in Cameroon (Robiglio et al. 2010). Mangroves characterize the coasts of the region, although these are being increasingly denuded through felling for fuelwood and invasion by the exotic swamp palm Nypa fruticans (Sunderland and Morakinyo 2002). An extensive mountain chain runs along the Cameroon-Nigeria border through to the Bamenda Highlands to the Adamawa Plateau in the northern savanna grasslands, where vegetation and habitat range from high-altitude and submontane forest, to savanna and alpine grassland on the highest peak, Mount Cameroon (4095 masl) (Sunderland-Groves et al. 2003). Relatively fertile volcanic soils predominate around Mount Cameroon (Watts 1994).

The region experiences high rainfall, varying from 1500 to more than $10,000 \mathrm{~mm}$ per annum at Debundscha, at the foot of Mount Cameroon; this is classified globally as the second wettest place in the world after Chiranpunji, India (Njohjam 2000). The climate is characterized by clearly recognized wet and dry seasons. Most rain falls during the months of March-September while the rest of the year remains fairly dry (McSweeney et al. 2010). However in the past 4-5 years seasonal patterns have changed resulting in increasingly rainy months from March through to November or even early December, and very short, dry seasons from December to February. The recent change in rainfall patterns has been favorable to some farmers who acknowledge that it enables them to have year-round cultivation of some food crops such as maize and vegetables. The temperature ranges from $24^{\circ} \mathrm{C}$ to $26.5^{\circ} \mathrm{C}$ (MINEF 1997) with high humidity throughout the year.

\section{Ecological context}

The region is rich in biodiversity and comprises of eight official protected areas, some of which are important biological 'hot spots' and heritage sites of global importance (e.g. the Mount Cameroon and Korup forests). These areas have attracted much interest from conservation initiatives nationally and internationally to ensure that the forests are conserved for the benefit of both humans and wildlife. In the Korup and Obang forest areas, for example, about 1050 species of butterflies have been recorded, which is the highest recorded number in Africa so far (MINEF 1997). Most of the forested area of the region has been classified into different forest-use types. These were grouped together to form technical operations units (TOUs) comprising of forest management units as well as permanent and non-permanent forests (WRI 2013). There are three TOUs in the region: Korup-Ndongere TOU, Takamanda-Mone TOU and Mount Cameroon TOU. Between 2007 and 2009, 10 national parks and wildlife sanctuaries were created in Cameroon with five of these in the Southwest Region alone; these include: Takamanda, Kagwene, Ndongere, Mount Cameroon and Mount Bakossi.

The biodiversity of the Nguti-Mundemba forest area consists of 403 vascular plant species belonging to 272 genera and 81 families. The most common plant families include: Fabaceae, Rubiaceae, Euphorbiaceae, Apocynaceae, Malvaceae, (including Tiliaceae, Sterculiaceae and Bombacaceae), Annonaceae, Meliaceae, Moraceae and 


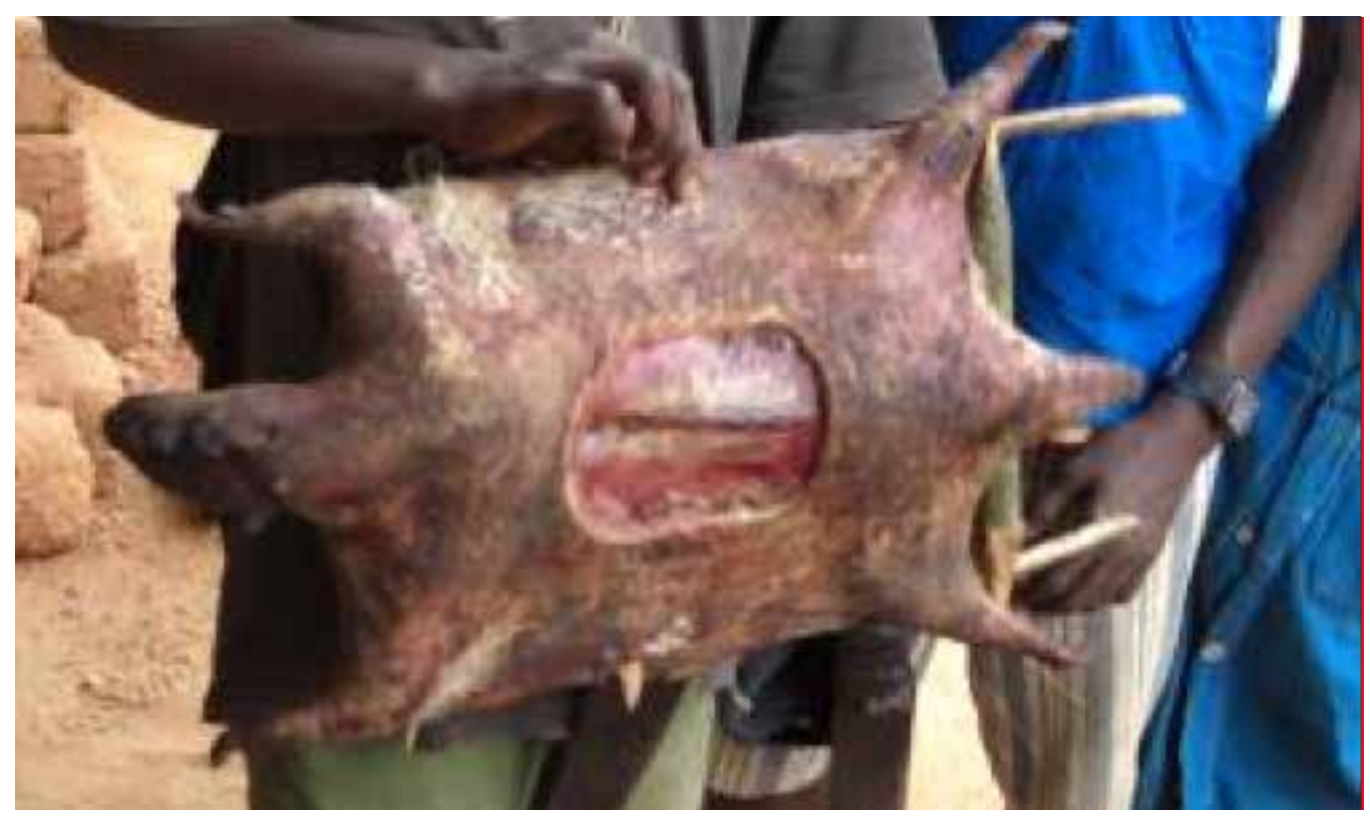

Children selling smoked porcupine. (N van Vliet/CIFOR)

Sapindaceae. Common plant species encountered are: Massularia acuminata, Pycnanthus angolensis, Rhektophyllum camerunense, Microdesmis puberula, Palisota hirsuta, Carpolobia lutea, Piptadenistrum africanum, Rothmania hispida, Anthonotha macrophylla, Cylicomorpha solmsii, Afrostyrax lepidophyllus, Amanoa strobilacea, Cola buntingii, Dicranolepis disticha, Dasylepis racemosa and Dichapetalum tomentosum (SG-SOC 2011a). Another report of the area highlights the presence of 19 species of large mammals within 13 families, including forest elephant (Loxodonta africana), drill (Mandrillus leucophaeus), buffalo (Syncerus caffer), deer (Cephalophus spp.), porcupine (Atherurus spp.), pangolin (Phataginus spp.), red colobus (Piliocolobus preussi), chimpanzee (Pan troglodytes) and water chevrotain (Hyemoschus aquaticus) (SG-SOC 2011b). The common species are hunted and trapped for consumption. The same report also lists a large number of birds, amphibians and reptiles in this forest area.

\section{Economic context}

Illegal and legal timber exploitations are a major forest activity in the region, with three official companies exploiting timber in at least five concessions. However, it is unclear how much illegal logging is actually taking place in Cameroon (Cerutti and Tacconi 2006). NTFPs are also an important source of income for forest-dependent communities of the Southwest Region and for the livelihoods of some urban dwellers who are involved in its trade (Tajoacha 2008). The trade in NTFPs is important, particularly across the porous borders with Nigeria and Equatorial Guinea. Many products, although not captured in formal revenue statistics, contribute significantly to livelihoods and an estimated production value of approximately USD 8 million per annum (Abwe et al. 1999). Ndoye et al. (1999) found that value from important NTFPs sold in markets in the humid forest region and border markets of Cameroon amounted to USD 753,000. 


\section{Settlement patterns and tenure}

Most villagers came from elsewhere to settle in the Southwest Region. After settlement, they set the boundaries with other villages using large streams, the distance to the next village on the trekking track and other landmarks. The borders remain vague and are often the cause of numerous conflicts between the villages, especially between hunters and local timber exploiters. A village closely surrounded by many other villages typically faces more difficulties with land availability than an isolated village; this is one of the reasons why one or two family heads go as far away as possible to settle and start their own small community or village.

Within villages, traditional land tenure and ownership regulations are put in place and are similar in most parts of the region, with slight differences in some places. These differences depend to a large extent on how accessible, exposed or developed the village has become. In a typical forest or remote settlement, most land is obtained and owned by the indigenes, or natives, in two ways; by natural means or by inheritance from either parent. An indigene is free to get as much forested land as they can, there is unrestricted access, no limits to how much one person can have and no control over what they want to plant. In contrast, a settler to the village does not have direct access to land. They can either buy from individuals within the village or from the village council.

The Government of Cameroon's land laws stipulate that the Government owns all the land in the country. The villagers are recognized as custodians of the land but their rights are limited. People have been unaware of this law in the past, resulting in

\section{Table 3.2 Landownership in the Nguti study area.}

\begin{tabular}{|l|r|}
\hline Landownership categories & Percentage of hous \\
\hline Self-owned & 92.7 \\
\hline Landlord/rented & 4.9 \\
\hline Owned by other household member & 1.6 \\
\hline Two party & 0.8 \\
\hline
\end{tabular}

a If a farmer cannot work on his or her farm, he or she gives the farm out to a laborer and at the end of the season the profit is shared on a 50-50 basis. This is a common arrangement for widows and older men.

\section{Table 3.3 Average number of people per household and estimated population of the three focal villages.}

\begin{tabular}{|l|c|c|c|}
\hline Villages & $\begin{array}{c}\text { No. of households } \\
\text { identified }\end{array}$ & $\begin{array}{c}\text { Average no. of people } \\
\text { per household }\end{array}$ & Estimated population \\
\hline Babensi I & 111 & 5.0 & 555 \\
\hline Babensi II & 107 & 4.3 & 460 \\
\hline Ayong & 60 & 4.0 & 240 \\
\hline
\end{tabular}


conflicts when agreements were signed for development activities to take place. Once forested land has been cultivated, ownership stays with the family and is passed on to younger generations. The different types of landownership are shown in Table 3.2.

The total population of the Nguti area is 14,600, distributed among 1435 households (SG-SOC 2011a). The population is made up of people from about nine indigenous ethnic groups and more than 14 non-indigenous groups from other parts of Cameroon and Nigeria. The estimated populations of the three focus villages are shown in Table 3.3 .

\section{Access and infrastructure}

Most of the villages in the study area are located on the Kumba-Mamfe highway and are fairly accessible year round by car, four-wheel drive vehicle and motorbike. Some of the villages can only be accessed by rocky and muddy roads, which are usually impassable during the peak of the rainy season.

The population of this area has access to two mission hospitals, the St John of God Catholic hospital at Nguti and the Presbyterian hospital at Manyemen. There are also small government health posts in some of the villages that can take care of minor illnesses, emergency cases and delivery of pregnant women. Some of the villages have piped potable water while others still carry water from streams, springs and rivers for drinking, bathing, washing and other household use. The use of chemicals for cocoa pesticides and insecticides are a common practice in the area; this a potential water contaminant, which is a major health concern in the area.

There is generally no access to electricity, even in the accessible settlements, and potable water only in a few homes. Some homes are powered by privately-owned fuel generators that are run only occasionally due to expensive running costs. There is telephone communication networks reception in all the on-road settlements but none in the less accessible settlements. News and information are received through the local Cameroon Radio and Television radio station, local radio stations in Mamfe and foreign stations, especially Akwa Ibom and Cross River FM radio stations. There is also some human movement in and out of villages, which is a common means of transmitting messages, particularly to areas with no mobile telephone networks.

The government's intention to bring education closer to the people with the aim of reducing illiteracy has created primary schools in almost all of the villages, though some are without trained teachers, classrooms, school desks and other basic needs. Secondary schools are now established in every small town or larger village to serve the surrounding population. In the Nguti area, there are government secondary schools in Nguti and Manyemen. This has encouraged education of children, although up to $14 \%$ of the adult population has had no formal education, as shown in Table 3.4. 
Table 3.4 Education levels of the adult population in the Nguti study area.

\begin{tabular}{|l|c|c|c|c|}
\hline Educational level & $\begin{array}{c}\text { No. of } \\
\text { females }\end{array}$ & $\begin{array}{c}\text { No. of } \\
\text { males }\end{array}$ & Total & Percentage of total (\%) \\
\hline None & 33 & 14 & 47 & 14 \\
\hline Primary school & 97 & 87 & 184 & 56 \\
\hline Secondary school & 40 & 52 & 92 & 28 \\
\hline University & 2 & 3 & 5 & 2 \\
\hline
\end{tabular}

\section{Market access and trading}

There are not many formal markets in the villages but trading of farm and forest products takes place. Traders from nearby towns go to these villages to purchase high market-value forest products such as bush mango (Irvingia gabonensis), njansang (Ricinodendron heudelotii), bush onion (Afrostyrax kamerunensis) and bushmeat, as well as farm products such as cocoa, plantains (Musa spp.), bananas (Musa spp.) and cocoyams (Colocasia spp. and Xanthosoma spp.). Some villagers prefer to travel further afield and take their product to local markets to sell it for better prices and to purchase other items for their households at the same time. People also buy household consumables such as sugar, soap and kerosene from small village shops and through home trading. This trading from home is small scale and seasonal, and is influenced by the availability of cocoa. The cocoa harvesting season (September-December) is a period when most people in the village have some money. During this time, both cocoa farm owners and others are engaged in cocoa activities in one way or another via harvesting, splitting, drying or transportation. Much of this money is spent on alcohol. During this season, more people come in from bigger towns to be part of this 'cash flow.' Farm laborers, motor-bike riders, traders, tailors and seamstresses, and other business people also come to take advantage of the increased business opportunities.

\section{Scoping study village descriptions}

\section{Ayong}

Ayong is located about $6 \mathrm{~km}$ off the main Kumba-Mamfe road (Figure 3.2). It is accessible by car and motorbikes on earth roads, which are often inaccessible during the rainy season. Ayong is a relatively small settlement made up mainly of cocoa farmers who are settlers from the Northwest Region and some parts of the Southwest Region of Cameroon. These people come from different ethnic backgrounds, but were attracted to this village by the abundance of forested land and their desire for cocoa cultivation. The village has a primary school and the nearest secondary school is at Manyemen, approximately $14 \mathrm{~km}$ away. There is no physical marketplace, and farm and forest products are purchased from house to house by traders from the nearby towns. They do not have access to electricity or piped water; they depend on water from streams for drinking, bathing and washing, and use kerosene lamps to light their houses. A few 'rich' people in the village own fuel generators, which are usually used only during the high cocoa season when they can afford fuel. Most of the houses are made of wooden planks with iron sheet roofs, although there are some mud houses dotted around the village. 


\section{Babensi I and II}

These two settlements are located adjacent to each other on the main highway from Kumba to Mamfe. They consist of about 200 and 100 houses respectively, most of which are made of wooden planks and iron sheets. A few houses have thatched roofs and a relatively large number have mud floors. The nearest market is at Wone, located less than $6 \mathrm{~km}$ away and situated on the main road. Here, villagers meet directly with traders from nearby villages and settlements and trade their farm and forest products. They also buy household items such as rice, soap, kerosene, clothes, matches, etc., as well as items for school for their children. They do not have access to electricity but use kerosene lamps. They both have primary schools but no secondary school. The population is mainly indigenous with only a few settlers from other parts of Cameroon. They are traditional people with Christian beliefs. The communities in these villages are dependent on farming, focusing mainly on cocoa farms and some other food crops such as plantains and bananas. These villages however are not noted for high production of any particular food crops.

\subsubsection{Land use: Changes, underlying drivers and impacts}

\section{Current and historical land-use practices}

The Nguti study area displays a mosaic of different land-use types including agriculture, human settlements, and protected and unprotected forest areas (Figure 3.3), all of which have undergone changes over the years.

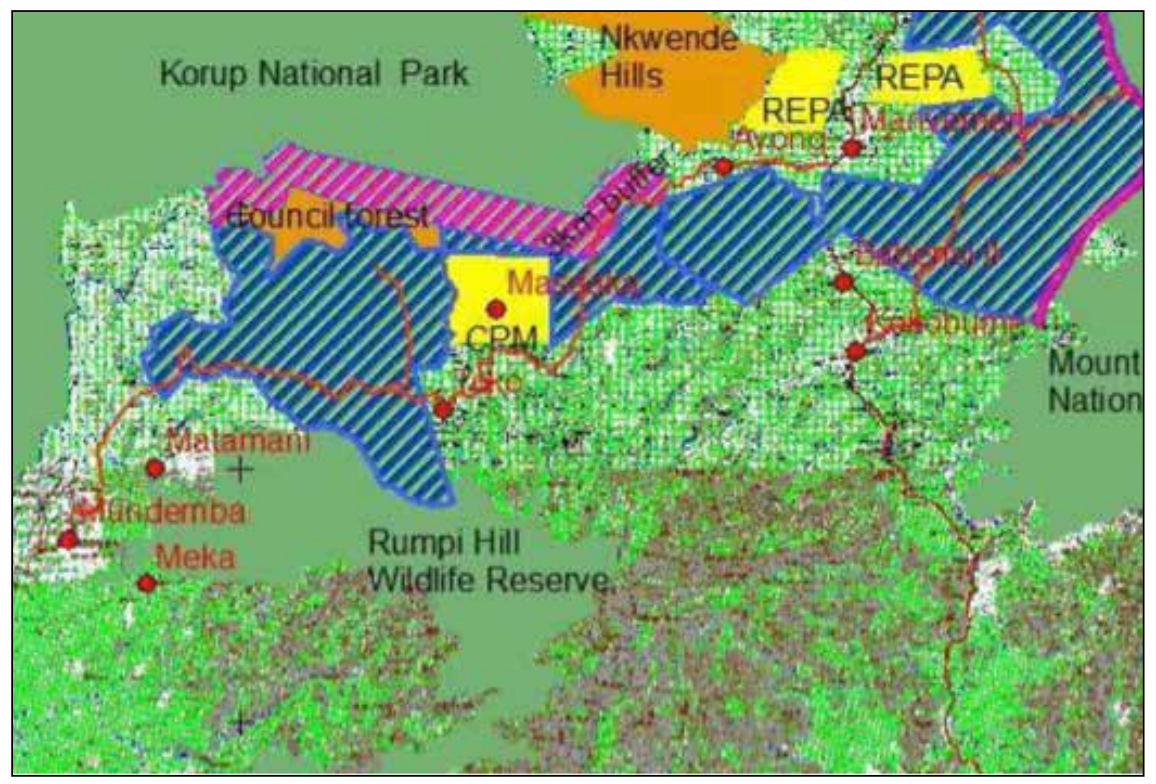

\section{Figure 3.3 Map highlighting different land-use types in Nguti study area.}

Note: Blue hashed area = SG-SOC oil palm plantation; red dots = settlements; red lines = roads; orange blocks = council forests; green blocks = national parks/reserves.

Source: SG-SOC (2011a) 


\section{Traditional agriculture}

Currently, the primary land use is agriculture, consisting of shifting cultivation (slash-and-burn) for primary subsistence purposes, vegetable gardens to supplement subsistence crops (cassava [Manihot esculenta], plantains, bananas, cocoyams) and perennial cash crops such as cocoa, coffee and oil palm. Livestock production is poor in the area and domestic animals are raised more for ceremonial occasions and honored guests rather than for household consumption. Over the last 10-12 years, cocoa prices have increased (Figure 3.4), which has resulted in more cocoa farming. This has been a major driver of population increases and in-migration to the area, especially from the Northwest Region of Cameroon and from Nigeria.

Shifting cultivation has been an indigenous farming practice in the study area for many years, where forested land is slashed and burned, cultivated for about 2 years and left to lie fallow for 2-3 years. However, in the last few decades, this has not been the case as jobless young people from cities flood the rural areas and retired people go back to the villages to concentrate on farming. Rich people from the cities also buy large portions of land for food crops and perennial cash crop plantations (personal communication from Chief Ebene, 2013). High demand for food crops from neighboring countries (Weise 2009) and the development of access roads, have instigated these changes. These factors have all increased demand for land, leading to shortages of cultivable lands in most areas and increasing use of degraded lands that have not been left fallow for long enough or at all.

Annual cropping farms are generally found in degraded areas with very little tree cover, and are generally called 'secondary bush.' These areas are suitable for annual crops that demand a good amount of sunlight. The crops planted here include maize (Zea mais), groundnuts (Arachis hypogaea), yams (Discorea spp.), cassava, sweet potatoes (Ipomoea batatas), cocoyams, egusi (Cucumeropsis mannii) and some common vegetables. Most of the food crops are harvested within 3-7 months of planting. Cassava is usually left and harvested a year or two later, depending on the variety. During this time, the farm undergoes some degree of fallowing before it is re-cultivated. Mixed cropping is common practice in both food crops and perennial cash crop farms. During the high farming season in February and March, it is common to see cassava, yams, groundnuts, beans (cowpea, [Vigna spp.]), maize and cocoyams planted on the same area of land. They mature at different times and are harvested accordingly. Cocoa is also cultivated with plantains, banana, fruit trees and vegetables. With increasing awareness of agroforestry farming systems, some NTFPs are being incorporated among cocoa plantations.

Horticultural practices are usually carried out in farm areas close to the villages or in home gardens in the backyard. Horticultural farms range from small vegetable farms along streams and rivers or in swampy areas to plantains, banana, fruits and vegetables in small patches around the village. 


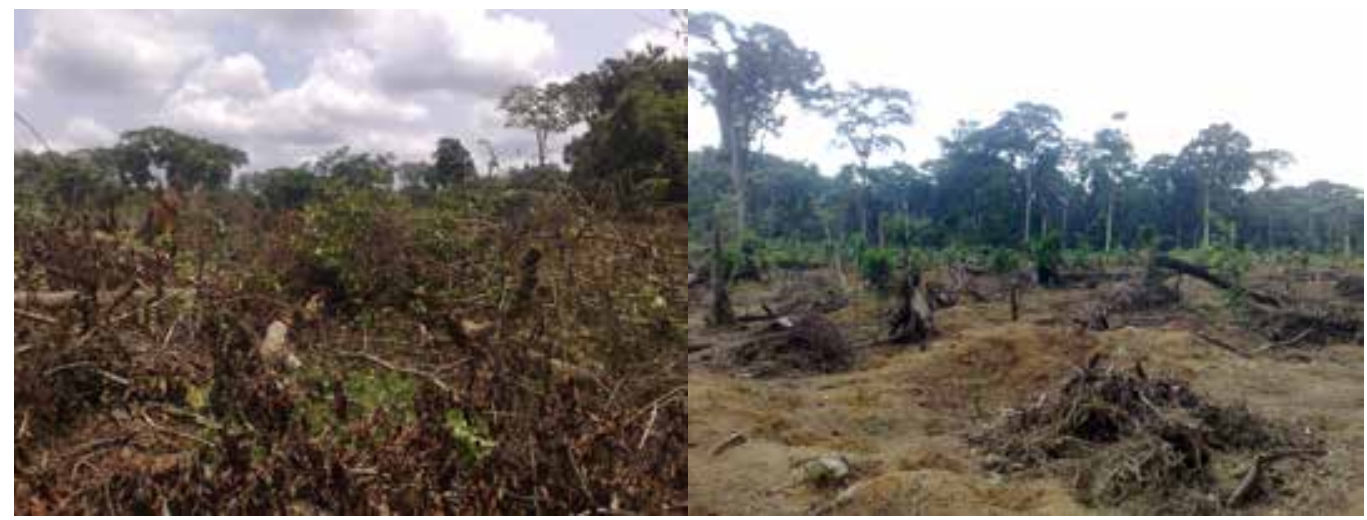

'Slash and burn' farming system. (Stella Asaha/FOREP)

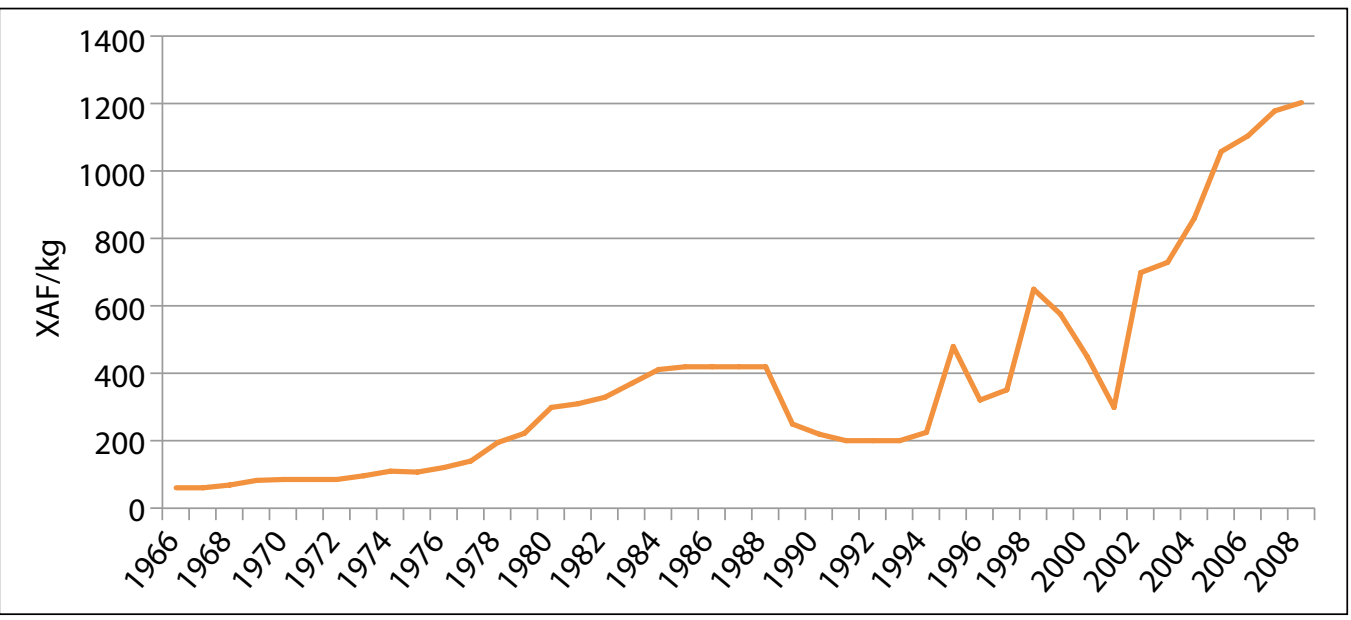

Figure 3.4 Mean annual buying prices of cocoa in Cameroon in Central African Franc (XAF) per kilogram.

Source: Blaevoet (2010)

\section{Forest cover}

Primary forests. These are undisturbed forests with more variety of plants and animals, which provide food, medicine, fuelwood, timber for construction and other services. In addition to its importance for the above-mentioned uses, some communities value this as future farmland for cocoa expansion.

Secondary forests. Abandoned farms and degraded forest are commonly called secondary forest. They are of different levels depending on how long they have been abandoned for. Very old secondary forest with a considerable amount of forest regeneration can be cleared for cocoa planting as it has gained humus over the years. The younger secondary forests are 'slashed and burned' for other food crops cultivation. 
Cocoa agroforest. These are cocoa plantations with different types of trees: timber, fuelwood, NTFPs and edible fruits. This is very common in the landscape; cocoa agroforestry systems with up to 40\%-50\% tree cover are usually hidden under the canopies of secondary forests and can be mistaken for perfect tree cover from satellite images. Cocoa agroforests are common in more accessible areas to ease transportation of the products to nearby towns. Accessibility attracts more farmers to cocoa and oil palms. This may be one of the reasons why according to the preliminary land-use change analysis, this landscape consists primarily of forest loss along or near the major roads.

\section{Protected areas}

The research area features four main protected forest areas (classified and proposed) in close proximity to one another, created mainly for conservation interests to protect key plant and animal species. The Korup National Park is the largest and oldest protected area. It was created in 1986 and has an area of 125,900 ha. Banyang Mbo Wildlife Sanctuary covers a land area of 66,000 ha and was created in 1996. Mount Bakossi is the youngest; it was officially designated as a national park in 2007 and covers a land area of 29,320 ha. The Rumpi Hills, with a land surface area of 45,675 ha, is still under processing to be approved as a national park.

\section{Timber exploitation}

Timber exploitation in this area has been carried out mainly on a small scale, providing wood to the domestic markets. More than $90 \%$ of this is illegal and is conducted with no permit of any kind (personal communication from L Aserk, 2013). The area has however experienced some commercial logging in the past decades; Forest License No. 1669 of surface area 26,800 ha was granted to Transformation Reef Cameroon, a company that carried out the exploitation from 1987 to 1991, and Vannier in the 1970s (MINEPAT 2007).

\section{Oil palm plantations}

The establishment of oil palm plantations is not new to the Southwest Region as a whole, but in 2010 the Herakles Farm and SG-SOC plantation began in the Nguti area. SG-SOC is new in Cameroon and intends to establish fairly large plantations of oil palm in the Nguti area. The initial negotiation by SG-SOC has given them access to 70,000 ha of land spanning across two Divisions of the Southwest Region (Kupe Muanenguba and Ndian divisions) and engulfing the entire Nguti study area. The plantation also cuts across three local tribal groups: the Oroko, Bassossi and Ejagham groups. The allocated land is bordered by four 'permanent forest' areas - Korup National Park, Banyang Mbo Wildlife Sanctuary, Rumpi Hills and the Mount Bakossi National Park - and is in a forest area that has 31 villages with an estimated human population of 14,600 (SG-SOC 2011a).

The influx of agro-industrial farms coupled with the increasing prices of palm oil in Cameroon (Figure 3.5) has motivated farmers to include oil palm in their agroforestry systems or in some cases establish oil palm monoculture farms. The historical trend exercise with men in the study area revealed a shift in interest from cocoa to oil palm, with the main reason being encouraging domestic prices for palm oil. 


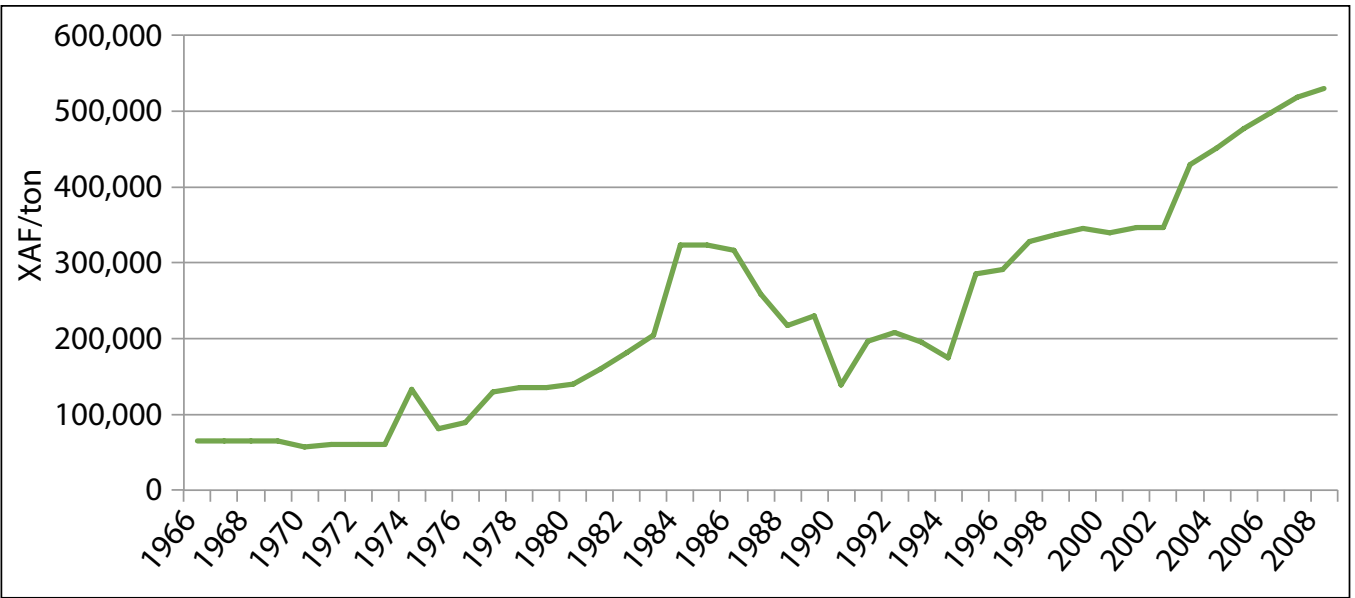

Figure 3.5 Mean annual buying prices of palm oil from Cameroon producers in Central African Franc (XAF) per ton.

Source: Blaevoet (2010)
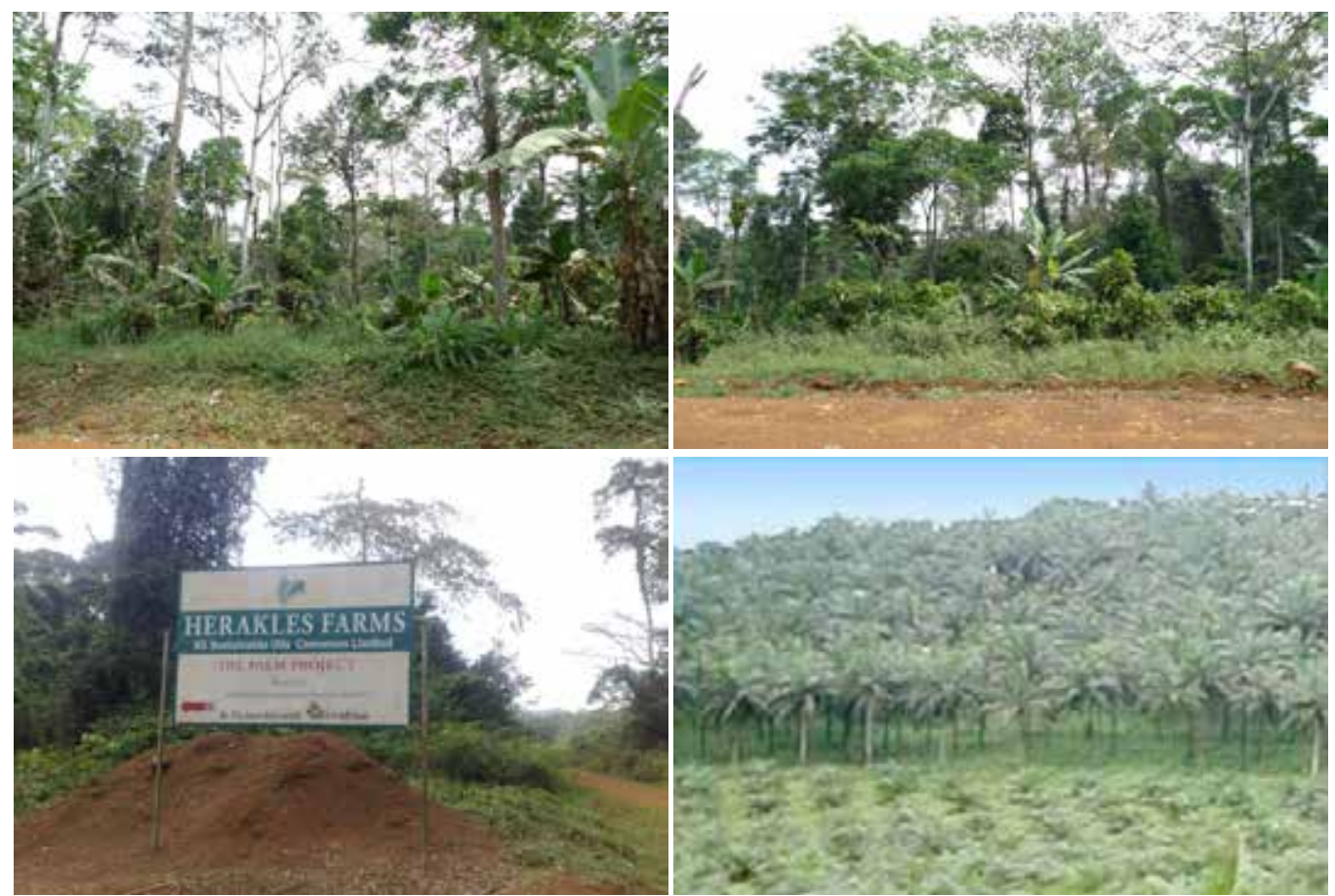

Different land-use types in the research site: banana and plantains agroforest (top left), cocoa agroforest (top right), SG-SOC nursery signpost and young (bottom left), and old oil palm plantations (bottom right). (Stella Asaha/FOREP) 
There are, however, some potentially negative consequences of such large-scale land acquisition for local people. If small-scale farmers currently use the land, it can result in the loss of the resources on which they depend for their food security and livelihoods. Furthermore, agro-industrial expansion may have negative impacts on the natural resource base, including air quality, water and biodiversity (Wilcove and Koh 2010).

\section{Deforestation and land-use change analysis}

A preliminary spatial analysis of forest cover change was performed on the Northwest Region of Cameroon using two Landsat images from December 2000 and two images from January, 2014. Images were converted to top of atmosphere reflectance and the NDVI was calculated. Figure 3.6 depicts the protected areas included in this study. There was a high level of cloud contamination especially along coastal regions, which will warrant additional analyses. A digital elevation model (not shown) was also derived from raster imagery. An improved GIS layer of national park boundaries was obtained which should also aid interpretation of landscape change results. This will enable a better depiction of elevation for the region and terrain information that will be useful in interpreting the results. The land-use change analysis was limited by the small number of Landsat images available for this region and the high degree of cloud contamination in the imagery. However, initial analyses showed that forest cover within protected areas appears to be mostly stable and possible construction of new roads was evident in Korup National Park between 2000 and 2014. Landscape change consisted primarily of forest loss along or near the major roads and outside of the park boundaries. This appears to be accelerating.

\section{Local rules governing the use of natural resources}

The use of other natural resources, especially forest resources, are generally free to the indigenes of a particular community except resources within the boundaries of protected areas, which are governed by a specific management plan. Communities have user rights to the resources in their area but this is limited to exploitation for use, not for commercial purposes. Access to the forest for NTFP collection, hunting and fishing is free to any indigene without restrictions and these resources are under no form of family or individual ownership. Timber trees and NTFPs found in farmlands or secondary forest are considered privately owned, meaning anyone who might exploit them would be considered a trespasser or thief.

\section{Local perceptions of land-use change and associated drivers}

The historical trends exercise conducted in the villages revealed some of the changes that have taken place over the last 20-30 years. Villagers noted a reduction in primary forest cover and the primary reason for this was cited as increased agricultural activities. The disappearance of primary forest was mentioned as the main reason for the dwindling resource base of NTFPs. This has encouraged the domestication and cultivation of some high-income generating NTFPs such as bush mango (Irvingia gabonensis,) eru (Gnetum africanum) and bitter cola (Garcinia kola). 


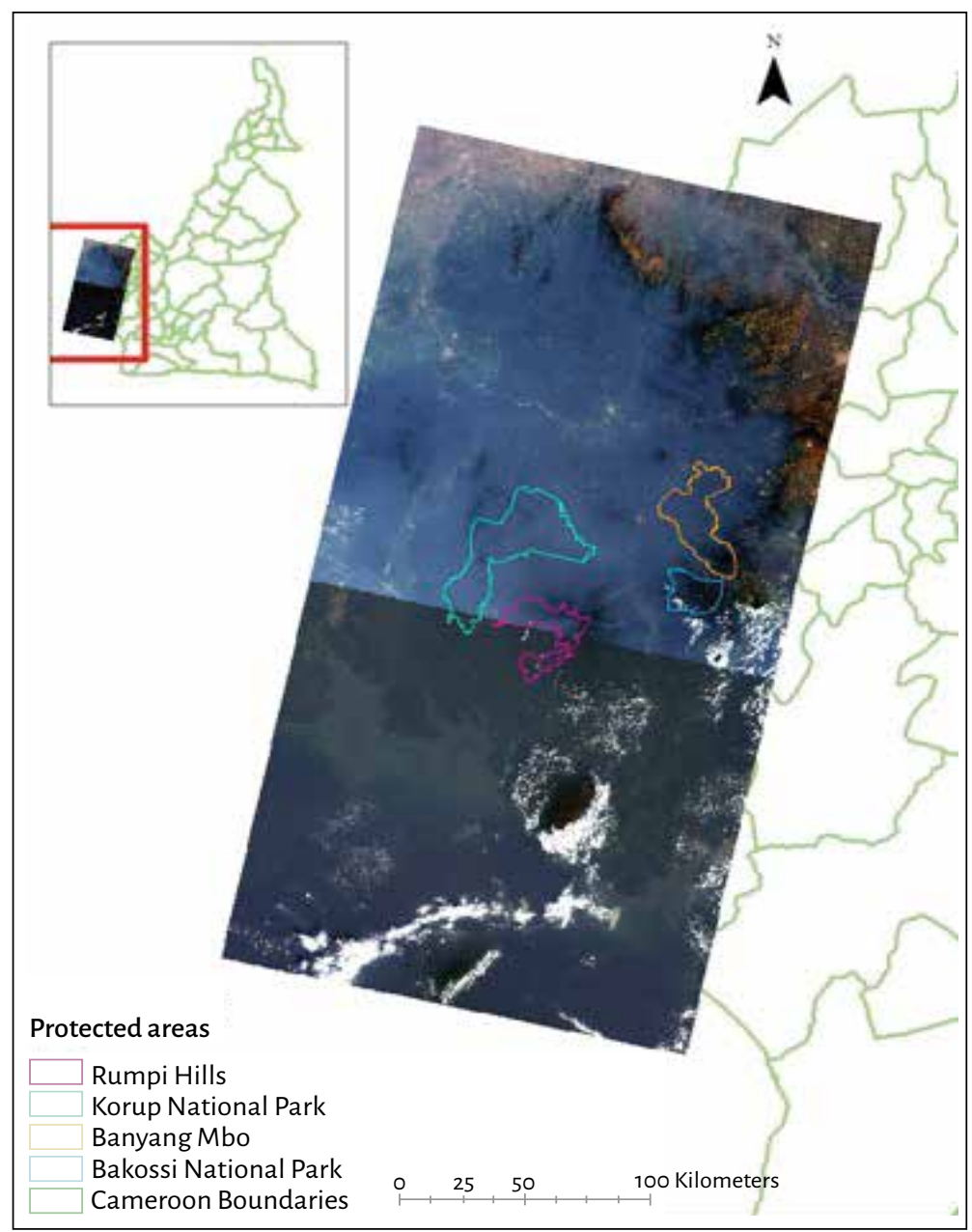

\section{Figure 3.6 Map of the extent of the study area and the boundaries of the selected protected areas of interest.}

Note: Two image tiles were needed to cover the area of interest. Imagery depicted is from Landsat 8 , captured January 2014.

Source: Sarah Gergel, University of British Columbia

Prior to the late 1970s, coffee was the main perennial cash crop and villagers were highly dependent on it for income in addition to the sale of bushmeat. Then cocoa was introduced in the late to mid-1970s, but at a minimal level, until there was a shift in interest from coffee to cocoa. This shift became very effective and widespread when the farmers experienced a drastic fall in coffee prices in the early 1990s. At this time more efforts were put into cocoa production. Cocoa has undergone many fluctuations in price, which has also affected farmers in the past. However the steady increase in price from the year 2000, saw the cocoa prices rising from XAF 300 per kg to up to XAF 1600 per $\mathrm{kg}$ in 2004/2005. Population increase has been the main driver for the increase in the number of cocoa farms. Young people grow up and open up new farms as well as expand the farms they inherit from their parents. 


\begin{tabular}{|c|c|c|c|c|}
\hline $1970-1980$ & $1980-1990$ & $1990-2000$ & $2000-2010$ & 2010-present \\
\hline \multicolumn{5}{|l|}{ Primary forest cover } \\
\hline \multirow[t]{2}{*}{ 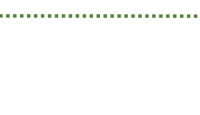 } & . & . & ........... & \\
\hline & & & Decline due to forest cle & ring for agriculture \\
\hline \multicolumn{5}{|c|}{ Agricultural practices } \\
\hline $\begin{array}{l}\text { Coffee } \\
\text { First cash crop } \\
\text { introduced }\end{array}$ & $\begin{array}{l}\text { Cocoa } \\
\text { Fall in coffee prices }\end{array}$ & $\begin{array}{l}\text { Cocoa } \\
\text { Fall in cocoa prices mid } \\
90 \text {, then rise in } 2000 \text { due } \\
\text { to Ivory Coast war }\end{array}$ & $\begin{array}{l}\text { Cocoa, palm oil } \\
\text { Secure market for palm } \\
\text { oil due to high local } \\
\text { consumption }\end{array}$ & $\begin{array}{l}\text { Cocoa, palm oil } \\
\text { Secure market for palm } \\
\text { oil due to high local } \\
\text { consumption }\end{array}$ \\
\hline \multicolumn{5}{|c|}{ Number of cocoa farms } \\
\hline Low & Low & $\begin{array}{l}\text { Medium } \\
\text { Increase in number of farm }\end{array}$ & $\begin{array}{l}\text { Medium } \\
\text { s due to migration to the a }\end{array}$ & $\begin{array}{l}\text { High } \\
\text { ea and population increase }\end{array}$ \\
\hline \multicolumn{5}{|l|}{ NTFP availability } \\
\hline & & & $\begin{array}{r}----- \\
\text { Declinedu }\end{array}$ & to forest loss \\
\hline
\end{tabular}

\section{Figure 3.7 Historical land-use trends in the Nguti study area.}

The cultivation of oil palm has been a common practice in recent years. Usually the palms are not planted by the farmers but appear through natural seed dispersal by rodents. These local palms provide families with palm oil and palm wine. In 2009 and 2010 there was an increase in interest in oil palm cultivation, attracting elites to country sites to purchase large tracts of land for this purpose (e.g. SG-SOC). The main motivation was the high rate of palm oil consumption locally in the form of vegetable oil, soap and cosmetics. These changes in land use and the perceived drivers of the change by villagers are summarized in Figure 3.7.

\section{Community land-use valuation}

From the habitat valuation exercise using the pebble distribution method, the valuation of land-use types was limited to primary forest, secondary forest, farmland, streams/rivers, swamps and home gardens (Figure 3.8). These were identified as important habitat types, valued for their different uses by the men and women of the communities (Figure 3.8). Both groups attached high value to farmland and secondary forest. While women valued home gardens as a source of vegetables and other food crops, the men did not value it as highly.

Primary forest was valued for its forest products including bushmeat for subsistence and income, as a source of fuelwood, traditional medicine and timber, for carrying out traditional rituals, and for future farmland for the expansion of cash crops. Meanwhile, secondary forest, which has already been exploited, was equally valued as a source of some forest products such as njansang, food crops, and wood for house construction and making other tools. 


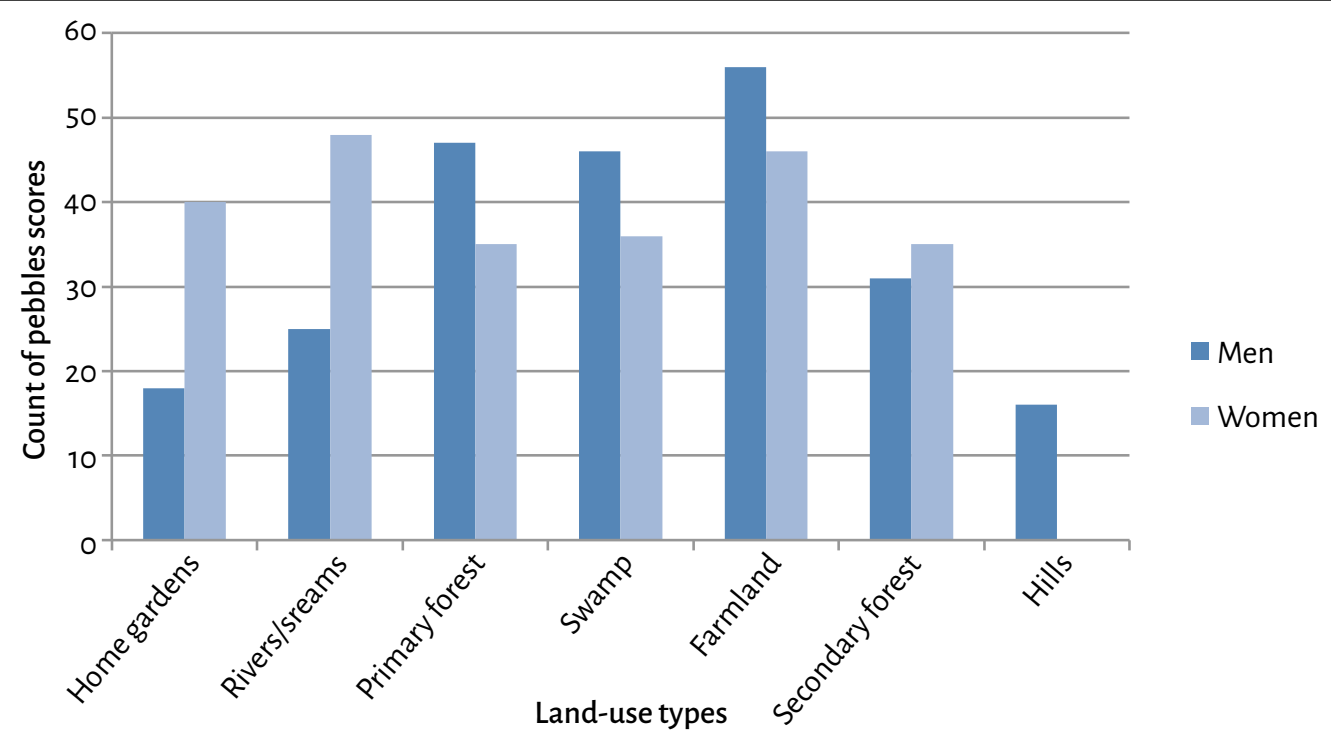

Figure 3.8 Summary of the scores from the land-use valuation by men and women in the three focal villages.

Farmland was ranked highly as a provider of food for families as well as for sales from farm produce. Streams and rivers were also valued highly but only by the villages that had a stream or river in close proximity. They were valued for fishing, providing water for other human uses including drinking and domestic uses, and for mixing of chemicals for cocoa spraying. Swamps were used during the dry months of the year, particularly for crops cultivated twice a year such as maize, beans and vegetables, because of the retained moisture. Due to this swamp access, during the dry season women could make considerable income and households had access to vegetables. Swamps were usually closer to homes and served immediate kitchen needs such as home gardens. Men used swamps and home gardens in various ways but swamps were often more appreciated by women, who cultivated varieties of vegetables, fruits, medicines and spices on them.

\section{Primary forest-use valuation}

The forest-use valuation exercise, which used the pebble distribution method, showed that there were contrasting views between men and women on the value of different forest uses. However, both men and women valued the forest as a source of water (Figure 3.9). The higher values assigned to water indicate that local people recognized the benefits of the forest related to the water catchment.

Both men and women did not place a high value on the forest as a cultural heritage site. This is thought to be due to the introduction of Christianity, which has gradually diverted people's attentions from culture and tradition. Generally, women seemed to value the forest higher than men did as women tended to value it for food, fuelwood, income and water. Men usually focused more attention on farm income than income from the forest. This was evident in most of the communities, especially the more accessible ones where, 


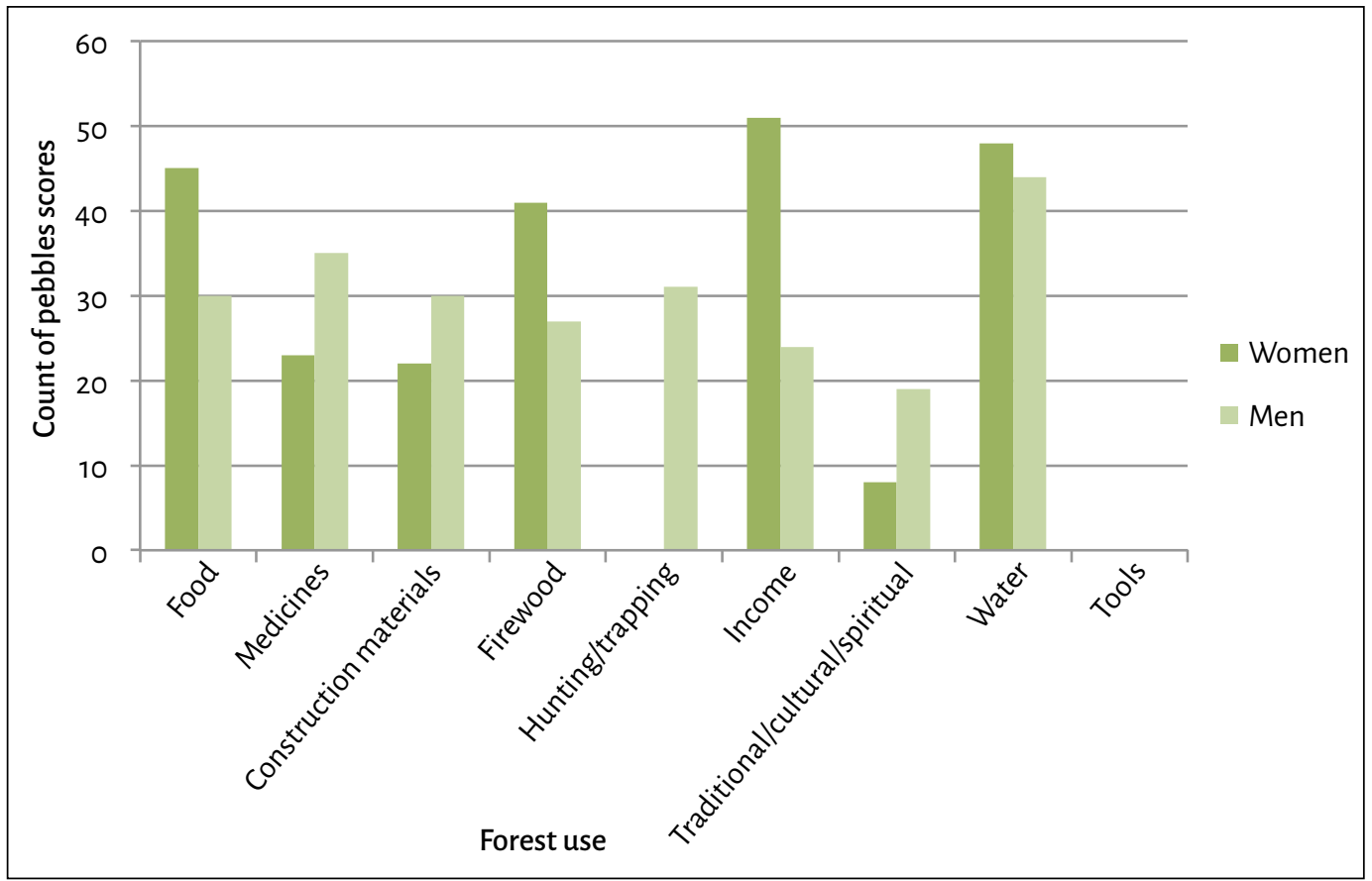

Figure 3.9 Summary of the scores from the forest-use valuation by men and women in the three focal villages.

unlike women, most men are dependent on perennial cash crops for income than on bushmeat or other forest activity. In the less accessible settlements it is easier to market forest products than farm products. For example buyers from towns and neighboring Nigeria will travel to the villages to purchase bush mango, eru, bitter cola and njansang, rather than cocoyams, cassava or plantains. Cocoa buyers will also go to extreme lengths to purchase cocoa in the most remote areas, giving the men reason to place a higher value on farming than on forests.

\subsection{Interventions}

\subsubsection{Protected areas}

From the early 1980s, the international community showed renewed interest in expanding the protected areas network in Cameroon (Table 3.5). Mainly driven by biological researchers and the rapidly increasing global interest in biodiversity conservation (outcomes of the Rio Convention and the Convention on Biological Diversity), international conservation NGOs - principally WWF and Wildlife Conservation Society (WCS) - proposed and/or supported the creation of new protected areas, or the upgrading of some existing forest reserves to national parks. These projects typically came with substantial funding in the form of bilateral aid projects supported by the British and German development cooperation agencies and the European Union. 


\section{Table 3.5 List of protected areas in the Southwest Region of Cameroon (not including forest reserves).}

\begin{tabular}{|l|c|c|}
\hline Name of protected area & Date of designation & Area (ha) \\
\hline Korup National Park & 1986 & 129,457 \\
\hline Mount Bakossi National Park & 2007 & 29,320 \\
\hline Mount Cameroon National Park & 2009 & 64,677 \\
\hline Takamanda National Park & 2008 & 67,599 \\
\hline Rumpi Hills & In process & 45,675 \\
\hline Banyang Mbo Wildlife Sanctuary & 1996 & 66,000 \\
\hline Ndongere National Park & In process & 233,400 \\
\hline
\end{tabular}

Source: WRI (2013)

Higher priority was given to protection of the biodiversity in the Southwest Region compared to other regions. Four of the 24 national parks in Cameroon are located in the southwest, even though it represents just $5 \%$ of national territory.

During the past 27 years, the following forest reserves in the Southwest Region have been modified and upgraded to the status of national parks:

- Korup Forest Reserve became Korup National Park

- Takamanda Forest Reserve became Takamanda National Park

- Part of Bambuko Forest Reserve became Mount Cameroon National Park

- Monts Bakossi Forest Reserve became Bakossi Mountains National Park.

In addition, three new protected areas have been proposed but have not yet been gazetted:

- Ndongere National Park (in the mangrove forests of the Bakassi Peninsula)

- Kupe Integral Ecological Reserve

- Muanengouba Integral Ecological Reserve.

In the high conservation value areas within the study area (Mount Cameroon National Park, Mokoko Forest Reserve, Korup National Park, the Banyang Mbo Wildlife Sanctuary and the Rumpi Hills), past and existing interventions funded by national and international organizations such as GIZ, WCS, WWF, Rumpi Hills Development Project and other local NGOs have worked in close collaboration with the Ministry of Forestry and Wildlife (MINFOF).

WCS carried out conservation activities to create the Banyang Mbo Wildlife Sanctuary from the mid 1990s to the early 2000s. The main focus was the protection of wild animals including the forest elephants common in the area. In the early 1990s the Korup National Park attracted a lot of attention from international donors including the UK Department for International Development (DFID), the European Union, GTZ (now GIZ) and USAID, who all contributed toward the conservation of a cultural heritage site in one of the oldest forest areas in the world. However, by 2000 , almost all of these donors had withdrawn support and the Government of Cameroon was left to continue 
the conservation activities. Progress was slow and conservation was unsuccessful. The German Development Bank (KfW) then came in to support MINFOF in its Program for the Sustainable Management of Natural Resources in the Southwest Region. This program began operating in 2006 and supports conservation and development activities in the Korup, Takamanda and Mount Cameroon National Parks and more recently in Banyang Mbo Wildlife Sanctuary.

\subsubsection{Community forests}

The Government of Cameroon's main goal is to decentralize forest management to democratic and community management. The Cameroon 1994 Forestry Law was introduced and gave local communities the legal right to manage and exploit the forest for livelihoods as well as community infrastructural development. These regulations outline a process whereby communities can enter a 25-year agreement with the government for the management and exploitation of a part of the non-permanent forest estate (Acworth 2011). Although this has been implemented - 178 community forests with final management plans were established by 2009 (WRI 2013) - there were some limitations including the hijacking of the community forests by some elites. Some of the limitations were portrayed in the manual of procedure, which was reviewed by local NGOs and the government in 2009.

\subsubsection{Council forests}

Council forests were introduced in 2007, when it was realized that there were some loopholes in the management of community forests. Unlike community forest, council forest is managed by the local council but has a committee made up of representatives of the villages bordering the forest in question. Bordering the proposed SG-SOC plantation plots in the Nguti study area, there are two council forests located in the buffer zones of the Korup National Park and the Banyang Mbo Wildlife Sanctuary that are managed by the Mundemba and Nguti councils, respectively. The Mundemba Council Forest was established in 2010 and covers an area of about 36,000 ha while the Nguti Council Forest is about 12,000 ha and was established in 2009.

\subsubsection{SG-SOC oil palm plantation}

Herakles Farms is a US-based company that went into partnership with SG-SOC to establish oil palm plantations in the Southwest Region of Cameroon. In September 2009, it officially signed an agreement with the Government of Cameroon in which 73,080 ha of land was allocated to SG-SOC to develop oil palm plantations including the operation of at least one oil mill. SG-SOC is committed to developing and maintaining a sustainable, environmentally sensitive oil palm project with wide-reaching benefits for many aspects of the Cameroon economy and the local communities (SG-SOC 2011a). This plantation spans across two divisions of the Southwest Region (Kupe Muanenguba and Ndian divisions), within the customary boundaries of 31 villages with varying characteristics related to infrastructural development and access to social amenities (including the three villages selected for the scoping study - Figure 3.10). The agreement was signed with the Ministry of Economy, Planning and Land Administration, in which the latter committed itself to find and allocate an unspecified amount of land through a 99-year lease around the area of Nguti and Mundemba (Acworth 2013). 


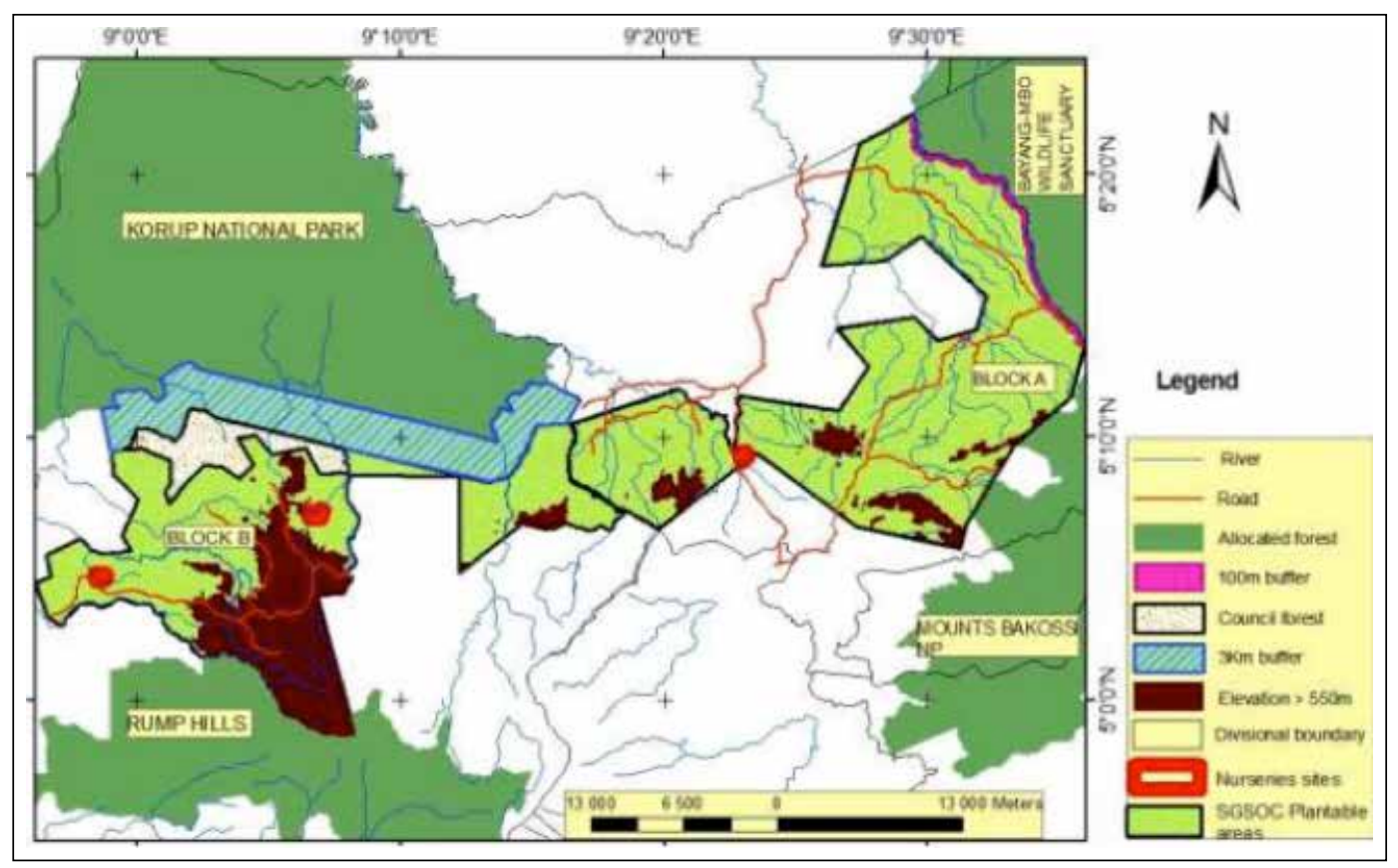

Figure 3.10 Location map of SC-SOC plantation.

Source: SG-SOC (2011a)

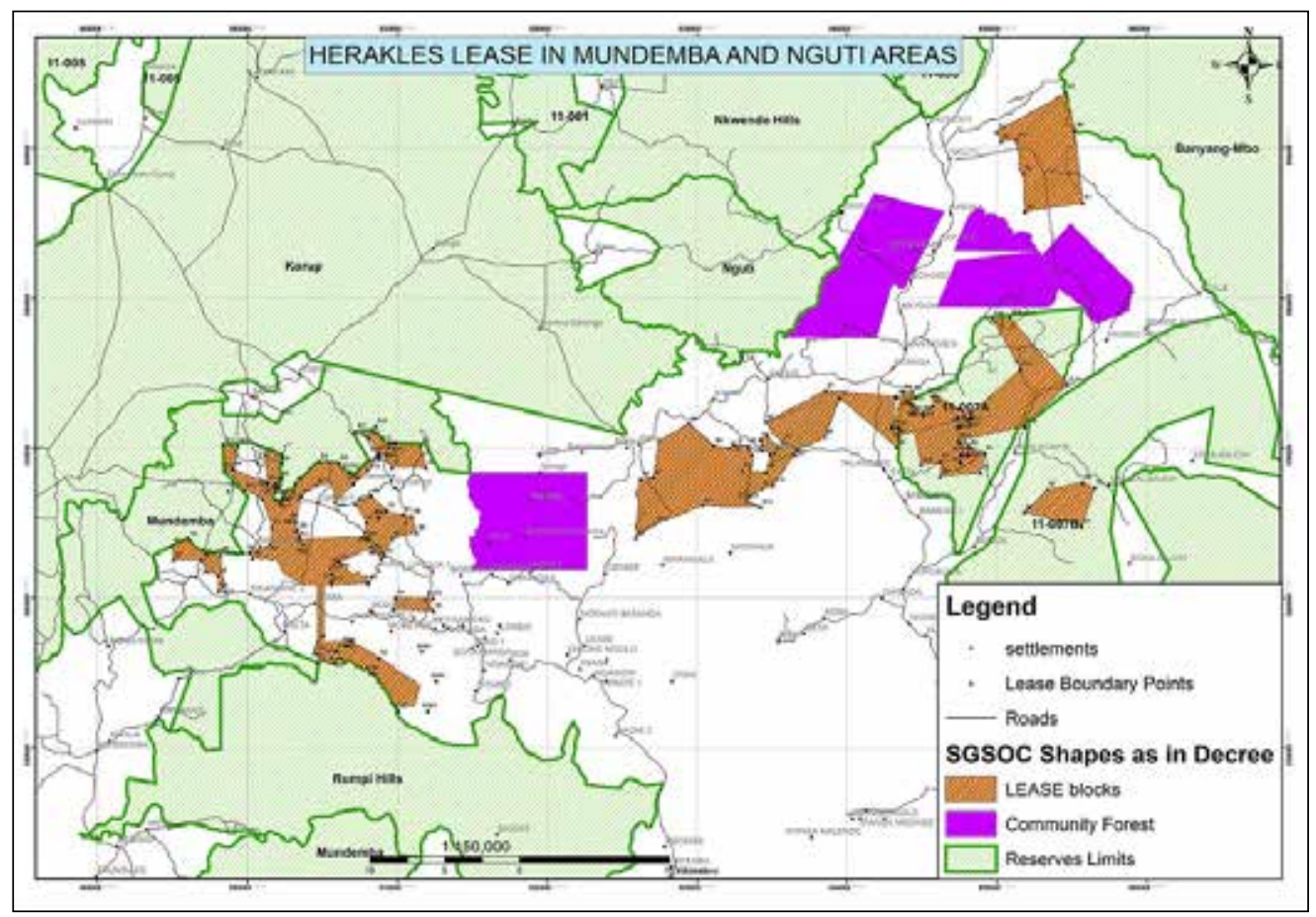

Figure 3.11 New SG-SOC allocated land.

Source: Map produced by Bakia Mor-Achankap (MINFOF) 
The expansion may lead to loss of traditional relics such as sacred trees and sites, and would definitely put more pressure on remaining lands for cultivation of food and cash crops and on the remaining primary forest. The company authorities ignored local opposition from villages despite that local cultural and international organizations were in strong opposition of the activities of the plantations. The protesting groups cited lack of transparency, lack of concern of local communities, illegal demarcation, clearing of land and potential adverse effects on livelihoods (Nguiffo and Schwartz 2012). Following these protests and criticisms, the government went back to review the signed document and eventually reduced the allocated land to less than half of its original size (Figure 3.11). The current size now stands at 23,000 ha. The protests and review process has greatly reduced the activities of SG-SOC in the field. Currently only about 600 ha of the land has been planted, despite the large nurseries that were created in different parts of the site in 2009.

\subsubsection{Other external interventions}

Analysis from the field shows that the livelihoods of most of the households in the research site mostly depend on agricultural activities. Most of these activities are conducted without government or external support. However, in some more accessible areas of the research sites, there was some degree of support received from the Ministry of Agriculture and Rural development (MINADER) and/or the Ministry of Fisheries, Livestock and Animal Industries (MINEPIA). This was usually more technical support through on-farm training in cocoa and other farm product cultivation, as well as animal rearing (mainly pigs, goats and chickens). MINFOF in collaboration with other international organizations has been active in conservation of the forest especially in and around the protected areas (Table 3.6). Some local NGOs with external funding also intervened in these areas with development programs that aimed to improve farming, empower women, and provide education and infrastructural activities. Before the arrival of Herakles Farms in 2010, these remote, inaccessible settlements were occupied mainly by cocoa farmers. The fight to stop the expansion of the plantation has exposed the site to many organizations from within Cameroon and abroad who work with the villages to demand fair negotiations or total abolishment of the project.

\section{Table 3.6 Interventions within the Nguti research area.}

\begin{tabular}{|l|l|l|l|}
\hline Intervention & $\begin{array}{l}\text { Implementing or managing } \\
\text { agency }\end{array}$ & $\begin{array}{l}\text { Funding } \\
\text { source }\end{array}$ & Date \\
\hline SG-SOC plantation & Foreign company (Herakles Farms) & Private & 2010 \\
\hline Council forests & MINFOF & KfW & 2009 and 2010 \\
\hline Korup National Park & MINFOF, GIZ and WWF & KfW & Ongoing \\
\hline Banyang Wildlife Sanctuary & GIZ & KfW & Ongoing \\
\hline $\begin{array}{l}\text { Forest management unit } \\
\text { (logging concession) }\end{array}$ & Government of Cameroon & $\begin{array}{l}\text { Logging } \\
\text { companies }\end{array}$ & 2012 \\
\hline
\end{tabular}

Source: WRI (2013) and field data 


\subsection{Livelihoods, poverty and nutrition}

\subsubsection{Livelihood options}

In the villages in the study area, people depend on at least one activity for income, including farming, collection of forest products and small businesses. All the villages reported very low or no value for forest incomes. Forest products were considered to be a subsidiary income source and hence not much importance was attached to it. All of the sites have a very high population of settlers; generally these groups were denied access rights to forest resources unless they paid extra money to the village council, although this did not happen very often.

\section{Farming}

In the three villages in the scoping study, as in other rural settlements in Cameroon, farming plays a key role in the lives of the people as its products provide food and income. Farming of both perennial cash crops and food crops is quite intensive; cocoa and oil palm are the main perennial cash crops and cassava, plantains, banana, cocoyams and egusi are the main income-generating food crops (Figure 3.12).

\section{Non-timber forest product harvesting, hunting and fishing activities}

Forest income barely features as an income source (Table 3.7) but NTFPs are commonly used and have traditionally been an integral component of forest livelihoods. Although they are not valued as important sources of income by most households, they are still collected for subsistence. However, modernization has limited the use of some products. For example, the use of modern medicines have replaced the use of herbs used previously, whilst the use of garlic, onions and purchased stock cubes have

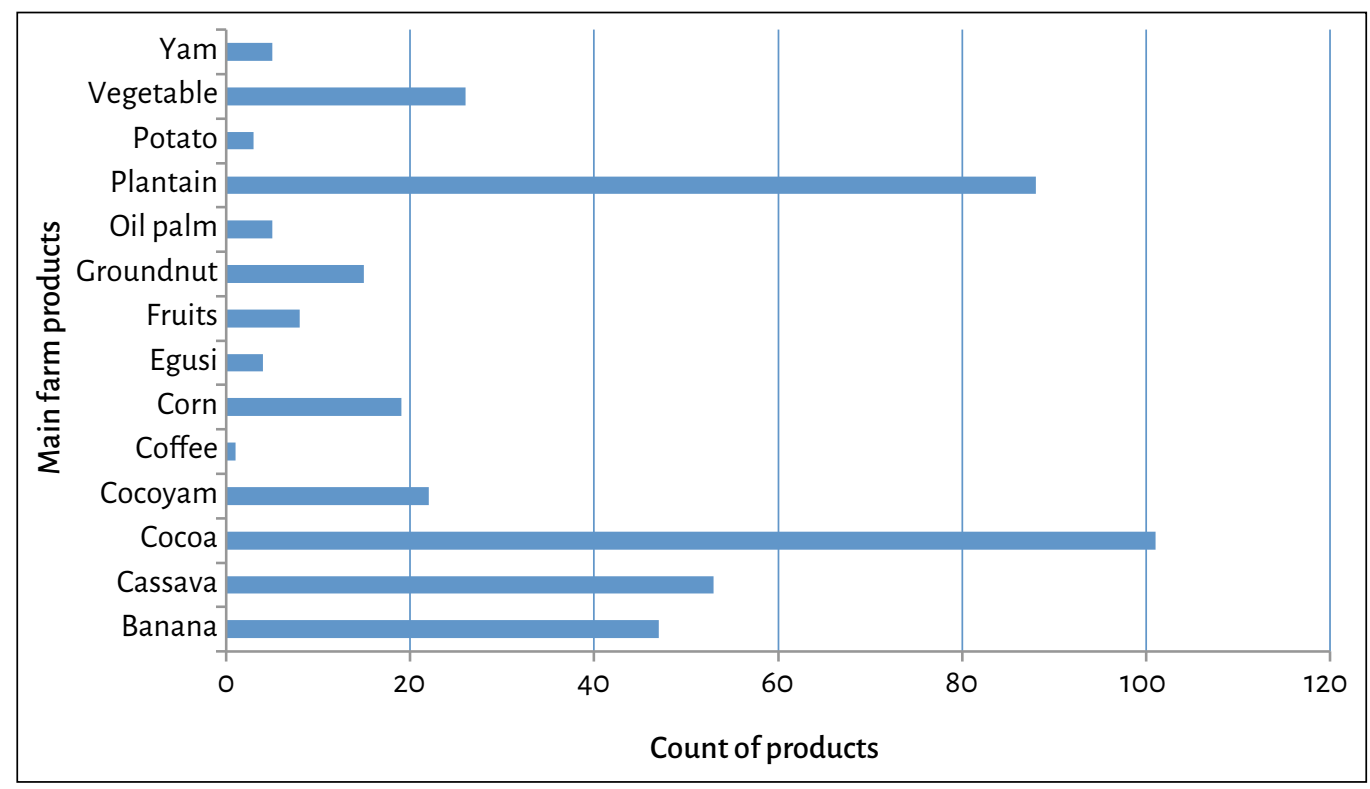

Figure 3.12 Main farm products in the study area. 
Table 3.7 Income summary for the most common income-producing products.

\begin{tabular}{|l|c|c|c|}
\hline Products & $\begin{array}{c}\text { Lowest annual } \\
\text { income (XAF) }\end{array}$ & $\begin{array}{c}\text { Highest annual } \\
\text { income (XAF) }\end{array}$ & Mean annual income (XAF) \\
\hline Cocoa & 37,500 & $3,600,000$ & 739,456 \\
\hline Palm products & 25,000 & $1,200,000$ & 319,250 \\
\hline Cassava & 2,000 & 750,000 & 85,805 \\
\hline Egusi & 20,000 & 252,000 & 82,000 \\
\hline Plantains & 3,000 & 500,000 & 68,882 \\
\hline Fruits & 5,000 & 300,000 & 63,857 \\
\hline Cocoyams & 7,500 & 648,000 & 61,429 \\
\hline Bush mango & 21,000 & 140,000 & 46,600 \\
\hline Banana & 600 & 300,000 & 36,440 \\
\hline Njansang & 5,000 & 30,000 & 18,750 \\
\hline
\end{tabular}

replaced leaves used as spices in the past. The main NTFPs identified in the three focal villages included: bush mango, njansang, bush pepper (Piper guineensis), bush onions, monkey cola (Cola lepidota), bitter cola, cola nut (Cola nitida and Cola acuminata), eru, African walnut fruit (ngak) (Tetracarpidium conophorum), chewing sticks (Garcinia mannii), alligator pepper (Aframomum spp.), mushrooms, snails and other traditional forest spices.

About $99 \%$ of households in all three villages admitted that they collect NTFPs. This is also an indication of how close the settlements are to the forest. Sale of NTFPs was dependent on quantity of products collected and whether the collector used it or not. For all the sites, an average of about $75 \%$ of the households reported that they sold and consumed the NTFPs that they collected.

Hunting and fishing were recorded as other activities carried out in all of the sites, but at a very minimal level. All three sites recorded less than $10 \%$ of households who reported involvement in hunting and fishing and most of this was for home consumption. Data on NTFP collection and sales was barely captured in this preliminary survey. When households were asked to give details of their income generating activities, NTFPs were rarely mentioned. People tended to minimize the income from this source because the income is relatively small and/or because it is generated only in one season and is therefore easily forgotten.

\section{Other activities}

Villagers are involved in other income-generating activities. These include petty trading (business), farm laboring, teaching, dressmaking, mechanics, carpentry and palm wine tapping, etc. 


\subsubsection{Income to communities}

From the information gathered during FGDs and wealth ranking exercises, cocoa stands out as the main income-generating perennial cash crop in the area, as seen in the number of households that mentioned it as their main farm product (Figure 3.12) and the average annual income generated by cocoa (Table 3.7). Although oil palms are fairly young, they are still recorded as generating considerably high amounts in average annual income with some households already making sales of up to XAF 1 million from palm oil. Cassava and egusi (melon seeds) farm products, which are usually cultivated by women, are also recorded as good income-generating products in the households. Of note, only two NTFPs featured as income generating and their mean annual amount was not as high as the farm products. This could be explained by the perceived scarcity of NTFPs, which discourages sales because households prefer to store for consumption.

\subsubsection{Wealth ranking}

The wealth ranking questionnaire showed that farm and house ownership, i.e. the capability to hire farm laborers, type of houses owned or rented and household possessions, were some of the indicators that contributed to the wealth index of communities. In addition to this, from the wealth ranking exercises conducted, the key informants in each village exemplified other wealth indicators (Table 3.8). This exercise highlighted that physical cash or money was not the only way people gauged wealth; other indicators such as the ability to afford education for children, the size and number of cocoa farms, the number of children and wives, and land assets were also considered.

\section{Table 3.8 Wealth ranking characteristics from key informant interviews.}

\begin{tabular}{|c|c|c|c|}
\hline Rich & Fairly rich & Poor & Poorest \\
\hline $\begin{array}{l}\text { Owners of } 12 \text { poles }{ }^{\mathrm{a}} \text { cocoa } \\
\text { farms, which produce about } 70 \\
\text { bags of } 75 \mathrm{~kg} \text { each } \\
\text { Own personal houses and rent } \\
\text { out others } \\
\text { Inherited properties (cocoa } \\
\text { farms, houses) } \\
\text { Children in secondary schools } \\
\text { and universities } \\
\text { Own large orange and palm } \\
\text { farms } \\
\text { Cocoa dealers } \\
\text { Fuel retailers }\end{array}$ & $\begin{array}{l}\text { Owners of } 10 \text { poles } \\
\text { cocoa farms, which } \\
\text { produce about } 10 \text { bags } \\
\text { Own personal houses } \\
\text { Inherited properties } \\
\text { (cocoa farms, houses) } \\
\text { Children in higher } \\
\text { education institutions } \\
\text { Employment e.g. } \\
\text { primary school } \\
\text { teachers }\end{array}$ & $\begin{array}{l}\text { Owners of } 5 \text { poles } \\
\text { cocoa farms } \\
\text { Own smaller houses } \\
\text { Inherited houses } \\
\text { Typically large two } \\
\text { party farms/newly } \\
\text { established farms } \\
\text { or owners of cocoa } \\
\text { farms on pledge }\end{array}$ & $\begin{array}{l}\text { Farm laborers, do } \\
\text { not own farms } \\
\text { Dependent on } \\
\text { parents' farms or } \\
\text { small two party } \\
\text { farm } \\
\text { Petty traders }\end{array}$ \\
\hline
\end{tabular}

a Poles are a local unit of measurements for land surface used by a few communities ( 4 poles $=1$ ha). 


\subsubsection{Local food security}

The availability of main staple foods such as cocoyams, yams, cassava, plantains and banana is usually not a problem for households because these are cultivated by almost all of the households (except for some single male households). However even though these crops are cultivated within the villages, some households still do not have enough to get three meals a day. To some extent, the main issues of food security focus on the constant unavailability of animal proteins from meat and fish consumption. Increasing government regulations as well as dwindling numbers of wildlife contribute to the unavailability of bushmeat and fish. Most of these communities now depend on smoked fish from coastal towns and imported fresh mackerel. For households to get access to these and other food and household items such as rice, beans, tomatoes, onion and kerosene, two important factors come into play: seasonal roads and the availability of money to buy (Table 3.9). During the low-income season, between planting and harvesting (March-July), there is rarely money for households to buy food, this period is usually considered the hunger season. Local vegetables are grown in the villages but become scarce in the dry season.

\section{Table 3.9 Typical food and food-related items, their accessibility, and access constraints in the Nguti study area.}

\begin{tabular}{|c|c|c|}
\hline Items & Accessibility & Constraints \\
\hline \multicolumn{3}{|l|}{ Food items } \\
\hline Bushmeat & Limited & $\begin{array}{l}\text { Legislation (government laws on bushmeat hunting) } \\
\text { Dwindling resource base due mainly to deforestation } \\
\text { and forest degradation } \\
\text { Poor road access to markets }\end{array}$ \\
\hline Fish & Limited & $\begin{array}{l}\text { Low fish stocks due to reduction in volume of water } \\
\text { Poor road access to markets }\end{array}$ \\
\hline Rice & Limited & $\begin{array}{l}\text { Not cultivated within the area } \\
\text { Poor road access to markets }\end{array}$ \\
\hline $\begin{array}{l}\text { Vegetables (e.g. tomatoes, } \\
\text { onions) }\end{array}$ & Limited & $\begin{array}{l}\text { Not cultivated within the area } \\
\text { Poor road access to markets }\end{array}$ \\
\hline Beans & Limited & $\begin{array}{l}\text { Not cultivated within the area } \\
\text { Poor road access to markets }\end{array}$ \\
\hline $\begin{array}{l}\text { Other forest products (e.g. } \\
\text { bush mango) }\end{array}$ & Limited & $\begin{array}{l}\text { Reduction in resource base due to deforestation and } \\
\text { forest degradation }\end{array}$ \\
\hline \multicolumn{3}{|l|}{ Other items } \\
\hline Water & $\begin{array}{l}\text { Readily } \\
\text { available }\end{array}$ & $\begin{array}{l}\text { Stand taps, streams and springs located 2-15 minute } \\
\text { walk from the village } \\
\text { Water not yet contaminated }\end{array}$ \\
\hline Fuelwood & $\begin{array}{l}\text { Readily } \\
\text { available }\end{array}$ & $\begin{array}{l}\text { From farms and nearby forest } \\
(2-90 \text { minute walk from the village) }\end{array}$ \\
\hline Kerosene & Limited & Poor road access to towns, expensive \\
\hline
\end{tabular}


Rice is now seen as a common food in most households. This is an indication of the change in food consumed by people. At this rate of deforestation and plantation establishment, there is a possibility of future shortages in local staple food, which will include rice and other purchased foodstuffs.

\subsection{Conclusion}

The main objective of this chapter was to give a preliminary overview of historical land uses, the underlying drivers of land-use change and the impacts of land-use change on rural communities in the study area. This study area is of great importance as it represents a complex mosaic landscape of competing land-use activities. The different land-use types range from primary undisturbed forest to farmland with only annual food crops, bare degraded lands to rivers and streams. These different land-use types within the landscape provide services such as drinking water for the local population, cultural values, medicinal values, carbon reduction, nutrition and household income, agricultural land as well as income to the State.

Within the last two and a half decades, local communities have experienced different land-use changes around them, especially from the conservation sector. This has introduced conflict. For example, the creation of the Banyang Mbo Wildlife Sanctuary, Mount Bakossi National Park and Korup National Park resulted in local villagers facing the prospect of resettlement and other limitations to their rights to use the forest. With the establishment of these protected areas, the communities felt cheated of their customary land and their rights to the resources therein. More recently, the SG-SOC oil palm development now accounts for about 23,000 ha of land. This new development was received with mixed feelings; some people see it as a great opportunity for development of their area and employment for them and their children, while others see it as a threat to the future of the village and their children in terms of future land shortages. The ever-increasing demand for agricultural land, especially for cocoa and more recently for oil palm, has also attracted village elites and other settlers from other parts of the country to the landscape. This influx has extended to inaccessible areas where land is considerably cheaper, land tenure systems are simple, and acquisition and ownership processes are not very complex, unlike in other more exposed or relatively developed areas. 


\section{References}

Abwe MD, Ebia RN, Ewane D, Mesue, Ntonifor CA, Nzoh-Ngandembou Z, Tangwa GW, Van Dorp M, Niemeijer R and Offermans D. 1999. The wealth offorests in Cameroon: Results of field testing a methodology for the valuation of non-timber forest products (NTFPs) in North-West and South-West Cameroon. Amsterdam: Centre for the Environment and Rural Transformation and AIDEnvironment.

Acworth J. 2013. A historical review of land use planning processes in the $S W$ region of Cameroon from pre-independence to date. One hundred and thirty years of plantations and protected areas in SW Cameroon. Draft final consultancy report. Bogor, Indonesia: Center for International Forestry Research.

Biopact 2007. GEM BioFuels raises $£ 3.5$ million to expand jatropha plantations in Madagascar. Mongabay. Accessed 2 October 2014. http://news.mongabay.com/bioenergy/2007/10/ gem-biofuels-raises-35-million-to.html

Blaevoet G. 2010. Analyse - diagnostic de l'agriculture aux abords des réserves forestières de la Manyu (Cameroun): Transition d'une agriculture d'autoconsommation à une agriculture de rente. Mémoire de fin d'étude. Paris: AgroParis Tech.

Cerutti PO and Tacconi T. 2006. Forests, illegality and livelihoods in Cameroon. Bogor, Indonesia: Center for International Forestry Research.

Colfer CJP. 1999. The BAG (basic assessment guide for human well-being). Bogor, Indonesia: Center for International Forestry Research.

Cotula L, Vermeulen S, Leonard R and Keeley J. 2009. Land grab or development opportunity? Agricultural investment and international land deals in Africa. International Institute for Environment and Development/Food and Agricultural Organisation/ International Fund for Agricultural Development

Ezilon. 2013. Cameroon map - Political map of Cameroon. Ezilon. Accessed 9 June 2013. http://www.ezilon.com/maps/africa/cameroon-maps.html.

[FAO] Food and Agriculture Organization of the United Nations. 2013. Forests, food security and gender: Linkages, disparities and priorities for action. Background Paper for the International Conference on Forests for Food Security and Nutrition: Increasing the Benefits for Rural People, 13-15 May. Rome: FAO.

Glaser B. 2013. A guide to qualitative research methods. Qualitative research: Grounded theory. [Master's thesis] Philadelphia, PA: Temple University.

GRAIN. 2008. Seized: The 2008 landgrab for food and financial security. GRAIN Briefing, October 2008. Barcelona, Spain: GRAIN. https://www.grain.org/article/entries/93seized-the-2008-landgrab-for-food-and-financial-security

Hance J and Butler R. 2011. Palm oil, poverty and conservation collide in Cameroon. Mongabay. Accessed 20 June 2013. http://news.mongabay.com/2011/09/palm-oilpoverty-and-conservation-collide-in-cameroon/

Liswanti N and Basuk I. 2009. Guidelines for adapted multidisciplinary landscape assessment methods for fire management projects in India. Bogor, Indonesia: Center for International Forestry Research. 
McSweeney C, New M and Lizcano G. 2010. UNDP Climate Change Country Profiles: Cameroon. United Nations Development Programme. Accessed 8 June 2014. http:// country-profiles.geog.ox.ac.uk

[MINEF] Ministry of the Environment and Forests. 1997. National Report to the Convention on Biological Diversity: Republic of Cameroon. Convention on Biological Diversity; United Nations Environment Programme.

[MINEPAT] Ministry of Economy, Planning and Regional Development. 2009. Cameroon Vision 2035. Working Paper (draft). Yaoundé, Cameroon: Government of Cameroon.

[MINEPAT] Ministry of Economy, Planning and Regional Development. 2007. Preliminary technical note for the gazettement of Nguti Council Forest. Yaoundé, Cameroon: Government of Cameroon.

[MINEPDED] Ministry of Environment, Protection of Nature and Sustainable Development. 2003. A management plan for Korup National Park and its peripheral zone. Yaoundé, Cameroon: Government of Cameroon.

[MINEPDED] Ministry of Environment, Protection of Nature and Sustainable Development. 2001. Management plan for Nta-Ali Forest Reserve. Yaoundé, Cameroon: Government of Cameroon.

Mukherjee N. 1992. Villagers' perceptions of rural poverty through the mapping methods of PRA. In Rapid Rural Appraisal Notes Number 15. Special Issue on Applications of Wealth Ranking. London: International Institute for Environment and Development.

Ndoye O. 1995. The market for non-products in the humid forest zone of Cameroon and its borders. Structure, conduct, performance and policy implications. Bogor, Indonesia: Center for International Forestry Research.

Nguiffo S and Schwartz B. 2012. Herakles' 13th labour. A study of SGSOC's land concession in south-west Cameroon. Yaoundé, Cameroon: Centre pour l'Environnement et le Développement.

Liswanti N and Basuki I. 2009. Guidelines for adapted multidisciplinary landscape assessment methods for fire management projects in India. Bogor, Indonesia. Center for International Forestry Research.

Njohjam NP. 2000. Integration of remote sensing and GIS in land use planning for sustainable natural resource management within the Mount Cameroon region, West Africa. International Archives of Photogrammetry and Remote Sensing XXXIII, Part B7: 947-54.

Robiglio V, Ngendakumana S, Gockowski J, Yemefack M, Tchienkoua M, Tchawa P, Tchoundjeu $\mathrm{Z}$ and Bolognesi M. 2010. Reducing emissions from all land uses in Cameroon. Final national report. Nairobi, Kenya: ASB Partnership for the Tropical Forest Margins.

[SG-SOC] SG Sustainable Oils Cameroon Ltd. 2011a. Environmental and social impact assessment report. Prepared for SG Sustainable Oils Cameroon Ltd. Bethesda, Maryland, USA; Yaoundé, Cameroon: H \& B Consulting USA.

[SG-SOC] SG Sustainable Oils Cameroon Ltd. 2011b. Consolidated field study report. Wildlife survey. Prepared for SG Sustainable Oils Cameroon. Bethesda, Maryland, USA; Yaoundé, Cameroon: H \& B Consulting USA. 
Sneyd A. 2014. Cameroon: Perspectives on food security and the emerging power footprint. Sustainability 6:1868-95. doi:10.3390/su6041868

Sneyd LQ. 2013. Wild food, prices, diets and development: Sustainability and food security in urban Cameroon. Sustainability 5:4728-59. doi:10.3390/su5114728

Sunderland TCH. 2011. Food security: Why biodiversity is important. International Forestry Review 13(3):265-74.

Sunderland TCH and Morakinyo T. 2002. Nypa fruticans, a weed in West Africa. Palms 46(3):154-55.

Sunderland-Groves JL, Sunderland TCH, Comiskey JA, Ayeni JSO and Mdaihli M. 2003. Takamanda Forest Reserve, Cameroon. In Comiskey JA, Sunderland TCH and Sunderland-Groves JL, eds. 2003. Takamanda: The Biodiversity of an African Rainforest. SI/MAB Series \#8. Washington DC: Smithsonian Institution. 1-8.

Tajoacha A. 2008. Market chain analysis of the main non-timber forest products from the Takamanda/Mone Forest Reserves, southwest province of Cameroon [Post-graduate diploma thesis]. Dschang, Cameroon: University of Dschang.

[UN] United Nations. 2014. UN Data: Cameroon. United Nations Statistics Division. Accessed 7 September 2013. http://data.un.org/CountryProfile. aspx?crName=CAMEROON

Watts J. 1994. Developments towards participatory forest management on Mount Cameroon: The Limbe Botanic Garden and Rainforest Genetic Conservation Project 1988-1994. Network Paper 17d. Rural Development Forestry Network.

Weise L. 2009. Production and marketing of economically important NTFPs of smallholders of the Korup Forest area, southwest Province, Cameroon [Master's thesis]. Dresden, Germany: Germany Dresden University of Technology.

Wilcove DS and Koh LP. 2010. Addressing the threats to biodiversity from oil-palm agriculture. Biodiversity and Conservation 19:999-1007.

[WRI] World Resources Institute. 2013. Interactive forest atlas of Cameroon. Version 3.0. Overview Report. Washington, DC: WRI.

[WWF] World Wide Fund for Nature. 2012. Emerging trends in land-use conflicts in Cameroon. Overlapping natural resource permits threaten protected areas and foreign direct investment. WWF; the Center for the Environment and Development; le Réseau de Lutte Contre la Faim au Cameroun. 


\section{Appendices}

\section{Appendix 3A Focus group discussion template}

\section{A) Ecological}

1. Which of the land-use types (habitats) do you value most?

2. Which areas of land have been under change since the plantation project was put in place (e.g. forest $\rightarrow$ plantation or areas where farmers are forced to go elsewhere to grow crops, which may involve cutting down forests)?

3. Was the land use very different 10 years ago? If so, where have these changes been and why have there been changes?

4. What do you use the forests for?

5. What are your reasons for valuing the habitat?

6. Are there sites kept for future exploitation (protected land, commercial forest)? Do you have protected areas?

7. How do you value the different goods (fuelwood, medicinal plants, timber and NTFPs)?

8. What are your reasons for the ranking?

9. What are the animals mostly hunted or animals mostly seen in your catch?

\section{B) Social/health/education}

1. How many houses are made of thatches and zinc?

2. Where is the health center located?

3. Where do women give birth (percentages)?

4. Is there a school in the community?

5. What are the cultural values of the village?

6. What traditional sanctions are imposed on people who damage the forests?

Are there any places traditionally protected from disturbance? If yes, please name them and state where.

7. Why are those places protected?

\section{C) Economical}

1. Where are the markets located?

2. Where are the traders coming from?

3. How many stores are there in the village?

4. What are the common things sold?

5. Where do you get (credit) money for business and agricultural inputs?

\section{D) Administration}

1. How is the village ruled?

2. How old is the village?

3. How is the structure organized and who is involved?

4. Who is on the council (note gender, local/stranger etc.)?

5. Are there any conflicts between people and wildlife?

6. How are conflicts managed?

7. What municipality is the village governed by?

8. Have there been any shocks/natural disasters recorded and how were they managed?

9. How are developmental issues carried out (e.g. development projects)? 
E) Land tenure

1. Who owns the land?

2. Do individuals or families own patches of land?

3. Is land inherited?

4. How is land acquired?

5. Can you own parts of the forest?

6. Are women allowed to own land?

7. How is the land partitioned for development in the future?

F) Agriculture

1. What types of farms do persons own?

2. What are the products harvested?

3. Are there extension workers (agricultural officers)?

\section{Appendix 3B List of categories used in pebble distribution method for habitat valuation exercise}

1. Primary forest

2. Secondary forest

3. Farmland

4. Home garden

5. Rivers and streams

6. Swamps

7. Hills

\section{Appendix $3 \mathrm{C}$ List of categories used in pebble distribution method for forest valuation exercise}
1. Medicine
2. Income
3. Tradition and culture
4. Water
5. Hunting
6. Food
7. Fuelwood
8. Construction materials 


\section{Appendix 3D Historical trend charts}

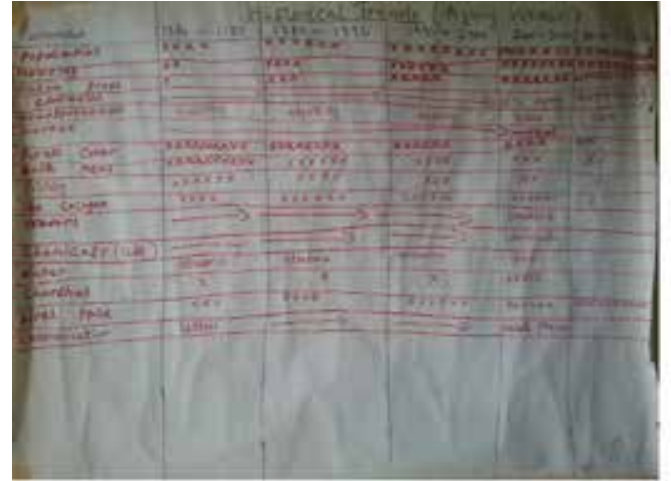

A

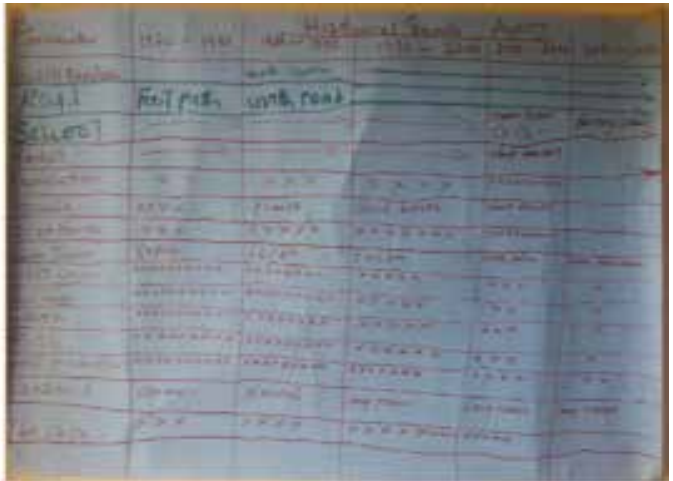

B

Figure 3D.1 Ayong men (A) and women (B) historical trend charts.

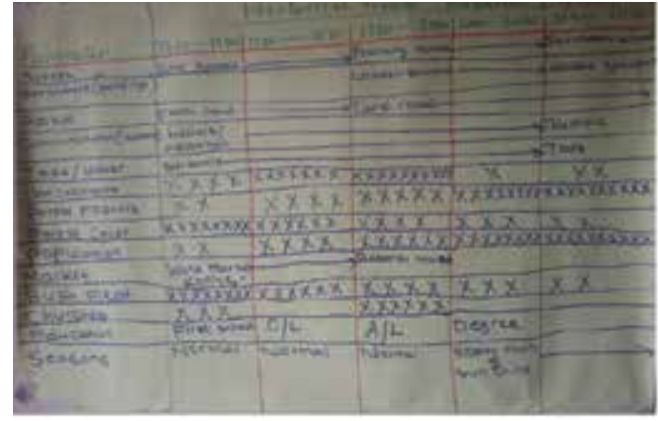

A

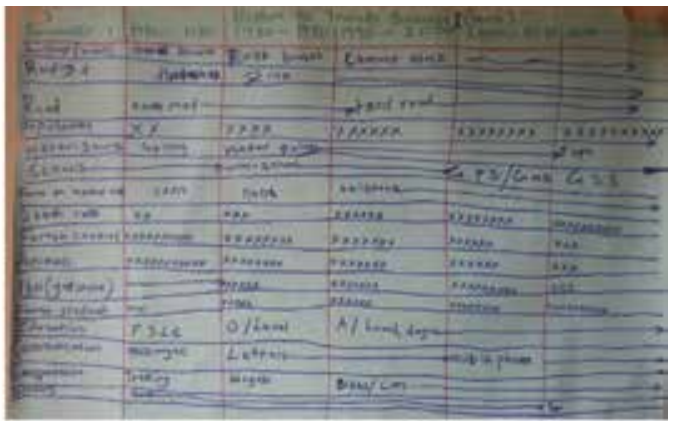

B

Figure 3D.2 Babensi I men (A) and women (B) historical trend charts.

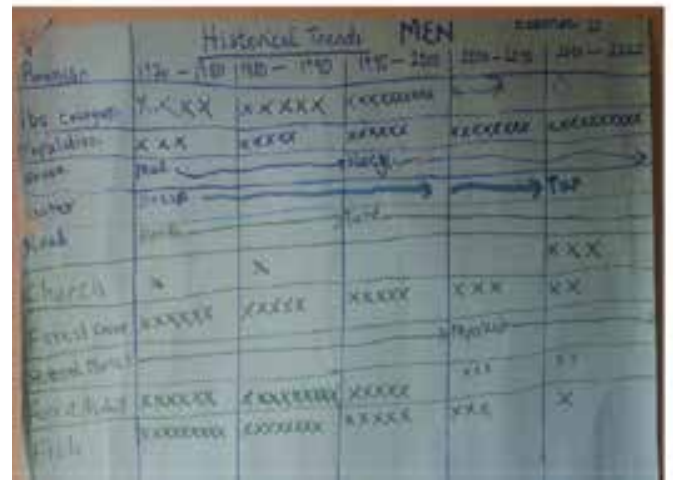

A

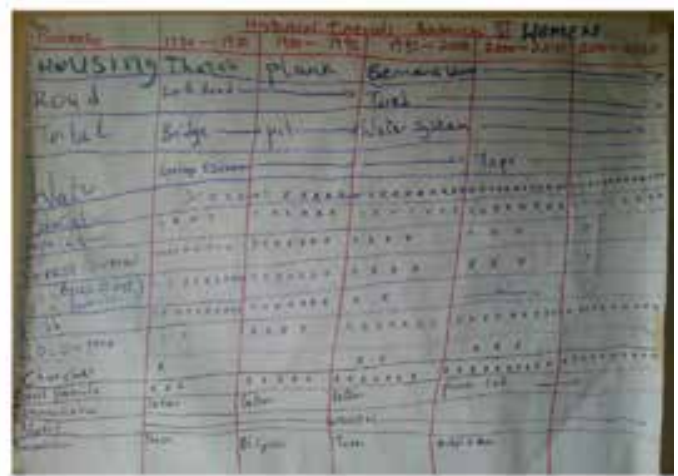

B

Figure 3D.3 Babensi II men (A) and women (B) historical trend charts. 
other hand, researchers and activists point out the destructive impacts of plantations upon biodiversity and numerous accounts of conflict between communities and companies suggest that local people can often experience negative consequences to their livelihoods as a result of loss of access to forestland (FPP 2007; Sandker et al. 2007; Fitzherbert et al. 2008; Rist et al. 2010).

Indonesia now has the highest rate of deforestation in the world (Hansen et al. 2013a), largely driven by the expansion of oil palm plantations as well as timber harvesting and mining (Potter 1991; Lucarelli 2010; Setijadji et al. 2010; van Leeuwen 2014). Over 70\% of Indonesia's land mass is designated as forestland equating to around 134 million ha (MOF 2012). The vast majority of deforestation is occurring on the islands of Sumatra and Kalimantan (the Indonesian half of the island of Borneo) (Curran et al. 2004; Margono et al. 2014). Since 1973, around the time that large-scale extractive industries (for timber, oil and minerals) began to operate, around one-third of Kalimantan's natural forests have been lost (based on 2010 data) (Gaveau et al. 2014). Deforestation in Kalimantan has been historically concentrated in lowland and coastal regions. With much of the lowlands already destroyed, there are increasing pressures on remote sub-montane and highland regions, which were previously too remote for commercial plantations and the extraction of timber and minerals. Almost all of the forested regions in Kalimantan outside of protected areas are under some form of concession for planned plantations for oil palm or rubber, or for the exploration or extraction of minerals. In the next 10 years, the landscape of this region will change beyond recognition, bringing with it enormous consequences for the local people who depend on these forests.

We focus on one specific region of Kalimantan, Kapuas Hulu Regency, situated in the northeast of the province of West Kalimantan. Containing two large national parks, large-scale commercial oil palm plantations and smallholder oil palm and rubber plantations, Kapuas Hulu is the subject of widespread debates around the role of tropical forest conservation and oil palm. As such, it operates as a microcosm of broader issues in Indonesia concerning the trade offs between agricultural expansion, intensification and forest conservation. Present day land use and land cover is shown in Figure 4.1. Rubber estates are shown in peach (34), newly opened oil palm plantations are shown in red (37) and established oil palm estates in dark yellow (36), mixed agroforestry in light yellow (40).

\subsection{Research objectives}

The Agrarian Change Project in Indonesia attempts to address the following research questions:

1. What are the historical and contemporary drivers of land-use change in Kapuas Hulu?

2. What are the effects of palm oil on local food security?

3. How do monoculture plantations compare with smallholder plantations and agroforestry systems in terms of local livelihoods and food security? 

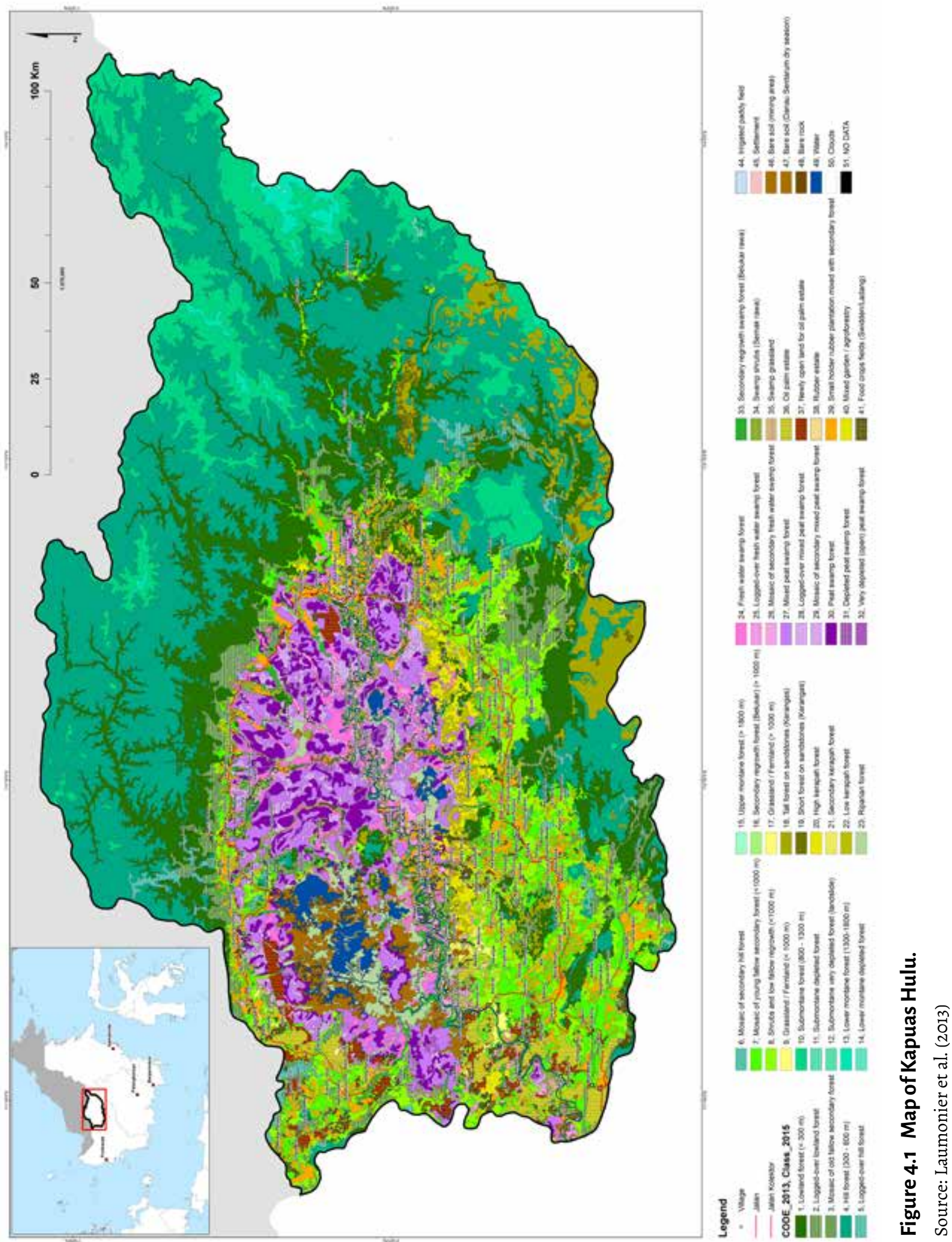


\subsection{Research Methods}

\subsubsection{Site selection}

Communities were selected as potential study sites on the basis of published and unpublished reports and literature, through examination of land-use maps and informal conversations with researchers and actors in the region. We used land-use maps created by the French Agricultural Research Centre for International Development (Centre de Coopération Internationale en Recherche Agronomique pour le Développement, CIRAD)/CIFOR for the region to first eliminate regions of peat-swamp forest as agricultural practices in these regions differ too greatly from other areas due to the underlying soil type and climatic conditions. We sought to identify three zones that typified different stages of the agrarian transition in the region. Since oil palm is the dominant driver of agrarian change in the region we aimed to identify sites with no oil palm (Zone 1), sites dominated by monoculture palm oil plantations (Zone 3) and sites that reflected intermediate stages of the transition between Zones 1 and 3 (Zone 2). We first identified potential Zone 1 sites that reflected relatively low levels of change by identifying remote and traditional communities, far from state infrastructure (e.g. roads, bridges, medical facilities). Zone 3 sites were identified using government concession maps of companies operating in the region. Zone 2 sites were identified through consultation with other researchers who had operated in the region, in particular those involved in the CIFOR-led Participating in REDD+ Measurement, Reporting and Verification (PMRV) project and the CIRAD-led Collaborative Land-Use and Sustainable Institutional Arrangements (COLUPSIA) project, who have conducted extensive preliminary surveys in the region.

Potential study sites identified using the method above were then discussed with stakeholders in the region during informal discussions and interviews. All sites identified as potential study locations were visited in order to select communities suitable for more in-depth research while in the field.

\subsubsection{Literature review}

We conducted a literature review of published academic research articles and gray literature. Peer-reviewed publications were accessed through Web of Science and Google Scholar. In addition, we were able to identify important literature through colleagues and fellow researchers in the region. Gray literature was sought by directly contacting organizations active in the region, specialized Google search techniques and through general calls for literature. Both literature in English and Bahasa Indonesia was sought. We focused on literature pertaining to agrarian change, local livelihoods, forestry, agriculture and biodiversity conservation in the region. In addition, government data was acquired through the Indonesian central statistics agency (Badan Pusat Statistik, BPS) and from regional government offices.

\subsubsection{Fieldwork}

Fieldwork was carried out in October 2014 by Dominic Rowland and Laurio Leonald with assistance from the CIRAD-led COLUPSIA team in Putussibau. Key informant interviews and consultation with stakeholders were first held in Putussibau to narrow the focus of the site selection process, after which the team travelled to each potential study site identified. 


\section{Key informant interviews}

General information was gathered through interviews and discussions with actors and stakeholders in the region including government officials, international conservation NGOs, local, conservation and social NGOs and active researchers in the region. We obtained interviews and informal discussions with all relevant district (kabupaten) government departments including the local forestry department (dinas kehutanan) and the local department of agriculture (dinas pertanian), the Spatial Planning Department (Badan Perencanaan Pembangunan Daerah, BAPPEDA), and the national park authorities. In addition, we conducted informal discussions with active stakeholders in the region including international NGOs/agencies (WWF; Flora and Fauna International, FFI; GIZ/Forests and Climate Change Project), collaborative research projects such as the CIRAD/CIFOR-led COLUPSIA project, and local NGOs (Lanting Borneo; Riak Bumi; Germawan; Forina; People Resources and Conservation Foundation). Discussions with stakeholders were held to obtain information about current and past activities in the region. In addition, we held informal discussions with other researchers active in the region.

\section{Village survey}

In potential study communities, we held informal discussions and meetings with senior community members and conducted semi-structured village surveys with the head of the village (kepala desa) where available. Due to the predominant livelihood strategies in these communities, many people spend days or weeks in the forest at a time so the kepala desa was not always available. In these cases, we spoke to the highest-ranking village official possible, usually the secretary of the village (sekdes), the village representative (badan permusyawaratan desa) or the head of the sub-village (kepala dusun). The village survey covered basic information about the village including village history, demographic and ethnic composition, land use and land tenure, infrastructure, medical and education facilities, village economy, forest resource use, agricultural practices and seasons, and government/NGO development programs.

\section{Semi-structured interviews}

The semi-structured interview contained a series of demographic livelihood and economic questions designed to give an overall picture of the general occupations and livelihoods of the community, as well as open-ended questions concerning perceptions of land-use change. The interviews began with general information about the village, including a brief village history and details of ethnic groups and migrations, followed by questions on the local economy, farming practices and seasons, general food security, healthcare facilities and forest use.

Interviews were conversational in nature and were conducted informally with senior members of the community, as well as in semi-spontaneous group sessions. Where possible, interviews were conducted in as many of the hamlets (dusuns) as possible and included both sexes and a wide range of ages. 


\subsection{Drivers of land-use change}

\subsubsection{Historical drivers of land-use change in Indonesia}

The extraction of resources in Kalimantan is not a recent phenomenon. Gold has been mined in the region since the 4th century and diamonds since the 7th century, although these were small-scale localized operations (Setijadji et al. 2010; van Leeuwen 2014). Kalimantan has seen industrial scale extraction since experiencing a gold rush in the 18th century and the establishment of commercial crude oil extraction by Royal Dutch Shell in 1885 (Wunder 2003). Coal has also been extracted for centuries, starting during colonial times (1849-1945) for use in steam ships (Lucarelli 2010). Many of the policies managing natural resources have changed little since colonial times (Kartodihardjo et al. 2009). The Agrarian Law (Agrarisch Wet) issued by the Dutch government in 1870, declared all land without proof of ownership (effectively all forestland) was the property of the State. The State was then entitled to issue permits to companies to cultivate the land and extract resources, in return for taxation. In practice, this model still applies today where the state authority issues companies with concession permits for predefined periods of time to operate while retaining ownership of the land.

Following independence in 1945-49 all commercial mining and timber concerns were nationalized under state-controlled companies with a small number of concessions controlled by the Indonesian military and the Indonesian Communist Party (Partai Komunis Indonesia, PKI) (Indonesian Law No. 58/1958). From 1961, forest management was regulated and controlled by the state forestry company, Perhutani, though lack of funding required extensive profit sharing initiatives with foreign companies (Kartodihardjo et al. 2009). Following the fall of nationalist president Soekarno and the rise of General Soeharto in a coup, Indonesia's forestry sector underwent dramatic militarization. Companies and foundations associated with the Indonesian military took control of vast areas of forest estates and senior military officials took personal control of large proportions of company shares (Samego 1999) leading to "quasi capitalism, state corporatism ... system of corruption, collusion and nepotism" (Kartodihardjo et al. 2009).

Since the fall of Soeharto in 1998, significant powers have been devolved to the regions of Indonesia under the policy of decentralization (decentralisasi) and over 80 million ha now fall under the control of district/regency governments (Indrato et al. 2012; Moeliono and Limberg 2012). The economic crisis that led to Soeharto's fall resulted in widespread illegal activity and the loss of state control. In addition, structural adjustment programs insisted on by the IMF in return for an economic bailout resulted in the lifting of restrictions on foreign investment and companies in forests and for the first time imposed limits on rates of natural forest conversion.

\subsubsection{A brief history of palm oil plantations in Indonesia}

The era of industrial-scale palm oil plantations in Indonesia began around 1983 when General Soeharto's government placed the responsibility for developing the sector under the control of the Ministry of Transmigration (Levang 1997). Under the policy of Transmigration (Transmigrasi), poor people from overpopulated areas of Indonesia 
such as Java, Bali and Madura were offered work and additional incentives to relocate to less densely populated regions of Indonesia, in particular Kalimantan, Sumatra and Papua. The history of palm oil in Indonesia is inextricably linked to state policies of transmigration, with the original companies, workers and infrastructure all coming from transmigrants (Rival and Levang 2014). During the 1980s, palm oil companies backed by state loans were given free access to land and began clearing large areas of forests, planting oil palm and building the mills and associated infrastructure. In return for state support, they were required to facilitate the development of an equivalent area of smallholder plantations. After the 1980s, the State no longer provided land free of charge to companies. Rather a policy known as Members' Primary Credit Cooperative (Koperasi Kredit Primer Anggota, KKPA) allowed local villagers and landowners (either transmigrants or indigenous people) to trade land with palm oil companies (Rival and Levang 2014). A local landowner might therefore trade his or her smallholding with the company in return for an area of land roughly between one tenth and one third of the size. In return, the company develops the land on their behalf paying the smallholder a share of the profits (minus costs to develop the land). Such schemes are now rarely seen as more smallholders opt instead to develop their own plantations, aided by the formation of cooperatives and improved access to credit.

\subsubsection{Historical drivers of land-use change in Kapuas Hulu Regency}

Over the past four-and-a-half decades, the main drivers of land-use change have altered greatly in Kapuas Hulu (as shown in Figure 4.2). Prior to the late 1960s and early 1970s, the forests of Kapuas Hulu were too remote for commercial operations and the main drivers of land use were local communities practicing small-scale shifting cultivation (slash and burn). From the 1970s to late 1990s, logging (both legal and illegal) was the main driver of land-use change. Timber harvesting began in Kapuas Hulu, beginning

\begin{tabular}{|c|c|c|c|c|}
\hline 1970-1980 & $1980-1990$ & 1990-2000 & $2000-2010$ & 2010-present \\
\hline \multicolumn{5}{|c|}{ Logging concession } \\
\hline \multicolumn{5}{|c|}{ Illegal logging } \\
\hline \multicolumn{5}{|c|}{ Paddy permanent (sawah) } \\
\hline \multicolumn{5}{|c|}{ Rubber communities } \\
\hline \multicolumn{5}{|c|}{ Oil palm communities and companies } \\
\hline \multicolumn{5}{|c|}{ Traditional gold mining } \\
\hline Mechanic gc & & & & \\
\hline
\end{tabular}

\section{Figure 4.2 Historical land use in Kapuas Hulu.}

Note: The $y$-axis shows relative increase/decrease in activity. 


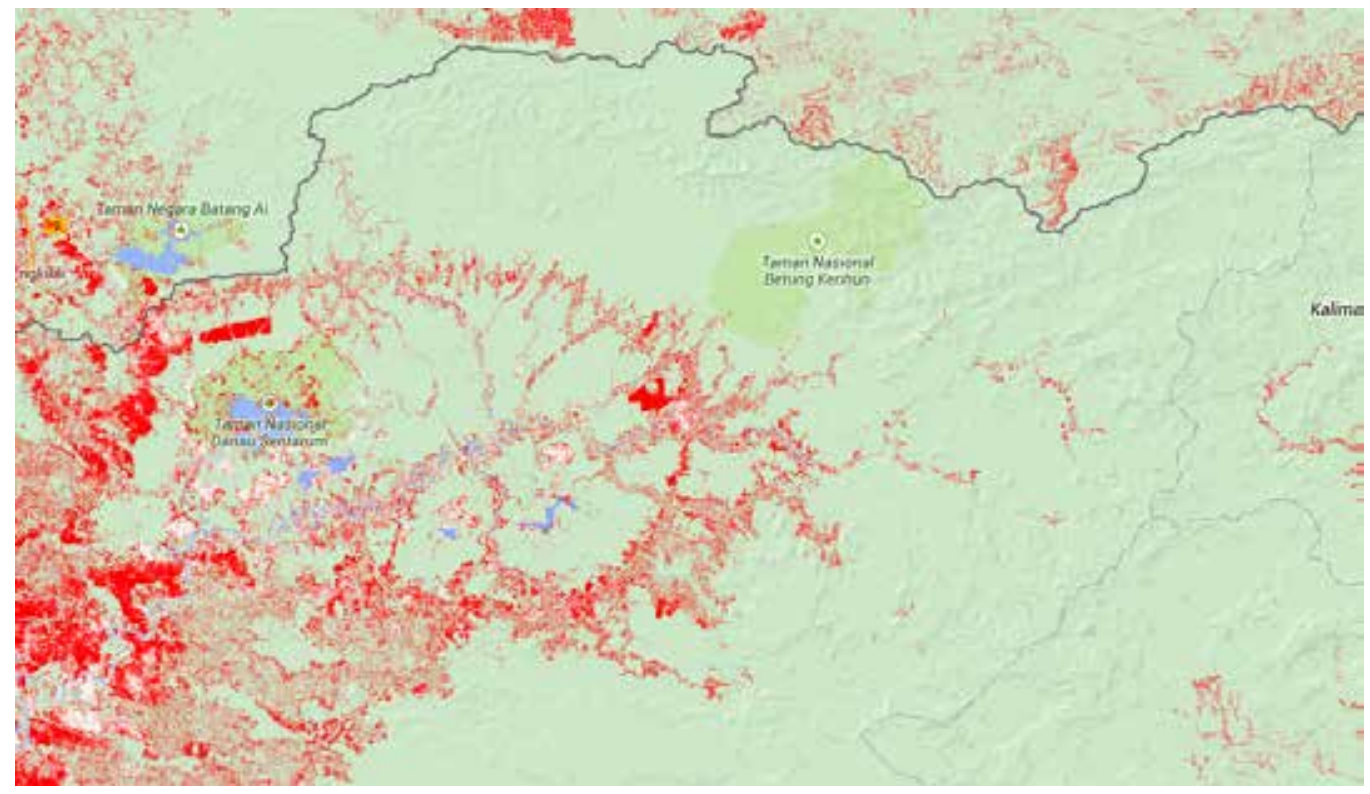

Figure 4.3 Forest loss in Kapuas Hulu 2000-13.

Source: Hansen/UMD/Google/USGS/NASA (2014)

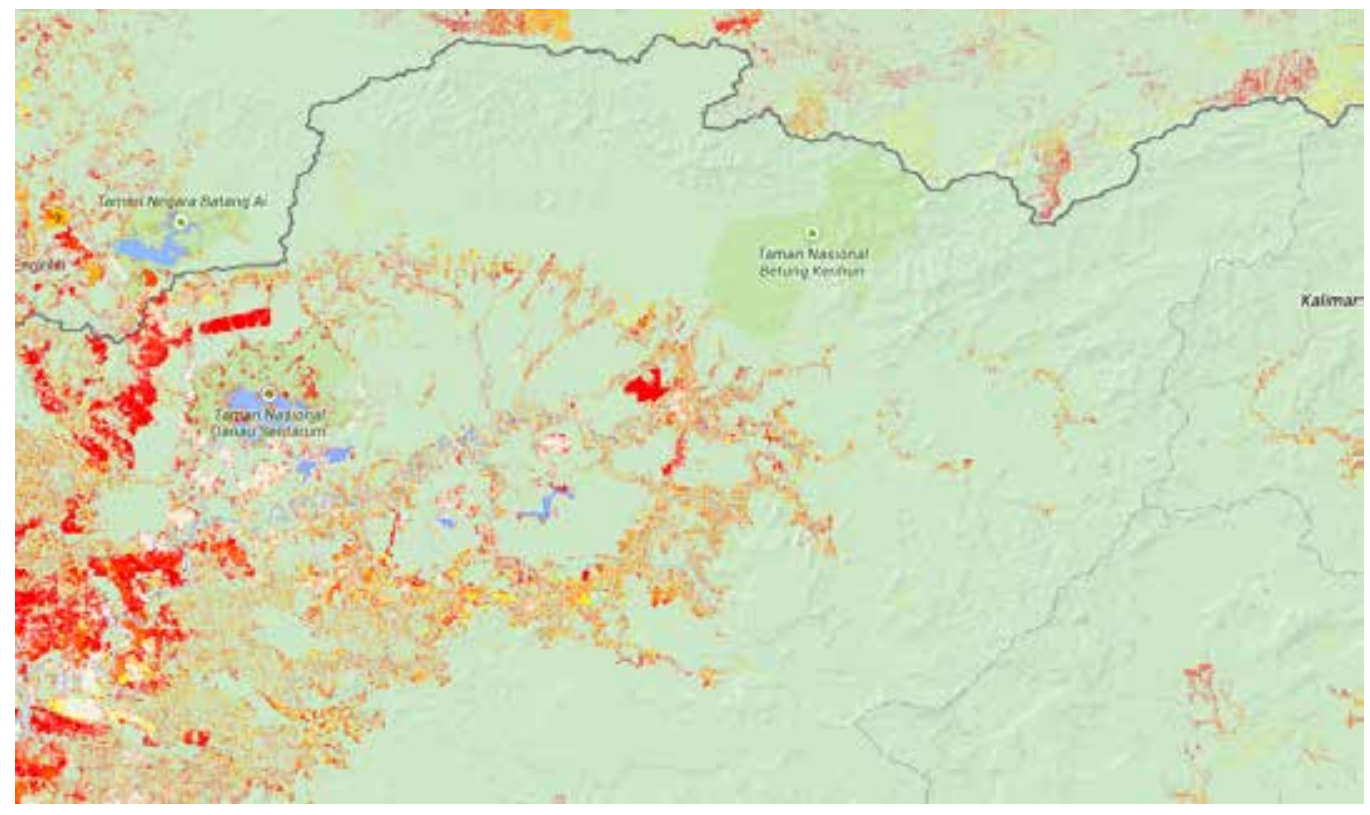

Figure 4.4 Forest loss by year in Kapuas Hulu 2000-13.

Note: Darker areas indicate deforestation closer to the year 2013. Red indicates forest loss during 2013, yellow indicates forest loss during the year 2000.

Source: Hansen/UMD/Google/USGS/NASA (2014) 
in the late 1960s/early 1970s. During this time large state-owned or military-controlled timber harvesting operations covered almost the entire border with Malaysia. Timber was exported both legally and illegally to the Malaysian state of Sarawak via a network of small border roads, with little to no timber being transported via other regions of Indonesia (see 4.6.3). During this time illegal logging steadily increased, reaching its peak in the aftermath of the 1997/8 financial crisis and fall of Soeharto.

Following decentralisasi in the early 2000s, the newly devolved powers to regional government led to significant investments in infrastructure resulting in a once remote region becoming attractive to Indonesian companies and investors. The building of the road to Sintang in the 1980s, further improved in the 1990 s and 2000 s. It not only connected Kapuas Hulu with the rest of West Kalimantan but also, crucially, connected Kapuas Hulu to the port of Pontianak. The improved infrastructure, combined with incentives from local government led to the development of large oil palm plantations, the first of which arrived in the region in the year 2000 .

Figure 4.3 shows the forest loss on Kapuas Hulu Regency between the years of 2000 and 2013 taken from online data (Hansen et al. 2013b). The maps clearly show deforestation concentrated in the western half of the region and a ring of deforestation that matches the location of the main circular road in Kapuas Hulu. Year-by-year forest loss (shown in Figure 4.4) indicates that much of the more recent deforestation has been occurring around the west and southwest while the deforestation around the road occurred longer ago, around the year 2000. A patch of deforestation around the city of Putussibau is the largest major area of recent deforestation in the central and eastern half of the district. The figures show that very little deforestation has occurred between 2000 and 2013 in the northern and eastern region of Kapuas Hulu, and none in the Betung Kerihun National Park (BKNP).

\subsection{The context of Kapuas Hulu}

\subsubsection{Study area description}

Kapuas Hulu Regency (Kabupaten Kapuas Hulu) is an administrative district in the province of West Kalimantan (Kalimantan Barat). Situated in the far northeast of West Kalimantan, bordering Central Kalimantan to the east and the Malaysian border to the north, the regency is one of the remotest in Kalimantan (Figure 4.5). Located between $0.5^{\circ} \mathrm{N}$ and $1.4^{\circ} \mathrm{S}$ latitude and $111.40^{\circ}-114.10^{\circ} \mathrm{E}$ longitude, it covers an area of nearly $30,000 \mathrm{~km}^{2}$, approximately one fifth of the area of West Kalimantan Province (see Figure 4.5). Kapuas Hulu (literally "upstream Kapuas") is centered along the Kapuas river, which for centuries has formed the main economic and transportation hub of the region. The Kapuas river stretches $1143 \mathrm{~km}$ from source to sea, making it the largest river in Indonesia. The source of the Kapuas is the Muller mountain range and meanders in a southwesterly direction, reaching the sea southwest of the provincial capital of Pontianak. The topography of the region varies from alluvial flat to hilly to mountainous (Table 4.1). Most areas are situated between 25 and 500 masl, though the highest point of Mt. Kerihun is 1790 masl. The most mountainous region lies to the northeast where the region borders the Muller mountain range in Central Kalimantan. 
Table 4.1 Slope class in Kapuas Hulu.

\begin{tabular}{|c|c|c|}
\hline Slope class & Area (ha) & Percentage (\%) \\
\hline $0 \%-2 \%$ & 898,240 & 30.10 \\
\hline $2 \%-15 \%$ & 336,150 & 11.26 \\
\hline $15 \%-40 \%$ & 583.240 & 19.54 \\
\hline$>40 \%$ & $1,116,570$ & 39.09 \\
\hline
\end{tabular}

Source: BPS (2005)

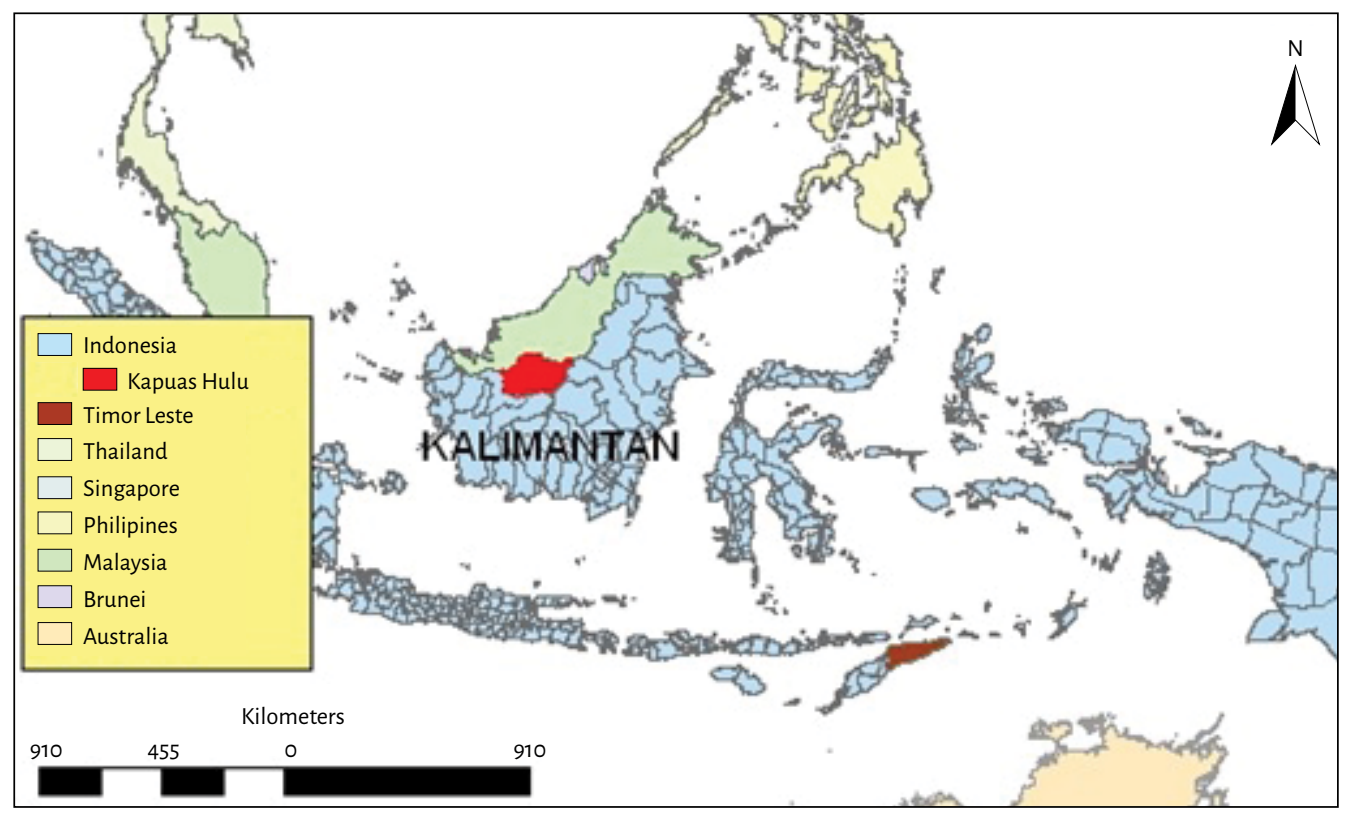

Figure 4.5 Location of Kapuas Hulu Regency in Indonesia.

\subsubsection{Population and ethnic composition}

Census data for the year 2013 reports a population of 231,000 people at an average population density of 7-8 people per $\mathrm{km}^{2}$ (BPS 2014). However, the population is unevenly distributed with the highest population centers situated in and around the administrative capital Putussibau (159 inhabitants $/ \mathrm{km}^{2}$ ) and the lowest in Embaloh Hulu subdistrict ( 1 inhabitant $/ \mathrm{km}^{2}$ ). Population growth in the region is expected to be steady due to a young population and immigration from Java and other regions of Kalimantan (Shantiko et al. 2013).

Kapuas Hulu is ethnically and culturally diverse. In general terms, the population can be classified as Malay and Dayak. However, the Dayak are distributed across the district and consist of 20 sub-ethnic groups and 20 languages (Institut Dayakologi 
Table 4.2 Education certificates obtained by the population of Kapuas Hulu.

\begin{tabular}{|l|c|c|c|}
\hline Highest certificate & Male (\%) & Female (\%) & Total (\%) \\
\hline No certificate & 33.10 & 31.51 & 32.36 \\
\hline Elementary school & 29.41 & 37.70 & 33.23 \\
\hline Junior high school & 18.95 & 16.59 & 17.86 \\
\hline Senior high school & 15.23 & 12.51 & 13.98 \\
\hline Vocational high school & 1.55 & 0.14 & 0.90 \\
\hline University & 1.76 & 1.56 & 1.66 \\
\hline
\end{tabular}

Source: BPS (2014)

2008). The majority of Dayaks in the population are Christian (Protestant and Catholic), while the Malay population is mostly Muslim. In addition, there are transmigrants from Java, who first arrived in 1975 as part of the national transmigrasi policy. The first transmigrant communities settled in the subdistrict of Silat Hilir, where they practiced permanent dryland agriculture. Each sub-ethnicity has its own language that is the primary language used in the household. Bahasa Indonesia is widely spoken and taught in all schools, and with the exception of some elderly people in remote villages is universally understood.

While the majority of the population has access to basic education, $32.36 \%$ of the population does not hold any form of education certificate. As the level of qualification increases, the frequency decreases sharply, with only $1.66 \%$ of the population graduating from higher education (Table 4.2). Most villages in the region have at least an elementary school, although it is common to have to travel to larger settlements for a high school education. A lack of teachers and poor infrastructure are contributing factors to the low levels of formal education.

\subsubsection{Ecological context}

Despite widespread deforestation, the region remains heavily forested. Tropical forests cover $74 \%$ of the total area of the district, consisting of $13,110.84 \mathrm{~km}^{2}$ of primary forest (42.08\%), $5229.50 \mathrm{~km}^{2}$ of secondary forest (16.78\%) and $4753.01 \mathrm{~km}^{2}$ of peat-swamp forest (15.25\%).

Kapuas Hulu has one of the highest proportions of protected forest in Kalimantan. Over half (57\%) of forest is under some form of conservation protection (Table 4.3), compared to an average of $26 \%$ for West Kalimantan (Shantiko et al. 2013). The entire region was designated a conservation area in 2003, a voluntary decision endorsed and legally enacted through a decree issued by the district head (Kantor Bupati 2003). 
Table 4.3 Forest area by official classification.

\begin{tabular}{|l|c|c|}
\hline Forestland classification & Area (ha) & Percentage (\%) \\
\hline National park & 930,940 & 29.80 \\
\hline Protected forest & 834,140 & 26.70 \\
\hline Limited production forest & 485,495 & 15.54 \\
\hline Production forest & 174,440 & 5.58 \\
\hline Production forest for conversion & 109,065 & 3.49 \\
\hline Area for other uses & 589,470 & 18.87 \\
\hline Total & $3,123,550$ & 100 \\
\hline
\end{tabular}

Source: BAPPEDA (2013)

\subsubsection{National parks}

Two national parks dominate the landscape; BKNP, a mixed dipterocarp forest that extends from the north of the region to the Malaysian border, and Danau Sentarum National Park, a network of lakes and forested islands situated in areas of peat-swamp forest in the west of the region (see Figure 4.6).

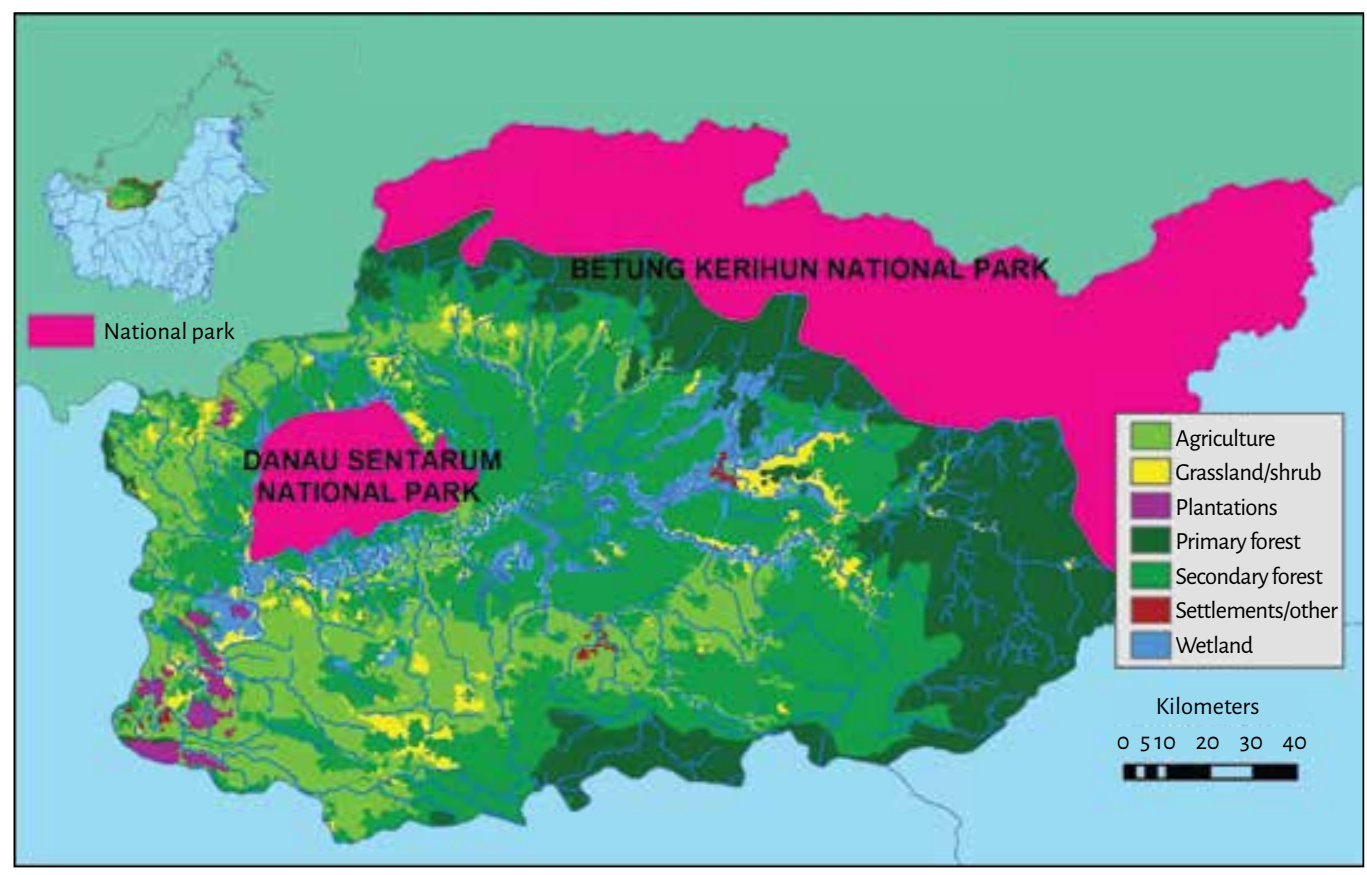

Figure 4.6 Map of national parks in Kapuas Hulu.

Source: WRI (2013) 


\section{Betung Kerihun National Park}

Betung Kerihun National Park (BKNP) covers 800,000 ha, making it the largest conservation area in West Kalimantan (Susilo 2003). Ranging from 150 to 2000 masl, the park is host to high levels of biodiversity including 54 mammal species (including 8 primate species, 17 rodent and 17 bat species), 112 species of amphibians and reptiles, and 695 woody plant species (of which 50 are endemic to Borneo) (Susilo 2003). Like most of Kalimantan's dipterocarp forests, BKNP is a masting forest, with mass-fruiting events thought to be triggered by the El Niño Southern Oscillation (Curran et al. 1999). The park is also the source of the Kapuas River, the largest river in Indonesia and an economic driver of the province of West Kalimantan. It is estimated that $80 \%$ of the upstream catchment of the Kapuas River lies within the national park (ITTO 2005). The park covers four administrative districts, Embaloh Hulu, Embaloh Hilir, Putussibau Utara and Putussibau Selatatan, but is under the management of the Forest Protection and Nature Conservation Department (Direktorat Jenderal Perlindungan Hutan dan Konservasi Alam, PHKA), a regional office of the national Ministry of Forestry.

Several communities live within the park boundaries and zones have been established regulating activities in different areas (Susilo 2003). The remote interior and northern regions of the park are classified as the 'core zone,' consisting of extremely high conservation value forest with high wildlife sensitivity and thus all forms of human activity are prohibited. Outside this zone lies the 'wilderness zone,' also of high conservation value but where human disturbance is considered less of a threat to wildlife. All forms of extraction of forest products including sustainable use of NTFPs are banned within the wilderness zones although ecotourism is permitted and indeed encouraged. All communities within BKNP lie within an 'intensive use zone' where the extraction of NTFPs, bushmeat hunting and shifting cultivation are permitted along with certain sanctioned agroforestry practices. In addition, a number of areas are categorized as 'reserve zones,' where special activities such as rehabilitation of wildlife and ecotourism are strictly permitted.

The monitoring of activities in the region is conducted by the National Park authorities, who patrol the area, although the patrol effort to area ratio is extremely low. There are reports of occasional conflicts between local people and the Park authorities, though most appear to be minor miscommunications surrounding the legality of certain land-use practices. WWF, the most active NGO in the national park, provide support to park authorities but in the past have criticized some of the management practices. In particular, WWF have highlighted the lack of park management personnel (57 professionals and 20 honorary local staff, of whom 24 are park rangers), lack of funding resulting in bi-monthly field visits only, the persistence of illegal logging in the park and limited engagement with local people (WWF 2005).

\section{Danau Sentarum National Park}

Danau Sentarum National Park, a network of wetlands, forested islands and freshwater lakes, is situated in seven subdistricts in the west of the regency; Batang Lupar, Badu, Embau, Bunut Hilir, Suhaid, Selimbau and Semitau districts. The park covers an area of 132,000 ha, surrounded by a buffer zone of approximately 65,000 ha. The buffer zone 
is more populated than BKNP with around 10,300 people living within the park (Indriatmoko 2010). These communities, of whom 93\% are ethnically Malay, are heavily dependent on the fisheries the lake provides. The remainder are Dayak Iban, who practice shifting cultivation (Wadley et al. 2010; Yuliani et al. 2014).

Danau Sentarum was initially established in 1985 as a wildlife reserve, and later converted to the higher protection status of national park in 1999 (Giesen 1987; Wadley et al. 2010). To this day, the exact boundaries of the park and its buffer zone remain unclear, and most management and protection is carried out by local communities themselves (Dennis et al. 2001; Indriatmoko 2010; Colfer and Minarchek 2012; Yuliani et al. 2008). Prior to the establishment of the National Park Management Unit in 2007, official protection was carried out solely by two forest rangers and two fire-patrol guards (Yuliani et al. 2008, 2014). Danau Sentarum provides habitat for a number of flagship species including the Bornean orang-utan and the proboscis monkey, as well as a vast range of other species including 143 species of mammals, 282 species of birds, 27 reptile species and 221 species of fish (Jeanes and Meijaard 2000; Kottelat and Widjanarti 2005).

As well as national parks, which fall under the authority of the Ministry of Forestry, district governments administer other forms of protected forest (Law No. 62 Forestry Act; Conservation Act; Government Regulation No. 62/1998). Protected forests are defined in forestry law as forested areas that have the principle function of water management, flood prevention or erosion control (Law No. 41 on Forestry 1999). Protected forest makes up $26.7 \%$ of forested land in Kapuas Hulu, although usually little-to-no on the ground management exists in these regions.

\subsubsection{Land tenure}

All forestlands in Indonesia are by default owned by the State, although significant areas of forest have yet to be gazetted (Indrato et al. 2012). State authority for the ownership of all forestlands was codified in 1999 by forestry law (Law No. 41 on Forestry 1999), based upon an assumption that the State owned the forests on behalf of the Indonesian people (Butt 2014). Following a constitutional court ruling in 2013 on a case brought by the Alliance of Indigenous Peoples (AMAN) in which the 1999 forestry law was ruled as being unconstitutional, the State has the legal obligation to grant ownership of forests to indigenous people (Butt 2014). In reality, few attempts to transfer ownership of forestlands to indigenous people have been successful (Sahide and Giessen 2015).

To date, there is no legalized customary forest (hutan adat) in Kapuas Hulu, though several local and national NGOs are involved in attempts to legally register land claims. AMAN campaigns for "local government policy changes in Kapuas Hulu and the protection and recognition of existence of indigenous people" (AMAN 2014). Other organizations such as the Registration Agency of Indigenous Territories (Badan Registrasi Wilayah Adat, BRWA), Forest Watch Indonesia, Sawit Watch, the Participatory Mapping Network (Jaringan Kerja Pemetaan Partisipatif, JKPP) and the Consortium for Supporting Community 
Table 4.4 Villages with community forest.

\begin{tabular}{|c|c|c|c|}
\hline Village & Subdistrict & Legally recognized & Unofficially recognized \\
\hline Ujung Said & Jongkong & $\square$ & \\
\hline Nanga Betung & Boyan Tanjung & $\square$ & \\
\hline Manua Sadap & Embaloh & $\square$ & \\
\hline Tanjung & Mentebah & $\square$ & \\
\hline Sri Wangi & Boyan Tanjung & $\square$ & \\
\hline Nanga Jemah & Boyan Tanjung & $\square$ & \\
\hline Penepian Raya & Jongkong & $\square$ & \\
\hline Nanga Lauk & Embaloh Hilir & $\square$ & \\
\hline Piasak & Selimbau & & $\square$ \\
\hline Jongkong Hilir & Jongkong & & $\square$ \\
\hline Buak Limbang & Pengkadan & & $\square$ \\
\hline Nanga Yen & Hulu Gurung & & $\square$ \\
\hline
\end{tabular}

Source: BAPPEDA (2013)

Based Forest System (Konsorsium pendukung Sitem Hutan Kerakyatan, KpSHK) also campaign for "[the] recognition of the existence of indigenous peoples and the rights over their customary lands" (KpSHK 2014).

Another form of local land tenure takes the form of village forest (hutan desa) (Table 4.4). Village forest is technically still owned by the State, but gifted to communities for sustainable use, such as the collection of forest products including eaglewood (gaharu) rattan and honey. Occasionally hutan desa can be used for small-scale plantations and agroforestry systems for gaharu and rubber. There are currently eight legally recognized hutan desas in Kapuas Hulu and a further four that are unofficially recognized or pending legal recognition.

\subsubsection{Economic context}

Agriculture is the largest sector of the economy in Kapuas Hulu accounting for $32 \%$ of regional GDP and $72 \%$ of employment (see Figure 4.7). The agricultural sector includes food crops (12.15\%), forestry (6.32\%), fisheries (5.41\%), plantations (4.66\%) and livestock (2.69\%). Construction is the second biggest contributor to gross regional domestic product $(24.42 \%)$ reflecting the steady flow of domestic and international investment in the region, though the sector employs comparatively few people (4.71\%).

The agricultural sector has remained relatively stable over time in Kapuas Hulu while extractive industries, especially timber, have fluctuated. Many people in Kapuas Hulu have more than one occupation and/or switch professions regularly depending on available economic opportunities (Table 4.5). 


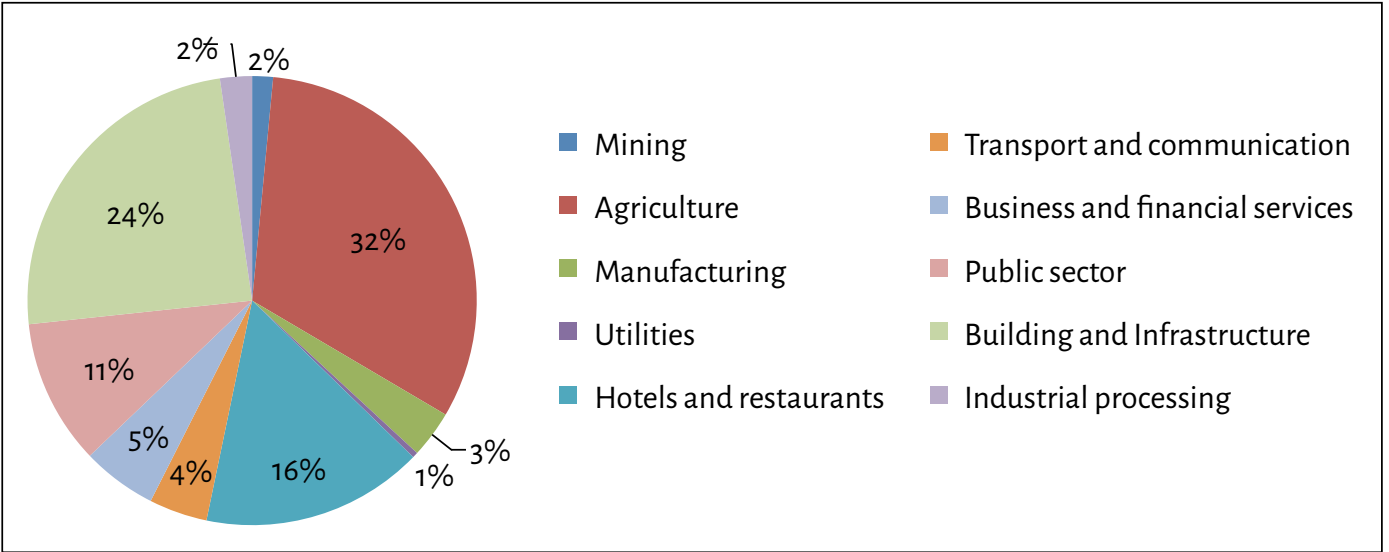

Figure 4.7 Contribution to regional GDP of economic sectors.

Source: BAPPEDA (2013)

Table 4.5 Percentage of population by occupation.

\begin{tabular}{|l|c|c|c|}
\hline Economic sector & Male (\%) & Female (\%) & Total (\%) \\
\hline Agriculture & 65.03 & 87.72 & 72.03 \\
\hline Mining & 9.57 & 1.73 & 6.47 \\
\hline Processing industry & 3.13 & 1.22 & 2.38 \\
\hline Electricity, gas and water & 0.13 & 0.00 & 0.08 \\
\hline Construction & 7.80 & 0.00 & 4.71 \\
\hline Trade, restaurants and hotels & 5.27 & 9.13 & 6.80 \\
\hline Transportation and communication & 1.31 & 0.000 & 0.79 \\
\hline Financial institutions and other services & 3.16 & 2.63 & 2.95 \\
\hline Other services & 4.59 & 2.57 & 3.79 \\
\hline
\end{tabular}

\subsection{Land use and land-use change in Kapuas Hulu}

\subsubsection{Oil palm plantations}

Oil palm plantations first appeared in Kapuas Hulu in the year 2000, in the subdistrict of Silat Hilir. This subdistrict borders the neighboring district of Sintang, where large-scale oil palm plantations had been in operation for many years. As a result, operational oil palm concessions are heavily concentrated in the west of the region, though in recent years new concessions have been opened and developed around 
the district capital of Putussibau and toward the north of the region in the "biodiversity corridor" (see Figure 4.8) between the two national parks (Shantiko et al. 2013). Indonesia's Ministry of Industry has established national production targets of 50 million tons of crude palm oil a year by 2020 (KOMPAS 2009; BPS 2010; Yuliani et al. 2014). In response, local and regional government are predicted to grant 20 million ha of new plantation concessions by 2020 (Clerc 2011). In Kapuas Hulu, the regional land-use planning process (Rencana Tata Ruang Wilayah, RTRWK) has allocated an additional 19\% of land to 'alternative land use,' a change in land classification necessary for the development of new plantations (Shantiko et al. 2013). The extent of oil palm is shown in Figure 4.9.

Two conglomerates dominate oil palm in the region: SMART Group and First Borneo International. SMART (Sinar Mas Agro Resources Technology), is the palm oil subsidiary of the Sinar Mas consortium, one of the largest conglomerates in Indonesia, which also includes Asian Pulp and Paper, one of the largest timber and pulp companies in the world, with operations extending as far as China. In Kapuas Hulu, SMART manages 159,500 ha of palm oil plantations, split over nine subsidiary companies (Table 4.6).

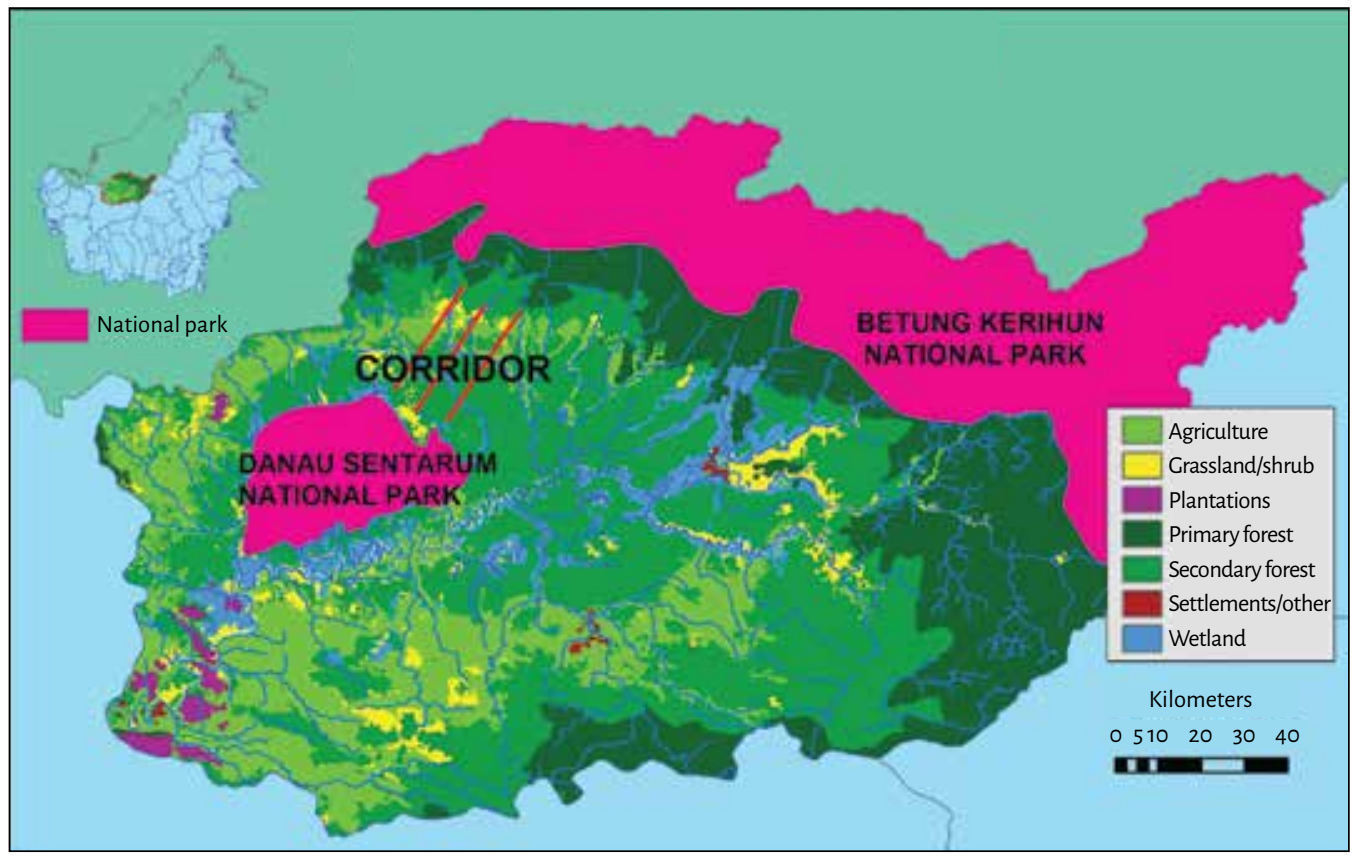

Figure 4.8 Proposed biodiversity corridor in Kapuas Hulu.

Source: Map created using data from WRI (2013), with additional information from WWF (personal communication, 2015) 
Table 4.6 Palm oil companies in Kapuas Hulu.

\begin{tabular}{|c|c|c|}
\hline Company & Group & Area (ha) \\
\hline PT. Borneo Estate Sejahtera ${ }^{a}$ & First Borneo International & 14,219 \\
\hline PT. Bumi Tani Jaya ${ }^{a}$ & Metro & 20,783 \\
\hline PT. Berkah Sawit Abadi ${ }^{a}$ & FBI 2006 & 12,778 \\
\hline PT. Kapuas Bio Agro ${ }^{a}$ & First Borneo International & 17,386 \\
\hline PT. Primanusa Mitra Serasi ${ }^{a}$ & SMART 2006 & 19,933 \\
\hline PT. Rimba Utara ${ }^{a}$ & Takeover 2005 & 26,514 \\
\hline Kud. Mitra Kenepai Kurnia ${ }^{a}$ & - & 9,060 \\
\hline PT. Tanjung Berkah Mulia ${ }^{a}$ & - & 17,825 \\
\hline PT. Tanjung Berkah Mulya ${ }^{a}$ & - & 17,784 \\
\hline PT. Mitra Kapuas Agro & FBI 2006 & 7,229 \\
\hline PT. Mitra Kapuas Hulu & First Borneo International & 22,846 \\
\hline PT. Karita Prima Cipta & SMART 2008 & 20,182 \\
\hline PT. Khatulistiwa Agro Abadi & First Borneo International & 16,873 \\
\hline PT. Buana Tunas Sejahtera & SMART 2006 & 15,844 \\
\hline PT. Sentrakarya Manunggal & SMART 2007 & 19,970 \\
\hline PT. Sawit Kapuas Kencana & Metro 2007 & 17,227 \\
\hline PT. Kapuas Indo Palm Industri & SMART 2006 & 19,068 \\
\hline PT. Duta Nusa Lestari & SMART 2006 & 16,480 \\
\hline PT. Anugrah Makmur Sejati & SMART 2006 & 21,912 \\
\hline PT. Paramita Internusa Pratama & SMART 2006 & 19,973 \\
\hline PT. Persada Graha Mandiri & SMART2006 & 18,762 \\
\hline PT. Riau Agrotama Plantation & Salim 2008 & 9,682 \\
\hline PT. Borneo International Anugerah & FBI 2006 & 8,681 \\
\hline PT. Borneo International Anugerah & FBI & 12,089 \\
\hline PT. Wahana Hamparan Hijau & FBI 2006 & 2,740 \\
\hline PT. Wahana Hamparan Hijau & FBI & 16,979 \\
\hline PT. HPHM & - & 4,995 \\
\hline PT. Dinamika Multi Prakasa & - & - \\
\hline Total & & 426,821 \\
\hline
\end{tabular}

a Yet to begin land clearing.

Source: BAPPEDA (2013) 
Table 4.7 Area of community-owned oil palm, 2009-12.

\begin{tabular}{|c|c|c|c|}
\hline Year & Yet to produce (ha) & Productive (ha) & Total area (ha) \\
\hline 2009 & 7,483 & 8,376 & 15,859 \\
\hline 2010 & 26,844 & 8,376 & 35,220 \\
\hline 2011 & 26,844 & 8,376 & 35,220 \\
\hline 2012 & 37.616 & 8,876 & 46,592 \\
\hline
\end{tabular}

Source: BPS (2014)

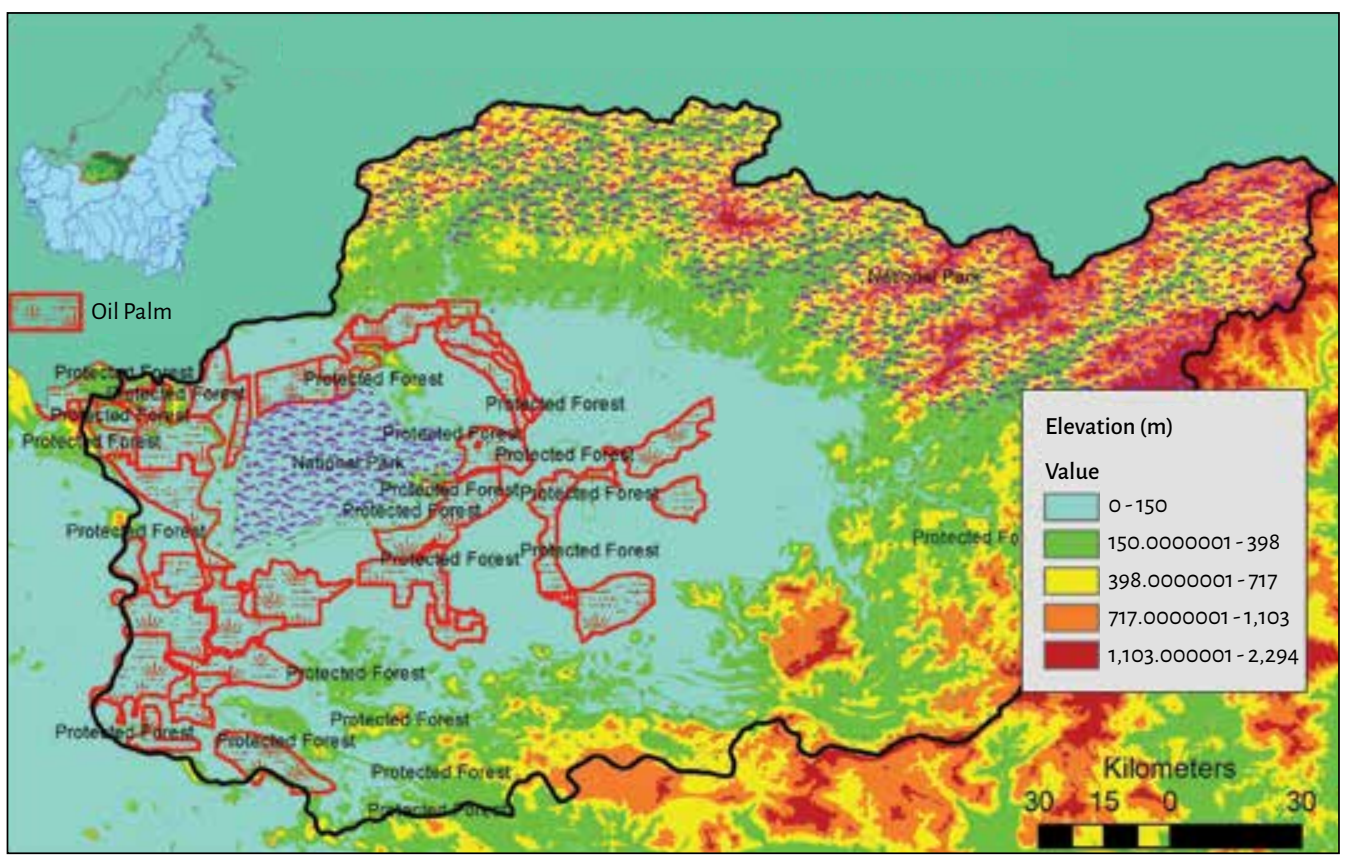

\section{Figure 4.9 Oil palm plantations in Kapuas Hulu.}

Note: $\mathrm{NP}=$ national park; $\mathrm{PF}=$ protected forest.

Source: Created using data from from WRI (2013)

The SMART group has received extensive criticism from environmental groups, most notably from Greenpeace, who have accused the company of clearing large areas of deep peat forests and of operating without appropriate permits and environmental impact assessments (Greenpeace 2010). Following criticism of Sinar Mas's practices, several buyers of palm oil, including Unilever, suspended or stopped the purchase of Sinar Mas oil palm (Unilever 2009).

In addition to corporate plantations, several communities have private or cooperative ventures (Table 4.7). Such community plantations are relatively recent with fewer than $20 \%$ of plantations in the production stage. 


\subsubsection{Mining}

Kapuas Hulu has considerable deposits of gold, coal, antimony, bauxite, mercury, lead and copper. To date, these mineral deposits have been relatively underexploited though a variety of companies are currently conducting exploration. Of the 69 mining companies operating in the region, 60 are in the exploration phase with only 9 companies involved in active extraction of minerals (see Table 4.8).

\section{Table 4.8 Mining operations in Kapuas Hulu.}

\begin{tabular}{|l|c|c|}
\hline Commodities & Number of Companies & Area (ha) \\
\hline Coal & 39 & 301,272 \\
\hline Gold & 18 & 193.439 \\
\hline Antimony & 7 & 22,095 \\
\hline Bauxite & 1 & 4,466 \\
\hline Copper & 1 & 1,978 \\
\hline Mercury & 1 & 1,000 \\
\hline Laterite ferro manganese & 1 & 4,970 \\
\hline Lead & 1 & 516 \\
\hline
\end{tabular}

Source: Personal communication with Dinas Pertambangan dan Energi (2012)

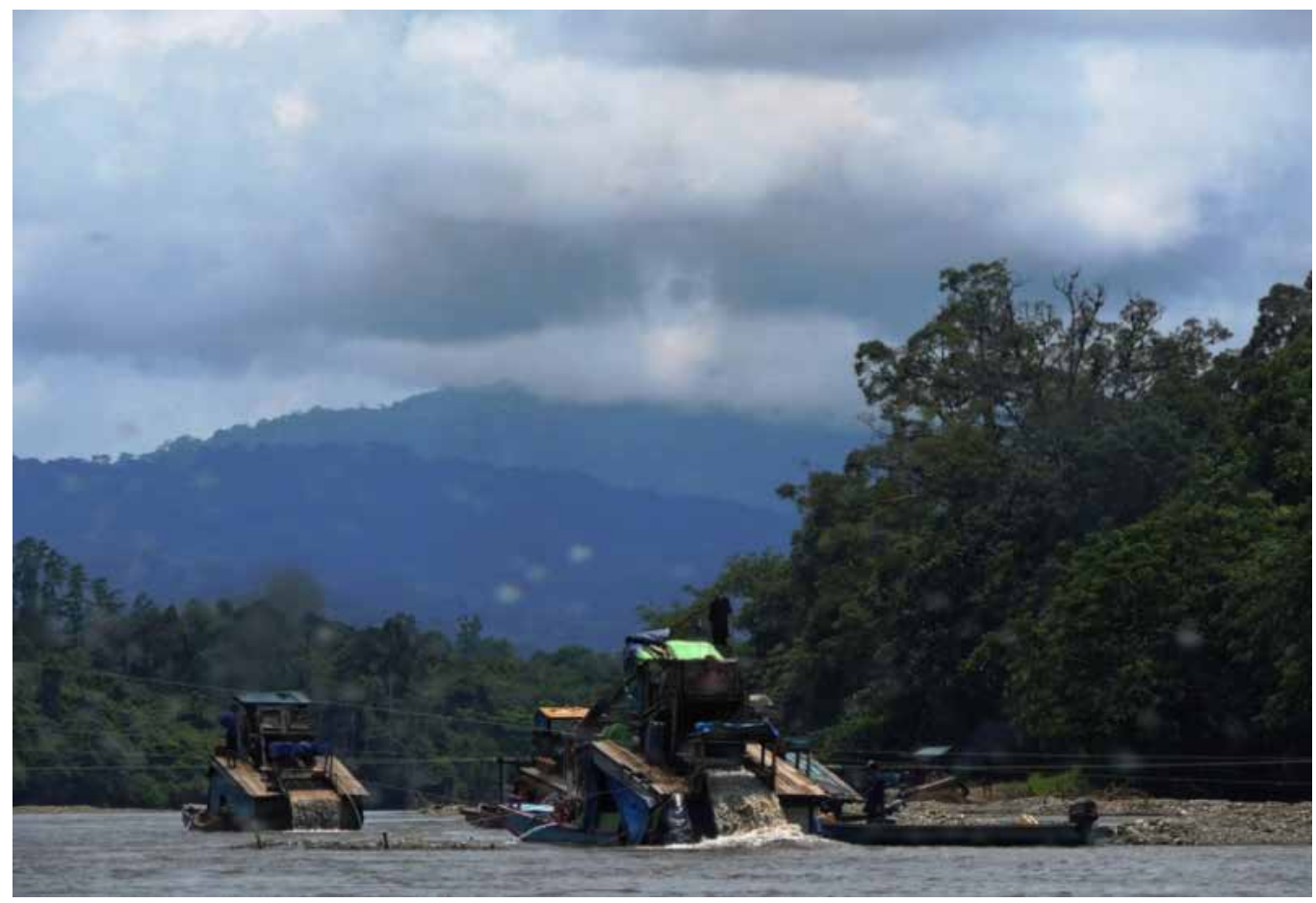


Traditional gold-panning has been conducted by many communities for centuries. Since 1984, some communities have had recognized legal mining operations. The vast majority of local mining activities are illegal but generally ignored by law enforcement. Today gold-panning has been largely replaced with mechanized mining consisting of rafts fitted with diesel powered pumps driving suction tubes, occasionally directed by a diver breathing surface air through a tube. Riverbed sediment is then cascaded over a series of surfaces on a manual conveyer belt to separate gold from other stones. Such work is extremely risky, both financially, due to high overheads, and in terms of safety. Accidents and even deaths are far from uncommon. The use of mercury as an amalgam to separate the gold from rocks is common in small-scale mining operations, especially in the more remote northern regions of Kapuas Hulu (Adijaya and Yamashita 2004). Mercury pollution in the Kapuas River is so high that fish are deemed to be unsafe for human consumption and even the municipal water supply in both Putusibau and Pontianak is affected (Lusiana et al. 2008). Mercury levels in human hair and nails are high across the region, highest in people living near mines, followed by miners themselves and consumers of municipal water supplies (Bider 2003).

\subsubsection{Timber}

Commercial timber harvesting has been carried out in Kapuas Hulu since the 1970s, growing rapidly in scale until the early 2000s. During the Soeharto era, logging concessions were run by or had close links to the military. Some companies were directly run by the military, while other owners of logging licenses were either former or current military personnel (Eilenberg 2009, 2012). These large-scale operations, conducted by companies such as PT Yamaker, often resulted in conflicts between local communities and companies. Community grievances included companies employing Javanese migrants rather than local people and ignoring traditional and customary claims to the land (Eilenberg 2009, 2012; Wadley et al. 2010). Community resistance against companies occasionally took the form of direct action, including the setting up of road blocks (van Klinken 2008; Eilenberg 2009, 2012). In Kapuas Hulu, with its border to Malaysia, domination by companies owned by or with close links to the military was also seen to have a national security motivation, or at least a national security justification. During this period concessions stretched across almost the entire border, effectively establishing military control of the border (Eilenberg 2009). It is widely accepted that the military were heavily involved in the smuggling of illegal timber across the border (Eilenberg 2012).

The collapse of the Soeharto New Order in 1998, and the economic crisis that precipitated it, led to significant changes in logging ownership and practices in the region. A process of decentralization (decentralisasi) gave back power, at least in theory, to local and regional authorities (Fox et al. 2005). Permits for companies with close links to the dictatorship were terminated (Eilenberg 2009). Whereas before the entire forest estate of Indonesia was under direct control of the Ministry of Forestry, a series of new laws and decrees lead to confusion and conflict over which section of government exerted authority over the land (McCarthy 2004; Fox et al. 2005). As a result, a power vacuum developed that was filled by illegal logging companies and entrepreneurs from Malaysia. The confusion over the legal status of forests, combined with the new requirement for provinces and districts to raise their own revenue and a great deal of corruption led to 
officially sanctioned yet illegal operations exporting to Malaysia via newly developed cross-border roads (Obidzinski et al. 2007). In 2004, it was estimated that $1000 \mathrm{~m}^{3}$ of timber were exported across the border to the Malaysian state of Sarawak every day (Pontianak Post 2004), and at one point it was estimated $80 \%$ of timber in Sarawak came from West Kalimantan (Eilenberg 2009, 2012). Illegal logging has recently declined as a result of government enforcement. Local-scale illegal logging still occurs yet is very small in scale relative to the large commercial operations of the post-Soeharto era.

\subsubsection{Rubber}

The province of West Kalimantan contains more commercial rubber trees than any other province in Indonesia, due predominantly to historical reasons (Peluso 2009). Some form of rubber has been collected and traded across Kalimantan for centuries, traditionally native wild rubber would be tapped and traded with Chinese merchants in exchange for goods such as metal tools, sugar, salt and tobacco not readily available in the region (Heidhues 2003). Smallholder rubber plantations, using exotic rubber species, became the norm during the British and Dutch colonial eras and continue to dominate the production to this day (Dove 1993; Peluso 2009).

Rubber still forms an important source of income for many people in rural Kapuas Hulu, though since the 1970s the tapping of wild rubber trees has largely been superseded by smallholder plantations and agroforestry systems. Unlike many other regions of Kalimantan, there are no company-owned rubber plantations in Kapuas Hulu. The popularity of rubber as a smallholder concern stems, in part, from its flexibility. Rubber tapping requires relatively little time investment and periods of non-tapping do not compromise yields. As a result, rubber can function as a safety-net when cash income is low and can be switched to when prices of other commodities fall (Belcher et al. 2004). In the past few years, the price of rubber has fallen considerably from IDR 10,000 (USD 0.74$)^{1}$ to IDR 4000-5000 (USD 0.29-0.37) per kg. As a result, many rubber farmers and smallholders have switched to waged labor on palm oil plantations, or less commonly to smallholder palm oil plantations.

\subsubsection{Fishing}

Fishing is common across Kapuas Hulu, both as a means of subsistence and as a source of income. Commercial aquaculture is predominantly found around freshwater lakes such as Danau Sentarum. Cultivation of fish for consumption, commonly focuses on the following species: jelawat (Leptobarbus hoeveni), goldfish (Cyprinus sp.), betutu (Oxyeleotris marmorata), toman (Channa micropeltes), belida (Notopetrus borneensis), nila (Oreochromis niloticus), gourami (Osphronemus goramy), lele (Clarias sp.), bawal (Colossoma sp.), patin (Pangasius sp.) and semah (Tor sp.). Prices for desirable species such as semah can reach up to IDR 300,000 (USD 22) per kg locally and retails in Malaysia for up to IDR 800,000 (USD 59). In addition to edible species, the cultivation of ornamental species is gaining increasing popularity with communities in Kapuas Hulu. Ornamental species such as arowana (Scleropages formosus) can sell for IDR 2,000,000-3,000,000 (USD 147-221) and broodstock individuals can sell for up to IDR 15,000,000 (USD 1103). 


\subsubsection{Non-timber forest products}

The collection of NTFPs is widespread in Kapuas Hulu, although it is a main livelihood strategy only in heavily forested regions in the north and northwest of the region. Gaharu, a resin caused by natural infection of eaglewood species (Aquilara spp.) is one of the highest value NFTPs in the world with high-grade resins reaching prices of over USD 10 per gram. High-grade gaharu is used to make incense, while medium and low grades are used for perfumes and cosmetics (Soehartono and Newton 2000). Throughout Indonesia, it is not unusual for high-grade gaharu to fetch prices of USD 500 per kg and USD 60-80 per $\mathrm{kg}$ for medium-grade resins (Paoli et al. 2001). In the 1990s, a gaharu boom led to massive overexploitation of gaharu, resulting in rapidly declining population numbers. As a result, it was placed on the Convention on International Trade of Endangered Species (CITES) Appendix II in 1995, effectively prohibiting international trade (Lim and Noorainie 2010). Despite the ban on trade, demand is still extremely high (Soehartono and Newton 2000) and gaharu is still a major source of income for large proportions of forest-based people across Indonesia (Paoli et al. 2001; Wollenberg 2001).

In addition to gaharu, edible swiftlet nests are a major source of income for NTFP collectors in Kapuas Hulu. Swiftlet nests, sometimes called 'the caviar of the East' (Marcone 2005), are highly valuable with prices reaching up to USD 2500 per $\mathrm{kg}$ for end consumers (Investvine 2014). Demand for swiftlet nests is particularly high in China where they are widely believed to have medicinal and aphrodisiac properties (Thorburn 2014). Wild harvesting of swiftlet nests usually occurs in caves in mountainous forested regions, though commercial harvesting with artificial towers is growing in popularity in villages near forests across Kalimantan. In Kapuas Hulu, our informants reported prices of approximately IDR 2,000,000 (USD 147) per kg, a lower price than reported elsewhere in Kalimantan where prices can reach as high as IDR 15,000,000-35,000,000 (USD 1103-2574). Other NFTPs collected in Kapuas Hulu include wild honey, which sells for IDR 120,000-200,000 (USD 8.8-14.6) per kg, as well as rattan and bamboo used to make handicrafts and furniture.

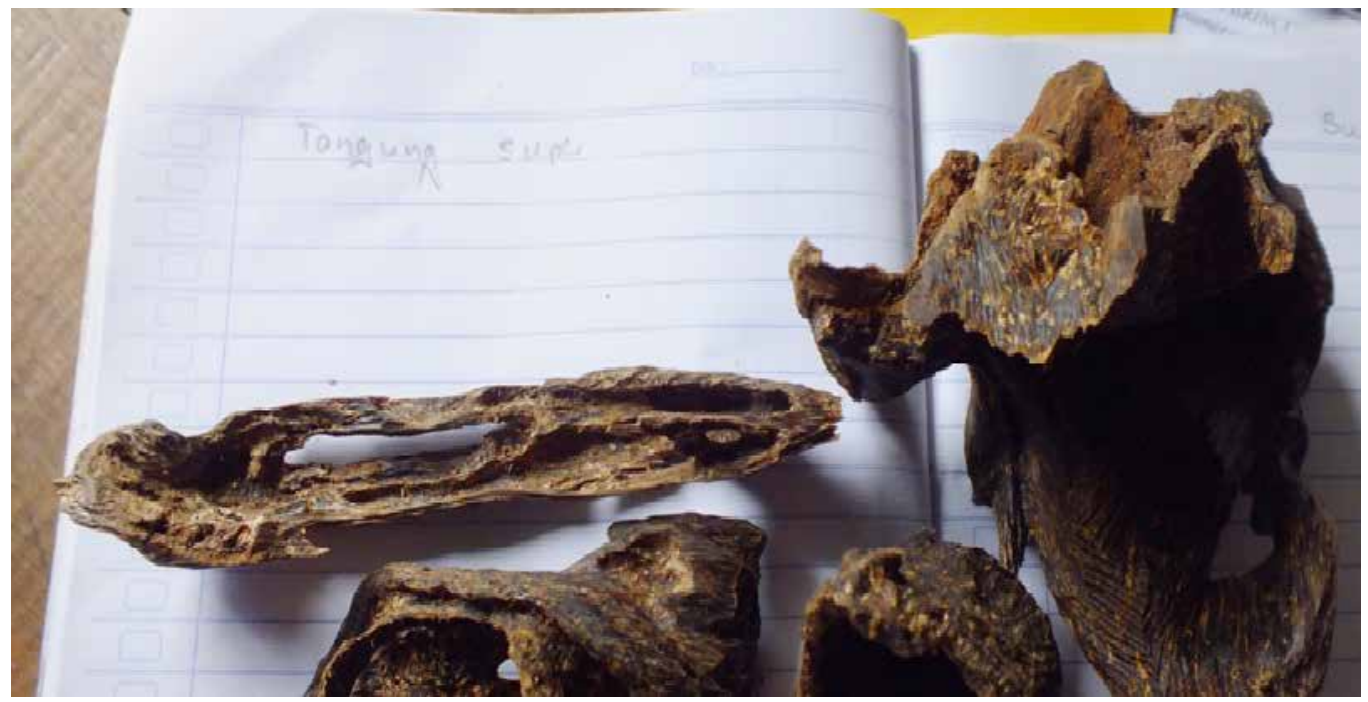




\subsection{Descriptions of zones}

We selected three zones as pilot sites to represent landscapes at different stages of agrarian change in Kapuas Hulu Regency (Figure 4.10). Zone 1 consists primarily of natural forest, Zone 2 of mixed agroforestry and Zone 3 of monoculture oil palm plantations.

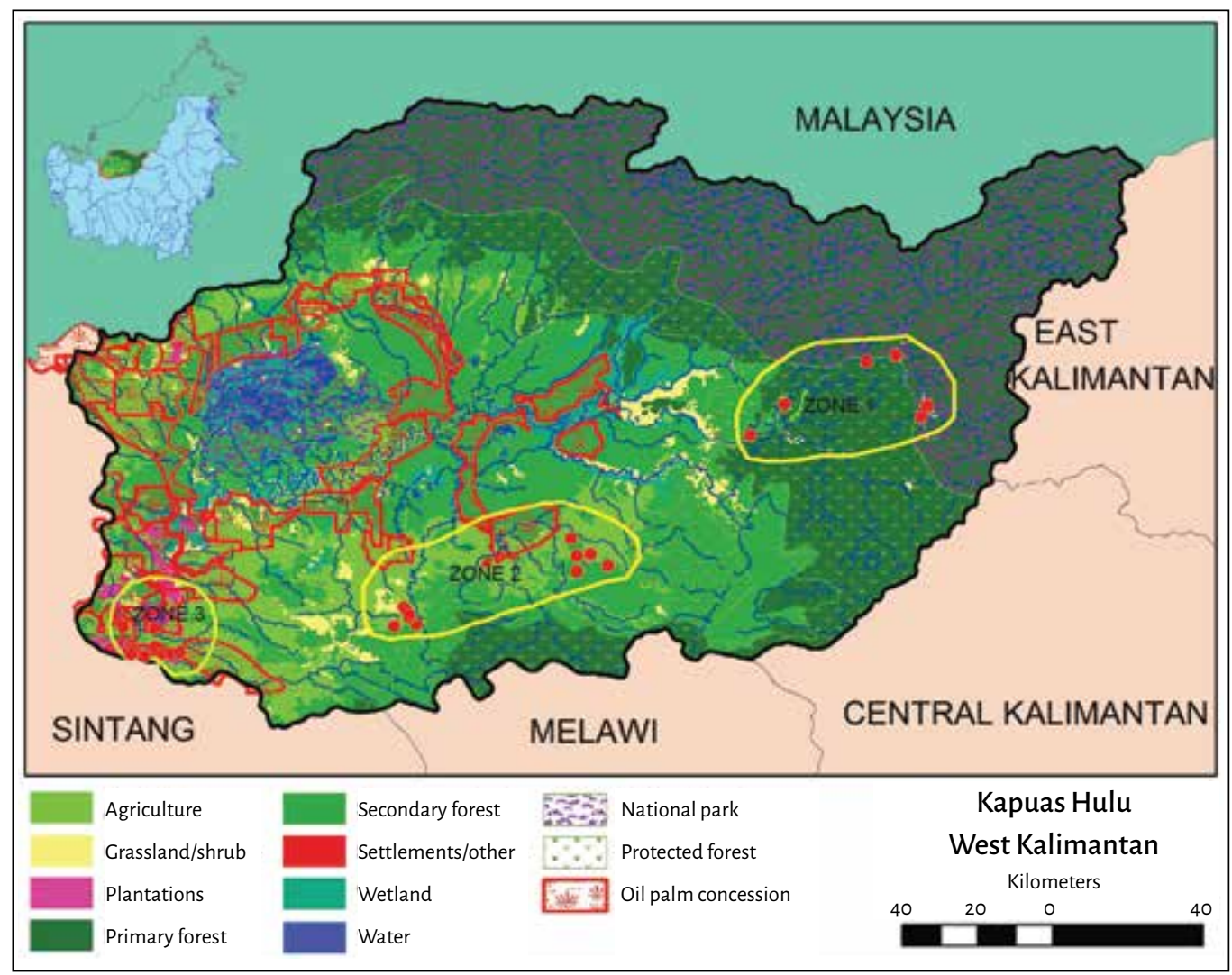

\section{Figure 4.10 Location of study zones.}

Source: Created using data from WRI (2013)

\subsubsection{Zone 1}

Zone 1 is geographically located in the upstream part of the Kapuas River within the boundary of BKNP. The region is accessible only by boat via a series of rapids, impassable during periods of heavy rain and periods of drought. The forest in the region primarily consists of montane and sub-montane dipterocarp forest. We selected three villages as pilot sites: Beringin Jaya, Bungan Jaya and Tanjung Lokang (see Figure 4.11).

Beringin Jaya and Bungan Jaya villages are located on the banks of the Kapuas River, while Tanjung Lokang village is located on the banks of Bungan River. Bungan Jaya and Tanjung Lokang share a boundary with BKNP, while Beringin Jaya is located in the BKNP buffer zone. Each village is separated into two or three hamlets (dusuns) usually a 


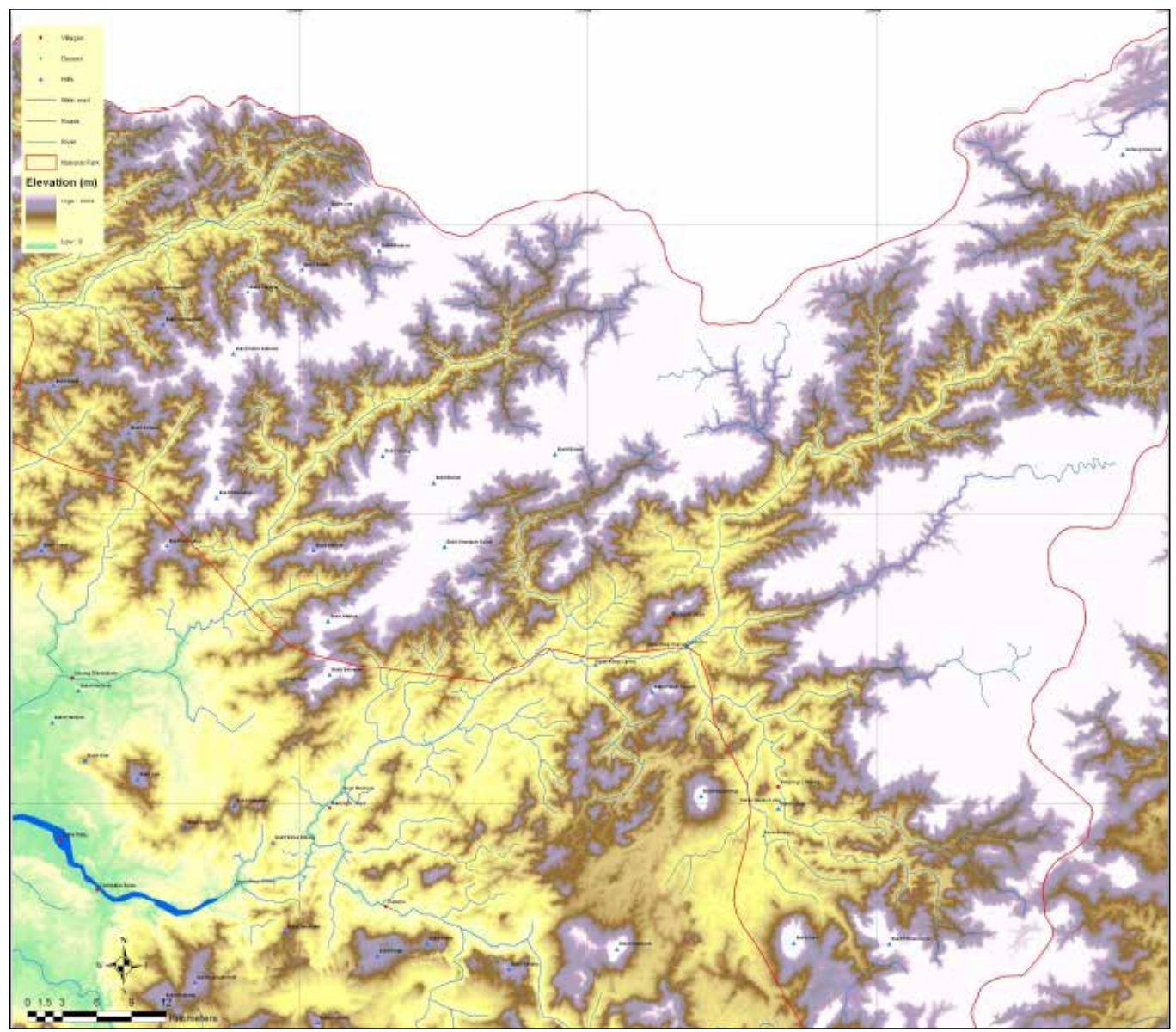

Figure 4.11 Map of Zone 1 settlements.

few kilometers away from one another by boat or forest trail. Communities in the region consist of two sub-ethnic groups namely the Bukat in Beringin Jaya and the Punan in Bungan Jaya and Tanjung Lokang. Traditionally, both ethnicities adopted a nomadic lifestyle, but became sedentary following the influence of the Christian missionaries in the 18th century. Their nomadic heritage means that unlike other sub-ethnic groups in the region such as the Iban, they do not practice the traditional long-house culture widely found in the region.

Livelihoods in Zone 1 consist primarily of subsistence agriculture, fishing and bushmeat hunting, supplemented by income from gold mining, gaharu seeking and the sale of swiftlet nests. Shifting cultivation (often called swidden in Southeast Asia) operates on a 3-4 plot (ladang) rotation with one plot per year actively planted and harvested although wild and semi-cultivated plants are harvested from fallow plots. Slash and burn activities are timed to coincide with the end of the wet season and start of the dry season, and crops mainly consist of upland rice cultivars and green leafy vegetables. Typically ladangs are located less than $50 \mathrm{~m}$ from the side of a river and cover an area of 1-2 ha. It is common for ladangs located far from the home village to have basic shelters/houses used during times of planting or harvest. 


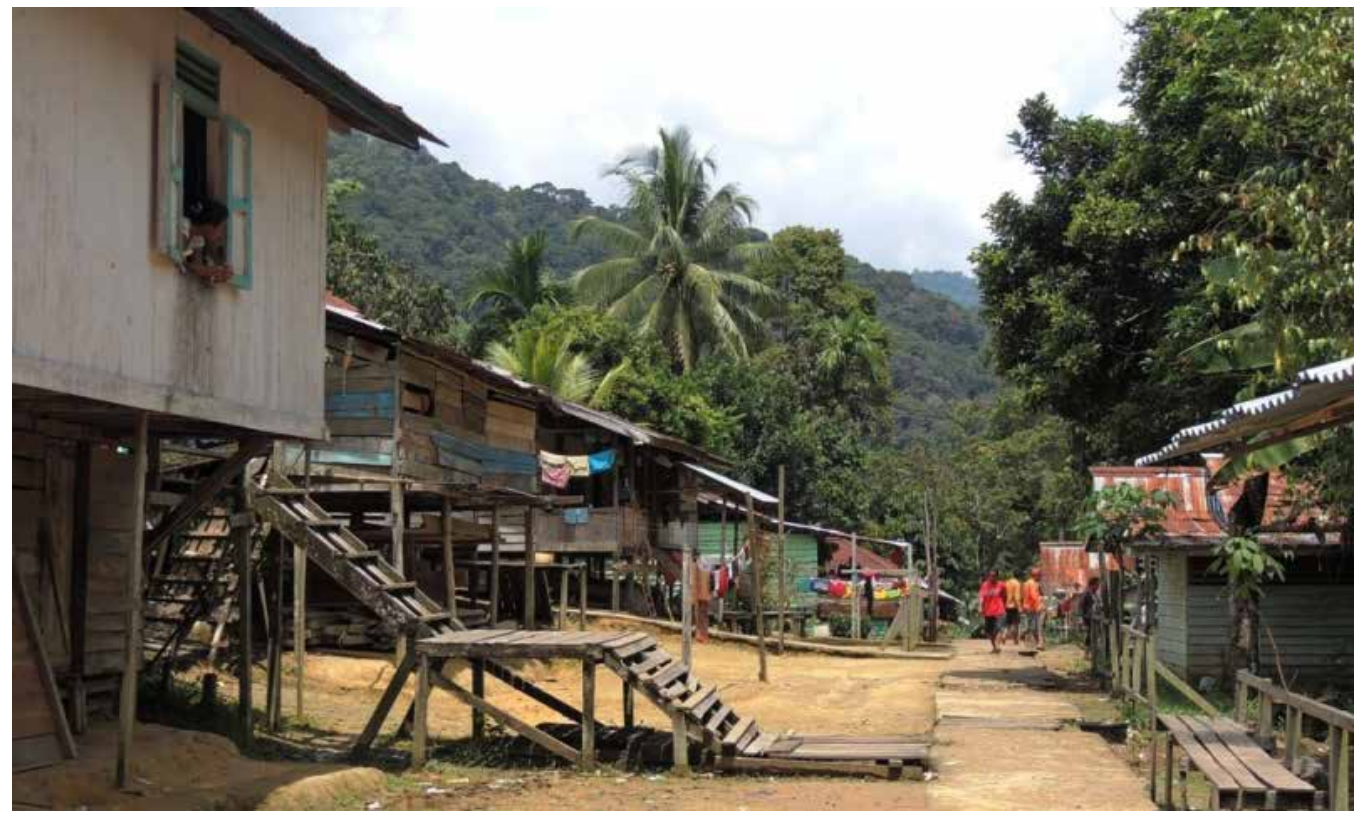

Bungun Jaya Village. (Laurio Leonald/CIFOR)

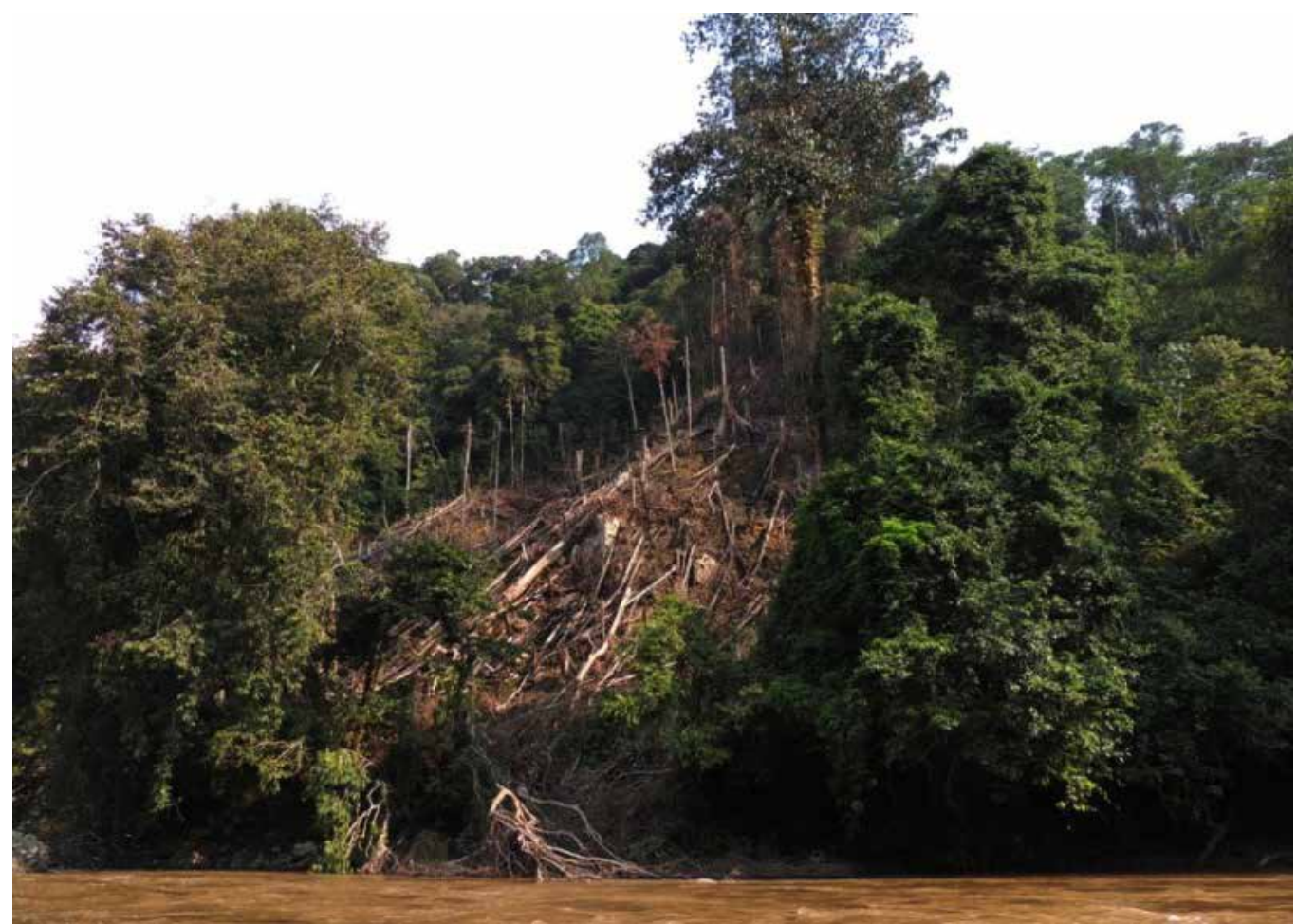

Ladang (shifting agriculture plot) near the village of Tanjung Lokang. (Laurio Leonald/CIFOR) 
Mining activities, traditionally carried out by panning, are now mechanized with the use of generator-powered pumps atop rafts that dredge river bed sediment and cascade them over carpet to separate gold from silt and stones. Timber harvesting, a significant source of income in the 1990s, is no longer present in the region with the exception of logging for construction of houses, boats and other uses within the villages. See Table 4.9 for a summary.

Table 4.9 Summary of Zone 1 settlements.

\begin{tabular}{|c|c|c|c|}
\hline Village & Beringin Jaya & Bungan Jaya & Tanjung Lokang \\
\hline Hamlets & $\begin{array}{l}\text { Nanga Balang, Mata } \\
\text { Lunai }\end{array}$ & $\begin{array}{l}\text { Nanga Bungan, Aso, } \\
\text { Lapung }\end{array}$ & $\begin{array}{l}\text { Tesoing Loing, } \\
\text { Buung, Belatung }\end{array}$ \\
\hline Area & $760 \mathrm{~km}^{2}$ & $1,984 \mathrm{~km}^{2}$ & $795 \mathrm{~km}^{2}$ \\
\hline Sub ethnicities & $\begin{array}{l}\text { Bayak Buket, Dayak } \\
\text { Punan }\end{array}$ & Dayak Punan & Dayak Punan \\
\hline Population size & 520 (133 households) & 677 (198 households) & 400 (170 households) \\
\hline Accessibility from Putussibau & 4-6 hours by speedboat & $\begin{array}{l}5-8 \text { hours by } \\
\text { speedboat }\end{array}$ & $\begin{array}{l}\text { 9-13 hours by } \\
\text { speedboat }\end{array}$ \\
\hline Settlement pattern & Side of river & Side of river & Side of river \\
\hline Educational facilities & $\begin{array}{l}\text { Elementary school, } \\
\text { junior high school }\end{array}$ & Elementary school & Elementary school \\
\hline Health facilities & Village clinic & Village clinic & Village clinic \\
\hline Religious buildings & $\begin{array}{l}\text { Protestant church, } \\
\text { Catholic church }\end{array}$ & Catholic church & Catholic church \\
\hline Electricity supply & $\begin{array}{l}\text { Generator } \\
\text { (micro hydro being } \\
\text { built at time of } \\
\text { writing) }\end{array}$ & $\begin{array}{l}\text { Micro hydro } \\
\text { electricity (Nanga } \\
\text { Bungan and Aso), } \\
\text { generator (Lapung) }\end{array}$ & $\begin{array}{l}\text { Micro hydro/ } \\
\text { generator }\end{array}$ \\
\hline Farming seasons & $\begin{array}{l}\text { April-May (slash and } \\
\text { burn), July-September } \\
\text { (planting), January- } \\
\text { February (harvesting) }\end{array}$ & $\begin{array}{l}\text { April-May (slash } \\
\text { and burn), } \\
\text { July-September } \\
\text { (planting), January- } \\
\text { February (harvesting) }\end{array}$ & $\begin{array}{l}\text { April--May } \\
\text { (slash and burn), } \\
\text { July-September } \\
\text { (Planting), } \\
\text { January-February } \\
\text { (harvesting) }\end{array}$ \\
\hline Livelihoods & $\begin{array}{l}\text { Main sources of } \\
\text { income: gold mining, } \\
\text { gaharu (eaglewood), } \\
\text { swiftlet nest, rubber } \\
\text { (newly planted at time } \\
\text { of writing) } \\
\text { Subsistence: swidden } \\
\text { agriculture, fishing, } \\
\text { hunting, NTFPs }\end{array}$ & $\begin{array}{l}\text { Main sources of } \\
\text { income: gold mining, } \\
\text { gaharu (eaglewood), } \\
\text { swiftlet nest } \\
\text { Subsistence: swidden } \\
\text { agriculture, fishing, } \\
\text { hunting, NTFPs }\end{array}$ & $\begin{array}{l}\text { Main sources of } \\
\text { income: gold mining, } \\
\text { gaharu (eaglewood), } \\
\text { swiftlet nest } \\
\text { Subsistence: swidden } \\
\text { agriculture, fishing, } \\
\text { hunting, NTFPs }\end{array}$ \\
\hline
\end{tabular}




\subsubsection{Zone 2}

Zone 2 is situated in the southern part of Kapuas Hulu (see Figure 4.12). We conducted interviews in eight villages identified as potential Zone 2 sites: Tangai Jaya, Suka Maju, Kepala Gurung, Tanjung, Nanga Betung, Sri Wangi, Nanga Jemah and Nanga Yen. The ethnic composition of the zone consists of two local sub ethnicities, Dayak Suruk/Su'yuk and Malay, though some villages contain significant populations of Javanese migrants. The communities are accessible by motorcycle or car, approximately 2-3 hours from Putussibau. Built in 1990, one main paved road transects the southern region of Kapuas $\mathrm{Hulu}$, though villages generally connect to this road via dirt or gravel roads or tracks that are dangerous or impassible during or after periods of heavy rain.

Land use in the region is highly variable with communities practicing shifting cultivation or permanent rice paddies. Where shifting cultivation is used, plots are used for approximately 1-2 years, returning to the initial plot after a cycle of 5 years. Rice paddies have been used in the region since the 1990 s as a reaction to concerns over

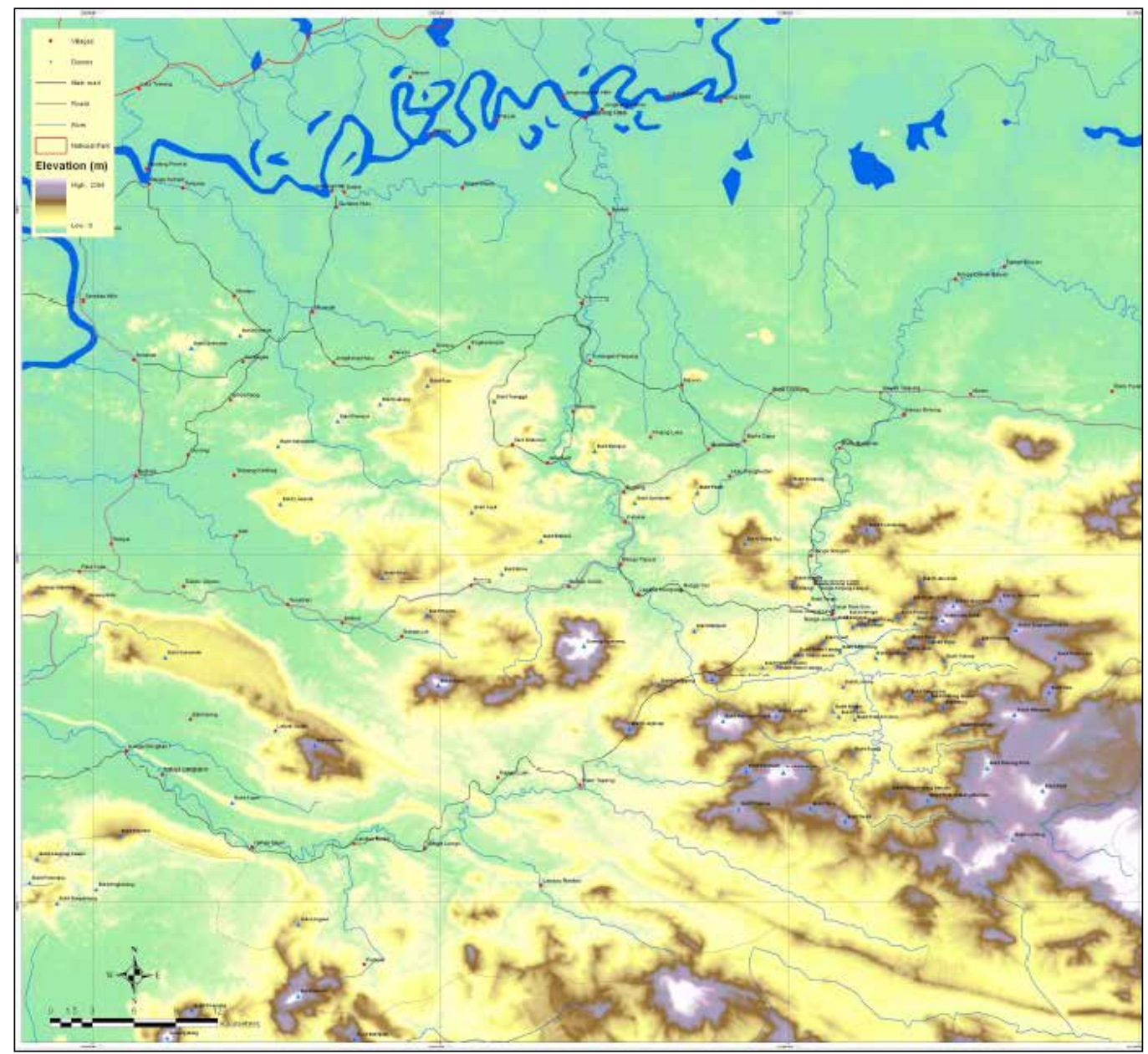

Figure 4.12 Map of Zone 2 settlements. 
food security. Food from agriculture is mainly used for subsistence and only sold on rare occasions of surplus. Bushmeat hunting and fishing, common 3-5 years ago, is in decline as forest cover and fish stocks decline. Rubber cultivation is the primary source of income generation for these communities, planted on old swidden plots (shifting cultivation), in mixed agroforestry gardens or in rare cases, through deliberate forest clearing. The average size of a rubber garden is between 1 and 3 ha. Where agroforestry is used to grow rubber, it is usually intercropped with mango trees, Borneo tallow nut trees and gaharu. Though rubber has been widely cultivated in the region since the 1970s, improved infrastructure in the 1990s significantly improved access to markets resulting in a notable increase in the number of households practicing rubber farming. Prior to rubber becoming the main source of household income for the majority of households, many communities also practiced traditional gold mining and gaharu seeking, but the declining availability of these resources in the past 3-5 years has resulted in most households transitioning to rubber farming as a source of cash income. Collection of NTFPs such as rattan, honey, fruits and medicinal plants is widely carried out and primarily used for subsistence; trade in NTFPs is rare.

Some villages in Zone 2 have legalized access to community forest (hutan desa), aided by community mapping carried out by FFI. The villages of Tanjung, Nanga Betung, Sri Wangi, Nanga Jemah have legally recognized hutan desa, while the village of Nanga Yen has unofficial recognition pending official approval. The latter community forest overlaps with a concession issued for a mining company for the exploration of antimony. See Table 4.10 for a summary.

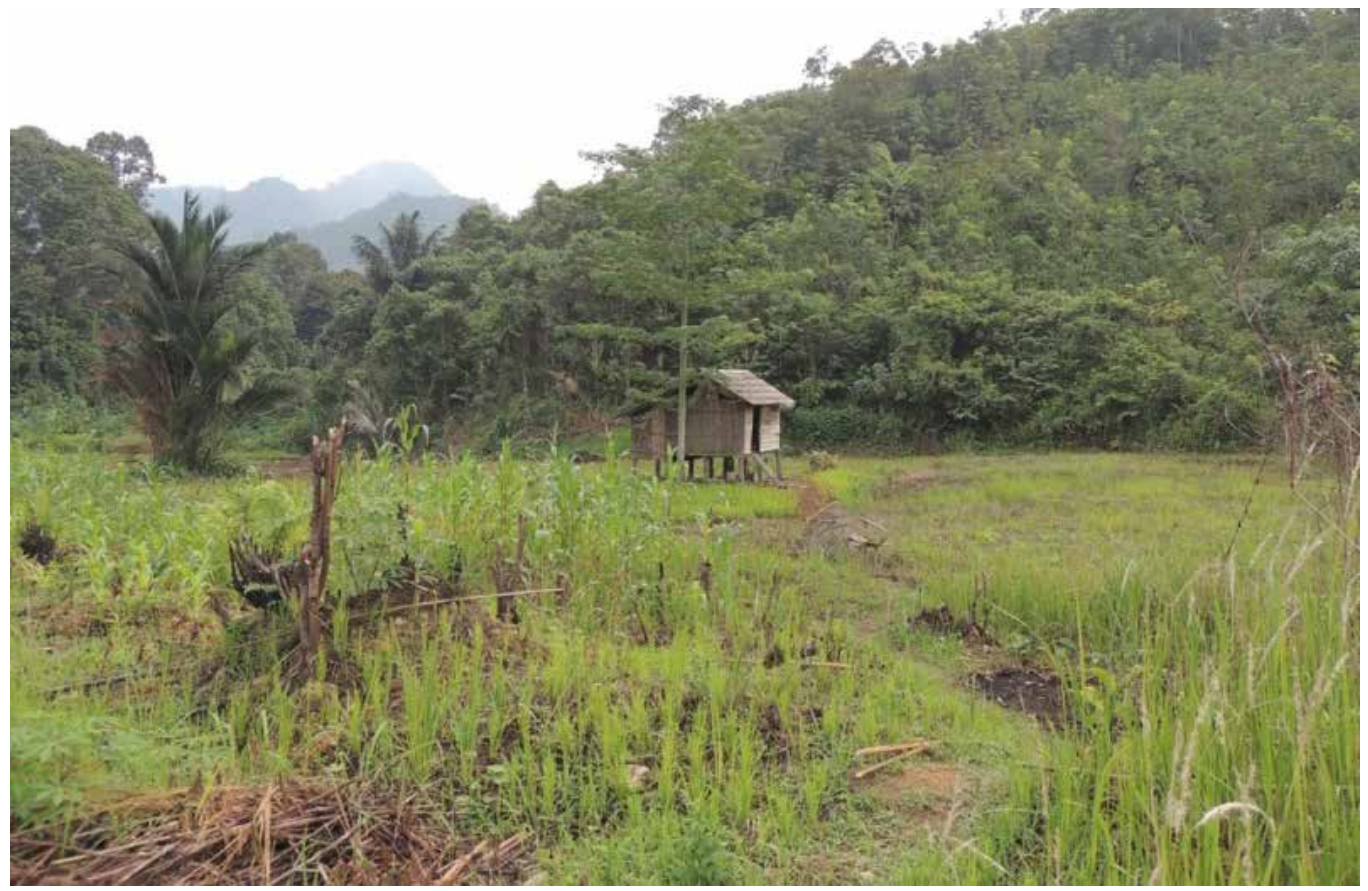

Dryland rice and vegetable farming in Zone 2. (Laurio Leonald/CIFOR) 


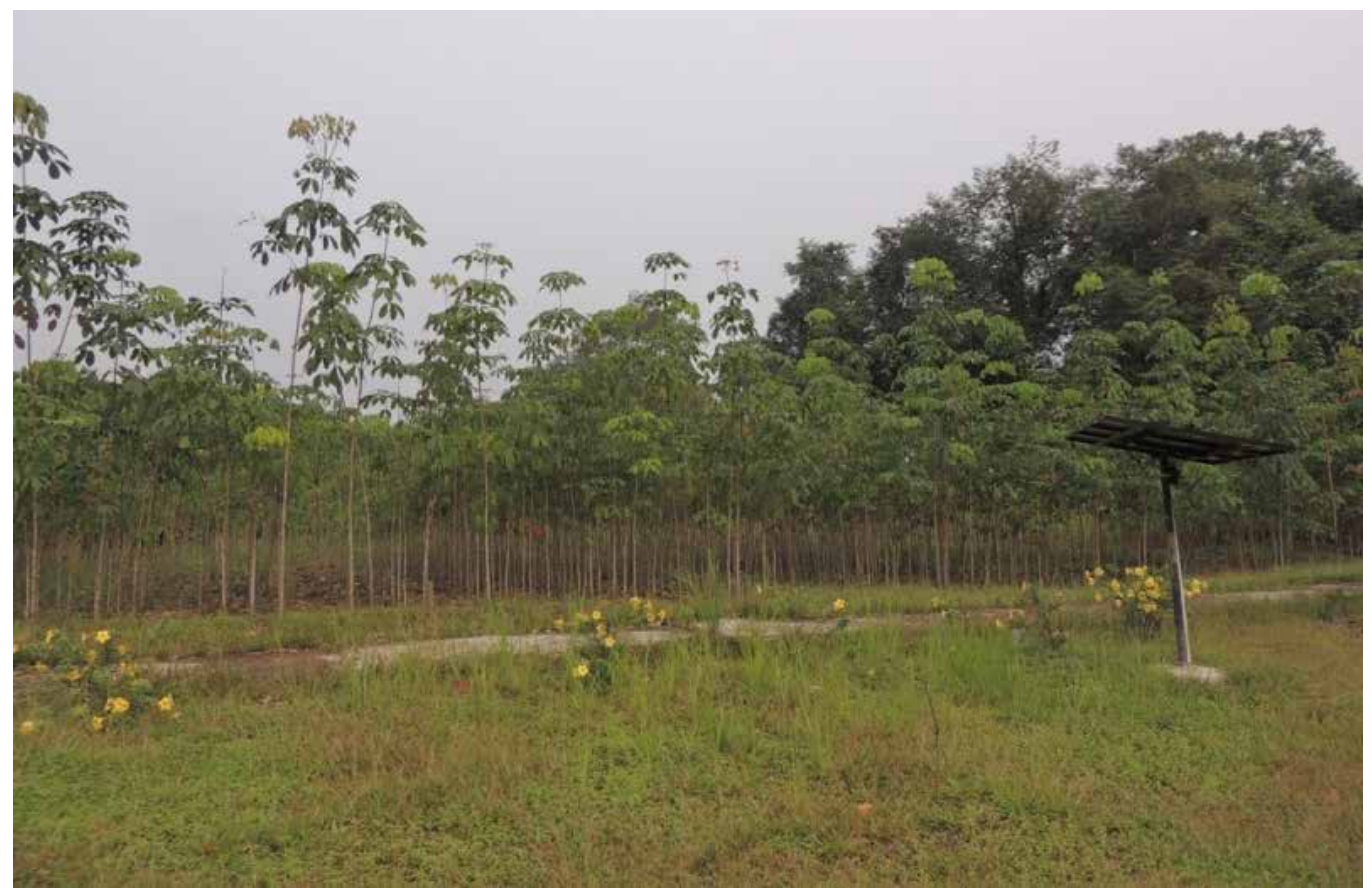

Small rubber garden in Zone 2. (Laurio Leonald/CIFOR)

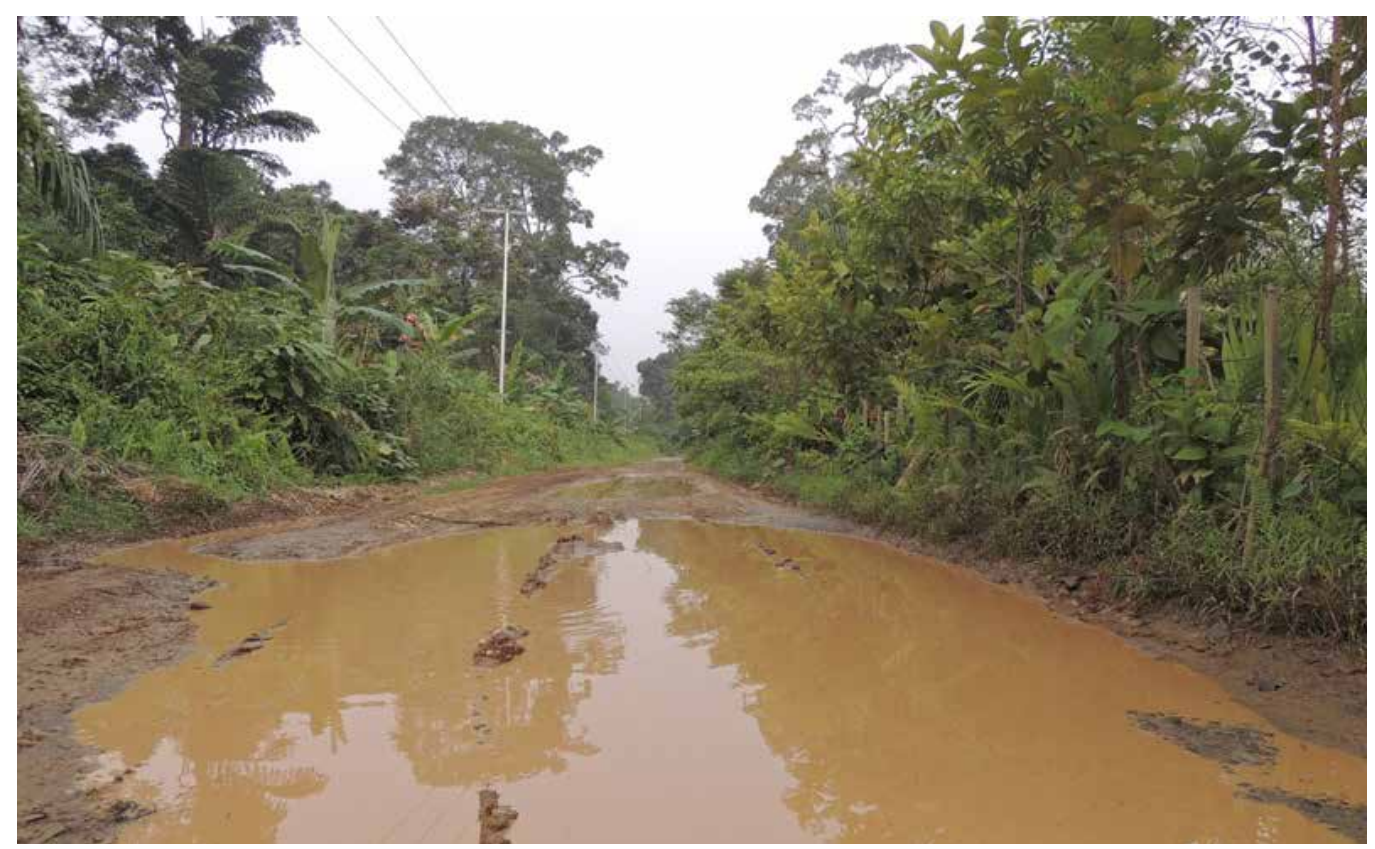

Typical access road to Zone 2 settlements. (Dominic Rowland/CIFOR) 


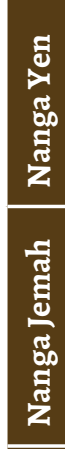

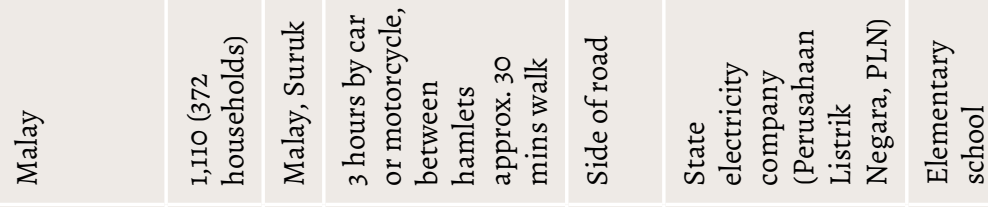

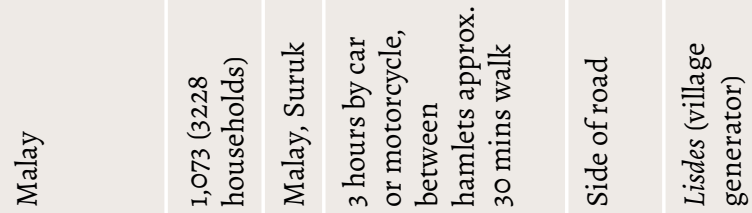

密

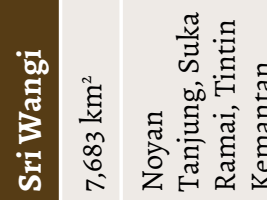

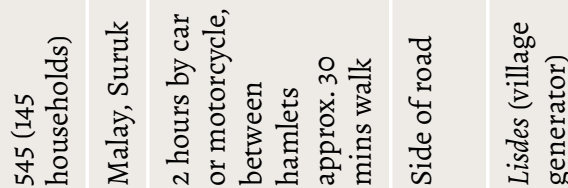

窟

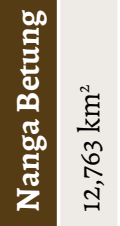

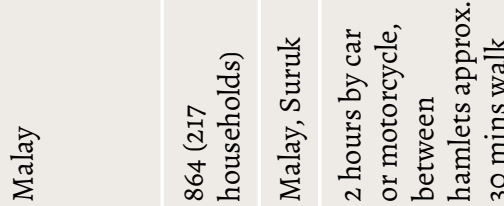

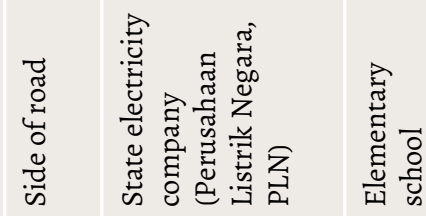

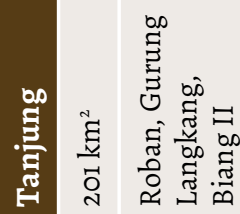

䬶

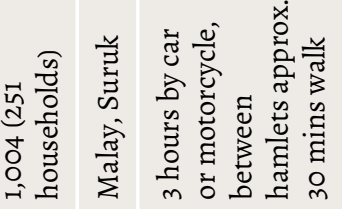

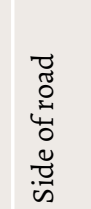

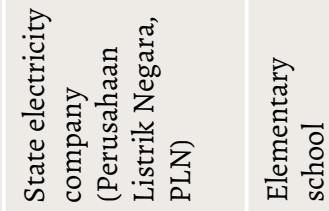

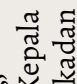

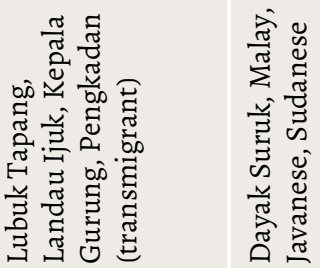

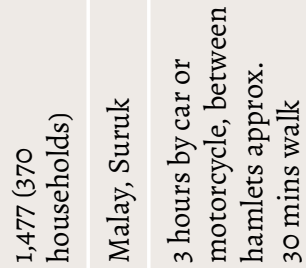

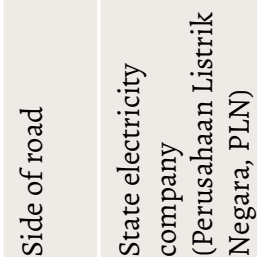

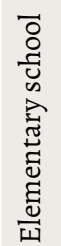

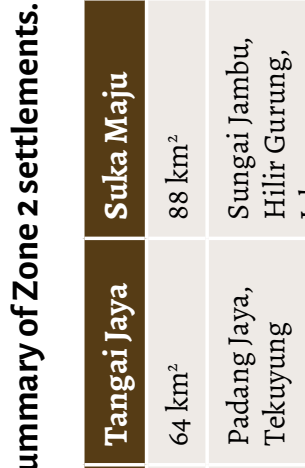

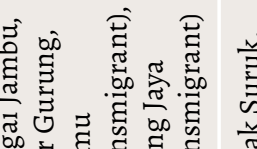

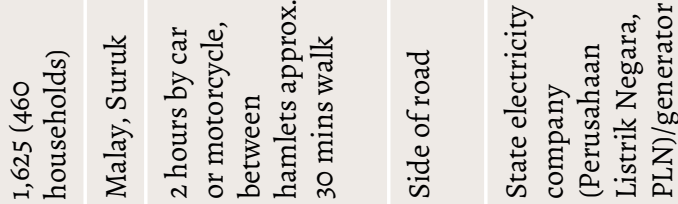

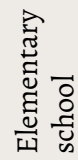

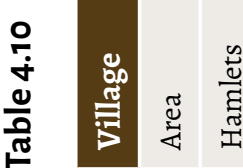

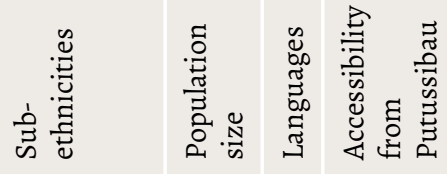

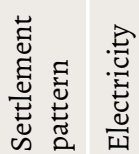




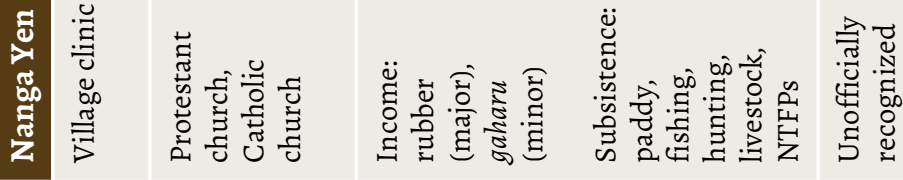

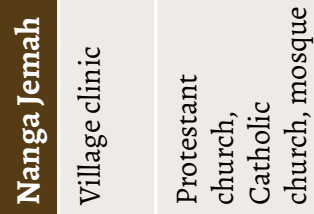

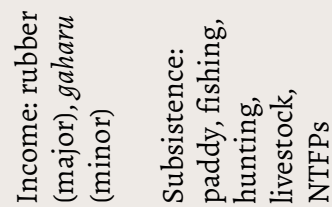

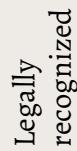

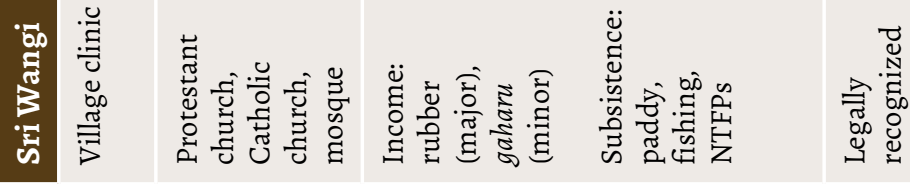

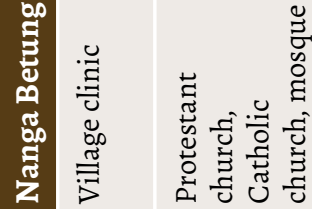

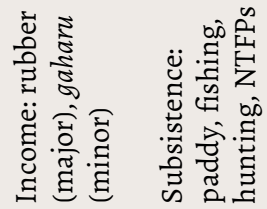

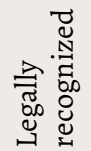

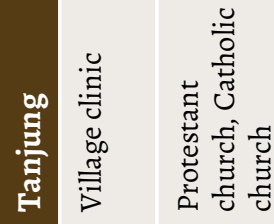

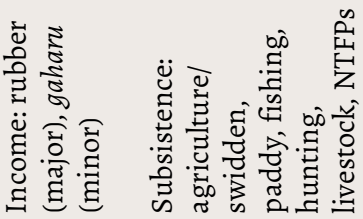

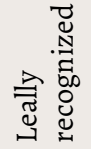

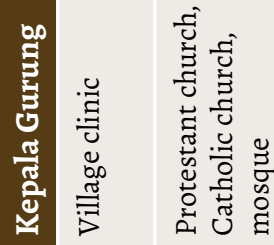

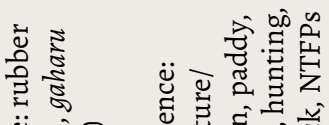

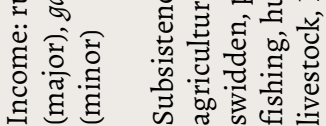

๕ั

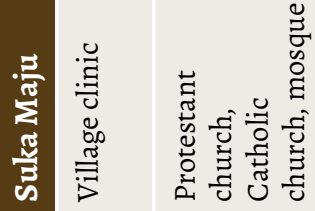

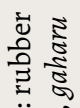

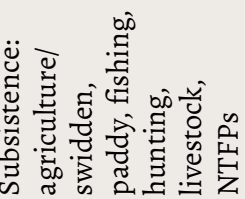

芩

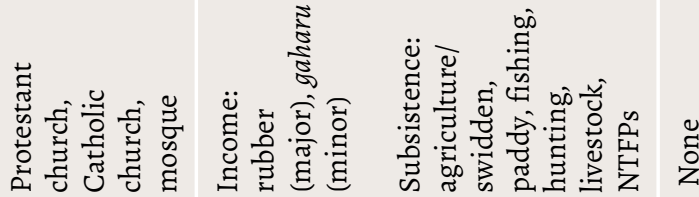

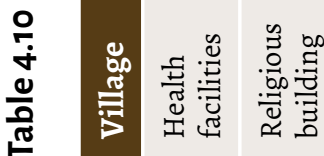

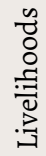

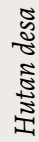




\subsubsection{Zone 3}

Zone 3 is situated in the southwest of Kapuas Hulu in the subdistrict (Kecematan) of Silat Hilir, bordering the district of Sintang (see Figure 4.13). The development of palm oil plantations in Kapuas Hulu spread from neighboring Sintang where commercial plantations have been in operation for many years. We conducted interviews in five villages in the region: Seberu, Nanga Nuar, Miau Merah, Pangeran and Sungai Sena. The region is accessible by car or motorcycle in 5-7 hours from Putussibau, though access to towns in Sintang is only a few hours away.

Ethnic diversity in Zone 3 is much greater than in Zones 1 and 2, partially reflecting higher levels of migration due to the presence of palm oil companies. Among the many local sub ethnicities are Dayak Sekapat, Dayak Ensilat, Dayak Sebaru, Dayak Desa. In addition to Dayak ethnicities, there are substantial populations of Malay, Javanese and Sudanese people, who settled in the region during the transmigration program in the 1980 s.

The dominant land-use type in Zone 3 is oil palm, which first appeared in the region in the early 2000 s. The vast majority of existing plantations are company owned, though community-owned and local cooperative plantations have recently emerged in almost all villages (though none have yet begun harvesting). Local and community palm oil operations are generally small in scale utilizing old swidden plots and rubber gardens.

Until recently, communities were able to balance their need for land for subsistence agriculture (either through shifting cultivation or paddy) with the demand for land required by palm oil operations. Recently, however, villagers have expressed concern about competing land use between subsistence agriculture and palm oil. Likewise, fishing and

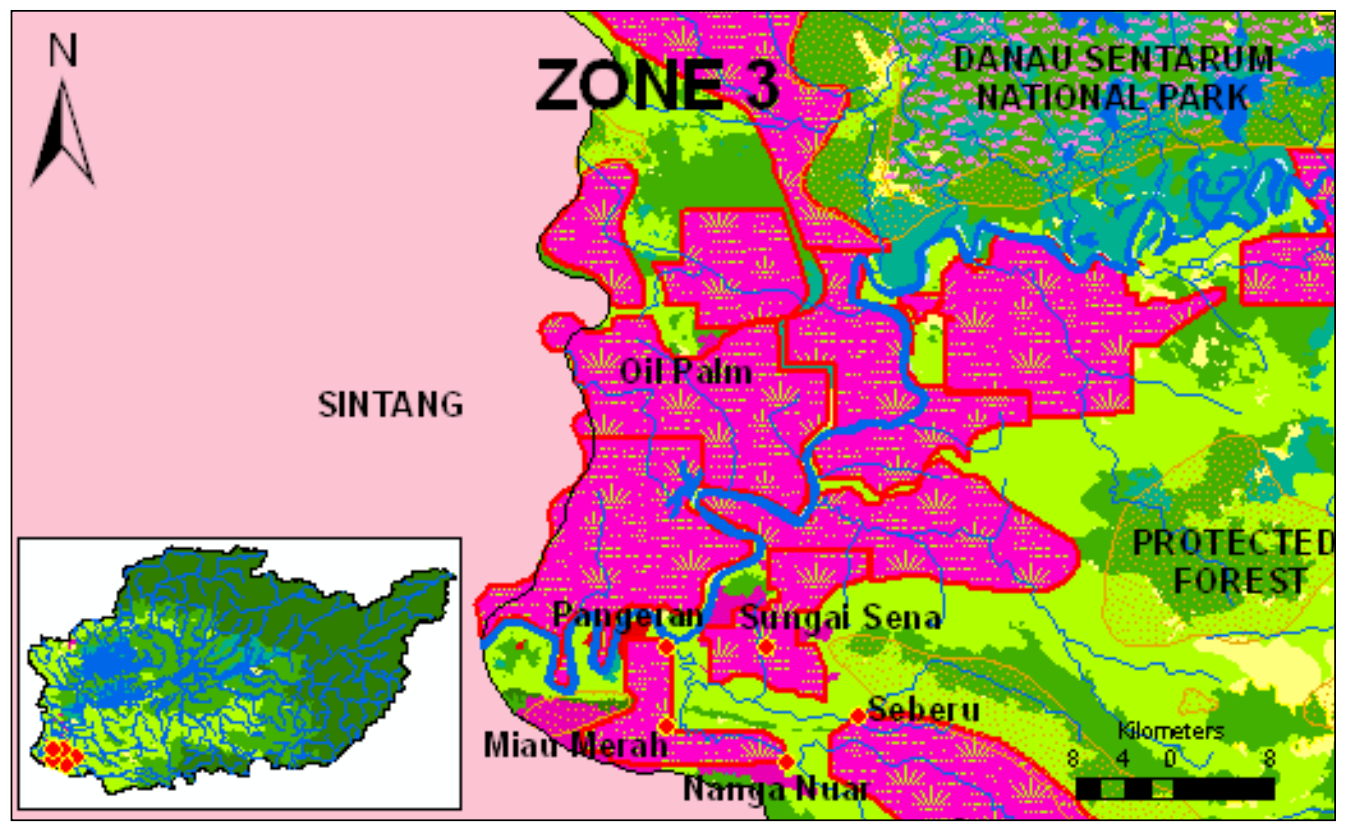

Figure 4.13 Map of Zone 3 settlements and oil palm plantations. 


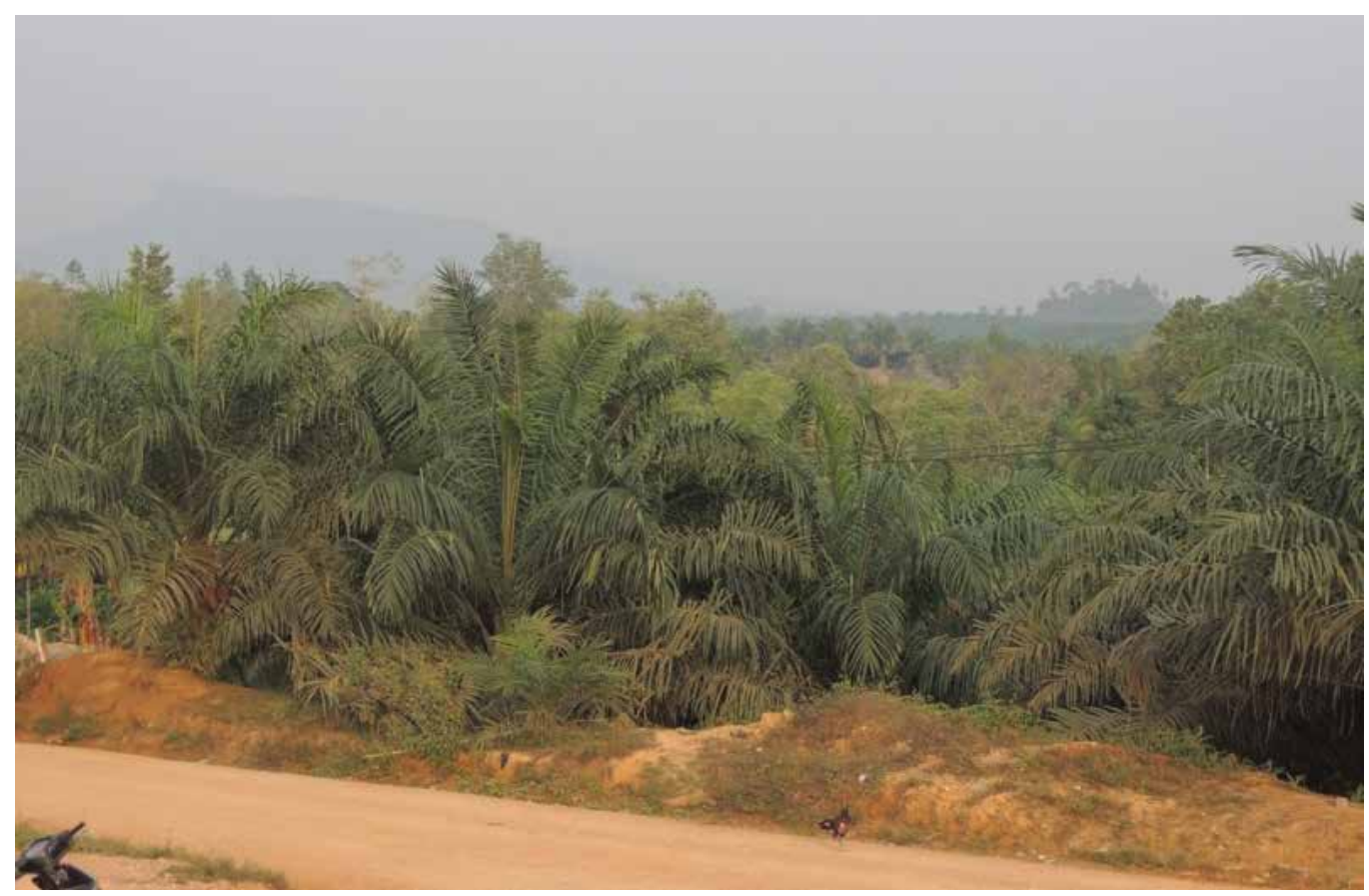

A community-owned palm oil plantation in Miau Merah. (Dominic Rowland/CIFOR)

hunting still take place, but due to the lack of natural forest in the region these are uncommon as a livelihood strategy (except in Pangeran village, where fish is sold to neighboring villages). Local opinions concerning oil palm developments are mixed. Many local people welcome the developments due to the availability of waged labor and improved infrastructure access to markets. However, some interviewees expressed concern over dust and pollution caused by trucks carrying palm oil, as well as the damage caused by large vehicles to the roads. Village officials in Nanga Nuar have also brought the alleged establishment of palm oil plantations on protected forest areas to the attention of legal authorities.

Waged labor on oil palm plantations is by far the largest source of income in Zone 3, where men can earn approximately IDR 60,000 (USD 4.4) per day for manual labor. A small number of local people are employed as managers on plantations, though these jobs usually go to Javanese migrants who generally have higher levels of education. Waged labor on plantations is currently popular due to the low market price for rubber (IDR $4000-5000 / \mathrm{kg}$ or USD $0.29-0.37 / \mathrm{kg}$ ), which means that a day's rubber tapping would earn roughly IDR 40,000 (USD 2.9) per day. A significant proportion of men interviewed stated that they also had access to rubber gardens, but did not tap them unless the price of rubber was higher than they could earn working for palm oil companies. Other sources of cash income available in the region are gold mining and gaharu seeking, both of which are increasingly rare due to the scarcity of gold and gaharu, which have been overexploited for decades in the region. The use of NTFPs is almost non-existent in the region, though a small number of households harvest the Borneo tallow nut one to four times a year from mixed cropping in rubber gardens. See Table 4.11 for a summary. 
Table 4.11 Summary of Zone 3 settlements.

\begin{tabular}{|c|c|c|c|c|c|}
\hline Village & Seberu & $\begin{array}{l}\text { Nanga } \\
\text { Nuar }\end{array}$ & Miau Merah & Pamgeran & Sungai Sena \\
\hline Hamlets & $\begin{array}{l}\text { Sekar Jaya, } \\
\text { Sungai Mali, } \\
\text { Sauk Atas, } \\
\text { Sungai Ringin }\end{array}$ & $\begin{array}{l}\text { Engkaras, } \\
\text { Bududaya } \\
\text { rantau, } \\
\text { keduway, } \\
\text { Teluk pau }\end{array}$ & $\begin{array}{l}\text { Bersatu, } \\
\text { jemeluk, } \\
\text { Panca Usaha } 1 \\
\text { (transmigrant), } \\
\text { Panca Usaha } 2 \\
\text { (transmigrant), } \\
\text { Sidorejo } \\
\text { Simpang } \\
\text { Silat (mixed } \\
\text { transmigrant } \\
\text { and local) }\end{array}$ & $\begin{array}{l}\text { Keluarga, } \\
\text { Rejosari } \\
\text { (local and } \\
\text { transmigrant), } \\
\text { Rejosari } \\
\text { (local and } \\
\text { transmigrant) }\end{array}$ & $\begin{array}{l}\text { Plangi I, Pelangi } \\
\text { II, Pelangi III, } \\
\text { Setia Usaha, } \\
\text { Sungai Ganggai }\end{array}$ \\
\hline Area & $139 \mathrm{~km}^{2}$ & $110 \mathrm{~km}^{2}$ & $105 \mathrm{~km}^{2}$ & $124 \mathrm{~km}^{2}$ & $108 \mathrm{~km}^{2}$ \\
\hline $\begin{array}{l}\text { Sub- } \\
\text { ethnicities }\end{array}$ & $\begin{array}{l}\text { Dayak } \\
\text { Seberuang, } \\
\text { Malay }\end{array}$ & $\begin{array}{l}\text { Dayak Silat, } \\
\text { Malay }\end{array}$ & $\begin{array}{l}\text { Dayak kantuk, } \\
\text { Dayak } \\
\text { Seberuang }\end{array}$ & $\begin{array}{l}\text { Dayak } \\
\text { Seberuang, } \\
\text { Malay, } \\
\text { Javanese }\end{array}$ & $\begin{array}{l}\text { Dayak Silat, } \\
\text { Javanese }\end{array}$ \\
\hline $\begin{array}{l}\text { Population } \\
\text { size }\end{array}$ & $\begin{array}{l}1,560 \text { (431 } \\
\text { households) }\end{array}$ & $\begin{array}{l}1,239 \text { ( } 365 \\
\text { households) }\end{array}$ & $\begin{array}{l}2,032 \text { (653 } \\
\text { households) }\end{array}$ & $\begin{array}{l}1,368 \text { (402 } \\
\text { households) }\end{array}$ & $\begin{array}{l}\text { 1,688 (508 } \\
\text { households) }\end{array}$ \\
\hline Languages & Malay & Malay & Malay & Malay & Malay \\
\hline Accessibility & $\begin{array}{l}5-6 \text { hours } \\
\text { by car or } \\
\text { motorbike } \\
\text { from } \\
\text { Putussibau }\end{array}$ & $\begin{array}{l}5-6 \text { hours } \\
\text { by car or } \\
\text { motorbike } \\
\text { from } \\
\text { Putussibau }\end{array}$ & $\begin{array}{l}5-6 \text { hours } \\
\text { by car or } \\
\text { motorbike from } \\
\text { Putussibau }\end{array}$ & $\begin{array}{l}6-7 \text { hours } \\
\text { by car or } \\
\text { motorbike } \\
\text { from } \\
\text { Putussibau }\end{array}$ & $\begin{array}{l}5-6 \text { hours by car } \\
\text { or motorbike } \\
\text { from Putussibau }\end{array}$ \\
\hline $\begin{array}{l}\text { Palm oil } \\
\text { workers }\end{array}$ & $50 \%$ & $70 \%$ & - & $70 \%$ & $70 \%$ \\
\hline $\begin{array}{l}\text { Settlement } \\
\text { patterns }\end{array}$ & Side of road & Side of road & Side of road & Side of road & Side of road \\
\hline $\begin{array}{l}\text { Educational } \\
\text { facilities }\end{array}$ & $\begin{array}{l}\text { Elementary } \\
\text { school }\end{array}$ & $\begin{array}{l}\text { Elementary } \\
\text { school }\end{array}$ & $\begin{array}{l}\text { Elementary } \\
\text { school, junior } \\
\text { high school, } \\
\text { senior high } \\
\text { school }\end{array}$ & $\begin{array}{l}\text { Elementary } \\
\text { school }\end{array}$ & $\begin{array}{l}\text { Elementary } \\
\text { school, junior } \\
\text { high school }\end{array}$ \\
\hline $\begin{array}{l}\text { Religious } \\
\text { buildings }\end{array}$ & $\begin{array}{l}\text { Protestant } \\
\text { church, } \\
\text { Catholic } \\
\text { church, } \\
\text { Mosque }\end{array}$ & $\begin{array}{l}\text { Protestant } \\
\text { church, } \\
\text { Catholic } \\
\text { church, } \\
\text { Mosque }\end{array}$ & $\begin{array}{l}\text { Protestant } \\
\text { church, } \\
\text { Catholic } \\
\text { church, Mosque }\end{array}$ & $\begin{array}{l}\text { Protestant } \\
\text { church, } \\
\text { Catholic } \\
\text { church, } \\
\text { Mosque }\end{array}$ & $\begin{array}{l}\text { Protestant } \\
\text { church, Catholic } \\
\text { church, Mosque }\end{array}$ \\
\hline Electricity & Generator & $\begin{array}{l}\text { State } \\
\text { electricity } \\
\text { company } \\
\text { (Perusahaan } \\
\text { Listrik } \\
\text { Negara, } \\
\text { PLN) }\end{array}$ & $\begin{array}{l}\text { State electricity } \\
\text { company } \\
\text { (Perusahaan } \\
\text { Listrik Negara, } \\
\text { PLN) }\end{array}$ & Generator & $\begin{array}{l}\text { Lisdes (village } \\
\text { generator) }\end{array}$ \\
\hline
\end{tabular}


Table 4.11 (continued)

\begin{tabular}{|c|c|c|c|c|c|}
\hline Village & Seberu & $\begin{array}{l}\text { Nanga } \\
\text { Nuar }\end{array}$ & Miau Merah & Pamgeran & Sungai Sena \\
\hline $\begin{array}{l}\text { Farming } \\
\text { Seasons }\end{array}$ & $\begin{array}{l}\text { April-May } \\
\text { (slash and } \\
\text { burn), } \\
\text { June-August } \\
\text { (planting), } \\
\text { December- } \\
\text { January } \\
\text { (harvesting) }\end{array}$ & $\begin{array}{l}\text { April-May } \\
\text { (slash and } \\
\text { burn), June- } \\
\text { August } \\
\text { (planting), } \\
\text { December- } \\
\text { January } \\
\text { (harvesting) }\end{array}$ & $\begin{array}{l}\text { April-May } \\
\text { (slash and } \\
\text { burn), } \\
\text { June-August } \\
\text { (planting), } \\
\text { December- } \\
\text { January } \\
\text { (harvesting) }\end{array}$ & $\begin{array}{l}\text { April-May } \\
\text { (slash and } \\
\text { burn), } \\
\text { June-August } \\
\text { (planting), } \\
\text { December- } \\
\text { January } \\
\text { (harvesting) }\end{array}$ & $\begin{array}{l}\text { April-May (slash } \\
\text { and burn), } \\
\text { June-August } \\
\text { (planting), } \\
\text { December- } \\
\text { January } \\
\text { (harvesting) }\end{array}$ \\
\hline Livelihoods & $\begin{array}{l}\text { Income: } \\
\text { rubber (major), } \\
\text { oil palm labor } \\
\text { (major), gaharu } \\
\text { (minor), gold } \\
\text { (minor) } \\
\text { Subsistance: } \\
\text { swidden/ } \\
\text { paddy, fishing, } \\
\text { hunting, } \\
\text { NTFPs }\end{array}$ & 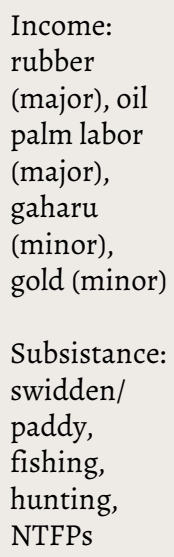 & $\begin{array}{l}\text { Income: rubber } \\
\text { (major), oil } \\
\text { palm labor } \\
\text { (major), gaharu } \\
\text { (minor), gold } \\
\text { (minor) } \\
\text { Subsistance: } \\
\text { swidden/ } \\
\text { paddy, fishing, } \\
\text { hunting, NTFPs }\end{array}$ & 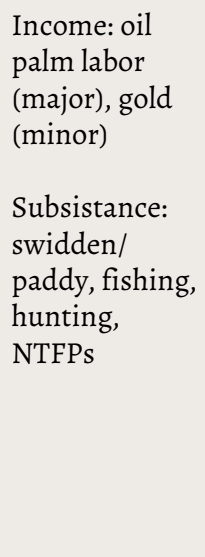 & $\begin{array}{l}\text { Income: oil palm } \\
\text { labor (major) } \\
\text { Subsistance: } \\
\text { swidden/paddy, } \\
\text { fishing, hunting, } \\
\text { NTFPs }\end{array}$ \\
\hline
\end{tabular}

\subsection{The agrarian change transition}

Under typical agrarian change scenarios in Kapuas Hulu Regency, West Kalimantan, smallholders (primarily shifting cultivators) begin to supplement subsistence-based agriculture with some form of agricultural commercialization in particular rubber, nuts and fruits. Agricultural commercialization is driven by improved infrastructure, providing access to markets and government rural development programs such as subsidized seeds. Shifting cultivation is not immediately abandoned, rather some fallow plots are taken out of rotation to become smallholder plantations and new swidden plots are opened in their place. Improved infrastructure, however, makes these regions more attractive to commercial investors and commercialization is often rapidly followed by large-scale agribusiness operations in the form of oil palm estates. During this stage, it is not uncommon for local people to combine waged labor on plantations with other occupations and sources of income, often switching professions depending on relative commodity prices.

Figure 4.14 shows three typical land-use change scenarios present in West Kalimantan. The most common trajectory in Kapuas Hulu involves the conversion of shifting cultivation plots (ladangs) into small-scale rubber plantations or mixed agroforestry rubber gardens (kebuns) (Scenario 1), after which large-scale commercial oil palm 


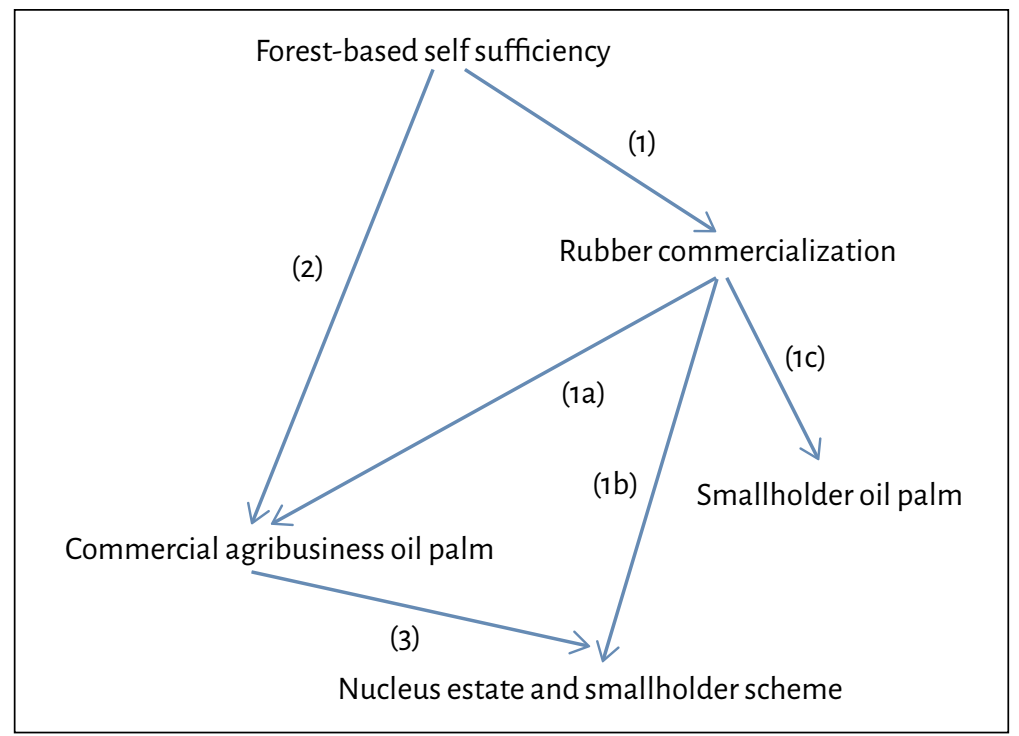

\section{Figure 4.14 Common agrarian transitions in Kapuas Hulu.}

Note: Numbers represent various land-use change scenarios. Scenario 1 represents land-use change scenarios where rubber agroforestry is an intermediate stage between smallholder oil palm (1c), nuclear estate and smallholder schemes (1b), and commercial agribusiness (1a). Scenario 2 is direct expansion of oil palm estates into forestlands. Scenario 3 represents the expansion of commercial oil palm into smallholder land through the use of nuclear estate and smallholder schemes.

plantations become established, dominated by large agribusiness (Scenario 1a) either by purchasing or incorporating smallholder land or, more commonly, simply displacing farmers due to the lack of legal land tenure. Occasionally, smallholder rubber plots are converted or supplemented by smallholder or cooperative palm oil plantations (Scenario 1c). This scenario is rare and has only emerged recently due to changes in district legislation concerning tenure and the legal process by which agribusiness can acquire usage rights over forestland. Another relatively recent development is the establishment of nuclear estate and smallholder (NES) schemes. This scenario, promoted by local and regional government involves the trade of land between smallholders and agribusiness. In a typical scenario, a farmer will trade approximately 10 ha of their land (whether legally owned or not) with the company in return for approximately 2 ha of the plantation. The 2 ha of smallholder plantation are then either developed by the company in return for a share of the profits (after costs are deducted) or less commonly are cultivated by the smallholder or a smallholder cooperative. Such schemes are present in Kapuas Hulu when new plantations are established (Scenario Ib, in Figure 4.14) or when a company attempts to expand an existing plantation into land currently used by smallholders (Scenario 3). Due to the rapidity of the expansion of commercial palm oil estates in the region, a great number of communities experience the entire transition from self-sufficiency to waged labor in a period of years without the intermediate stage of rubber at all (Scenario 2). Each of the transitions outlined in the scenario above are likely to have different consequences for the food security and nutrition of local people. 


\subsubsection{Smallholder commercialization}

Transitions 1 and $1 \mathrm{~b}$ shown in Figure 4.14 reflect the process of smallholder commercialization widely studied in the rural development literature. Despite some controversy, smallholder commercialization, market orientation and cash crop production appears to lower poverty and improve nutrition, provided that such ventures are not subject to market failures. Traditionally, economists have argued that agricultural commercialization and specialization allows households to increase their income by focusing production on crops that provide the highest income (Timmer 1997). Assuming a functioning market, households can then use their comparative advantage to purchase foods using their increased incomes. Other advantages of agricultural commercialization include household level synergies, whereby cash cropping can provide access to resources that can also be used for food crops, such as increased access to credit, fertilizer, animal traction/mechanization, support and training, and improved infrastructure. Agricultural commercialization can also have positive effects for farmers who are not practicing cash crop farming via regional spillover effects increasing access to credit and infrastructure of all farmers in a region regardless of whether or not they are farming cash crops (Govereh and Jayne 2003). There is some opposition to this dominant model both within academia and more broadly in civil society. Within academia, there is a tradition of Marxist critique of the process, based partially in colonial history and cases of forced commercialization (von Braun and Kennedy 1994). Such work, however, is often based upon an idealized view of smallholders as self-sufficient or 'food sovereign'. Such positions are often rooted in historical and ideological reasoning and support for this position suffers from methodological flaws based on "generalizations and extrapolations" (von Braun and Kennedy 1994; Longhurst 1988). Most well-designed studies appear to show that when agricultural commercialization occurs as a result of well-designed interventions, the effects on nutrition are generally positive. In civil society, the issue is intractable from wider campaigns from green lobbies, antiglobalization movements, pro- and anti-technology movements and concerns over the extent of corporate power (Stone 2002). There is a widely held perception among civil society groups that agricultural commercialization directly undermines food security and nutrition by competing with food production for land, labor and other resources (Stone 2002).

Within Kapuas Hulu, rubber commercialization is widespread, but smallholder palm oil is relatively undeveloped. The prevalence of rubber in part stems from low capital costs associated with rubber commercialization and its flexibility as a crop; rubber does not have to be regularly harvested and long periods of not tapping rubber do not affect yields. As a result, many smallholders use rubber as an income safety net. Likewise, rubber gardens often fall outside of the scope of government spatial planning processes meaning that it is not necessary to ensure secure land tenure before planting. In contrast, palm oil requires secure land tenure and high capital costs. Recent co-ventures with commercial agribusiness in the form of the NES scheme have increased the area of palm oil under the control of smallholders and communities but smallholder plantations remain a relatively minor concern. In Kapuas Hulu, smallholder palm or community palm oil occupies around $10 \%$ of the total palm oil land, less than $20 \%$ of which has reached the production stage (BAPPEDA 2013). Almost no research has been conducted into the food 
security and nutrition implications of smallholder rubber and oil palm plantations in Indonesia, though studies on smallholder livelihoods appear to show higher household incomes compared to subsistence farmers (Rist et al. 2010). Because smallholder palm oil plantations not operating under an NES scheme require significant capital and agricultural skill, the benefits are disproportionately allocated to migrant workers and local elites over poorer farmers and indigenous populations (Obidzinski et al. 2012).

\subsubsection{Commercial agribusiness}

Large-scale estate farms have potential to contribute to food security utilizing economies of scale, providing greater market access, sources of employment, increasing investment in a region and contributing to regional economic growth. Palm oil plantations have contributed greatly to economic growth in West Kalimantan and other regions of Indonesia (Bunyamin 2008; Obidinski et al. 2012). In general, the presence of commercial palm oil appears to raise incomes and lower poverty rates (McCarthy and Cramb 2009; Rist et al. 2010), but broader negative social consequences are widespread (FFP 2006). In certain cases commercial palm oil plantations have been documented to displace populations of swidden agriculturalists, directly threatening food security (Orth 2007), and conflicts between company land rights and customary land rights are common. For example, 630 separate land disputes between communities and companies were recorded in the year 2010 alone (Colchester and Chao 2011). In general, those most likely to suffer negative livelihood consequences are customary landowners, those dependent on the collection of NTFPs and those practicing traditional agriculture (Obidinski et al. 2012). Despite concerns over the impacts of commercial palm oil, and numerous cases of egregious corporate malpractice, the limited evidence that exists from Indonesia suggests that remote forest communities suffer from higher infant mortality rates than those in less remote areas where commercial palm oil operates (Levang et al. 2005). However, there is also limited evidence that the nutritional status of individuals may be higher among more traditional societies (Dounias and Froment 2006). It is clear that improved access to healthcare and higher cash income, along with access to schooling and markets does lower poverty rates and result in better health. Indeed, this is the vision of development that many indigenous people in Indonesia themselves profess to want (Levang et al. 2005). The distribution of these benefits within society, the longevity of their effects and the long-term consequences for food security however, remain to be seen.

Proponents of forest conversion for development would argue that commercial palm oil estates provide a source of waged labor, lead to higher household incomes, improved infrastructure and development, and therefore access to state-provisioned services such as schooling and healthcare. With respect to food security and nutrition it is argued that increases in household income lead to higher purchasing power and thus improved nutritional status. While there are some merits to this argument, the situation is likely to be more complicated.

Firstly, links between increased household income and nutrition are far from clear. Increased household income can have effects upon energy/calorie consumption, though its effects on nutritional status are often weak or insignificant (Kennedy et al. 1992). Within forest-based communities the links between waged labor, income and nutrition 
are even more complex. Income from waged labor does not necessarily lead to higher household incomes as forest-dependent people often lose important sources of income from the sale of NTFPs. In addition, economic analyses often fail to take into account the role of environmental income (Angelsen et al. 2014). If for instance a community without forest has a higher income but now needs to purchase firewood, fuel, food, medicinal products, etc. (products that were previously free), their net state of economic security is not necessarily higher. In addition, the effects of income on nutrition are dependent both on market access to nutritious foods (fruits, vegetables, animal source foods) and a preference to use income to purchase these foods. There is almost no empirical evidence from Indonesia that such assertions are true and the relationship between income and nutrition remains controversial.

Secondly regional economic growth, although often associated with improved health and nutrition, does not automatically lead to improved food security. The effects of economic growth on food security have mostly been examined in terms of energy (calorie) consumption and protein consumption, and have been shown to have significant positive effects upon reducing the prevalence of hunger and undernutrition. In terms of the nutritional quality of diets consumed however, economic growth is widely regarded as "necessary but not sufficient" for improving nutritional standards (FAO 2012).

Thirdly, the issue of who benefits from palm oil expansion is central to understanding its effects upon nutrition. Economic simulations based on empirical evidence suggest that average household incomes are in the long term raised under land-use scenarios dominated by palm oil (Sandker et al. 2007), yet there is concern both over the longevity of such effects and which sections of society benefit the most. Plantations in Kalimantan are associated with high levels of migration from Java, and Javanese migrants tend to be favored over local people by companies due to their higher levels of educational attainment. Several authors have suggested that those who really benefit are migrants and local elites, while the local middle class experience modest improvements in health and the local poor experience declines (e.g. Myers et al. 2013). As noted by multiple authors, indigenous populations and the forest dwelling poor in general are often neglected by the services of the state (Coimbra et al. 2004; Stephens et al. 2006; King et al. 2009). Forest-based people, in particular indigenous people, are among those least likely to benefit from regional economic booms (Stephens et al. 2006) and in Indonesia are among the poorest communities with the most limited access to state services (Sunderlin et al. 2007). The long-term effects of rapid investment in these historically remote and isolated regions of Indonesia are still unknown and inter- and intra-community inequality, corruption, nepotism, economic possibilities and livelihood strategies will all play a role in determining the trajectory a household or community ultimately take.

\subsubsection{Nuclear estate and smallholder schemes}

Existing evidence suggests that the effect of NES schemes raises the average level of household income for smallholder farmers (Rist et al. 2010). However, income is only one dimension of food security and broader livelihood impacts have not been fully investigated (Colchester and Jiwan 2006). Such schemes are also not universally 
favored by farmers themselves. Contracts between farmers and companies are often not clear and farmers frequently do not understand or have not even read the contract agreements, in some cases leading to uncertainty over the amount and terms of debt repayment owed by the farmer in return for the plantation (Rist et al. 2010). Lack of secure land tenure, the frequent absence of free and informed prior consent, negative impacts upon ecosystem services for agriculture, and broader cultural and social implications for NES schemes have yet to be sufficiently addressed. In addition, while in some circumstances, palm oil can mitigate the effects of price shocks (Feintrenie et al. 2010), concerns over income dependence on food security that result from such schemes are still widespread (Butler et al. 2009; Syafriel 2009).

\subsubsection{Agrarian change in the Agrarian Change Project zones in Kapuas Hulu}

The three zones examined in this preliminary study exhibit different stages of agrarian change and each can be considered a stage of an overall transition from forest-based agriculture to permanent monoculture oil palm plantations. In Zone 1 , the dominant form of agriculture is forest-based shifting cultivation, supplemented by bushmeat hunting. Although cash income is available though gold mining, gaharu seeking, swiftlet nest seeking and the trade of other NTFPs, income is generally not used to purchase food. Food is almost never purchased from outside the village (except for snacks and certain luxuries), as transport to the nearest town or market is too far, too expensive and too difficult.

Zone 2 represents an intermediate stage between forest dependence and dependence on cash income. While households have the option of purchasing food, which is readily available, most households still grow at least their staple foods themselves, either through shifting cultivation or through permanent paddies. The transition toward increased use of permanent agriculture has been driven by several factors, including the high proportion of transmigrants from Java, who have no traditional heritage of shifting cultivation as well as loss of forest area and concerns over food security.

Another factor affecting food security in Zone 2 settlements is the popularity of rubber as a cash crop. Rubber is a versatile and reliable crop that can be used as an income safety net in times of need. As a result, it is common practice (though not universal) to plant rubber in old ladangs after harvesting, making them unavailable for subsistence agriculture and out of the rotation cycle. While this utilizes forest that has already been cleared, it leads either to the need to clear more forest for shifting agriculture, or to a dependence on cash income to purchase food. Many households within Zone 2 settlements appear to switch activities between waged labor on plantations and rubber tapping, depending on the market price of rubber and labor.

The number of households practicing subsistence agriculture in Zone 3 is greatly outnumbered by the households conducting waged labor for palm oil. Households engaged in waged labor generally purchase food from nearby villages, though many households will still maintain small home gardens to supplement their diet. Any form of significant agriculture in Zone 3 is rare, with very few households engaged in sufficient levels of farming to meet their food requirements. Food security is therefore very much dependent on the availability of work. 


\section{Acknowledgments}

This report uses primary field research, secondary literature, GIS and remote sensing analysis, and interviews with key stakeholders. Fieldwork was conducted by Laurio Leonald and Dominic Rowland in Kapuas Hulu Regency, West Kalimantan, in October 2014. Remote sensing and GIS analysis was conducted by John Arnet, Ian Eddy and Sarah Gergel of the University of British Columbia. Support was provided by CIFOR, in particular by Liz Deakin, Mrigesh Kshatriya, Terry Sunderland and Yves Laumonier. The team are especially grateful to the COLUPSIA project team for their assistance with the study, in particular Yves Laumonier and Ade Yanuwardi. 


\section{References}

Adijaya M and Yamashita T. 2004. Mercury pollutant in Kapuas River basin: Current status and strategic approaches. Annuals of Disaster Prevention Research Institute, Kyoto University 47.

[AMAN] Aliansi Masyarakat Adat Nusantara. 2014. Kalimantan Barat. Available at: http://www.aman.or.id/tag/kalbar/

Angelsen A, Jagger P, Babigumira R Belcher B, Hogarth NJ, Bauch, S, Börner J, SmithHall C and Wunder S. 2014. Environmental income and rural livelihoods: A globalcomparative analysis. World Development 64:S12-S28.

[BAPPEDA] Badan Perencana Pembangunan Daerah. 2013. Data Pokok 2013. Kabupaten Kapuas Hulu: Putussibau (unpublished).

Belcher B, Imang N and Achdiawan R. 2004. Rattan, rubber, or oil palm: Cultural and financial considerations for farmers in Kalimantan. Economic Botany 58(1):S77-S87.

Bider B. 2003. Mercury spells disaster in W.Kalimantan. The Jakarta Post July 15. http:// www.thejakartapost.com/news/2003/07/15/mercury-spells-disaster-w-kalimantan. html

[BPS] Badan Pusat Statistik. 2014. Website. Accessed 20 November 2014. http:// kapuashulukab.bps.go.id/

[BPS] Badan Pusat Statistik. 2010. Website. Accessed 20 November 2014. http://www. bps.go.id/sector/agri/kebun/table2.shtml

[BPS] Badan Pusat Statistik. 2005. Berita Resmi Statistik. Accessed 20 November 2014. http://www.bps.go.id/

Bunyamin B. 2008. Dampak pengembangan PIR kelapa sawit terhadap perekonomian regional Kalimantan Barat. [Impacts of Oil Palm Plantations on the Regional Economy of West Kalimantan Region]. Pontianak, Indonesia: Untan Press.

Butler RA, Koh LP and Ghazoul J. 2009. REDD in the red: palm oil could undermine carbon payment schemes. Conservation Letters 2(2):67-73.

Butt S. 2014. Traditional land rights before the Indonesian constitutional court. Law, Environment \& Development Journalio:1.

Clerc J. 2011. Tenure security and oil palm expansion on customary lands in Indonesia: Case study in West Kalimantan. Sustaining Commons: Sustaining Our Future, the Thirteenth Biennial Conference of the International Association for the Study of the Commons (Conference Paper). Hyderabad, India.

Coimbra CEA, Santos RV, Salzano FM and Hurtado AM. 2004. Emerging health needs and epidemiological research in indigenous peoples in Brazil. In Salzano FM and Hurtado AM, eds. Lost Paradises and the Ethics of Research and Publication. New York: Oxford University Press. 89-109.

Colchester M and Chao S. 2011. Oil palm expansion in South East Asia: Trends and Implications for Local Communities and Indigenous Peoples. Moreton-in-Marsh, UK: Forest Peoples Programme. 
Colchester M and Jiwan N. 2006. Ghosts on Our Own Land: Indonesian Oil Palm Smallholders and the Roundtable on Sustainable Palm Oil. Moreton-in-Marsh, UK, and Bogor, Indonesia: Forest Peoples Programme, and Perkumpulan Sawit Watch.

Colfer C, Pierce J and Minarchek RD. 2012. Forest research and gender: A review of available methods for promoting equity. Forests, Trees and Livelihoods 21(4):221-40.

Curran LM, Trigg SN, McDonald AK, Astiani D, Hardiono YM, Siregar P, Caniago I and Kasischke E. 2004. Lowland forest loss in protected areas of Indonesian Borneo. Science 303(5660):1000-3.

Dennis RA, Colfer CJP, Puntodewo A and Byron Y. 2001. Forest cover change analysis as a proxy: Sustainability assessment using remote sensing and GIS in West Kalimantan, Indonesia. People Managing Forests: The Links Between Human Well-being and Sustainability 362-87.

Dounias E and Froment A. 2006. When forest-based hunter-gatherers become sedentary: Consequences for diet and health. Unasylva 227 57(2):26-33.

Dove M. 1993. Rubber Eating Rice, Rice Eating Rubber. Agrarian Studies Seminar Series. New Haven, CT: Yale University.

Eilenberg M. 2009. Negotiating autonomy at the margins of the state: The dynamics of elite politics in the borderland of West Kalimantan, Indonesia. South East Asia Research 17(2):201-27.

Eilenberg M. 2012. At the Edges of States: Dynamics of State Formation in the Indonesian Borderlands. Leiden: KITLV Press.

[FAO] Food and Agriculture Organization of the United Nations. 2012. The State of Food Insecurity in the World 2012: Economic Growth is Necessary but not Sufficient to Accelerate Reduction of Hunger and Malnutrition. Rome: FAO.

Feintrenie L, Chong WK and Levang P. 2010. Why do farmers prefer oil palm? Lessons learnt from Bungo district, Indonesia. Small-scale Forestry 9 (3):379-96.

Fitzherbert EB, Struebig MJ, Morel A, Danielsen F, Brühl CA, Donald PF and Phalan B. 2008. How will oil palm expansion affect biodiversity? Trends in Ecology and Evolution 23(10):538-45.

[FPP] Forest People's Programme. 2007. Promised Land: Palm Oil and Land Acquisition in Indonesia: Implications for Local Communities and Indigenous Peoples. Bogor, Indonesia: Forest People's Programme and Perkumpulan Sawit Watch Forest People's Programme.

Fox JJ, Adhuri DS and Resosudarmo IAP. 2005. Unfinished edifice or Pandora's box? Decentralisation and resource management in Indonesia. In Resosudarmo BP, ed., The Politics and Economics of Indonesia's Natural Resources. Institute of Southeast Asian Studies. 92-108.

Gaveau DLA, Sloan S, Molidena E, Yaen H, Sheil D, Abram NK, Ancrenaz M, Nasi R, Quinones M, Wielaard N and Meijaard E. 2014. Four decades of forest persistence, clearance and logging on Borneo. PLoS One 9(7):e101654.

Giesen W. 1987. Danau Sentarum Wildlife Reserve: Inventory, Ecology and Management Guidelines. Gland, Switzerland: World Wildlife Fund. 
Greenpeace. 2010. Sinar mas cannot handle the truth: What Sinar Mas are not telling you about the 'verification' exercise. Amsterdam, The Netherlands: Greenpeace. http://www.greenpeace.org/france/PageFiles/266591/sinar-mas-ne-supporte-pasla-v-3.pdf

Govereh J and Jayne TS. 2003. Cash cropping and food crop productivity: Synergies or trade-offs? Agricultural Economics 28(1):39-45.

Hansen/UMD/Google/USGS/NASA. 2014. Forest change data measure tree cover loss, tree cover gain, or forest disturbance. Creative Commons CC BY 4.0. Washington, DC: Global Forest Watch. http://50.18.182.188.6080/arcgis/rest/services/ForestCover_lossyear/ Imageserver

Hansen MC, Potapov PV, Moore R, Hancher M, Turubanova SA, Tyukavina A, Thau D, Stehman SV, Goetz SJ, Loveland TR, Kommareddy A, Egorov A, Chini L, Justice CO and Townshend JRG. 2013a. High-resolution global maps of 21st-century forest cover change. Science 342(6160):850-3.

Heidhues MFS. 2003. Golddiggers, Farmers, and Traders in The 'Chinese Districts' of West Kalimantan, Indonesia. Ithaca, NY: SEAP Publications.

Indrato G, Murharjanti J, Khatarina I, Pulungan F, Ivalerina J, Rahman M, Prana I, Resosudarmo P and Muharrom E. 2012. The context of REDD+ in Indonesia: Drivers, agents and institutions. Working paper 92. Bogor, Indonesia: Center for International Forestry Research.

Indriatmoko Y. 2010. Rapid human population growth and its impacts on Danau Sentarum. Borneo Research Bulletin 41.101-108.

Institut Dyakologi. 2008. Mozaik Dayak: Memahami Keberagaman Subsuku dan Bahasa Dayak di Kalimantan Barat. Pontianak, West Kalimantan, Indonesia: Institut Dyakologi.

[ITTO] International Tropical Timber Organization. 2005. The Implementation of a Community-based Transboudary Management Plan for the Betung Kerihun National Park, West Kalimantan, Indonesia, Phase II. ITTO Project PD 44/00 Rev.3 (F). Yokohama, Japan: ITTO.

Jeanes K and Meijaard E. 2000. Danau sentarum's wildlife. Part 1: Biodiversity value and global importance. Borneo Research Bulletin 31:150-229.

Kartodihardjo H, Jhamtani H, Djogo T and Havard M. 2009. Environmental Politics and Power in Indonesia. Jakarta: Equinox Publications.

Kantor Bupati. 2003. Decree by Bupati's Office 2003. Accessed 20 November 2014. http:// kapuashulukab.go.id/semua-kdownload-5.html

Kennedy E, Bouis H and von Braun J. 1992. Health and nutrition effects of cash crop production in developing countries: A comparative analysis. Social Science and Medicine 35(5):689-97.

King M, Smith A and Gracey M. 2009. Indigenous health part 2: The underlying causes of the health gap. The Lancet 374(9683):76-85.

KOMPAS. 2009. Pada 2020, Indinesia Produksi 50 Juta Ton CPO [In 2020, Indonesia will produce 50 million tons of CPO]. Jakarta: KOMPAS, May 29. 
Kottelat M. and Widjanarti E. 2005. The fishes of Danau Sentarum National Park and the Kapuas lakes area, Kalimantan barat, Indonesia. Raffles Bulletin of Zoology:139-73.

[KpSHK] Konsorsium pendukung Sistem Hutan Kerakyatan. 2014. Bogor, Indonesia: Konsorsium pendukung Sistem Hutan Kerakyatan. http://en.kpshk.org/

Laumonier Y, Setiabudi and Hadi D. 2013. Kapuas Hulu land cover maps 1:50,000. Bogor, Indonesia: the French Agricultural Research Centre for International Development-Center for International Forestry Research. http://www1.cifor.org/ colupsia/home.html

Levang P. 1997. La Terre D'en Face: La Transmigration En Indonésie. Marseille, France: IRD Editions.

Levang P, Dounias E, and Sitorus S. 2005. Out of the forest, out of poverty? Forests, Trees and Livelihoods 15(2):211-35.

Lim TW and Noorainie AA. 2010. Wood for the Trees: A Review of the Agarwood (Gaharu) Trade in Malaysia. Petaling Jaya, Malaysia: TRAFFIC Southeast Asia.

Lucarelli B. 2010. The history and future of Indonesia's coal industry: Impacts of politics and regulatory framework on industry structure and performance. Working Paper \#93, July 2010. Stanford, CA: Program on Energy and Sustainable Development.

Longhurst, R. 1988. Cash crops, household food security and nutrition. IDS Bulletin 19(2):28-36.

Lusiana B, Widodo R and Mulyoutami E. 2008. Assessing hydrological situation of Kapuas Hulu basin, Kapuas Hulu regency, West Kalimantan. Working Paper. Bogor, Indonesia: World Agroforestry Centre.

Marcone MF. 2005. Characterization of the edible birds nest the caviar of the east. Food Research International 38(10):1125-34.

Margono BA, Potapov PV, Turubanova S, Stolle F and Hansen MC. 2014. Primary forest cover loss in Indonesia over 2000-2012. Nature Climate Change 4(8):730-5.

McCarthy JF. 2004. Changing to gray: Decentralization and the emergence of volatile socio-legal configurations in Central Kalimantan, Indonesia. World Development 32(7):1199-223.

McCarthy JF and Cramb RA. 2009. Policy narratives, landholder engagement, and oil palm expansion on the malaysian and indonesian frontiers. The Geographical Journal 175(2):112.

Moeliono M and Limberg G. 2012. The Decentralization of Forest Governance: Politics, Economics and the Fight for Control of Forests in Indonesian Borneo. New York: Routledge.

[MOF] Ministry of Forestry of Indonesia. 2012. Statistik kehutanan Indonesia tahun 2011. Jakarta, Indonesia: Kementrian kehutanan republik Indonesia. www.Dephut.Go.Id/ index.Php?Q=id/node/8347.

Myers SS, Gaffikin L, Golden CD, Ostfeld RS, Redford KH, Ricketts TH, Turner WR and Osofsky SA. (2013) Human health impacts of ecosystem alteration. Proceedings of the National Academy of Sciences of the United States of America 110(47):18753-60.

Obidzinski K, Andrianto A and Wijaya C. 2007. Cross-border timber trade in Indonesia: Critical or overstated problem? Forest governance lessons from Kalimantan. International Forestry Review 9(1):526-35. 
Orth M. 2007. Subsistence Foods to Export Goods. The Impact of An Oil Palm Plantation on Local Food Sovereignty. North Barito, Central Kalimantan, Indonesia: Sawit Watch.

Paoli GD, Peart DR, Leighton M, and Samsoedin I. 2001. An ecological and economic assessment of the nontimber forest product gaharu wood in Gunung Palung National Park, West Kalimantan, Indonesia. Conservation Biology 15(6):1721-32.

Peluso NL. 2009. Rubber erasures, rubber producing rights: Making racialized territories in West Kalimantan, Indonesia. Development and Change 40(1):47-80.

Pontianak Post. 2004. Penyelundupan Kayu Lewat Laut Jalan Terus. Pontianak Post 9 June 2004.

Potter L. 1991. Environmental and social aspects of timber exploitation in Kalimantan, 1967-1989. In Hardjono JM, ed. Indonesia: Resources, Ecology, and Environment. New York: Oxford University Press. 177-211.

Rist L, Feintrenie L and Levang P. 2010. The livelihood impacts of oil palm: Smallholders in Indonesia. Biodiversity Conservation 19(4):1009-24.

Rival A and Levang P. 2014. Palms of Controversies. Bogor, Indonesia: Center for International Forestry Research.

Sahide, MAK and Giessen L. 2015. The fragmented land use administration in Indonesia: Analysing bureaucratic responsibilities influencing tropical rainforest transformation systems. Land Use Policy 43:96-110.

Samego. 1999. Militer Dan Bisnis: Peran ABRI Dalam Pembangunan Ekonomi. Jakarta: PPW-LIPI.

Sandker M, Suwarno A and Campbell BM. 2007. Will forests remain in the face of oil palm expansion? Simulating change in Malinau, Indonesia. Ecology and Society 12(2):37.

Setijadji B and Prihatmoko. 2010. Kalimantan mineral resources: An update on exploration and mining trends, synthesis on magmatism and proposed models for metallic mineralization. Proceedings PIT IAGI Lombok. The 39th IAGI annual Convention and Exhibition, Indonesia.

Shantiko B, Fripp E, Taufiqoh T, Heri V and Laumonier Y. 2013. Socio-economic considerations for land-use planning: The case of Kapuas Hulu, West Kalimantan. Bogor, Indonesia: Center for International Forestry Research.

Soehartono T and Newton AC. 2000. Conservation and sustainable use of tropical trees in the genus Aquilaria I. Status and distribution in Indonesia. Biological Conservation 96(1):83-94.

Sunderlin WD, Dewi S and Puntodewo A. 2007. Poverty and forests. Multi-country analysis of spatial association. Occasional Paper No. 4. Bogor, Indonesia: Center for International Forestry Research.

Susilo HD. 2003. Lessons learnt from Betung Kerihun National Park, Kalimantan, Indonesia. Asean Biodiversity:16-18.

Stephens C, Porter J, Nettleton C and Willis R. 2006. Disappearing, displaced, and undervalued: A call to action for indigenous health worldwide. The Lancet 367(9527):2019-28.

Stone GD. 2002. Both sides now. Current Anthropology 43(4):611-30. 
Syafriel A. 2009. Crude palm oil increases: Fact or fiction? The Jakarta Post 17 June 2009. Accessed 15 June 2009. http://www.thejakartapost.com/news/2009/06/17/crudepalm-oil-price-increases-fact-or-fiction.html.

Thorburn C. 2014. The edible birds' nest boom in Indonesia and South-east Asia: A nested political ecology. Food, Culture and Society 17(4):535-53.

Timmer, C.R, 1997. Farmers and markets: The political economy of new paradigms. American Journal of Agricultural Economics 79(2):621-62.

Unilever. 2009. Unilever takes stance against deforestation. London: Media Centre, Unilever Global. Accessed 15 December 2014. http://www.unilever.com/mediacentre/ pressreleases/2009/Unilevertakesstanceagainstdeforestation.aspx

van Klinken G. 2008. Blood, timber, and the state in West Kalimantan, Indonesia. Asia Pacific Viewpoint 49(1):35-47.

van Leeuwen TM. 2014. 25 years of mineral exploration and discovery in Indonesia. Journal of Geochemical Exploration 50:13-90.

von Braun JV and Kennedy E. 1994. Agricultural Commercialization, Economic Development, and Nutrition. Baltimore, MD: Johns Hopkins University Press.

Investvine. 2014.Vietnam seeks investors for edible bird's nest industry. Investvine. Accessed 15 December 2014. http://investvine.com/vietnam-seeks-investors-for-edible-birdsnest-industry/

Wadley RL, Pierce Colfer CJ, Dennis RA and Aglionby J. 2010. The 'social life' of conservation: Lessons from Danau Sentarum. Ecology and Society 15(4):39.

Wollenberg EK. 2001. Incentives for collecting gaharu (fungal-infected wood of Aquilaria spp. Thymelaeaceae) in east Kalimantan. Economic Botany 55(3):444-56.

[WRI] World Resources Institute. 2013. Suitability mapper. Creative Commons CC BY 4.0. Washington, DC: World Resources Institute. http://www.wri.org/resources/maps/ suitability-mapper

Wunder S. 2003. Oil Wealth and the Fate of the Forest. A Comparative Study of Eight Tropical Countries. London: Routledge.

[WWF] Worldwide Fund for Nature. 2005. Betung Kerihun National Park, Indonesia. Betung Kerihun National Park, Indonesia: WWF. http://wwf.panda.org/who_we_are/ wwf_offices/indonesia/?uProjectID=ID0194

Yuliani EL, Hasantoha A, Colfer CJP and Indriatmoko Y. 2014. Problem-solving versus appreciative inquiry approaches in community-based conservation. Forests, Trees and Livelihoods 24(2):1-15.

Yuliani L, Indriatmoko Y, Heri V, Ernawati S, Prasetyo LB and Zulkiflie MS. 2008. Promoting good governance in managing Danau Sentarum National Park through adaptive collaborative management approach. Governance and Ecosystem Management for the Conservation of Biodiversity. Thessaloniki-Perea, Greece: EU funded Gemconbio project. 
conversion of forest to farms. The conversion of forest to farming systems is regarded as the most common and widespread land-cover or land-use change and as such, agriculture is viewed as the greatest threat to forest conservation (Rudel et al. 2009; Gibbs et al. 2010; Lambin and Meyfroid 2011). Settlement of forestland, commonly termed colonization, accounts for the majority of tropical deforestation in Latin America (Geist and Lambin 2002). However, despite an agreement that colonization is the problem, there is a lack of understanding in many frontier forests about what has historically driven settlement and migration into a region over time.

Recent research on deforestation trends in Central America has revealed that Nicaragua has one of the highest deforestation rates in the region. Hansen et al. (2013) report a net forest loss of $7563 \mathrm{~km}^{2}$ in Nicaragua between 2000 and 2012 , accounting for $34 \%$ of the net forest loss in Central America as a whole. Aide et al. (2013) reported a similar net forest loss of $7961 \mathrm{~km}^{2}$ in Nicaragua between 2001 and 2010 , the highest calculated deforestation rate in the region. Redo et al. (2012) reported Nicaragua to have the highest net deforestation rate $\left(8574 \mathrm{~km}^{2}\right)$ in Central America's moist broadleaf forest in 2000-2010 and the second lowest overall percentage of forest cover (29\%). Redo et al. (2012) further reported that northeastern Nicaraguan municipalities of Waspam, Rosita, Bonanza and Siuna were "hot spots" of deforestation; each of these municipalities share jurisdiction with the Bosawas Biosphere Reserve.

This chapter examines and contributes to the theory that many ongoing processes and events act in concert and combine to drive temporal variation in the annual rates of deforestation. It is also reflective of the role of migration and subsequent forest clearing that occurs in agricultural frontiers and recognizes that there are push and pull factors that drive the migration (Geist and Lambin 2002; Carr 2009). A qualitative and narrative approach was used to provide a list of interrelated processes and events that have been responsible for the advance of Nicaragua's agricultural frontier into the municipality of Siuna and the Bosawas Biosphere Reserve. Specifically, this work seeks to address the following questions: What are the community perspectives of historical and present day drivers of land-use change? How does this vary between communities? What are the historical and present day drivers of migration and settlement in Siuna? How does settlement and migration history vary by community? What impact do local people perceive the historical changes in forest cover and land-use practices to have had on their food security and nutrition? What are the problems with food security and nutrition as perceived by local people?

\subsection{Background}

\subsubsection{Bosawas Biosphere Reserve}

North central Nicaragua is home to one of the largest terrestrial protected areas in Central America. The Bosawas Biosphere Reserve, known as Bosawas, is a UNESCO designated Man and Biosphere Reserve, the boundaries of which cover $15 \%$ of the country's land area, or approximately $20,000 \mathrm{~km}^{2}$ (Figure 5.1 ). Bosawas is reportedly home to an estimated $3.5 \%$ of global biodiversity of flora and fauna including 500 species of butterflies, 200 species of 


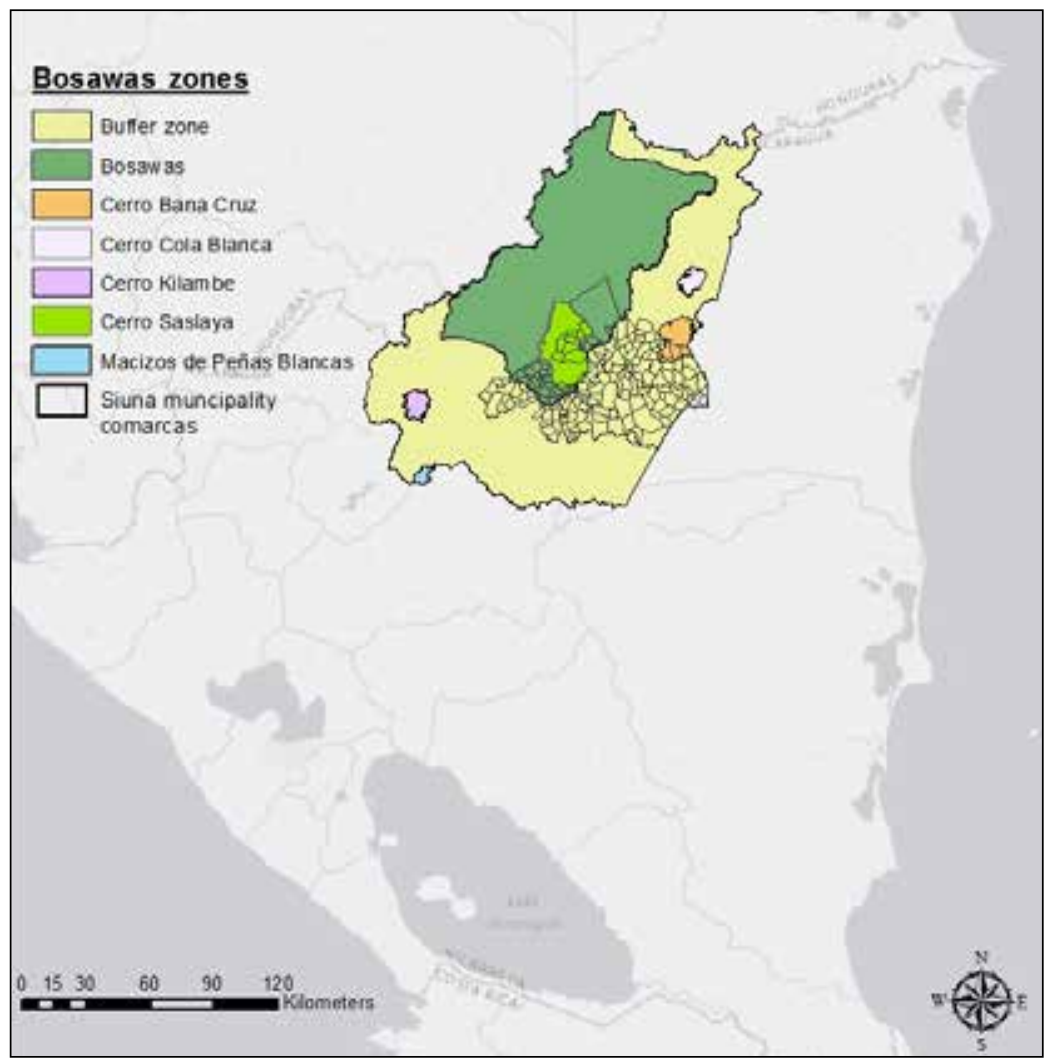

Figure 5.1 Bosawas Biosphere Reserve and Siuna Municipality with comarcas, Nicaragua.

dragonflies, 50 species of bats, 400 residential and 756 migratory birds, 120 species of mammals, 120 species of amphibians and reptiles, and 180 families of flora, including 400 species of orchids (Comisión Nicaragüense de Cooperación con la UNESCO 2011). Several of these species are rare in other parts of Central America, particularly the giant anteater, jaguar, harpy eagle and American crocodile, and a few are some of the world's last populations, for example Baird's tapir and the Central American spider monkey (SETAB 2012). These are but broad estimates as adequate data on the population status of wildlife, especially threatened species, is wanting due to a dearth of monitoring and assessment.

Bosawas together with three neighboring protected areas in Honduras (Rio Patuca National Park, Tawhaka Anthropological Reserve and Rio Plantation Biosphere Reserve) is the largest protected area complex of moist tropical forest north of the Amazon Basin. The Governments of Nicaragua and Honduras hope to have these four protected areas collectively designated as a UNESCO transboundary reserve known as Corazon del Corredor Biologico Mesoamerican (IEG 2011). The region has been coined the "Heart of Mesoamerica," known more formally as the Mesoamerican Biological Corridor. International efforts to create a connected system of protected areas in the region were initiated with a Joint Declaration signed in 1997 at the 19th Summit of 
the Central American Heads of State, Panama. The declaration states that the Mesoamerican Biological Corridor is:

A territorial planning system consisting of natural protected areas under a special regime whereby core, buffer, multiple use and corridor zones are organized and consolidated in order to provide an array of environmental goods and products to the Central American and the global society, offering spaces for social harmonization to promote investments in the conservation and sustainable use of natural resources, with the aim of contributing to the improvement of the quality of life of the inhabitants of the region.

(IEG 2011, v)

An array of challenges exist to such a large conservation endeavor in Central America, especially the increasing number of people in the region dependent on agriculture and forest-based resources for food and livelihoods. The administrative jurisdiction for Bosawas is shared by eight municipalities set within three Departments: Wiwilí de Nueva Segovia (Department of Nueva Segovia), Wiwilí de Jinotega, El Cuá y San José de Bocay (Department of Jinotega), Waslala, Bonanza, Mulukukú, Rosita, Waspam and Siuna (North Atlantic Autonomous Region). The combined population of each municipality was more than 367,000 in 2005 (see Figure 5.2). Of Bosawas' $20,000 \mathrm{~km}^{2}$, approximately 8000 are designated as the interior core or nuclear zone (zona nucleo) and 12,000 are designated the outer buffer zone (zona amortiguamiento); Bosawas lacks a transition zone, commonly found in other biosphere reserves (UNESCO 2015).

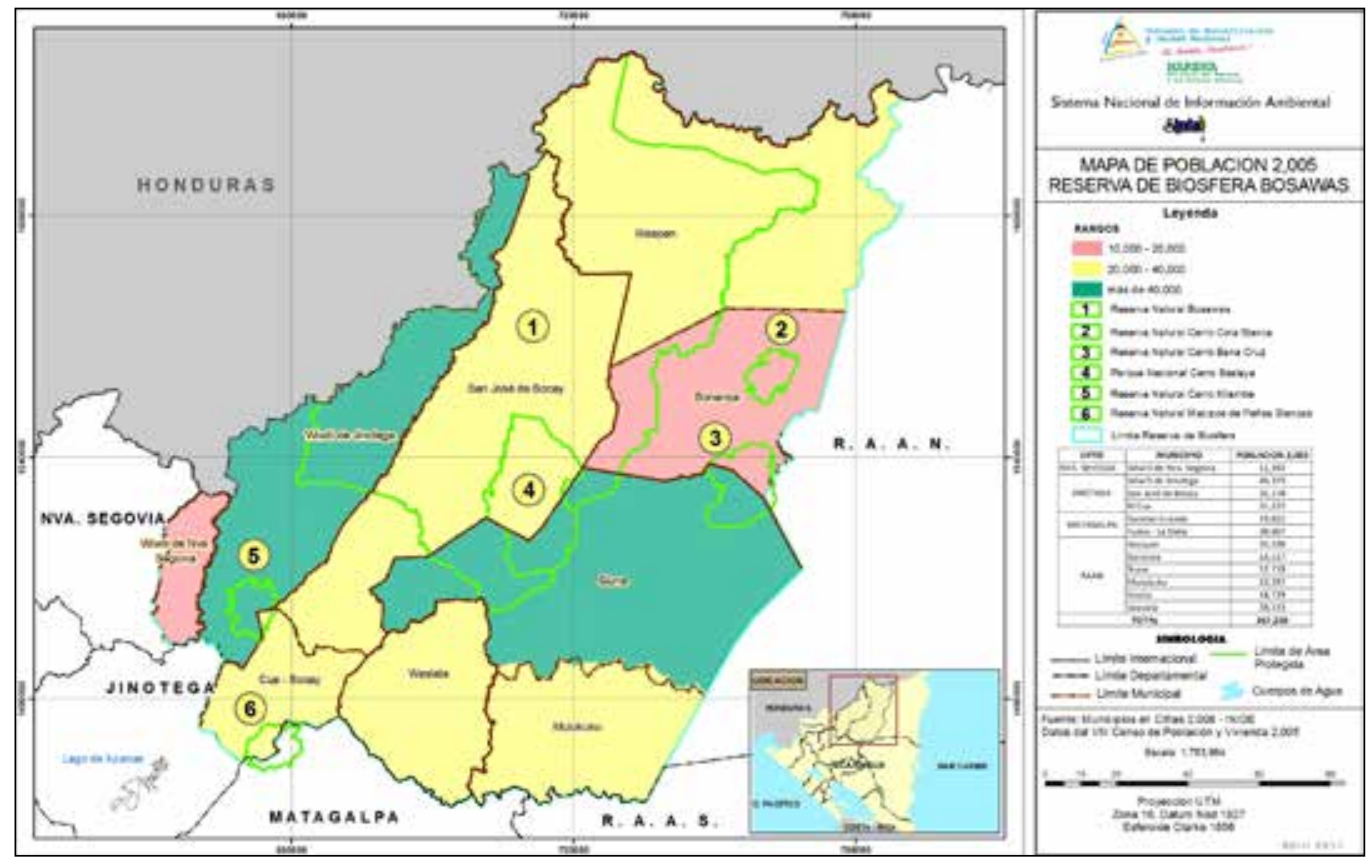

\section{Figure 5.2 Departments, municipalities and population of Nicaragua in 2005.}

Source: Map prepared by Nicaragua Ministry of Environment and Natural Resources (MARENA), and made available by the University of the Autonomous Regions of the Nicaraguan Caribbean Coast (URACAAN). Population data was based on the 2005 census (Instituto Nacional de Información de Desarrollo n.d.). 


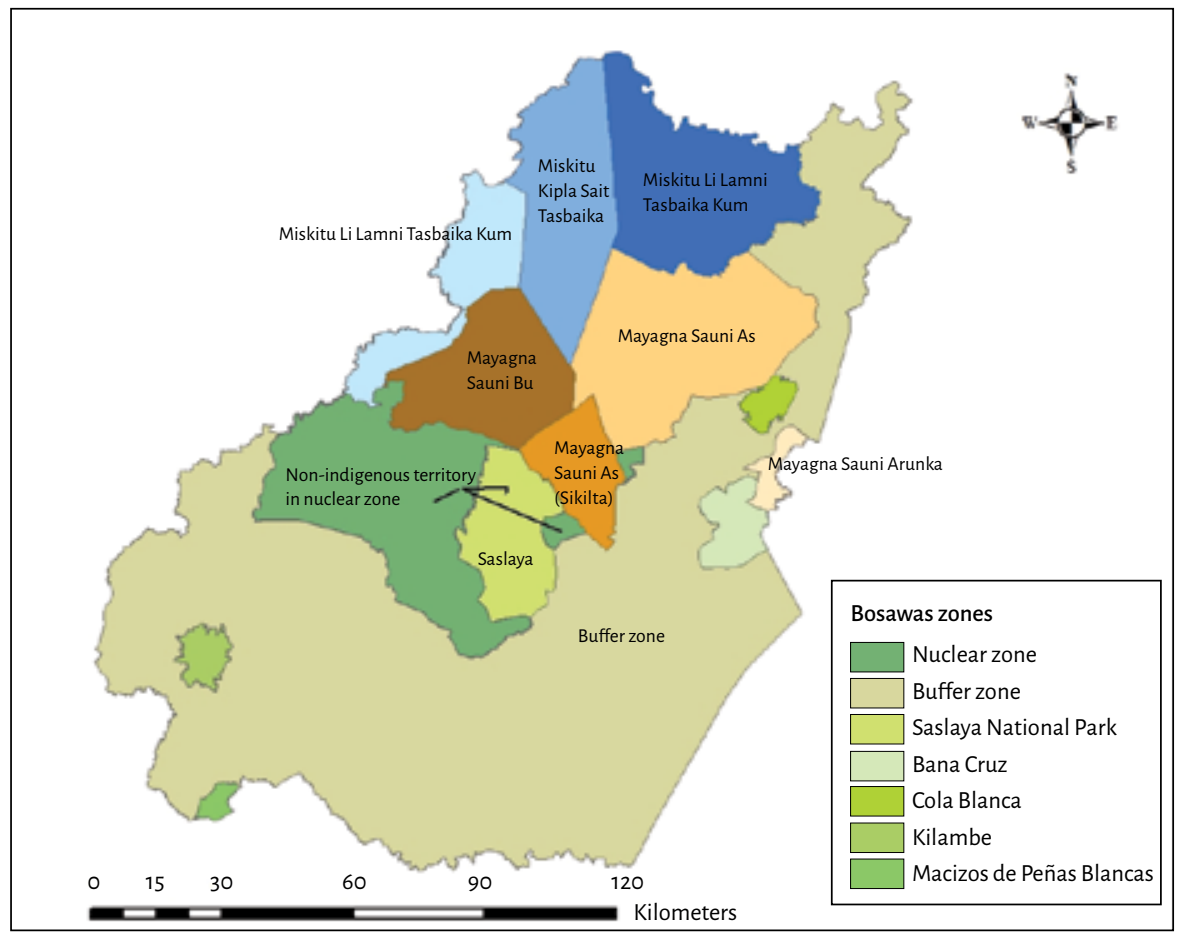

\section{Figure 5.3 Bosawas with indigenous territories and zones.}

Within the nuclear zone, approximately $80 \%$ of the land has been granted as common property indigenous land titles to Mískitu and Mayagna tribes (Figure 5.3) following their fight to win their traditional land titles (see Kaimowitz et al. 2003; Hayes 2007; Stocks et al. 2007; Hayes and Murtinho 2008; Larson 2010). The remaining $20 \%$ of the nuclear zone was not granted as indigenous territory and falls under jurisdiction of the municipalities of Siuna, San Jose de Bocay and Wiwili de Jinotega, affording them responsibilities for the land and resource management on behalf of the State. Mestizo peasants with origins throughout Nicaragua make up the majority of the population in this $20 \%$ of the nuclear zone. Few Mískitu or Mayagna live in the rural areas outside of their territorial boundaries but some have settled in urban areas.

\subsubsection{Study landscape}

This research focuses on Siuna municipality, which covers an area of $5039 \mathrm{~km}^{2}$, divided into approximately 190 comarcas (political subunits of communities that are often divided further into sectores, or sectors). Nearly all of Siuna's comarcas are set within Bosawas (Figure 5.4). The majority of comarcas are located within the buffer zone, but a significant number are situated in Bosawas' nuclear zone mainly south of Saslaya National Park, known as Saslaya. Additionally, there are at least ten comarcas in Siuna found entirely or partially within the boundaries of Saslaya. In short, political boundaries of Siuna's comarcas overlap with different zones of Bosawas. 


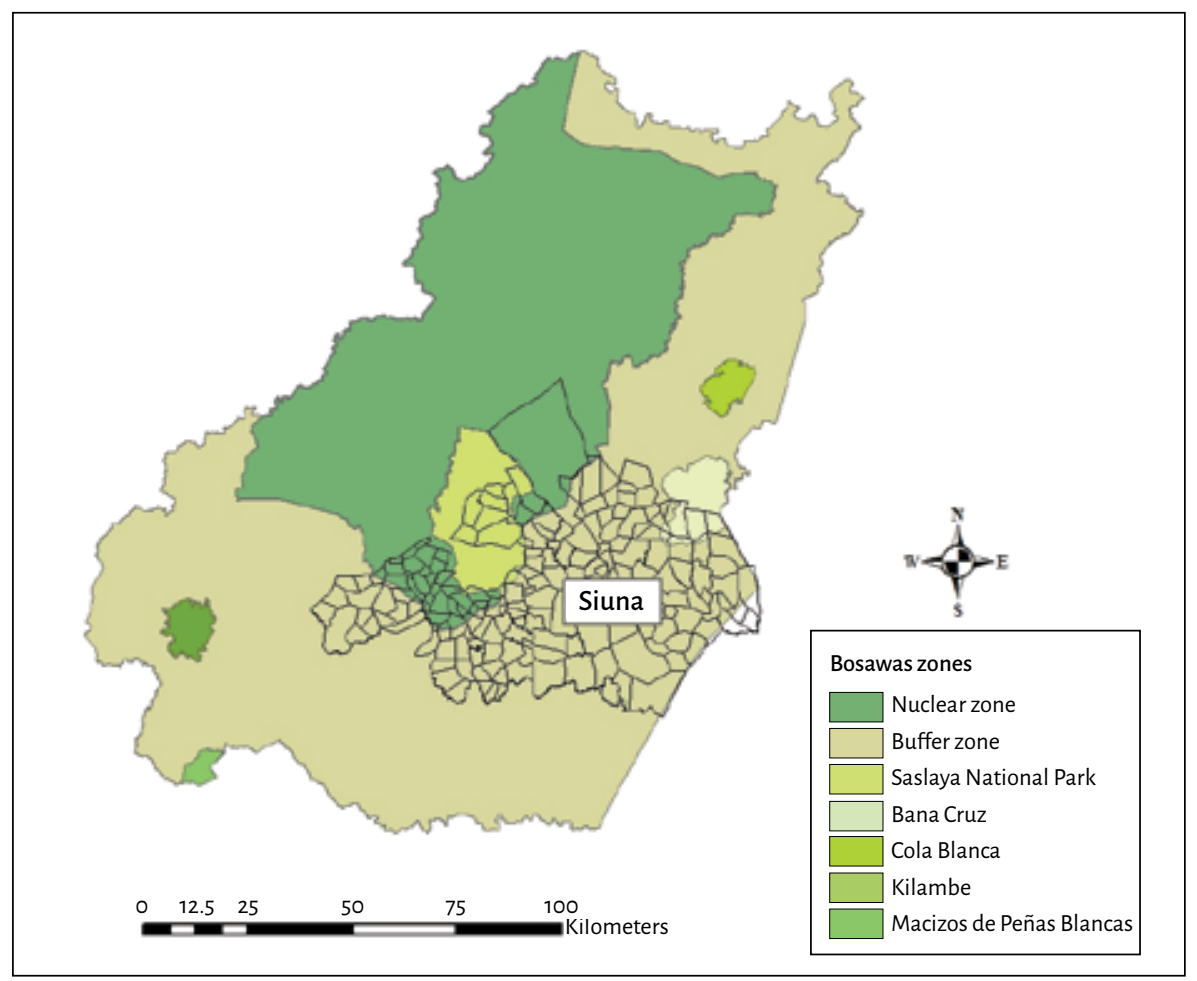

Figure 5.4 Siuna municipality in Bosawas with zones and comarcas.

In total, Saslaya's boundaries cover $633.8 \mathrm{~km}^{2}$ (approximately $8 \%$ of Bosawas' nuclear zone). Saslaya contains the largest contiguous patch of old growth rainforest remaining outside of indigenous territory in southern Bosawas, which is partially attributed to the topographic conditions of the Saslaya mountain range. The highest peak (Cerro Saslaya) is 1371 masl. Deforestation has recently occurred both outside Saslaya's boundaries, as well as inside the park's boundaries in the northern region (through Siuna from the east and through San Jose de Bocay from the west).

Siuna is located halfway between both Managua (the capital) and the Atlantic coast town of Bilwi (Puerto Cabezas); the journey to both locations is approximately 8 hours. It is also connected to Matagalpa (an important agricultural hub) by highway (approximately 8 hours). The urban center (cabecera) of Siuna - Siuna town - is at the intersection of three highways connected to Managua, Puerto Cabezas and Matagalpa; the distance to each is $318 \mathrm{~km}, 210$ $\mathrm{km}$ and $207 \mathrm{~km}$ respectively (Figure 5.5). Siuna was historically part of the Department of Zelaya but later become part of the Northern Atlantic Autonomous Region (the RAAN) - one of two autonomous regions in Nicaragua - in 1987. Siuna is also part of a region known as the mining triangle that includes the nearby municipalities of Rosita and Bonanza; mineral extraction has strongly shaped the history of the region.

The climate in the region is varied. Precipitation varies between 1800 and $3200 \mathrm{~mm}$ per year (MARENA 2003). The majority of rainfall takes place during the rainy season commencing in May and lasting until October. Heavy rains and damage from hurricanes are historically common in the region, although they are not as severe as elsewhere in the country. 


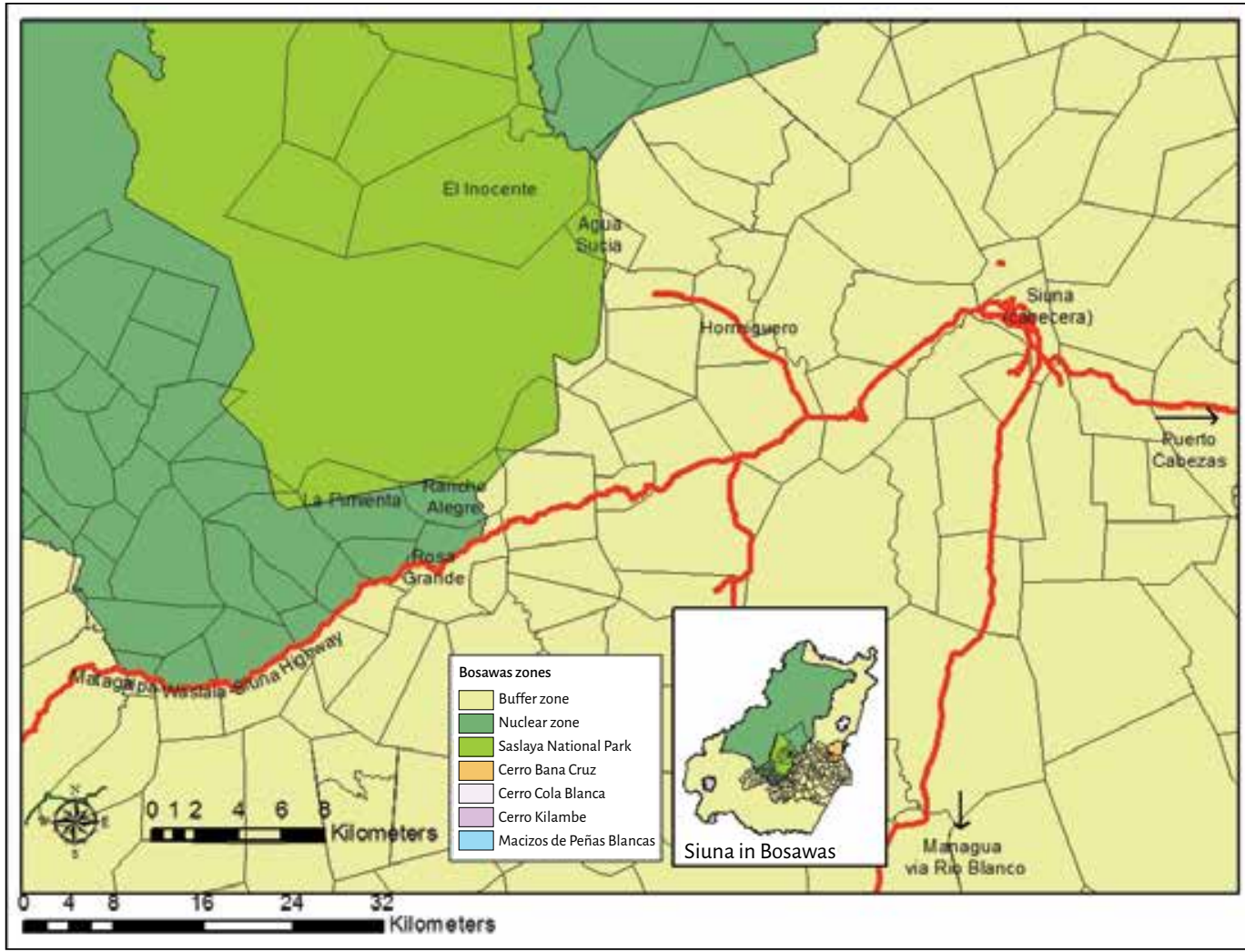

Figure 5.5 Map of the study communities, highways and Bosawas zones in Siuna.

According to a poverty analysis conducted in 2005 (INIDE 2008), Siuna is among the poorest municipalities in the country, with $75 \%$ of people surveyed identified as living in extreme poverty, ranking eighth worst in the nation. Given that Nicaragua is ranked as the second poorest country in Latin America and the Caribbean after Haiti, the region has some of the most marginalized communities in the Western hemisphere.

\subsubsection{Study communities}

Communities in Siuna surrounding Saslaya National Park were selected for this research to understand how, when and why deforestation has occurred in the region, where frontier advancement has stopped and where it is still occurring. Using GIS layers of Siuna's comarcas and Bosawas' boundaries, we identified 40 comarcas with territory in the southern nuclear zone of Bosawas below Saslaya National Park, nine comarcas with territory in the northern half of Saslaya National Park and three with territory in the nuclear zone north of Saslaya near Sikilta (indigenous Mayagna territory), indicating that nearly one quarter (52/190) of Siuna's comarcas have territory within the nuclear zone of Bosawas and/or Saslaya.

Because deforestation patterns do not reflect zoning and management regulations of Bosawas, selection of the six study communities was stratified based on timing of settlement and deforestation, in addition to ensuring selection of communities within different zones to understand why zoning was effective or ineffective in different areas. 
Table 5.1 Location of study communities (comarcas) within Bosawas and Saslaya.

\begin{tabular}{|c|c|c|c|}
\hline $\begin{array}{c}\text { When the majority of } \\
\text { deforestation occurred }\end{array}$ & Nuclear zone & $\mathbf{5 0 / 5 0 ~ n u c l e a r}$ and buffer & Buffer zone \\
\hline Before 1986 & - & Rosa Grande & Hormiguero \\
\hline $1986-2001$ & La Pimienta & Rancho Alegre & - \\
\hline $2001-11$ & El Inocente & - & Agua Sucia \\
\hline
\end{tabular}

Preliminary spatial analysis (prior to fieldwork) revealed different timing of deforestation depending on geographic location of the comarca, reflecting spatial patterns of human settlement and advance of the agricultural frontier. Following meetings with organizations and individuals working in the area, preliminary visits to eight communities, and meetings with community leaders, six communities were selected to focus ethnographic research. Of the six communities selected (see both Figure 5.5 and Table 5.1), the majority of deforestation occurred prior to 1986 in two communities (Rosa Grande and Hormiguero), deforestation started prior to 1986 but majority occurred between 1986 and 2001 in another two (La Pimienta and Rancho Alegre), and the highest rates of deforestation occurred between 2001 and 2011 in two (Agua Sucia and El Inocente).

\subsection{Methodology}

Utilizing a spatially defined landscape is a useful focal point for inter-or transdisciplinary research. According to Scherr et al. (2013) a 'landscape' is a socioecological system that consists of a mosaic of natural and/or human-modified ecosystems, with a characteristic configuration of topography, vegetation, land use and settlements that is influenced by the ecological, historical, economic, and cultural processes and activities of the area. In this study, the macro political boundaries of the study landscape is the municipality of Siuna, but we focus in on the comarca level (community-level political planning unit) for ethnographic fieldwork and restrict our study to communities in and around Saslaya.

Whilst there are some general agreements on what drives deforestation across large geographical regions, these broad-based regional drivers may not be appropriate for conservation or land-use planning polices, programs, plans or projects in specific places (Rudel et al. 2009). This research uses community accounts of historical settlement patterns and local perspectives of deforestation history, spatial analyses of land cover change, and secondary historical data and literature as its main tools to support what Lambin et al. (2003) refers to as a "narrative perspective" of the underlying drivers of deforestation in and around Saslaya National Park in Siuna. Given the importance of landscapes for food security as well as livelihoods, we interviewed participants about dietary changes to understand how diets were affected alongside community development and deforestation of the agricultural frontier. This inductive historical narrative approach was deemed appropriate given the paucity of data and information about the region particularly within the Mestizo communities. Settlers in the region are typically portrayed in the conservation media as illegal land traffickers, drug smugglers, loggers, colonists, ex-militia, cattle ranchers using extensive pasture and agriculturalists using expansive agricultural practices. 


\subsubsection{Ethnographic fieldwork}

Research took place over 6 weeks between July and August 2013 and 8 weeks between May and July 2014. An interview schedule that covered basic characteristics of community, governance, population, land-use activities, social issues and development interventions prior to fieldwork was used for semi-structured interviews with community leaders. Leaders assisted in arranging FGDs with community elders (those who had lived in the community for the longest time). FGDs were designed to develop historical timelines of population change and land-cover change and identify drivers of land-use change from the community perspective. They were also used to better understand historical events, motivations for migration, dietary changes and food security issues that have developed over time or occurred during different time periods/events.

Additional key informant interviews were also held with farmers involved in cooperatives and other development interventions. Field walks were conducted in all communities to better understand land use throughout the community, farming practices, on-farm tree use, how and where fuelwood, thatch and timber were collected, community perspectives of park boundaries, and seasonal variations in activities. Elders, present and historical political leaders (i.e. leaders of health and education), and forest guards (guarda bosques) were interviewed to provide further detail on historical events/policies/programs as well as historical changes to park policy rules and enforcement. Seasonal calendars, wealth ranking and communitybased mapping were used in Hormiguero, Rancho Alegre and Agua Sucia to garner further detail on poverty, livelihoods and farming.

Interviews were held with representatives from NGOs, government agencies, cooperatives and associations, international agencies for development cooperation, and academics from URACAAN. This allowed us to clarify events, historical data and policy-related questions. It also provided important insight on the role of development interventions in the landscape, what activities were occurring and how they functioned in relation to the land-use policies of Bosawas. These interviews were held in Siuna cabecera as well as in Managua.

\subsubsection{Spatial analysis}

Due to the limitations of available satellite imagery, the spatial analysis was conducted on a $2500 \mathrm{~km}^{2}$ subset of Mount Saslaya and the surrounding area, which included the six research communities (Figure 5.6). Because adjacent scenes were not available for similar months in the years selected, the spatial area of the analysis does not cover the entire municipal boundaries of Siuna, nor does it cover the entire geopolitical boundaries of Saslaya or Bosawas. A spatial analysis of forest cover change was performed using Landsat imagery in 1986-2011, which was integrated into maps of forest loss and gain. Three Landsat surface reflectance files of one scene (path 16, row 51) were obtained from the United States Geological Survey (USGS) Landsat archive for 1986, 2001 and 2011. Atmospheric differences were corrected using the image multivariate alteration detection (iMAD) transformation (Canty and Nielsen 2006). Clouds, cloud shadows and water bodies were removed using a combination of supervised classification, manual digitization and masks provided 
by the USGS. Overall cloud cover ranged from < 1\% in 1986 to $24 \%$ in 2011 . Vegetation indices were used to distinguish primary forest from deforested and disturbed areas. Several vegetation indices were derived and compared, including the disturbance index (Healey et al. 2005), the NDVI and the normalized burn ratio. Lastly, a threshold was used to classify forest and non-forest values from the disturbance index. Ultimately the normalized burn ratio provided the clearest delineation of forest disturbance, upholding previous findings by Stocks et al. (2007). A threshold was used to separate intact, primary forest from disturbed forest and generate binary classifications of primary forest extent. These classifications were used to produce maps of forest change between the two time periods, 1986-2001 and 2001-11.

Landscape change was analyzed at two spatial scales, at the level of the landscape as a whole and within different park boundaries. At the scale of the landscape, a basic Markovian transition model (Urban and Wallin 2002) was used to quantify forest change using 500 randomly sampled points on cloud-free areas. For the park boundary level analysis, a subset of three areas (the Bosawas buffer zone, Bosawas nuclear zone and Saslaya National Park) was sampled with 200 random points in each area. Map accuracy has not been assessed, though field data collected in November 2013 was used to inform classification.

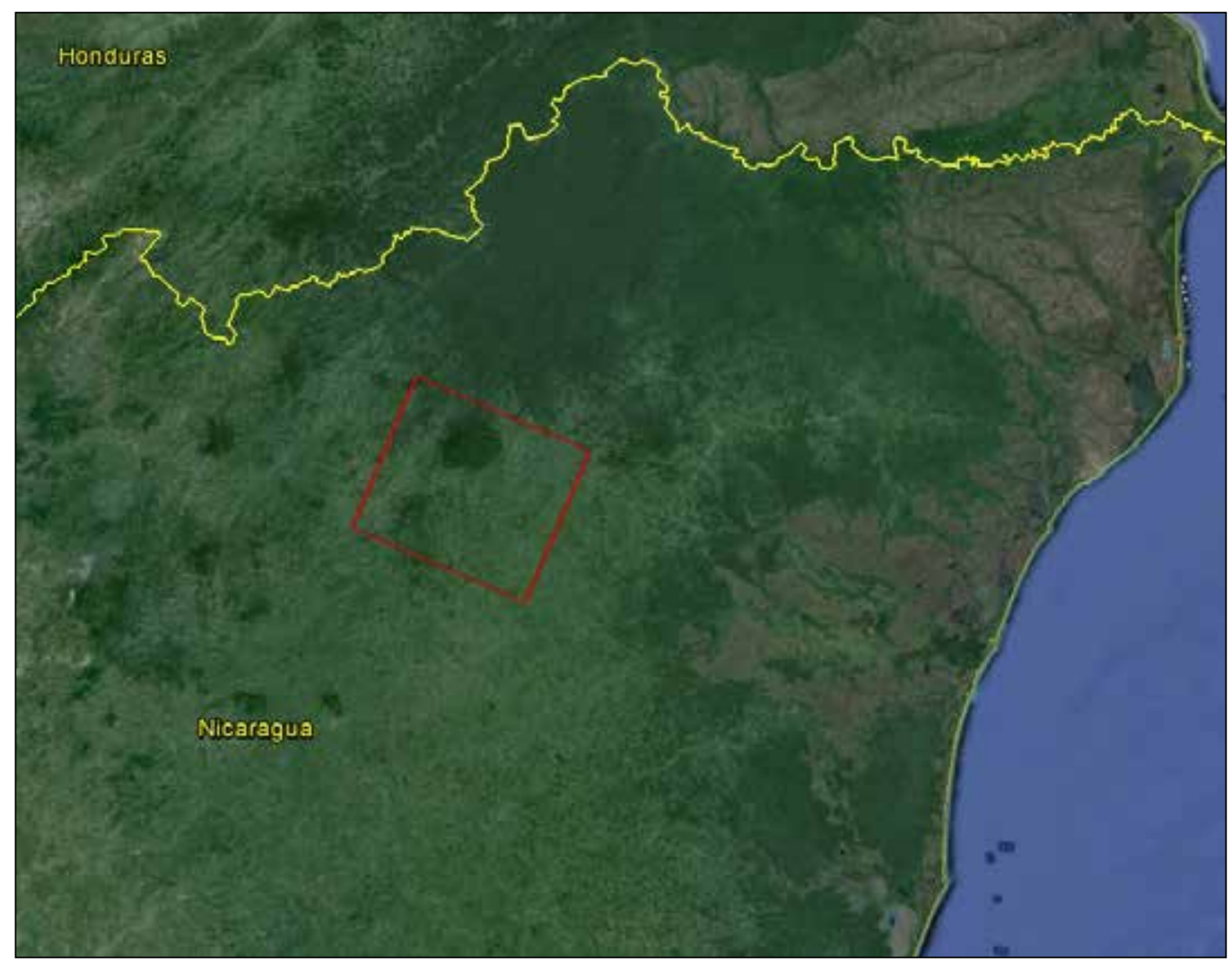

Figure 5.6 Spatial analysis study limits (Landsat scene path 16, row 51). 


\subsubsection{Historical review}

In order to complement and triangulate information collected at the community level, secondary data and literature were used to provide supporting evidence and context via a historical narrative of the history of drivers influencing migrations into study communities.

\subsection{Population growth and land-cover change}

We collected community estimates of population (number of households) at 10-year periods in FGDs with long-term residents (Table 5.2). Communities with territory in the nuclear zone along the southern edge of Saslaya (Rosa Grande, Rancho Alegre, La Pimienta) noted that there were settlers in the region as early as the 1950 s with small communities formed by the 1970s. Rosa Grande was settled rapidly in the 1980 as it was made a Sandinista (Sandinista Front for National Liberation or FSLN) cooperative during the Contra War, whilst other surrounding communities were evacuated (i.e. Rancho Alegre). Settlement in Hormiguero also began early, community members suggested that there were settlers there as early as the 1940s, and its population increased during the 1980 s as it was also a FSLN cooperative. Agua Sucia and El Inocente (north of Hormiguero) are both newly settled communities; community members believe there were few settlers there before the 1990s. Agua Sucia and El Inocente's late settlement is reflective of their geographic location on the migratory route of the agricultural frontier that has expanded north of Hormiguero since the 1990s.

We calculated that the annual loss of primary forest loss inside the Bosawas nuclear zone fell from $2.43 \%$ per year in $1986-2011$ to $1.6 \%$ in $2001-11$. Figure 5.7 displays results from spatial analysis of deforestation in the study communities, revealing the heavy deforestation in the southern nuclear zone below Saslaya between 1986 and 2001. In 1986-2001, the Waslala-Siuna highway can also be seen, as well as the heavy deforestation within Hormiguero. Agua Sucia and El Inocente along with other communities northeast of Saslaya had some deforestation prior to 2001 but appear to be hot spots of deforestation compared to southern Saslaya between 2001 and 2011. This reflects the path of advancement of the agricultural frontier in Siuna through northeast Saslaya.

Communities reported in FGDs that forest cover in Rancho Alegre, Rosa Grande and La Pimienta (southern nuclear zone) began in the 1960 s and1970s and by 2000 more than $70 \%$ of virgin forest had been cleared in all three communities, with high rates of loss between 1990 and 2000 (Table 5.3). El Inocente community members estimated that forest clearing in the past decade in Saslaya was less than the period between 1990 and 2000. Spatial analyses report that deforestation in Saslaya increased from $0.13 \%$ between 1986 and 2001 to $0.95 \%$ between 2001 and 2011 , which may be because the spatial area for analysis included communities to the northwest (where the frontier was expanding). Across the entire area included in the spatial analysis, forest loss over the 1986-2001 time period was 83,335 ha at a rate of $2.16 \%$. Over the $2001-11$ period it was 35,466 ha at a similar rate of $2.21 \%$. The rates of forest loss in the buffer zone were similar in both time periods, at approximately $2.20 \%$. 
Table 5.2 Estimated population change of study communities from 1950 to 2014 as indicated by estimated number of households.

\begin{tabular}{|c|c|c|c|c|c|c|c|c|}
\hline & 1950 & 1960 & 1970 & 1980 & 1985 & 1990 & 2000 & 2014 \\
\hline Hormiguero & 2 & 5 & $18-20$ & 23 & 113 & 113 & 155 & $\begin{array}{c}270+ \\
(2010)\end{array}$ \\
\hline Rancho Alegre & 2 & 2 & 5 & 12 & 2 & 54 & 65 & 108 \\
\hline Rosa Grande & 2 & 7 & 12 & 15 & 100 & 100 & 150 & 200 \\
\hline $\begin{array}{l}\text { La Pimienta } \\
(\text { Sector } 1)^{\mathrm{a}}\end{array}$ & - & - & 7 & 7 & $0-2$ & 10 & $40-45$ & 75 \\
\hline Agua Sucia & - & - & - & 2 & - & 13 & 30 & 158 \\
\hline $\begin{array}{c}\text { El Inocente } \\
\text { (Sector } 1 \text { ) }\end{array}$ & - & - & - & 1 & - & 1 & $40^{b}$ & 200 \\
\hline
\end{tabular}

a Population estimates are only for half the comarca as they were taken from 1 of 2 sectors.

b Population was reduced to zero in 2003 following evictions.

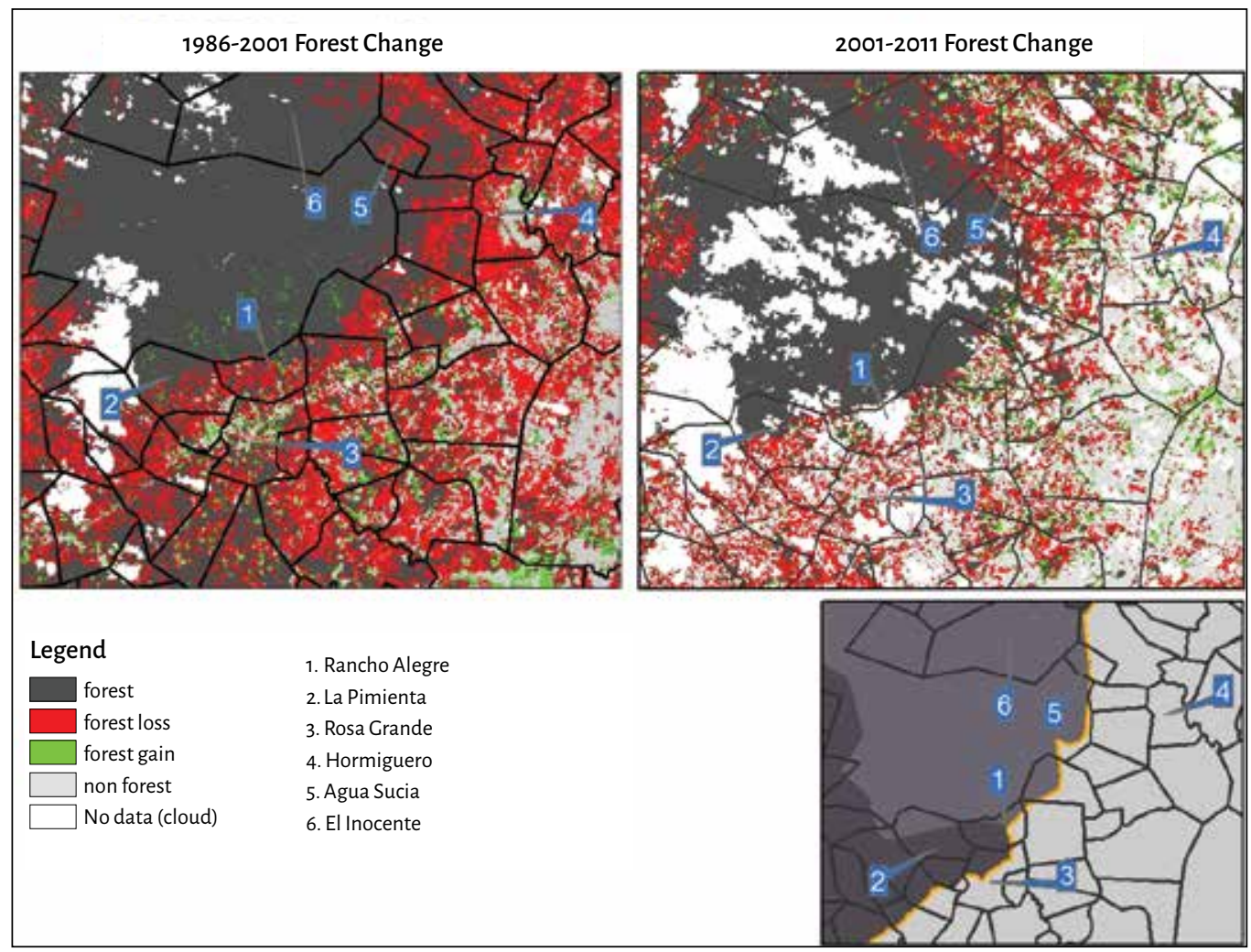

Figure 5.7 Forest cover change in the study landscape. 
Table 5.3 Percentage land-cover change from 1940 to 2014 as estimated by study communities.

\begin{tabular}{|c|c|c|c|c|c|c|c|}
\hline & $\begin{array}{c}1940 \text { and } \\
1950\end{array}$ & 1960 & 1970 & 1980 & 1990 & 2000 & 2014 \\
\hline Rancho Alegre & $100 \% \mathrm{~F}$ & $90 \% \mathrm{~F}$ & $\begin{array}{c}80 \% \mathrm{~F} \\
15 \% \mathrm{Ag} \\
5 \% \mathrm{P}\end{array}$ & $\begin{array}{c}70 \% \mathrm{~F} \\
20 \% \mathrm{Ag} \\
10 \% \mathrm{P}\end{array}$ & $\begin{array}{c}70 \% \mathrm{~F} \\
15 \% \mathrm{Ag} \\
15 \% \mathrm{P}\end{array}$ & $\begin{array}{c}30 \% \mathrm{~F} \\
40 \% \mathrm{Ag} \\
30 \% \mathrm{P}\end{array}$ & $\begin{array}{c}30 \% \mathrm{~F} \\
30 \% \mathrm{Ag} \\
40 \% \mathrm{P}\end{array}$ \\
\hline Rosa Grande & $100 \% \mathrm{~F}$ & $\begin{array}{l}98 \% \mathrm{~F} \\
2 \% \mathrm{Ag}\end{array}$ & $\begin{array}{l}96 \% \mathrm{~F} \\
4 \% \mathrm{Ag}\end{array}$ & $\begin{array}{c}90 \% \mathrm{~F} \\
10 \% \mathrm{Ag}\end{array}$ & $\begin{array}{c}50 \% \mathrm{~F} \\
40 \% \mathrm{Ag} \\
10 \% \mathrm{P}\end{array}$ & $\begin{array}{c}12 \% \mathrm{~F} \\
38 \% \mathrm{Ag} \\
30 \% \mathrm{AgF} \\
20 \% \mathrm{P}\end{array}$ & $\begin{array}{c}10 \% \mathrm{~F} \\
35 \% \mathrm{Ag} \\
35 \% \mathrm{AgF} \\
20 \% \mathrm{P}\end{array}$ \\
\hline Hormiguero & $100 \% \mathrm{~F}$ & $100 \% \mathrm{~F}$ & $\begin{array}{l}95 \% \mathrm{~F} \\
5 \% \mathrm{Ag}\end{array}$ & $\begin{array}{c}90 \% \mathrm{~F} \\
10 \% \mathrm{Ag}\end{array}$ & $\begin{array}{c}85 \% \mathrm{~F} \\
10 \% \mathrm{Ag} \\
5 \% \mathrm{P}\end{array}$ & $\begin{array}{c}50 \% \mathrm{~F} \\
25 \% \mathrm{Ag} \\
25 \% \mathrm{P}\end{array}$ & $\begin{array}{c}15 \% \mathrm{~F} \\
35 \% \mathrm{Ag} \\
50 \% \mathrm{P}\end{array}$ \\
\hline La Pimienta & $100 \% \mathrm{~F}$ & $100 \% \mathrm{~F}$ & $\begin{array}{l}95 \% \mathrm{~F} \\
5 \% \mathrm{Ag}\end{array}$ & $\begin{array}{c}90 \% \mathrm{~F} \\
10 \% \mathrm{Ag}\end{array}$ & $\begin{array}{c}80 \% \mathrm{~F} \\
10 \% \mathrm{Ag}\end{array}$ & $\begin{array}{c}30 \% \mathrm{~F} \\
65 \% \mathrm{Ag} \\
5 \% \mathrm{P}\end{array}$ & $\begin{array}{c}8 \% \mathrm{~F} \\
12 \% \mathrm{AgF} \\
60 \% \mathrm{Ag} \\
20 \% \mathrm{P}\end{array}$ \\
\hline $\begin{array}{l}\text { Agua Sucia } \\
\text { Sector } 2^{\mathrm{a}}\end{array}$ & $100 \% \mathrm{~F}$ & - & - & $\begin{array}{c}50 \% \mathrm{~F} \\
20 \% \mathrm{~B} \\
30 \% \mathrm{Ag}\end{array}$ & $\begin{array}{c}50 \% \mathrm{~F} \\
20 \% \mathrm{~B} \\
30 \% \mathrm{Ag}\end{array}$ & $\begin{array}{c}5 \% \mathrm{~F} \\
93 \% \mathrm{Ag} \\
2 \% \mathrm{P}\end{array}$ & $\begin{array}{c}5 \% \mathrm{~F} \\
5 \% \mathrm{Fs} \\
85 \% \mathrm{Ag} \\
5 \% \mathrm{P}\end{array}$ \\
\hline El Inocente & $100 \% \mathrm{~F}$ & $100 \% \mathrm{~F}$ & - & - & $\begin{array}{l}70 \% \mathrm{~F} \\
30 \% \mathrm{Fs}\end{array}$ & $\begin{array}{l}10 \% \mathrm{~F} \\
30 \% \mathrm{Fs} \\
60 \% \mathrm{Ag}\end{array}$ & $\begin{array}{c}5 \% \mathrm{~F} \\
80 \% \mathrm{Ag} \\
10 \% \mathrm{P} \\
5 \% \mathrm{AgF}\end{array}$ \\
\hline
\end{tabular}

Note: $\mathrm{Ag}=$ agricultural crops including rice, beans, corn, musas (plantain/bananas) and staple root crops; $\mathrm{AgF}=$ agroforest $\mathrm{F}=$ primary old-growth forest; $\mathrm{Fs}=$ secondary forest $\mathrm{P}=$ pasture.

a Missing data for Agua Sucia Sector 1.

\subsection{Landownership and agricultural activities}

\subsubsection{Landownership}

The social structure in Siuna can be modeled into the classes described by Enriquez (1991): the bourgeoisie or large landowners; the peasant farmer or campesino sector; and the agricultural proletariat. Land in Nicaragua is measured in manzanas (mz), which is equivalent to $0.7 \mathrm{ha}$. We have classified the bourgeoisie class in Siuna as those that own more than $100 \mathrm{mz}(70 \mathrm{ha})$, the middle-class campesino sector are those who hold $20-100 \mathrm{mz}(14-70 \mathrm{ha}$ ), the poor peasantry holding between $10-20 \mathrm{mz}$ (7-14 ha) and the agricultural proletariat as those who own less than $10 \mathrm{mz}(<7 \mathrm{ha})$. The agricultural proletariat has little to no access to land and is frequently dependent on agricultural wage labor or other forms of labor for all or a portion of the year. Table 5.4 presents data on the area and number of farming families in each social class, as well as the division of land area between the different categories of farming landownership classes (compiled from data from the 2011-12 agricultural census for 
Table 5.4 Social farming classes and landholding sizes.

\begin{tabular}{|c|c|c|c|c|c|}
\hline Rural class & $\begin{array}{c}\text { Holding size } \\
\text { (mz) }\end{array}$ & $\begin{array}{c}\text { Number of } \\
\text { holdings }\end{array}$ & $\begin{array}{c}\text { Proportion } \\
\text { of holdings }\end{array}$ & $\begin{array}{c}\text { Land area } \\
\text { (mz) }\end{array}$ & $\begin{array}{c}\text { Proportion of } \\
\text { land area }\end{array}$ \\
\hline Rural proletariat & $<1$ & 115 & 1.85 & 20 & 0.006 \\
\hline Rural proletariat & $1-5$ & 499 & 8.05 & 1,747 & 0.504 \\
\hline Rural proletariat & $5-10$ & 687 & 11.08 & 5,507 & 1.588 \\
\hline Poor peasantry & $10-20$ & 1,093 & 17.63 & 16,744 & 4.827 \\
\hline Middle peasantry & $20-50$ & 1,839 & 29.66 & 62,665 & 18.065 \\
\hline Medium-sized & $50-100$ & 1,185 & 19.11 & 86,324 & 24.886 \\
\hline landowner & & & & & 40.086 \\
\hline Bourgeoisie & $100-500$ & 746 & 12.03 & 139,053 & 10.03 \\
\hline Bourgeoisie & $>500$ & 37 & 0.6 & 34,824 & 100 \\
\hline Total & & 6,201 & 100 & 346,884 & \\
\hline
\end{tabular}

Siuna municipality). ${ }^{1}$ These data reveal that the poor to middle class of peasantry (farms between $10-100 \mathrm{mz}$ ) are common and make up $66.4 \%$ of the farms and $47.7 \%$ of the land in Siuna. The bourgeoisie class ( $>100 \mathrm{mz}$ ) make up only $12 \%$ of the farms but hold $50 \%$ of the land while the rural proletariat $(<10 \mathrm{mz}$ ) make up $20 \%$ of the farms but hold less than $3 \%$ of the land. The 514 farming families that own less than $5 \mathrm{mz}$ own less than $0.5 \%$ of the land.

Informants in Rancho Alegre, Hormiguero and Agua Sucia also discussed these patterns of landownership during community-based mapping exercises to understand landownership, property subdivisions, property consolidations and settlement patterns within the study communities. Each community had very few farmers with more than $100 \mathrm{mz}$, as well as few with less than $5 \mathrm{mz}$. Those who were reported to farm on less than $5 \mathrm{mz}$ typically rented or borrowed this land from other farmers. Landownership patterns also revealed that people did not always live on their farms and that they may have multiple plots of land both within and outside the community that they owned or rented. Communities with road access typically had a row of houses and shops along the street/ highway; farmers often had land elsewhere in the community for farming but preferred to live next to the road.

The majority of farmers in the study communities were middle-class, mixed-use farmers, cultivating basic grains and raising livestock, yet a significant portion had enough land for at least one cow. Large landholdings were uncommon; Rosa Grande reported ten farmers with more than $100 \mathrm{mz}$, Hormiguero reported two, Rancho Alegre identified one, and La Pimienta and Agua Sucia reported none. The bourgeoisie class of landowners were reported to live outside of the study communities in the comarcas of Mutiwas, Union La Bu, San Marco Nasawe, El Guinea, Tazadna, Cooperna, Tadaznita and Santa Juania. These

1 The 2011-12 census data was provided by the Ministry of Agriculture and Forests (MAGFOR). 
large landowners were typically cattle ranchers who preferred flat terrain and access to water and roads. The steeper topography of the study communities (especially La Pimienta and Rancho Alegre) explains the lack of large-scale ranchers there.

Most communities reported that there was little land available for sale and that subdivision of family farms during inheritance was increasingly a problem. For example, one village leader explained that people are "sticking to their fathers land"; landowners who originally had $25 \mathrm{mz}$ have since had children, for whom they have subdivided their land; their grandchildren are now faced with limited access to land. Access to affordable land is no longer possible for many young people in the study communities. To find cheap land, migrants today have to settle beyond the boundaries of Saslaya, which many communities try to prevent (discussed later) or they migrate to northern Saslaya beyond El Inocente (Figure 5.5), which is more than 8 hours from the nearest road.

\subsubsection{Agricultural production}

According to data from Nicaragua's agricultural census for the 2010-11 growing year, $97 \%$ of households in Siuna with agricultural activity were producing basic grains. Half of the households had at least one permanent or semipermanent crop; the most commonly reported permanent crops were bananas/plantains (2188), followed by cacao (1068), coffee (699), sugarcane (256) and citrus (207). The adoption of permanent or semipermanent crops is still relatively limited compared to basic grains or pasture. Overall, only $3 \%$ of the total farmland was dedicated to permanent or semipermanent crops, while $14 \%$ and $28 \%$ was used for basic grains and fallow, respectively, and $52 \%$ was dedicated to natural and cultivated pasture.

The majority of the poor to middle peasantry (10-100 mz) were engaged in mixed crop-livestock production. Farmers grew rice, beans and corn (basic grains) along with several staple root crops, bananas and plantains. A portion of the land was set aside for pasture, depending on farmer preference and land area. Around the homestead, farmers planted and allowed natural regeneration of fruit trees, ornamentals, spices and herbs in patios. Poultry and pork were common domestic livestock and most middle peasantry owned at least one mule, used for transporting crops to market. Depending on farmer preference, education, cultural background and development support, they carried out coffee and/or cacao farming, typically in small-scale agroforests. As of June 2014, the largest cacao holding in Siuna was $18 \mathrm{mz}$.

\section{Cacao agroforestry}

The cacao industry in Nicaragua has grown substantially over the past 10 years, with the assistance of the Government of Nicaragua, international development organizations and the private sector. According to the International Cocoa Organization (ICCO), Nicaragua was among the seven largest fine flavor cocoa producing countries in 2010/2011. The industry has boomed in Siuna; the value of cacao has increased as global demand has exceeded supply for the last 10 years. The environmental benefits of agroforestry cropping systems have lead many conservation organizations to promote cacao agroforestry as the ideal land use in the buffer zones of protected areas, particularly for restored degraded areas (López Sampson et al. 2013). A steady increase 
in development activities since 2007 has raised export levels of cacao by $300 \%$ with 2408 tons reported for exportation in 2012 (from 898 tons in 2007). Nationally, an estimated 7500 families were involved in cultivation on 11,000 ha of land, 50\% of which were less than 3 years of age and were not in production (López Sampson et al. 2013).

GIZ initiated actions to improve the cacao value chain in Nicaragua in the early 1990s through Pro Mundo Humano, which had a collaborative arrangement with the multinational private enterprise Ritter Sport. GIZ, through La Cooperacion Alemana, has contributed to the development of the cacao sector with the stated aims of contributing to the sustainable management of natural resources and forests, and reducing the progress of the agricultural frontier, while encouraging better integration into the cacao value chain, enhancing value of agroforestry products and improving the incomes of farm families (López Sampson et al. 2013). In Siuna, GIZ provided technical assistance and capacity development to the Municipal Association of Cacao Producers, cacao cooperatives and producers in the management and design of cacao systems. Extension workers tended to work with medium-sized producers with secondary or remnant forest on their land that was underused, with the goal of turning them into productive agroforestry systems that incorporated fruit trees, timber species, musas (for shading and pollination of young cacao) and staple root crops (yuca and malanga).

Catholic Relief Services, supported by the Ford Foundation, worked with hundreds of new cacao farmers in Siuna. For several years they have been encouraging medium to large producers to convert a portion of their land to cacao agroforestry. At the time of research, they reported working with 700 producers in 13 communities in Siuna. A new project led by the Swiss Agency for Development and Cooperation (SDC) and the United Nations Industrial Development Organization (UNIDO) aims to expand the number of cacao producers in Siuna. Additionally, MLR, a Nicaragua enterprise associated with Norteak, wanted to acquisition land from existing landholders and begin producing cacao in Siuna. Further details on their land acquisition and proposed production methods could not be obtained at the time of research. Smaller projects supporting producers with cacao agroforestry systems in specific communities were implemented by Bridges to Community in Rosa Grande and Rancho Allegre, and URACAAN conducted extension work in El Carao.

According to the 2010-11 agricultural census for Siuna, cacao was planted on 1068 holdings on a total of $1535 \mathrm{mz}$. Yet, according to a 2012 census of 692 farms from 16 different communities in Siuna (conducted by the Municipal Association of Cacao Producers), $1038 \mathrm{mz}$ had plants of 1 year or more and only 573 were in production. Based on our observations, cacao production was rapidly increasing in Siuna. Communities with strong agricultural cooperatives (typically ex-Sandinista cooperatives) were recipients of the most development assistance. Care should be taken to aid families outside of cooperative kinship groups and communities that are difficult to access. Interestingly, dozens of farmers in El Inocente were also growing cacao despite a complete lack of formal assistance from any development or government agencies. 


\subsection{Historical drivers of settlement and deforestation}

\subsubsection{The first settlers, the gold mine, US exports and rebellion (1880-1934)}

The first wave of settlers in Siuna arrived in the late 1800 s and were predominately independent gold prospectors (güiriseros), who set up several small-scale nonmechanical mining operations in the headwaters of the Prinzapolka, Bambama and Waspuk rivers (Jastrzembski 2014). By 1896, the first police station was established in Siuna cabecera (Rocha 2001) and in 1897, entrepreneur José Aramburó built a steam-powered gold processing mill and founded the La Luz and Los Angeles Mining Company (Jastrzembski 2014). Siuna cabecera and the hamlet of Wany were the first modern settlements in the municipality of Siuna; Rocha (2001) reports 200 inhabitants in Wany as early as 1904. Prior to migrant settlement in Siuna, the Mayagna were the primary inhabitants of the region but were forced out, died of illness (or contamination from mine tailings) or underwent acculturation. Rocha (2001) notes the indigenous Mayagna were perceived to be at the bottom of the social ladder and were forced to work in the mine to repay debts generated from loans for seed, food, housing, tools and services provided by the mine.

In 1904, the La Luz and Los Angeles mine was purchased by an American James Deitrick, who had successfully obtained huge mining concessions for the northeast Atlantic coast from President Zelaya (Gismondi and Mouat 2002). Deitrick's activities brought in Pittsburgh investors with close ties to the political elite in Washington, DC and in 1909 the mining company supported a rebellion against President Zelaya who had implemented policies that were no longer favorable to foreign resource and agro-export industries (Gismondi and Mouat 2002; Jastrzembski 2014). President Zelaya resigned in 1911 but his designated replacement was forced out of office with US pressure and replaced by US-backed Adolfo Díaz, the former secretary of Siuna's gold mine. The US military officially occupied Nicaragua in 1912 - remaining until 1933 - in order to manage rebellions against Díaz, protect interests in export commodities and ensure

Table 5.5 Summary of key historical drivers/events of land-use change in Siuna (1904-34).

\begin{tabular}{|l|l|l|}
\hline Year & Drivers of land-use change & Impact on Bosawas' resources \\
\hline 1904 & Siuna gold mine established & $\begin{array}{l}\text { Employment opportunity pulls settlers into the } \\
\text { region }\end{array}$ \\
\hline $1909-33$ & US military occupies Nicaragua & $\begin{array}{l}\text { Timber and gold extraction benefits foreign } \\
\text { companies, little invested back into local economy }\end{array}$ \\
\hline $1927-34$ & $\begin{array}{l}\text { Augusto Sandino leads revolutionary civil } \\
\text { war against the United States }\end{array}$ & $\begin{array}{l}\text { Conflict driven by US occupation. Impact on land } \\
\text { use unknown }\end{array}$ \\
\hline 1928 & Siuna gold mine is destroyed & $\begin{array}{l}\text { Loss of jobs, switch to subsistence farming, } \\
\text { hunting and fishing }\end{array}$ \\
\hline $1929-34$ & $\begin{array}{l}\text { Great Depression leads to collapse of agro- } \\
\text { export industries and economic recession }\end{array}$ & $\begin{array}{l}\text { Increase in subsistence farming, hunting and } \\
\text { artisan gold mining }\end{array}$ \\
\hline
\end{tabular}


that the proposed interoceanic canal through Nicaragua would not be constructed by any other nation (Jastrzembski 2014). These events were part of the famous region-wide "banana wars" where Western economic interests in agricultural, forest and mineral export commodities in Latin America and the Caribbean largely drove conflicts (Langley 2002).

By 1926, US exports out of the Atlantic from the United States Bluefields consular district (comprising the eastern half of Nicaragua) were valued at USD 3,801,122. Products included: mahogany $(19,801,609$ board feet at USD 1,566,586), Spanish cedar $(4,845,719$ board feet at USD 320,914$)$, bananas $(2,558,805$ bunches at USD $1,565,260)$, gold (21,787 ounces at USD 186,378), coconuts (737,345 at USD 20,537), rubber $(34,264 \mathrm{lb}$ at USD 14,912) and miscellaneous goods at USD 123,535 (American Consulate 1926). The US also dominated import markets into the Atlantic; $85 \%$ of imports to the region in 1926 arrived from the United States (American Consulate 1926). Because Siuna was $300 \mathrm{~km}$ away from the Atlantic Coast, it is unlikely that much of the timber exported from Bluefields would have been sourced in Siuna. Nonetheless, timber harvesting for house construction and mine operations would have begun during this period.

The US occupation of Nicaragua and foreign ownership of Nicaraguan land and resources were primary drivers behind a national guerrilla war and campesino rebellion, famously led by Augusto César Sandino between 1927 and 1933. During this period, conflict and infrastructural damage was a frequent occurrence as Sandino and his supporters strategically dismantled many foreign resource extraction, forestry, agro-export and shipping operations. In 1928, Sandino and his armed supporters wrecked the surface plant of the La Luz and Los Angeles mine in Siuna and a series of raids/clashes occurred afterwards (see Jastrzembski 2014). Sandino viewed the American-owned mine as a symbol of betrayal to the Nicaraguan people and their land. The destruction of the mine reflected the antagonism toward the American presence in Nicaragua (Gismondi and Mouat 2002). The Sandino rebellion continued until 1933, when the US military was forced to withdraw due to the high costs of military operations during the Great Depression.

The Great Depression also caused a decrease in the price of export commodities and a surge in unemployment as export industries collapsed. Given the importance of the export economy (i.e. bananas, coffee and cotton) to peasant livelihoods at the time, the Great Depression is suspected to have been a major driver of deforestation and wildlife depletion as many people turned to subsistence farming, hunting and fishing in order to cope during those difficult years. In Siuna, the jobless mineworkers may have also supported themselves through artisan gold mining, using gold as a currency to trade against food and other goods. Those that turned to farming are likely to have moved into forested areas, but it is difficult to estimate drivers of deforestation without additional evidence. For example, it is unknown whether steamboats continued to import goods from the Atlantic up the Prinzapolka River to Siuna during this time. Table 5.5 summarizes the aforementioned key historical drivers/events of land-use change from 1904 to 1934. 


\subsubsection{Urban and rural growth: A period of prosperity (1935-1968)}

In 1936, Anastasio Somoza Garcia - the head of the National Guard - successfully implemented a military coup, assassinated rebellion leader Sandino and seized presidential power through rigged elections (Walker 2000). This succession marked the beginning of the Somoza family dynasty, which included successive leadership of Anastasio Somoza Garcia's sons Luis Somoza Debayle (1956-63) and Anastasio Somoza Debayle (1967-72 and 1974-79). According to Enriquez (1991) the Somoza family ran the country like their own private estate or "medieval fiefdom" so that by the 1950s, Anastasio Somoza Garcia had become the wealthiest man in Central America. The Somoza family earned their fortune by acquiring businesses and properties in the transportation, dairy, rum and beef industries, holding immense power over various components of the agro-export value chains and markets. Many of the family's properties and businesses were acquired at very low costs and through corrupt and coercive measures (Enriquez 1991). The Somoza dynasty also earned money through voluntary taxes paid directly to them by mining companies, providing impetus for new government support of foreign mining investments (Enriquez 1991).

\subsubsection{The re-invigoration of Siuna's mine}

In 1938, two years after the Somozas' succession of leadership and after a decade of abandon, Pittsburgh- (Tonopah) and Toronto-based (Ventures) mineral extraction companies purchased the Siuna gold mine. Jointly they formed a new company know as La Luz Mine Limited. Canadian mining entrepreneur Thayer Linsley - the father of mining giants Falconbridge Ltd., Ventures Ltd. and Frobisher - was the president of all three companies (Jastrzembski 2014). Investments made by the new ownership resulted in significant profits for the company, a proportion of which was reinvested in Siuna's infrastructure This resulted in Siuna's transformation from a mere mining camp to a corporate mining town (Jastrzembski 2014). La Luz Mine Ltd. was responsible for the construction of a hydroelectric dam in 1942, which brought electricity into the town. The company constructed local roads, which facilitated vehicular transport from the hydroelectric dam to Siuna cabecera, as well as to river ports on the Prinzapolka River and to the town of Rosita, where a second mine was in operation (Jastrzembski 2014). An airport was established, reducing travel time to the region from weeks to hours, dramatically influencing the rate at which goods, personnel and equipment could be imported and exported, and greatly improving the mine's efficiency.

The reinvigoration of the Siuna mine offered new opportunities following the economic hardships of the Great Depression (Crawley 2007). By 1941 the company employed 1073 people (Jaztrzembski 2014). The mine drew in hundreds of Mestizo, Creole and indigenous migrants into Siuna, forming the diverse cultural heritage of the region. Jastrzembski (2014) reports migrants to Siuna in the 1940s had origins in La Cruz, an Atlantic coast town off the Rio Grande River (many of whom were likely to be Miskitu), as well as the western agricultural highlands of Boaco, Chontales, Matagalpa and Nueva Segovia. Migrants typically traveled by trails. According to an archived report from 1933 (US Marine Corps 1933), there was a trail (footpath/mule path) from the Atlantic to the Pacific that started in Puerto Cabezas, passed through San Luis (present location unknown), Pis Pis (Bonanza), Siuna, Wany and Iyás, and then branched off to Jinotega and Matagalpa. 


\subsubsection{World War II, agro-estates and Somoza's agrarian reform}

While Siuna was experiencing new growth and prosperity, Nicaragua's agro-export industries (especially coffee, cotton and bananas) continued to struggle from late 1930 s throughout World War II. Nicaragua's main trading partners during this period included Germany, Britain, the United States and Japan (see Crawley 2007), and as such its export prices and trading partners were dramatically affected by international politics. However by the 1950s, a cotton boom spurred by demand during the Korean War created a resurgence in the agro-export industry and generated wealth outside of the Somoza family. This wealth was primarily obtained by a bourgeoisie capitalist class of cotton producers and not by small- or medium-sized farmers. The national acreage of cotton multiplied fivefold between 1950 and 1955, accounting for 39\% of foreign exchange earnings (Enriquez 1991). The cotton industry expanded by buying out or forcibly evicting small and medium farmers located on lands ideal for cotton cultivation, typically farms previously used for cattle rearing and subsistence production. Evictions were easily facilitated due to the lack of legal land titles held by the smaller farmers (Enriquez 1991). Cotton production was key for making agro-export production the base of Nicaragua's economy. It changed the social structure and had a profound impact on labor and class relations. According to data presented by Enriquez (1991), by 1963, $40 \%$ of land was owned by $1.5 \%$ of the farming families, all of which were $500 \mathrm{mz}$ or greater in size. Conversely, approximately $50 \%$ of farms were less than $10 \mathrm{mz}$ in size, accounting for approximately $3 \%$ of the agricultural land area. Coffee production was similarly important during this time period with the number of acres under coffee cultivation doubling between 1950 and 1963, leading to further expropriation of land (Enriquez 1991).

Sugar, tobacco, bananas, seafood and beef production also expanded in the 1950 s and 1960s. The beef industry had existed since colonial times, exporting tallow, hides and meat abroad. However in the late 1960s, beef production increased substantially, primarily to support national demand as well as beef exports driven by America's fast food industry (Enriquez 1991). Nicaragua's cattle herd grew by 46\% between 1963 and 1971, cattle exports doubled and the area occupied by pastures grew by $31 \%$ during the same period (Enriquez 1991). This expansion of large agro-export farms pushed small and medium farmers off their land, forcing them to establish farms on more marginal terrain, and pushed migrants into frontier forests. These land acquisitions (via negotiations and coercion) displaced farmers throughout the Pacific from the 1930s to the 1960s, widened class divisions and caused growing resentment amongst those impacted (Stanfield 1995).

To ease rural opposition caused by the loss of agricultural land, Somoza promoted settlement in Nicaragua's interior forests. Somoza's agrarian reform provided peasants with free land titles for the first $50 \mathrm{mz}$, allowing additional land to be purchased at very low prices (one informant equated this being equivalent to USD $1 / \mathrm{mz}$ today). As such, many of the original settlers in Siuna have large landholdings. The extent to which the initial settlers who claimed these large properties actually received titles and paid for the land is not entirely clear. For example, Rancho Alegre community members reported that prior to the 1980s, just one person owned the entire community; portions of the land were subsequently sold to incoming settlers. Similarly, an elder from Hormiguero reported that his family and three others purchased portions of land from a farmer who owned more than $2000 \mathrm{mz}$. Nonetheless, the first settlers were a mix of poor peasants with at least 50 $\mathrm{mz}$ and wealthier landowners with $>500 \mathrm{mz}$. 


\subsubsection{Rural resource extraction and farming in study communities}

The first agrarian settlers in Siuna were not alone; people engaged in forest resource extraction enterprises had reached Siuna and many of the research communities by the 1940s. Chicleros (chicle harvesters), uleros (rubber harvesters) and banqueros (timber harvesters) established camps in several of the study communities as well as in other rural communities in Siuna. The earliest record through oral history of their presence was the 1940 s but it is possible that they might have arrived earlier. Timber extraction was reported along the trail from Waslala-Siuna including in Rosa Grande, as well as along the road to Hormiguero and the banks of the Prinzapolka River into Agua Sucia. Mahogany and Spanish cedar were harvested primarily for export to American and European markets led by American companies. Until the 1950s, timber harvesting was entirely by hand axe, which was later upgraded to handsaw in the 1960s. By the 1970s, the chainsaw was introduced. This technological evolution was important in reducing the time required for harvesting and the rate at which forest clearing for agriculture and timber could occur. The species harvested for timber diversified beyond cedar and mahogany as infrastructure and construction projects in Siuna cabecera expanded. An elder in Hormiguero noted that a large amount of wood harvested from the community went to supply the La Luz mining company.

Rosa Grande and Hormiguero were the first of the six study communities that were settled. At the time of settlement, less effort was put into crop production than today, as diets were heavily supported by bushmeat, fish and food provided by commissaries and labor at a resource camp could be traded for food. Those who cultivated crops practiced swidden cultivation, clearing forest for planting basic grains where they would be cultivated for 2 years before moving on to a new plot of forest. Fallows (rastrojo) were used again for cultivation of basic grains after 4 years or were converted into bananas/plantain (musas) fields. Since landholdings were large at the time (at least $50 \mathrm{mz}$ ) only a portion of the farm was used for agriculture, the rest remained as forest. Many wealthier farmers also had cattle but they were mainly used for subsistence dairy production.

\subsubsection{The collapse of the Siuna mine}

After approximately 30 years of growth and prosperity, Siuna's economy slammed to a halt in a matter of days. On 12 August 1968, heavy rains caused the hydroelectric dam on the Yy River supplying the mine to collapse under the weight of the floodwater. The floods damaged multiple villages (none of the six study communities) leaving many homeless (Jastrzembski 2014). Without an affordable source of electricity for water pumps, the mine was flooded and operations ceased. The Siuna mine was abandoned by the company and all equipment was moved to Rosita where the company subsequently focused their operations (Jastrzembski 2014). In the 30 years of production by the La Luz mining company, over 15.42 tons (17 million imperial tons) of ore and 1.8 million ounces of gold were extracted from Siuna (Jastrzembski 2014). The closure of the Siuna mine had a dramatic impact on Siuna's economy with more than half the workers becoming unemployed instantaneously (Jastrzembski 2014). Those who didn't leave Siuna (many left for Rosita), found work through artisan gold mining as gold could still be sold or traded for goods and services (Jastrzembski 2014). Others turned to subsistence farming to support basic dietary needs. Fur trading and timber harvesting may have also provided income sources, but whether the mine's lumber mill continued to operate from 1968 to the 1980 s is unknown. 


\subsubsection{Saslaya's creation}

Three years after Siuna's mine collapsed, Nicaragua's conservation movement began making strides toward creating a national system of protected areas. Nicaragua's second national park, Saslaya National Park, was created by executive decree in September of $1971,{ }^{2}$ encompassing Saslaya mountain and several other adjacent peaks in the mountain range, originally covering a total area of $118 \mathrm{~km}^{2}$. According to Ryan (1978), Saslaya was created due to the pressures from a concerned group of citizens. These citizens likely observed an increase in rural settlement, hunting and timber extraction following the collapse of the mine, and sought to protect it for personal reasons (i.e. hunting/food supply and water sources), as well as environmental ethics.

\subsubsection{Managua earthquake and drought}

A year after Saslaya's creation, Nicaragua suffered a catastrophic earthquake that leveled massive sections of Managua, the nation's capital. Kates et al. (1973) reports that of an estimated 420,000 people in the city, $1 \%$ died, $4 \%$ were injured, $50 \%$ of previously employed became unemployed, $60 \%$ fled the city and $70 \%$ were left temporarily homeless. On a national scale, $10 \%$ of the industrial capacity, $50 \%$ of the commercial property and $70 \%$ of the government facilities were made inoperative (Kates et al. 1973). To make matters worse, the country simultaneously experienced the worse drought in over a century (BBC n.d.) causing massive production losses for agrarian subsistence and export farmers. The droughts coupled with the earthquake triggered another wave of migration toward the countries rainforests, where affordable land and access to water were a major pull factor. A key informant in La Pimienta reported that they had left the western highland community of Dario in the 1970s for Siuna after 3 years of drought, which forced the family to sell their land and move east to the wetter and more fertile forested area.

\subsubsection{Corruption, rebellion, terror and displacement}

The political situation in Nicaragua took a turn for the worse when the president Anastasio Somoza Debayle misappropriated earthquake relief aid by funneling it through family-owned banks, hiring only family-owned construction companies, and prioritizing rebuilding on Somoza family land and property, thereby profiting immensely from the calamity (Montgomery 1980). This corrupt use of funds fueled an already growing public dissatisfaction with the regime. Support for the Sandinista National Liberation Front (FSLN) and the peasant guerrilla army they supported grew. In an effort to repress the opposition, Somoza's National Guard undertook a siege of terror in the north central highlands of the Pacific between 1975 and 1976. Search and destroy missions in rural communities led to the destruction of houses, crops and livestock and various human rights abuses (Enriquez 1991). An estimated $80 \%$ of the rural population in the northwestern countryside was uprooted and displaced during this period, many into temporary refugee camps (Brown 2015) or remote forested areas such as Siuna.

2 Created by Executive Decree \#1789 signed by Somoza and published in Gazette No.78 on 2 April 1971 (Asamblea Nacional de la República de Nicaragua 1971). 
In January 1978, Joaquin Chamorro, the editor of La Prensa newspaper and conservative activist against the military dictatorship, was assassinated. His family claimed Somoza had ordered the killing. Joaquin Chamorro's death catalyzed a massive popular uprising in major urban areas around the country (Zimmerman 2000; Walldorf 2008). The government responded by instating martial law and attacking areas of uprising with aerial bombing and artillery attacks leading to an estimated 5000 deaths (Zimmerman 2000; Walldorf 2008). Social and economic conditions in the country reached desperation, causing 50,000 refugees to flee to Honduras, Costa Rica and El Salvador (Zimmerman 2000). This insurrection must have been one of the most barbaric military attacks against a civilian population in the Americas (Sklar 1988).

\subsubsection{The revolutionary war}

The Nicaraguan mass-based uprising was eventually successful in ousting the Somoza regime on 19 July 1979, ending the 42-year reign (Kallen 2009). The social cost of the revolution was steep with an estimated 50,000 casualties (Nolff 1982), 600,000 homeless (Kallen 2009) 10,000 wounded and 150,000 internal or external refugees (Fitzgerald and Grigsby 2001). The material damage of the war was an estimated USD 481 million, raising external debt to USD 1.65 billion (Nolff 1982).

\subsubsection{Settlement and migration 1970-79}

The years of property loss, drought, poverty and oppression, followed by a revolution and barbaric military campaign were key factors pushing migration into agricultural frontiers during the late 1970s. The Somoza regimes legacy of greed, corruption and military oppression created a dire situation amongst the socially repressed peasant class, which was characterized by low income, illiteracy, malnutrition and high mortality rates (Zalkin 1990; Walker 2000). Much of the rural population was comprised of migrant farmworkers, squatters and sharecroppers living in poor conditions (Walker 2000). The harsh living conditions in rural areas triggered migration to urban areas (Walker 2000), as well as rural-rural migration to the agricultural frontier.

By 1976, the journey to Siuna from the Pacific could be completed by vehicle (bus or truck) as the Somoza Government completed the Matagalpa-Waslala-Siuna highway. This was the first time Siuna had a land-based vehicular connection to the Pacific. Migrants arrived and established farms and large landowners began selling plots to incoming migrants. By the start of the 1980s, settlements were established within all study communities (with the exception of El Inocente), and forest clearing was well underway. Farms and houses located along the new highway were established earlier; property with road access was coveted. The road also provided basic grain producers and cattle ranchers with a means to sell produce, shifting the economic opportunities available in rural communities and founding rural siunas agrarian society. Until improvements in the 1980s, the road was rudimentary; it took 1 week to get to Siuna from Matagalpa (which today is an 8-10 hour drive). Table 5.6 summarizes the aforementioned key historical drivers/events of land-use change from 1935 to 1979. 
Table 5.6 Summary of key historical drivers/events of land-use change in Siuna (1935-79).

\begin{tabular}{|c|c|c|}
\hline Year & Drivers of land-use change & Impact on land-use change \\
\hline 1936 & Somoza dynasty dictatorship begins & \\
\hline 1938 & La Luz Gold Mine purchased & $\begin{array}{l}\text { Surge in migrants pulled by opportunity for } \\
\text { employment }\end{array}$ \\
\hline $1938-44$ & WWII & $\begin{array}{l}\text { High price volatility due to WWII international } \\
\text { politics hurts Nicaraguan farmers and triggers } \\
\text { migration }\end{array}$ \\
\hline $1950-79$ & Somoza dynasty policies & $\begin{array}{l}\text { Land appropriation by Somoza family and } \\
\text { bourgeoisie class for coffee, beef and cotton } \\
\text { pushes poor farmers into agricultural frontier } \\
\text { Land reform policies provide land titles for first } 50 \\
\text { mz pulling settlers in the agricultural frontier }\end{array}$ \\
\hline 1968 & Siuna mine collapses & $\begin{array}{l}\text { Devastates local economy, unemployed turn to } \\
\text { agriculture, artisan gold mining, hunting and } \\
\text { timber extraction }\end{array}$ \\
\hline $1970 \mathrm{~s}$ & Introduction of the chainsaw & $\begin{array}{l}\text { Likely increased rate of timber extraction and rate } \\
\text { of land clearing for agriculture }\end{array}$ \\
\hline 1972 & Earthquake devastates capital of Managua & $\begin{array}{l}\text { Many leave city for rural areas, including } \\
\text { agricultural frontiers }\end{array}$ \\
\hline $1972-75$ & Droughts & $\begin{array}{l}\text { Migrants pushed into agricultural frontier in } \\
\text { search of wetter climate }\end{array}$ \\
\hline $1975-76$ & Seige of terror in Pacific highlands & Migrants pushed to Siuna for safety \\
\hline 1976 & $\begin{array}{l}\text { Matagalpa-Waslala-Siuna Highway made } \\
\text { suitable for motorized vehicles }\end{array}$ & $\begin{array}{l}\text { Migrants pulled by improvement of region for } \\
\text { trade and settlement }\end{array}$ \\
\hline 1977-79 & $\begin{array}{l}\text { Rebellion, conflict and Sandinista } \\
\text { revolution }\end{array}$ & $\begin{array}{l}\text { Thousands displaced and thousands seeking land } \\
\text { and retribution for decades of oppression }\end{array}$ \\
\hline
\end{tabular}

\subsubsection{Agrarian reform and the Contra War (1980-90)}

Following the revolution, an interim government ran the Nicaraguan State - the Junta of National Reconstruction. In 1981, FSLN leader Daniel Ortega assumed power following the resignation of the rest of the Junta. The new leadership immediately undertook actions toward implementing agrarian reform with the intention of reducing class-based inequity and improving the balance between production for export and domestic consumption, and thus improving the standard of living of the rural poor (Enriquez 1997). To do this, a massive campaign of land expropriation from wealthy landowners was undertaken. Approximately 3 million $\mathrm{mz}$ from nearly 6000 properties were confiscated; nearly one third was from the Somoza family and people with close ties to it.

According to Enriquez (1997), land redistribution and complementary policies were implemented in various stages. During 1979-81 the Sandinistas formed State farms (from the large private agro-export enterprises), massively extended the opportunities 
for obtaining agricultural loans and began a limited distribution of land to collectively organized peasants (Enriquez 1997). Following the ratification of the 1981 Agrarian Reform Law, the land distribution process accelerated and land was primarily distributed to collective farming groups. In the mid 1980s, additional forms of land distribution offering benefit to more diverse groups were introduced (Stanfield 1995):

- Cooperativas Agricolas Sandinistas (CAS) - title given to a group of farmers expected to form collective farming enterprises, sharing land, labor, produce and income

- Collectivos de Trabajo (CT) - title given to smaller familial groups of farmers also expected to farm collectively

- Cooperativos de Surco Muerto (CSM) and Cooperativas de Crédito y Servicio (CCS) - group title given to individual farmers who farmed individually

- Individual titles and indigenous titles.

Complementary policies were introduced by the Sandinistas including: guaranteed state prices for crops, state marketing services, bank credit, technical assistance, support for peasant organizations, agricultural research, and social programs for literacy and health care (Zalkin 1990). However as Enriquez (1991, 1997) reveals, these goals were contradictory to the agrarian class structure that had developed between basic grain producers and agro-export industries. Historically, the marginalization of basic grain producers (by Somoza) had required them to work seasonally on agro-export estates (i.e. coffee, cotton and cattle ranches). Because the Sandinistas now provided the basic grain producers with access to credit, seeds, training, education and food rations, many farmers chose not to work on the coffee and cotton export estates as basic needs were met. According to Enriquez (1991), "the increase in food security that resulted from the redistribution of credits undermined the fundamental motivation that had led these workers to the harvest in the past - hunger." This and several other factors led to decreased production of export-crops and significantly inhibited the growth of the agro-industrial sector during the 1980 s.

The acquisition of cooperative land by the Sandinistas also caused numerous problems for middle and poor peasants wishing to hold onto their titles. Because cooperative land needed to be spatially connected, several adjacent farms needed to be acquired if the holding wasn't large enough. A key informant reported how he was jailed for several months after refusing to hand over his land to one of the cooperatives. Another told us how one cooperative took a portion of his father's land and they could do nothing about it. Thus, in addition to the dissent the Sandinistas faced from the wealthier classes who had their land expropriated, less wealthy peasants were unhappy with the acquisition process. Many others were unsatisfied with the distribution process having not received land despite Sandinista promises.

\subsubsection{The counter-revolutionary force: The contras}

A counter-revolutionary force grew rapidly following the Sandinista revolution. Their local resistance efforts were nearly dismantled by the Sandinista military but support from the United States' Reagan administration aided in the regrouping and facilitated links with exiled Somoza National Guards in Honduras. They formed the Nicaragua Democratic Front (FDN), a counterrevolutionary army known as "the contras" (Enriquez 1991). The FDN was armed and supported logistically and financially by the US (i.e. the 
Iran-Contra Affair), whilst the Sandinistas were supported by Communist bloc countries. The formation of the FDN was part of a wider US strategy to overthrow the Sandinista regime, as it was perceived as a threat to American geopolitical interests in Central America in the context of the Cold War. In 1982, civil war broke out again, marking the beginning of the famous Contra War, which lasted until 1990 (Enriquez 1991).

\subsubsection{The Contra War in Siuna: Evacuations and cooperatives}

In order to defend certain rural areas against heavy contra activity, the FSLN decided that rural areas would need to be cleared of the agrarian population. In 1981, peasants throughout Siuna were evacuated from their farms; some left the country, some returned to their areas of origin, some joined the contras and others were integrated into Sandinista agricultural cooperatives. Because of the war, the Sandinista cooperatives were transformed into armed peasant self-defense cooperatives (cooperativas de auto-defensia), a strategic military defense tactic of the Sandinistas. Peasants who tried to remain on their farm were under great risk; being kidnapped by the contras and taken to Honduras was the most commonly reported risk. Arnson and Holiday (1991) provide further details of how the war wreaked havoc on the civilian population as the contras engaged in murder, torture and kidnapping of any civilian presumed to be supporters of the Sandinistas. Brody (1985) reports that the road connecting Siuna and Matagalpa was the scene of many ambushes by the contras on trucks carrying food shipments, health workers and schoolteachers. Additionally, entire communities were invaded and forcibly conscripted into the resistance forces (Phillips 2004).

The FSLN created at least 14 CAS cooperatives, which served as cooperativas de autodefensia in Siuna to which peasants were evacuated, encouraged and coerced to join. We identified historical cooperatives in Hormiguero, Rosa Grande, Las Quebradas, El Ocote, Ully, Floripon, Union-Labu, San Pablo Asa, Wany, Cooperna, Mongallo, Tadazna, Las Delicias and El Torno. A key informant estimated that there were approximately 100 smaller cooperatives (CC, CCS, CSM and CT types) in Siuna as well. The Hormiguero cooperative was the second largest in Siuna (after La $\mathrm{Bu}$ ) holding collective titles for approximately $3500 \mathrm{mz}$ for its 200 family members. They produced basic grains, roots and sugarcane, had $\sim 200$ head of cattle, and reported harvesting timber for the mine, which was again in operation during the 1980 s having been taken over by the Sandinistas - although operations were not very lucrative and continued only until 1984 (Jastrzembski 2014).

The Las Quebradas coop (below La Pimienta) held $1728 \mathrm{mz}$ for 77 families. The Rosa Grande coop was also one of the largest and productive. Rosa Grande community members reported that most deforestation occurred during the 1980 s as the population grew from 15 to 100 households and forest cover decreased from $90 \%$ to $50 \%$. The CAS cooperatives continued their collective farming activities throughout the 1980s, receiving health care, education, seeds, credit and food packages. The government purchased produce from the cooperatives, reportedly paying good prices for it. Conditions in many cases were better in terms of food and livelihood security in cooperatives but many coops were continuously subject to attacks by contra soldiers. By mid 1986, an estimated 
20,000 families and >100,000 individuals had been moved to cooperatives (Zalkin 1990). According to a participant who was part of the Hormiguero cooperative:

Yes. It's to say that when it was the war...we had to...be evacuated. In my case, the San Jose Bocay estate was not sold, it was dumped, we lost it. They evacuated us, left us there [unclear where 'there' is]. Then, the government came up with the idea to save the lives of the country persons, of the producers who used to be in the deep forests, they [the FSLN] took them out so that the opposition wouldn't kill them...Then, they threw us in groups, in settlements like Hormiguero. They handed out programs, gave them land and introduced agricultural programs.

This person raises an important issue for further research relating to post-war land tenure. Many people who were forced to evacuate their land and join cooperatives were unable to reclaim their land (which was outside of the cooperative) following the war. This may have been due to the fact that the Sandinistas adapted the agrarian reform law in 1986 to allow for the confiscation of any size farm that was idol land or for various other reasons such as occupation/confiscation by armed ex-contra soldiers or other landless persons (Stanfield 1995).

\subsubsection{Peasant farmer land seizures}

In addition to evacuations and resettlement led by the FSLN, the mid-1980s was also filled with landless peasants organizing and claiming land by force. Ryan (1995) discusses several instances where peasants decided not to wait for Sandinista land handouts and cooperative titles, and instead seized farms and immediately began planting corn to demonstrate ownership. Many of these seizures resulted in the ex-post legalization of land seizures and the granting of titles to individual peasants. These activities occurred in part due to historical repression and landlessness, war and a mounting economic crisis, which threw the agrarian class into deeper poverty.

\subsubsection{The late 1980 s economic crisis}

The overall cost of the Contra War including physical damage, lost production, displacement of people from war zones and interruption of energy supplies was estimated at USD 2 billion (Leogrande 1996). At the end of the 1980s, Nicaragua's already dire economic situation worsened. In 1986, GDP contracted by $5.9 \%$ and inflation reached $320 \%$ (Leogrande 1996). One year later, it soared to $1300 \%$. In an effort to reduce inflation, public spending was reduced causing a severe recession. By 1988 the economy contracted by $15 \%$ and hyperinflated to $33,600 \%$ rendering the currency worthless and reducing trade to simple bartering (Leogrande 1996; Enriquez 1997). The economic crisis forced those who could farm to try to survive from one year to the next while the value of their harvests decreased and the prices of other goods increased. According to Enriquez (1997) most peasants were unable to farm without $100 \%$ of the costs being assumed by the State through agricultural credit.

The economic crisis was a result of various factors including: problems with the Sandinista development strategy (see Enriquez 1991, 1997), wartime expenditures and economic policies imposed by the US Government during the 1980s. The Reagan administration suspended economic aid to Nicaragua (Leogrande 1996), used its veto power or political influence to block numerous loans to Nicaragua (including from the 
IMF, the World Bank and the Inter-American Development Bank), and pressured other countries not to make bilateral loans (Leogrande 1996). In 1983, the United States reduced Nicaragua's share of the US sugar quota by $90 \%$ and escalated the economic sanctions by imposing a full trade embargo in 1984 (Leogrande 1996). Although the embargo was found one year later to be in violation of international law by the International Court of Justice, ${ }^{3}$ the United States continued the embargo for four more years (Anon. 1989). This embargo had significant impacts on Nicaragua as $30.4 \%$ of its trade in 1980 was with the US. That reduced to $14.9 \%$ in 1984 , forcing Nicaragua to increase trading partnerships with Japan, Western Europe and the Soviet bloc, and to incur higher transport costs to the new markets (Leogrande 1996). The main exports affected were bananas, beef, shellfish, tobacco and sugar (Leogrande 1996). The economic sanctions imposed by the United States had a negative impact on various sectors, especially agro-export production as delivery of imported fertilizer, pesticides, irrigation equipment and industrial machinery parts were delayed (Anon. 1989; Leogrande 1996).

\subsubsection{Resettlement, road construction and Hurricane Joan (1986-89)}

Rancho Alegre study participants reported that people were allowed to return to the community in 1986 due to reduced Contra Activity in the region. A few new migrants

\section{Table 5.7 Summary of key historical drivers/events of land-use change in Siuna (1981-90).}

\begin{tabular}{|c|c|c|}
\hline Year & Drivers of land-use change & Impact on land-use change \\
\hline 1980-90 & $\begin{array}{l}\text { Sandinista agrarian reform - millions of } \\
\text { hectares of land appropriated and redistributed } \\
\text { and State takes ownership of large agro-export } \\
\text { farms and employs millions } \\
\text { Land seizures by peasant groups }\end{array}$ & $\begin{array}{l}\text { Low impact in Siuna at this time but when } \\
\text { land is redistributed (post-1990) back to } \\
\text { original owners, landless migrants move to } \\
\text { agricultural frontier }\end{array}$ \\
\hline $1981-90$ & $\begin{array}{l}\text { Contra War - Wartime evacuations of rural } \\
\text { peasants into agricultural cooperatives }\end{array}$ & $\begin{array}{l}\text { Forest regeneration occurs in scattered areas } \\
\text { where peasants abandoned but deforestation } \\
\text { increases in agricultural cooperatives, which } \\
\text { were highly productive farms producing food } \\
\text { for the state during wartime }\end{array}$ \\
\hline $1985-90$ & $\begin{array}{l}\text { US economic blockades halt foreign aid, prevent } \\
\text { international loans and impose a trade embargo } \\
\text { (breaking international treaty) - hyperinflation, } \\
\text { recession and devaluation of currency }\end{array}$ & $\begin{array}{l}\text { Increases hunting, fishing, artisan gold } \\
\text { mining, timber extraction and subsistence } \\
\text { farming, which continued to have an impact } \\
\text { into the mid to late } 1990 \text { s }\end{array}$ \\
\hline 1986 & People in Siuna begin returning to their farms & $\begin{array}{l}\text { Clearing of regenerated forest (fallow) and } \\
\text { primary forest }\end{array}$ \\
\hline 1987 & $\begin{array}{l}\text { Highway (suitable for motor vehicles) between } \\
\text { Waslala and Siuna completed }\end{array}$ & Surge in migration and settlement \\
\hline 1988 & Hurricane Joan & $\begin{array}{l}\text { Forest degradation, economic loss to crops } \\
\text { increases pressure on wild resources }\end{array}$ \\
\hline
\end{tabular}

3 According to Article 292(7) of the International Court of Justice, 1986: Case Concerning Military and Paramilitary Activities in and against Nicaragua, the court voted in favor of the decision that the United States embargo breached obligations under Article XIX of the 1956 Treaty of Friendship, Commerce and Navigation between the US and Nicaragua. 
also arrived at this time. When people returned to their farms, agricultural fields had turned to fallows outside of cooperative farming communities (i.e. Rancho Alegre and La Pimienta).

This had a positive effect on soil quality and wildlife populations, which had reportedly thrived in the fallow agricultural fields (the rodent population was reported to be much higher when they returned). Just as settlers were returning, in 1987, the Sandinista Government improved the Matagalpa-Waslala-Siuna highway, significantly shortening the journey from a multi-day to a day trip by vehicle. This aided imports and exports of coops along the highway, as well as migrant travel. Hurricane Joan was reported to have caused flooding, landslides, crop and infrastructural damage in 1988 in Siuna, exacerbating already difficult conditions for returning farmers. Table 5.7 summarizes the aforementioned key historical drivers/events of land-use change from 1981 to 1990.

\subsubsection{Demobilization, resettlement and conservation (1990-2000)}

On 25 April 1990 following elections, Violetta Chamorro, head of the National Opposition Union (UNO), unseated FSLN leader Daniel Ortega, bringing an end to the revolutionary government. ${ }^{4}$ One of the first priorities of the new government was the end of the civil war, requiring the demobilization of both the Sandinista and contra armies. In total, there were approximately 100,000 soldiers and military officials $(\sim 22,000$ contras, 72,000 Sandinistas and 5100 members of the Ministry of the Interior) who would become veterans. In addition, Chamorro was also faced with an economic recession. According to Arnson and Holiday (1991) the economy was still in hyperinflation, foreign debt was over 10 billion and unemployment was at 40\%-50\%.

\subsubsection{Disarmament and relief aid}

After negotiations and agreements were signed with contra military officials (see Stedman et al. 2002 for details) on 6 July 1990, approximately 22,000 contras were disarmed. The Chamorro Government offered several incentives in exchange for their disarmament. These included: (1) ensuring the security of disarmed generals and soldiers; (2) provision of humanitarian aid; and (3) the creation of special development poles (polos de desarollo) for the resettlement of the contra military. An International Support and Verification Commission (CIAV), jointly managed by the United Nations and the Organization of American States, was established to manage the phases of assistance to the demobilized, including the distribution of food, clothing, medical assistance, household construction and farming tools and implements, and USD 50 per soldier to 111,481 ex-contra soldiers, their families and other refugees (Stedman et al. 2002).

\subsubsection{Promises of land and development poles}

The contra military was primarily comprised of young, undereducated males $(60 \%$ with no education at all) who were from rural peasant families of Nicaragua's interior and Atlantic coasts including Matagalpa, Jinotega, Chontales, Boaco, Rio San Juan, the RAAN and the South Atlantic Autonomous Region (RAAS) (Abu-Lughod 2000). A survey of

4 See Smith $(1996,356)$ for detailed information on the role of the US Central Intelligence Agency in aiding Chamorro in electoral defeat of the Sandinistas. 
the contra soldiers suggested that $83 \%$ were involved in agriculture or cattle ranching prior to joining the military and intended to return to these activities, $67 \%$ claimed they did not own land and $49 \%$ planned to resettle somewhere different from where they had previously lived (Abu-Lughod 2000). Abu-Lughod (2000) proposes that the choice to resettle elsewhere was due to feared reprisals from Sandinistas in their former communities and lack of economic opportunities due to collapse of the cotton industry. Most contra soldiers wanted access to land in exchange for disarmament; many were told they would receive $50 \mathrm{mz}$ of land. However the failure to specify in any formal documentation a specific plot size, is suspected to have been a political tactic by the incoming government, as more than 1.1 million $\mathrm{mz}$ would have been very difficult to find and distribute (Abu-Lughod 2000). The fact that this promise was never kept caused widespread dissent amongst Contra War veterans.

The development poles are widely regarded as a failed resettlement strategy in Nicaragua as they were hastily planned and inadequately equipped. Of the USD 49 million given by the US Government for demobilization, only USD 3 million was allocated to the contra resettlement (Stedman et al. 2002). Due to inadequate funding, the contra resettlements had poor infrastructure, and were remote and far from veterans' original communities (Abu-Lughod 2000). According to Abu-Lughod (2000), "ex-contras languished in soggy camps, huddling in black plastic huts, as their sense of desperation, hopelessness, demoralization and betrayal consumed them." Key informant interviews revealed there were three development poles within the municipal boundaries of present day Siuna in the communities of La Bu, El Guayabo and Santa Juana. According to a key informant, "these [development poles] were regarded only as development poles by name, because in reality, they weren't provided with the support they needed."

\subsubsection{The land market}

Due to the chaos surrounding the agrarian reform titles, development poles and soldier demobilization, an estimated $25 \%-40 \%$ of Nicaraguan households were involved in conflicts over property rights in the 1990s (Stanfield 1995). Many of those that were not in conflict feared future conflict or validity of their titles and sold their land to incoming migrants. Titles given to agrarian reform beneficiaries or ex-contra soldiers in development poles were also sold because they became too severely indebted, the legal procedures for clearing title were too cumbersome or because neighboring landowners would not allow them to work in peace (Abu-Lughod 2000). With thousands of people seeking and selling land in the span of a few years, the government failed to manage disputes and illegal land acquisitions. Much of the land market in Nicaragua remains outside of the legal oversight of the State today. The majority of new migrants who have arrived in agricultural frontiers in the past decade have paid for their land, buying it from previous landowners or someone who has illegally claimed the land and made 'improvements' to it, simply to profit from the sale of State land.

\subsubsection{Frontier advancement: North of Hormiguero and Saslaya}

Hormiguero is locally known as puerto de montaña (mountain port), which effectively describes its role for the 30 or more Siuna comarcas to the north and west. It is a mountain port because it is an urban center and hub for these $30+$ communities that 
have formed with the progress of the agricultural frontier. The highway terminates in Hormiguero. It is thus the only connection for these communities to the rest of Nicaragua by vehicular transport. Multiple mule paths/footpaths connect remote communities located 1-10 hours from Hormiguero (Agua Sucia typically takes 2-4 hours, whilst El Inocente takes 6-8 hours).

A myriad of factors have pushed migrants north of Hormiguero and west into Saslaya. With a collapsed economy, political turmoil and civil unrest in the early 1990s, many people were driven to become self-sufficient farmers. Study participants throughout Siuna who migrated in the 1990 s identified safety as a major pull factor toward settling in the region. In discussion with migrants in El Inocente, it appears that many who settled in the early 1990s were ex-contra soldiers who were tired of waiting for the government to assist with resettlement. The remote forests were chosen as a place to settle as they offered safety and protection for families and the independence to begin a new life. Moreover, land was affordable, abundant and in some cases 'free'. Migration into the frontier at the beginning of the 1990 s was a means of survival for many. FGD participants revealed that most people arrived at this time from surrounding departments including Waslala, Rio Blanco, Wiwili, Jinotega and Matagalpa.

\subsubsection{Tenure, land acquisition and deforestation economics}

Several forms of land/tenure acquisition and forest clearing were observed within Siuna, demonstrating a suite of agroeconomic actors in Siuna's agricultural frontier. This research revealed important differences between what has driven and what is driving deforestation when viewed from an agroeconomic perspective.

\section{The static settlers}

The first settlers in Siuna owned extensive plots of land, much of which they did not clear. When the next phase of settlers arrived, many acquired subtitles from these settlers, cleared the land within their subplot and constructed a fence to mark the boundaries. Thus, for a while, deforestation mainly occurred on privately held land through the gradual clearing of larger farms. In many cases, the initial purchasing or acquisition of farmland took into account future children and grandchildren's needs, and the families acquired as much land as they could afford. However, there were also plenty of families that were unable to purchase sufficient land to support the third generation. Discussions with these families about how they cope with insufficient land today indicated that it is common for them to adapt their livelihood strategies and uncommon to clear additional forest. Instead, common coping strategies include seeking paid labor, renting farmland or borrowing land from a family member to increase a seasons harvest.

This pattern of land subdivision is similar to what Bilsborrow et al. (2004) observed in the Peruvian Amazon, demonstrating that frontier advancement follows different models based on land acquisition behaviors. This research provides further evidence that shifting cultivation/swidden agriculture should not be presumed as the primary mode/means by which deforestation takes place. In Siuna, further deforestation is not an option in many areas due to respect for Saslaya's boundaries, as well as that the frontier is far from many farms. Instead, alternative agroeconomic strategies are being adopted to cope with insufficient and degrading land for land-poor households. 


\section{The nomadic settlers}

In addition to the settlers that remain in their communities permanently, there are also those who don't permanently settle. Typically, these settlers acquire a smaller plot of land and work it for a few years farming maize and root crops. Because these farmers have made improvements to the land (clearing the land makes it easier to use for the next settler) the land value increases. As such, the farmers can sell the land for a higher price, sometimes allowing them to fetch a larger holding. This allows for incremental holding size increases. In Siuna, we suspect this model has been implemented successfully by many farmers due to the inflation of land prices between 2000-2010. Also as a result of this, land traffickers are widespread such that an illegal market has developed whereby false titles are provided for forested land. Locals and experts on the topic described that land traffickers acquire forested land within Bosawas, clear part of it, construct a fence and then seek out landless and land-poor families in other areas to move to it. Based on local accounts, at least one new family moves into the communities north and west of Hormiguero every day.

\subsubsection{Re-armament and citizen gangs}

The Andres Castro United Front (FUAC) was an armed citizen gang that formed in the 1990s, predominately made up of ex-Sandinista soldiers and their supporters. When the Sandinistas lost power, cooperatives were no longer provided with government benefits including credit, health care, education, agricultural tools and food rations (Staver et al. 2007), causing wide dissent toward the government. Their motivation for taking up arms was primarily the protection of the property they had obtained through the agrarian reform from the ex-contras seeking to invade the land, as well as the previous landowners whose lands had been expropriated. With the downfall of the Sandinistas, thousands of the original landowners made legal claims to recover their land or financial losses, claiming their properties were acquired under duress and under forced agreement, and that they received inadequate compensation for the land and property (Stanfield 1995). To date, Nicaragua has paid at least USD 1.2 billion in compensation for property lost (Rogers 2014).

\section{The Northern Front}

Alongside the FUAC was the rearmament of ex-contra soldiers, known as the re-contras who aligned with another group, the Revolutionary Democratic Alliance to form the Northern Front 3-80 (FN 3-80). Their primary motivations for rearmament were the failed resettlement strategy. According to Staver et al. (2007), at various times between 1992-97 the FN 3-80 took control over parts of Cua-Bocay, Waslala and Wilwili, reducing these areas to vigilante-style order and even taking control of normally State-run development, agriculture and land-titling activities.

\section{State farm conflicts}

Following their confiscation of agro-export estates, the Sandinistas had provided the peasant class with jobs on State farms. The State farms were one of the sources of land used by Chamorro when land was needed for ex-contra soldiers. This led to a loss of jobs for the farmworkers. The problem was exacerbated when the original land and business 
owners wanted restitution for their property. Farmworkers who were typically neutral peasants or Sandinista supporters caused two nationwide strikes in June of 1990 that paralyzed the countries agricultural outputs via occupation of the farms (Abu-Lughod 2000). Abu-Lughod (2000) argues that the linking of land rights to a veterans program rewarded insurgent activity and marginalized nonpartisans as opposed to the civilian majority of poor peasants.

\subsubsection{Bosawas' creation, conflict and lack of consultation}

In Siuna, the post-war uprisings of citizen gangs was also motivated by the creation of the Bosawas Biosphere Reserve, which further contributed to land scarcity. Shortly after the contras were disarmed in November 1991, Violetta Chamorro signed Presidential Decree No. 44-91 declaring an $8000 \mathrm{~km}^{2}$ area of land surrounding Saslaya National Park as a national reserve (Asamblea Nacional de la República de Nicaragua 1991). The text of the decree highlights that the underlying motivation behind Bosawas was to prohibit the advance of the agricultural frontier, urgently required for the conservation of biodiversity. According to Staver et al. (2007) and McNeely (2003) the then Minister of the Environment (Jaime Incer) felt the region would come under pressure from mining, timber companies and agricultural expansion driven especially by resettling soldiers. According to Staver et al. (2007), the incoming Chamorro Government made Bosawas part of a larger Tropical Forest Action Plan for Central America in order to garner support from the international community. Unfortunately, the demarcation of Bosawas' zones placed several communities and Sandinista cooperatives north of the Siuna-Waslala highway inside the Bosawas nuclear zone without any public consultation (i.e. Rosa Grande, Rancho Alegre, Las Quebradas, La Pimienta). Hence, many communities and farms that were well established, including Sandinista cooperatives, were placed inside the biosphere reserve. At this time, little effect of the decree on land-use activities, livelihoods, tenure and development was noted by participants; this was likely due to an absence of a clear management strategy or enforcement measures.

\subsubsection{El Niño fires (1996-98)}

During the dry months of 1996-98, fires raged throughout Nicaragua and elsewhere in Central America, caused by severe El Niño-induced droughts. Siuna had one of the highest densities of fire occurrences of all municipalities in the country in 1998, potentially reflective of the influx of settlers in the region (de Dixmude et al. n.d.). The community of Agua Sucia attributed $30 \%$ of their primary forest loss to these fires and explained that they worked collectively for months trying to save the forests on Saslaya mountain slopes from incineration. La Pimienta also indicated that $35 \%$ of their primary forest loss was due to these fires.

\subsubsection{UNESCO Man and Biosphere Reserve}

Just months after fires wiped out significant amounts of old growth forest surrounding and within Bosawas, and 6 years following Bosawas' creation by presidential decree on 28 October 1997, Bosawas received international recognition and was approved for designation as a UNESCO Man and Biosphere Reserve. The international designation brought in funding to allow for the hiring of a few forests guards (guarda bosques) who then informed communities that they were not allowed to hunt or cut down trees. Most people reported 
1996 and 1997 as the years when they were informed about Bosawas and that there were limits to land and resource use. There was confusion over the boundaries of the reserve in communities south of Saslaya and north of the Waslala-Siuna highway. A ditch with concrete markers was created around Saslaya with funds from GIZ. There was further confusion between the boundaries of Saslaya and Bosawas, especially for communities that were told they were in the new reserve without understanding the difference between Saslaya and Bosawas (La Pimienta and Rancho Alegre).

\subsubsection{Hurricane Mitch (1998)}

On 28 October 1998, a Category 5 hurricane caused catastrophic flooding throughout Central America; $1600 \mathrm{~mm}$ of rain was recorded in Chinandega, Nicaragua (ECLAC 1999). The most severe damage occurred along the Pacific Coast especially in the cities

Table 5.8 Summary of key historical drivers/events of land-use change in Siuna (1991-2000).

\begin{tabular}{|c|c|c|}
\hline Year & Drivers of land-use change & Impact on land-use change \\
\hline $1990-95$ & $\begin{array}{l}\text { Failed resettlement strategy for military } \\
\text { veterans and refugees creates thousands of } \\
\text { impoverished ex-military land claimants } \\
\text { Informal land market booms out of fear of loss } \\
\text { of titles and dissatisfaction with development } \\
\text { poles; further fueled by dissent, lack of } \\
\text { enforcement and financial gain } \\
\text { Bosawas is declared a reserve, enticing further } \\
\text { dissent, lack of respect for protected area } \\
\text { as government failed to adequately consult } \\
\text { communities within reserve prior to creation } \\
\text { Food and livelihood insecurity fueled } \\
\text { the demand for land for people to feed } \\
\text { their families }\end{array}$ & $\begin{array}{l}\text { Thousands of people migrating to the } \\
\text { agricultural frontier; land clearing for the } \\
\text { establishment of new farms explodes }\end{array}$ \\
\hline 1991 & $\begin{array}{l}\text { Bosawas is declared a reserve by presidential } \\
\text { decree, failure to adequately consult existing } \\
\text { settlers and incoming migrants }\end{array}$ & $\begin{array}{l}\text { No discernible impact on contributing to } \\
\text { forest conservation or gain } \\
\text { Entices dissent amongst existing and } \\
\text { incoming settlers, especially landless } \\
\text { soldiers and refugees } \\
\text { Creation of reserve, dissent and lack of } \\
\text { enforcement may have triggered land rush } \\
\text { in defiance of government }\end{array}$ \\
\hline $1996-98$ & $\begin{array}{l}\text { Forest fires caused by series of droughts during } \\
\text { El Niño period }\end{array}$ & $\begin{array}{l}\text { Extensive deforestation, amount requires } \\
\text { further investigation but estimate } \\
10 \%-30 \% \text { of virgin forests in communities } \\
\text { surrounding Saslaya lost due to fires } \\
\text { Cleared land acts as a pull factor drawing in } \\
\text { more settlers }\end{array}$ \\
\hline 1997 & $\begin{array}{l}\text { Bosawas is formally recognized as a biosphere } \\
\text { reserve by UNESCO }\end{array}$ & $\begin{array}{l}\text { Settlement in nuclear zone discouraged but } \\
\text { not well enforced, low impact }\end{array}$ \\
\hline 1998 & Hurricane Mitch & $\begin{array}{l}\text { Damage from forest fires worsened by } \\
\text { hurricane, increased degradation and } \\
\text { forest loss }\end{array}$ \\
\hline
\end{tabular}


of Leon and Chinandega. Housing and farms located on hillsides, riverbanks and lakeshores were heavily affected (ECLAC 1999). An estimated 867,000 were left homeless, 4000 lost their lives, 287 were wounded and 1000 were reported missing (ECLAC 1999). According to Piñon (2001), Hurricane Mitch caused the most dramatic increase in poverty ever recorded in Nicaragua. Despite Mitch's intensity, it had only a modest impact in Siuna relative to other hurricanes. Hurricane Joan (1988), Beta (2005) and Felix (2007) were reported across study communities as the most significant in terms of damage to infrastructure, flooding, tree loss and erosion. Table 5.8 summarizes the aforementioned key historical drivers/events of land-use change from 1991 to 2000.

\subsubsection{Hurricanes Beta and Felix $(2005,2007)$}

The study communities reported damage to infrastructure and farms with both hurricane Beta in 2005 and Felix in 2007. Hurricane Felix was responsible for the destruction of the bridge over the La Bu River in Rosa Grande, slowing transport between Siuna and Waslala.

\subsubsection{Neo-liberalism, migration, projects and protected area management (2001-14)}

\section{Boundaries redefined and management plan (2001-2)}

In 2001, 10 years following Chamorro's presidential decree, Bosawas' boundaries were redefined by Law 407: Ley que Declara y Define la Reserva de la Biosfera Bosawas. Prior to this, Bosawas was around $8000 \mathrm{~km}^{2}$. With Law 407, the boundaries of Bosawas were expanded to approximately $20,000 \mathrm{~km}^{2}$ and a buffer zone and nuclear zone were created. The difference in the latitude and longitude coordinates between the original declaration and Law 407 reveal that the territory of Saslaya National Park was extended north to the limits of the comarca of Sikilta (Mayagna territory), perhaps as a measure to prevent additional colonization. Unfortunately, thousands had already migrated into Saslaya over the past decade and the extension placed several communities in Siuna and San Jose de Bocay within the park. One year later, the first management plan for Bosawas was drafted. It failed to mention how to manage existing settlers within the national park or Bosawas' nuclear zone despite reports that an estimated 242,200 people resided within the reserve limits (including the buffer zone) (MARENA 2003).

\section{Conservation induced displacement (2003)}

The failure to develop a management plan for settlers inside Bosawas/Saslaya, or a suitable strategy for resettlement if evicted, led to unfortunate events in 2003. In May 2003, 117 families (750 people) were evicted from El Inocente and adjacent communities within Saslaya in accordance with the newly established boundaries of Saslaya National Park. The eviction was poorly coordinated and the actions taken appear to have resulted in several human rights violations.

During the eviction, settlers' houses, crops and animals were destroyed or confiscated. The displaced and newly homeless peasants were not provided with any land, housing, money or food provisions to assist with their resettlement and were forced out of the community and into Hormiguero. Only those with strong kinship ties were 
accommodated in Hormiguero; most were forced to squat on others' land and live in rudimentary, temporary housing. According to multiple accounts and documentation of the event (including a formal letter from the community appealing to the government for support), three children died due to malnutrition and hundreds of others suffered from malnutrition and sickness due to poor housing and sanitation. Eventually, due to the humanitarian crisis, the mayor of Siuna instructed the evicted to return to their community. Nearly $100 \%$ of the surviving evicted returned to El Inocente in 2004 and have lived peacefully there without further evictions over the past decade.

\section{Teak expansion}

The private company Norteak began planting teak trees in 2010 and expanding the land area of the plantations by 400 ha per year. By the end of 2015 , the area owned and planted by the plantation was expected to be 2000 ha. Norteak has been gaining land area in Siuna by purchasing and renting farmland. A few small communities surrounding the plantation have since dissolved entirely. Teak planting led to improved tree cover and wildlife habitats as land previously cultivated for pasture and basic grains was typically converted to forestry. However, further research is needed to understand where those people who sold their land migrated to and if this land purchasing was encouraging migration into Bosawas.

\section{Migration}

Hormiguero, Agua Sucia and El Inocente reported greater population increases between 2000 and 2014 than in the decade following the war, 1990-2000. Based on discussions and review of secondary household survey data, a greater number of migrants arrived in these communities in the past decade compared to the previous decade. Thus, whilst there was clear motivation for post-war migration and settlement in the 1990s, the drivers of migration over the past decade appear to be equally if not more important than those pushing and pulling migrants into the region in the 1990s. Based on household survey data collected by the Institute for Development and Democracy (IPADE) ${ }^{5}$ in Agua Sucia, approximately $80 \%$ of those surveyed reported that they had arrived or were born in the community after 2000 .

Based on our key informant interviews and FGDs, the pull factors for migration into Siuna since 2000 have been predominately related to the accessibility to land of adequate size for family farming and the price of land. Land prices in communities without direct road access in 2000 were reported at NIO 500 per $\mathrm{mz}$ (USD 20/0.7 ha). The price doubled in 2005, and increased tenfold between 2005 and 2010 to NIO 10,000 per mz (USD 400/0.7 ha), reflecting the change in demand due to the growing resident population and immigration. In 2014, land prices in Siuna were between NIO 15,000-30,000 per mz (USD 600-1200/mz), although cheaper prices could be found further into the frontier. Properties with road access and improvements (i.e. housing and piped water) typically fetched a higher market value. Due to the recent inflation of land prices, migration into La Pimienta and Rancho Alegre appeared to be slowing down at the time of research. Additionally, because the communities are within Bosawas and the land is on steep terrain, they are less desirable places for settlement.

5 Data collected by IPADE and presented in summary report of March 2012, the title is Comunidad Agua Sucia but only covers data for Sector 1 . Report and data made available by community leaders. 
Table 5.9 Summary of key historical drivers/events of land-use change in Siuna (2001-14).

\begin{tabular}{|c|c|c|}
\hline Year & Drivers of land-use change & Impact on land-use change \\
\hline 2000-2003 & Bosawas and Saslaya boundaries redefined & $\begin{array}{l}\text { Settlers evicted from Saslaya, human rights } \\
\text { issue; low impact on land-use change as settlers } \\
\text { return in } 6 \text { months }\end{array}$ \\
\hline 2005 & Hurricane Beta & Damage to on-farm trees and forest edges \\
\hline $2005-8$ & $\begin{array}{l}\text { Cacao cooperative union formed } \\
\text { Chocolate factory in Rosa Grande built } \\
\text { UNAG provides extension work in } \\
\text { management and nutrition of cattle, } \\
\text { development of pasture, methods of } \\
\text { harvest and technology }\end{array}$ & $\begin{array}{l}\text { Increase in tree cover on farms; farm } \\
\text { sustainability increases farmer economic } \\
\text { return; less likely to sell land and move into new } \\
\text { frontier or require forest resources }\end{array}$ \\
\hline 2007 & Hurricane Felix & Increased forest degradation \\
\hline 2008-13 & $\begin{array}{l}\text { Multiple development projects focused } \\
\text { on improving livestock and basic grain } \\
\text { production } \\
\text { Ecological battalion (military division) } \\
\text { formed improving enforcement, focus } \\
\text { is large forest clearing captured through } \\
\text { satellite } \\
\text { Major projects related to cacao production } \\
\text { facilitated ducts by Catholic Relief Services, } \\
\text { GIZ (project MASRENACE), Bridges to } \\
\text { Community and UNIDO }\end{array}$ & $\begin{array}{l}\text { Increase in farm productivity, decrease in } \\
\text { settlement in the agricultural frontier, increase } \\
\text { in agroforestry } \\
\text { Ecological battalion improves enforcement but } \\
\text { measures are primarily reactionary; no park } \\
\text { offices or patrol stations in rural communities } \\
\text { or along roads into Bosawas } \\
\text { Virgin forest thinning and clearing for cacao } \\
\text { should be carefully monitored; cacao justified } \\
\text { as better farming practice then alternative, } \\
\text { however may lead to further clearing in Saslaya }\end{array}$ \\
\hline
\end{tabular}

There are many push factors behind migration into Siuna and Bosawas over the past decade. Landlessness continued to be a problem; many reported that people were settling in Bosawas simply because it was what was available. Soil and water degradation in other agricultural regions may have also contributed to migration in the past decade. The droughts of 2014 induced by El Niño may have triggered a new wave of land sales and acquisitions. Further research is needed on the role of family size and land subdivisions combined with land degradation in frontier migration. Table 5.9 summarizes the aforementioned key historical drivers/events of land-use change from 2001 to 2014 .

\subsection{Conservation challenges and management issues}

\subsubsection{Community-based conservation}

In communities adjacent to the boundaries of Saslaya (i.e. La Pimienta, Rancho Alegre and Agua Sucia) the management of migrants who sought to settle and clear land beyond the boundaries of the park was discussed during the research. In Rancho Alegre and La Pimienta, there were older communities with settlers that have resided there since Saslaya's creation in 1971; the boundaries of Saslaya were more clearly established and community members worked to maintain them. New migrants who 
tried to settle beyond the boundaries were told to leave by community leaders and by the forest guard who resides in Rancho Alegre. In Agua Sucia, boundaries were less clear and there was some debate as to whether part of the comarca was inside Bosawas. According to the community, they are not and according to the maps, they are. The community leaders of Agua Sucia tried to prevent settlement in the forest and worked to "save the mountain" during the forest fires of 1997-98. Boundaries need to be clearly marked and redefined in this community to prevent further settlement within Saslaya.

Community members reported the dangers they faced with regard to reporting illegal activities to authorities. During fieldwork in 2014, a community member in Parawas (inside Saslaya) reported the clearing of $80 \mathrm{mz}$ of forest to the authorities and the culprit retaliated by murdering the person who made the report. The community leader of Agua Sucia has received death threats for similar actions after reporting forest clearing in Saslaya and in response, he had to move his entire family to Hormiguero where it is safer due to larger size and police presence. In some cases, communities would risk their lives by denouncing illegal activities. There is clearly a need for a permanent police or military presence beyond Hormiguero and into Bosawas. The irregular presence of the authorities only encourages further illegal activities and jeopardizes the safety of communities that are trying to conserve what remains.

\subsubsection{Conservation issues}

\section{Cattle}

The clearing of forest for pasture and cattle ranching is a significant problem within Bosawas; key informants from MARENA estimate there are 20,000 head of cattle within the nuclear zone of the reserve. In an effort to dissuade cattle ranching in the nuclear zone, MARENA implemented a traceability program, which would provide certification to beef for local and international markets if it was from a farm outside of the Bosawas' nuclear zone. A major challenge to the program was cattle ranchers whose land was in the buffer zone but who rented pasture from people in the nuclear zone. There appears to be no system of tracking this.

The animals were not exclusively raised for beef; thousands of animals were produced for the dairy industry, which has grown substantially both for local consumption and international exports. The majority of farmers in the study area were or aspired to be mixed-crop dairy producers. This farming strategy is culturally preferred and has also been widely promoted by development agencies and government programs due to its benefits for livelihoods and food security. Raising a few dairy cows provides families with milk and cheese (quajada) - a source of micronutrients (such as calcium) that might otherwise be deficient in local diets - and helps with seasonal hunger gaps. The milk can also be sold, providing the family with an income beyond seasonal harvest earnings. In short, the traceability program will not assist small farmers with production of dairy cows in Bosawas' nuclear zone but will help to regulate medium-large ranchers engaged in beef exports.

\section{Land titles}

Access to land titles in Siuna was first gained through Somoza agrarian reform titling and beneficiaries of the Sandinista agrarian reform titling. New land titles have been given since the 1990s for land purchased through the formal market as well as the informal 
market, the latter typically being for land acquisitions within Bosawas. A major problem in the region was the lack of documentation and official registry of land titles. Some landowners held the original deed to the land if issued during Somozas time (which typically lists the name of a relative or a previous owner). In many cases, these old documents have been lost, destroyed and even confiscated. Others had Sandinista agrarian reform titles if they had managed to retain their land. Many people, possibly the majority, only held informal tenure documents that were issued by a lawyer but not officially recorded in the public registry (escrituras). Others had no formal documentation. Since the 1990s, land sales had been taking place based on less-than-adequate title documents. One reason for the lack of formal titling of land in the buffer zone was the high costs (of time and money) required to register land. At the time of research, people from Siuna had to travel to Puerto Cabezas, which took 8 hours by bus, and stay overnight in a hotel to have their land registered; this was too great a burden for many poor and already indebted farmers. Broegaard (2005) identifies similar problems elsewhere in Nicaragua.

Research revealed that there were numerous people within the nuclear zone of Bosawas who obtained legal titles to land within the nuclear zone of Bosawas through the Somoza and Sandinista agrarian reforms. It is not clear whether these titles are recognized or not by the current government. How the government perceives people living within the nuclear zone and their rights to use and manage land as their own private property (i.e. relative to others without legal title), is yet to be determined. Based on discussions, it seems that permits were more easily issued to Sandinista agrarian reform beneficiaries (the current government since 2008 is the FSLN). It was reported that those with Somoza agrarian reform titles had difficulty obtaining permits from MARENA. Favoritism and power dynamics between the State and peasants was troublesome and appeared to be creating dissent that could potentially result in displays of defiance (i.e. cutting trees and setting fires).

\section{Policy of no incentives and no permissions}

Through discussions with communities and government officials, it became apparent that MARENA was implementing a policy of no incentives for communities within the nuclear zone of Bosawas in Siuna. For decades, development projects related to health, sanitation, infrastructure and agriculture have occurred in communities along the Waslala-Siuna highway, including in communities within the Bosawas nuclear zone (most notably, Project Campesino a Campesino). However, in the 2 years prior to this research, MARENA had been trying to dissuade government and international projects from assisting communities inside the nuclear zone, under the assumption that if people were not being assisted, they would leave.

\section{Cacao}

MARENA's no-incentive policy included cacao agroforestry projects although many of the communities in the nuclear zone of Bosawas on the Waslala-Siuna highway had well established cooperatives and mature cacao agroforests, notably Rancho Alegre, Rosa Grande and El Balsamo. El Guayabo, a 1.5-hour drive west of Rosa Grande had the largest number of cacao producers in Siuna and the largest cooperative, as well as many farmers within the nuclear zone of Bosawas. Organizations helping with improving the 
production of cacao amongst existing producers were clearly frustrated at being told they could not work with these communities. It is ironic that the current Sandinista-aligned government, through MARENA, was implementing a policy that was having a negative effect on the cooperatives they had created two decades prior to that.

Despite a lack of development assistance for communities inside Saslaya, communities reported that they have continued to improve their agricultural practices through farmer-farmer learning and exchange. Everyone travels to Hormiguero for goods, services and the sale of produce, and to learn new agricultural extension information. At least 20 farmers in El Inocente began planting cacao on their farms, in spite of a distinct lack of assistance and having been evicted 10 years prior. In discussion with them about their choices for planting cacao, their motivations were primarily financial as it provided a consistent source of income. They reported that cacao would show that they were using "good practices," which they could use to support their land claims if ever faced with another forced eviction. These farmers had little knowledge about genetic quality, pest and disease management, shade trees or soil health relative to those in Rancho Alegre or Rosa Grande. By inhibiting extension work in the region, cacao has a high risk of failure due to low productivity and disease risks, which would result in the destruction of cacao trees and reversion of agroforests to basic grains or pasture.

\section{Timber permits}

Communities in the nuclear zone are required to apply for permits for the use of live standing or dead fallen wood on their properties. No wood is allowed to be sold outside of the community but can be used by residents for home and farm improvements. Residents of Rancho Alegre complained of waiting 6 months to receive permission for using a tree on their own property for basic home improvements. They were frustrated as they have resided in the community for decades and most landowners have planted and protected trees on their farms. One farmer commented: "I've planted $10 \mathrm{mz}$ of agroforest and I've waited 6 months to use one tree to fix my kitchen."

\section{Fire permits}

Fire is commonly used for the preparation of agricultural fields and was permitted on a small scale until 2012. In the 2014 planting season, communities were told they would not receive permits for fire and firefighting equipment was not distributed. This approach was not effective as many farmers continued to use fire due to a lack of alternatives. By not providing equipment for firefighting, forests were put at additional risk especially as it was a very dry year due to El Niño. At the time of research, those who used fire risked being fined. However, fines were not consistent and appeared to be related to power gained through kinship ties with authorities (i.e. government and police).

\subsection{Food security and nutrition issues}

\subsubsection{Historical dietary changes}

The composition of diets within the communities surrounding Saslaya Park in Siuna have evolved over the past 70 years as the landscape has transformed from a forested settlement 
frontier to an agricultural mosaic. It appears that until the late 1960s, the majority of the first settlers arriving in the study region spent little time farming. Labor for food was better and time was spent hunting and working for the timber, rubber or chicle (gum) industries, as well as in artisan gold mining and selling animal skins. Basic foodstuffs (i.e. sugar, oil, powdered milk, sardines, basic grains, canned foods, bananas and other staples) could be purchased/traded for labor at the commissaries that were owned by resource extraction agencies. According to archives from the American Consulate (1926) a significant amount of staple foods such as corn, rice, beans and sugar were imported (via the Prinzapolka River) as early as the 1920s.

Basic grain and staples were complemented with bushmeat and fish; the abundance of both in 1940-80 was noted by all study communities. Discussions about wildlife consumption were lively, with men recalling hunting stories and women recalling participating in meal preparation and recounting their fathers' stories. The words of an elderly man in his 90 s in Hormiguero who worked as a rubber tapper in the 1950s, reflect the prior role of hunting. When asked how often he consumed wild game, he replied, "That was my life," and likened his old age to the high frequency of meat consumption in earlier years. All communities reported historical consumption of wildlife; the most commonly reported terrestrial wildlife that were hunted for bushmeat are listed in Table 5.10.

At the end of the 1960s, with the collapse of the gold mine and access to large land titles in Siuna through Somozas agrarian reform, more farmers settled in the study area, typically occupying at least $50 \mathrm{mz}$. The first agriculturalists produced enough to support their families and sold/traded what they could. It was a multi-day trip

\section{Table 5.10 Wildlife historically consumed on a regular basis in Siuna, Nicaragua.}

\begin{tabular}{|l|l|l|}
\hline Local name & English name & Latin name \\
\hline Chancho de monte & White-lipped peccary & Tayassu pecari \\
\hline Cusuco & Armadillo & Dasypus novemcinctus \\
\hline Danto & Tapir & Tapirus bairdii \\
\hline Gallina de monte & Great tinamou & Tinamous major and others \\
\hline Guardiolla & Agouti & Agouti paca \\
\hline Guatuza & Central American agouti & Dasyprocta punctata \\
\hline Pava & $\begin{array}{l}\text { Crested guan } \\
\text { Highland guan }\end{array}$ & $\begin{array}{l}\text { Penelope purpurascens } \\
\text { Penelopina nigra }\end{array}$ \\
\hline Pavón & Great curassow & Crax rubra \\
\hline Pisote & Coati & Nasua narica \\
\hline Saino & Collard peccary & Tayassu tajacu \\
\hline Venado & Red brocket deer & White-tailed deer \\
\hline
\end{tabular}


into Siuna cabecera from the study communities until the mid 1970s when the Matagalpa-Waslala-Siuna highway was built, but the trip was usually necessary to pick up supplies. Until the 1980s, diets were still supported by bushmeat although game became harder to find as the animals were also hunted for pelts, which fetched a high price in Siuna's markets. These pelts were typically taken down the Prinzapolka and put on ships to be sold to European and North American markets, reportedly often by Chinese merchants. Once the highway was constructed, trucks and buses passed through rural areas along the Waslala-Siuna highway. These vehicles brought new goods into the region and were essential in the operation of private pulperias (general stores/commissaries), which found it easier to improve their stock of basic foodstuffs. Rural agriculturalists produced predominately for subsistence but with the opening of the road, basic grains could be sold and transported to Siuna and Pacific markets.

During the 1980s, everything changed, and those who remained in Siuna were relocated into cooperatives where food production was carried out collectively and production was complemented by food aid packages. Hunting was reduced significantly during the war due to the danger of being killed by contra forces, but some of the braver cooperative members, typically those with military training, would go hunting on occasion. Traps were set around the cooperative. Ex-members of the Hormiguero cooperative did not identify hunger, food security and malnutrition as being problems during the war. The cooperative was very productive, even producing excess produce that was sold to the Sandinista Government.

Immediately following resettlement in the late 1980s, food and financial insecurity was a major problem for most. Farming became an immediate necessity and a way of coping with the economic downturn. Timber harvesting, hunting and fishing were also used as coping mechanisms for food insecurity. Community leaders in Rosa Grande recalled people using ichthyotoxin s $^{6}$ to fish on the La $\mathrm{Bu}$ and Wany rivers during this time. The 1990s were a productive time as newly cleared forested land was nutrient rich as were the fallows that had developed during the war. Increased migration brought increased forest clearing in the late 1990s. In 1997 forest clearing was exacerbated by wildfires that spread due to a prolonged drought. According to study communities, the fires marked a turning point in rural diets as wildlife and fish populations were significantly diminished (due to both overharvesting and loss of habitat). Also, the El Niño fires and turn of the millennium marked an important shift from diets being partially agrarian and partially wild to being fully agrarian.

\subsubsection{Diet, food production and food access today}

\section{Basic grains and staples}

The average rural diet in study communities surrounding Saslaya today consists predominately of basic grains (rice, beans and maize), staple root crops including yuca (Manihot esculenta), quiquisque (Xanthosoma sp.), malanga (Xanthosoma sp.) and musas. A farmer from La Pimienta gave the following description of the rural diet: 
Look, I will be honest, at the least we produce corn, which is for personal consumption; sometimes we sell the corn to sustain the family, we always have yuca and malanga as well. And, we always have rice and beans. Sometimes we are rummaging around for food. For example, today we eat tortillas, tomorrow we eat yuca, later in the day or at dinner we eat malanga. There are plantain and banana as well, and if you are too busy to cook tortillas, you put your boots on and you cut a banana and you eat.

\section{Meat and dairy}

The frequency of consumption of meat and dairy was identified as a problem. Most people in the study communities reported they did not feel they consumed adequate amounts of meat and dairy, especially the poorest. Poultry and eggs were the most commonly consumed. Based on wealth ranking exercises, in Agua Sucia, the wealthiest community members ate chicken or eggs four times a week but only consumed beef or pork once or twice a year on special occasions. Wealthier members of Rosa Grande and Hormiguero consumed beef and pork more frequently, as both communities had pulperias that sold frozen meat and had several medium-income cattle ranchers and middle-class residents with government jobs and private businesses (due to their location on the road).

There was a significant difference in the nutritional quality of the diets of families who owned at least one cow relative to families that had none. Regular consumption of milk can improve dietary quality and additional food can be purchased through the sale/trade of milk, especially important during seasonal hunger gaps.

\section{Vegetables}

The only vegetables produced on farms in Siuna were chayote (Sechium edule) and ayote (squashes), as well as culantro (Eryngium foetidum) a leafy green vegetable used for seasoning and marinating food. All of these were fairly common but were produced in small quantities, typically in patio gardens around the home. The other vegetables that were consumed included onions, tomatoes and cabbage that were typically imported from elsewhere in the country and purchased at pulperias. We were unable to identify any successful growers of these vegetables in Siuna. In discussions about why farmers weren't producing these crops, most claimed they had tried but the vegetables were always getting plaques (plant diseases and pests). Those communities without road access had less access to imported vegetables, thus dietary diversity was partially a function of distance to road. In communities off the road some informants reported that they only ate imported vegetables when they cooked meat. Rosa Grande and Hormiugero had the highest diversity of vegetables available in its pulperias due to their locations on the Matagalpa-Waslala-Siuna highway (Figure 5.5). Little to no produce was available in pulperias in remote communities. The high consumption of legumes (bean) and fruits may help to minimize the nutritional impact of low vegetable consumption. In adequate quantities, legumes and fruit can provide fiber, folic acid, vitamin $\mathrm{C}$ and many of the other micronutrients that would otherwise be provided by vegetables.

\section{Fruits}

A large range of fruit tree species was present in the study landscape but farm diversity and the quality of fruits produced was highly variable. Only older farms that had planted fruit trees reported on-farm access to fruit and it was not common for people to purchase 
Table 5.11 Fruits grown on Siuna farms (indigenous and imported).

\begin{tabular}{|l|l|l|}
\hline Local name & English (plant form) & Latin and plant form/description \\
\hline Sapote & Sapote & Multiple species (Pouteria sapota most common) \\
\hline Annona/Guanabana & Sour sop & Annona muricata \\
\hline Calala/maracuya & Passion fruit & Passiflora foetida \\
\hline Castana & Breadnut & Artocarpus camansi \\
\hline Cherimoya & Cherimoya & Annona cherimoya \\
\hline Fruta de pan & Breadfruit & Artocarpus altilis \\
\hline Granadilla & Pomegranate & Punica granatum \\
\hline Guaba & Ice cream bean & Inga spp. (4+ types) \\
\hline Guayaba & Guava & Psidium guajava \\
\hline Jocote & Jocote & Spondias purpurea \\
\hline Melocoton/Carambola & Starfruit & Averrhoa carambola \\
\hline Nancite & & Byrsonima crassifolia \\
\hline Nispero & Loquat & Eriobotrya japonica \\
\hline Noni & Noni & Morinda citrifolla \\
\hline Ohoche & Fig & Brosimum alicastrum \\
\hline Papaya & Papaya & Carica papaya \\
\hline Pejibaye & Peach palm & Bactris gasipeas \\
\hline Pera de agua & Pera de malaca & Syzygium malaccense \\
\hline Pina & Waneapple & Ananas comosus \\
\hline Sandilla & Citrullus lanatus \\
\hline
\end{tabular}

fruit. There was a potential nutrition gap amongst new settlers arriving on to land without fruit trees. The most commonly consumed and planted fruits were citrus species (lime, lemon, grapefruit, orange), avocados and mangoes. The varietal diversity of these tended to be low, which is probably due to the remote location of Siuna from ports (for transport of new genetic materials), past political turmoil and the recent settlement history. Although less common, many other fruit species (Table 5.11) were found on farms, adding to the agrobiodiversity and dietary diversity of rural families.

Sapote (Pouteria spp.), makenque palm (Euterpe precatoria), peach palm (Bactris gasipaes), ohoche (Brosimum alicastrum), nancite (Byrsonima crassifolia) and aguacate montero (Ocotea paulli) are all native species to the region that have been allowed to naturally regenerate on farms. Sapote, peach palm and nancite were the most common and were sold in rural and urban markets. People reported that trips to the forest were not made specifically to collect wild fruits. The earliest settlers reported that when they first arrived and were surrounded by forest it was more common to go collecting fruit. 
All fruit trees are privately owned. However, because of kinship land subdivisions, fruit is often shared amongst the larger kinship unit. People reported that children are taught at a young age not to take fruit or climb the fruit trees of their neighbors without permission. Despite this, walking through these communities we often met children who were climbing trees and eating fruit. We observed many children eating the seeds of Guaba (Inga spp.) between May and June on walks between Hormiguero and El Inocente (8 hours).

\section{Seasonal food shortages}

In Siuna and elsewhere in Nicaragua (see Bacon et al. 2014) between the months of June and August and sometimes into September, there is a seasonal food shortage before the harvest, requiring families to depend on stored rations of basic grains. We asked all community members about how farmers cope (in addition to storing basic grains) with financial and food supply needs during this period, particularly if there are shocks (i.e. low productivity). Several coping mechanisms were identified including: temporary employment, credit, and reliance on alterative staple crops such as plantains and tubers.

The most common coping strategy reported was to seek employment. In Siuna, it was common for people to find employment on cattle ranches clearing pasture. Fortunately, the hunger season coincided with seasonal employment on cattle ranches; the start of the heavy rains causes growth in herbaceous vegetation. Many people in the study communities found employment clearing pasture in $\mathrm{La} \mathrm{Bu}$, a community between Rosa Grande and Siuna cabezcera (Figure 5.5). At the time of research, many others at Norteak teak plantation reported to employ 200-400 seasonal workers (June-August) and 250-350 fulltime employees. The Rosita gold mine also attracted many young men as one day of labor in the mine earned them twice the amount of a day of labor on farms. Others were reported to travel to the coffee regions of Matagalpa and Jinotega for coffee harvests in December-March but this supplementary income must be saved for the difficult months. Others found work in Costa Rica on agro-export farms, whilst women often found work in Siuna town as cooks or housemaids. Increasingly, people were reported to find work on cacao farms in the region but farm managers tended to prefer people who had completed some training at URACAAN in agroforestry. Credit was identified as a coping mechanism but was not as common as labor as it was difficult to acquire. Many people reported that the local pulperias provided loans but would only do so if a good relationship was established. If the farmer could not pay back the loan, they would have to provide labor in exchange for lack of repayment.

Diets were reported to shift dramatically between June and August to be largely composed of root crops, bananas and plantains. Informants reported that most people could purchase only a few items due to a lack of cash flow. The establishment of cacao forests with musas appears to have increased the amount of on-farm food available during this season. As the cacao trees mature and produce fruit (after 3 years) they provide a biweekly income source to producers that helps with the purchase of food during difficult months. Most cacao farmers interviewed reported positive dietary changes associated with cacao production, although many mentioned that they had too many bananas (musas). 


\subsection{Conclusions}

Both historical events that occur over a few days or those that occur over several years can have lasting impacts on the way landscapes and societies evolve. The deforestation of Bosawas within Siuna is a result of historical events including conflict, policy change, economic conditions, dictatorships, natural disasters, droughts and wildfires. Possibly most significant are the drivers of migration. For example, this research has shown the role of multiple drivers of migration to Siuna including: the collapse of agro-exports and mineral extraction industry on human migration; forced evictions and land acquisitions of the Somoza Dynasty that created a class of land-poor peasants dependent on plantation labor; the Managua earthquake; the Sandinista agrarian reform land acquisitions; and the displacements of the Contra War. These events caused migration to Siuna from across Nicaragua as peasants sought new affordable or free land so that they could survive. The continued migration of people into the non-indigenous and indigenous areas of Bosawas has been and will continue to be the major driver of deforestation. Focusing development funds and management attention toward agricultural solutions when faced with human migration problems will not stop deforestation.

We also view deforestation in protected areas as a result of failed protected area management. Given that UNESCO Man and Biosphere Reserves are intended to be learning sites for sustainable development, we must also learn from the mistakes that are made in conservation planning. The following list summarizes how deforestation has not been prevented via the management of Bosawas:

- Creating Bosawas in 1991 by Presidential Decree was a top-down process by a new government that wasn't necessarily respected by the campesino class or the communities that were placed in the reserve. Bosawas already had a significant human population and deforested land the day it was created.

- The creation of Bosawas in 1990 coincided with economic recession, a land ownership crisis and thousands of people needing to be resettled.

- The lack of funds and adequate long-term plans for development poles and soldier resettlement pushed people to take matters into their own hands by settling and cultivating land.

- Failing to prepare a management plan until 2002 and failure to create any plans in consultation with existing settlers has resulted in rules that are arbitrarily enforced and not respected by community members.

- Expanding Saslaya National Park secretively using Law 407 and then evicting settlers in 2003 without a resettlement plan was a failure and a potential human rights violation.

- The logic behind the no-incentives and no-permissions policy currently being enforced assumes that if people aren't helped or their lives become difficult, they will leave. However, this may actually have the opposite effect, as communities that are not involved in conservation measures or supported by the government will not work to protect the forest that remains, both out of dissent and lack of better alternatives.

Improved management of Bosawas will only be achieved by recognizing the communities residing within it and working with them to manage the settlement of new migrants and the outmigration of existing migrants. 


\section{Acknowledgments}

This research was conducted by researchers from the Faculty of Forestry at the University of British Columbia. PhD student Lisa Hansen, guided by her supervisors Dr. John Innes, Dr. Janette Bulkan and Dr. Bronwen Powell, was responsible for the fieldwork, secondary data collection, literature review and report writing. We are grateful to our University of British Columbia colleagues Dr. Sarah Gergel and Ian Eddy for their support in the spatial analysis.

We would like to thank the communities of El Carao, La Pimienta, Rosa Grande, El Inocente, Hormiguero, Las Quebradas and Rancho Alegre for allowing us to undertake this research, sharing their stories and helping us in every way that they could. We are grateful to Oscar Montalvan for his work as a field guide, mentor and community liaison; his assistance was key to making this work happen. The staff at the following organizations in Siuna provided valuable assistance and information for this research: URACAAN, Catholic Relief Services, GIZ, UNAG, Bridges to Communities, MAGFOR, MARENA and IPADE. We would like to thank the field assistants/translators Marco Zolly and Mauricio Pena and transcriptionists Karla Lara and Jennifer Temmer for their help. We would also like to thank Heirbert and the Siu family and staff of Hotel Siu for their kindness, friendship and support. 


\section{References}

Abu-Lughod DI. 2000. Failed buyout: Land rights for contra veterans in postwar Nicaragua. Latin American Perspectives 27:32-62.

Aide TM, Clark ML, Grau HR, López-Carr D, Levy MA, Redo D, Bonilla-Moheno M, Riner G, Andrade-Núñez MJ and Muñiz M. 2013. Deforestation and Reforestation of Latin America and the Caribbean (2001-2010). Biotropica 45:262-71.

American Consulate. 1926. General Information Sheet: Bluefields Consular District. United States Consulate, Bluefields, Nicaragua. Accessed 10 February 2014. http://www. sandinorebellion.com/omePages/eastcoast.html

Anon. 1989. US policy, economic embargo: The war goes on. Envio 98. Accessed 15 March 2014. http://www.envio.org.ni/articulo/2695

Asamblea Nacional de la República de Nicaragua. 1971. Declárase Parque Nacional Saslaya los Macizos Montañosos de los Cerros de Saslaya y el; Decreto No. 1789 de 17 de 24 de marzo de 1971. Publicado en La Gaceta No. 78. http://legislacion.asamblea.gob.ni/normaweb.nsf/3133C od121ea3897062568a1005eof89/2ca1a52755826060062570a10057841d?OpenDocument

Asamblea Nacional de la República de Nicaragua. 1991. Declaracion de la Reserva Nacional de Recursos Naturales "Bosawas"; Decreto No. 44-91 del I de octubre de 1991. Publicado en La Gaceta No. 208. http://legislacion.asamblea.gob.ni/normaweb.nsf/\%28\$\%20All\%29/C147 6414BC61074C062570A10057D915?OpenDocument

Arnson C and Holiday D. 1991. Fitful Peace: Human Rights and Reconciliation in Nicaragua under the Chamorro Government. July 1991. Human Rights Watch: New York.

Bacon CM, Sundstrom WA, Flores Gómez ME, Ernesto Méndez V, Santos R, Goldoftas B and Dougherty I. 2014. Explaining the "hungry farmer paradox": Smallholders and fair trade cooperatives navigate seasonality and change in Nicaragua's corn and coffee markets. Global Environmental Change 25:133-49.

$[\mathrm{BBC}]$ British Broadcasting Cooperation. n.d. 1972: Earthquake wreaks devastation in Nicaragua. On this day: 23 December. Accessed 10 March 2015. http://news.bbc.co.uk/ onthisday/hi/dates/stories/december/23/newsid_2540000/2540045.stm

Bilsborrow RE, Barbieri AF and Pan W. 2004. Changes in population and land use over time in the Ecuadorian Amazon. Acta Amazonica 34:635-47.

Brody R. 1985. Contra Terror in Nicaragua: Report of a Fact-finding Mission, September 1984-January 1985. Cambridge, MA: South End Press.

Broegaard RJ. 2005. Land tenure insecurity and inequality in Nicaragua. Development and Change 36:845-64.

Brown S. 2015. Faces of Power: Constancy and Change in United States Foreign Policy from Truman to Obama. 3rd ed. New York: Columbia University Press. 315-18.

Canty MJ and Nielsen A. 2006. Visualization and unsupervised classification of changes in multispectral satellite imagery. International Journal of Remote Sensing 27:3961-75.

Carr D. 2009. Population and deforestation: Why rural migration matters. Progress in Human Geography 33:355-78.

Comisión Nicaragüense de Cooperación con la UNESCO. 2011. Reserva de Biosfera Nicaragua: Manual Informativo. Comisión Nicaragüense de Cooperación con la UNESCO: Managua, Nicaragua. 
Crawley A. 2007. Somoza and Roosevelt: Good Neighbour Diplomacy in Nicaragua, 1933-1945. Oxford Historical Monographs. Oxford: Oxford University Press.

de Dixmude AJ, Navarro P, Flasse S, Downey I, Sear C, Williams J, Ceccato P, Alvarez $\mathrm{R}$, Uriarte F, Zuniga Z, et al. n.d. The use of low spatial resolution remote sensing for fire monitoring in Nicaragua: A survey of three successive burning seasons. Accessed 15 April 2015. http://www.fire.uni-freiburg.de/other_rep/research/ni/ni_re_1.htm

[ECLAC] Economic Commission for Latin America and the Caribbean. 1999. Nicaragua: Assessment of the damage caused by Hurricane Mitch, 1998. LC/MEX/L.372. 19 April 1999.

Enriquez LJ. 1997. Agrarian Reform and Class Consciousness in Nicaragua. Gainsville: University Press of Florida.

Enriquez LJ. 1991. Harvesting Change: Labor and Agrarian Reform in Nicaragua 1979-1990. Chapel Hill, NC: University of North Carolina Press.

Fitzgerald V and Grigsby A. 2001. Nicaragua: The political economy of social reform and armed conflict. In Stewart F and Fitzgerald V, eds. War and Underdevelopment: Country Experiences. Oxford: Oxford University Press. 119-54.

Geist HJ and Lambin E. 2002. Proximate causes and underlying driving forces of tropical deforestation. BioScience 52:143-50.

Gibbs HK, Ruesch AS, Achard F, Clayton MK, Holmgren P, Ramankutty N and Foley JA. 2010. Tropical forests were the primary sources of new agricultural land in the $1980 \mathrm{~s}$ and 1990s. Proceedings of the National Academy of Sciences 107(38):16732-37

Gismondi M and Mouat J. 2002. Merchants, mining and concessions on Nicaragua's Mosquito Coast: Reassessing the American presence, 1895-1912. Journal of Latin American Studies 34:845-79.

Hansen MC, Potapov PV, Moore R, Hancher M, Turubanova SA, Tyukavina A, Thau D, Stehman SV, Goetz SJ, Loveland TR, et al. 2013. High-resolution global maps of 21stcentury forest cover change. Science 342:850-53.

Hayes TM. 2007. Does tenure matter? A comparative analysis of agricultural expansion in the Mosquitia Forest Corridor. Human Ecology 35:733-47.

Hayes TM and Murtinho F. 2008. Are indigenous forest reserves sustainable? An analysis of present and future land-use trends in Bosawas, Nicaragua. International Journal of Sustainable Development and World Ecology 15:497-511.

Healey S, Cohen W, Zhiqiang Y and Krankina O. 2005. Comparison of tasseled capbased Landsat data structures for use in forest disturbance detection. Remote Sensing and Environment 97:301-10.

[IEG] Independent Evaluation Group. 2011. The Mesoamerican Biological Corridor. Regional Program Review Vol. 5, Issue 2.

[INIDE] Instituto Nacional de Información de Desarrollo. 2008. Siuna en Cifras. Nicaragua Gobierno de Reconciliación y Unidad Nacional. March 2008, Managua.

Instituto Nacional de Información de Desarrollo. n.d. Cifras Municipales; Nicaragua. Instituto Nacional de Información de Desarrollo. Accessed 15 April 2015. http://www. inide.gob.ni/censos2005/CifrasMun/tablas_cifras.htm

Jastrzembski B. 2014. History of Siuna, Nicaragua. Licensed under Creative Commons Attribution: Non-Commercial 4.0 International License. Accessed 14 January 2015. http://www.jastrzembski.com/siuna/siuna.pdf 
Kaimowitz D, Fauné A and Mendoza R. 2003. Your biosphere is my backyard: The story of Bosawas in Nicaragua. CIFOR Working Paper 25. April 2003. Accessed 1 January 2015. http://webdoc.sub.gwdg.de/ebook/serien/yo/CIFOR_WP/WP25.pdf

Kallen SA. 2009. The Aftermath of the Sandinista Revolution. Minneapolis, MN: TwentyFirst Century Books.

Kates RW, Haas JE, Amaral, DJ, Olson RA, Ramos R and Olson R. 1973. Human impact of the Managua earthquake. Science 182(7):981-90.

Lambin EF, Geist HJ and Lepers E. 2003. Dynamics of land-use and land-cover change in tropical regions. Annual Review of Environment and Resources 28:205-41.

Lambin EF and Meyfroidt P. 2011. Global land-use change, economic globalization, and the looming land scarcity. Proceedings of the National Academy of Sciences 108(9):3465-72.

Langley LD. 2002. The Banana Wars: United States Intervention in the Caribbean, 1898-1934. Wilmington, DE: Scholarly Resources.

Larson AM. 2010. Making the "rules of the game": Constituting territory and authority in Nicaragua's indigenous communities. Land Use Policy 27:1143-52.

Leogrande WM. 1996. Making the economy scream: US economic sanctions against Sandinista Nicaragua. Third World Quarterly 17: 329-48.

López Sampson A, Orozco Aguilar L, Breuer B and Navarro M. 2013. Sistematización de Experiencia: Fomento de la Cadena de Valor de Cacao en Nicaragua: Cooperación Alemana 2000-2012. Programa Manejo Sostenible de Recursos Naturales y Fomento de Capacidades Empresariales (MASRENACE). GIZ: Managua.

McNeely J. 2003. Biodiversity, war and tropical forests. In Price SV, ed. War and Tropical Forests: Conservation in Areas of Armed Conflict. New York: Haworth Press. 1-20.

[MARENA] Ministerio del Ambiente y los Recursos Naturales. 2003. Plan de Manejo: Reserva de la Biosfera Bosawas. Secretaria Técnica de Bosawas (SETAB). Managua.

Montgomery RN. 1980. The fall of Somoza: Anatomy of a revolution. Parameters: Journal of the US Army War College 10(1):47-57.

Nolff M. 1982. La vía crucis de la revolucion Sandinista. Nueva Sociedad 63:33-46.

Phillips J. 2004. Repatriation and social class in Nicaragua. In Long LD and Oxfeld E, eds. Coming Home? Refugees, Migrants, and Those who Stayed Behind. Pennsylvania: University of Pennsylvania Press. 150-69.

Piñon JP. 2001. Nicaragua: No way out of rural poverty? In The Geopolitics of Hunger 2000-2001. Action Against Hunger. Boulder, CO: Lynne Rienner Publishers. 101-12.

Redo DJ, Grau HR, Aide TM and Clark ML. 2012. Asymmetric forest transition driven by the interaction of socioeconomic development and environmental heterogeneity in Central America. Proceedings of the National Academy of Sciences of the United States of America 109:8839-44.

Rocha JL. 2001. Siuna: A hundred years of abandonment. Envio 239. Central American University: Managua. Accessed 12 March 2015. http://www.envio.org.ni/articulo/1507

Rogers T. 2014. US Extends Property Waiver for Nicaragua. The Nicaragua Dispatch. 5 August 2014. Accessed 10 March 2015. http://nicaraguadispatch.com/2014/08/us-extendsproperty-waiver-for-nicaragua 
Rudel TK, Defries R, Asner GP and Laurance WF. 2009. Changing drivers of deforestation and new opportunities for conservation. Conservation Biology 23:1396-405.

Ryan DA. 1978. Recent development of national parks in Nicaragua. Biological Conservation 13:179-82.

Ryan P. 1995. The Fall and Rise of the Market in Sandinista Nicaragua. Montreal, Canada: McGill-Queen's University Press.

Scherr SJ, Shames S and Friedman R. 2013. Defining Integrated Landscape Management for Policy Makers. Ecoagriculture Policy Focus. 10 October 2013.

[SETAB] Secretaria Technica de Bosawas. 2012. Diagnóstico Ambiental y Socioeconomic del Parque Nacional Cerro Saslaya en la Reserva de Biosfera Bosawas. March 2012. Managua.

Sklar H. 1988. Washington's War on Nicaragua. Cambridge, MA: South End Press.

Smith C. 1996. Resisiting Reagan: The U.S. Central America Peace Movement. Chicago: University of Chicago Press.

Stanfield JD. 1995. Insecurity of land tenure in Nicaragua. Land Tenure Center, University of Wisconsin-Madison. Research Paper 120. Accessed 25 February 2015. http:// ageconsearch.umn.edu/bitstream/12760/1/rp950120.pdf

Staver AC, De Jong W and Kaimowitz D. 2007. Nicaragua's frontier: The Bosawas Biosphere Reserve. In De Jong W, Donovan D and Abe K-I, eds. Extreme Conflict and Tropical Forests. Dordrecht, The Netherlands: Springer. 57-74.

Stedman SJ, Rothchild, DS and Cousens EM. 2002. Ending Civil Wars: The Implementation of Peace Agreements. Boulder, CO: Lynee Rienner Publishers.

Stocks A, McMahan B and Taber P. 2007. Indigenous, colonist, and government impacts on Nicaragua's Bosawas Reserve. Conservation Biology 21:1495-505.

[UNESCO] United Nations Educational, Scientific and Cultural Organization. 2015. Biosphere Reserves - Learning sites for sustainable development. Accessed 3 February 2015. http://www.unesco.org/new/en/natural-sciences/environment/ecologicalsciences/biosphere-reserves

Urban DL and Wallin DO. 2002. Introduction to Markov models. In Gergel SE and Turner MG, eds. Learning Landscape Ecology. 1st ed., New York: Springer Verlag. 35-48.

US Marine Corps. 1933. Monograph of Nicaragua. 12 December 1933. Sandino Rebellion Archives. Accessed 10 February 2015. http://www.sandinorebellion.com/EastCoast/ ATL-1933+/ATL-331215b-Monograph.JPG

Walker TW. 2000. Nicaragua: Transition through revolution. In Armony AC and Walker TW, eds. Repression, Resistance, and Democratic Transition in Central America. Wilmington, DE: Scholarly Resources. 67-88.

Walldorf CW. 2008. Just Politics: Human Rights and the Foreign Policy of Great Powers. Ithaca, New York: Cornell University Press.

Zalkin M. 1990. The Sandinista agrarian reform: 1979-1990? International Journal of Political Economy 20(3):46-68. 



\subsection{Introduction}

Bangladesh has 2.52 million ha of tropical forest, amounting to $10 \%$ of its total land (BFD 2015). More than two-thirds of its population live in rural areas and are directly and indirectly dependent on forests - from using forest resources as a direct source of food to using forest resources for primary energy and health care. Despite the linkages between rural livelihoods with forest and tree uses, deforestation has been a major threat to the protection of biodiversity and associated ecosystem goods and services.

An FAO (2010) study reported that approximately 2000 ha of forest cover per year was lost between 2000 and 2005. During the 19th century, approximately $50 \%$ of the area of natural forests in southeastern (hill forests) and central regions (sal forests) decreased. ${ }^{1}$ Among the underlying causes were excessive collection of forest resources including NTFPs, encroachment of land for agriculture use and human settlement, and ineffective institutional measures for plantation and commercial harvesting causing massive degradation (Salam et al. 1999).

Bangladesh is one of the most densely populated countries in the world; there is increasing pressure on land, particularly in forest areas due to food production, building settlements and industries (Salam et al. 1999). Agriculture related activities cover $60 \%$ of total land use and provides major livelihoods to more than two-thirds of the rural population (Ghose et al. 2014). However, lower land availability per person, given geographical constraints and lack of effective cultivation practices, limits food production capacity. Although poverty has reduced in the last few decades, landownership still determines the level of food production and access to other natural resources. The average agricultural land size has declined to $0.68 \mathrm{ha}$; this is unlikely to sustain livelihoods in this sector.

Forest and agriculture land uses have an important role in the livelihoods of people living in the CHT region of Bangladesh (Miah et al. 2012). Historically, forest landscapes provided a wide range of local and regional benefits such as food, energy, timber, water, health and national revenue generation. However pressures from exploitation and degradation that commenced during the last century (Rasul 2007) and continue to the present have implications for sustaining livelihood benefits of forest dependent people in terms of direct and indirect provisioning services (Rasul 2009).

Agriculture makes a large contribution ( $80 \%$ of the food intake) to the annual food needs of households in the region (UNDP 2009). Shifting cultivation has played a vital role in the food system of traditional ethnical people. But this land-use practice has faced severe pressure from increasing population for food production, limited availability of land and market demands. During the last few decades, most of the agricultural system has experienced a decline in yield, degradation of the forest areas and a threat to food security. Agriculture has effectively intensified in order to maintain household food levels; it has transformed through use of a short fallow period for shifting agriculture, adopting cash crops, and fruit and tree management. However, sustainable land use to secure food stocks and reduce forest degradation is a challenge in this region.

1 There are three types of forest in Bangladesh (hill and sal forest, and mangroves). Geographically, CHT has hill forests that are tropical evergreen and semi-evergreen. 


\subsubsection{Aim of the study}

This scoping study aimed to explore forest and agrarian change processes in the CHT region of Bangladesh. Food production and conservation of forests are important to sustain many direct and indirect services for supporting rural livelihoods in CHT. This study was conducted to:

- understand forest and agricultural land-use systems in CHT

- identify the trends and underlying causes of forest and agricultural land-use changes in the region

- identify a suitable landscape(s) with different land-use intensification for further research.

\subsubsection{Methods}

The study was conducted in five villages (Uluchari, Bagmara Headmanpara, Paglachara, Angadpara and Kamalchari) ${ }^{2}$ in Rangamati, Bandarban and Khagrachari districts in CHT (Figure 6.1). The villages were selected after consultation and discussion with local government and NGO officials and local elected union ${ }^{3}$ chairman/members in the region following an introduction to the aims of the research and criteria for selecting three intensification zones in this landscape. The field visit was conducted from 3-24 May 2015. Three field assistants participated in the scoping survey and discussions. They organized FGDs with local people, guided the field trips and facilitated in translating the question and answers into local languages (Chakma, Tanchangya and Marma). The research comprised a combination of tools including semi-structured FGDs, key informant interviews and personal observation. The FGDs were mostly informally organized in the village centers, such as at the village shop or the house of the local headman and karbari. ${ }^{4}$ The research assistants were representatives of a local NGO (Tahzingdong) and staff of the traditional king's (raja or chief of each circle) office. They communicated with the local head of the village (i.e. headman) to invite participants.

In each FGD, 5-6 local participants attended and a total of 30 people participated. The participants were mostly (male) farmers and also included local elites, elderly people and women farmers. Each discussion continued for approximately 90-120 minutes. During the FGD, topics included local land-use types, agricultural farming practices and different crop production. The role of agricultural crop production in food and cash incomes of the villages was also documented. Questions about the major changes in their land uses or agriculture practices, the underlying causes, diverse effects on food productions and conservation were also raised. Participants shared their views on impacts on forest and tree cover in the region, access to forests and products, changes in forest types, and the impacts on their food security and diversity, and on other ecosystem services.

2 Uluchari falls in Farua union under Belaichari subdistrict in Rangamati district. Bagmara Headmanpara falls in Rajbila union under Bandarban subdistrict. Paglachara and Angadpara fall in Rowangchari union under Rowangchari subdistrict in Bandarban district. Only Kamalchari falls in Kamalchari union under Khagrachari district.

3 The lowest administrative unit in Bangladesh.

4 A headman is the head of a mauza (a mauza is a local revenue collection point covering a collection of villages). A karbari is the head of a village. 


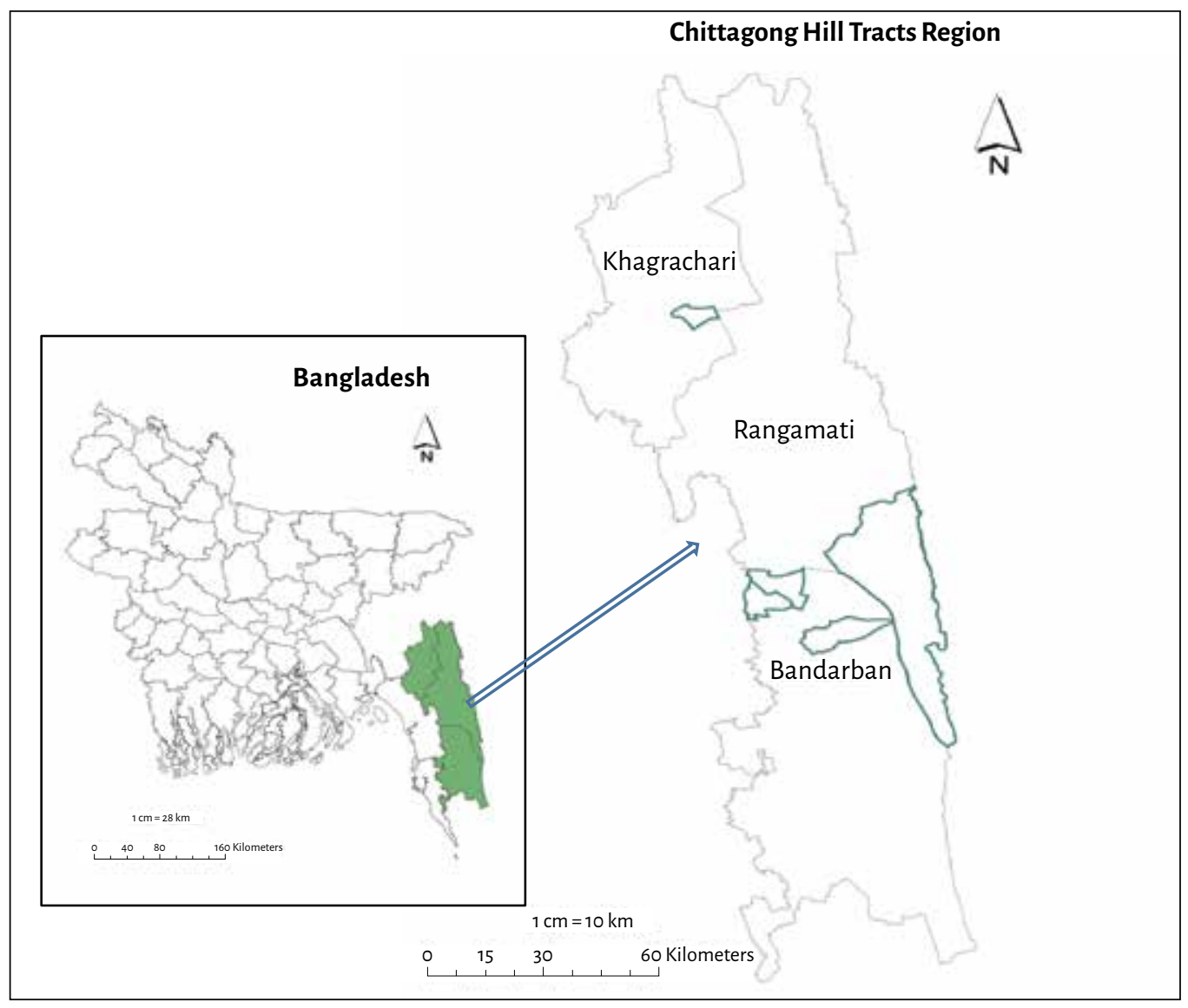

\section{Figure 6.1 Map of the Chittagong Hill Tracts region, Bangladesh.}

Note: The green colour boundary indicates the location of the five villages visited during the scoping study.

General observations were also recorded by undertaking transect walks along the village roads and farming lands, and two to three visits to the nearby markets in Belaichari and Rowangchari subdistricts of Rangamati and Bandarban districts to capture the daily livelihood activities of local communities. This assisted in observing informal social interactions of people within the locality. Visits to agricultural plots (i.e. shifting cultivation) were undertaken to observe the land preparation (i.e. clearing, burning, weeding, sowing etc.) and different farming activities (i.e. harvesting and processing of paddies). The use of different forest and tree products in households was observed, as well as the processes people used to collect and use the forest products. While observing different forest and tree-covered lands, notes were recorded on the direct and indirect contributions to ecosystem services.

The findings of the interviews and discussions were summarized. Information was also collected through reviewing government documents, websites, books and articles. 


\subsection{Brief description of Chittagong Hill Tracts region}

The CHT region is a unique geographical and cultural landscape of Bangladesh. Located in the southeast of the country, it has three administrative districts: Rangamati, Bandarban and Khagrachari (Figure 6.1). The approximately 13,300 $\mathrm{km}^{2}$ area of the region covers $8 \%$ of the total land area in the country (BBS 2014). The CHT region is bordered by Assam and Tripura states of India on the northeast, Arakan state of Myanmar to the southeast and Cox's Bazar district in the southwest. A brief description of the historical context and events, ethnic composition, population growth, migration patterns, tenure arrangement and institutional settings of the region is provided below.

\subsubsection{Political history of Chittagong Hill Tracts}

Historically, the social and institutional structure of CHT was unique in Bangladesh (Rasul 2007). Traditionally established customary rules of local ethnic communities were the only instrument to control natural resource management, collect taxes and implement any other social and cultural activities in most parts of the region (Khan et al. 2007). There were three traditional chiefdoms in CHT: Chakma raja (king of Chakma circle, a traditional administrative division in $\mathrm{CHT}$ ), Bomang raja (king of Bomang circle) and Mong raja (king of Maung circle).

Until the beginning of the colonial period in 1757, the ethnic communities had absolute control over local resource management and major administrative activities (Rasul 2007). After 1757, external rulers gradually influenced administrative work. The East India Company expanded their rules and business in the Indian subcontinent including CHT. The British Government took over the control of India from the East India Company and expanded their tax collection in the region from 1857. As a result, the hills of the Chittagong district were classified as CHT, a separate subdivision in 1860 (Khan et al. 2012).

In 1900, the British Government introduced The Chittagong Hill Tracts Regulation of 1900 Act (or the CHT Manual 1900) (Rasul 2007). One of the main goals was to demarcate the boundaries of $\mathrm{CHT}$, regulate the reserved forests and maintain traditional administration of the region with national administrative process. Until 1947, the region was a part of the Indian subcontinent. India became independent followed by a division into Pakistan and India in 1947 and CHT fell within the East Pakistan area.

During the Pakistan regime, in 1962 a dam on the Karnafuli River was constructed under the Kaptai Hydroelectric project to generate electricity. An artificial lake known as Kaptai Lake was eventually created that caused inundation of about $40 \%$ of the farming land and resulted in a loss of forest biodiversity (Khan et al. 2007). As a result, at least 100,000 people lost their land and livelihoods and many of them migrated within the region and outside into neighboring states of India (Rasul and Thapa 2006). 
After Bangladesh became independent in 1971, there was a growing movement by local ethnic communities (under a group of activists called Parbatya Chattagram Jana Samhati Samiti (PCJSS)) demanding a sovereign state (Shelly 1992). From 1973, a state of insurgency was declared with armed conflict between the armed wing of PCJSS and the law enforcing agencies (mainly the Bangladesh military wing of $\mathrm{CHT}$ ). This armed conflict continued until the mid-1990s. To end the violence and conflict, the Bangladesh Government signed a peace accord with PCJSS in 1997. Since the treaty, the incidence of violence has reduced and government agencies and NGOs have increased their development work in the region (Khan et al. 2007).

\subsubsection{Ethnic composition}

The people of CHT are diverse in terms of ethnicity, language, clothes, buildings and religion. Twelve ethnic groups live in the region and are known as Chakma, Marma, Tripura, Mrung, Tanchangya, Bawm, Chak, Pangkhua, Lushai, Khyang, Khumi and Rakhain (UNDP 2009). Chakma, Marma and Tripura comprise the largest proportion at $46 \%, 29 \%$ and $13 \%$ of the local ethnic population, respectively (Figure 6.2).

Apart from these traditional ethnic groups in the region, Bangalee (the main race in the country) comprise almost half of the population at present. Indigenous ethnic groups comprise $51 \%$ of the population. Chakma comprise the largest ethnic group and the Lushai is the smallest of the ethnic groups. The average household size in the region is 5.2, which is slightly higher than the national average of 4.8 . Despite the local ethnic diversity, almost $57 \%$ of villages/settlements are comprised of a single ethnic or language group. More than one ethnic group is located in $20 \%$ of the villages. Only $16 \%$ of villages in the region are Bangalee dominated.

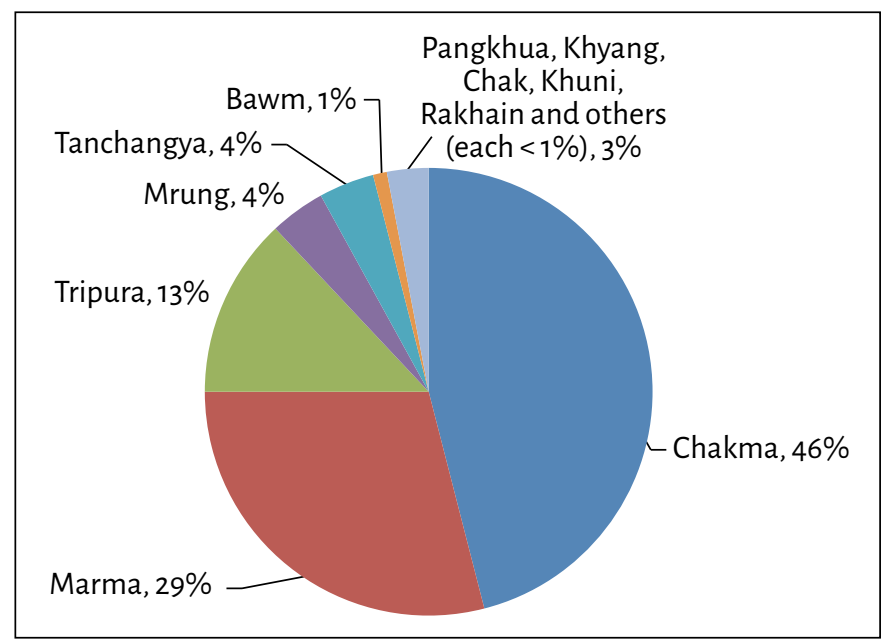

Figure 6.2 Proportion of local ethnic groups (not including Bangalee) in the population of Chittagong Hill Tracts.

Source: UNDP (2009) 


\subsubsection{Population growth and migration patterns}

The CHT region has experienced a steady increase of population in the last few decades. The current population density is $87-230$ persons per $\mathrm{km}^{2}$ in the region (BBS 2014). According to the last population and housing census of 2011, the total population of CHT is 1.59 million while the total population of Bangladesh is 158 million (BBS 2015). Until 1951 , the population in the region was 287,274 people, mostly comprised of local ethnic groups. Since the 1960 s onwards there has been a rapid influx of lowland people into the region, which has been responsible for its population growth.

The Bangalee population in CHT has increased about five times from 26,000 in 1961 to 119,000 in 1981 (Khan et al. 2007; UNDP 2009). Most of the Bangalee population migrated into the region through different government settlement programs. Figures for the transmigrant population are not available for the region. Approximately 350,000-450,000 people migrated between 1979 and 1981 (Khan et al. 2012). As such, the number of newly settled people comprises up to $60 \%$ of the local population. The population data show that the total population of CHT was 974, 445 in 1991, and increased to $1,342,740$ in 2001 . The recent census shows that the population is steadily increasing (Figure 6.3).

Apart from in-migration to $\mathrm{CHT}$, there was migration of ethnic groups within and outside the region. Among the total 183,000 households in rural CHT, nearly 56,000 households have experienced at least one displacement since 1978 (UNDP 2009). About $13 \%$ of all CHT rural households had at least one household member who migrated from his/her village/settlement before the 1997 Chittagong Hill Tracts Peace Accord.

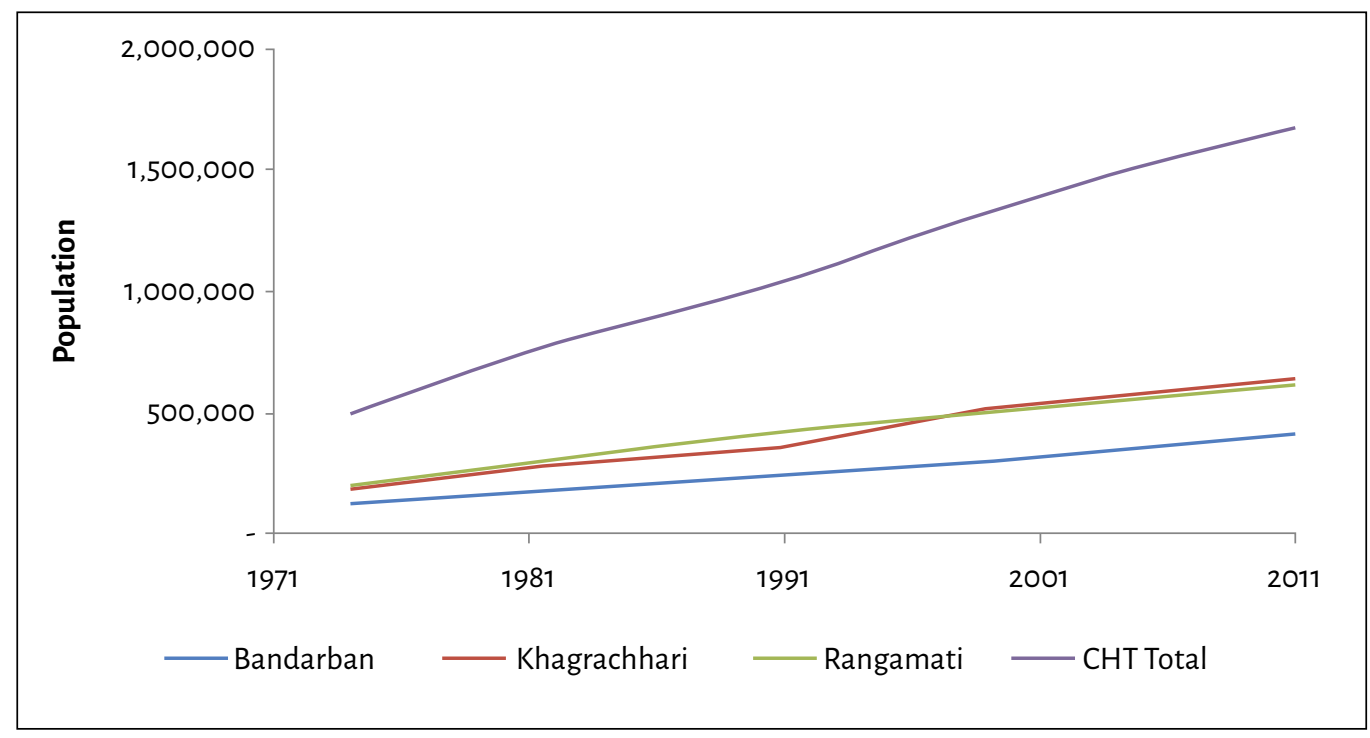

Figure 6.3 Trend in population growth in Chittagong Hill Tracts.

Source: GoB and FAO (2013) 
More than one in five ethnic households experienced migration within CHT, to other regions and to other neighboring countries. Long-term security issues (i.e. the movement for constitutional rights on lands and regional autonomy) due to political unrest from 1976 until 1997 was one of the underlying reasons for in- and out-migration. Eviction from farm land and lack of adequate work opportunities were also reasons for out-migration.

\subsubsection{Land tenure and ownership}

The land tenure conditions and ownership system in CHT are different to that in the rest of the country (Roy 2012). Ownership patterns include the dual arrangement of the customary and formal administrative process for accessing lands. In most cases, the ownership of land and accessibility to forests and shifting cultivation land are based on complex arrangements (Islam et al. 2007). While customary rules guided access to the use of land in the region until 1950s, the gradual introduction of new administrative systems and changes in forest management practices has influenced the ownership patterns in the region since then (Rasul and Thapa 2006).

Historically, common property systems have been the traditional way of accessing land and deciding on ownership of settlement and cultivation areas in the villages in CHT (Rasul 2007). This comprises a de facto ownership type where local ethnic people enjoyed rights to use land and forest areas for subsistence livelihood activities. Based on customary rules, the local headman is responsible for distribution of cultivable lands. The local headman maintains a record of the land-use distribution but many also remain unrecorded. The absence of a legal framework in the last century mean that people seldom claimed their possession over land (UNDP 2009). People lived and cultivated a piece of land for a short period and then moved to other cultivable hills within the settlement or outside it. However in the customary system, a farmer can take ownership of post-harvested farming areas if he decides to cultivate trees and fruit plants there (Khan et al. 2012).

At present, there is an increasing legal or de jure arrangement for accessing land. However, only one-third of the total population in CHT has legal registered rights to land and this is higher among the Bangalee community than other local ethnic groups. Over $50 \%$ of the Chak community has legal ownership of lands (UNDP 2009). The total population who have access to land in terms of combined registered and customary ownership (recorded) is much higher than only those who are registered. Recorded customary ownership is higher among local ethnic groups than among Bangalee people. Taking into consideration all forms of ownership (legal, customary-recorded and unrecorded common property), more than $90 \%$ of the population has access to land (UNDP 2009).

Land tenure is unclear and ambiguous in the case of accessing agricultural cultivation and forest areas in CHT. Traditionally, people accessed forest areas for different forest product collection and shifting cultivation (i.e. subsistence farming) following customary rules. Many of these rights have reduced as government control on management of forests and adjacent land-use systems has increased. Although people have access to government forests in some cases, their secure tenure rights have not yet been properly addressed (Khan et al. 2012). Overlapping of resource jurisdiction areas between customary land and government reserves also creates complexities in the management of traditional common property (i.e. forests and shifting cultivation lands). 
Forests cover one-third of the total land in CHT at present and are mostly government owned (Islam et al. 2007). Since the 1880 s, over 394,300 ha of land classified as reserve forests and another 905,000 ha of shifting cultivation land have been unclassed state forests (Khan et al. 2012). During 1900-2000 there has been a gradual expansion of state ownership of different land uses including reserve forests covering more than $50 \%$ of total forest areas. This trend has impacted on the livelihoods of local ethnic people by limiting their accessibility to forests and traditional ownership of land (GoB and FAO 2013). At present, a limited number of local people have accessed lands with secure title for private forest and agricultural use.

A secure tenure arrangement is appropriate in CHT when there are questions of improving food security and sustaining forest and land uses (Bala et al. 2012). Tenure rights on settlement and available farming lands are a sociopolitical issue in the region (Roy 2012). Withdrawal of customary tenure rights of local ethnic people occurred during the construction of the Kaptai Reservoir in the 1960s, causing a loss of food production areas. Tenure arrangements have been further complicated with the settlement of lowland Bangalee people since the 1980s; they have received formal land title and leases for plantations (Rasul 2007).

Ethnic communities are less familiar with formal land title processes, so their ownership remains unspecified or not adequately documented in their rights to farming land (Islam et al. 2007). Displaced local ethnic people including traditional shifting cultivators were settled through a government monoculture plantation or horticulture livelihood development program without sufficient institutional support for proper land titles (Khan and Khisa 1999). Insecure tenure of local ethnic communities is still the case for many who follow customary rules and they may be negatively affected if not adequately involved with forest management and land improvement practices in the region.

\subsubsection{Institutional setting}

Bangladesh follows formal administrative systems at national and local levels to plan, regulate and implement overall development work. A number of government agencies regulate the local administration, infrastructure development, health, education, agriculture/forest/fisheries/livestock related extension and management services. A traditional institutional structure headed by kings ${ }^{5}$ has perpetuated in the region in parallel with the government administrative system. Here we discuss the institutional arrangement in relation to managing forests and land resources in CHT through a review of mostly unpublished documents.

\section{Formal institutions}

There is a range of organizations that have responsibility for land and forest management in CHT of Bangladesh (Table 6.1).

5 The entire CHT region has three taxation circles in traditional rules. Each circle has a king or chief (also known as a raja). Three chiefs/kings represent Chakma, Bomang and Mong circles respectively. The king of each circle serves different ethnic groups located within their jurisdiction irrespective of any specificity. 
Table 6.1 Key institutions related to land and forest management in the Chittagong Hill Tracts of Bangladesh.

\begin{tabular}{|c|c|c|}
\hline Institutions & Key roles & Legislation implemented \\
\hline $\begin{array}{l}\text { Ministry of } \\
\text { Chittagong Hill } \\
\text { Tracts Affairs }\end{array}$ & $\begin{array}{l}\text { Coordinating agency between national and } \\
\text { regional and district councils, Chittagong Hill } \\
\text { Tracts Development Board on local resource } \\
\text { management programs }\end{array}$ & $\begin{array}{l}\text { Established as of the Peace } \\
\text { Accord, } 1997\end{array}$ \\
\hline $\begin{array}{l}\text { Local section of } \\
\text { national Forest } \\
\text { Department of } \\
\text { Bangladesh }\end{array}$ & $\begin{array}{l}\text { Decision making for the management of } \\
\text { natural and plantation forests including } \\
\text { control of agriculture practices } \\
\text { - Declaration of any lands to be reserved as } \\
\text { protected forest } \\
\text { - Protection of illegal collection and } \\
\text { marketing of forest products including } \\
\text { timber and animals } \\
\text { - Collection of revenue from forest products }\end{array}$ & Bangladesh Forest Act, 1927 \\
\hline $\begin{array}{l}\text { District } \\
\text { administration } \\
\text { headed by the deputy } \\
\text { commissioner of } \\
\text { local government }\end{array}$ & $\begin{array}{l}\text { Control of unclassed state forests, decisions on } \\
\text { land lease for private ownership, settlement and } \\
\text { plantation or farming activities }\end{array}$ & $\begin{array}{l}\text { CHT Manual } 1900 \\
\text { Chittagong Hill Tracts } \\
\text { Land Acquisition } \\
\text { Regulation, } 1958\end{array}$ \\
\hline $\begin{array}{l}\text { The Chittagong } \\
\text { Hill Tracts Regional } \\
\text { Council headed } \\
\text { by an elected } \\
\text { representative from } \\
\text { local ethnic groups }\end{array}$ & $\begin{array}{l}\text { - Representing the interests of } 13 \text { ethnic groups } \\
\text { for land rights while undertaking measures } \\
\text { toward land rights development } \\
\text { - Coordination with forest department and } \\
\text { district administration on land allocations } \\
\text { - Technical support to government on land } \\
\text { management related programs }\end{array}$ & $\begin{array}{l}\text { - CHT Manual } 1900 \\
\text { - The Chittagong Hill } \\
\text { Tracts Regional Council } \\
\text { Act, } 1998 \\
\text { - The Hill Districts } \\
\text { Councils Act, } 1989\end{array}$ \\
\hline $\begin{array}{l}\text { District council in } \\
\text { each district }\end{array}$ & $\begin{array}{l}\text { - Land resource improvement programs } \\
\text { - Prevention of any further settlement } \\
\text { - Formulate and review projects related forest } \\
\text { and agriculture land uses }\end{array}$ & $\begin{array}{l}\text { The Hill Districts Councils } \\
\text { Act, } 1989\end{array}$ \\
\hline $\begin{array}{l}\text { Chittagong Hill } \\
\text { Tracts Development } \\
\text { Board }\end{array}$ & $\begin{array}{l}\text { Implementation of development projects focused } \\
\text { on upland settlement through agroforestry, } \\
\text { fisheries and livestock related programs }\end{array}$ & \\
\hline $\begin{array}{l}\text { Circle chief office } \\
\text { (traditional king) }\end{array}$ & $\begin{array}{l}\text { Collection of tax from agriculture land farming } \\
\text { as a royalty for traditional administration and } \\
\text { government treasures } \\
\text { - Supporting government for maintaining } \\
\text { appropriate land use } \\
\text { Appointment of headman and karbari for } \\
\text { appropriate tax collection, land allocation } \\
\text { and taking preventive measures against } \\
\text { intentional fires and illicit felling of trees in the } \\
\text { customary forests }\end{array}$ & CHT Manual 1900 \\
\hline
\end{tabular}

Source: Islam et al. (2007) 
Forest resource management is the key role of the Bangladesh Forest Department, which is under the Ministry of Environment and Forests. It is responsible for at least one-third of the land in the region and is an important stakeholder in natural resource management (Roy 2012). The process in planning, decision-making and implementing any plantations and protection activities for forest areas (i.e. reserves, national park, wildlife sanctuary etc.) of the Bangladesh Forest Department is formal. To a large extent, community involvement in forestland management is limited except in a few upland settlement programs for plantation activities.

The Department of Agriculture Extension (Figure 6.4) have a role in building advanced skills and introducing improved farming technology to rural households. However, their institutional capacity and size are inadequate, and they are generally unavailable and inaccessible to remote households in the region (GoB and FAO 2013).

The district administration headed by the deputy commissioner (i.e. head of the local administration in each district) is another agency that has certain power and institutional arrangement for control of public lands in Bangladesh. This is also the case in CHT where the agency provides an essential role in permitting access to land for local ethnic, displaced and poor people. But the deputy commissioner has special power (in the CHT Manual 1900) to follow the traditional structure of local ethnic people in landownership distribution. As noted above, landownership remains a complicated issue. This is particularly critical in areas of "unclassed state forest" management (Islam et al. 2007). Most of this type of forestland was degraded due to shifting cultivation or commercial plantation programs during the 1960 s to 1980 s. The district administration controls this land for certain purposes, mainly farming, settlement and plantation programs. ${ }^{6}$

The Ministry of Chittagong Hill Tracts Affairs was formed in 1998 to conduct and monitor the activities from a national level. Appointed by the Prime Minister of Bangladesh, a minister is selected from the region to represent the local population. The Ministry guides the overall development plan for the region and undertakes the responsibility for operation of the regional council, district council, Chittagong Hill Tracts Development Board (CHTDB), upazila (subdistrict) parishad (council or assembly), ${ }^{7}$ union parishad ${ }^{8}$ and traditional administrative circles of the region. These institutionalized agencies work independently and are guided under district and upazila administration in land-related issues (Khan et al. 2012). There are also a few autonomous government agencies such as the Chittagong Hill Tracts Regional Council, Hill district councils and CHTDB working in the region (Table 6.1; Figure 6.4).

The CHTDB, established in 1976, operates as a regional autonomous agency (Khan and Mentel 2007). The CHTDB covers the development of agriculture, infrastructure, water, education sectors and other social welfare related works. It also implemented a

6 This department also controls line agencies such as upazila administration and land offices for implementing any land survey and settlement programs.

7 Upazila parishad have the key roles to plan, coordinate and monitor the activities of government agencies.

8 Union parishad are local councils of elected chairman and members of villages in Bangladesh. 
resettlement program that supported the relocation of poor people from the Bangalee community into the region to improve their economic wellbeing. The CHTDB also undertook a resettlement program in the 1980s for shifting cultivators who were local ethnic people. However, both the agency and local ethnic people were disappointed with this resettlement program and its influence on land rights issues (Islam et al. 2007).

Under the Peace Accord of 1997, the Chittagong Hill Tracts Regional Council aimed to supervise and coordinate activities of local councils, government agencies and customary institutions at district and subdistrict levels (Islam et al. 2007). Any development activity in the region requires approval or consent from the agency before implementation. It coordinates law-related issues, customary rules, activities of NGOs and the necessary steps for disaster management and relief. The chairman represents all the ethnic people in three districts. However, the overall institutional and financial capacity of the regional council is considered insufficient to date (Islam et al. 2007).

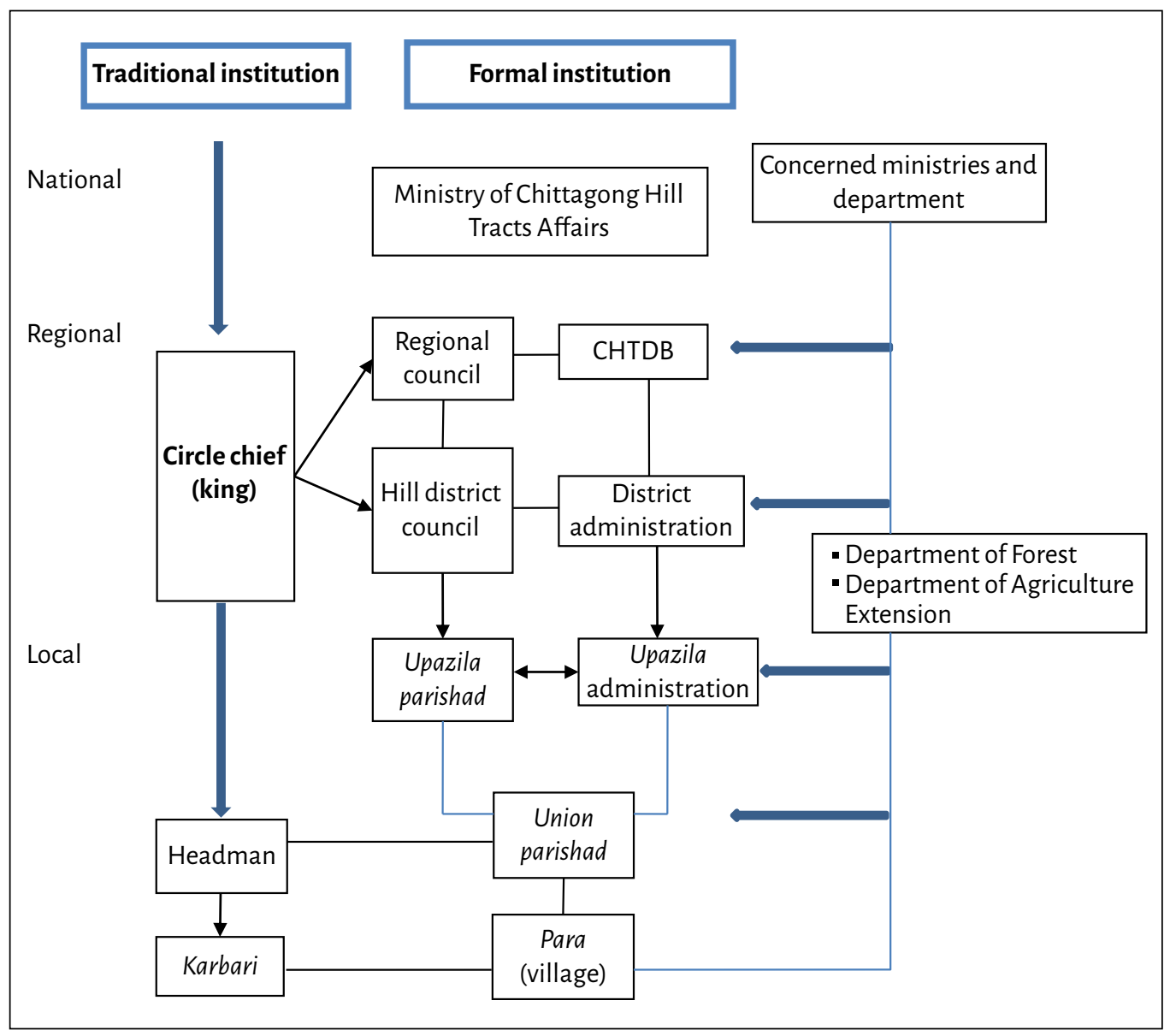

Figure 6.4 Institutional framework related to forest and land management in the Chittagong Hill Tracts region of Bangladesh.

Source: Data from GoB and FAO (2013) 
In each district, a Hill district council plays a vital role in planning, financing and implementing natural resource management activities. The district council develops programs based on local priorities (e.g. improved agriculture practices), gets approval from the Ministry of Chittagong Hill Tracts Affairs and implements the programs through government departments. The district council also acts as focal agency for coordinating between government departments (Khan and Mantel 2007). The relationship between these national, regional and local institutions is shown in Figure 6.4.

\section{Traditional institutions}

Forest and land management are the major tasks of the traditional (informal) institutions in the $\mathrm{CHT}$ region (Figure 6.4). The CHT region is divided into three taxation circles. Each circle has a king who determines the revenue and rules for the respective circle. There are boundaries or small units within each circle known as mauza for collection of revenues. The mauza controls land distribution among the local ethnic people for yearly farming activities. A headman in each mauza controls a number of villages and collects revenue for the chief and government and supports villager access to legal documents for permanent ownership. A karbari from each village assists the headman in collecting the revenue (Islam et al. 2007).

This circle structure is different from the formal boundaries of the government administration but it corresponds to the district government administration. The CHT Manual 1900 ensures the formal functions of the circles in the region. The distribution of total collected revenue from each mauza is $42 \%$ for the king, $37 \%$ for the headman and $21 \%$ for the government.

Common forestland is traditionally maintained in each mauza depending on the availability of this resource. This is however recognized as village common forests and has received greater environmental and economic potential in the recent decades for this region. Each household head of the community is traditionally a member of the forest commons. Local people follow a set of informal rules for annual harvesting, collection of timber and NTFPs, clearing and burning activities (Misbahuzzaman and Smith-Hall 2015).

\subsection{Major economic activities in Chittagong Hill Tracts}

The economy of CHT is largely based on the forest, agriculture, fishery and livestock sectors. Forests contribute a significant portion of the economy (46\%) at local and national levels, followed by crop/fruit production in the region (Khan et al. 2007). Historically, traditional shifting cultivation practices contributed to local livelihoods through the production of locally available foods and sources of subsistence economic activities. In the last two decades, the intensity of shifting cultivation has decreased or been modified with cropping patterns, mostly involving planting fruits and trees

9 Revenue collection points. 
that have increased economic benefits. Plough-based agriculture for intensive cultivation in plain lands ${ }^{10}$ has increased in recent years. However, lack of suitable lands, irrigation sources and adequate extension services are still major constraints to improving the economic capacity of rural households. Drawing on reviews of existing studies (UNDP 2009; Kar and Jacobson 2012; Miah et al. 2012; Rahman et al. 2014; Misbahuzzaman and Smith-Hall 2015) and the results of the scoping study, the key economic activities or sources of household food and incomes in CHT are discussed.

\subsubsection{Agriculture}

The majority of rural households in CHT are dependent on agriculture related activities for producing food and income. Over $50 \%$ of the annual net income of all CHT households comes from different agriculture related sources (Figure 6.5; UNDP 2009). Food and cash incomes are generated by at least one agricultural related activity. Agricultural activities include ploughing lands, shifting cultivation, paid wage labor, livestock and poultry rearing, trees/nurseries, fruit gardening, fishing and making agriculture implements. The share of agriculture related annual income is higher in local ethnic households than in the Bangalees (63\% vs. 49\%) (UNDP 2009). Among the ethnic groups, the Khumi, Marma, Mro and Bawm people generate more than $67 \%$ of their net annual household income from agriculture related activities (UNDP 2009).

More than 35 different types of crops are cultivated in CHT annually. Agriculture crops including fruits and trees provide both subsistence uses and cash incomes for local ethnic groups. But the main cultivated crops are limited to seven including rice paddy, turmeric, ginger and banana. Cotton and sesame were once valuable cash crops but have gradually declined in recent years due to a decline in productivity. Different fruit species (i.e. banana, jackfruit, mango and litchi) have gradually replaced shifting cultivation crops due to increasing demand for cash incomes

The CHT region is one of the highest fruit production regions in Bangladesh (BBS 2015). Banana is a commonly produced horticulture crop in the region that is mostly cultivated in shifting cultivation areas with other crops for cash incomes that people harvest during fallow periods. More than $25 \%$ of households produce banana in their annual farming plots and home gardens (Khan et al. 2012). The annual yield of banana is about 88,000 tons, which is considerably higher than other fruits (BBS 2011). However, pineapple, jackfruit and papaya production also contribute significantly to the average household economy. There are also increasing levels of pineapple production as potential source of cash income, particularly in the last two decades.

10 Bangladesh forms the largest delta in the world and a large part of its landmass is plains inundated with rivers and tributaries. Small plain lands in valley bottoms, river banks and lower slopes in CHT only retain water during monsoon. 


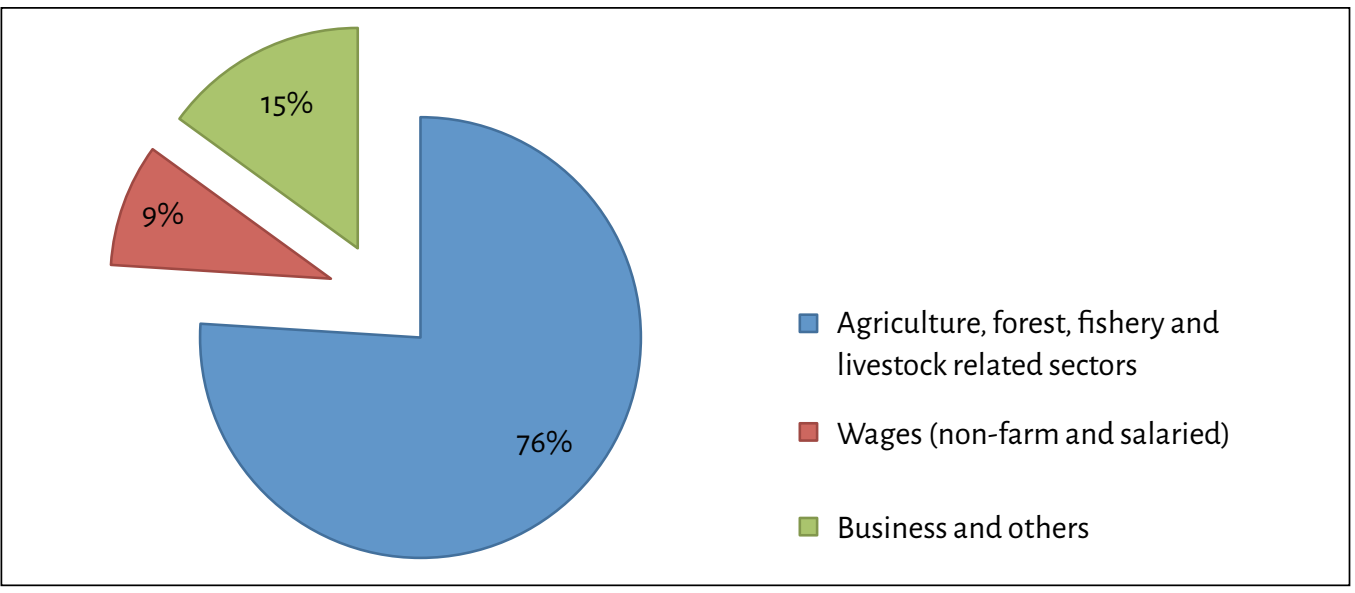

\section{Figure 6.5 Different economic activities in Chittagong Hill Tracts.}

Source: UNDP (2009)

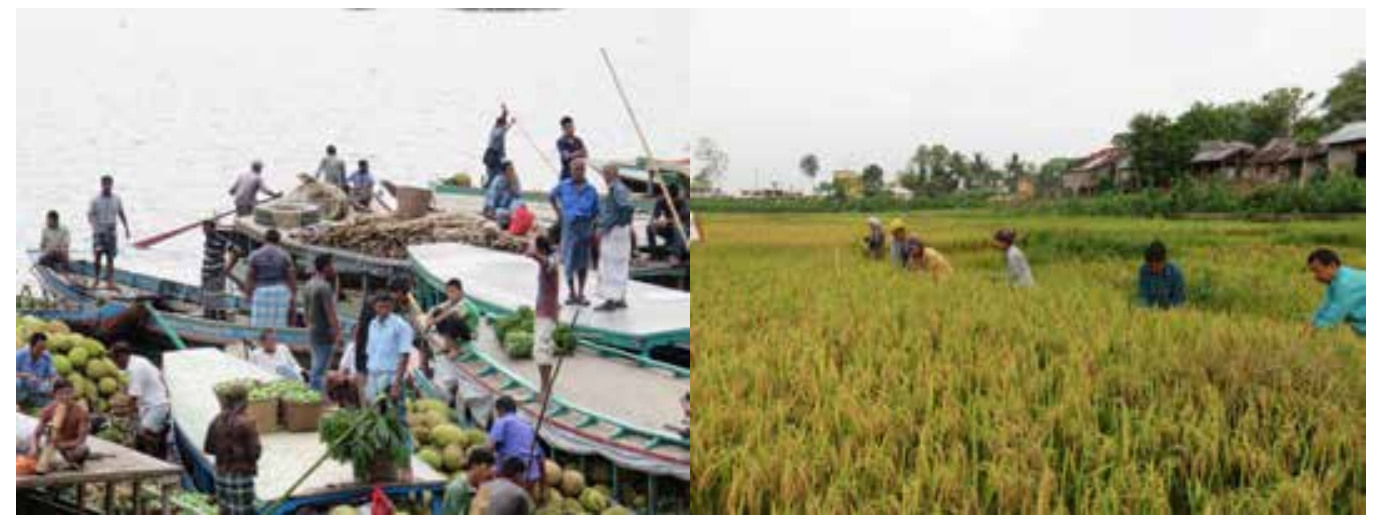

Fruit farmers/sellers in Rangamati town (left) and farmers harvesting rice at Rangamati (right). (Ronju Ahammad/Charles Darwin University)

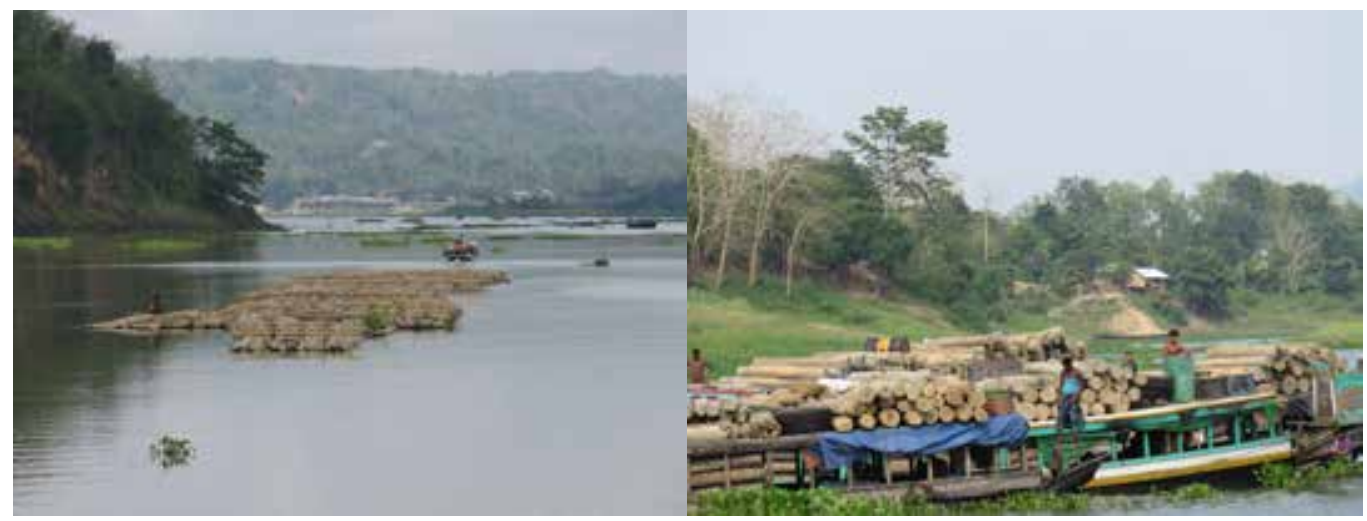

Bamboo rafting for water transportation in remote areas of Rangamati (left) and timber stored in a water vessel for transportation at Rangamati (right). (Ronju Ahammad/Charles Darwin University) 


\subsubsection{Forestry}

Household fuelwood, food, medicines, shelter building materials and agricultural implements are common uses of forest resources in Bangladesh. Forest and trees provide direct and indirect economic benefits to local communities in CHT, as well as to the national economy. ${ }^{11}$ Timber, bamboo, rattan, fuelwood, fruits and different types of grasses are the major sources of forest-based annual income. However, the number of people dependent on forest-based economic activities is difficult to estimate due to a lack of available studies for the region and across the nation.

In CHT, more than $60 \%$ of forest products including NTFPs are used at the household level and the remaining 40\% are sold at local markets to generate cash income (Kar and Jacobson 2012; Misbahuzzaman and Smith-Hall 2015). At present timber is largely collected from planted forests. Natural forests still provide the largest stocks of bamboo, which are a potential source of forest-based economic activities in the region. However, the availability and sustainability of bamboo is yet to be clearly estimated.

NTFPs play a vital role in the traditional culture and life supporting functions of ethnic communities in the CHT region, as well as in the rest of Bangladesh (Mukul 2010; Miah et al. 2012). Although often regarded as small-scale, forest-based artisan activities (i.e. manufacturing different handicrafts) are important sources of informal employment. However, a lack of formal economic valuations of NTFPs may often undermine the appropriate numbers of people's dependency and their potential benefits to regional and national economies. For example, bamboo- and cane-made products (i.e. different handicrafts) and raw materials are in demand in the building construction industry and in nearby urban markets and cities, contributing important incomes to those manufacturing and trading them.

Among the NTFPs, bamboo is the most commonly used for making baskets, collecting and storing food grains and fencing around farming plots. People manage and collect at least four different bamboo species for household subsistence use and commercial purposes. The available information indicates that poor households are engaged in different steps of collection, processing and marketing of NTFPs and have relatively higher dependency on receiving annual income from forest-based economic activities (Kar and Jacobson 2012; Misbahuzzaman and Smith-Hall 2015).

\subsubsection{Other economic activities}

Bangladesh, as a riverine country, has large economic opportunities in small-scale fishing activities in almost parts of the country. Rivers, seasonally flooded lands and lakes are the main protein source for many people in the region. But the quantity of fish catches in rivers and flood lands have declined due to loss of natural habitats or degradation of watersheds in the last few decades (Khan et al. 2007). Only Kaptai Lake still provides major fish protein sources. The annual fish catch in the lake is 7336 tons per annum, which meets the local demand for consumption and a small

11 Karnafuly Paper Mill, the largest paper mill in the country, is located in CHT and annually uses millions of tons of bamboo as raw material for paper production. Bangladesh Forest Industries Development Corporation operates a number of wood processing units to produce the major wooden products and generate national revenue. 
commercial supply to markets in the nearest Chittagong city (BBS 2011). More than 5000 people are registered to fish in the lake. There are more than 35 fish species that are commercially important in Bangladesh. Though fish capture in the lake has increased, the sustainability of production and ongoing contribution to the regional economy could be problematic in the future due to overcapacity (Khan et al. 2012).

Livestock (mainly cows, goats and pigs) and poultry rearing contribute to household food supplies and small amounts of cash income. The sector also contributes about $5 \%$ to regional annual products (Khan et al. 2007). The average size of livestock used for subsistence in a household is slightly higher in CHT (4-12 animals/household) than the national average (2-8 animals/household) (BBS 2011).

\subsection{Land-use practices in Chittagong Hill Tracts}

The CHT region is different in terms of physical, geomorphic and soil characteristics to the rest of Bangladesh. The main land types are high and medium hills and there is a small area of lowland valleys and plain lands (Khan et al. 2007). The hills range between 150 and 500 masl. Forests including timber/fruit tree farming and shifting cultivation are the major land cover on the hills. Paddy cultivation is largely prevalent in the valley parts or the plain land areas of the region. Hills cover more than $85 \%$ of the land types with medium to steep slopes, so conventional agriculture is limited and instead managed for shifting cultivation or forest (Islam et al. 2007). Agroforestry practices with intensive fruit cultivation have also increased as another land-use practice. Here we explain forest and agriculture land-use practices in CHT. Most of the information is sourced from literature and key informant interviews during the scoping study.

\subsubsection{Forestlands}

Forested areas in CHT make up almost $43 \%$ of total forestlands in Bangladesh (BFD 2015). In terms of forest types, natural forests and plantation forests cover more than $70 \%$ of land areas in all three districts. The total forest area managed under the Bangladesh Forest Department in CHT is 483,000 ha, with 86,000 ha designated as plantation land (BBS 2015). The major plant species in the region are tropical wet evergreen/semi-evergreen and deciduous, and are classified as 'hill forests.' Among the plantation covers, teak (Tectona grandis) is the dominant type of plant in both government and private forestlands.

During the last century, commercial plantations with largely teak (Tectona grandis) plants increased in the region. Teak was primarily introduced as an exotic species in small patches of Kaptai National Park around 1920. One of the reasons was that the region had a major push for the harvesting of valuable forest timbers during British regimes. This was one of the reasons that commercial plantations preceded at the expense of natural forest coverage. Throughout the 19th century, planted forests replaced a large portion of natural forests. Along with these, commercial plantations with fast growing species, such as gamar, used for raw materials in paper and pulp making industries also expanded. The CHT region is a large source of plant-based industries managed under the Bangladesh Forest Industries Development Corporation. 


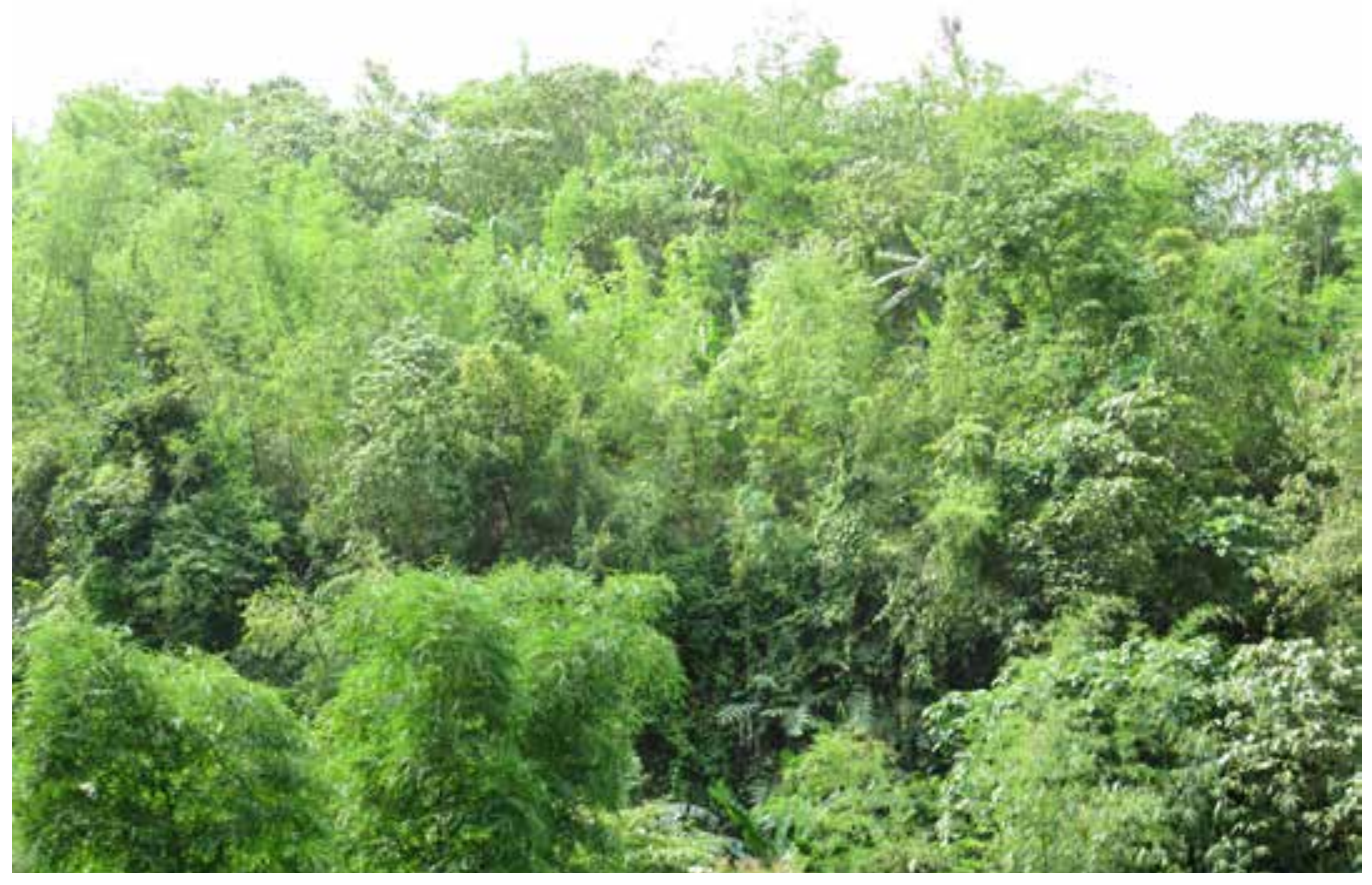

Naturally grown bamboo forests in Bandarban. (Ronju Ahammad/Charles Darwin University)

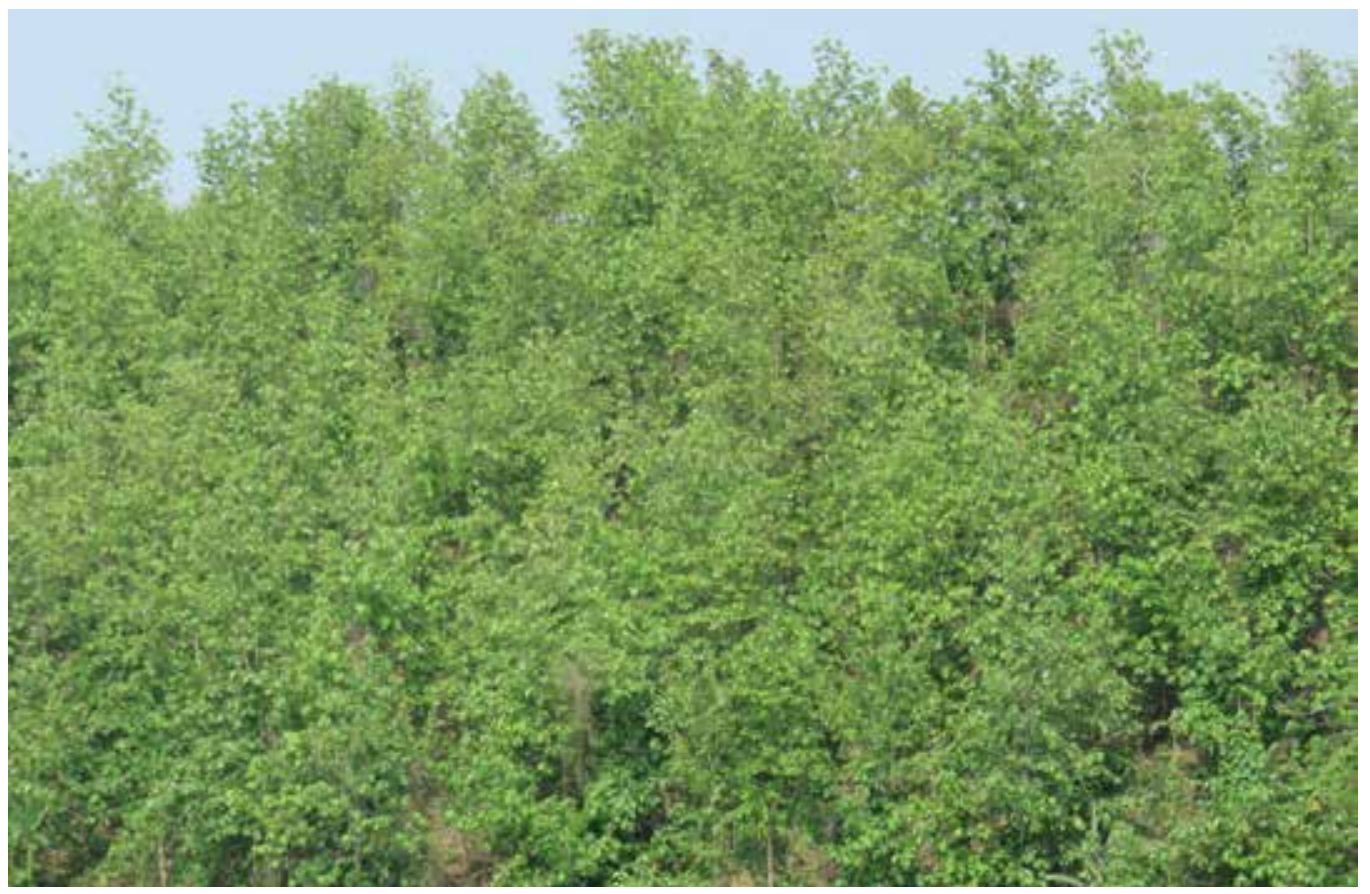

Monoculture plantation of teak (Tectona grandis) in Rangamati. (Ronju Ahammad/Charles Darwin University) 


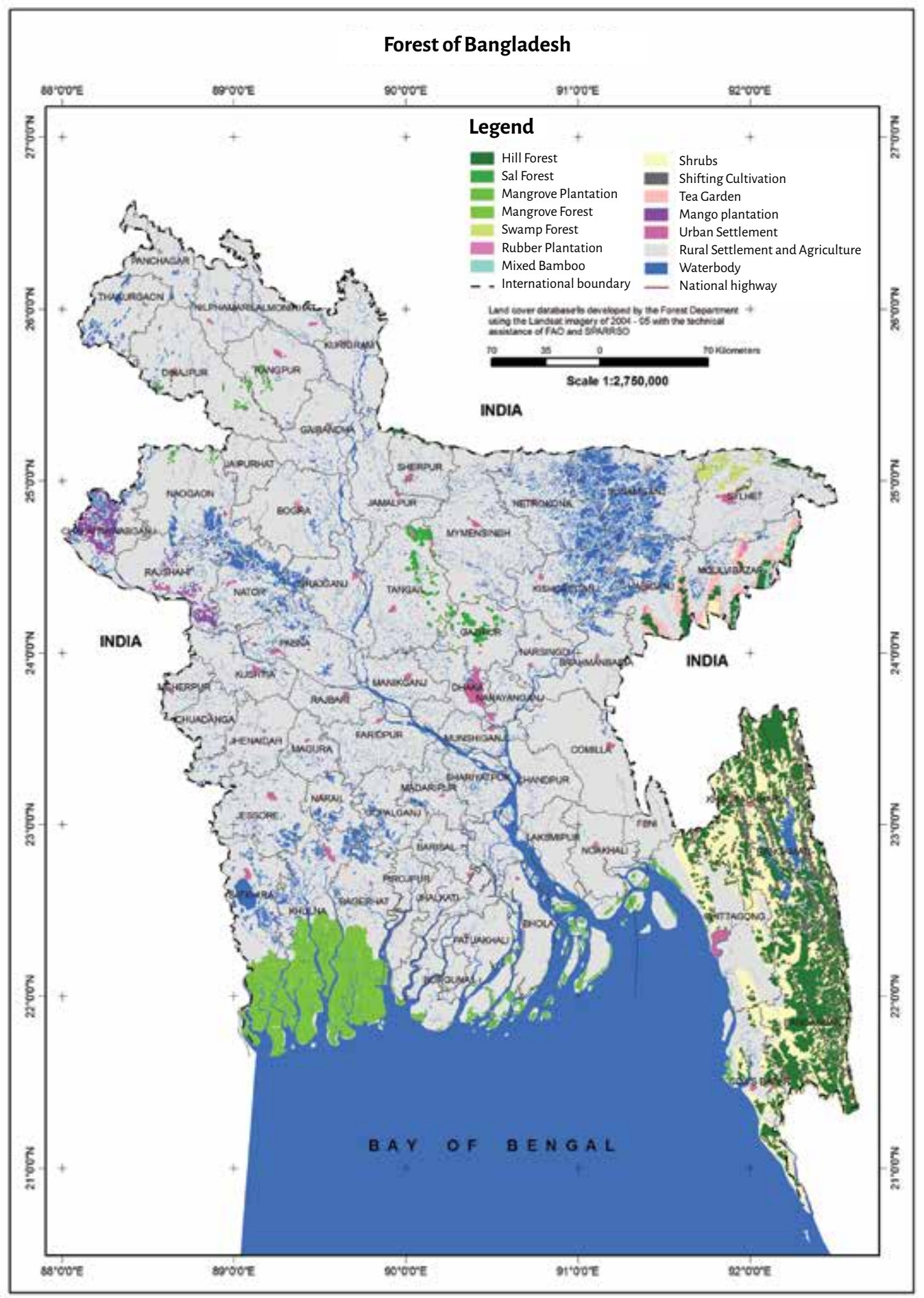

Figure 6.6 Forest cover map of Bangladesh and encircled forest areas in Chittagong Hill Tracts.

Source: BFD (2015) 
Forestal Forestry and Engineering International Ltd, a Canadian consulting company, reported that more than $70 \%$ of land in the $\mathrm{CHT}$ region is suitable for plantation-based land use after a land-use survey in CHT in 1966 (Rasul and Thapa 2006). Government policy also supported the undertaking of large-scale plantation programs. As a result, plantation areas increased throughout the 1980 s and 1990s. At present, plantations with teak cover the largest tract of the forests in government reserve areas, as well as private lands. Although timber harvesting from government forests has been banned since the 1980s in Bangladesh, the region still supplies a significant amount of valuable timber to meet the large demand at the regional and national level.

Historically, local ethnic communities depend on timber for day-to-day traditional uses such as fuelwood, making seasonal agricultural implements (i.e. baskets for crop harvesting and storing and constructing shelters in the village). For example, 50\% of the raw materials used in building permanent or temporary shelters are timber or NTFPs. Commercial approaches to increasing timber plantations on hilly lands or home gardens is a relatively new concept and has been popular since the 1990s. In many villages in the CHT region, agricultural lands have been gradually converted with monoplantations, mainly with teak or gamar (Khan et al. 2012).

There is no record of the amount of privately owned land that has been converted for commercial timber uses, but generally these types of smallholder plantation areas range from $0.4-4$ ha. The conversion of agricultural lands into timber plots is an increasing trend among large landholding families. Although customary ownership of the region dictates the distribution of farming lands for food production among local ethnic communities, poor households are yet to access this timber-based economy because of insecure tenure. The expansion of timber plantation areas might have economic value to some extent for those with secure ownership. But these replacements will not benefit subsistence communities in enhancing their food production due to decline in their access to productive lands or further threats to soil erosion (Khan and Mantel 2007).

\subsubsection{Shifting cultivation}

Shifting cultivation is a traditional land-use practice of ethnic populations in the region. Known as 'slash and burn agriculture' and referred to locally as 'Jhum cultivation', it is a common land-use type in CHT. At present, $16 \%$ of land is cultivated with this traditional system each year (Bala et al. 2012). Following a certain fallow cycle (3-8 years), farmers cultivate a plot of hill lands in different years. Locally available paddy varieties, ginger, turmeric, maize, sweet potato, other vegetables and banana are the most common crops in this system.

For many families, the shifting cultivation system is a significant source of locally accessible food for largely subsistence use and for a small amount of cash income throughout the year. The main feature of this land use is a combination of diverse crops for cultivation in one season (March-May) and harvesting gradually to secure food for the rest of month (August-December) (Table 6.2). Traditional and local knowledge held by generations of shifting cultivation farmers have contributed to this long-standing land-use practice in the region.

The extent of shifting cultivation agriculture is higher in Rangmati and Bandarban districts than in Khagrachari district (GoB and FAO 2013). Hilly lands cover much more area in the 
former two districts than in Khagrachari. The size of shifting cultivation practices range from $0.5-3$ ha in a family. The availability of farming lands and land suitability often determines the areas to be undertaken for annual cultivation. At present, shifting cultivation activities also comprise the planting of fruit species (e.g. pineapple, banana, jackfruit and mango). Traditional forms of shifting cultivation were based on only annual crops and retaining trees largely available in remote areas. Intensive forms of agriculture (i.e. mix of fruit trees and teak plantations) are now increasing in areas closest to markets and roads (Thapa and Rasul 2005).

Table 6.2 Major seasonal land-use practices in Chittagong Hill Tracts.

\begin{tabular}{|c|c|c|c|c|c|c|c|c|c|c|c|c|}
\hline Activities & Jan & Feb & Mar & Apr & May & Jun & Jul & Aug & Sep & Oct & Nov & Dec \\
\hline $\begin{array}{l}\text { Agriculture } \\
\text { (shifting } \\
\text { cultivation) }\end{array}$ & & & & S & S & & & $\mathrm{H}$ & $\mathrm{H}$ & $\mathrm{H}$ & $\mathrm{H}$ & $\mathrm{H}$ \\
\hline $\begin{array}{l}\text { Agriculture (plain } \\
\text { land plough } \\
\text { cultivation) }\end{array}$ & S & $\mathrm{H}$ & $\mathrm{H}$ & $\mathrm{H}$ & & & S & S & & & $\mathrm{H}$ & $\mathrm{H}$ \\
\hline Fruit collection & & & & $\mathrm{H}$ & $\mathrm{H}$ & $\mathrm{H}$ & $\mathrm{H}$ & $\mathrm{H}$ & $\mathrm{H}$ & & & \\
\hline $\begin{array}{l}\text { Fuelwood } \\
\text { collection }\end{array}$ & + & + & + & + & + & + & - & - & - & - & + & + \\
\hline $\begin{array}{l}\text { Collection of } \\
\text { NTFPs (mainly } \\
\text { bamboo) }\end{array}$ & + & + & + & + & + & - & - & - & - & + & + & + \\
\hline Wage labor & - & + & + & + & + & + & - & - & - & - & - & - \\
\hline
\end{tabular}

Note: $\mathrm{H}$ = harvesting; $\mathrm{S}=$ land preparation and sowing; + = higher; - = lower.
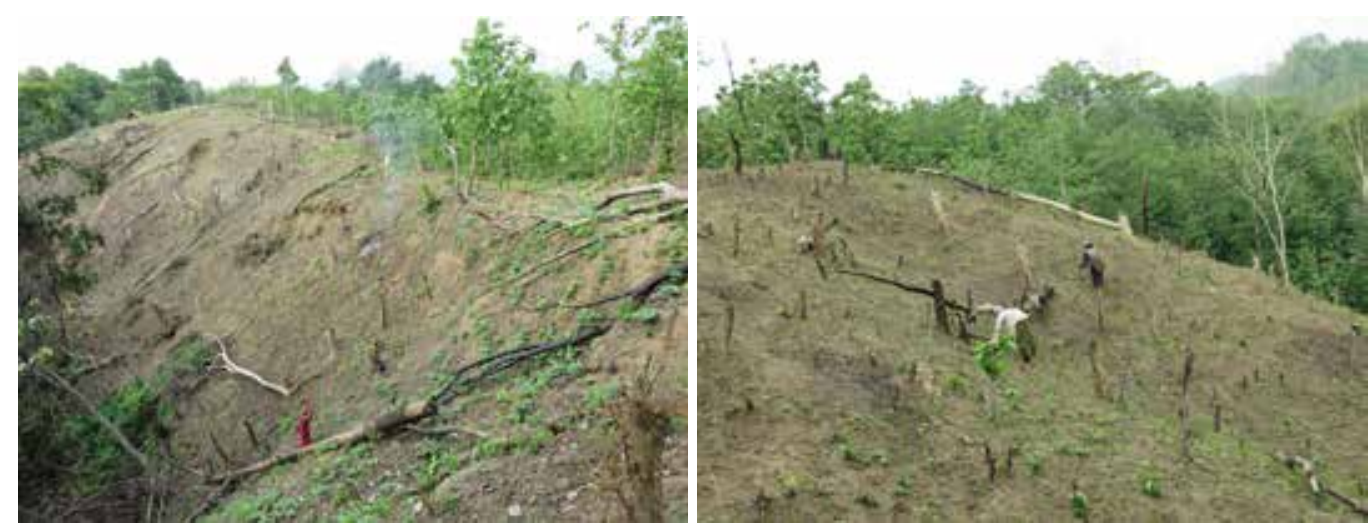

Family members sowing seeds in a shifting cultivation plot in Rangamati district (left) and weeding management after paddy cultivation in Bandarban district (right). (Ronju Ahammad/Charles Darwin University) 


\subsubsection{Plain land plough agriculture}

Ploughing agriculture is the most common type of farming in the plain lands of Bangladesh. The CHT region has much less area of plain lands and ploughing practices. Traditional practices by ethnic people involve digging soil with spades for cultivation instead of ploughing lands in their shifting plot. Ploughing was introduced by a small number of the lowland Bangalee migrants during the 1870 s (Islam et al. 2007). With higher amounts of food production, plough cultivation expanded in all plain lands of the region and ethnic people since that time. Ploughing agriculture is only prevalent in valleys, riverbanks and lower slopes of the region.

The total cropped area under plough cultivation is much less in CHT compared to the other plain land regions of Bangladesh. Valleys and floodplains suitable for plough agriculture cover only $3.2 \%(270,812 \mathrm{ha})$ of the total land in the region. At present, less than one-fifth of these lands can be cultivated through ploughing for producing rain fed and irrigated agricultural crops (GoB and FAO 2013). The size of plain land declined in the region due to submersion of the cultivable lands after establishment of a hydroelectric dam resulting in approximately 21,850 ha of plain lands (which covered $40 \%$ of the best productive lands) being inundated (Olarieta et al. 2007).

Rice paddy, tobacco, sugarcane, maize, groundnuts, beans, different vegetables and fruit species are cultivated with the plough technology in the plain lands. The cropping intensity is still lower and often a single season farming is maintained for intensive and monoculture crop cultivation. Though there are increasing amounts of crop production in the plain lands in recent years, the overall productivity of this farming system is still lower compared to other areas of Bangladesh. However, plough cultivation provides opportunities for increasing cash crop cultivation with sugarcane, maize, tobacco, vegetables and rice.

\subsubsection{Alternative land-use practice}

In the last few decades, alternative land uses with horticulture (orchards) with or without timber trees have increased in CHT. Bala et al. (2012) point out that horticulture covers $28 \%$ of the land. Most of this land use are spatially distributed in the form of a patch of monoculture fruit plant (i.e. mango, pineapple) or mixed with different annual crops and trees. The average size of the horticultural plots vary from 0.2-0.4 ha.

Maintaining natural or cultivated trees alongside agricultural croplands is a common land-use practice in Bangladesh. Often this is characterized by planting trees in the vicinity of shelters or between shelters and agricultural land in rural areas. These agroforestry systems provide food, timber, NTFPs and fuelwood (Rahman et al. 2014). This type of crop and tree combination is also widespread in different forms across the region.

In traditional shifting cultivation, farmers usually retain a number of trees or fruit species for restoring soil fertility, improving biodiversity and harvesting of foods in successive years. However average tree size and numbers have decreased in this shifting cultivation practice to some extent due to short fallow periods and over-felling. Many studies have identified this type of land use as less suitable for enhancing food production in the CHT region. Modification of land uses with multi-strata agroforestry system, consisting of a combination of trees, fruit plants and crops is an intensive land use for increasing food production and restoring soil nutrients. 


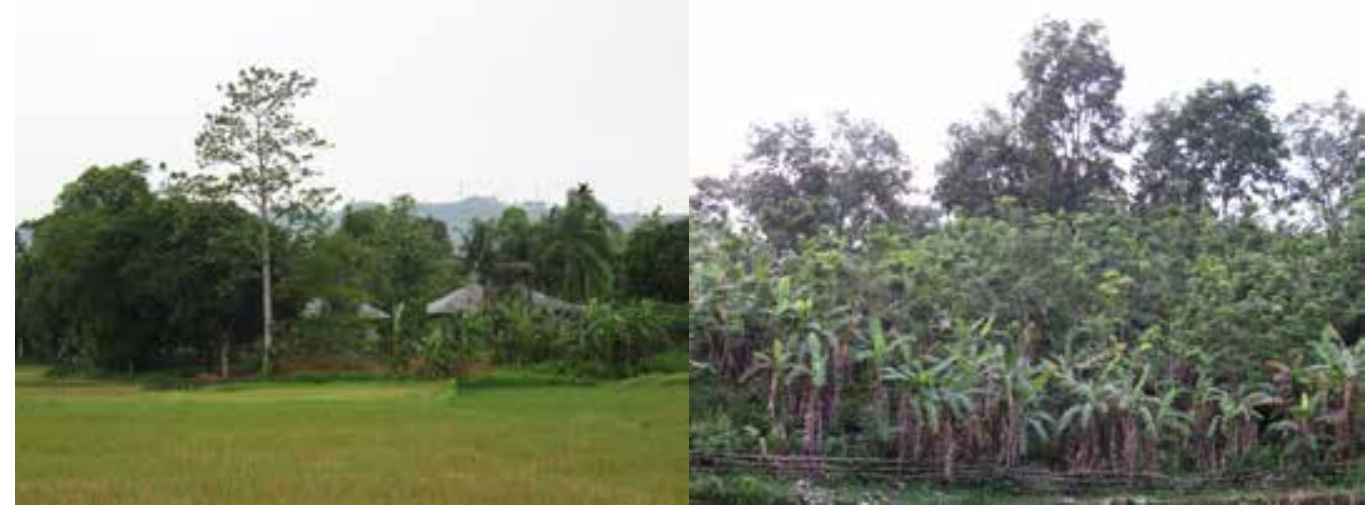

Trees and paddy land - a common agroforestry system (left), and fruit-and tree-based intensive agroforestry system (right) in Khagrachari. (Ronju Ahammad/Charles Darwin University)

\subsection{Land-use changes in the Chittagong Hill Tracts region}

The degradation of forest resources puts food production and biodiversity conservation at risk in CHT. Historically, shifting cultivation practices caused a loss in forest area and increased soil erosion. Over-harvesting of forest products during the colonial period, lack of effective national forest policy for the region and development practices at local level have triggered further deforestation. During the 1960 s to the 1980 s, population growth and mismatch of local development interventions followed by the construction of a large hydroelectricity dam further exacerbated land-use changes in CHT. In this section, we discuss key trends, the current state of land-use change, and their implications for food security and conservation. Most findings in the following section are sourced from literature and personal discussions with institutional interview respondents.

\subsubsection{Agricultural land-use changes}

Shifting cultivation is a major agricultural land use for local food production in the region although it has undergone changes in terms of fallow period, cropping patterns and productivity. Traditionally it was a more extensive land-use type for production and diverse annual foods in this forest landscape. Until the middle of the last century, traditional people maintained a 10-12 year fallow period for this land use that was effective for the enrichment of forest vegetation and essential soil nutrients in lands.

Studies have indicated that the land-use system changed through the decline of the fallow period (3-4 years) to maximize annual food production given the shortage of land (Rahman et al. 2012). Again, farmers previously cultivated a much larger number of crop varieties ( $>35$ different annual crops) in their traditional practices with minimal inputs. At present, they only cultivate 3-4 annual crops and perennial fruit varieties for subsistence needs and for increasing their cash income.

Trends in these changes were observed during the scoping study. Cultivation of cash crops, fruits and/or monoculture tree plantations has increased in recent decades in CHT. People either cultivate a single crop or a mixture of crops (two to three types) and/or fruit trees 
using large quantities of fertilizers and pesticides. The annual crop cover includes spices (turmeric and ginger) with rice paddy, cotton, maize, vegetables, beans and seasonal fruits (mainly lemon, mango, jackfruit and cashew apple). Compositions of these cash crops vary in terms of land type (hills or plains), ownership, land size and access to roads/markets. Evidently people cultivate only two to three types of agricultural crop or fruit plants in the traditional shifting cultivation system. Monoculture crop cultivation increased on a seasonal basis and was dominated by rice paddy, tobacco and seasonal vegetables in the plain lands (Table 6.3).

\section{Table 6.3 Historical trends of forest and agriculture land-use changes, their causes and effects in Chittagong Hill Tracts.}

\begin{tabular}{|c|c|c|c|}
\hline Land-use types & Key changes & $\begin{array}{l}\text { Underlying } \\
\text { causes }\end{array}$ & $\begin{array}{l}\text { Effects on food security } \\
\text { and ecosystems }\end{array}$ \\
\hline $\begin{array}{l}\text { Agriculture land } \\
\text { use until 1970s: } \\
\text { - Shifting } \\
\text { cultivation with } \\
\text { a long fallow } \\
\text { period ( }>10 \\
\text { years) } \\
\text { - Low level of } \\
\text { agriculture } \\
\text { input systems } \\
\text { and subsistence } \\
\text { oriented } \\
\text { - Much more } \\
\text { forest vegetation } \\
\text { - Diversity of } \\
\text { annual crops }\end{array}$ & $\begin{array}{l}\text { After } 1970 \text { and to date: } \\
\text { - Decrease of fallow } \\
\text { period in shifting } \\
\text { cultivation } \\
\text { - Intensive cultivation of } \\
\text { lands with agriculture } \\
\text { inputs (i.e. fertilizer, } \\
\text { water and labor) } \\
\text { - Increased cash crop } \\
\text { production (mainly } \\
\text { horticulture, lower } \\
\text { yields of annual crops } \\
\text { e.g. ginger, turmeric, } \\
\text { paddy, tobacco, } \\
\text { maize etc.) } \\
\text { - Increased use of } \\
\text { plough agriculture for } \\
\text { cultivation of cash crops }\end{array}$ & $\begin{array}{l}\text { - Limited land } \\
\text { availability and } \\
\text { accessibility } \\
\text { - Lower } \\
\text { productivity of } \\
\text { land } \\
\text { - Population } \\
\text { growth } \\
\text { - Loss of forest } \\
\text { vegetation and } \\
\text { soil nutrients }\end{array}$ & $\begin{array}{l}\text { Positive: } \\
\text { - Increased food quantity of } \\
\text { few crop varieties and cash } \\
\text { incomes } \\
\text { - Limited forest area or land } \\
\text { required for cultivation } \\
\text { Negative: } \\
\text { - Less numbers of food crops } \\
\text { cultivated } \\
\text { - Loss of locally available food } \\
\text { crops and seed sources }\end{array}$ \\
\hline $\begin{array}{l}\text { Forestland uses } \\
\text { until 1960s: } \\
\text { Intact forests of } \\
\text { natural origin } \\
\text { A good numbers } \\
\text { of watersheds } \\
\text { (annual and } \\
\text { perennial for } \\
\text { major water } \\
\text { supply to the } \\
\text { local population) }\end{array}$ & $\begin{array}{l}\text { Fragmentation of } \\
\text { natural forests into } \\
\text { semi-natural or mixed } \\
\text { ecosystems (bamboo } \\
\text { with timber) or large } \\
\text { grasslands } \\
\text { - Man-made intensive } \\
\text { plantations of } \\
\text { commercially important } \\
\text { timber plants (teak) } \\
\text { increased in both } \\
\text { government and } \\
\text { private lands } \\
\text { Rubber and different } \\
\text { pulp wood species } \\
\text { increased as raw } \\
\text { materials for } \\
\text { government and private } \\
\text { industries }\end{array}$ & $\begin{array}{l}\text { - Excessive } \\
\text { logging for } \\
\text { government } \\
\text { revenue } \\
\text { earning and } \\
\text { infrastructural } \\
\text { development } \\
\text { - Illegal logging } \\
\text { of trees and } \\
\text { encroachment } \\
\text { of forest areas } \\
\text { - Clear felling } \\
\text { methods } \\
\text { - Pressures for } \\
\text { increasing } \\
\text { shifting } \\
\text { cultivation areas } \\
\text { Increased } \\
\text { demand for raw } \\
\text { materials for } \\
\text { industries }\end{array}$ & $\begin{array}{l}\text { Positive: } \\
\text { - Increased cash incomes } \\
\text { in a small number of } \\
\text { households } \\
\text { Negative: } \\
\text { - Increased intensive use of } \\
\text { commercial plantations, } \\
\text { reduced agriculture } \\
\text { cultivation areas } \\
\text { - Declines of availability } \\
\text { of forest and NTFPs can } \\
\text { affect the livelihoods of } \\
\text { subsistence users } \\
\text { - Loss of watershed affects } \\
\text { forest ecosystem services } \\
\text { (i.e. small fish catch, } \\
\text { irrigation, daily use of } \\
\text { household water, climate } \\
\text { regulation etc.) }\end{array}$ \\
\hline
\end{tabular}


In the long term, shifting cultivation may not be environmentally and economically appropriate in the region (Rasul and Thapa 2006; Bala et al. 2012; Rahman et al. 2012), where it is thought modification of shifting agriculture with intensive crop and fruit cultivation can reduce soil erosion, sustain production and meet the burgeoning demand for food. Different regional (CHTDB) and local government agencies (Department of Agriculture Extension) also attempted to change agricultural systems with either horticulture or rubber-based agroforestry practices at different scales. Recently, NGOs have also promoted horticulture-based land uses. However, the trends and effects of intensification for enhancing food security and the relationships with conservation of forests are not evident or documented.

\subsubsection{Forest land-use changes}

Historically, CHT was designated for forest resources, particularly as a source of timber harvesting in Bangladesh (Rasul 2007). But most of the forestlands are barren, covered with grass or with scattered trees and bamboo. At present, forest areas cover almost $70 \%$ of the total lands that are either natural, planted or grasslands with scattered timber trees and bamboo in the region. Natural forest only covers approximately 72,000 ha or only $15 \%-20 \%$ of the total forestlands in CHT. The remaining area is largely secondary forest with mixed natural and planted forests (i.e. a mix of naturally regenerating bamboo and planted timber species) and monoculture planted forests.

Most of the primary forest declined between 1700 and 1800 in the region, although there is no accurate information available on forest cover change for that period. Limited information on CHT for the periods 1960-80 and 1990-2005 show that natural forest cover declined during this time (FAO 2010). Data on historical changes in Kassalong and Rankhiang, the two major reserves in the region, showed that in 1963, natural forest cover was 172,000 ha, which declined to 84,000 ha in 1990 and to 70,000 ha in 2005 (FAO 2010).

Forest cover changes in $\mathrm{CHT}$ are due to the conversion of large areas into nonforestlands (i.e. agriculture, grassland and scattered tree patches). Tree harvesting and shifting cultivation has caused degradation of the forest landscape in CHT (Islam et al. 2007; Rasul 2007; Rahman et al. 2012). A gradual loss of trees either for revenue generation or through illegal felling and clearing/burning practices in shifting cultivation has increased the area of non-forestlands. Encroachment and illegal felling has caused the loss of 21,000 ha of planted forests and valuable trees of regenerating capacity in natural forests (e.g. garjan - Dipterocarpaceae spp.) throughout the region (Khan et al. 2012).

Deforestation is still higher in CHT compared to other forested areas of Bangladesh, although areas of monoculture plantations have increased or remained stable since the 1990s (FAO 2010). Altogether, approximately 90,000 ha of forested land (either natural or planted with timber and bamboo forests) have been converted into agriculture lands or grasslands (Khan et al. 2012). But the forest cover change on barren land is much higher at about 287,461 ha of lands (GoB and FAO 2013). 
The underlying reasons for deforestation in the region are often related to agriculture systems and institutional arrangements. The state forest policy has inadequately addressed local realities and ecosystem capacity in the region. They focused on nationalization of forests with a focus on logging to feed the wood industries. Intensive plantation programs with monoculture species (mainly teak and gamar [Gmelina arborea]) for commercial clear felling caused severe loss of natural vegetation, soil nutrients and biodiversity. The construction of the Kaptai Hydroelectricity Dam in the 1960 s affected 22,000 ha of forest and agricultural areas and displaced local ethnic groups from available cultivable lands.

Higher population growth in the region will cause direct and indirect pressures on forests and agriculture land uses for food production. Forest uses may be higher among the ethnic people in this region compared to other areas of the country. A range of traditional forest uses exists in the region for energy, wild foods, shelter and water. However, the trends in historical forest cover change may threaten the whole landscape in terms of declined ecosystem services necessary for local, regional, national and global benefits.

\subsection{A brief summary of conservation practices in Chittagong Hill Tracts}

The CHT region is topographically diverse with steep hills slopes, valleys and plain lands. This is one of few ancient formations of largely igneous rock in the Hindu Kush Himalayas (Khan et al. 2012). Most of its landforms comprise forests or grasslands, farming areas and watersheds. Historically, forest loss and agriculture land-use changes caused threats to loss of biodiversity including plants and animals, soil erosion and degradation of watersheds. The region remains a major focus for conservation practice as a way to improve biodiversity, ensure associated social and environmental benefits and sustain food production. Here we explain the conservation efforts in terms of forest and agricultural land uses in the region based on the available literature.

\subsubsection{Forest conservation}

Forests are an important repository of biodiversity, with the highest concentration of endemic species in the country found in CHT (Khan et al. 2012). However, there are no accurate estimates of total plant and animal populations currently available in the region. Over 20 different animals have become extinct in the last century or are facing various threats. Another 25 plant species are under threat of becoming extinct in the near future (Khan et al. 2007). As such, conservation of forest biodiversity is important to sustaining the valuable benefits it provides for the region. Many of the plant species have important medicinal uses. At least 69 plant species identified by local ethnic people contribute to primary health care (Khan et al. 2012). However, identification of total biodiversity and appropriate conservation efforts are poor at both local and national levels. 
There are a few significant conservation efforts that the government has taken to date in the region. Most of the Forest Department's initiatives were centered on declaration of reserve forests, facilitating plantations and establishing management boundaries. Three large forest reserves (Sanghu-Matamuhuri, Kassalong and Rankhiang) consist of fragmented forest patches of natural and planted ecosystems. Two protected areas declared during 1980-90 are Pablakhali Wildlife Sanctuary (42,087 ha) and Kaptai National Park (5464 ha) (BFD 2015). However, there is not any systematic assessment of biodiversity in these reserves or protected areas.

From the 1970 s to early 2000 the Forest Department also implemented plantation programs to restore degraded forest ecosystems (Khan et al. 2007). But monoculture plantation with teak and gamar trees in their program has increased vulnerability of the land system in the region. Teak planted areas often have lower undergrowth and little regrowth of natural vegetation. Soil erosion is one of the major problems in teak-based tree ecosystems, as it has caused degradation of natural watersheds (Hossain 2003).

During the 1980 s and 1990s, the CHTDB also undertook fruit- and rubber-based agroforestry programs on 6986 ha of land for settling shifting cultivation practices (GoB and FAO 2013). The goals of the programs were to increase agroforestry practices for cultivating crops and to increase fruit/timber tree cover. It was thought that limiting the expansion of shifting cultivation practices might reduce loss of trees. However, the monoculture plantation approach failed to achieve conservation benefits due to the focus on increasing tree cover rather than restoring biodiversity (Islam et al. 2007). Though horticulture can have potential economic benefits, remote locations and limited market access constrains its long-term success.

Lack of adequate studies on biodiversity has thwarted effective evidence-based conservation practices for the region. The decline of natural forest is not well recorded or the government has not identified the remaining areas to be conserved. A few small patches of natural forest cover (approximately 700-800 ha) scattered throughout CHT are still sources of valuable plants and watersheds though these have not been largely recognized in national policy and practices (Khan et al. 2012). As part of traditional systems, communities manage these natural forest patches (i.e. sizes from 3-260 ha) as common resources for maintaining environmental health, in particular protecting watersheds. Since 1800, this type of natural forest was designated as village forest and this is still unique compared to other areas of the country.

There was no formal or external support undertaken for demarcation of spatial boundaries and documentation of any changes in biodiversity status of this forest commons. Only recently has this type of forest common received formal recognition and some NGOs have identified their spatial distribution and biodiversity. Community forests are now available in 112 patches across CHT. The village headmen that control the mauza maintain oral or written rules about activities (dos and don'ts) within these forests. The Arannayk Foundation (a national organization) has supported the community to effectively manage the forest and watersheds in a few areas and established a local management committee for monitoring and stopping any illegal felling, hunting, clearing and fire activities within the forest and nearby watersheds. 


\subsubsection{Conservation in agriculture systems}

Conservation of soil and sustainable food production are twin development issues in CHT. Food productivity in shifting cultivation systems has declined due to soil erosion and associated reduction in essential soil nutrients (Islam et al. 2007). Conversely shifting cultivation has also been blamed for increasing soil erosion and unsustainable land uses. Until the 1980 s there were also not sufficient programs for the improvement of these farming systems. In a few cases, the Department of Agriculture Extension and the CHTDB undertook experimental agroforestry and horticulture practices to conserve soil nutrients and improve farming in fragile hill slopes. Agroforestry systems comprise a modification of shifting cultivation into a combination of multistoried vegetation (crops, fruit and timber). In this type of practice, land remains covered with vegetation and soil erosion is reduced.

Improvement of existing agriculture systems gained momentum due to pressures of a large population on the limited lands to increase food production in the region. Bulk studies on CHT largely indicated that short-rotation in shifting cultivation for annual cropping has negative effects on ultimate food production capacity of the lands (Miah and Islam 2007; Rasul 2009; Rahman et al. 2014). By contrast, they emphasized fruit/tree-based systems as beneficial for conservation of soils, restoration of forests and enhancing food security. But switching into sustainable agriculture systems is still difficult due to existing demands for annual foods over the required long-term investments, time and constraints in tenure access.

\subsection{Potential land-use zones in Chittagong Hill Tracts}

Land uses in CHT can be divided into three broad zones (1, 2 and 3) depending on land use types, ethnic composition, population density, accessibility and crop intensity (Figure 6.7). Here we discuss the key characteristics of three land-use zones identified for the purpose of the Agrarian Change Project.

\section{Zone 1}

This zone covers the southeast part of Rangamati district and is bounded by Mizoram State of India on the east side (Figure 6.7). The zone is located in Farua union within Belaichari subdistrict in Rangamati district.

The only way to access the area is from Rangamati town by water transportation. Kaptai Lake separates the area from Rangamati town. People have to use water transport (motorized boat) to travel to the market and district town and it takes about 2-3 hours.

Most human settlements have developed in the center of the hills near to two community managed natural forests (each range from 70-90 ha on average). Kaptai National Park and government reserve forests are located within $45 \mathrm{~km}$ of the settlements. Households are sparsely distributed due to the nature of their farming systems and changing locations of shifting cultivation. Ethnic cultures also influence the settlement system. For instance, the Chakma community tend to scatter themselves, the Marma live closely together, the Mrung community live on the top of hills and the Tanchangya live in dense jungles or in remote locations. 


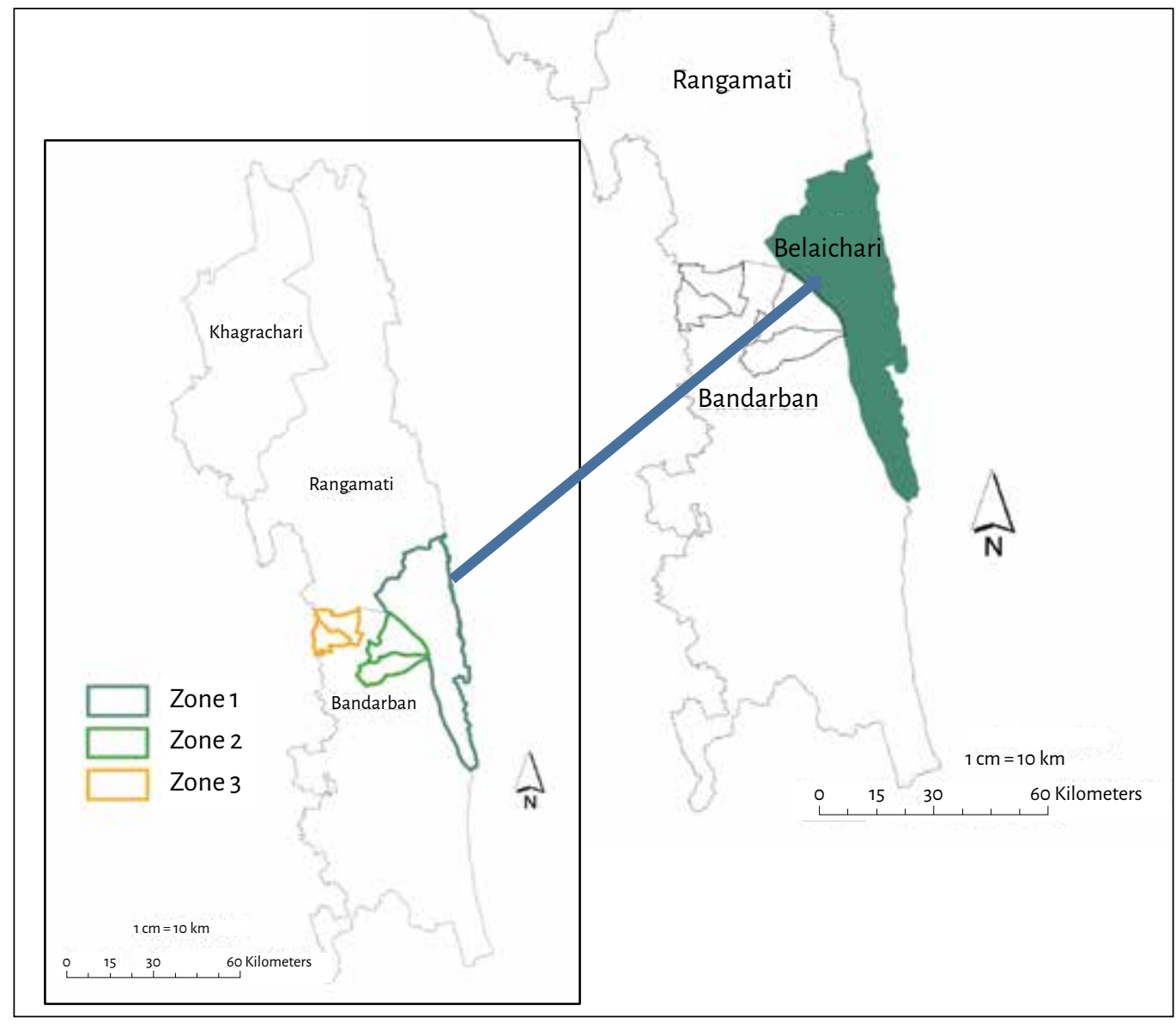

Figure 6.7 Map of potential land-use Zone 1 in the Chittagong Hill Tracts region of Bangladesh.

Source: Adapted from LGED (2015)

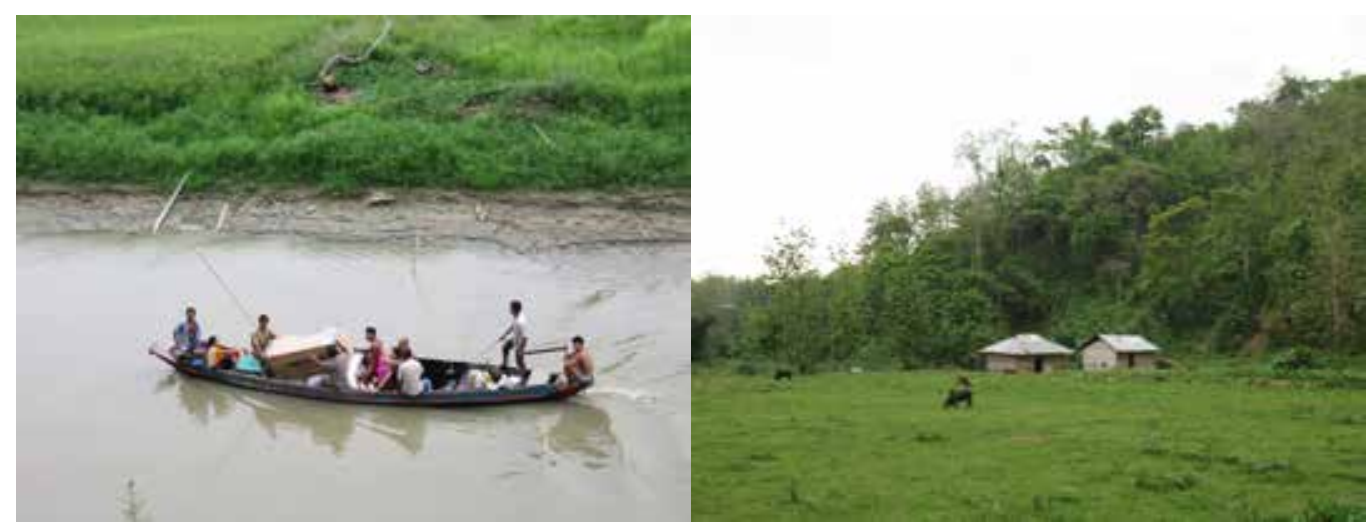

The main transportation system (left) and land used for single cropping subsistence farming (right) in Zone 1. (Ronju Ahammad/ Charles Darwin University) 
In the villages, people usually walk long distances carrying agricultural produce and necessary goods to visit local shops and neighbors. Both valley/plain lands and hill slopes are used for farming. A part of the lower lands remain seasonally submerged by water that is only cultivable for single season crop or fallow for cattle grazing. Key features of Zone 1 are summarized in Table 6.4. Four villages of Uluchari, Chainda, Pangkhu and Marma villages were selected for further study in this zone.

Table 6.4 Salient features of Zone 1.

\begin{tabular}{|c|c|c|}
\hline Features & \multicolumn{2}{|c|}{ Description of the zone } \\
\hline Potential sites & \multicolumn{2}{|c|}{$\begin{array}{l}\text { The site is located in Farua union within Belaichari subdistrict under Rangamati } \\
\text { district. Uluchari, Chainda, Pangkhu and Marma villages are selected for further study } \\
\text { in this zone. }\end{array}$} \\
\hline Population density & \multicolumn{2}{|c|}{ Average 46 persons per $\mathrm{km}^{2}$} \\
\hline Ethnic groups & \multicolumn{2}{|l|}{$\begin{array}{l}\text { - Chakma } \\
\text { - Tanchangya } \\
\text { - Pangkhua } \\
\text { - Marma }\end{array}$} \\
\hline Livelihood activities & \multicolumn{2}{|c|}{$\begin{array}{l}\text { - Agriculture } \\
\text { - Seasonal wage labor (agriculture) }\end{array}$} \\
\hline Land-use types & \multicolumn{2}{|c|}{$\begin{array}{l}\text { - More than } 90 \% \text { people use lands for agriculture to meet subsistence uses and income } \\
\text { - Farming of different seasonal agriculture crops mainly paddy, beans, vegetables, } \\
\text { tubers and turmeric } \\
\text { - Single season for rice cultivation on valleys and hill slopes } \\
\text { - Seasonal fallow lands used for cattle grazing and source of wild vegetables }\end{array}$} \\
\hline Agricultural crops & $\begin{array}{l}\text { Cash crops: } \\
\text { - Banana } \\
\text { - Groundnut } \\
\text { - Turmeric } \\
\text { - Beans }\end{array}$ & $\begin{array}{l}\text { Subsistence crops: } \\
\text { - Vegetables ( } 40 \% \text { cultivated and } 60 \% \text { wild sources) } \\
\text { - Paddy }\end{array}$ \\
\hline \multicolumn{2}{|l|}{ Forest types } & $\begin{array}{l}\text { - Semi-natural forest patches } \\
\text { - Mixed trees of bamboos, timber plants, herbs and shrubs } \\
\text { - Monoculture teak plantation }\end{array}$ \\
\hline \multicolumn{2}{|c|}{ Distance to forest reserves } & Government forest reserve (o-1 km) \\
\hline \multicolumn{2}{|l|}{ Accessibility to market } & 2 hours travel by boat \\
\hline \multicolumn{2}{|l|}{ Forest ownership } & Government owned forest reserve \\
\hline Forest uses & \multicolumn{2}{|c|}{$\begin{array}{l}\text { - Fuelwood (100\%) } \\
\text { - NTFPs, mainly bamboo } \\
\text { - Building materials } \\
\text { - Agriculture implements (e.g. a different size of crop/food grain store tool) }\end{array}$} \\
\hline Electricity & \multicolumn{2}{|c|}{$\begin{array}{l}\text { - More than } 80 \% \text { use kerosene for lighting } \\
\text { - A small use of solar panel }\end{array}$} \\
\hline Health services & \multicolumn{2}{|c|}{$\begin{array}{l}\text { - A small, temporary clinic provides primary health services } \\
\text { - No government facilities }\end{array}$} \\
\hline
\end{tabular}




\section{Zone 2}

This zone falls in the southwest part of the $\mathrm{CHT}$ region and covers Rowangchari subdistrict in Bandarban district (Figure 6.8). The settlements are established in the valleys and on hill slopes and are located within $10-15 \mathrm{~km}$ of government reserve forests; there are no access rights to the government reserves except where there is private ownership of land within the reserves.

The area is well connected to the main town of Bandarban district. The north of the zone is bound by Rangamati district. It takes 30 minutes to travel to nearby markets/rural growth centers and 1 hour to reach Bandarban town depending on the mode of transport used (bus/motorbike) (Table 6.5).

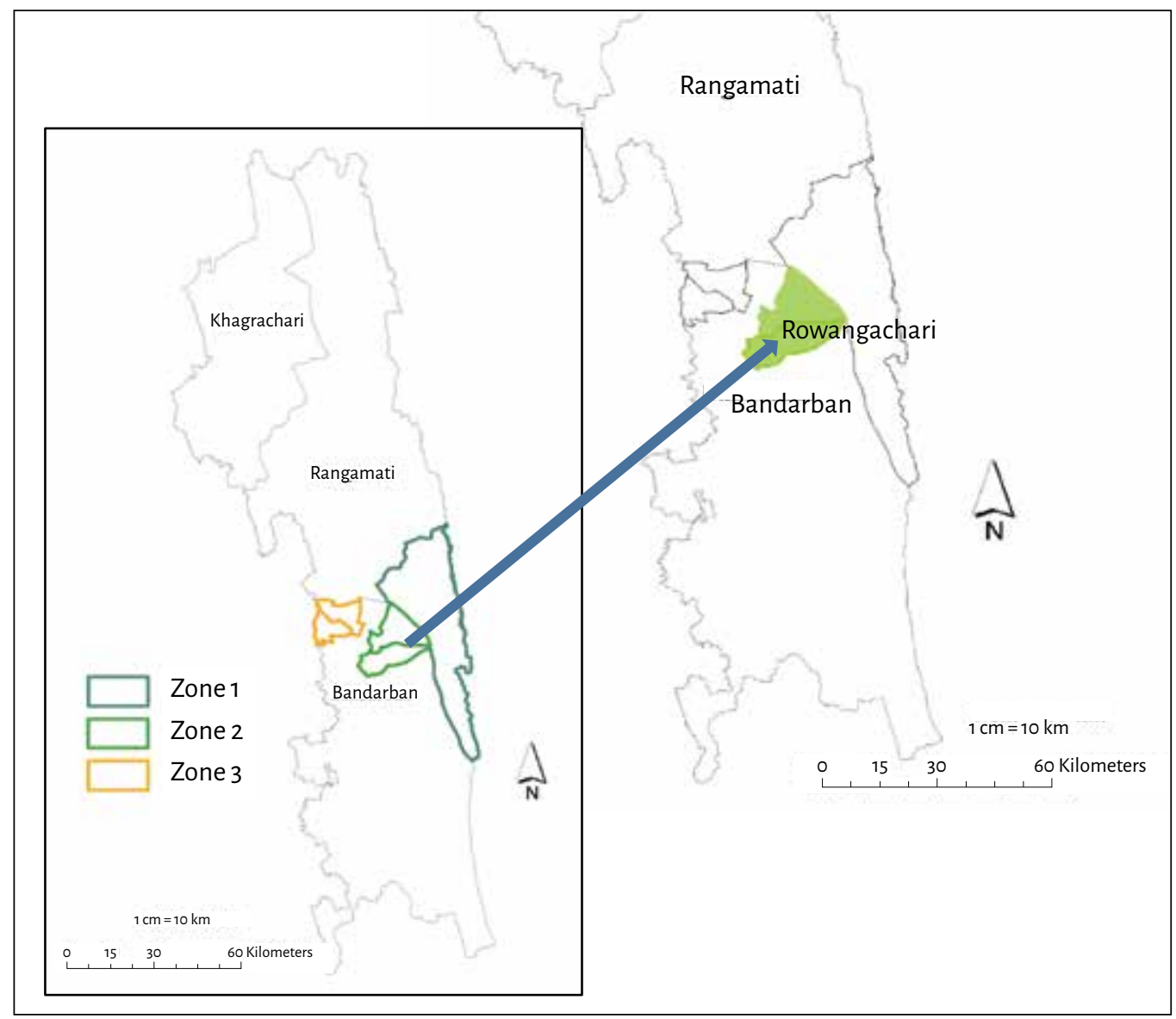

Figure 6.8 Map of potential land-use Zone 2 in the Chittagong Hill Tract region of Bangladesh.

Source: Adapted from LGED (2015) 


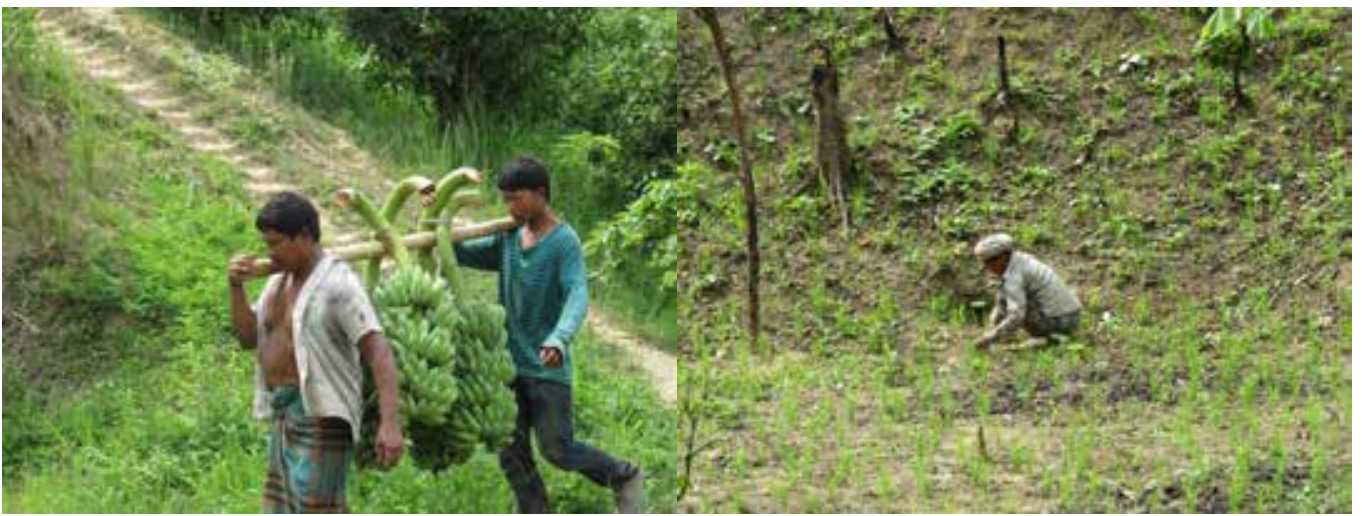

Banana for subsistence use and cash income (left) and subsistence cultivation of rice crop (right) in Zone 2. (Ronju Ahammad/ Charles Darwin University)

\section{Table 6.5 Salient features of Zone 2.}

\begin{tabular}{|c|c|c|}
\hline Features & \multicolumn{2}{|l|}{ Description of the zone } \\
\hline Potential sites & \multicolumn{2}{|c|}{$\begin{array}{l}\text { The site is located in Rowangchari and Alikhyong union of Rowanchari } \\
\text { subdistrict in Bandarban district. } \\
\text { The four villages selected are Suanlu para, }{ }^{a} \text { Paglachera para, Aungad para and } \\
\text { Bijoy para. }\end{array}$} \\
\hline Population density & \multicolumn{2}{|l|}{ Average 62 persons per $\mathrm{km}^{2}$} \\
\hline Ethnic groups & \multicolumn{2}{|l|}{$\begin{array}{l}\text { - Tanchangya } \\
\text { - Bawm } \\
\text { - Marma }\end{array}$} \\
\hline Livelihood activities & \multicolumn{2}{|l|}{$\begin{array}{l}\text { - Farming } \\
\text { - Wage labor (agriculture) }\end{array}$} \\
\hline Land-use types & \multicolumn{2}{|c|}{$\begin{array}{l}\text { - About } 70 \% \text { of the lands are used for farming of different seasonal crops } \\
\text { - Different fruits (i.e. banana, mango, cashew apple) are important for } \\
\text { subsistence uses and cash incomes } \\
\text { - Agriculture on valleys and shifting cultivation along hill slopes } \\
\text { - Plantations with monoculture tree of teak }\end{array}$} \\
\hline Agricultural crops & $\begin{array}{l}\text { Cash crops: } \\
\text { - Banana } \\
\text { - Turmeric and ginger } \\
\text { - Cashew apples } \\
\text { - Ground nuts } \\
\text { - Maize } \\
\text { - Fruits (mango, lemon, pineapple) }\end{array}$ & $\begin{array}{l}\text { Subsistence crops: } \\
\text { - Vegetables } \\
\text { - Paddy }\end{array}$ \\
\hline Forest types & \multicolumn{2}{|l|}{$\begin{array}{l}\text { - Community-owned natural forest patches } \\
\text { - Government forest reserve } \\
\text { - Mixed tree and fruit garden } \\
\text { - Monoculture teak plantation }\end{array}$} \\
\hline Forest ownership & \multicolumn{2}{|c|}{$\begin{array}{l}\text { - Customary ownership (locally called para reserve) } \\
\text { - Government forest reserves }\end{array}$} \\
\hline
\end{tabular}


Table 6.5 (continued)

\begin{tabular}{|l|l|}
\hline Features & Description of the zone \\
\hline $\begin{array}{l}\text { Distance to forest } \\
\text { reserves }\end{array}$ & $\begin{array}{l}\text { - Community forest reserve }(2-4 \mathrm{~km}) \\
\text { - Government forest reserve }(10 \mathrm{~km})\end{array}$ \\
\hline $\begin{array}{l}\text { Accessibility to } \\
\text { market }\end{array}$ & Half an hour travel on foot to regional market \\
\hline Forest uses & $\begin{array}{l}\text { - } 90 \% \text { of the people depend on fuelwood for cooking } \\
\text { - } 70 \%-80 \% \text { use NTFPs (mainly bamboo) for own uses and cash incomes }\end{array}$ \\
\hline Electricity & $\begin{array}{l}\text { - } 50 \%-60 \% \text { of the area covered with grid electricity } \\
\text { - Solar energy is also used }\end{array}$ \\
\hline Health services & Government and non-government community clinic available \\
\hline
\end{tabular}

a A village is locally known as a para.

Source: BBS (2015)

\section{Zone 3}

The zone covers the southeastern part of $\mathrm{CHT}$ and falls within the Bandarban subdistrict in Bandarban district (Figure 6.9). The west side of the zone is bordered by Cox's Bazar district, which has one of the world's largest coastal beaches and is a major tourism attraction in Bangladesh. The Sanghu-Matamuhri forest reserve is located on the east side of the zone.

This zone has the largest population compared to other areas of the CHT region. There is a diversity of ethnic groups including local ethnic populations (Marma, Bawm, Tanchangya, Mrung) and Bangalee people, who have coexisted throughout the last century in the area. A number of national and multinational companies have invested in tobacco-based agro-farming and rubber gardens to promote industrial raw materials. Road transport, availability of lands and government institutional support have allowed for easier access to company's investments (Table 6.6).

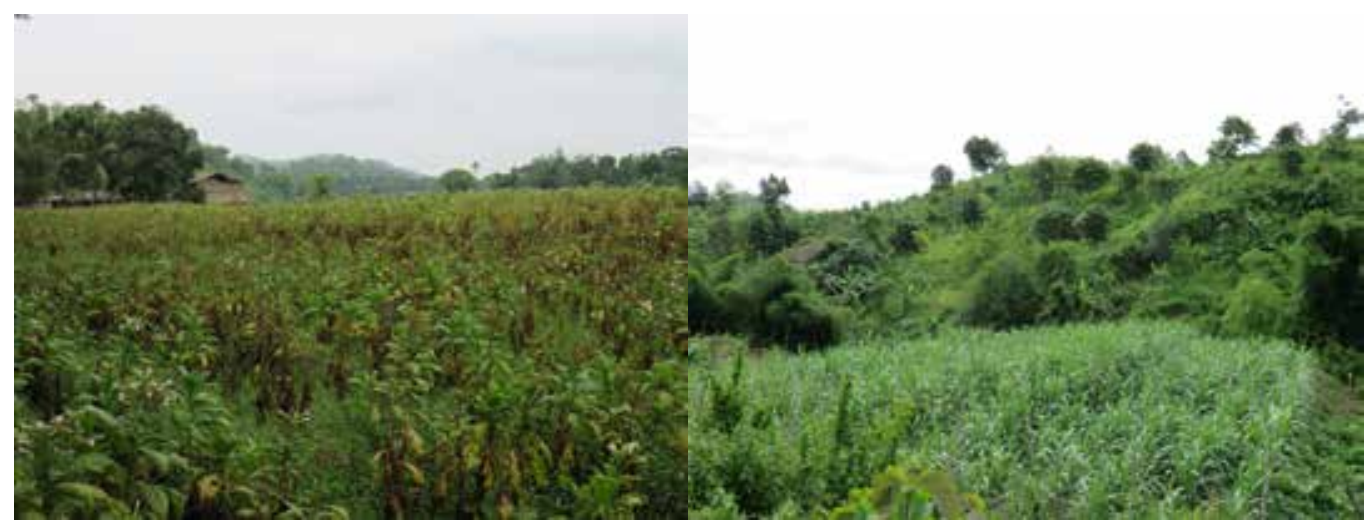




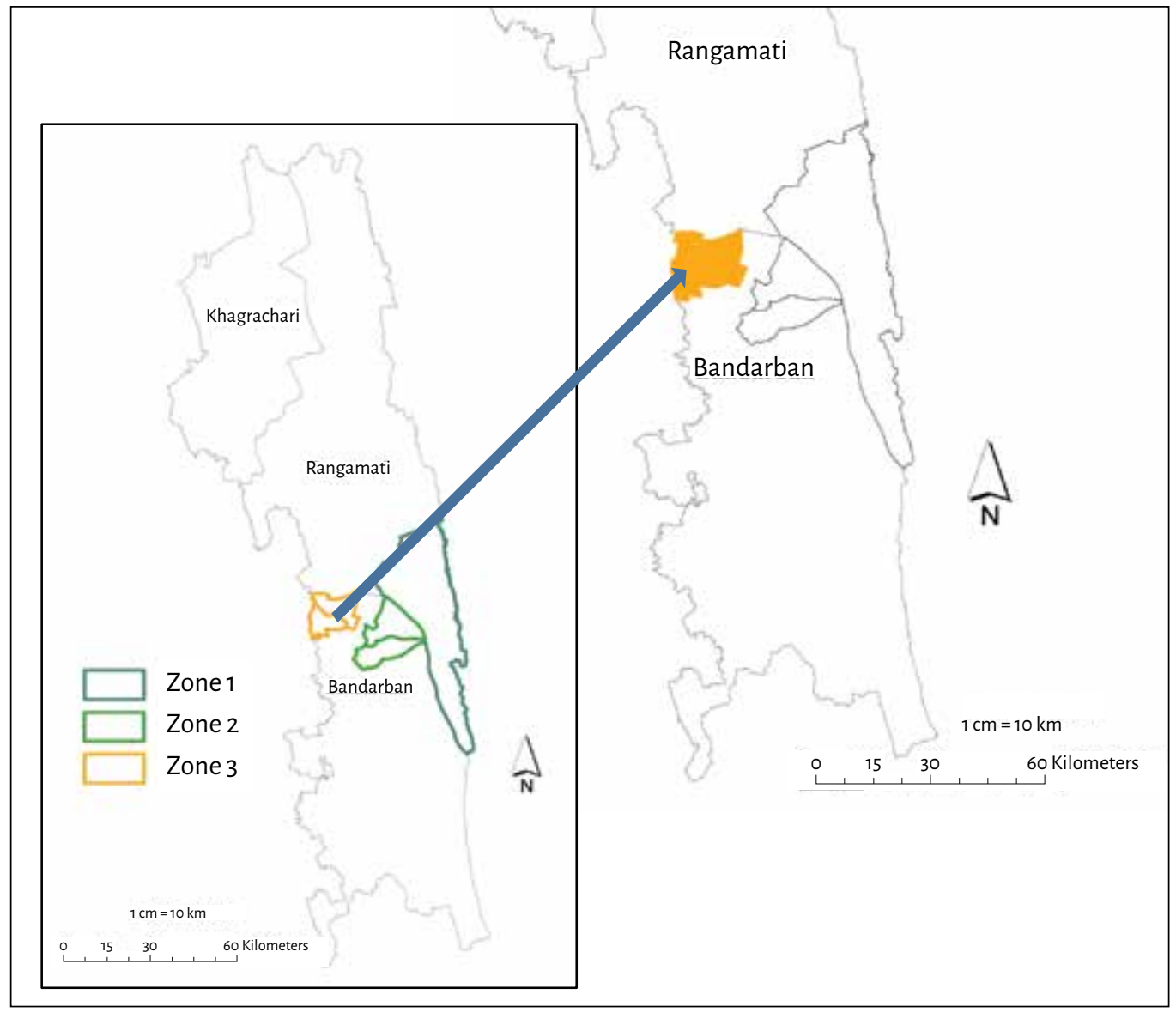

\section{Figure 6.9 Map of potential land-use Zone 3 in the Chittagong Hill Tracts region of} Bangladesh.

Source: Adapted from LGED (2015)

\section{Table 6.6 Main features of Zone 3.}

\section{Features}

1. Potential sites

2. Population density

3. Ethnic groups

4. Livelihood activities

\section{Description of the zone}

The zone covers (Khamadang para, Bagmara Headmanpara, Jogesh Karbaripara and Kamalong para) under Rajvila and Kuhalong union of Bandarban subdistrict in Bandarban district.

Average 100-120 persons per $\mathrm{km}^{2}$

- Marma

- Chakma

- Tanchangya

- Farming

- Business (i.e. mainly agriculture related crops, fisheries and timber/fuelwood/ NTFPs)

-Wage labor in agriculture, sawmills, small mining etc. 
Table 6.6 (continued)

\begin{tabular}{|c|c|c|}
\hline Features & \multicolumn{2}{|l|}{ Description of the zone } \\
\hline 5. Land use types & \multicolumn{2}{|c|}{$\begin{array}{l}\text { - More than } 80 \% \text { people use lands for farming of cash crops including different } \\
\text { seasonal agriculture crops } \\
\text { - Intensive land uses with monocropping practices of tobacco and paddy. } \\
\text { - Plantations with monoculture of teak }\end{array}$} \\
\hline 6. Agriculture crops & $\begin{array}{l}\text { Cash crops: } \\
\text { - Tobacco } \\
\text { - Fruit (mango, papaya) } \\
\text { - Bean } \\
\text { - Seasonal vegetables }\end{array}$ & $\begin{array}{l}\text { Subsistence crops: } \\
\text { - Paddy }\end{array}$ \\
\hline 7. Forest types & \multicolumn{2}{|c|}{$\begin{array}{l}\text { Secondary tree vegetation mixed of degraded forest patches and plantations } \\
\text { Monoculture planted forests }\end{array}$} \\
\hline 8. Forest ownership & \multicolumn{2}{|c|}{$\begin{array}{l}\text { - Only government reserved forest exist where no access right for local } \\
\text { community } \\
\text { - Individual ownership in private forests }\end{array}$} \\
\hline $\begin{array}{l}\text { 9. Distance to forest } \\
\text { reserves }\end{array}$ & \multicolumn{2}{|c|}{ Government forest reserve (10-15 km) } \\
\hline $\begin{array}{l}\text { 10. Accessibility to } \\
\text { district market }\end{array}$ & \multicolumn{2}{|c|}{$\begin{array}{l}\text { 15-20 minutes travel to district market by taxi/ } 30 \text { minutes walking distance to } \\
\text { village market }\end{array}$} \\
\hline 11. Forest uses & \multicolumn{2}{|c|}{$\begin{array}{l}\text { - Timber for building construction and income generation } \\
\text { - About } 50 \% \text { use fuelwood for cooking while a number of people use for income }\end{array}$} \\
\hline 12. Electricity & \multicolumn{2}{|c|}{$\begin{array}{l}\text { - Most of area has grid electricity } \\
\text { - A few households also use solar energy }\end{array}$} \\
\hline 13. Health services & \multicolumn{2}{|c|}{ Available government health services } \\
\hline
\end{tabular}

Source: BBS (2015)

\subsubsection{Key agriculture crops and land uses in the three zones}

Agriculture cultivation with annual crops (food and non-food), perennial fruit and timber tree seedlings are grown in all the zones. Depending on cropping intensity, infrastructural characteristic and land-use patterns, there is a variation in overall contributions to subsistence and cash incomes. In Zone 3, tobacco, seasonal vegetables and sugarcane are the dominant cash crops. Different fruit-bearing plants such as pineapples, jackfruits, mangoes, lemons and bananas are also cash crops in Zone 2 . The fruit plants found in agroforestry systems (shifting cultivation plots) and home gardens provide subsistence income. Zone 1 is mostly dominated by annual crop cultivation and a small amount of fruit production that is mostly used for subsistence and limited to incomes to buy food. The key characteristics of the dominant crops and trees in the different land-use zones are summarized below.

\section{Fruit}

Fruit species are common sources of household foods and cash incomes in the region. Banana, pineapple, papaya, jackfruit, guava, lemon, litchi, mango, cashew apple and orange are the major fruit crops grown. Almost all crops have commercial values; 
Zone 2 has the largest cultivation area of all three zones. Easy access to markets, agriculture inputs and extension services are the key factors that determine production. Hill slopes used for shifting cultivation in the past are now being planted with single or multiple fruit species.

A few fruit varieties are also cultivated annually in shifting cultivation lands and in home gardens in Zone 2. Banana is mostly cultivated in shifting cultivation lands while jackfruit is common in traditional home gardens of Zone 2. Compared to Zone 3, these are for commercial purposes, not subsistence. Fruit plants are also available in Zone 1 but these are largely used for subsistence rather than cash income.

In the last few decades, fruit production areas have expanded in the three zones of CHT. At least $30 \%$ of total land uses currently cover different types of fruit plantation in the region (Bala et al. 2012). This land-use practice improves farming systems through retaining vegetation on land and increases the quantity of food produced. But the potential benefits to food security are yet to be seen due to ineffective management of multiple crops and application of different agriculture inputs, particularly the use of fertilizers and pesticides. Planting fruit species as a replacement or complementary to traditional shifting cultivation practices may decrease land degradation (i.e. soil erosion) in the long term. Maintaining essential and available sources of diverse crop and tree production will be important in Zone 1, where limited alternative livelihoods exist and land degradation is severe.

\section{Vegetables}

The CHT region has enriched sources of a wide range of vegetables compared to other parts of Bangladesh. Both cultivated and wild types of vegetables are in demand locally as direct food uses and economic benefits for rural households. The quantity of cultivated vegetable areas is higher in Zones 2 and 3. Farmers in these zones have availability of plain lands, access to markets, good quality seeds, fertilizers and advanced training for improved farming. A significant amount of vegetables produced in different seasons provide household income to the people in these two zones. People cultivate those vegetables that are in demand in local markets. Vegetable cultivation is highly seasonal; land is often used for vegetable cultivation as it is not suitable for paddy or other cash crops.

The quantity of cultivated vegetables is less in Zone 1 compared to the other two zones. Most of the people in this zone follow traditional practices of shifting cultivation for growing diverse types of crops in their single plot each year. This type of annual crop combination can only meet the subsistence needs of diverse foods including vegetables and cereals. Limitations include lack of access to markets and intensive agriculture inputs. Therefore, it is not possible to cultivate any specific commercial vegetables or cash crops. To a large extent, the food production capacity of the people living in Zone 1 has decreased due to lower land fertility and less availability of productive lands. Despite the practice of maintaining a good source of different traditional seeds for annual cultivation from year to year, the vegetables are only sufficient for subsistence and are not an adequate source of income. Often, communities in this zone depend on wild vegetables for reducing their food shortage risks. 


\section{Tobacco}

Tobacco is one of the six major cash crops alongside jute, cotton, sugarcane, tea, betel leaf and tobacco in Bangladesh. This is also one of the most important cash crops in almost all areas of CHT, particularly in Zones 2 and 3. Since 1984, the multinational British American Tobacco Company (BATC) has financed local growers on a contractual basis to cultivate tobacco. Now, there are about eight national companies involved in tobacco cultivation.

People cultivate tobacco in October-January and harvest in April-May of the following year. This largely occurs in Zone 3 where available plain lands are major areas for this non-food crop. In recent years, tobacco expansion increased by 304\% in the region (Akhter 2011). Initially there was 300 ha of tobacco farming in Bandarban, which increased to 1922 ha in 2005-6 - an increase of 540\%. In 2010-11, 4232 ha of land was cultivated with tobacco in Bandarban district (BBS 2011). The highest areas of tobacco farming are located in Bandarban and Khagrachari districts. At present, approximately 28,050 ha of land is cultivated for tobacco in Bandarban and 21,000 ha in Khagrachari (GoB and FAO 2013). This study reported the highest concentration of tobacco farming as a cash income in Lama subdistrict of Bandarban district.

Tobacco is largely grown as a monocrop by intensive farming (i.e. application of fertilizers, pesticides, irrigation and labor) for 6 months of the year. Although it has increasing acceptance among the local farmers as a cash crop, the economic benefits are less than the cost production inputs. As a result, there has been no increase in tobacco farming areas since 2007/2008 season. At present, tobacco farming competes with at least 20 food crops, causing a decline in availability of local food production areas and soil fertility. There are also negative effects on forests as tobacco curing, packaging and rolling tobacco for cigarettes requires a huge amount of fuelwood.

\section{Sugarcane}

Cultivation of sugarcane as a cash crop in the region is a growing prospect. In Zone 3, better communication, access to markets and extension services favor crop production. Plain lands and soil conditions are important for crop production, which is more available in Zones 2 and 3. At least 2300 ha of land were cultivated for sugarcane in 2014 in all three districts of $\mathrm{CHT}$ (Hossein 2014). Bandarban has the highest amount of production areas ( $1200 \mathrm{ha}$ ) and produced 4800 tons of the crop. Khagrachari has the second highest production area with about 850 ha cultivated in 2013-14.

Sugarcane cultivation has increased because of market demands from local and national markets and the introduction of high yielding varieties (chewing variety). In 2006, the Bangladesh Sugarcane Research Institute (BSRI) initiated a project on introducing sugarcane cultivation in $\mathrm{CHT}$ with necessary training and production inputs to farmers. In recent years, there has been a gradual increase in sugarcane cultivation areas. The advantage of intensive cultivation of sugarcane is that it can be cultivated with other crops, such as seasonal vegetables, for the first 5 months.

Farmers cultivate the crop in November-December and harvest in October-December in the following year. As a long, durable crop, the economic output is two times higher than production cost in this land-use system. On average, sugarcane production is 
175,000 pieces per ha, equivalent to BDT 220,000/USD 2820 (USD $1=B D T 78$ ). However, it requires intensive farming inputs including water, fertilizers and labor for weeding and supervision for increasing the quantity of production.

\section{Cotton}

Cotton is a fiber cash crop in Bangladesh that has been grown for a long time. During the British colonial period, cotton was exchanged for land revenue in the region. CHT was famous for production of the finest quality white cotton. Karpas cotton, locally known as pahari tula (Gossypium hirsutum) is of superior quality in the markets compared to other local varieties found in Bangladesh. Although a decline in cotton production due to lack of high yielding and short-duration varieties, it still has market demand at local, national and international levels. Used as raw materials for the textile industries, annual demand of raw cotton is about 0.73 million tons in Bangladesh (CDB 2015). Bangladesh is the fifth largest user of cotton in the world and largely depends on the import of the raw materials for the local industries.

Farmers generally maintain cotton with their food crops to generate incomes in all zones. People in Zone 1 and 2 also cultivate cotton for small amounts of cash returns, but mostly for personal use (i.e. traditional household clothes). Cotton is maintained in Zone 1 for making traditional clothing, particularly winter clothes. Roughly 12,000 farmers cultivated 14,280 ha of hilly lands with cotton in CHT in 2013-14 (CDB 2015). There are three types of cotton varieties cultivated, hilly cotton with shifting cultivation crops and another two varieties in plain lands. Hilly cotton is cultivated in April-May and harvested in November-January and has no production input costs except labor. In 2014-2015, 5810 bales ( $182 \mathrm{~kg} /$ bale) were produced in CHT and total production in Bangladesh was 1.45 million bales. Despite the market demand within Bangladesh, there is an overall deficit in cotton production due to low agriculture inputs (i.e. yield varieties, land and fertilizer).

\section{Rice}

Rice is an important staple food crop in Bangladesh. It is the preferred food of most ethnic populations in CHT and is a major component of their three meals a day. In Zone 3 , rice cultivation in monocropping systems is the dominant land-use system and the main source of generating cash income. There has been an increasing trend of plough agriculture cultivation of rice in two seasons, one is rain fed and another is using irrigation in the dry season. Most rice cultivation is now becoming intensive in Zone 3. Availability of plain and valley lands, access to improved high-yielding seed varieties and appropriate training and agricultural inputs are essential for rice production. However, Zone 2 has lower amounts of rice cultivation where irrigation is not adequate or where small areas of plain lands can only be used for one season.

The amount of rice production is lower in Zone 1 where people only cultivate the crop to meet their annual household demand. Most people use the traditional system of cultivating rice with other crops along the hill slopes. Shifting cultivation is the only practice that can produce a small amount of this food crop. Average rice yield per unit of land has been decreasing with this system due to increasing land fertility loss due to soil erosion, insufficient access to land, and competition from other high-yielding crop varieties has affected rice production in Zone 1. 
People usually store local seed varieties from one season to the next so they require fewer inputs for rice cultivation in the traditional shifting cultivation system. There is less area available for maintaining rice cultivation with other cash crops; soil fertility has also been affected as a result of the productivity of shifting cultivation systems. People mostly produce rice for subsistence uses in Zones 1 and 2. While rice production capacity is likely to increase in Zone 2 and 3 due to available plain lands, this is insufficient to meet the food demand in Zone 1 . The overall rice production capacity in CHT is low compared to other areas of Bangladesh. As a result, the existing rice production system will have negative effects on its accessibility and availability.

\section{Teak plantations}

Commercial teak (Tectona grandis) plantations are the most dominant land-use types in Zone 3, despite being prevalent in all zones. Better accessibility to transport, markets and availability of planting materials favors this land use in Zone 3. The economic value of timber is higher in local and national markets. A significant quantity of teak timber is harvested from private forests each year. However, accurate estimates on the amount of annual harvesting and contributions to rural household economies are not available.

Teak-based, smallholder economic activities have continued to expand in CHT. People manage teak in small patches in their home gardens and shifting cultivation areas. The tree cover is either a monoculture ecosystem or a mosaic of natural trees and different fruit plants in shifting cultivation lands. The use of land for teak is more common in Zones 2 and 3 where traditional crop cultivation is changing. People see more economic benefits from this tree-based land use though it takes a long time (15-30 years) before harvesting can take place. At present, people either convert traditional farming areas into fruit gardens or successively replace them with teak plantations. However, the contributions of increasing tree cover to household economies and the effects on food production systems are not yet evident.

\subsection{Forest and agrarian transition in Chittagong Hill Tracts}

Traditional land-use systems (i.e. shifting cultivation) may not be adequate to meet the food demands of large populations and maintain the multiple benefits of forests in CHT. Shifting cultivation was once a source of diverse foods although there is debate about its benefits in terms of subsistence compared to other economic activities; it has negative impact on the ecosystem such as lower productivity, loss of forest areas (due to forest clearing) and soil erosion. Food productivity from this traditional form of agriculture has reduced by half due to lower soil fertility and lack of adequate tree vegetation (Khan et al. 2007). More agricultural inputs (e.g. lands, seeds, technology for plough agriculture, extension services etc.) are required to increase food productivity in CHT.

Effective agricultural land use is vital to sustain food production and conservation in the region; achieving this will be challenging due to the complex problems and opportunities involved. A gradual shift from extensive to intensive cultivation of cash 
crops, perennial fruit and timber trees has started in the last two decades. This has different manifestations in terms of access to lands, management patterns, remoteness and access to markets. These issues might have different influences on forests and agriculture systems and relationships with food production capacity at the landscape level.

Forests and trees have historically contributed to the livelihoods of traditional ethnic people in the $\mathrm{CHT}$ region of Bangladesh. Land-use changes may have direct and indirect effects on the associated ecosystem services provided by forests. Thus a detailed focus on diversity of trees and agricultural-based land uses will be essential to examine their management, roles in food production systems and overall effects at a landscape level.

\subsection{Feasibility of the Agrarian Change Project in Chittagong Hill Tracts}

The CHT region has been confronting multiple challenges on the sustainable management of its key agriculture and forest based land-use systems. Historical trends of forest and land-use changes discussed in this report have showed that the entire landscape underwent a dynamic social and institutional process during the last century. Initiatives by external institutions to intensify land uses or multi-strata agroforestry systems, managing forests and tree cover had a view to restoring degraded lands and conserving watersheds. But the current trends and the benefits of these diverse land uses to food security and conservation are yet to be fully explored across the landscape.

It would be worth investigating how agrarian change currently takes place in this landscape and in particular, the relationship with livelihoods, management and ownership of forests and ecosystem services. A better understanding on the utilization and management of forests and agriculture systems across the landscape will provide us with integrated landscape management options that are of national and regional interest as well as achieving global environment sustainability.

Considering the complexity of the social and ecological systems in CHT, we propose three areas or zones for future research activities. Drawing on the findings of the scoping study, 12 villages have been selected, four in each of the three land-use zones covering two districts (Rangamati and Bandarban) and three subdistricts (Belaichari, Bandarban and Rowangchari) (Figures 6.7, 6.8 and 6.9).

Further research into forest-based livelihoods, resource use, conservation and sustainability in this changing landscape will use a range of methods from household and farm surveys, key informant interviews, FGDs, participatory rural appraisal tools (e.g. farming typology, habitat evaluation, mapping of ecosystem services, historical trends, scenario development) and GIS mapping. 


\section{Acknowledgments}

We would like to thank CIFOR, in particular Terry Sunderland, for giving us the opportunity to be a part of the Agrarian Change Project and for providing funding for fieldwork. We would also like to thank Liz Deakin and Mrigesh Kshatriya for providing input into the scoping study, for organizing meetings and for sharing essential field documents and the experiences of other project team members.

We are grateful to the Bangladesh Forest Department, Department of Agriculture Extension and Arannayk Foundation (Bangladesh Tropical Forest Conservation Foundation) for providing background information on and support in the CHT region. We are also grateful to Maung Hla Myant, project coordinator and Chandasen Chakma, field assistant of the Chittagong Hill Tracts Watershed Co-Management Activities Project. Thanks also to the Chakma Circle King for organising the field trips in Rangamati District; Piching U Marma of Tahzingdong in Bandarban district and Proshika for organizing field trips in Khagrachari district.

The cordial support of traditional leaders and local communities in each district made it possible for us to access remote villages and organize community meetings.

The research was supported by funding from: a Charles Darwin University international postgraduate research scholarship; and an Australian postgraduate award and Faculty of Engineering, Health, Science and the Environment postgraduate research funding; CIFOR; and the South Asian Network for Development and Environmental Economics (SANDEE) through the Asian Centre for Development, Bangladesh. 


\section{References}

Akhter F. 2011. Tobacco cultivation and its impact on food production in Bangladesh, Dhaka. Accessed 07 June 2015. http://www.fairtradetobacco.org/wp-content/ uploads/2011/07/Farida-Akhter_Tobacco-to-Food-Production.pdf

Bala BK, Majumder S, Altaf Hossain SM, Haque MA and Hossain MA 2012. Exploring development strategies of agricultural systems of Hill Tracts of Chittagong in Bangladesh. Environment, Development and Sustainability 15(4):949-66.

[BBS] Bangladesh Bureau of Statistics. 2015. Accessed 10 June 2015. http://www.bbs.gov. bd/home.aspx

[BBS] Bangladesh Bureau of Statistics. 2014. Statistical pocketbook of Bangladesh 2013. 07 June 2015. http://www.bbs.gov.bd/WebTestApplication/userfiles/Image/ LatestReports/PB2013.pdf

[BBS] Bangladesh Bureau of Statistics. 2013. District statistics 2011. Government of the People's Republic of Bangladesh.

[BBS] Bangladesh Bureau of Statistics. 2011. Yearbook of agricultural statistics book of Bangladesh. Government of the People's Republic of Bangladesh. 07 June 2015. http:// www.bbs.gov.bd/PageWebMenuContent.aspx?MenuKey=234

[BFD] Bangladesh Forest Department. 2015. Forest cover of Bangladesh. Accessed 20 June 2015. http://fd.portal.gov.bd/

[CDB] Cotton Development Board. 2015. E-Newsletter, Bangladesh. 20 June 2015. http:// cdb.gov.bd/

[FAO] Food and Agriculture Organization of the United Nations. 2010. Global forest resources assessment country report: Bangladesh. Rome: FAO.

Ghose B, Razib B and Sharmistha G. 2014. Reviewing the status of agricultural production in Bangladesh from a food security perspective. Russian Journal of Agricultural and Socio-Economic Sciences 25(1):19-27.

[GoB] Government of Bangladesh and [FAO] Food and Agriculture Organization of the United Nations. 2013. Support to preparation of an integrated project for environment friendly agriculture in the Chittagong Hill Tract. Technical Report. Dhaka, Bangladesh: GoB; FAO.

Hossain M. 19 May 2014. Massive sugarcane cultivation drive undertaken in CHT. The Financial Express. 2014. Accessed 20 June 2015. http://www.thefinancialexpress-bd. com/2014/05/19/34664/print

Hossain MK. 2003. Growth performance and critics of exotics in the plantation forestry of Bangladesh. XII World Forestry Congress, FAO. http://www.fao.org/docrep/ARTICLE/ WFC/XII/0113-B1.HTM

Islam MS, Alam M and Mantel S. 2007. Land use planning and environmental control in the Chittagong Hill Tracts. CHARM Project Report No. 3. Dhaka, Bangladesh.

Kar S and Jacobson G. 2012. NTFP income contribution to household economy and related socio-economic factors: Lessons from Bangladesh. Forest Policy and Economics $14: 136-42$. 
Khan MH, Aziz MA, Uddin M, Sharif S, Chowdhury SU, Chakma S, Chowdhury GW, Jahan I, Akter R, Myant MH and Mohsanin S. 2012. Community conserved areas in Chittagong Hill Tracts of Bangladesh. In Islam, MA, ed. Wildlife Trust of Bangladesh, Dhaka, Bangladesh.

Khan NA and Khisa SK. 1999. Sustainable land management with rubber-based agroforestry: A Bangladeshi example of uplands community development. Sustainable Development 8:1-10.

Khan MFA and Mantel S. 2007. Planning for improved natural resources management: pilot study in Bandarban Sadar Upazila. CHARM Project Report No. 8. Dhaka, Bangladesh.

Khan MFA, Mantel S and Choudhury EH. 2007. State of the environment of Chittagong Hill Tracts. CHARM Project Report No. 2. Dhaka, Bangladesh.

[LGED] Local Government Engineering Department. 2015. Digital map. Local Government Engineering Department, Dhaka, Bangladesh. Accessed 10 September 2015. http://www.lged.gov.bd/ViewMap.aspx

Miah MD, Chakma S, Koike M and Muhammed N. 2012. Contribution of forests to the livelihood of the Chakma community in the Chittagong Hill Tracts of Bangladesh. Journal of Forest Research 17(6):449-57.

Miah MMA and Islam SMF. 2007. Shifting cultivation and its alternatives in Bangladesh: Productivity, risk and discount rates. SANDEE Working Paper No. 24. South Asian Network for Development and Environmental Economics (SANDEE), Kathmandu, Nepal.

Misbahuzzaman K and Smith-Hall C. 2015. Role of forest income in rural household livelihoods: The case of village common forest communities in the Chittagong Hill Tracts, Bangladesh. Small-Scale Forestry 14(3): 315-30. doi:10.1007/s11842-015-9290-1

Mukul SA 2010. Changing consumption and marketing pattern of non-timber forest products in a competitive world: Case study from an urban area of north-eastern Bangladesh. Small-Scale Forestry 10(3):273-86.

Olarieta JR, Rodriguez-Ochoa R and Ascaso E. 2007. Land management in the Chittagong Hill Tracts and sustainable alternatives. CHARM Project Report No. 4. Dhaka, Bangladesh.

Rahman SA, Rahman MF and Sunderland T. 2014. Increasing tree cover in degrading landscapes: 'Integration' and 'intensification' of smallholder forest culture in the Alutilla Valley, Matiranga, Bangladesh. Small-Scale Forestry 3:237-49. doi:10.1007/ s11842-013-9251-5.

Rahman SA, Rahman MF and Sunderland T. 2012. Causes and consequences of shifting cultivation and its alternative in the hill tracts of eastern Bangladesh. Agroforestry Systems 84(2):141-55.

Rasul G. 2009. Ecosystem services and agricultural land-use practices: a case study of the Chittagong Hill Tracts of Bangladesh. Sustainability: Science, Practice and Policy 5(2):15-27.

Rasul G. 2007. Political ecology of the degradation of forest commons in the Chittagong Hill Tracts of Bangladesh. Environmental Conservation 34(2):153-63. 
Rasul G and Thapa GB. 2006. Financial and economic suitability of agroforestry as an alternative to shifting cultivation: the case of the Chittagong Hill Tracts, Bangladesh, Agricultural Systems 91(1):29-50.

Roy RD. 2012. Country technical notes on indigenous peoples' issues: People's Republic of Bangladesh. IFAD and AIPP.

Salam M, Noguchi T and Koike M. 1999. The causes of forest cover loss in the hill forests in Bangladesh. GeoJournal 47:539-49.

Shelly MR. 1992. The Chittagong Hill Tracts of Bangladesh: The untold story. Centre for Development Research, Bangladesh. Dhaka, Bangladesh.

Thapa GB and Rasul G. 2005. Patterns and determinants of agricultural systems in the Chittagong Hill Tracts of Bangladesh. Agricultural Systems 84(3):255-77.

[UNDP] United Nations Development Programme. 2009. Socio-economic baseline survey of Chittagong Hill Tracts. Chittagong Hill Tracts Development Facility (CHTDF), Dhaka, Bangladesh. 


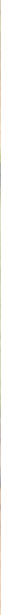

\section{Agrarian changes in the Nyimba District of Zambia}

Davison J Gumbo, Kondwani Y Mumba, Moka M Kaliwile, Kaala B Moombe and Tiza I Mfuni

\section{Summary}

Over the past decade issues pertaining to land sharing/land sparing have gained some space in the debate on the study of land-use strategies and their associated impacts at landscape level. State and non-state actors have, through their interests and actions, triggered changes at the landscape level and this report is a synthesis of some of the main findings and contributions of a scoping study carried out in Zambia as part of CIFOR's Agrarian Change Project. It focuses on findings in three villages located in the Nyimba District. The villages are located on a high (Chipembe) to low (Muzenje) agricultural land-use gradient. Nyimba District, which is located in the country's agriculturally productive Eastern Province, was selected through a two-stage process, which also considered another district, Mpika, located in Zambia's Muchinga Province. The aim was to find a landscape in Zambia that would provide much needed insights into how globally conceived land-use strategies (e.g. land-sharing/land-sparing trajectories) manifest locally, and how they interact with other change processes once they are embedded in local histories, culture, and political and market dynamics.

Nyimba District, with its history of concentrated and rigorous policy support in terms of agricultural intensification over different epochs, presents Zambian smallholder farmers as victims and benefactors of policy pronouncements. This chapter shows 
the impact of such policies on the use of forests and other lands, with agriculture at the epicenter. Such outcomes will be compared with the experiences of other households and farms in five landscapes in Burkina Faso, Ethiopia, Cameroon, Bangladesh and Indonesia. The results of this scoping study will provide a basis for a comparison of the various scenarios of agricultural modification, productivity, changing forest cover, dependency on forest resources, and integration with local and global commodity markets found across the six focal countries of the Agrarian Change Project.

\subsection{Introduction}

In Zambia, agrarian change is closely intertwined with forest and other land-use changes that can in turn be related to the country's pre-colonial (pre-1898), colonial (1898-1964) and post-independence (post-1964) epochs (Wood et al. 1990; Chileshe 2005; Moyo and Yeros 2005; Sitko and Jayne 2014). As argued by Bates (1984), in each of these phases the interplay within and among issues central to agrarian change defined macroeconomic policies, commercialization of smallholder agriculture, development programs, and extension and service delivery, and often sets the trajectory of change. The agriculture sector received a lot of support in each of these historical epochs, as this was viewed as presenting the greatest opportunity through which change in the lives of smallholder farmers could be effected (Momba 1989; Mellor 1995; World Bank 1996; GRZ 2002; Sitko and Jayne 2014). Throughout these epochs, smallholder farmers ${ }^{1}$ were and are still the primary focus for policy action and programming as seen through their exclusion (colonial) (Zgambo 1983), inclusion (post-independence) (Pletcher 1986) or as active participants in the market-led post-structural adjustment program (SAP) (Machina 1996; GRZ 2013; Sitko and Jane 2014).

The entire rural development thrust has, over the years, continued to be the vanguard of development with programs such the Zambia Agricultural Investment Support Programme and lately the Farmer Input Support Programme (FISP) - previously referred to as the Fertilizer Support Program - providing the strategic direction for agriculture (World Bank 1995; GRZ 2004, 2008; CSPR 2005; Mason et al. 2012, 2013; Mofya-Mukuka et al. 2013). In most cases, these programs became the guiding light for development programs (Kakulwa 2012). In an attempt to move away from what has been viewed as a political social contract between smallholder farmers and the State, and also viewed as public sector sponsored out-grower scheme, the government has been increasingly calling for the involvement and participation of the private sector (EDF 1994; World Bank 1996; Chapoto et al. 2013; Sichoongwe et al. 2014). Cash crops, such as cotton and tobacco, have been presented as part of a strategy to diversify smallholder farming. Contracts with private sector companies cover the provision of both inputs and access to markets. Lately, the National Agricultural Policy, as well as the National Agriculture Investment Plan 2014-2018 have called for strong private sector involvement (Chapoto et al. 2013; GRZ 2004, 2013). Smallholder farmers currently work through these two arrangements and these strongly influence the direction of agrarian change in the country.

1 The sum total of small-scale and emergent farmers (i.e. cultivating $0.1-20 \mathrm{ha}$ ) are referred to as 'smallholders' while farmers cultivating more than 20 ha are known as 'large-scale' farmers (Sitko and Jayne 2014). 
Yet, much as agriculture has been at the forefront of development, other sectors have also had policies guiding sector activities. Non-agricultural policies coming into effect in the same historical epochs relate to lands (GRZ 2006), forests (GRZ 1998a), wildlife (GRZ 1998b) and national policy on the environment (GRZ 2007). In the forest sector, forest action plans (GRZ 1998c) and joint forest management (JFM) guidelines which sought to bring smallholder farmers into forest management (GRZ 2005) did not progress due to lack of clarity on benefit sharing as well as the non-implementation of the 1998 Forests Act, which was meant to authorize the establishment of JFM areas. Unlike agriculture where incentives were clear, community members under JFM did not have legal access or use rights to the forest and saw no need to support the initiative. Lately, experiences obtained from policy engagement over the epochs have led to the formation of a community-centered forest policy (GRZ 2015). Programs have also been developed such as the National Biodiversity Strategy and Action Plan and the National Biodiversity Strategy and Action Plan Two (GRZ 1999, 2015) to address conservation and management of biodiversity in an environment where agriculture is being favored through significant state investment in maize production (Sitko and Jayne 2014). The negative social and environmental impacts of agriculture were largely ignored and the unraveling unfair distribution of land triggered by these policies was not addressed, for example informal land markets that not only disadvantaged some farmers but also weakened customary authorities (Chimhowu and Woodhouse 2006; Sitko 2010). In the same vein, traditional authorities, such as chiefs and headmen/women who throughout these epochs granted usufruct ${ }^{2}$ rights to individuals, found themselves powerless to prohibit the buying and selling of this land (Ranger 1983; Berry 1993).

The implications of the agriculture policies that were enacted in the colonial, post-colonial and structural adjustment periods in Zambia are examined in selected villages in the Nyimba District. The three villages of Muzenje (forested); Chifukuzi (medium forested) and Chipembe (sparsely forested) were selected on an agricultural intensification continuum from the district's plateau ( $\geq 900 \mathrm{masl}$ ) to the valley ( $\leq 600 \mathrm{masl})$. The differences in the levels of forest cover appear to be the result of the extent to which each village has been exposed to agriculture support programs.

\subsubsection{National context of agrarian change in Zambia}

The existence of multifunctional landscapes that simultaneously provide food security, livelihood opportunities, maintain species and ecological functions, while fulfilling cultural, aesthetic recreational needs is widely recognized in Zambia (GRZ 1999; Dalal-Clayton and Child 2003). The management of land and resources for agriculture, grazing, forest production, water and all other uses are closely interconnected. However, as modern agriculture develops, due to pushes by the government, both farmers and policymakers have focused largely on the farm. These actors have mainly sought to maximize productivity and address food security and poverty issues, without due regard for impacts on other land uses, for example forests. Agriculture is a dominant land use in Zambia, particularly the production of hybrid maize and cash crops such as cotton and tobacco, and has been at the forefront of the country's development thrust. However, this poses a challenge in terms of linking agricultural practices, institutions and policies with other landscape activities.

2 Usufruct: legal right to use another property, in this case land. 
Agrarian change in Zambia has been driven by the introduction of improved maize seed varieties among smallholder farmers in the 1970s leading to an increased use of agricultural inputs such as fertilizers and sedentary agriculture among smallholder farmers. Maize is an important crop in Zambia and pre- and post-independence agricultural policies have centered on increasing its production to meet urban demand, especially in the country's copper mining towns (World Bank 1995; GRZ 2004). The role of the smallholder farmers has been central to these efforts. Whatever achievements have been realized through this, the opening up of forests for agriculture stands today as one of the country's primary drivers of deforestation (Chileshe 2001; MTENR 2007; GRZ 2010).

In Zambia, agriculture has been highlighted as the number one strategy for poverty reduction (GRZ 2002). As such, the process of agrarian change can be seen through attempts to convert smallholder shifting cultivation households into sedentary farmers that are active in agricultural markets (World Bank 1995; GRZ 2004, 2013; Mofya-Mukuka et al. 2013; Sitko and Jayne 2014). This has been achieved through an implementation of tailor-made agricultural policies for smallholder farmers. While colonial policies limited agricultural development for native smallholders (Zgambo 1983), post-colonial policies like extension training and visiting, agricultural research and pan-territorial pricing, helped boost agricultural production (Kumar 1994; World Bank 1996; GRZ 2013). The realignment of these institutions and withdrawal of the services provided after the economic structural adjustment presented a new turn in agrarian change as farmers sought new livelihood strategies (Machina 1996). These included opening up forests for additional arable lands or relocation to new areas, where settlements were set up and new lands were opened up for agriculture, leading to loss of forest resources (GRZ 2010). This was a component of previous strategies but was dropped as farmers gained easier access to fertilizers.

\subsubsection{Policy and agrarian change in Zambia}

As with most countries, policies aimed at maintaining forest cover, protecting biodiversity and increasing agricultural production often combine to drive landscape change. Prior to 1964, efforts were made to develop agriculture among smallholder farmers, but agricultural and related policies, like land alienation and dual-pricing systems, were structured to benefit settler farmers (Zgambo 1983; Chileshe 2005; Moyo and Yeros 2005). This contributed to the underdevelopment of smallholder agriculture. After 1964, the Zambian government promoted policies that encouraged smallholder farmers to participate in agricultural markets. These policies were, on one hand, aimed at guaranteeing increased income for smallholder farmers, while, on the other hand, keeping maize prices low for urban consumers (Momba 1989). This meant heavy financial support from the government. Key features of these post-independence policies include provision of extension services, introduction of fertilizer subsidies and credit facilities for smallholder farmers (World Bank 1995; Chomba 2004; GRZ 2004).

Policies in the forest and wildlife sectors also impacted smallholder farmers. Prior to the colonial period, the management and use of forests and wildlife were under the control of traditional authorities. The first form of wildlife legislation in Zambia was the Ostrich Export Prohibition in 1912, which was followed by the Plumage Bird's Protection 
Ordinance of 1915 (Chomba et al. 2011). The game (wildlife) ordinance of the 1930 s vested all wildlife in the state and provided for the delineation of game reserves, such as North Luangwa in 1935, which was later turned into a national park in the 1940s. One of the largest national parks in the country, the Kafue National Park was created in 1950 (Chomba et al. 2011). The 1960s also witnessed the enactment in 1965 of the country's first forest policy in Zambia, which consisted of a set of instructions to the Forest Department. Under this policy, an exclusive mandate over forest protection was given to the government. This covered the management of forests, especially forest reserves, and forests were subsequently policed by forest guards (Chileshe 2001).

The development of these policies and legislation was driven by a global commitment toward the protection of biodiversity. It resulted in the creation of 432 forest reserves ( 4 of which are in Nyimba District), 59 botanical reserves, 2 bird sanctuaries, 19 national parks and 34 game management areas (part of the West Petauke Game Management Area is in Nyimba), in total covering an area of over 30 million ha (GRZ 1999). Most of these were excised from customary land, thereby reducing the amount of land available to smallholder farmers and restricting access to the wildlife and other resources that they had previously enjoyed. The early forest policies had no provisions for participatory forest management, but a new policy was formulated in 1998, supported by the Forest Act of 1999, aimed at promoting a participatory approach in management, planning and protection of forests, among other things (Chileshe 2001).

Flagrant disregard of laws protecting conservation areas combined with a laxity in enforcement has led to encroachment onto these protected areas as smallholder farmers expanded their agricultural fields (GRZ 2007). Encroachment onto protected areas can also be seen from the point of view of land claims being made by the local farmers who consider these areas as lands they lost as part of the drive for conservation (Anderson and Grove 1989; Hansungule et al. 1998). The SAP in Zambia led to massive retrenchments forcing some people to occupy protected areas next to urban areas (Palmer 2001). Agricultural expansion has been identified as one of the leading causes for loss of forest cover (GRZ 2010). In recent years, efforts have been made to formulate policies aimed at reducing forest loss and are bolstered by the 2007 national policy on the environment. This categorically states that increased agricultural production should be based on improved agricultural systems as opposed to land expansion (GRZ 2007).

\subsubsection{Selection of focus landscape}

The search for a landscape where the Agrarian Change Project could be studied started with a collation and review of information on agriculture, forests and other land-use changes across four districts. These included Chadiza $\left(2674 \mathrm{~km}^{2}\right)$, Nyimba $\left(10,509 \mathrm{~km}^{2}\right)$, Mpika $\left(40,935 \mathrm{~km}^{2}\right)$, and Mumbwa $\left(21,103 \mathrm{~km}^{2}\right)$, which are located in the Eastern, Muchinga and Central provinces of Zambia (Figure 7.1), respectively. In addition, smallholder farmers located in these districts have diversified their agricultural activities to include the growing of cash crops such as tobacco and cotton through a combination of public and private sector support. 


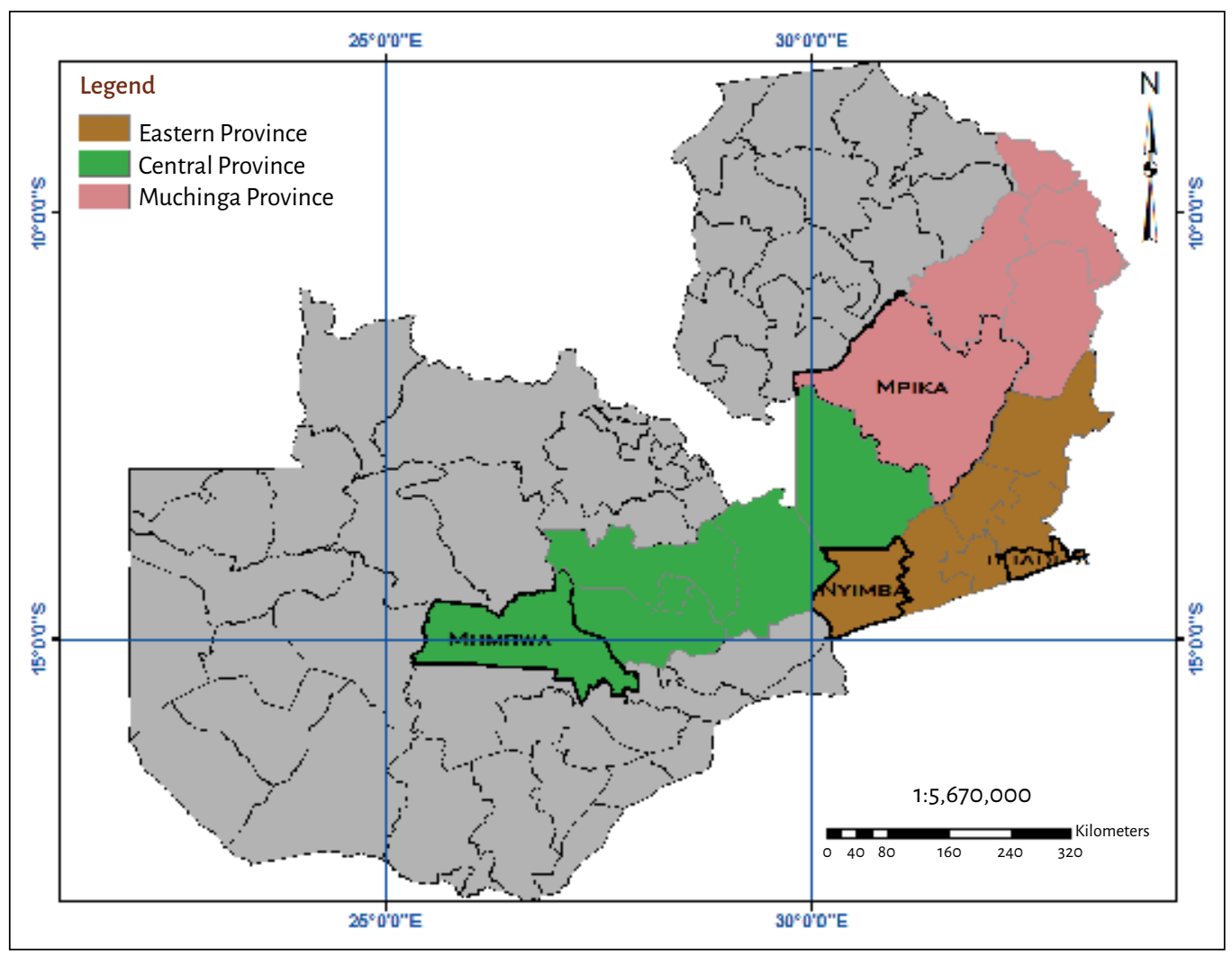

Figure 7.1 Districts considered for the Agrarian Change Project.

While similarities were noted among these districts, data and information collated pointed toward the need for a greater focus on Mpika and Nyimba Districts. To this end, a number of technical field visits and consultations with district-based experts were organized to these districts. The first of such visits was made to Mpika by a combined team from CIFOR Lusaka and Bogor. The Mpika visit presented the first opportunity to develop criteria for the selection of a landscape that would be tested on the ground. Zambia-based staff applied the same criteria in Nyimba a month later and benefitted from the fact that the same team had been implementing a project in Nyimba for 24 months.

In Mpika District, site visits were undertaken to villages and settlements around Mpika District center, including Lwitikila National Forest Reserve. Discussions with district and provincial government officials had led the team to conceptualize that changes in both forest cover and extent would be apparent as one moved away from the forest reserve into the villages. In addition, the district technocrats had also highlighted that older villages had, over time, received support (public or private) for agricultural activities such that they would have in place the necessary support infrastructure (e.g. cooperatives, extension and out-grower schemes) to carry out agricultural activities. The same technocrats reported that these villages would have good access to improved 
seed varieties, access to draught power and agrochemicals, as well as markets, which, over time, have resulted in substantial forest areas being brought under cultivation leading to low forest extent and cover. Thus, the team sought to test whether this was true through observations and further discussions with farmers.

Mpika National Forest, which is $28.11 \mathrm{~km}^{2}$ in extent and shares a boundary with the district administrative center of Mpika. Personnel from the Forestry Department claimed that the forest has not only been a major source of construction timber, firewood or charcoal, but had been heavily encroached upon so much that some sections had been de-gazetted (excised from the reserve) and turned into residential stands. Mpika Forest Reserve has a limited rural hinterland and the dynamics of forest loss were more related to pressure and demand for land from the inhabitants of the district center. Encroachment started with land being turned into arable fields and, over time, conversion into residential stands. The team concluded that the site was not suitable for an agrarian change project as no continuum of spatial change in forests outside of the forest reserve could be observed. The team shifted its focus onto the $1050 \mathrm{~km}^{2} \mathrm{Lwitikila}$ National Forest, which shares borders with the chiefdoms of Kopa and Luchembe (see Figure 7.2). Chiefdoms are areas under the jurisdiction and control of a traditional

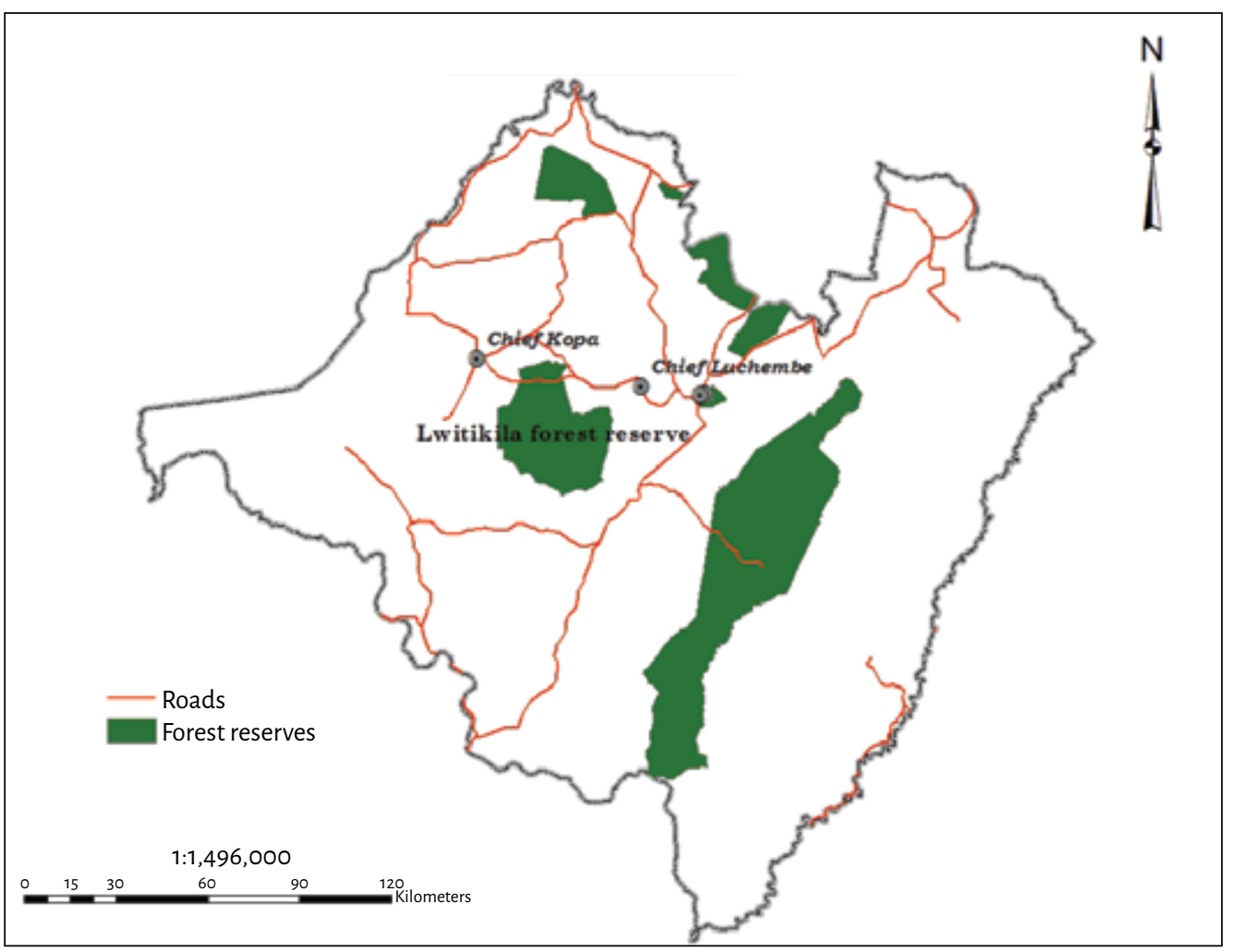

Figure 7.2 Mpika District showing Lwitikila National Forest No. 291. 
leader (chief), made up of several villages of people of the same ethnic background. While chiefs can allocate land for agriculture to individual households, their greater power lies in being custodians of the chiefdom's natural resources management (Ranger 1983; Herbst 2000; Chikulo 2009). In this instance, both Chief Kopa and Luchembe, and their respective headmen or women, had been allocating land to their inhabitants against the wishes of central government in terms of agriculture. In support of central government, these chiefs have encouraged farmers to move away from shifting cultivation to more sedentary agriculture (Kakeya et al. 2006). With these issues in mind, the team examined how arable fields and forest cover varied with distance from the Lwitikila Forest Reserve in those areas abutting the sides of the chiefdoms.

Forest cover was noted as varying with distance from the forest reserve in both chiefdoms. Brief discussions with locals showed that the level of agricultural support and the levels of agro-input use, for example improved maize seed varieties and associated agrochemicals, were behind the changes. Implied in this was the issue of the history of agricultural expansion into forests, which has been highlighted as one of the drivers of deforestation in Zambia (GRZ 2010). This confirmed the existence of an agricultural intensification continuum where sparse tree vegetation was noted in the older and more settled villages, while those closer to the forest reserve still had some forests on them. Discussions with older members of the villages indicated that there was some knowledge of the three historical epochs, i.e. the colonial, post-independence and structural adjustment periods, and how the policies associated with them had influenced agriculture and related activities had been carried out over the years. This offered a partial explanation as to how agricultural activities had led to the conditions described above.

The observations made by the team meant that the land-use zone selection criteria stipulated by the experimental design of the Agrarian Change Project could be fulfilled through the use of an agricultural intensification continuum in Zambia.

Without losing the essence of the project's original land-use zone selection criteria, detailed criteria specific to Zambia were developed and further reviewed in Lusaka (see Appendix 7A). These criteria were applied during the technical visit to Nyimba District ${ }^{3}$ by the CIFOR Lusaka team and combined with existing field knowledge and data available on the two districts. A comparative analysis was carried out for Mpika and Nyimba Districts. Initial analysis showed that there was very little separating the two landscapes and after conducting a SWOT (strengths, weaknesses, opportunities and threats) analysis on both potential landscapes (Table 7.1), Nyimba District was chosen as the study landscape.

\subsubsection{Geographical context}

The Nyimba District, which was chosen as the landscape for study, is $10,509 \mathrm{~km}^{2}$ in area and is located in Eastern Province of Zambia. It is the second largest district in this province (see Figure 7.3). The agrarian history of Nyimba cannot be separated from that of Zambia's Eastern Province and therefore some brief aspects pertaining to the Eastern

3 The Zambia team also benefitted from prior knowledge and data from a project the team had completed in 2014. 


\section{Table 7.1 Strengths, weaknesses, opportunities and threats (SWOT) analysis used to compare} Mpika and Nyimba.

\begin{tabular}{|c|c|c|c|c|}
\hline District & Strengths & Weaknesses & Opportunities & Threats \\
\hline Mpika & $\begin{array}{l}\text { - Relationship } \\
\text { established with the } \\
\text { district agricultural } \\
\text { coordinating officer } \\
\text { (DACO) and district } \\
\text { forestry officer } \\
\text { - CIFOR holds a } \\
\text { database on shifting } \\
\text { cultivation in three } \\
\text { villages } \\
\text { - Creation of new } \\
\text { sites, additional } \\
\text { operational area, } \\
\text { additional data and } \\
\text { relationships }\end{array}$ & $\begin{array}{l}\text { - Limited district } \\
\text { level baseline data } \\
\text { except for three } \\
\text { villages } \\
\text { - No project } \\
\text { structures in } \\
\text { place } \\
\text { - Costly exercise } \\
\text { to establish } \\
\text { such structures } \\
\text { (recruiting and } \\
\text { - training of } \\
\text { research } \\
\text { assistants) }\end{array}$ & $\begin{array}{l}\text { - Creation of } \\
\text { additional database } \\
\text { for selected villages } \\
\text { - Enrichment of } \\
\text { organization's } \\
\text { profile - additional } \\
\text { study sites } \\
\text { - Potential of } \\
\text { conducting a new } \\
\text { study on the social } \\
\text { economic impact } \\
\text { of the Zampalm oil } \\
\text { palm plantation on } \\
\text { local communities } \\
\text { - Creation of } \\
\text { new partners } \\
\text { (traditional leaders, } \\
\text { NGOs, government } \\
\text { officials) }\end{array}$ & $\begin{array}{l}\text { - Study time is } \\
\text { limited and not } \\
\text { long enough } \\
\text { to establish a } \\
\text { presence; distance } \\
\text { between Lusaka } \\
\text { and Mpika is a } \\
\text { constraint (long } \\
\text { travel time - dead } \\
\text { mileage) } \\
\text { - No existing } \\
\text { relationship with } \\
\text { communities } \\
\text { - } 75 \text {-10o households } \\
\text { targeted per zone } \\
\text { for the household } \\
\text { survey may not be } \\
\text { found (population } \\
\text { sparsely } \\
\text { distributed) }\end{array}$ \\
\hline Nyimba & $\begin{array}{l}\text { - Strong relationships } \\
\text { with stakeholders } \\
\text { in the district (e.g. } \\
\text { with the District } \\
\text { Commissioner, } \\
\text { DACO, District } \\
\text { Forestry Officer, } \\
\text { Zambia Wildlife } \\
\text { Authority, and chiefs } \\
\text { and communities in } \\
8 \text { villages) } \\
\text { - Biophysical and } \\
\text { social economic } \\
\text { databases available } \\
\text { - Secondary data on } \\
\text { agriculture available }\end{array}$ & $\begin{array}{l}\text { - Access to some } \\
\text { households would } \\
\text { be a challenge } \\
\text { - Shift by } \\
\text { CIFOR from } \\
\text { a forest focus } \\
\text { to agriculture } \\
\text { research may } \\
\text { be a challenge } \\
\text { for some of the } \\
\text { community to } \\
\text { understand } \\
\text { - Familiarity with } \\
\text { institutions could } \\
\text { lead to working } \\
\text { on assumptions }\end{array}$ & $\begin{array}{l}\text { - Enriching existing } \\
\text { CIFOR database on } \\
\text { Nyimba } \\
\text { - Entrenching our } \\
\text { work } \\
\text { - Demonstration of } \\
\text { commitment to } \\
\text { existing partners } \\
\text { - Strengthening } \\
\text { relationships with } \\
\text { stakeholders } \\
\text { - Linkages with } \\
\text { miombo sentinel } \\
\text { landscape work }\end{array}$ & $\begin{array}{l}\text { - Over } \\
\text { familiarization } \\
\text { may affect } \\
\text { probing } \\
\text { and robust } \\
\text { questioning } \\
\text { - Research becomes } \\
\text { less rigorous } \\
\text { - Maintaining } \\
\text { existing } \\
\text { incentive systems } \\
\text { (which must be } \\
\text { increased) is a } \\
\text { challenge }\end{array}$ \\
\hline
\end{tabular}

Province are covered here. The Eastern Province of Zambia sits on the country's Eastern Plateau, at an altitude of $\geq 900$ masl with a small section of the province located in what is known as the Luangwa valley (part of the Rift Valley) at an altitude of $\leq 600$ masl. The Eastern Province was one of the country's first areas to grow improved maize varieties and use chemical fertilizers. Used initially by the province's large-scale farmers in the early 1960s, such technologies would only come to smallholder farmers a decade later, until then they continued to grow traditional maize varieties (Harvey 1973; Kumar 1994; Rainer et al. 1999). The post-independence period witnessed a greater focus on improving the livelihoods of smallholder farmers through agriculture (Sitko and Jayne 2014). This meant that the maize production base was expanded in the Eastern Province 


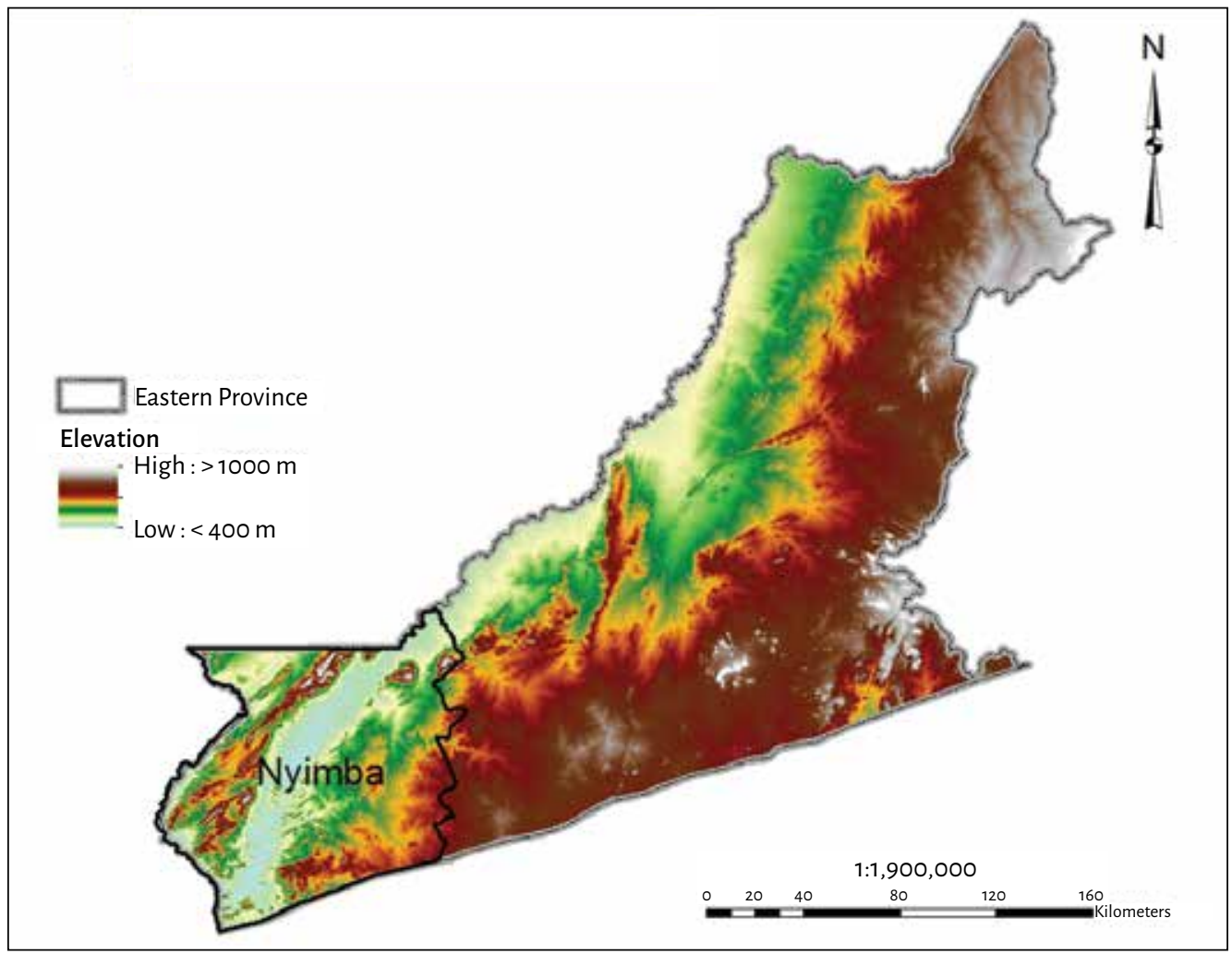

Figure 7.3 Eastern Province elevation.

so much that by the late 1980 s and early 1990s, the province had earned the title of the nation's maize basket (Saasa 2003). This trend has continued and as late as the $2009 / 2010$ cropping season, some $20 \%$ and $40 \%$ of smallholder farmers used hybrid seed and fertilizer, respectively, and produced 420 tons of maize in the same season (Tembo and Sitko 2013). Agrarian change across Zambia has largely been seen through the adoption of improved maize varieties, agrochemical use and increased utilization of draft power by smallholder farmers (Kumar 1994; World Bank 1995; Saasa 2003; GRZ 2004, 2013; Sitko and Jayne 2014).

\subsubsection{Historical context of agrarian change in Eastern Province}

The agricultural scene in the Eastern Province is dominated by productive smallholders who are also involved in livestock production. The province has higher population density (30.9 persons $/ \mathrm{km}^{2}$ compared to the national average of 17.4 persons $/ \mathrm{km}^{2}$ ) and lower land availability than other provinces in the country (CSO 2010). The province is one of the most important agricultural regions in the country where smallholder farmers have excelled since independence in 1964. 
Landscape change in the Eastern Province started with the arrival of the Chewa in the 15th century. They were later followed by the Nsenga, Ambo and Wiza ethnic groups (Zgambo 1983). The native farmers practiced a form of shifting cultivation known as the 'Eastern Plateau Agricultural System' (Tembo 2011). Under this system, crops were planted on mounds and in most cases finger millet and maize were the first crops planted in the first season. Groundnuts, beans and cowpeas were planted alongside maize later in the planting season. Planting in the subsequent seasons followed a similar pattern, with the exception of millet whose planting was not normally repeated on the same pieces of land (Zgambo 1983; Tembo 2011). Planting on each field site was repeated for 4 to 5 years, after which the site would be abandoned and left to fallow for a period of 25 to 30 years for fields on poor soils and 20 to 25 years for richer soils (Tembo 2011).

In 1898 , colonial authorities set about dismantling the traditional shifting cultivation practiced by the native communities as it was considered wasteful and damaging environmentally. They sought to change this approach by limiting the amount of land available to smallholder farmers and introduce a native agricultural development program. Land available to smallholder farmers was limited through the declaration and creation of native reserves in 1906 (Zgambo 1983). By 1928, native reserves covered an area of over $8000 \mathrm{~km}^{2}$. These reserves were located in areas with poor soils. Population increases in these reserves led to competition for land for shifting cultivation, and the long fallow periods required to restore soil fertility could no longer be accommodated (Zgambo 1983). The Eastern Plateau agricultural system was only suitable for populations of not more than 9 persons per $\mathrm{km}^{2}$, while population densities in some reserves were as high as 31 persons per $\mathrm{km}^{2}$, forcing smallholder farmers to cultivate the same fields year after year without fallowing, and therefore not allowing for the revitalization of soils. Continuous cultivation of native lands led to soil nutrient loss, removal of tree stumps and elimination of coppicing and regeneration of forest resources (Tembo 2011).

As noted under the general discussion of policies, additional policies were introduced banning the hunting of game, which in turn resulted in increased wildlife populations and tsetse fly re-infestation. This led to a significant decline in the number of livestock units owned by native communities (Tembo 2011). Prior to 1911, colonial authorities made efforts to develop native agriculture, with the aim of ensuring a cheap food source for the settlers and later mining towns. In addition, by improving the livelihoods of native Africans they too would be able to pay taxes. This was done through distribution of Irish potato and vegetable seed and the promotion of cotton farming among the native farmers (Tembo 2011). However, the failure of cotton trials and pursuit of land alienation policies meant that African agriculture remained largely abandoned and restricted to the growing of maize.

Following the tobacco boom of 1914, it was anticipated that a large number of white settler farmers would come to the Eastern Province of Zambia to engage in tobacco farming. This did not occur as prices in the tobacco markets fell in the 1920 s (Tembo 2011). By 1931 only $1600 \mathrm{~km}^{2}$ (15\%) of the $9000 \mathrm{~km}^{2}$ of the land reserved for white settlers had been occupied. The rest of the land was underutilized and had reverted to bush 
only suitable for wildlife and tsetse fly. The presence of tsetse fly meant the unoccupied area could not be used for cattle rearing, thus providing a level of forest protection. The pre-independence period presents a scenario where, on one hand, native reserves were overcrowded and forest resources were degrading, while on the other, trust lands were largely unoccupied and had thus reverted to forest.

The great economic depression of the 1930s led to a sharp decline in demand for copper, resulting in decreased demand for agricultural produce in the mining towns. Settler farmers switched to maize production, but faced stiff competition from the native smallholders who also grew maize, albeit using traditional maize varieties. In order to eliminate this competition, the colonial government introduced the maize control act of 1931, which led to the creation of the Maize Control Board in 1936 (Robinson et al. 2007). Maize selling by smallholder native farmers was severely restricted and they could only sell to the State through the Maize Control Board but the price offered was well below that of export markets (Rothermund 1996; Robinson et al. 2007).

The advent of the Second World War triggered an increase in copper demand, resulting in a renewed and increased demand for food in the mines, which in turn triggered increased agricultural production. At the same time, colonial authorities introduced hut tax, which forced native farmers (men) to abandon farming to seek waged employment in the mines and commercial farms to earn money to pay taxes (Mwanza 1992). This resulted in less food being produced. Among smallholders, tasks that were normally done by men, like land clearing, were left to women, reducing the efficiency of agricultural production and contributing to food shortages in the 1950s in the Eastern Province (Mwanza 1992).

Following the attainment of independence in 1964, new agricultural and land policies were promulgated and were aimed at encouraging subsistence farmers to participate in agricultural markets. The policies were supported by the formation of the Agricultural Rural Marketing Board (ARMB) to service rural areas, while the Federal Marketing Board was renamed the Grain Marketing Board (GMB) and serviced commercial farmers along the line of rail. The newly formed ARMB established agricultural depots in areas that were considered less viable for agriculture outside the Central, Eastern and Southern Provinces. These depots were taken over by the National Agricultural Marketing Board (NAMBOARD), which was established in 1967 through the amalgamation of the GMB and ARMB (Jansen and Rukuvo 1992).

Fertilizer use among smallholder farmers in the Eastern Province was non-existent until the late 1960 s and early 1970s (Harvey 1973). Despite the low adoption rates after the introduction of fertilizer, use increased with the introduction of improved maize seed varieties and grain marketing facilities, as this made fertilizer use more profitable. Agricultural research and extension services in the Eastern Province were targeted at agriculture on the Plateau leaving the Luangwa Valley largely neglected (Jha and Hojjati 1993).

Fertilizer subsidies to small-scale maize farmers were introduced in 1971, while uniform pricing of maize was introduced in the 1974/75 farming season. The Registration and Development Villages Act was also introduced in 1971 (Kwesiga et al. 2003; Chikulo 2009). Under this act, village productivity committees were established whose main task was 
to plan for the growth and development of the village, effectuating the establishment of new villages and establishing cooperatives for the purpose of marketing village agricultural produce. This prompted the growth of small- and medium-scale farmers from $23 \%$ to $36 \%$ of the rural population (Jansen and Rukuvo 1992).

The earliest efforts at agricultural extension were made in 1977 with the introduction of the Lima program, targeted at smallholder farmers able to farm 1 Lima ( $0.25 \mathrm{ha}$ ) of cash crop per season. This was complemented by the establishment of an Adaptive Research Planning Teams in each province, which used participatory approaches to involve farmers in identifying constraints to increasing yield among smallholder farmers. This was extended by introducing the 'train and visit' program in 1982 that meant farmers had increased access to information on agricultural practices like fertilizer application ratios (Saasa 2003). Clearer land rights and availability of agricultural inputs (through subsidies and agricultural loans) led to a change from shifting cultivation to sedentary agriculture. Farmer's increased maize production as grain marketing boards made it possible to earn income from the sale of this crop (Sugiyama 2007). Adoption of sedentary agriculture meant that there was little need to open up more agricultural land as farmers could return to the same fields year after year. This served as a safeguard for forests as these were not cleared for agricultural purposes.

A change in government in 1991 ushered in SAP, underwritten by the IMF, which called for reduced central government spending in services. The objectives of SAP in the agricultural sector were to improve food production, promote non-traditional (agricultural) export by reducing government intervention in the markets allowing a greater hand for the private sector (Simatele 2009). Under these reforms, marketing boards and parastatals were abolished (e.g. NAMBOARD) or privatized (e.g. Zamseed) (Mason et al. 2009; Simatele 2009). In addition, agricultural markets were liberalized while direct in put subsidies and credit controls were removed. The implication was that farmers would have to compete for access to credit with other potential borrowers, hence farmers with limited collateral had significantly reduced access to credit facilities (Simatele 2009). The government could not completely do away with subsidies, as it was one of the visible ways of demonstrating government support for the rural poor. From the late 1990s, several programs were introduced to provide some level of subsidized input to smallholder farmers (Mason et al. 2009).

The SAP froze agricultural expansion as people did not have access to agricultural inputs and extension services that they had enjoyed before, and reductions in crop production, especially maize, were noted (Simatele 2009). As an adaptation measure, rural farmers opted to open up new land in search of more fertile soils by clearing forests, as this was the only viable alternative to increase crop production in the absence of subsidies. The SAP, through the removal of services (e.g. extension and forest guards) that protected agriculture and forests, triggered an expansion into previously unused areas.

From the above discussion, it is evident that in each of the three epochs discussed (colonial, post-colonial and post-SAP), policy played a key role in influencing the development of smallholder agriculture. This has been seen through policies like centralization of smallholder communities and exclusive support for large-scale farmers 


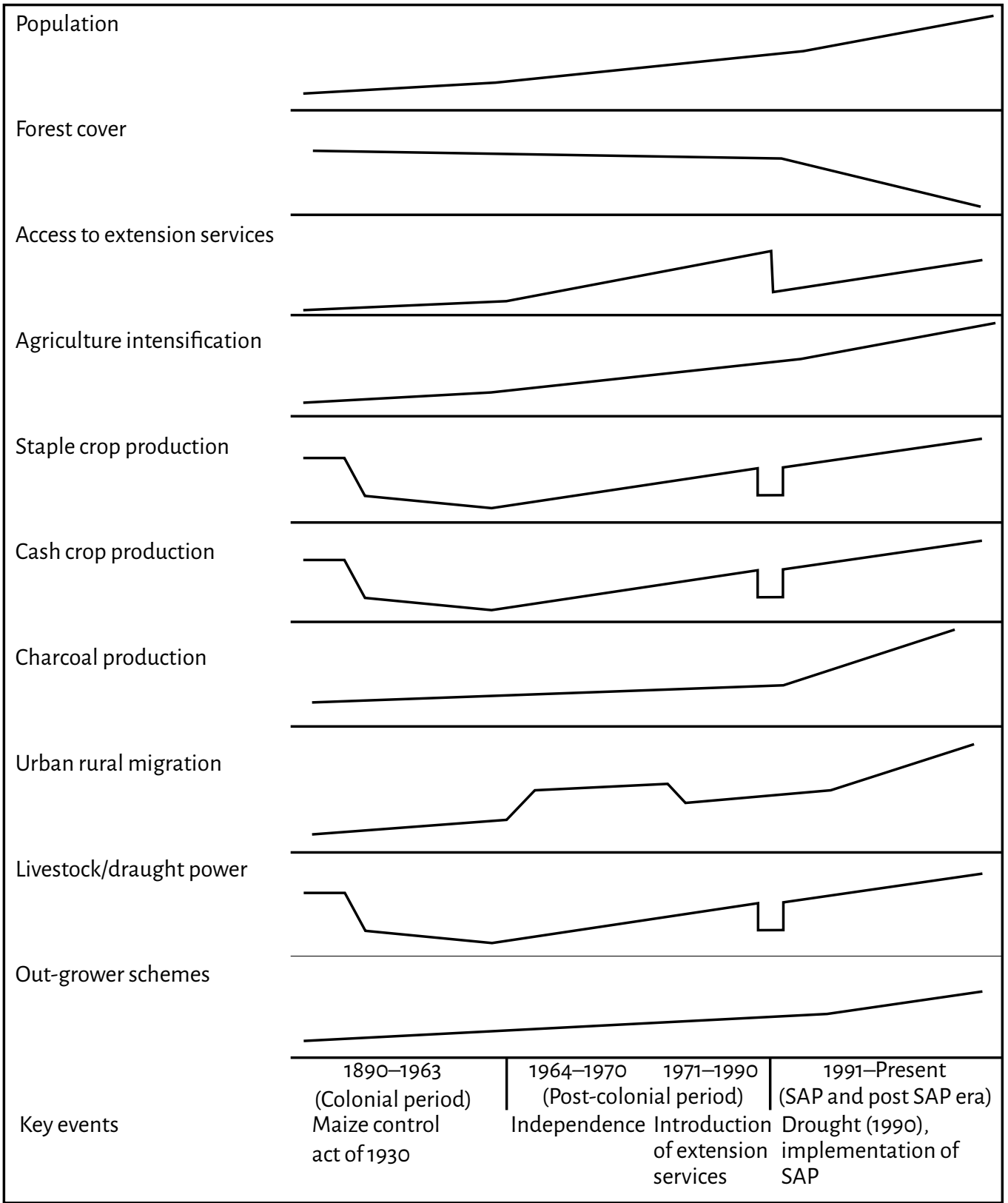

Figure 7.4 Historical trend lines and important events in the Eastern Province.

in the colonial era, increased government support for smallholders and direct market interventions in the post-colonial era, and liberalization of agriculture markets following the economic structure adjustment (Tembo 2011). The agrarian transition in the Eastern Province and Nyimba District, in particular, has as such been underwritten by policy, and major policy shifts throughout the three epochs have impacted land use and land-use change over time, thus shaping the Nyimba landscape. This interaction between land use/land-use change and policy across the three epochs is summarized in Figure 7.4. 


\subsubsection{District background to Nyimba District}

Nyimba District has a population of 80,025 , with population density of 8.1 persons per $\mathrm{km}^{2}$, which is the lowest in the Eastern Province (Figure 7.5; CIFOR 2014). Nyimba District was previously part of Petauke District, thus most historical data available references Petauke. It shares an international boundary with Mozambique. Nyimba District has two key geographical features, the Luangwa Valley on the western side of the district and the Eastern Plateau to the east (Figure 7.5). Nyimba District's geography is unique in that part of the district lies on a plateau and the other in a valley, and as such land-use practices here mirror to a great extent those of the entire province (see Figure 7.6).

\subsection{Scoping study results}

\subsubsection{Agro-ecological zone and vegetation type}

The Luangwa Valley lies in agro-ecological Zone 1 (AEZ1), which covers the southern part of Zambia. AEZs are "geographical areas exhibiting similar climatic conditions that determine their ability to support rain fed agriculture" and may be used to determine

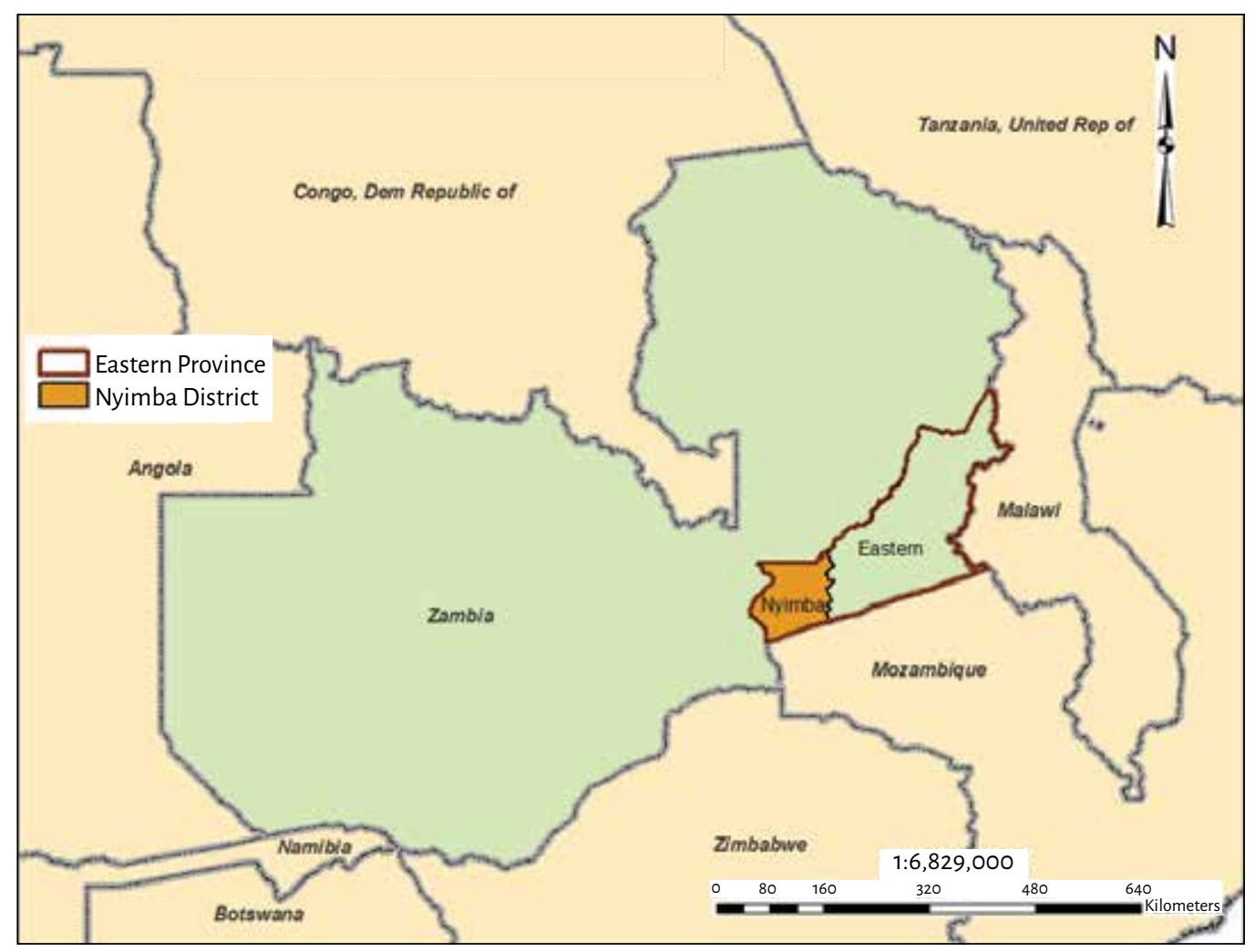

Figure 7.5 Location of Nyimba District in Eastern Province, Zambia. 


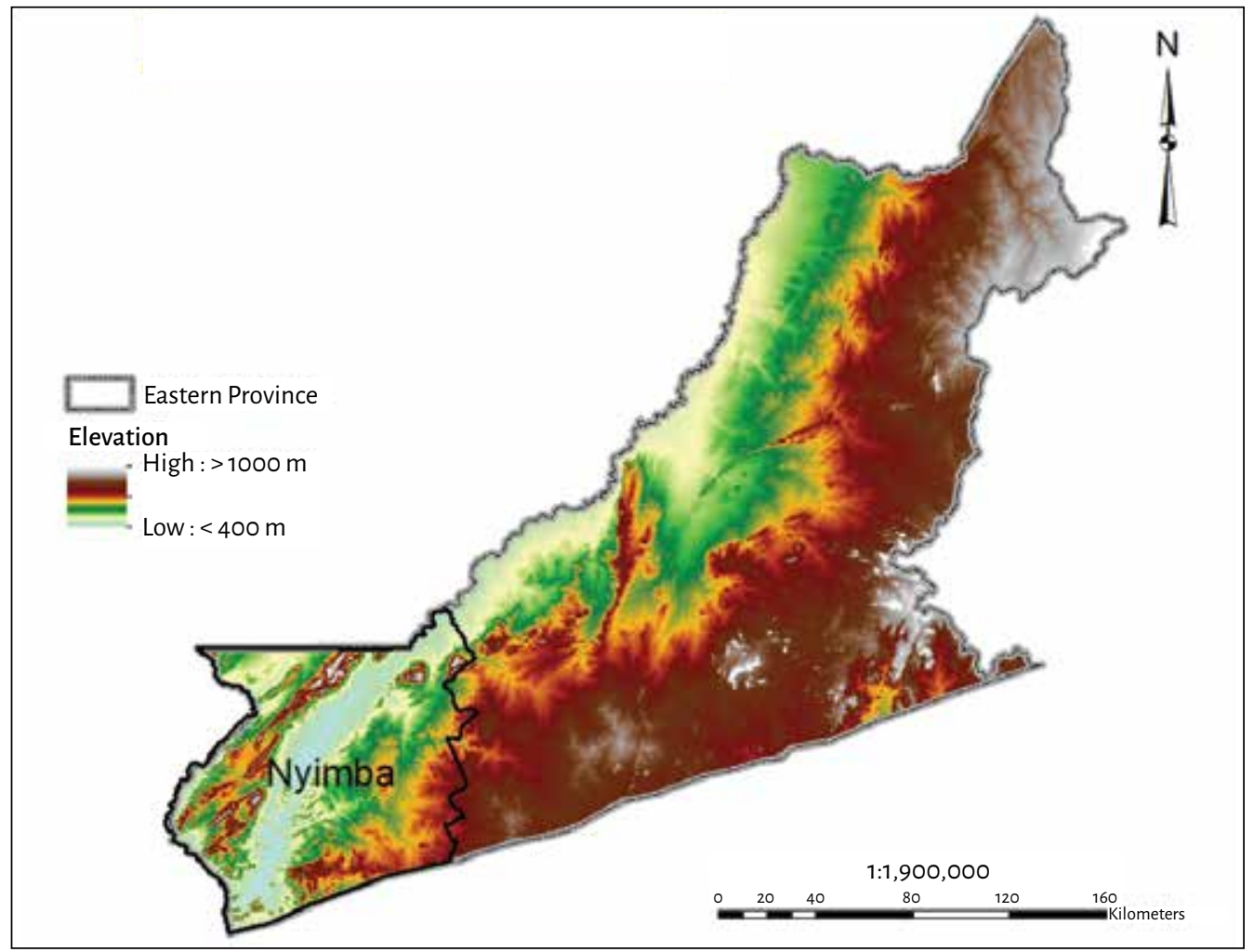

Figure 7.6 Eastern Province elevation.

crop types (Sebastian 2014). Agro-ecological Zone 1 sits on an altitude range of 300-900 masl. The Luangwa Valley receives an annual rainfall of $600 \mathrm{~mm}$ to $800 \mathrm{~mm}$, much of which is erratic and unreliable. The valley also experiences a short crop growing season of between 80 and 120 days (JAICAF 2008). The most suitable crops are drought resistant crops such as sorghum, millet, and cotton. Soils in the valley are typically shallow and sandy, which are not suitable conditions for agriculture (Mukosha and Siampale 2008). In Nyimba, the Luangwa Valley hosts part of the West Petauke game management area (GMA) and a number of game ranches and, as such, farming households in the valley co-exist with wildlife. Presence of wildlife in the valley has led to tsetse fly infestation and human-wildlife conflict limiting the livestock production potential of the area (Siegel 2008).

The Eastern Plateau of Nyimba District is in agro-ecological Zone 2 (AEZ2). The plateau is characterized by an altitude of 900-1200 masl and receives moderately good rainfall of $800-1000 \mathrm{~mm}$ per annum. The growing season often lasts between 100 to 140 days. The soils found here are moderately leached sandy loam soils, which are good for agriculture. Absence of tsetse flies makes livestock rearing possible and the most common livestock include cattle, pigs and goats (Siegel 2008). 


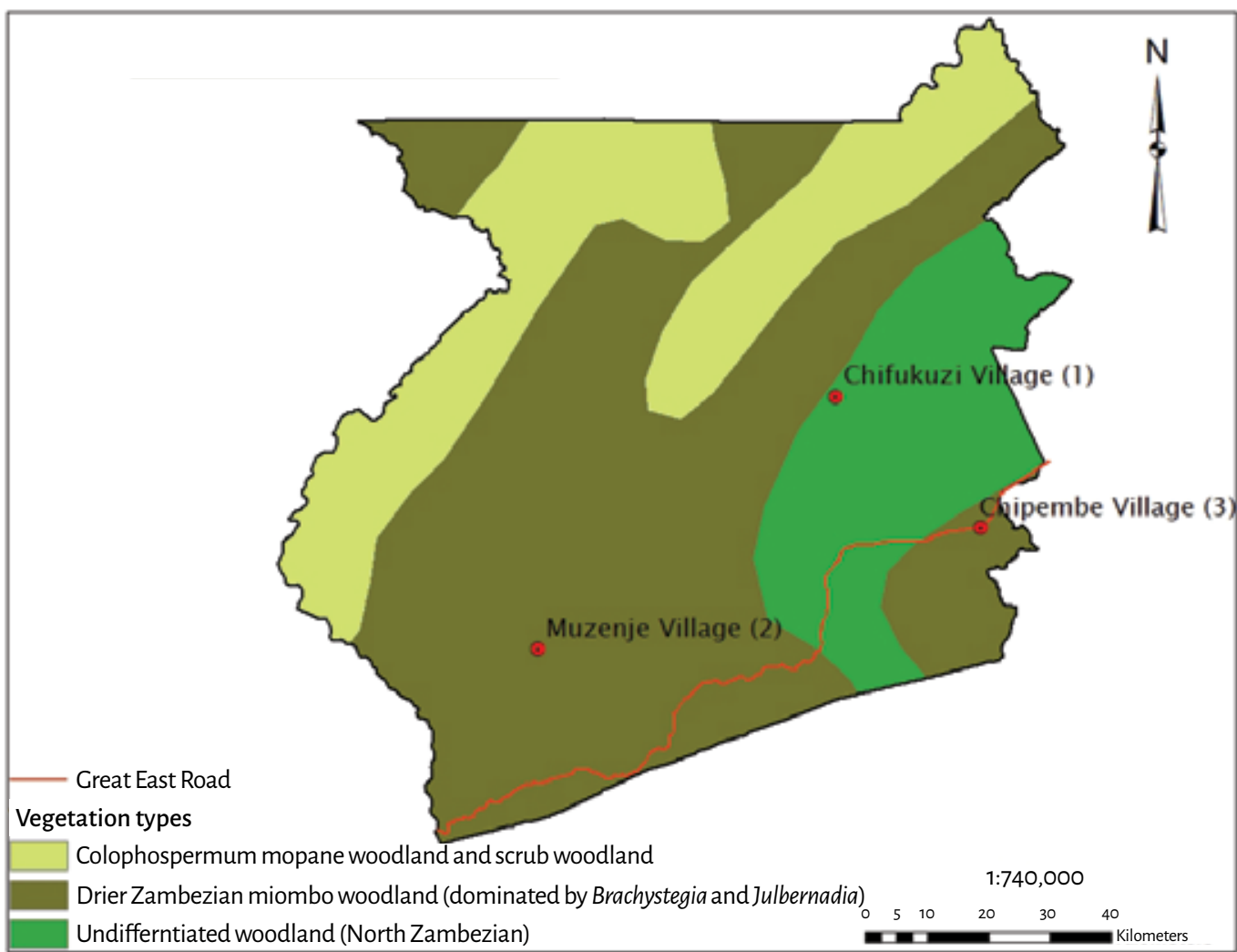

Figure 7.7 Vegetation of Nyimba District.

The predominant vegetation in Nyimba District is miombo (see Figure 7.7). Miombo woodlands are the most wide-ranging deciduous woodlands in Africa (2.7 million $\left.\mathrm{km}^{2}\right)$, and are dominated by the Brachystegia, Julbernadia and Isoberlinia genera (Campbell 1996; Backeus et al. 2006). The miombo woodlands are often located on the upper slopes and sit on soils that are inherently low in soil fertility (Dewees et al. 2011), with the lower slopes hosting mopane/acacia woodlands where the soils tend to be more fertile. Thus, the plateau is largely covered by miombo and the valley is covered by mopane with mixes of acacia species in places.

\subsubsection{Agriculture}

Over $90 \%$ of the population in Nyimba District is rural, with $91.7 \%$ of the smallholder households living below the poverty line (Tembo and Sitko 2013). Agriculture is the main stay of the district, with $87.7 \%$ of the total household income coming from farm activities (both sale and domestic consumption of farm produce and livestock) while only $12.3 \%$ of the total household income is realized from off-farm activities. Maize is the major crop cultivated; other crops include rice, sunflower, groundnuts, soya beans and cotton. As of $2012,24,027$ ha of land were under cultivation, with $71.1 \%$ of this area under maize cultivation (see Table 7.2; Tembo and Sitko 2013). The total maize harvest in 2012 was 34,375 tons, and the average harvest per household was 2.49 tons in the same 
Table 7.2 Crop productivity figures for Nyimba District for 2012.

\begin{tabular}{|l|c|c|c|c|c|c|}
\hline Attribute & Maize & Sunflower & Groundnuts & Soya beans & Cotton & Sweet potatoes \\
\hline $\begin{array}{l}\text { Crop yield } \\
\text { (tons/ha) }\end{array}$ & 2.3 & 0.57 & 0.48 & 0.39 & 1.22 & 3.97 \\
\hline $\begin{array}{l}\text { Total harvest } \\
\text { (tons/ha) }\end{array}$ & $34,375.8$ & 664.94 & 1457 & 0.7 & $1,802.8$ & 981.1 \\
\hline $\begin{array}{l}\text { Average } \\
\text { harvest per } \\
\text { household } \\
\text { (tons/ha) }\end{array}$ & 2.49 & 0.21 & 0.17 & 0.05 & 0.50 & 0.52 \\
\hline
\end{tabular}

Source: Adapted from Tembo and Sitko (2013)

year (see Table 7.2). Fertilizer usage is restricted to maize with the average smallholder household using $510 \mathrm{~kg}$ of fertilizer, while maize yields are 2.3 tons per ha (Tembo and Sitko 2013). Fertilizer use in the valley is almost non-existent and as such low yields are generally experienced, thus limiting arable cropping as a source of income.

In Table 7.2, emphasis is placed on maize and fertilizer and less so on cash crops such as cotton and tobacco that are also grown in the district. Whereas maize is produced for household consumption and partly for the market through the Food Reserve Agency and private buyers, the production and marketing of most cash crops is done through out-grower schemes underwritten by private companies. In Nyimba, the most active are NWK (formerly Dunavant) (cotton) and Alliance One (tobacco) supported by the Cotton Board of Zambia and Tobacco Board of Zambia, respectively. Companies involved in out-grower schemes not only supply agro-inputs but also expertise (extension) and always guarantee a market for the product. What has been observed is that the pre-planting price offered by the company often determines the amount of land under the crop. Whereas the demand for additional land under tobacco maybe limited, the forest is impacted through the harvesting of wood for flue curing. Estimates indicate that approximately $7.8 \mathrm{~kg}$ of wood is needed to produce $1 \mathrm{~kg}$ of tobacco (Geist et al. 2009). These estimates have not been verified for Nyimba, but the contribution to woodland change cannot be questioned.

\subsubsection{Market access}

The district market located at the district center is the main source of household goods, farming inputs and implements, and can be accessed via the Great East Road. The presence of the Food Reserve Agency (FRA) depot and private companies, like Export Trading, make it a major market for farm produce (GRZ 2004). Within the villages, the FRA is the main market for the staple crop, maize, through its satellite depots. Private companies like NWK and Cargill provide a market for other cash crops, such as cotton and soya beans.

Inter-household trade is common, and a portion of farm produce is usually traded this way, for cash, other goods or labor. 


\subsubsection{Land tenure}

In Zambia, land has been governed by several laws including the Land Deeds Registry of 1914, Land Acquisition Act of 1970, Lands (Conversion of Titles) Act of 1975 and the current Lands Act of 1995 (Adams 2003). Under current law, all land is vested in the president of the republic. Two tenure systems are present, customary and statutory (Malambo 2013). Under customary land tenure, vacant land is allocated to families or individuals by traditional authorities (chiefs) usually through subordinate leaders like village headmen (Ranger 1983; Berry 1993). Under statutory tenure, government allocates land through relevant organs and individual landowners have title deeds, hence can sell, rent or transfer the land. The lands tribunal established by the Lands Act of 1995 is tasked with sorting out land related disputes and its focus thus far has been on state land (Adams 2003). Statutory land covers only $6 \%$ of the total land area while the remaining 94\% is customary land (Adams 2003).

Efforts have been made to secure land rights for women. An example of this is the requirement of the Ministry of Lands that $30 \%$ of all plots should be allocated to women and that the remaining $70 \%$ should be competed for by both men and women (GRZ 2006). By law, both men and women are allowed to request land. Under customary systems, however, women's land rights are generally considered to be insecure, as they have access to land (usually through a male relative, e.g. husband or father) but have no control over it (Chapoto et al. 2009). This assertion is affirmed by Kajoba (2002), who found that women in Chibombo, a similar district to Nyimba but located in the Central Province, lost their land after the death of a spouse, and were, in some instances, evicted from the villages and asked to return to their villages of origin (Kajoba 2002). Matrimonial societies with matri-local marriages are perceived to have more secure rights for women (Chapoto et al. 2009).

All land in the Nyimba landscape is under customary control, and locals access land either through inheritance or through their respective village headmen. Existing land can be increased by requesting additional land from the chief or headman. Households can also increase the amount of land under cultivation by borrowing land from neighbors to use in the farming season. In the study area, land disputes within the village are uncommon but where they arise, they are resolved by the headman.

\subsubsection{Nutrition and health}

Using a 24-hour food recall method, the 2007 demographic and health survey showed that at the time of the survey, $89.7 \%$ of children (aged 6 to 35 months) in the Eastern Province consumed foods rich in vitamin A and $45.5 \%$ consumed iron rich foods (CSO et al. 2009). The study further found that $61.4 \%$ and $64.0 \%$ of children under the age of 5 took vitamin A supplements and deworming medicine, respectively, within 6 months of the study. According to the 2013/14 demographic and health survey, $17.4 \%$ of children under the age of six in the Eastern Province were stunted and $43.3 \%$ severely stunted (national averages $17.2 \%$ and $40.1 \%$ respectively) (CSO et al. 2014). Close to $5.0 \%$ of children were wasted and $6.0 \%$ severely wasted, while $2.2 \%$ were underweight and $12.8 \%$ severely underweight (CSO et al. 2014). 
Based on body mass index (weight to height ratio), the 2007 study found that $6.6 \%$ of all women in the province were underweight, $14.4 \%$ were obese and $79 \%$ were considered normal. Of all mothers, $98.3 \%$ breastfed their children and the average period of breastfeeding was 21 months (CSO et al. 2009). Health facilities are available in all three study sites.

\subsubsection{Land use and cover change}

In Nyimba, land uses have been changing, resulting in land-use mosaics across the district dominated by arable fields and forests. Under CIFOR's Nyimba Forest Project, land-use and land cover analysis, including change detection, were carried out for the period 1990 to 2013 (see Gumbo 2015). The dominance of agricultural activities as a driver of forest change was noted (0.4\%/annum between 1990 and 2013) in line with provincial and national rates. Between these 2 years, agriculture has continued to expand at the expense of forests (Figure 7.8) leading to a decrease in woody biomass by 2013. It is noted that the same forests have also been changing through activities such as charcoal production, cutting of construction timber, tobacco curing in some places and fire. Thus, forests are dominated by trees with stem diameters of $\leq 13 \mathrm{~cm}$ calling for stringent management regimes (Gumbo 2015).

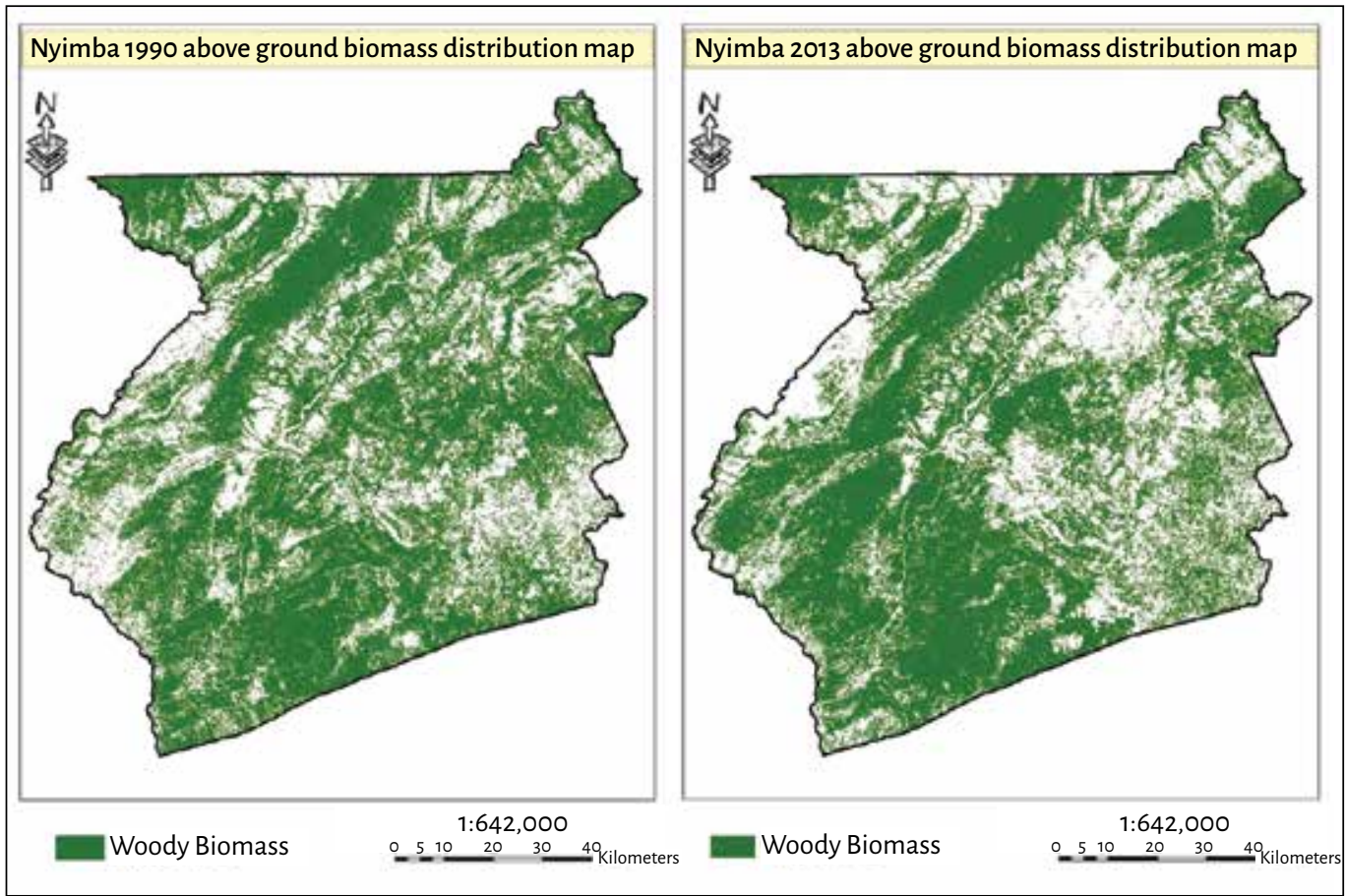

Figure 7.8 Wood biomass change in Nyimba District from 1990 to 2013. 


\subsection{Description of selected villages}

As with the rest of the province, early development work in Nyimba was pegged to agriculture, albeit with a greater focus on the plateau. As such, landscapes in villages like Chipembe have been undergoing modification since the 1930s and present contemporary mosaics of cultivated, fallow, and homestead field and gardens, with scattered trees and patches of remnant forests. It was observed that the continuum lay between protected areas (forest reserves and GMAs) in the Luangwa Valley (390-450 masl) and old settlements (villages) on the plateau (»900 masl). ${ }^{4}$

There are a number of villages on this continuum, some $74 \mathrm{~km}$ in length, and the major differences among them can be explained by how widely cultivated they are as well as the intensive use of agrochemicals over time. An examination of the status of forest cover in the villages led to the selection of three villages for study: Muzenje ( $30.4^{\circ}$ east, $14.7^{\circ}$ south; $450 \mathrm{masl}$ ), Chifukuzi ( $30.8^{\circ}$ east, $14.3^{\circ}$ south; 786 masl), and Chipembe $\left(31.0^{\circ}\right.$ east, $14.5^{\circ}$ south; 909 masl) (Figure 7.9). The human populations in the villages

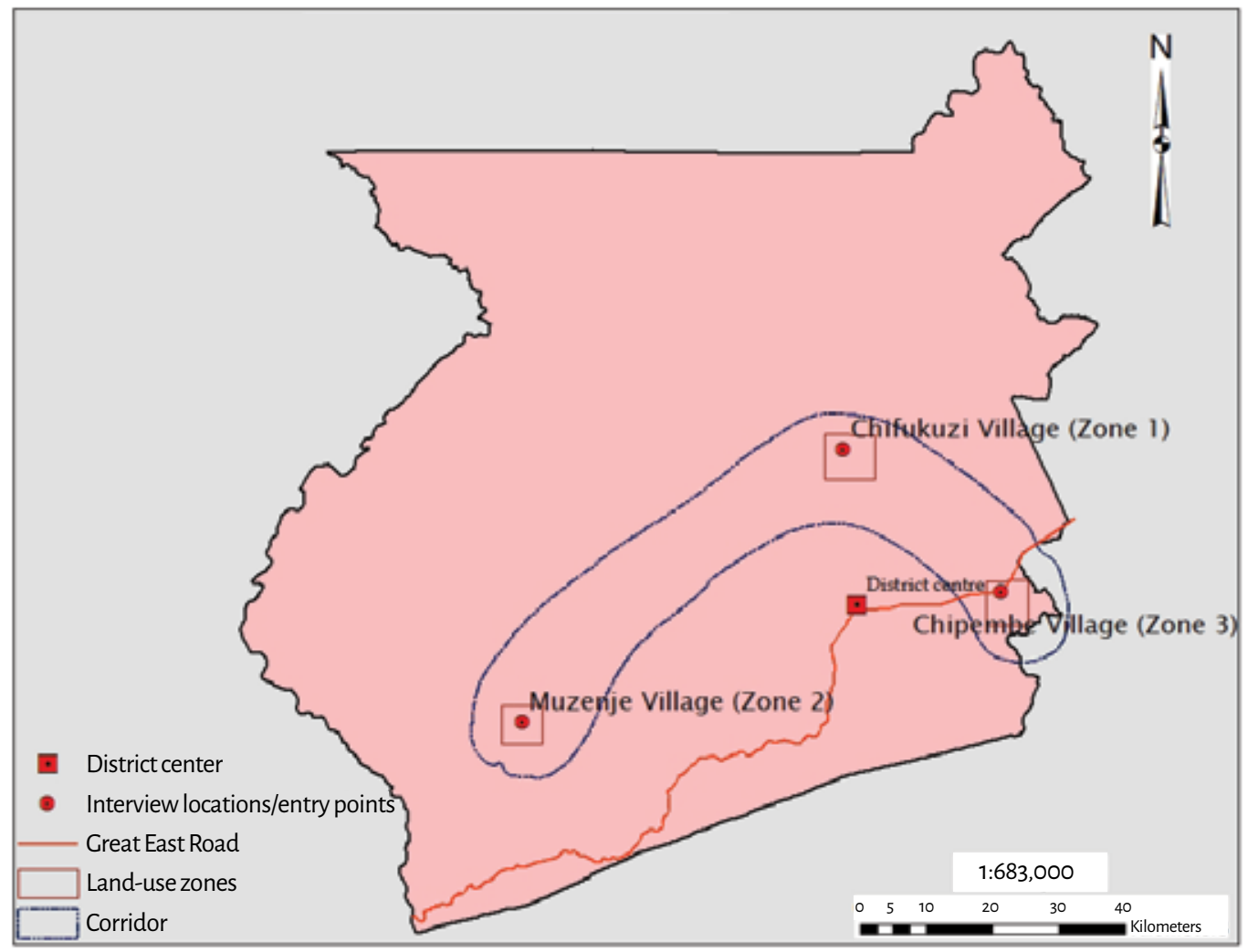

Figure 7.9 Nyimba District map showing the selected landscape and location of the settlements.

4 The plateau was settled first due to the absence of tsetse flies, which still occur in some sections of the valley (Mwanza 1992). 
were 585, 3072 and 9000, respectively. Muzenje village sits in the valley and shares a boundary with Damiano Game Ranch, which is part of the $4140 \mathrm{~km}^{2}$ West Petauke GMA. Whereas Muzenje is sparsely populated (9.4 persons $/ \mathrm{km}^{2}$ ), Chipembe on the plateau is densely populated ( 230 persons $/ \mathrm{km}^{2}$ ) immediately raising issues on the status of forest cover (Table 7.3).

The continuum presented three zones of varying agricultural intensification, with subsistence agriculture with high forest cover in Zone 1 and market-oriented high intensification agriculture and low forest cover in Zone 3. Zone 2 sits between the two extremes, in an area transitioning from Zone 1 to Zone 3.

On this continuum, the three selected settlements (Muzenje, Chifukuzi and Chipembe) represent land-use zones 1, 2 and 3, respectively (Figure 7.9). Muzenje (Zone 1) is a frontier village located in the Luangwa Valley (altitude $450 \mathrm{masl}$ ) and shares a boundary of West Petauke GMA and is also close to the Damiano Game Ranch. Muzenje is an area of high forest cover and has several seasonal and annual streams. Due to presence of

\section{Table 7.3 Key aspects of the revised land-use zone selection criteria.}

\begin{tabular}{|c|c|c|c|}
\hline Criteria & Muzenje (Zone 1) & Chifukuzi (Zone 2) & Chipembe (Zone 3) \\
\hline Land-use zone & 1 & 2 & 3 \\
\hline Zone defined & $\begin{array}{l}\text { Low agricultural } \\
\text { intensification }\end{array}$ & $\begin{array}{l}\text { Intermediate agricultural } \\
\text { intensification }\end{array}$ & $\begin{array}{l}\text { High agricultural } \\
\text { intensification }\end{array}$ \\
\hline Chiefdom & Nyalugwe & Mwape & Ndake \\
\hline Population & 585 & 3072 & 9000 \\
\hline Area of village & $61.6 \mathrm{~km}^{2}$ & $54.8 \mathrm{~km}^{2}$ & $39.2 \mathrm{~km}^{2}$ \\
\hline Forest cover & High & Medium & Low \\
\hline Agricultural activity & Subsistence & $\begin{array}{l}\text { Mixed (subsistence and } \\
\text { cash cropping) }\end{array}$ & $\begin{array}{l}\text { Mixed (subsistence and } \\
\text { cash cropping) }\end{array}$ \\
\hline Use of draft power & Low & Medium & High \\
\hline $\begin{array}{l}\text { Presence of extension } \\
\text { services }\end{array}$ & No & Yes & Yes \\
\hline $\begin{array}{l}\text { Levels of agricultural } \\
\text { inputs use }\end{array}$ & Low & Medium & High \\
\hline $\begin{array}{l}\text { Market-oriented crop } \\
\text { production }\end{array}$ & None & $\begin{array}{l}\text { Cotton, soya beans, } \\
\text { sunflower }\end{array}$ & $\begin{array}{l}\text { Maize, cotton, soya } \\
\text { beans, sunflower }\end{array}$ \\
\hline Out-grower schemes & No & Yes & Yes \\
\hline Distance to district center & $100 \mathrm{~km}$ & $30 \mathrm{~km}$ & $21 \mathrm{~km}$ \\
\hline Land tenure & Customary & Customary & Customary \\
\hline Proximity to protected area & Near & Far & Distant \\
\hline Level of in migration & High-medium & Medium-low & Low \\
\hline
\end{tabular}




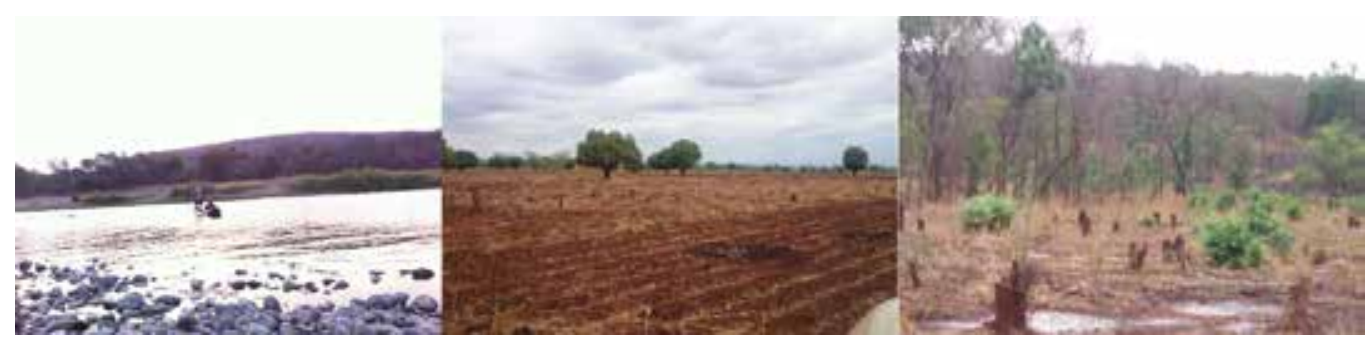

Intensification gradient from Zone 1, a settlement on the boundary of west Petauke GMA (left), to Zone 2, a high tree density zone that is currently being opened up for agriculture (center), and Zone 3, a low tree density zone (right). (Moka Kaliwile/CIFOR)

tsetse flies, limited access to extension and markets and human-wildlife conflict, agriculture in Muzenje is highly underdeveloped and oriented toward subsistence production. As such, the landscape has more trees and few agriculture fields.

Chifukuzi (Zone 2) and Chipembe (Zone 3) villages are on the plateau. Chifukuzi was settled around 2000. However, due to easy access, presence of livestock (cattle) and migration, more land has been opened up for agriculture and is slowly transitioning from pristine forest to agriculture based landscape. Chipembe (Zone 3) village has been cultivated over a long period of time and is now sparsely forested. Chipembe thus presents a matrix of settlements and agricultural fields dotted with mango trees on old and abandoned home fields (Table 7.3).

\subsubsection{Muzenje village}

Muzenje (Zone 1) is made up of a cluster of six villages, namely Muzenje, Kautukilo, Musonda, Nyamulika, Chausi and Lameck (all located within a radius of $3 \mathrm{~km}$ ) that were established in 1975 in Chief Nyalugwe's area..$^{5}$ Inhabitants of this cluster of villages are mainly Nsenga speaking and migrated to this area from different parts of the chiefdom. It is unclear why they moved to this area, but they seem to have been attracted by the perceived benefits they would gain from the forest, and hunting and fishing along the Luangwa River and the GMA. Land is not a constraint in the area for it is still readily available. The villages in this cluster was established in the post-colonial era when agricultural policies favored agro-expansion. This zone has approximately 120 households with a population of 585 people (CIFOR 2014). The main sources of income for Muzenje village are agriculture, fishing and hunting. The head woman explained that extension services are not available due to the remote location of the village $(100 \mathrm{~km}$ from Nyimba District center). Where elephants are dominant, they destroy crops every year and are a threat to lives resulting in human-wildlife conflict. The village is less than $10 \mathrm{~km}$ from Damiano Game Ranch and on the boundary of West Petauke GMA.

5 Clustered for the purpose of the study to meet the minimum 75 households per zone required. 
Much of the cultivation in the village is carried out on permanent crop lands with some farmers using crop rotation as a strategy for soil fertility management. Presence of tsetse fly has hindered livestock rearing and hence curtailed the use of draft power. As a result, agricultural expansion is low because cultivation is hand-hoe based. In addition, there is limited access to extension services (both public and private), agricultural cooperatives and markets. The head woman explained that due to the low incomes and low crop production by households, families are not food secure throughout the year. Households in Muzenje have limited access to markets and have to take their produce (farm and off farm) to the district market, which is $100 \mathrm{~km}$ away. As such, farm production is oriented toward domestic consumption.

The Muzenje village community is highly dependent on forest resources for household energy in the form of firewood and wild fruits, which can be easily accessed. Game meat is an important source of protein, while trees with large diameter stems are used for construction and making dugout canoes. Households have exotic fruit trees, such as mangoes, in their homesteads and agriculture fields. Off-farm activities include formal employment in the game ranches, fishing and selling of reed mats and baskets from materials harvested from local streams and the Luangwa River.

The village has access to a clinic and a school, which are both $5 \mathrm{~km}$ from the settlement. The village can be accessed via a gravel road, which is maintained by the district council and game ranch owners in the area.

\subsubsection{Chifukuzi village}

The settlement selected in Zone 2 is Chifukuzi village, and is located in Mwape chiefdom. This village was established in 2000 by households that relocated to the area from Chinsimbwe village some $60 \mathrm{~km}$ away, but within the same chiefdom. The migration to Chifukuzi village was triggered by human-wildlife conflicts in Chinsimbwe village, which shares a boundary with the West Petauke GMA. Chifukuzi was established after SAP, when most rural farmers in Zambia were seeking new agricultural land and livelihood opportunities. The village grew as more families from different chiefdoms came to settle in the area. Included in these migrants are government retirees from within and outside Nyimba. This has resulted in mixed agricultural expertise and farming practices in the village. Agricultural land in the village is being opened up by new settlers as some of these have resources (pensions, remittances etc.) that enable them to hire labor to expand their agricultural fields.

Chifukuzi village has approximately 668 households with a population of 3072 people (Gumbo 2015). The main source of income for Chifukuzi village is agriculture. Extension services are available through an agricultural camp extension officer who visits the village before land preparation and during of the distribution agriculture inputs. Access to farming inputs under FISP is facilitated by two cooperatives while NWK and Olam cotton companies have out-grower schemes in the village. Farmers in Chifukuzi have permanent crop lands where, besides the use of fertilizers, they also practice crop rotation as part of fertility management and pest control. Use of animal draft power has contributed to the expansion of cultivated land in the village, while markets for cash crops are provided within the village by private companies through out-grower schemes. Private individuals also buy maize from locals, while some is exchanged for services especially during the planting season. 
Remittances, pensions and cash earned from the sale of farm produce have contributed to the increased use of farming inputs (usually fertilizer, seed and at times herbicides). The main market for maize is the FRA though the depot is located $22 \mathrm{~km}$ from the village. The headman explained that as a result of the income generated from agriculture produce, remittances and retirement benefits most households are food secure all year round. Inhabitants of Chifukuzi village are dependent on the forests for fuelwood, wild fruits and game meat. Exotic fruit trees like mangos, guavas and pawpaws are available in homesteads and agricultural fields.

Off farm activities for households include charcoal production, beer brewing and trading, which are possible sources of income for farming inputs. The village has access to a clinic and a school, which are both within the village. Water for household use and domestic animals is sourced from four bore holes within the village as there are no surface water bodies. The village can be accessed through a gravel road, which is maintained by the district council and game ranch owners in the area.

\subsubsection{Chipembe village}

Chipembe village, located in Ndake Chiefdom was selected as the Zone 3 study site. This village was established in the 1930 s by Chewas, Nsengas and Ngonis who migrated from Mozambique. The village sits at the junction of Great East Road (GER) from Lusaka to Malawi, and the Mozambique road to the border between the two countries. The accessibility of the village has led to an influx of people from different parts of Zambia, resulting in a cultural mix and an introduction of different agricultural techniques.

Chipembe village was established during the colonial era and has gone through all three phases of agrarian change. Inhabitants of the village benefited from the agriculture policies of the post-colonial era and as such agriculture is well developed. According to the agricultural Camp Extension Officer, the village has approximately 1800 households and has a population of 9000 people (Gumbo 2015). The main sources of income in Chipembe village are agriculture, formal employment in business enterprises, such as grocery and agriculture input retail and wholesale shops, schools, clinics, shops, depots, etc. The village has 21 agricultural cooperatives, which facilitate access to FISP, 13 savings and multipurpose clubs and a cotton out-grower scheme supported by NWK and Cargill cotton companies. There is an active agricultural camp office that has four members of staff who support farmers by providing extension services and coordinating the distribution of inputs supplied by government through FISP. Private companies provide market for cash crops (cotton), while the FRA provides the main market for maize within the village.

Chipembe village has limited land available for new settlers, as most of the land has been apportioned. The farmers have sufficient land to allow fallowing and practice crop rotation on an annual basis. Households in Chipembe village use animal draft power and this has contributed to current crop productivity. The headman explained that the income generated from the sale of agricultural produce and other off-farm activities has contributed to the households in the area being food secure. Chipembe has a FRA depot within the village but villagers complain the depot often delays making payments. Chipembe village community has a low dependence on the forest resources because of 
the small diameter stems, which are less suitable for construction and energy (in the form of firewood). There are few wild fruits and game meat is generally unavailable. The zone is approximately $2 \mathrm{~km}$ from the homestead to the nearest open forest were these products can be harvested. Households have exotic fruit trees at both their homesteads and agricultural fields.

The village has one clinic and two primary schools, which are all within the village. Along the GER and the Mozambique road, there are multiple shops constructed from burnt bricks and metallic roofing sheets. The main sources of household water are bore holes and streams and rivers that run through the area.

\subsection{Conclusion}

Nyimba District presents itself as an excellent site for a study on agrarian change. Lying in the Eastern Province of Zambia and one of the earliest provinces to receive support for smallholder farmers and most productive agricultural areas, Nyimba is a landscape where policy changes driven by pre-and post-colonial objectives in the area of agriculture, environment and natural resources had high impacts at the landscape level. Policy focus on smallholder farmers has not changed since independence and, even in the current post-SAP period, the focus has not been lost. Although other issues such as charcoal production are also coming to the fore vis-à-vis land-use change at district level. Further, the interplay between agriculture and other related polices (e.g. forestry, land and environment) can still be seen influencing change at landscape level.

The three selected villages in Nyimba, two on the plateau and one in the valley, lie on a continuum of agriculture driven land-use modification and represent areas where policy impact can be discerned. The landscapes surrounding these villages are the result of decisions and actions made at household level, but that are not only based on the provisions of various policies but also the land and other attributes, such as rainfall. The continuum of land-use modification identified across the three zones shows changes in land use from low to high agricultural intensification defined by levels of use of improved maize varieties, fertilizers and other agrochemicals. Equally important are issues related to access to extension services, draft power, out-grower schemes (mainly cash crops), density of cooperatives and markets; these vary across the three zones.

The changes at village/zone level are made more apparent through the analysis of remotely sensed data, which reveals that there are differences in forest cover and agricultural land cover among the three villages. Chipembe shows more land covered by cultivated areas than forests, while Muzenje shows the opposite with more forest cover. A comparison of woody biomass change in the two extremities shows an increase in Muzenje between 1990 and 2013 as opposed to Chipembe, which shows a decrease in woody biomass in the same time period. As already indicated, Muzenje village lies close to a GMA and a game ranch where other aspects like human-wildlife conflict and occasional re-infestations by tsetse fly have curtailed agricultural activities. Further, the presence of game and game meat, fish and forest foods, which do not require 
modification of the environment, make a contribution to the food security in this village. Chipembe on the other hand is an agricultural village, with all the support needed to make agriculture viable and as a consequence it is devoid of trees.

The Nyimba landscape thus sets the scene for understanding how polices together with other factors have defined the agrarian change trajectory. It presents a continuum of varied policy penetration, giving rise to three zones of varied land-use configuration. Further, it presents an opportunity to understand how households have responded to policies, and how this has translated into change at landscape level.

\section{Acknowledgments}

We would like to recognize the support of Mr. Evaristo Nonde (Muchinga Province Forestry Office), Mr. Francis Mutale (Mpika District Forestry Office) and Mr. Edward Hachuundu (Mpika District Agricultural Office) during the fact finding mission in Mpika District. We further wish to extend our gratitude to Mr. James Ngalamila (Nyimba District Agricultural Office), Mr. Raymond Ngulube (Nyimba District Forestry Office), Mr. Andrew Goods Nkhoma (Zambia Wildlife Authority), Ms. Carol Miti and Mr. Edward Chipungu (Community Youth Concern).

The team would also like to acknowledge the contribution of his and her Royal Highnesses Senior Chief Leumbe, Chief Nyalugwe, Chief Ndake and Chieftaness Mwape. They provided the necessary support and permission for the study to be carried out in their chiefdoms. Furthermore, we are grateful to Ms. Grace Mwanza, Ms. Kelida Tembo, Mr. Jackson Tembo, Mr. Musaiwale Phiri, Mr. Nevers Daka, Mr. Lembelani Zulu, Mr. Anoya Mphende, Mr. Richard tembo, Mr. Michael Njobvu, Mr. Credence Mwelwa, Mr. Gibby Njobvu and Mr. Robert Kahyata for collecting the data and organizing community meetings. Finally, we appreciate all the village indunas, headmen/women and community members in the working areas for allowing us into their locales, facilitating and participating in community meetings. 


\section{References}

Adams M. 2003. Land tenure policy and practice in Zambia: Issues relating to the development of the agricultural sector. DCP/ZAM/018/2002. London: Mokoro Ltd.

Amberntsson P. 2011. The Past of Present Livelihoods. Historical Perspectives on Modernisation, Rural Policy Regimes and Smallholder Poverty: A Case from Eastern Zambia. Publications edited by the Departments of Geography, University of Gothenburg, Series B, No. 118. Gothenburg: Department of Human and Economic Geography, University of Gothenburg.

Anderson D and Grove R. 1989. Conservation in Africa: People, Policies, and Practice. Cambridge and New York: Cambridge University Press.

Backeus I, Pettersson B, Stromquist L and Ruffo C. 2006. Tree communities and structural dynamics in Miombo (Brachystegia julbernadia) woodlands, Tanzania. Forest Ecology and Management 230:171-8.

Bates RH. 1984. Some Conventional orthodoxies in the study of agrarian change. World Politics 36(2):234-54.

Berry S. 1993. No Condition Is Permanent: The Social Dynamics of Agrarian Change in SubSaharan Africa. Madison, WI: University of Wisconsin Press.

Campbell B, ed. 1996. The Miombo in Transition: Woodlands and Welfare in Africa. Bogor, Indonesia: Center for International Forestry Research.

Celis R, Milimo JT and Wanmali SM, eds. 1992. Adopting Improved Farm Technology: A Study of Smallholder Farmers in Eastern Province, Zambia. Washington, DC: International Food Policy Research Institute (IFPRI).

Chapoto A, Haggblade S, Hichaambwa M, Kabwe S, Longabaugh S, Sitko N and Tschirley D. 2013. Institutional models for accelerating agricultural commercialization: Evidence from maize, cotton and horticulture in Zambia, 1965 to 2012 . In Hillbom E and Svensson P, eds. Agricultural Transformation in a Global History Perspective. London: Routledge Press. 300-29.

Chapoto A, Jayne TS and Mason NM. 2009. Widows' land security in the era of HIV/ AIDS: Panel survey evidence from Zambia. Economic development and cultural change 59(3):511-47.

Chikulo B. 2009. Local governance reforms in Zambia: A review. Commonwealth Journal of Local Governance 2:98-106.

Chileshe A. 2005. Land tenure and rural livelihoods in Zambia: Case studies of Kamena and St. Joseph [PhD thesis]. Cape Town, South Africa: University of the Western Cape.

Chileshe A. 2001. Forestry outlook studies in Africa (FOSA): Zambia. Lusaka, Zambia; Rome: Ministry of Natural Resources and Tourist; Food and Agriculture Organization of the United Nations.

Chomba GN. 2004. Factors affecting smallholder farmers' adoption of soil and water conservation practices in Zambia [Master's thesis]. East Lansing, MI: Michigan State University.

Chombe C, Mwenya NA and Nyirenda V. 2011. Wildlife legislation and institutional reforms in Zambia for the period 1912-2011. Journal of Sustainable Development in Africa 13(3). 
[CSO] Central Statistical Office, [MOH] Ministry of Health, [TDRC] Tropical Diseases Research Centre, University Teaching Hospital-Virology Laboratory, University of Zambia, and ICF International. 2014. Zambia demographic and health survey 2013-14: Preliminary report. Lusaka: CSO.

[CSO] Central Statistical Office. 2010 census of population and housing population summary report. Lusaka: Central Statistical Office.

[CSO] Central Statistical Office, [MOH] Ministry of Health, [TDRC] Tropical Diseases Research Centre, University of Zambia and Macro International Inc. 2009. Zambia demographic and health survey 2007. Calverton, Maryland, USA: CSO and Macro International Inc.

[CSPR] Civil Society for Poverty Reduction. 2005. An assessment of the implementation and effectiveness of the Fertilizer Support Programme. Lusaka: Civil Society for Poverty Reduction.

Dalal-Clayton B and Child B. 2003. Lessons from Luangwa. The Story of the Luangwa Integrated Resource Development Project, Zambia. Wildlife and Development Series, 13. London: International Institute for Environment and Development.

Dewees P, Campbell B, Katerere Y, Sitoe A, Cunningham AB, Angelsen A and Wunder S. 2011. Managing the Miombo Woodlands of Southern Africa: Policies, Incentives, and Options for the Rural Poor. Washington, DC: Program on Forests (PROFOR).

[EDF] European Development Fund. 1994. Commodity chain study: an analysis of producerconsumer chains for maize, wheat, soyabean. SC/05/1995. Lusaka: GRZ, EDF and Mano Consultancy Services Ltd.

Geist H, Chang K-t, Etges V and Abdallah J. 2009. Tobacco growers at the crossroads: Towards a comparison of diversification and ecosystem impacts. Land Use Policy 26:1066-79.

[GRZ] Government of the Republic of Zambia. 2015. Zambia's second national biodiversity strategy and action plan (NBSAP-2). Lusaka: Ministry of Lands, Natural Resources and Environmental Protection.

[GRZ] Government of the Republic of Zambia. 2013. National Agriculture Investment Plan (NAIP) 2014-2018. Lusaka: Ministry of Agriculture and Livestock.

[GRZ] Government of the Republic of Zambia. 2009. Farmer Input Support Programme Implementation Manual, 2009/2010 Agricultural Season. Lusaka: Ministry of Agriculture and Cooperatives.

[GRZ] Government of the Republic of Zambia. 2007. National Policy on Environment. Lusaka: Ministry of Tourism, Environment and Natural Resources.

[GRZ] Government of the Republic of Zambia. 2006. Land Policy. Lusaka: Ministry of Lands.

[GRZ] Government of the Republic of Zambia. 2005. Joint Forest Management Guidelines. Lusaka: Forestry Department/ Ministry of Environment and Natural Resources.

[GRZ] Government of the Republic of Zambia. 2002. Zambia Poverty Reduction Strategy

Paper 2002-2004. Lusaka: Ministry of Finance and National Planning.

[GRZ] Government of the Republic of Zambia. 1999. National Biodiversity Strategy and Action Plan. Lusaka: Ministry of Tourism, Environment and Natural Resources.

[GRZ] Government of the Republic of Zambia. 1998a. National Forestry Policy. Lusaka: Ministry of Environment and Natural Resources. 
[GRZ] Government of the Republic of Zambia. 1998b. Policy on National Parks and Wildlife. Lusaka: Ministry of Tourism.

[GRZ] Government of the Republic of Zambia. 1998c. Zambia Forest Action Plan. Lusaka: Ministry of Environment and Natural Resources.

Gumbo D. 2015. Nyimba Forest Project dataset. UNF:5:18pkbj/I/onhGlLNPoSI1g== Center for International Forestry Research [Distributor]. V2 [Version]. http://hdl.handle. net/11463/10055

Hansungule M, Feeny P and Palmer R. 1998. Report on Land Tenure, Insecurity on the Zambian Copper Belt. London: Oxfam.

Harvey, RH. 1973. Some determinants of the agricultural productivity of rural households: Report of a survey in Kalichero District, Eastern Province. Chipata, Zambia: Msekera Regional Research Station.

Herbst J. 2000. States and Power in Africa. Comparative Lessons in Authority and Control. Princeton, NJ: Princeton University Press.

Mukosha J and Siampale A. 2008. Integrated land use assessment report. Lusaka: Zambia Forestry Department, Ministry of Tourism, Environment and Natural Resources; Food and Agriculture Organization of the United Nations.

[JAICAF] Japan Association for International Collaboration of Agriculture and Forestry. 2008. Agriculture and forestry in Zambia: Present situation and issues for development. Tokyo: Japan Association for International Collaboration of Agriculture and Forestry.

Jansen DJ and Rukovo A. 1992. Agriculture and the policy environment: Zambia and Zimbabwe political dreams and policy nightmares. Technical Paper \#74 for the Research Program on Developing Country Agriculture and International Economic Trends. Geneva: OECD Development Center.

Jha D and Hojjati B. 1993. Fertilizer use on smallholder farms in Eastern Province, Zambia. Research Report 94. Washington, DC: International Food Policy Research Institute.

Kajoba GM. 2002. Land use and land tenure in Africa: Toward an evolutionary conceptual framework. Presentation, Workshop on Agricultural Sustainability in Africa, 14-17 December 2002. Kampala, Uganda: CODESRIA-IFS.

Kakeya M, Sugiyama Y and Oyama S. 2006. The Chitemene system, social leveling mechanism, and agrarian changes in the Bemba villages of northern Zambia: An overview of 23 years of 'fixed-point' research. African Study Monographs 27(1):27-38.

Kakulwa C. 2012. Rural development through agriculture: History of Mununshu Banana Scheme 1967 to 2010. Unpublished M.Phil. thesis. Lusaka: University of Zambia.

Kumar KK. 1994. Adoption of hybrid maize in Zambia: Effects on gender roles. Food consumption and nutrition. Research report 100. Washington, DC: International Food Policy Research Institute.

Kwesiga F, Frazel S, Mafiongoya P, Ajayi O, Phiri D K, Rosa E, Kantashula K, Place F and Chirwa F. 2003. Improved fallows in Eastern Zambia: History, farmer practice and impacts. A paper prepared for the IFPRI Workshop on "Successes in African Agriculture," Lusaka, Zambia, June 10-12, 2002. Pretoria: International Food Policy Research Institute. 
Machina H. 1996. The impact of agricultural liberalisation on small-scale maize production in Zambia, 1975-90. MSc Dissertation. Cambridge, UK: Department of Land Economy, University of Cambridge.

Malambo A. 2013. Land administration in Zambia since 1991: History, opportunities and challenges. Global Research Journal of History, Political Science and International Relations 24:53-66.

Mason M, Jayne TS and Mofya-Mukuka R. 2013. A Review of Zambia's Agricultural Input Subsidy Program: Targeting, Impacts and the Way Forward. Lusaka: Indaba Agricultural Policy Research Institute.

Mason NM, Jayne TS and Myers RJ. 2012. Smallholder behavioral responses to marketing board activities in a dual channel marketing system: the case of maize in Zambia.

Presentation, International Association of Agricultural Economists (IAAE) Triennial Conference, 18-24 August. Foz do Iguaçu, Brazil: IAEE.

Mellor JW. 1995. Agriculture on the Road to Industrialization. Baltimore, MD: Johns Hopkins University Press for IFPRI.

Mofya-Mukuka R, Kabwe S, Kuteya A and Mason NC. 2013. How can the Zambian Government improve the targeting of the farmer input support program? IAPRI Policy Brief No. 59. Lusaka, Zambia: IAPRI.

Momba JC. 1989. The state, rural class formation and peasant political participation in Zambia: The case of Southern Province. African Affairs 88:331-357.

Moyo S and Yeros P, eds. 2005. Reclaiming The Land: The Resurgence of Rural Movements in Africa, Asia and Latin America. London: Zed Books.

Mwanza KC. 1992. Understanding Zambia's agricultural crisis: the role of economic structure and class interests. In Seidman A, Mwanza K C, Simelane N and Weiner D, eds. Transforming Southern African Agriculture. Trenton, NJ: Africa World Press, Inc. 119-135.

Palmer R. 2001. Land tenure insecurity on the Zambian Copperbelt, 1998: Anyone Going Back to the Land? Lusaka: Oxfam GB.

Pletcher JR. 1986. The political uses of agricultural markets in Zambia. Journal of Modern African Studies 24(4):603-617.

Rainer W, Ulrich H and Dennis KC. 1999. Impediments to agricultural growth in Zambia. TMD Discussion Papers No. 47. Washington, DC: Trade and Macroeconomics Division International Food Policy Research Institute

Ranger T. 1983. The invention of tradition in Colonial Africa. In Hobsbawm E and Ranger T, eds. The Invention of Tradition. Cambridge: Cambridge University Press. 211-62.

Robinson P, Govereh J and Ndlela D. 2007. Distortions to agricultural incentives in Zambia. Agricultural Distortions Working Paper 40.

Rothermund D. 1996. The Global Impact of the Great Depression 1929-1939. London: Routledge.

Saasa OS. 2003. Macro-study: Agricultural intensification in Zambia. The role of Policies and Policy Processes. Lusaka: Institute of Economic and Social Research, University of Zambia. 
Sebastian K. 2014. Agroecological Zones In Atlas of African Agriculture Research 8 Development: Revealing Agriculture's Place in Africa. Washington, DC: International Food Policy Research Institute. 34-35.

Sichoongwe K, Mapemba L, Ng'ong'ola D and Tembo G. 2014. The determinants and extent of crop diversification among smallholder farmers: A case study of Southern Province, Zambia. Working Paper 05. Washington DC: IFPRI.

Siegel PB. 2008. Profile of Zambia's smallholders: Where and who are the potential beneficiaries of agricultural commercialization? Africa Region Working Paper Series No. 113.

Simatale CM. 2006. Impacts of Structural Adjustment on Food Production in Zambia. Hartsfield, UK: University of Hertfordshire.

Sitko N. 2010. Fractured governance and local frictions: the exclusionary nature of a clandestine land market in southern Zambia. Africa 80(1):36-55.

Sitko $\mathrm{H}$ and Jayne TS. 2014. Structural transformation or elite land capture? The growth of 'emergent' farmers in Zambia. Food Policy 48:194-202.

Sugiyama Y. 2007. Agricultural policy change and indigenous agriculture: Experience and re-evaluation of a shifting cultivation system in Northern Zambia. Africa Study Monographs 34:91-113.

Tembo A. 2011. The colonial state and Africa Agriculture in Chipata District of Northern Rhodesia, 1895-1964. Unpublished MSc dissertation. Lusaka: University of Zambia.

Tembo S and Sitko N. 2013. Technical compendium: Descriptive agricultural statistics and analysis for Zambia. Working Paper number 76. Lusaka: Indaba Agricultural Policy Research Institute. Accessed 10 December 2014. http://www.iapri.org.zm/index.php? And http://www.aec.msu.edu/fs2/zambia/index.htm

Wiggering H, Müller K, Werner A and Helming K. 2003. The concept of multi functionality in sustainable land development. In Helming $\mathrm{K}$ and Wiggering $\mathrm{H}$, eds. Sustainable Development of Multifunctional Landscapes. Berlin, Germany: Springer.1-11.

Wilkie DS and Finn JT. 1996. Remote Sensing Imagery for Natural Resources Monitoring. New York: Columbia University Press.

Wood AP, Kean SA, Milimo JT and Warren DM, eds. 1990. The Dynamics of Agricultural Policy and Reform in Zambia. Iowa City: Iowa State University Press.

World Bank. 1996. Zambia Agricultural Sector Investment Programme, Staff Appraisal Report. Washington, DC: Southern Africa Dept. Agriculture and Environment Division, World Bank.

World Bank. 1995. Zambia: Agricultural Sector Investment Program. Washington, DC: World Bank. Accessed 3 January 2015. http://documents.worldbank.org/curated/ en/1995/03/697541/z

Zgambo L H. 1983. Farm labor in the Eastern Province of Zambia, 1898 to 1964. Unpublished MSc dissertation. Lusaka: University of Zambia. 


\section{Appendices}

\section{Appendix $7 \mathrm{~A}$ Criteria and characteristics of the selected villages}

\section{Table 7A.1 Criteria and characteristics of the selected villages.}

\begin{tabular}{|c|c|c|c|}
\hline Criteria & $\begin{array}{l}\text { Low agriculture } \\
\text { intensification }\end{array}$ & $\begin{array}{l}\text { Moderate agriculture } \\
\text { intensification }\end{array}$ & $\begin{array}{l}\text { High agriculture } \\
\text { intensification }\end{array}$ \\
\hline Area visited & $\begin{array}{l}\text { Clustered } \\
\text { villages:(Muzenje, } \\
\text { Kautukilo, Muzonda, } \\
\text { Nyamulika, Chushi and } \\
\text { Lameck) }\end{array}$ & Chifukuzi village & Chipembe village \\
\hline $\begin{array}{l}\text { Village } \\
\text { settlement }\end{array}$ & $\begin{array}{l}\text { Nyalugwe Chiefdom: } \\
\text { MIGRATED to current } \\
\text { settlement from a } \\
\text { different part of the } \\
\text { chiefdom in } 1975 \text { (post- } \\
\text { colonial era) }\end{array}$ & $\begin{array}{l}\text { Mwape Chiefdom: } \\
\text { resettled to current } \\
\text { location from a different } \\
\text { part of the chiefdom in } \\
2000 \text { (post-SAP) because } \\
\text { of human-wildlife } \\
\text { conflict, others settlers } \\
\text { coming from other } \\
\text { chiefdoms including } \\
\text { government retirees }\end{array}$ & $\begin{array}{l}\text { Ndake Chiefdom: } \\
\text { Migrated to the village in } \\
\text { 1930s (Colonial era) from } \\
\text { Mozambique, and village } \\
\text { sits at the junction of GER } \\
\text { from Lusaka to Malawi } \\
\text { and Mozambique road to } \\
\text { the border of Zambia and } \\
\text { Mozambique. Accessibility } \\
\text { of the village has led to } \\
\text { an influx of people from } \\
\text { different parts of Zambia }\end{array}$ \\
\hline $\begin{array}{l}\text { Geographical } \\
\text { features }\end{array}$ & $\begin{array}{l}450 \text { masl; valley; no use } \\
\text { of animal draught power } \\
\text { because of the presence of } \\
\text { tsetse flies; } 600-800 \mathrm{~mm} \\
\text { annual rainfall }\end{array}$ & $\begin{array}{l}786 \text { masl, plateau; use } \\
\text { animal draught power } \\
\text { because there are no } \\
\text { tsetse flies; between } \\
800-1000 \mathrm{~mm} \text { annual } \\
\text { rainfall }\end{array}$ & $\begin{array}{l}909 \text { masl; plateau; use } \\
\text { animal draught power } \\
\text { because there are no } \\
\text { tsetse flies; between } \\
800-1000 \mathrm{~mm} \text { annual } \\
\text { rainfall }\end{array}$ \\
\hline Population data & $\begin{array}{l}120 \text { households; } \\
\text { population approximately } \\
585 \text { people }\end{array}$ & $\begin{array}{l}668 \text { households; } \\
\text { population approximately } \\
3072 \text { people }\end{array}$ & $\begin{array}{l}1800 \text { households; } \\
\text { population approximately } \\
9000 \text { people }\end{array}$ \\
\hline Land tenure & \multicolumn{2}{|c|}{$\begin{array}{l}\text { Customary land; land is not a constraint; it is all } \\
\text { communal land }\end{array}$} & $\begin{array}{l}\text { Customary land; limited } \\
\text { land available for new } \\
\text { settlers }\end{array}$ \\
\hline $\begin{array}{l}\text { Dependence on } \\
\text { forest resources }\end{array}$ & $\begin{array}{l}\text { High dependence on } \\
\text { forest; stems with } \\
\text { diameters above } 20 \mathrm{~cm} \text { are } \\
\text { available and are widely } \\
\text { used for construction } \\
\text { and fuelwood; wild fruits } \\
\text { and animals available for } \\
\text { consumption }\end{array}$ & $\begin{array}{l}\text { High dependence on } \\
\text { forest; stems with } \\
\text { diameters above } 20 \mathrm{~cm} \text { are } \\
\text { available and are widely } \\
\text { used for construction and } \\
\text { fuelwood; wild fruits and } \\
\text { animals available 7-10 km } \\
\text { from area }\end{array}$ & $\begin{array}{l}\text { Low dependence on } \\
\text { forest; small stems } \\
\text { available are less suitable } \\
\text { for construction and } \\
\text { energy (firewood); very } \\
\text { few wild fruits and } \\
\text { animals for consumption }\end{array}$ \\
\hline $\begin{array}{l}\text { Proximity to } \\
\text { protected areas } \\
\text { (forest reserves, } \\
\text { GMAs) }\end{array}$ & $\begin{array}{l}\text { Less than } 10 \mathrm{~km} \text { to game } \\
\text { ranch; human-wildlife } \\
\text { conflict present, has an } \\
\text { impact on agriculture } \\
\text { expansion }\end{array}$ & $\begin{array}{l}\text { Less than } 20 \mathrm{~km} \text { to game } \\
\text { ranch; no human-wildlife } \\
\text { conflicts }\end{array}$ & $\begin{array}{l}\text { More than } 10 \mathrm{~km} \text { to } \\
\text { nearest forest where } \\
\text { forest products are } \\
\text { harvested; no human- } \\
\text { wildlife conflicts }\end{array}$ \\
\hline
\end{tabular}


Table 7A1. (continued)

\begin{tabular}{|c|c|c|c|}
\hline Criteria & $\begin{array}{l}\text { Low agriculture } \\
\text { intensification }\end{array}$ & $\begin{array}{l}\text { Moderate agriculture } \\
\text { intensification }\end{array}$ & $\begin{array}{l}\text { High agriculture } \\
\text { intensification }\end{array}$ \\
\hline Area visited & $\begin{array}{l}\text { Clustered } \\
\text { villages:(Muzenje, } \\
\text { Kautukilo, Muzonda, } \\
\text { Nyamulika, Chushi and } \\
\text { Lameck) }\end{array}$ & Chifukuzi village & Chipembe village \\
\hline Migration & Mainly Nsengas & $\begin{array}{l}\text { Mixed culture: Nsenga, } \\
\text { Bemba, Lozi, Tonga, etc. }\end{array}$ & $\begin{array}{l}\text { Mixed culture: Nsenga, } \\
\text { Bemba, Lozi, Tonga etc. }\end{array}$ \\
\hline $\begin{array}{l}\text { Existence } \\
\text { of shifting } \\
\text { cultivation }\end{array}$ & No shifting cultivation & $\begin{array}{l}\text { Famers use permanent } \\
\text { crop land for cultivation } \\
\text { while practicing crop } \\
\text { rotation }\end{array}$ & $\begin{array}{l}\text { Famers have sufficient } \\
\text { land to allow fallow and } \\
\text { practice crop rotation on } \\
\text { an annual basis }\end{array}$ \\
\hline $\begin{array}{l}\text { Access to inputs } \\
\text { and market }\end{array}$ & $\begin{array}{l}\text { No access to FISP; no out- } \\
\text { grower schemes; no FRA } \\
\text { depot in the village; village } \\
\text { is } 100 \mathrm{~km} \text { from Nyimba } \\
\text { District center }\end{array}$ & $\begin{array}{l}\text { Out-grower schemes } \\
\text { packages provided } \\
\text { by Chipata cotton, } \\
\text { NWK-Dunavant and } \\
\text { Olam cotton; access to } \\
\text { fertilizer through FISP; } \\
\text { retiree pension, invested } \\
\text { in inputs; no FRA maize } \\
\text { purchasing depot present } \\
\text { in the area, nearest is } \\
\text { between } 16-22 \text { km away; } \\
\text { maize and cotton prices } \\
\text { known before crop } \\
\text { planted }\end{array}$ & $\begin{array}{l}\text { Out-grower schemes } \\
\text { packages provided by } \\
\text { NWK- Dunavant and } \\
\text { Cargill cotton; access } \\
\text { to FISP; FRA maize } \\
\text { purchasing depot present } \\
\text { in village but failing to } \\
\text { meet demand for the } \\
\text { commodity, need more } \\
\text { market for the agricultural } \\
\text { products; maize and } \\
\text { cotton prices known } \\
\text { before crop planted }\end{array}$ \\
\hline $\begin{array}{l}\text { Access to } \\
\text { extension } \\
\text { services and } \\
\text { presence of } \\
\text { agricultural } \\
\text { cooperatives }\end{array}$ & $\begin{array}{l}\text { No camp officers; no } \\
\text { agriculture zones; no } \\
\text { active cooperatives and } \\
\text { clubs }\end{array}$ & $\begin{array}{l}\text { No camp officer based } \\
\text { in the area but visited } \\
\text { by a camp officer } \\
\text { from Nyimba; two } \\
\text { cooperatives; } 30 \mathrm{~km} \text { to } \\
\text { Nyimba District center }\end{array}$ & $\begin{array}{l}\text { Presence of camp } \\
\text { officers; } 21 \text { cooperatives; } \\
13 \text { clubs (savings, } \\
\text { multipurpose, etc.) }\end{array}$ \\
\hline $\begin{array}{l}\text { Conservation } \\
\text { agriculture }\end{array}$ & $\begin{array}{l}\text { Practice conservation } \\
\text { farming (limited) }\end{array}$ & $\begin{array}{l}\text { Practice conservation } \\
\text { farming; new settlers } \\
\text { are coming in with } \\
\text { different agriculture } \\
\text { techniques including the } \\
\text { use of rippers, pot holing; } \\
\text { knowledge transfer from } \\
\text { camp officer }\end{array}$ & $\begin{array}{l}\text { Practice conservation } \\
\text { farming; new settlers } \\
\text { are coming in with } \\
\text { different agriculture } \\
\text { techniques, including the } \\
\text { use of rippers, pot holing; } \\
\text { knowledge transfer from } \\
\text { camp officer. }\end{array}$ \\
\hline $\begin{array}{l}\text { Agriculture } \\
\text { expansion }\end{array}$ & $\begin{array}{l}\text { Minimal expansion because } \\
\text { of human-wildlife conflict } \\
\text { and the lack of extension } \\
\text { services; no use of animal } \\
\text { draught power to cultivate; } \\
\text { the terrain is mountainous, } \\
\text { difficult to expand }\end{array}$ & $\begin{array}{l}\text { Expanding agriculture } \\
\text { land; area has a number } \\
\text { of land conflicts; use } \\
\text { animal draught power } \\
\text { to cultivate leading to } \\
\text { expansion }\end{array}$ & $\begin{array}{l}\text { Limited forest land } \\
\text { available for expansion; } \\
\text { use animal draught power } \\
\text { to cultivate }\end{array}$ \\
\hline
\end{tabular}


Table 7A1. (continued)

\begin{tabular}{|c|c|c|c|}
\hline Criteria & $\begin{array}{l}\text { Low agriculture } \\
\text { intensification }\end{array}$ & $\begin{array}{l}\text { Moderate agriculture } \\
\text { intensification }\end{array}$ & $\begin{array}{l}\text { High agriculture } \\
\text { intensification }\end{array}$ \\
\hline Area visited & $\begin{array}{l}\text { Clustered } \\
\text { villages:(Muzenje, } \\
\text { Kautukilo, Muzonda, } \\
\text { Nyamulika, Chushi and } \\
\text { Lameck) }\end{array}$ & Chifukuzi village & Chipembe village \\
\hline $\begin{array}{l}\text { Presence of fruit } \\
\text { trees }\end{array}$ & $\begin{array}{l}\text { Indigenous fruits: } \\
\text { Present in forest around } \\
\text { homesteads (120 m away) } \\
\text { Exotic fruits: Mangoes } \\
\text { present at homesteads and } \\
\text { abandoned field, started } \\
\text { planting when they settled }\end{array}$ & $\begin{array}{l}\text { Indigenous fruits: } \\
\text { Present at homesteads } \\
\text { and forests around the } \\
\text { settlement } \\
\text { Exotic fruits: Mainly } \\
\text { mangoes, mature mango } \\
\text { trees only found at } \\
\text { homesteads of those who } \\
\text { settled early, current } \\
\text { settlers have young trees }\end{array}$ & $\begin{array}{l}\text { Indigenous fruits: Very } \\
\text { few indigenous fruits } \\
\text { in the area, community } \\
\text { members have to go to the } \\
\text { nearby open forest, which } \\
\text { is approximately } 2 \mathrm{~km} \\
\text { away } \\
\text { Exotic fruits: Mangoes } \\
\text { present at homesteads, } \\
\text { started planting when } \\
\text { they settled in the area }\end{array}$ \\
\hline $\begin{array}{l}\text { Off-farm } \\
\text { activities }\end{array}$ & $\begin{array}{l}\text { Sell products made } \\
\text { from reeds such as } \\
\text { baskets; fishing; formal } \\
\text { employment in game } \\
\text { ranches; no charcoal } \\
\text { production } \\
\text { Income realized is usually } \\
\text { spent on agriculture and } \\
\text { household food }\end{array}$ & $\begin{array}{l}\text { Remittance from family } \\
\text { members; pension, } \\
\text { grocery shops; very little } \\
\text { charcoal production, } \\
\text { village is far from market; } \\
\text { Income realized is usually } \\
\text { spent on agriculture and } \\
\text { household food }\end{array}$ & $\begin{array}{l}\text { Selling labor to farmers; } \\
\text { formal employment } \\
\text { (shop attendants, } \\
\text { clinics, schools etc.); } \\
\text { business enterprises } \\
\text { (agro-inputs, grocery } \\
\text { shops, restaurants, etc.); } \\
\text { charcoal produced using } \\
\text { small stems available } \\
\text { Income realized is usually } \\
\text { spent on agriculture and } \\
\text { household food }\end{array}$ \\
\hline $\begin{array}{l}\text { Source of } \\
\text { cooking energy }\end{array}$ & Firewood & Firewood & $\begin{array}{l}\text { Charcoal used by civil } \\
\text { servants, firewood/ } \\
\text { charcoal }\end{array}$ \\
\hline $\begin{array}{l}\text { Food security } \\
\text { and self- } \\
\text { sufficiency }\end{array}$ & $\begin{array}{l}\text { Approximately } 50 \% \text { of } \\
\text { total households not food } \\
\text { secure and self-sufficient }\end{array}$ & $\begin{array}{l}75 \% \text { of total households } \\
\text { are food secure and self- } \\
\text { sufficient }\end{array}$ & $\begin{array}{l}75 \% \text { of total } \\
\text { households are food } \\
\text { secure and self-sufficient }\end{array}$ \\
\hline $\begin{array}{l}\text { Presence of } \\
\text { woodlots }\end{array}$ & Absent & Absent & Absent \\
\hline $\begin{array}{l}\text { Infrastructure } \\
\text { development }\end{array}$ & $\begin{array}{l}\text { Nearest clinic in the area is } \\
5 \mathrm{~km} \text { away; access road }\end{array}$ & $\begin{array}{l}1 \text { health post; primary } \\
\text { school is a shed } \\
\text { constructed by the } \\
\text { community from pole } \\
\text { and dagga }\end{array}$ & $\begin{array}{l}\text { 1 clinic; } 2 \text { primary schools; } \\
\text { multiple shops constructed } \\
\text { from burnt bricks; market } \\
\text { place, roads graded; some } \\
\text { houses constructed with } \\
\text { burnt bricks and iron } \\
\text { sheets; water mono pumps }\end{array}$ \\
\hline
\end{tabular}


the extent of reliance on cash crop production. In Zone 3, farmers leaned toward cash crop production. In the remote communities of Zone 1 , cereal-based cropping is commonly combined with livestock husbandry. Zone 2 communities, clustered as the semi-intensive land modification gradient, engaged in diversified land uses of both intensive cash crop production and extensive food crop systems. Migration from the Sahel region of Burkina Faso to areas in and around our research sites is a major driver of forest cover decline and agricultural expansion, as is the high population growth rate of $3.6 \%$ per annum. Agricultural practices have intensified around cotton and maize cropping systems using subsidized fertilizer inputs. Tree cover is important within crop production systems known as parkland agroforestry, and forests are important for supporting income generating activities of commercial woodcutting and harvesting, and trade of shea and parkia (néré) fruits. Forests also provide livestock feed and fodder.

\subsection{Introduction}

Burkina Faso is one of the developing nations lagging behind in achieving goals on reducing global hunger by half in 2015 as stipulated in the Millennium Development Goals. As much as $85 \%$ of the active workforce is involved in the agricultural sector and most of these people are classified as food insecure, with a high proportion of children under 5 years old classified as malnourished (Von Grebmer et al. 2014). Growing concerns about availability and quality of productive land for agriculture further exacerbates food insecurity and malnutrition. With current projections of needing to double food production to feed the global population by 2050, Burkina Faso faces an acute challenge in trying to stem degrading land, and produce more and diverse food to improve food security and human nutrition.

With a rural population accounting for $73 \%$ of the national total (INSD et al. 2009), Burkina Faso is a country dependent on agriculture both for subsistence and income generation. It is riddled with climate vulnerabilities - from seasonal droughts to flooding- that frequently plague food production. Food insecurity remains high as the country recovers from the latest drought and crop failure in 2010. The country currently ranks 65 out of 78 on the worldwide hunger index (Von Grebmer et al. 2014). Susceptibility to natural disasters and higher frequency of climate stresses is influencing cultivation of crops, availability of fodder for livestock and reliance on forest products for food and rural income. The country also has one of the fastest growing populations worldwide, with a 3.2\% annual growth rate (INSD 2007; INSD et al. 2009).

The national economy is dependent on cotton, maize and gold exports (Kramer 2010; Kaminski 2011). The Government's millennium economic growth strategies ${ }^{1}$ are targeted toward diversification of agriculture to reduce poverty among the rural population. Intensification of farming systems is a high priority and so is promoting

1 SCADD stands for the Strategy for Accelerated Growth and Sustainable Development set by the Government of Burkina Faso, from 2001 to 2015 . This strategy broadly focuses on pro-poor development and reducing poverty among the agricultural sector, which involves close to $70 \%$ of the national working population. 
agri-businesses. ${ }^{2}$ Cotton has become the national economic crop since the early 1980 , and by early 1997 accounted for 60\% of national export earnings (Kaminski 2011). Specific agricultural diversification and intensification strategies are based on regional farming practices, climatic and agro-ecological conditions. At the national level for example, fruit tree cultivation is being promoted to diversify farming incomes beyond cotton and maize in wetter climatic regions. Production of cotton increased from 2772 tons in 1960 to 471,945 tons in 2003/2004, and has now reached 600,000 tons per year (Kaminski 2011). However, it is unclear the extent to which benefits flowed to rural smallholders that produce the crop. National enthusiasm initially surrounded introduction of cotton, with promises of improvement in livelihoods and reduction in poverty (Kaminski 2011). In the one and a half decades after the cotton adoption (i.e. early-to mid-1990s), the proportion of the population classified as 'poor' declined from $52 \%$ to $44 \%$ (Grimm and Günther 2004). As a result of favorable world market prices for cotton, steady social spending and various structural adjustments that took place in the same period. This growth was deemed to have excluded the majority of rural smallholders who produce cotton for export (Grimm and Günther 2004).

Central Burkina Faso is composed of fragmented dry forests, shrub and grassland savannah (Arbonnier 2004). Important species include trees of the Fabaceae family that are acclimatised to semi-arid zones. Parkia biglobosa, Acacia sp. and Faidherbia albida are important examples. Shea (Vitellaria paradoxa) and baobab (Adansonia digitata) from the Sapotaceae and Malvaceae families respectively are other prominent species that make up the landscape. Forest cover in the area is approximately 10\% canopy cover (Olson et al. 2001; Townshend et al. 2006). Agricultural land is interspersed with trees forming what is known as agroforestry parklands (Paré et al. 2008; Bayala et al. 2011). Forest cover, which is interspersed in the landscape, has declined over the last three decades according to a few accounts (Söderström et al. 2003; Ouedraogo 2006). Deforestation has been attributed to human activities primarily from expansion of crop production and demand for fuelwood and timber. In central parts of Burkina Faso, increasing population due to a high growth rate (approximately 3.2\% per annum) and migration are the major documented drivers of forest cover decline (Henry et al. 2004; Ouédraogo et al. 2009). The diversity of trees species in forest has also decreased in areas outside of national parks (Belem et al. 2007; Traoré et al. 2008).

Across central Burkina Faso, forest cover is distributed into national parks, managed forests and open forests (Coulibaly-Lingani et al. 2009). National parks are protected forests under State ownership. They are reserved for biodiversity conservation purposes. Managed forests are especially demarcated for controlled harvesting of wood, wild foods and grazing livestock (Ouedraogo 2009). These forests are owned collectively by their surrounding communities and managed with technical assistance from national forestry and environmental ministries. Such arrangements are known as chantier d'aménagement forestier (CAF) throughout Burkina Faso (Ouedraogo 2009). CAF

2 PNSR 2011-2015: The National Rural Sector Program, Burkina Faso. The program was put forward by the Government of Burkina Faso focusing on diversification of rural economies and income generation streams. The ideas within the strategies focus on rural agro-businesses (fruit trees and rice) establishment and dry season irrigated cropping. 
forests throughout central Burkina Faso were set up in the early 1990s (between 1990-93) in response to mass deforestation and the need to sustain the supply of fuelwood and NTFPs (Ouedraogo et al. 2009). The third category - open forests - include village and sacred forests. Village and sacred forests can be found in or around communities. They fall under communal ownership and are used and conserved by the respective local community. Sacred forests provide cultural and religious services to the community. Village forests are open to harvesting of fuelwood, fodder and wild foods. Outside of national parks, conservation of trees in open and managed forest is limited to trees that are important for supply of fuel, food and fodder, such as the shea tree and parkia (Belem et al. 2007).

Mosaic landscapes are the most widespread land configuration in Burkina Faso and West Africa in general (Boffa 1999). The majority of smallholders combine the goods and services provided by mosaic landscapes, including savannah woodlands, pastures and farmlands to produce food and generate income. Over time, farmers have maintained a traditional agro-silva-pastoral system where trees are scattered within cereal (sorghum, maize, millet) fields. NTFPs, for example shea, Vitellaria paradoxa (locally known as karité) and parkia (African locust bean or néré) are key supplements to the diets and income of rural households and the trees are maintained by smallholder farmers for their crucial value. A study by Lamien and Vognan (2001) in southern Burkina Faso showed that the contribution of NTFPs represents $16 \%-27 \%$ of women's income, which plays an important role in household food provisioning and nutrition of infant children. In addition, the importance of forest and trees for food security is coupled with its role as a safety net during the 7-month-long dry spell (Djoudi et al. 2013). The same landscapes support cattle, sheep and goats through fodder provisioning. Approximately $70 \%$ of livestock fodder is sourced from shrub savannah and forests (Sawadogo et al. 2005).

Migration in Burkina Faso between 1980 and early 2000 has been studied in the context of forest cover and land use (Howorth and O'Keefe 1999; Wardell et al. 2003). Typically, people have migrated from the drier north of the country and moved to the southwest and central regions (Henry et al. 2003, 2004). Previous authors portray this trend as a form of livelihood improvement/diversification strategy (Ouedraogo et al. 2009). The north of the country is a dry Sahel climate characterized by a short wet season and a growing period of less than 90 days a year. This environment permits the cultivation of cereal staples with limited possibility for long duration cash crops that are cultivated elsewhere in the country (Howorth and O'Keefe 1999). During the droughts of the early 1980s, this agro-climatic zone became even less suitable for crop production. The drought and famine triggered the migration of northerners toward central and southern Burkina Faso and this continues up to today (Ouedraogo et al. 2009).

The migrant population in central Burkina Faso was approximately 3\% in 1976 according to the first documentation (Paré et al. 2008). By 2007, 57\% of the local population was migrant Mossi, Walla and Fulani smallholders and pastoralists (Ouedraogo et al. 2009). At the same time, Gourounsi (also locally known as Nouni) indigenous people in central provinces are migrating further south to wetter agro-climatic zones in northern Ghana. Such trends were attributed to degrading land and loss in soil fertility, and Roose et al. 
(1999) show that failing traditional soil water conservation techniques was causing people to leave the northern regions. For example, the laborious Zaï technique of creating pockets of moisture and soil fertility using manure and compost were no longer adequate to sustain cropping (Roose et al. 1999). The Gourounsi land tenure system is classified as flexible and welcoming to the settling and integration of migrants within Gourounsi-owned lands (Howorth and O'Keefe 1999; Kevane and Gray 1999). The land tenure arrangement has played an enabling role for Mossi and Fulani pastoralists to access land relatively easily (Ouedraogo et al. 2009).

The objective of this scoping study was to select research sites in Burkina Faso for the Agrarian Change Project. We employed tools provided by the project's methods manual in carrying out this inquiry and adapted them to fit the context of Burkina Faso where needed. The scoping study and this resulting chapter has laid the foundation for in-depth data collection in the subsequent phase of the project.

\subsection{Methods}

A mix of approaches was used for site selection and to help describe the landscape. The scoping study focused on communities in Cassou, Bakata and Gao districts in Ziro Province of Centre-Ouest Region, one of Burkina Faso's 15 administrative regions. The sites selected were located approximately $120 \mathrm{~km}$ southwest of the capital Ouagadougou. A questionnaire was designed for this study to enable us to collect data on local farming systems, forest management, food security, and history of development and agricultural interventions. The questionnaire was used in semi-structured interviews with selected key informants and also used more broadly to guide FGDs in six communities.

\subsubsection{Study area}

Ziro Province has six districts and we selected villages from three of these, namely: Cassou, Bakata and Gao. The preliminary selection of villages involved considering sites where studies by CIFOR were ongoing in different part of Ziro Province. Demographic data, climate and agro-ecological information, and general village information was retrieved from CIFOR's Burkina Faso (CIFOR-BFA) office in Ouagadougou. Cassou village in Cassou district is the central location for CIFOR's work in the area and we chose this community as our point of entry. All villages in the three districts are within a $30 \mathrm{~km}$ radius from this epicenter. The total size of the research site was 279,900 ha. We reviewed 13 villages that CIFOR-BFA had preliminary household data on (see Appendix 8A). The three districts form part of a forest management scheme - CAF - that has been set up since 1990. This scheme is one of only a few sustainable forest use and conservation interventions throughout central Burkina Faso. A map of Ziro Province showing the scoping villages is provided in Figure 8.1. 


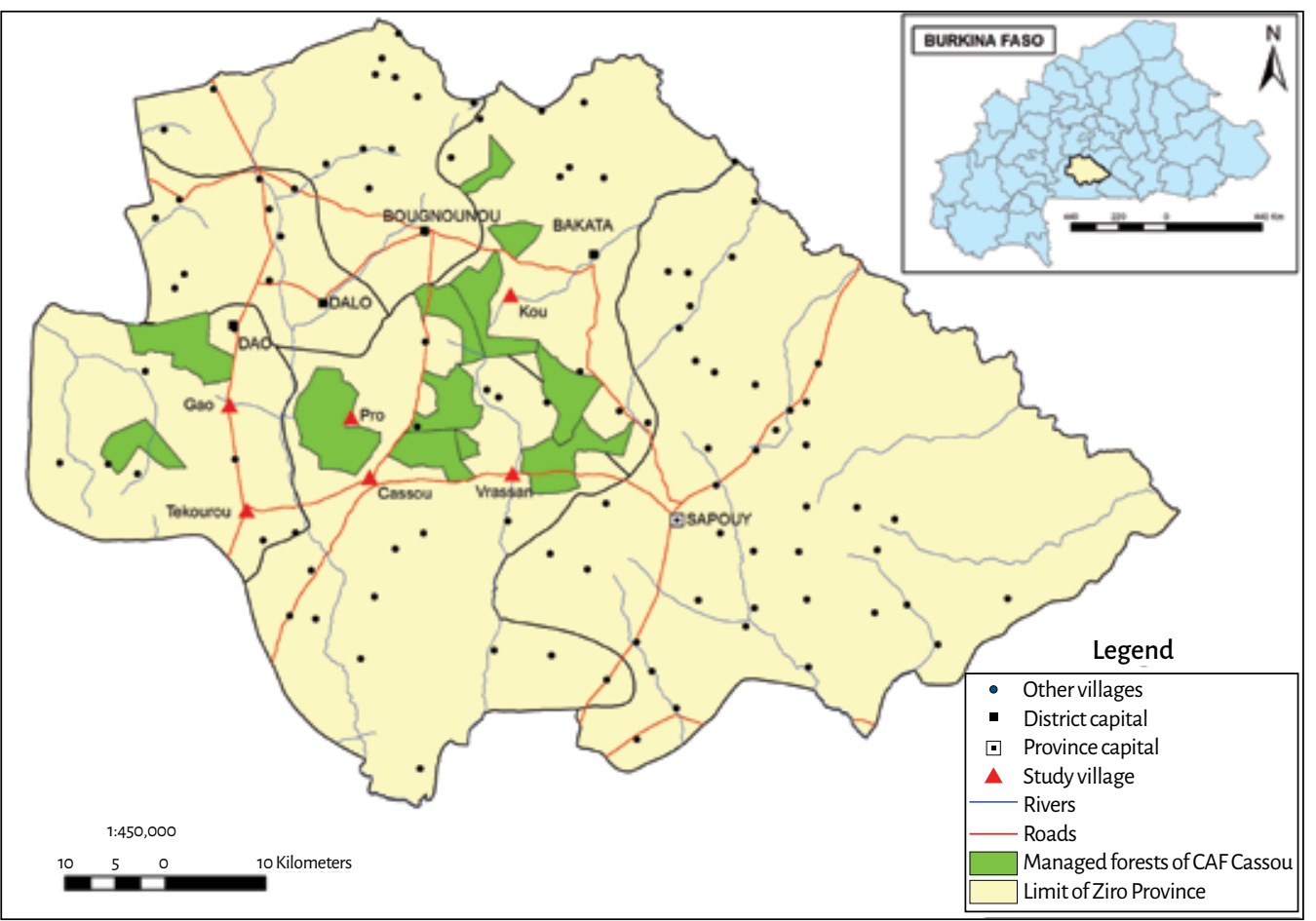

\section{Figure 8.1 Ziro Province, which includes Cassou, Gao and Bakata districts located in Centre-Ouest Region of Burkina Faso.}

Note: Scoping study sites are highlighted in red triangles. Green polygons show the limits of managed forest under the CAF scheme.

To identify land-use intensification in our landscape, a preliminary literature review on farming systems in the Sudan and Sahel savannah was performed. This was done to attain background knowledge of agriculture and commodity production patterns. The information sought after included crops cultivated, important cash crops, data on agricultural input use, regional cropping systems, etc. Sources of data included published peer-reviewed articles and project documents from CIFOR and its partners working in the area. State rural development strategy documents, which focus largely on agricultural expansion and intensification, were also accessed through CIFOR-BFA colleagues.

Prior to the scoping visits, we collaborated with GIS experts from the University of British Columbia to obtain long-term vegetation change maps of our landscape. The maps were intended to reflect a sequence of vegetation cover change in the last 30-35 years. This timeline was chosen because it encompasses important environmental, social and policy events in the history of Burkina Faso that have influenced agriculture and land-use dynamics in Ziro Province. We took GPS waypoints in the field to mark the different settlements, schools, clinics and other rural infrastructure. 


\subsubsection{Interviews and discussions}

Data collection entailed semi-structured interviews and FGDs in the following six villages (see Figure 8.1): Cassou, Pro and Vrassan in Cassou District; Kou in Bakata District; and Tekourou and Gao in Gao District. A questionnaire was administered to selected key informants. Three key informant interviews were conducted, one each in Cassou, Gao and Vrassan villages. Key informants were state forestry technicians, a rural development council (Conseil Villageois de Développement) representative and the local chief who was also part of the forest management body/cooperative (Union des Groupements de Gestion Forestière or UGGF). An informal discussion was held with the provincial director of forest management in Ziro Province. In each of the six villages, FGDs were held and involved 10-15 participants per session. Our visits coincided with the harvesting season for cereals in late October and throughout November. This posed a challenge in assembling larger numbers for the FGDs. During every FGD, the village chief or his representative were present alongside smallholders, artisanal woodcutters, women farmers and/or NTFP processors, and a CAF representative. The FGDs lasted approximately 3-3.5 hours.

\subsubsection{Food security}

The pebble distribution method (Kumar 2002) was adapted as an approach to evaluate local food provisioning. The method involves asking respondents to allocate a certain number of pebbles (or other materials such as sticks and marbles) out of a total of 10 to the different sources of food. The sources of food were farms, forests and markets. We asked respondents to score their food self-sufficiency for each month in a year. Food self-sufficiency refers to available food in the household to feed all members. A score code between 1 and 4 was used: a score of 1 for severe food deficit, 2 representing scarce food, 3 indicating enough food and 4 meaning enough food with a surplus to sell.

\section{Land use and modification gradients}

A core exercise of the scoping study was to identify zones of different land uses within our focal landscape and to classify these into zones based on the intensity of the land modification. We collected information on livelihood activities and diversification at the village level from FGDs. A list of markets, roads, rural health centers and schools was collected, and their GPS waypoints recorded. We aimed to link the information to produce an impression of the level of development of the individual communities and of the village clusters or zones.

Population size, crop production (i.e. differentiating between subsistence and cash crops), proximity to markets and level of infrastructure development were key indicators to determine land modification intensities. Data obtained from key informant interviews on the above variables aided the clustering of land modification zones. Population density, available infrastructure and markets further played a role in defining the zones. The above demographic data was used to indicate levels of access to information, tools and inputs as factors enabling the modification of land. Table 8.1 shows the full criteria used for the land-use classifications in our study sites. 
Table 8.1 Criteria for classification of land modification gradients in Ziro Province.

\begin{tabular}{|c|c|c|c|c|}
\hline Criteria & Sub-criteria & Zone 1 & Zone 2 & Zone 3 \\
\hline \multirow[t]{3}{*}{ Demographics } & $\begin{array}{l}\text { Population } \\
\text { density }\end{array}$ & Low $(<1,000)$ & $\begin{array}{l}\text { Medium }(1,000- \\
3,000)\end{array}$ & High $(>3,000)$ \\
\hline & Settlement types & $\begin{array}{l}\text { Scattered } \\
\text { households }\end{array}$ & $\begin{array}{l}\text { Clustered } \\
\text { settlements/village }\end{array}$ & $\begin{array}{l}\text { Town/district } \\
\text { market }\end{array}$ \\
\hline & $\begin{array}{l}\text { Household sizes } \\
\text { (available labor) }\end{array}$ & $\begin{array}{l}\text { Small to medium } \\
\text { households, labor } \\
\text { exported off-farm } \\
\text { for cash income }\end{array}$ & $\begin{array}{l}\text { Medium to large } \\
\text { households, no } \\
\text { labor exported } \\
\text { off-farm }\end{array}$ & $\begin{array}{l}\text { Large, wealthy } \\
\text { households. Hire } \\
\text { labor for cropping }\end{array}$ \\
\hline \multirow[t]{4}{*}{ Agriculture } & Orientation & $\begin{array}{l}\text { Subsistence cereal- } \\
\text { based systems }\end{array}$ & $\begin{array}{l}\text { Mixed subsistence } \\
\text { and cash crops }\end{array}$ & $\begin{array}{l}\text { Cash crops: cotton } \\
\text { and commercial } \\
\text { scale maize }\end{array}$ \\
\hline & $\begin{array}{l}\text { Cropping } \\
\text { systems }\end{array}$ & $\begin{array}{l}\text { Intercropping } \\
\text { cereals and other } \\
\text { food crops }\end{array}$ & $\begin{array}{l}\text { Mixed - both } \\
\text { monocrop of } \\
\text { cash crops and } \\
\text { intercropping of } \\
\text { cereals }\end{array}$ & $\begin{array}{l}\text { Monocropping } \\
\text { systems of cash } \\
\text { crops }\end{array}$ \\
\hline & Livestock & $\begin{array}{l}\text { Semi-sedentary } \\
\text { pastoralist groups }\end{array}$ & $\begin{array}{l}\text { Small ruminants, } \\
\text { goats and sheep } \\
\text { tethered at the } \\
\text { homestead }\end{array}$ & $\begin{array}{l}\text { Small ruminant } \\
\text { livestock tethered in } \\
\text { the homestead and } \\
\text { outsourced livestock } \\
\text { husbandry to } \\
\text { pastoralist groups }\end{array}$ \\
\hline & $\begin{array}{l}\text { Input use and } \\
\text { hired labor }\end{array}$ & $\begin{array}{l}\text { No external inputs } \\
\text { or hired labor }\end{array}$ & $\begin{array}{l}\text { External inputs } \\
\text { applied to cash } \\
\text { crops }\end{array}$ & $\begin{array}{l}\text { Relatively intensive } \\
\text { use of external } \\
\text { inputs and hired } \\
\text { labor }\end{array}$ \\
\hline \multirow[t]{2}{*}{$\begin{array}{l}\text { Forest } \\
\text { products }\end{array}$} & Fuelwood & $\begin{array}{l}\text { Fuelwood collection } \\
\text { for household } \\
\text { demand }\end{array}$ & $\begin{array}{l}\text { Fuelwood } \\
\text { collection and } \\
\text { trade at district } \\
\text { level }\end{array}$ & $\begin{array}{l}\text { Collection of } \\
\text { fuelwood for sale to } \\
\text { regional market }\end{array}$ \\
\hline & $\begin{array}{l}\text { Forest products } \\
\text { (NTFPs) }\end{array}$ & $\begin{array}{l}\text { Small-scale } \\
\text { processing and trade } \\
\text { in forest products in } \\
\text { local market }\end{array}$ & $\begin{array}{l}\text { Medium to large } \\
\text { processing and } \\
\text { trade in forest } \\
\text { products at district } \\
\text { market }\end{array}$ & $\begin{array}{l}\text { Large-scale } \\
\text { processing and } \\
\text { trade in forests } \\
\text { products for district } \\
\text { market and sale to } \\
\text { middlemen }\end{array}$ \\
\hline \multirow[t]{3}{*}{ Infrastructure } & Road network & $\begin{array}{l}\text { Dirt roads, } \\
\text { challenging to } \\
\text { commute during } \\
\text { wet season }\end{array}$ & $\begin{array}{l}\text { Access to secondary } \\
\text { roads passable } \\
\text { throughout the } \\
\text { year }\end{array}$ & $\begin{array}{l}\text { Secondary road } \\
\text { network through } \\
\text { these district market } \\
\text { centers }\end{array}$ \\
\hline & Education & $\begin{array}{l}\text { One public primary } \\
\text { school }\end{array}$ & $\begin{array}{l}\text { Primary schools } \\
\text { available }\end{array}$ & $\begin{array}{l}\text { Primary and high } \\
\text { school available }\end{array}$ \\
\hline & Health & $\begin{array}{l}\text { No local health } \\
\text { services }\end{array}$ & $\begin{array}{l}\text { Local dispensary/ } \\
\text { pharmacy }\end{array}$ & $\begin{array}{l}\text { Center for rural } \\
\text { clinic serving } \\
\text { satellite villages }\end{array}$ \\
\hline
\end{tabular}




\subsection{Scoping study results}

\subsubsection{Landscape description}

Ziro Province falls in the Sudan Savannah agro-ecological zone of Burkina Faso. Rainfall is unimodal (one rainy season per year) and fluctuates between 800-1100 mm per annum (see Figure 8.2). The wet season extends from mid June to late September. Soils are ferruginous, turning into waterlogged floodplains during the wet season. There is a wide variability in vegetation composition. This is a function of the inherent soil characteristics as well as a result of anthropogenic degradation. The official census estimated the population at 175,000 inhabitants in 2006 (INSD 2007). By 2010, this increased to 199,000 inhabitants distributed over 128 villages. Four major ethnic groups make up the population of Ziro Province: Gourounsi who are the indigenous population, and Mossi, Fulani and Wallas who constitute the migrant population. According to the census of 1996, the population of Cassou district, for example, was estimated as 28,000 inhabitants. In 2006 , this reached 40,000 inhabitants, reflecting a $43 \%$ increase in the population at a staggering annual growth rate of $3.9 \%$.

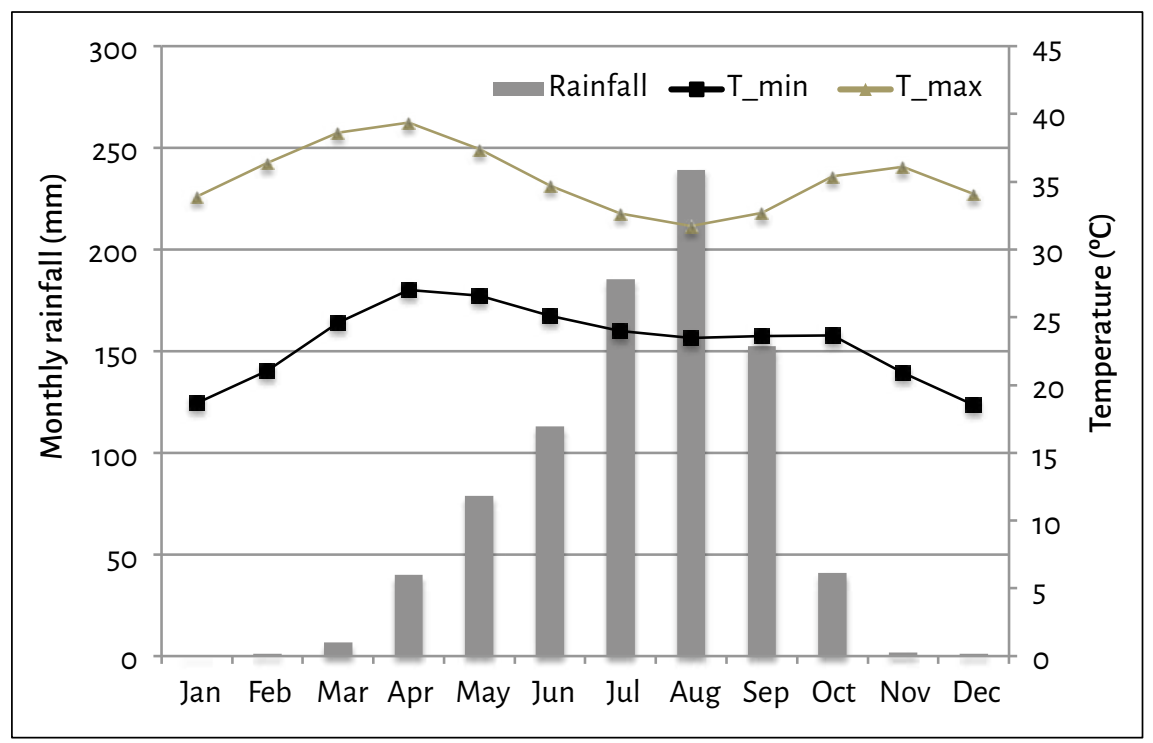

Figure 8.2 Climate data showing monthly rainfall (1980-2013) and minimum-maximum temperature ranges.

Note: $\mathrm{T} \_\mathrm{min}=$ minimum temperature; $\mathrm{T} \_\mathrm{max}=$ maximum temperature.

Source: Data was obtained from the nearest weather station in Sapouy, Ziro Province $\left(11.5495673^{\circ} \mathrm{N}\right.$, $\left.-1.7711807^{\circ} \mathrm{E}\right)$ 


\subsubsection{Land-use change in Ziro Province}

The landscape is composed of shrub and woody savannah interspersed with deciduous trees. Relief is flat with an average elevation of 260 masl. Agroforestry parklands dominate the agricultural landscape with intermittent fragmented dry forests. The dry forests are composed of deciduous shrub and tree species (Arbonnier 2004). Tree cover is around 10\% in these forests (Olson et al. 2001; Townshend et al. 2006). Agroforestry parklands are classified as areas of agricultural production interspersed with important species. In Ziro Province, shea (Vitellaria paradoxa) and parkia (Parkia biglobosa) trees dominate parklands. These two tree species are among the most important livelihood trees (Abonnier 2004). The majority of forest area in our study sites are preserved for wood harvesting and conservation of important tree species (Ky-Dembele et al. 2007). The main tree species are Detarium microcarpum, Parkia biglobosa, Vitellaria paradoxa, Lanea microcarpa, Acacia spp. and Bombax costatum. Riparian formations along rivers are dominated by species such as Saba senegalensis and Mitragyna inermis. Shrub and shrubby tree species include Piliostigma thonningii, Faidherbia albida and Zizuphus mauritiana. Grass and pasture cover consists of perennial species such as Andropogon gayanus and A. pseudapricus. Annual grass species include Pennisetum pedicellatum, P. americamun, and Loudetia togoensis. Protection of certain indigenous trees species is practiced in the forest areas of Ziro Province, for example shea (Vitelaria paradoxa), néré (Parkia biglobosa) and bombax (Bombax costatum) that are integral to local provisioning of food, medicine and fodder. Conservation activities include annual tree planting, extension on improved methods of coppicing and preventative burning of grass undergrowth to prevent wildfires in the dry season. Table 8.2 presents a comprehensive list of tree species and their uses in our research sites.

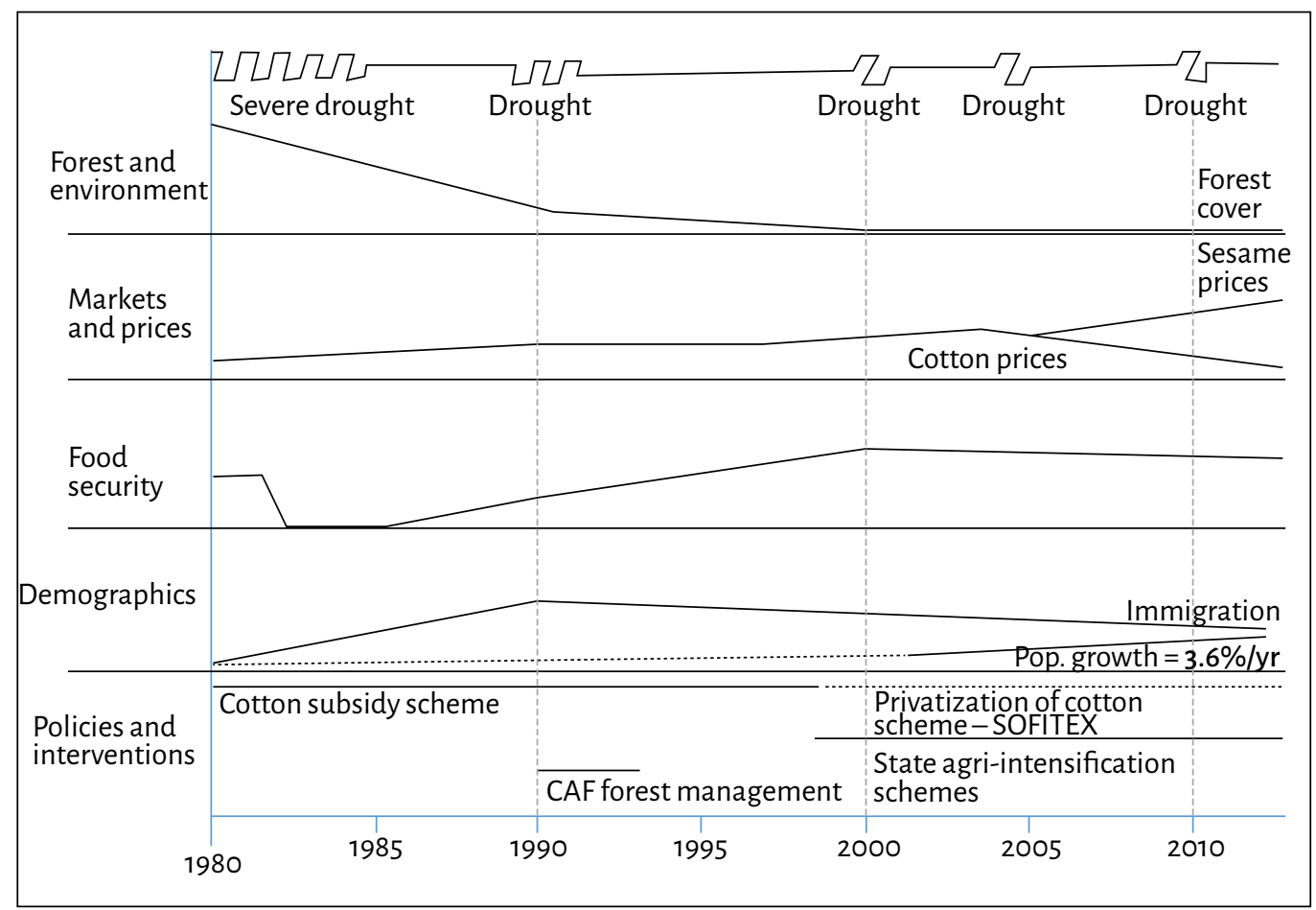

Figure 8.3. Timeline of forest cover change, and the drivers and outcomes in Ziro Province. 
Figure 8.3 summarizes findings from our scoping visit and desk review. We report local perceptions of rapid forest decline since the 1980s. Forest loss has been heavily influenced by migration and associated expansion of agricultural land. Local demand for productive land also exists partly due to the high annual population growth, which currently stands at $3.6 \%$ per annum. This substantial loss of forests has given way to the establishment of protected plots of controlled forest use known as CAF. We also summarize local food provisioning from forest, markets and farms. Long-term food security in terms of availability has been impacted by re-occurring droughts. Detailed information on the various aspects of forest and vegetation cover, agriculture and food security is outlined in the subsequent sections of our study findings.

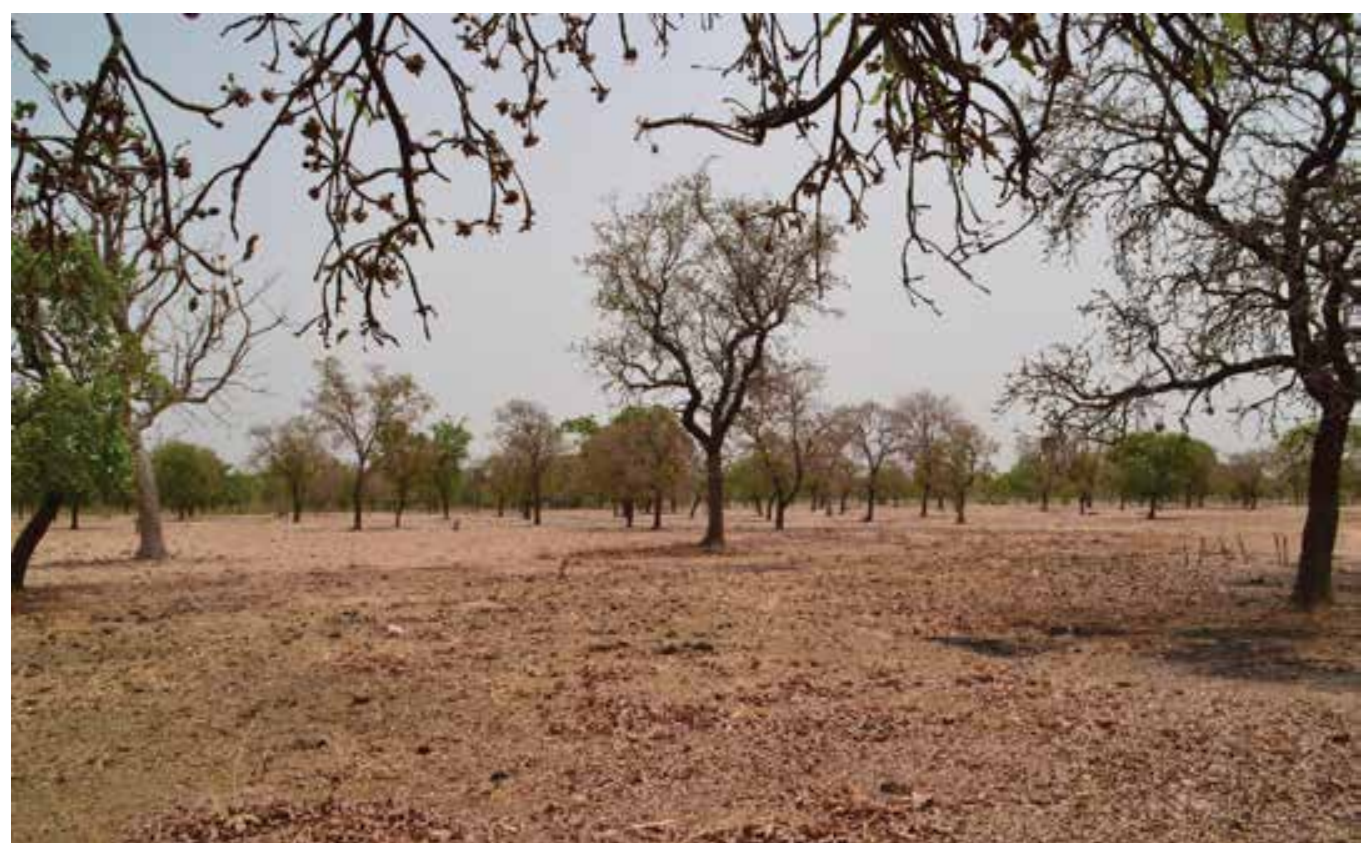

An agroforestry parkland and dry forest in the research sites of Ziro province, Burkina Faso. (Samson Foli/CIFOR)

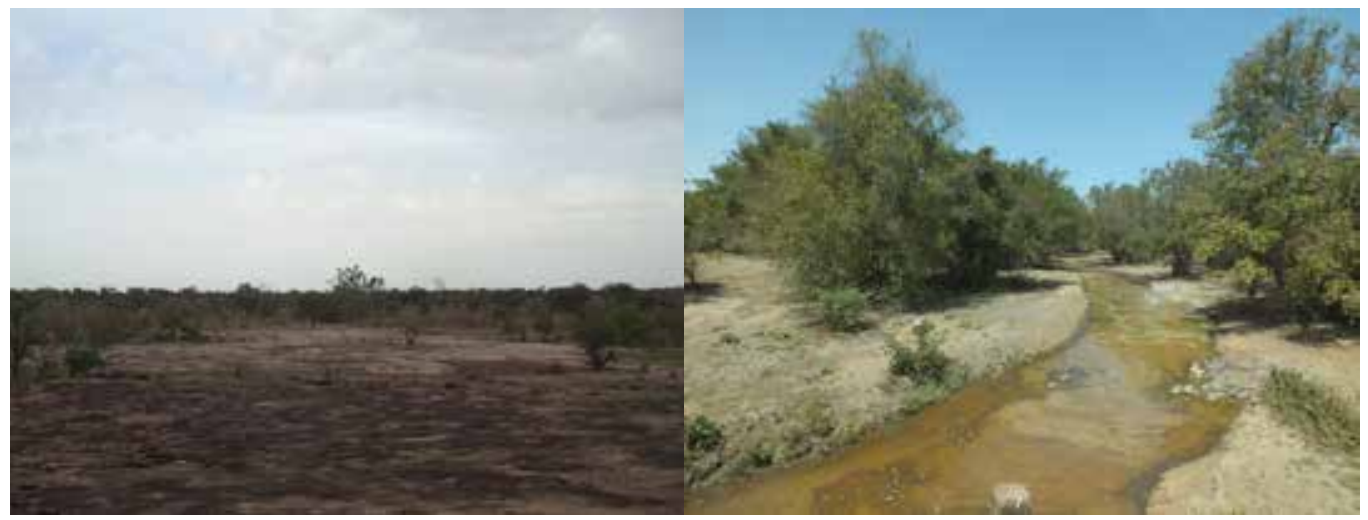




\section{Table 8.2 Important trees and shrubs of the Sudan-Sahelian savannah and their local} uses specific to the research site.

\begin{tabular}{|c|c|c|c|}
\hline Species name & Common name & $\begin{array}{l}\text { Local name } \\
\text { (in Mossi) }\end{array}$ & Main local uses \\
\hline Tamandus indica & Tamarind & Pousga & Food \\
\hline Bombax costatum & Bombax & Voaka & Food \\
\hline Saba senegeliansis & Liane/saba & Wedga & Food \\
\hline Parkia biglobosa & Néré & Rouang & Food, medicine, feed \\
\hline Balanites aegyptiaca & Aduwa & Kièglèga & Food, medicine \\
\hline Adansonia digitata & Baobab & Toèga & Food, fodder \\
\hline Afzelia africana & Afzelia/Doussi & Kankalga & Food, fodder \\
\hline Strychos spinosa & Spiny orange & Katré & Food, medicine \\
\hline Accacia macrostachya & Bakin gumbi & Zamenè & Food, medicine \\
\hline Detarium microcarpum & Tallow tree & Kagadaga & Food, medicine \\
\hline Lannea microcarpa & African grape & Saabga & Food, medicine \\
\hline Diospyros mespiliformis & Jackalberry & Ganka & Food, medicine \\
\hline Zizuphus mauritiana & Jujubier & Mougounouga & Food, medicine \\
\hline Ximenia americana & Tallow wood/yellow plum & Laihga & Food, medicine \\
\hline Vitalaria paradoxia & Shea/karité & Taanga & Oil, food, medicine \\
\hline Pterocarpus erunaseus & Muninga & Noega & Fertilizer, medicine \\
\hline Piliostigma thonningii & Camel's foot & Bagandé & Feed, fodder \\
\hline Faidherbia albida & Winter thorn & Zaanga & Fodder \\
\hline Mitrgyna inermis & Unknown & Yilga & Medicine \\
\hline Acacia seyal & Red acacia & Gonpelga & Medicine, fertilizer \\
\hline Vachellia sieberiana & & Gonsablega & Feed \\
\hline
\end{tabular}

Ziro Province lost approximately 60,000 ha of forest annually from the late 1970 s to the mid-1980s (Ouedraogo 2009). The expansion of cropland, the lucrative price of cotton on the world market and ongoing agri-intensification schemes to improve cereal productivity spurred transformation of virgin forest into arable land. Mass migration from the northern Sahelian belt into this province further increased pressure on forestland. Throughout this time until the present day, the forests of Ziro Province supply fuelwood locally and to the national capital Ouagadougou, which depends on wood as major energy source for cooking.

The formation of the forest management body of CAF, linking donors, state forestry departments and rural communities, pioneered the first establishment of forest management in Burkina Faso. Forest management areas under CAF (and their 


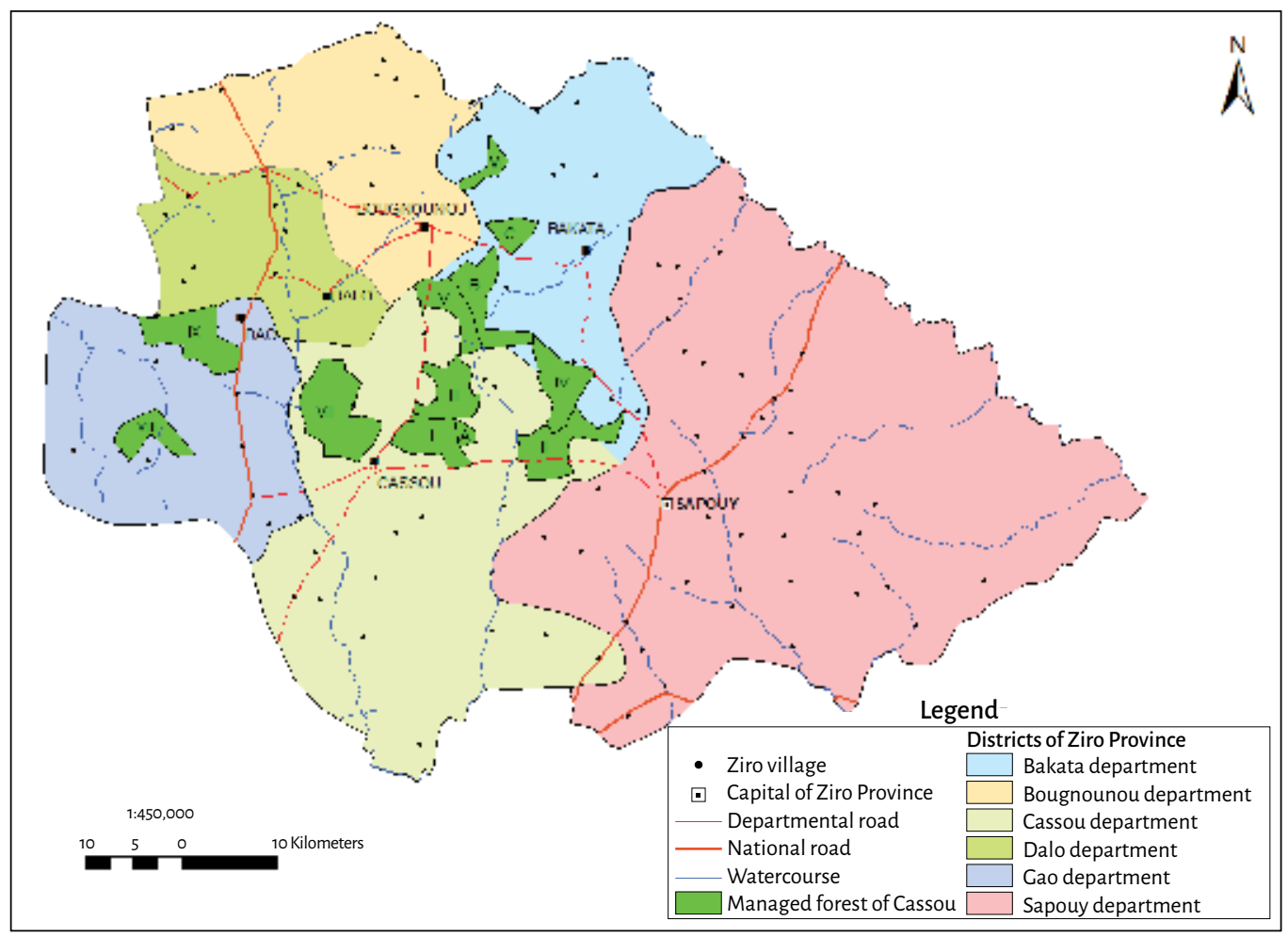

\section{Figure 8.4 Map of Ziro Province showing the 12 management units under the CAF demarcation.}

Source : Abdoulaye Rabdo, CIFOR-BF

respective governing bodies) were set up in Bakata, Cassou, and Gao districts (see Figure 8.4). The current surface area of managed forests in these districts is estimated at 30,000 ha, divided into 12 management units (unités d'aménagement forestier or UAF). By committing to CAF, the indigenous population that owned the forests combined family and communally-owned forested tracts into concessions. The local communities then formed cooperatives with selected village elders to enforce the harvesting and preservation of the newly established forest demarcations. A quota system was introduced to limit the exploitation of timber and fuelwood. These concessions crossed village boundaries that were unclear to start with. Community elders and chiefs, together with rural development counsels and forestry technicians formed the governing bodies of the UAF. These bodies operate as cooperatives known as UGGF (union des groupements de gestion forestière). Figure 8.4 shows the boundaries of CAF forest demarcations in our landscape.

Demarcation of the CAF area began in 1990 with the establishment and operation of the first plots in 1991. This continued into 1993 until all three districts were set up. At the onset, CAF was a donor-funded project implemented by relevant state agencies in forestry and environmental sectors. CAF management became autonomous in December 2001 with the formation of clustered concession management cooperatives 


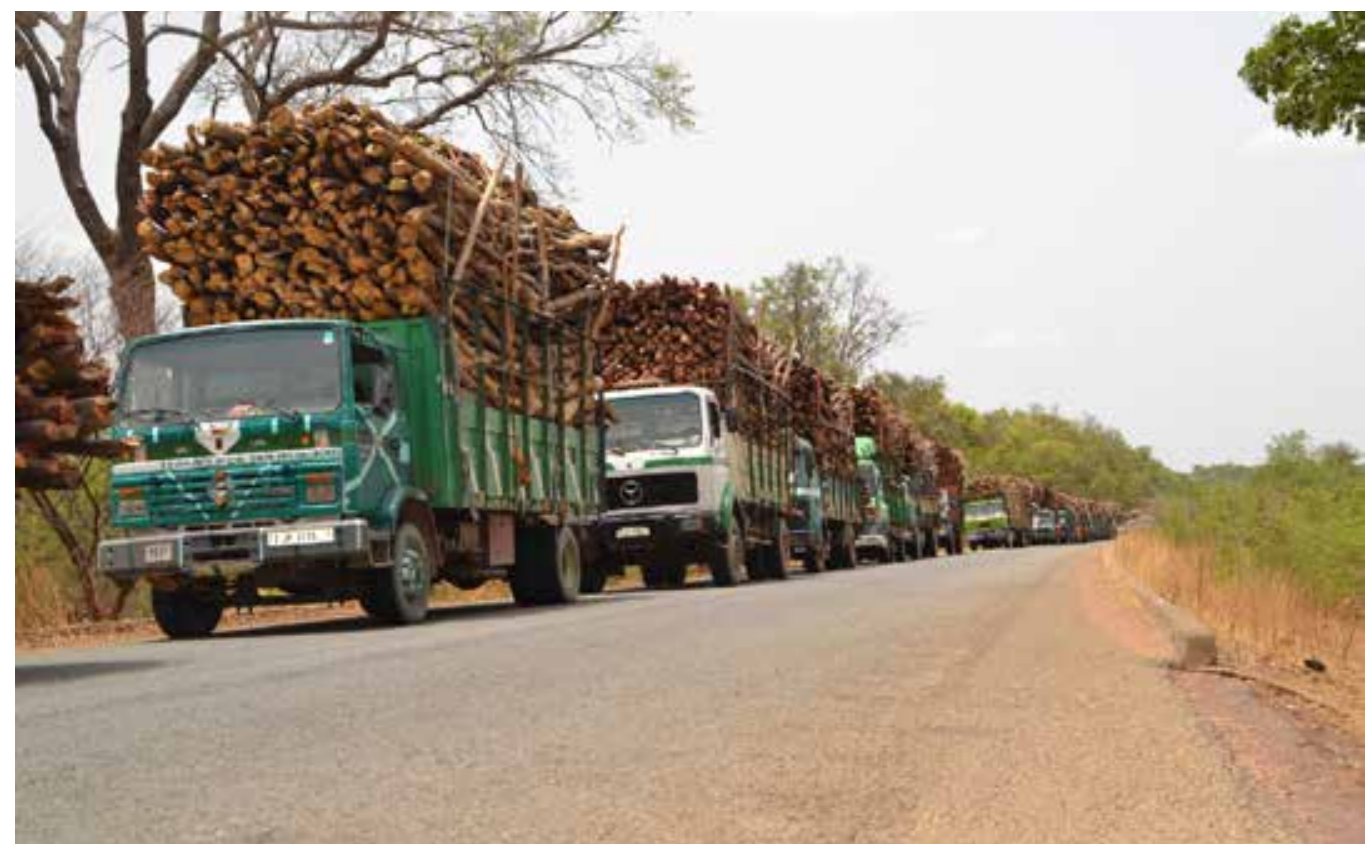

Fuelwood trucks with wood harvested from managed forests in Ziro Province. The green trucks and their operators are authorized to harvest wood from CAF (chantier d'aménagement de forêts) forests under a quota and levy arrangement. (Samson Foli/CIFOR)

(UGGF). State forestry services serve a monitoring, advisory and support role within this arrangement. After the establishment of these concessions, CAF and the environmental ministries introduced tree species conservation and replanting into the CAF scheme.

From expert consultations with the local forestry department and from earlier work by Paré et al. (2008) and Ouedraogo (2009), forest and vegetation cover in Ziro Province has declined considerably in the past 30 years. Satellite images showing vegetation cover change were available for the period 1999-2013 (see Figure 8.5). The forest areas inside CAF show hot spots of increasing vegetation cover, with little to no vegetation decline happening within these managed demarcations. Mild to severe vegetation cover change occurred in areas outside of managed forest. Observations made in the field tell us that land use outside of CAF is cropland interspersed with trees (parklands) and seasonal grasslands. The satellite images (Figure 8.5) show that remote areas far from settlements are experiencing the most recent conversion to cropland. These are areas adjacent to CAF forests with comparable tree cover but are unprotected by arrangements defining their harvesting and conservation. These tracts are increasingly being cleared for food and cash crop production. Semi-sedentary Fulani pastoralists occupy the fringes of village communities where these remnant unprotected forests can be found. Due to their large herd sizes, pastoralists prefer to settle in remote village boundaries with readily available fodder and pasture for livestock. Although the pastoralists cultivate nearby fields of subsistence cereals, fodder is the major reason for their habitat preferences. Appendix 8B elaborates on guidelines for interpreting NDVI derived forest cover change trends, presented in Figure 8.5. 


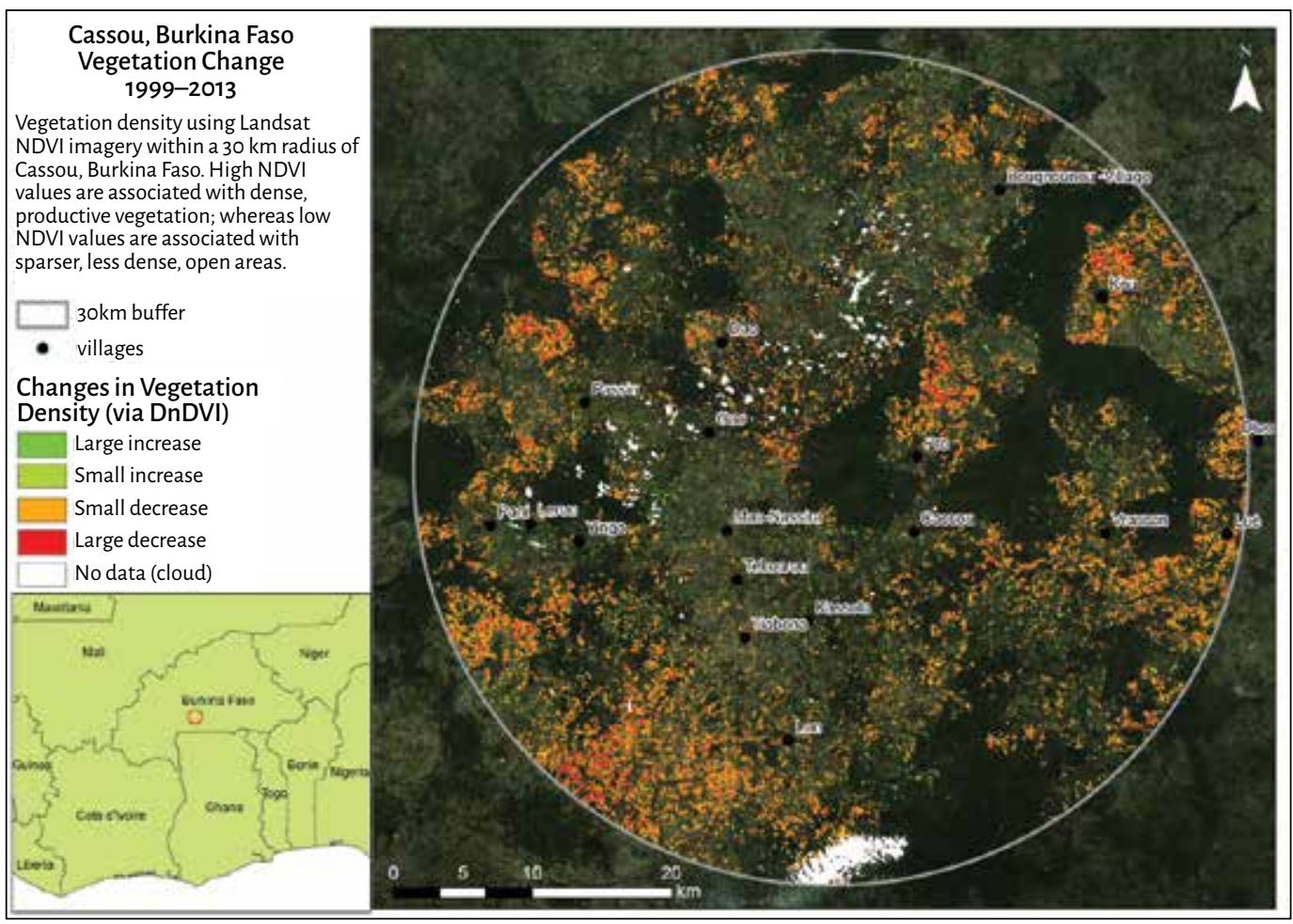

\section{Figure 8.5 Vegetation cover change visualized between 1999 and 2013 in the $30 \mathrm{~km}$ radius of our study site in Ziro Province.}

Note: Darker green areas represent the demarcated and managed CAF.

\subsubsection{Livelihood activities}

Approximately $80 \%$ of household income is derived from crop production and livestock husbandry in our study area. All respondents interviewed for this study were involved in more than one livelihood activity. The dominant activities highlighted by the respondents were agriculture (crop production and livestock husbandry), harvesting and processing of NTFPs, wood cutting (fuelwood and timber) and seasonal employment. Shea nut collection, processing and trade, which used to be dominated by female household members is now increasingly involving men due to a lucrative market in global cosmetic value chains. The utilization and conservation of the shea tree remains largely within agroforestry systems. It is protected from felling in the forest areas and spared within crop fields where other species have been removed. Néré or Parkia biglobosa has a similar protected status in this landscape. The beans are processed by women into a local condiment known as dawadawa or sumbala, which is sold and consumed locally. The néré tree is protected under CAF and prohibited from felling for timber and fuelwood in cropland and common lands. The pods of the tree also serve as a feed source for livestock. Residues from processing are fed to livestock. 
Participatory forest management under the CAF scheme is a major component of the poverty reduction strategy and as a source of income for rural people in Ziro Province. Between 1998 and 2011, wood and forest products generated XOF 733 million (USD 1.462 million in 2011). Income and remuneration for people involved in the sector amounted to XOF 366 million (USD 730,000) in the same period. Income generation data is sparse for our research sites and is often aggregated at a coarse level. Village-level data is unavailable, but we obtained district-level data on sources of income in Cassou compared with nearby districts. The data was from a USAID-CIFOR study published in 2009, which found that, felling activities contributed to $50 \%$ of annual household income (Ouedraogo 2009; Table 8.3). Sale of farm produce accounted for $32 \%$. A third category of 'others,' mainly value chains of NTFP harvest, processing and trade, contributed $19 \%$.

\section{Table 8.3 Sources of household income in Cassou district in Ziro Province compared to neighboring districts.}

\begin{tabular}{|l|c|c|c|c|c|}
\hline District & $\begin{array}{c}\text { Wood felling } \\
(\%)\end{array}$ & $\begin{array}{c}\text { Charcoal } \\
(\%)\end{array}$ & $\begin{array}{c}\text { Agriculture } \\
(\%)\end{array}$ & $\begin{array}{c}\text { Honey } \\
(\%)\end{array}$ & $\begin{array}{c}\text { Others } \\
(\%)\end{array}$ \\
\hline Cassou & 49.5 & - & 31.5 & - & 19.0 \\
\hline Billy-Pouni-Zawara & 41.2 & 42.0 & 13.9 & - & 2.9 \\
\hline Sud-Ouest Sissili & 24.3 & 37.2 & 31.7 & 0.5 & 6.3 \\
\hline Sapouy Bieha & 90.8 & - & - & - & 9.2 \\
\hline Nazinon & 75.5 & 2.6 & 14.4 & 2.0 & 5.4 \\
\hline Nakambe & 99.1 & - & 0.9 & - & - \\
\hline Bougnounou & 92.7 & - & 3.8 & - & 3.5 \\
\hline Mean per activity type & 53.6 & 24.2 & 16.5 & 0.2 & 5.6 \\
\hline
\end{tabular}

Source: USAID-CIFOR survey (Ouedraogo 2009)

\subsubsection{Infrastructure}

Major towns in Ziro Province are not connected to a national road network but are connected by dirt roads $45 \mathrm{~km}$ away from the nearest tarred road. The most common local mode of transport is bicycle and motorcycle for personal transport, and donkey-drawn carts for transport of farm produce and wood. There are three markets centers in Cassou, Gao and Mao-Nassira. All communities visited had at least one local primary school in the village. Nearby high schools were in Cassou, Gao or Mao-Nassira. On average, pupils travel $8 \mathrm{~km}$ (30-40 minutes by bicycle) to the nearest high school. Beyond high school education, students need to travel to Sapouy, the capital of Ziro Province. Two types of rural health care exist in Burkina Faso: rural clinics and maternity centers. Maternity centers provide subsidized care during childbirth. The maternity care program aims to train local midwifes in each village. Both types of health services are available in Cassou, Gao and Mao-Nassira, but are not found in Pro, Tekourou, Vrassan or Kou. 
Domestic water supply is from open wells and boreholes. Energy sources are fuelwood for cooking and kerosene for lighting. Solar panels and petrol/diesel-powered generators are used in charging batteries to power electrical appliances. None of the villages we visited for the scoping study were connected to a public electricity supply.

\subsubsection{Farming systems}

Crop production in Ziro Province and much of the Sudan savannah belt is cereal-based (Foli 2012). These systems have been well documented by previous authors (Carsky et al. 2002; Sanginga et al. 2003). Average farm size per household is 4.25 ha (range 2-7 ha) in the study area. Farms are typically divided into 2-4 fields: the home garden (champ de case) for food crops and vegetable production, and the outfields (champ de brousse) where cereals, cotton and sesame is cultivated. We classified three different field types based on their distance from households: (1) home-fields/home gardens, (2) intermediate fields and (3) remote fields (Tittonell et al. 2005). Subsistence crops, vegetables, legumes and pulses are grown near the homestead, while cash crops are grown on outfields. Other commercial crops such as fruit trees and rice are planted near water bodies and seasonal floodplains. Home fields are smallest in surface area - typically below 0.25 ha. Total farm area or number of fields cropped per season varies depending on available seed, fertilizer inputs (both from organic and mineral sources), available labor and rainfall. Uncropped land is left to fallow.

Cropping is rain-fed, using manual labor mostly from household members. Irrigated cropping is not common and occurs near seasonal water bodies. Cassou and Tekourou communities for example practice dry season irrigated cropping due to proximate water bodies. Dry season cropping includes early maturing vegetables (e.g. tomato Solamun

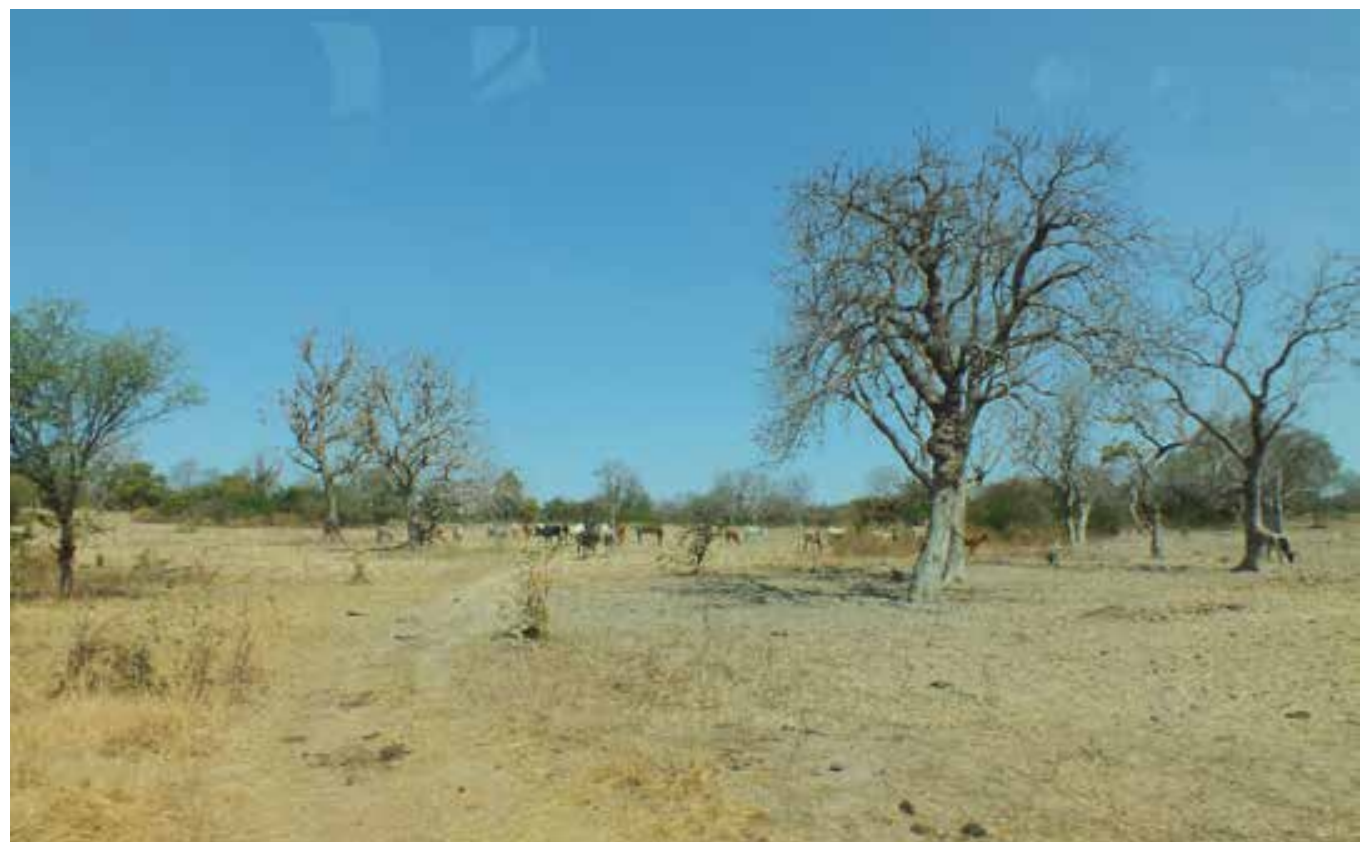


lycopersicum and onion Allium cepa) and fruits (sweet melon Citrullus lanatus and papaya Carica papaya). These crops are cultivated and sold at district markets. Farmers rely on organic nutrient sources of farmyard compost and cattle manure to replenish soil fertility. Organic household waste is composted with dung from small livestock (poultry, goats and sheep). This is applied to crop fields during land preparation. Cattle manure is deposited on crop fields when livestock graze on crop residues during the dry season. Farmers plough the manure into the soil during land preparation before cropping in the following season. Mineral fertilizer sources of nitrogen, phosphorous and potassium include compound fertilizers such as NPK and urea. Access to agricultural inputs is predominantly through SOFITEX (Société Burkinabè des Fibres Textiles), an input subsidy program for cotton production in Burkina Faso. SOFITEX provides seeds, fertilizers and chemical inputs to farmers under a credit system. It is the main buyer of cotton from farmers in our study sites and throughout Burkina Faso.

Fallow practices that allow rejuvenation of soil fertility are diminishing due to increasing pressure on productive land (Söderström et al. 2003). Declining soil quality and fertility is major challenge to crop productivity in this area. The limited availability and use of nutrient inputs means soils are increasingly being depleted, with resulting negative nutrient balances (Harris 1998). In addition to soil fertility decline, farmers are reporting an increasing problem of striga (Striga hermonthica or witchweed). Striga infestations have been reported in cereal cropping systems across the Sudan savannah region (Kuchinda et al. 2003). Reported crop damage can be up to $85 \%$ after striga attach (Carsky et al. 2000).

Table 8.4 Example of a typical cropping calendar in the study sites.

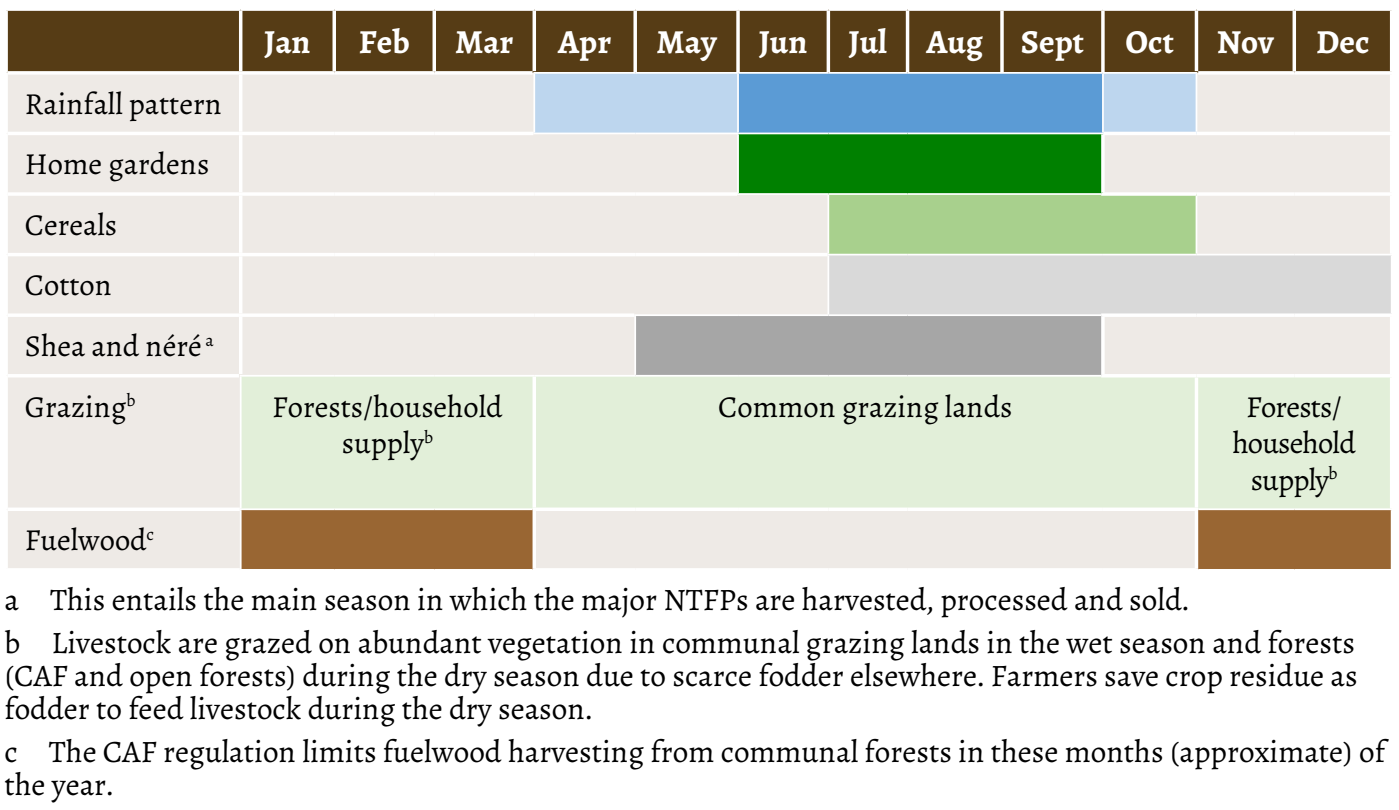


Livestock is an important asset and an indicator of resource endowment in this area. Livestock are grazed on pasture and given a number of fodder sources throughout the year depending on availability. Important tree species for fodder are Saba senegalensis, Afzelia africana, Balanites aegyptiaca and others. Farmers also collect and store crop residue of cereals and legumes after harvest to feed livestock during the dry season. These are used to feed household livestock, mainly sheep and goats during the dry spell. Cattle are herded over long distances in search of pasture in the dry season. Livestock are integrated into cropping systems and are important for replenishing soil fertility and nutrient cycling (Harris 1998; Hoffmann et al. 2001). In this practice, cattle manure deposited on fields during grazing is ploughed into the soil prior to cropping. Nutrients are recycled through crop residues that are fed to small ruminants and the manure is returned to crop fields. Table 8.4 shows a typical example of annual cropping calendars in Ziro Province.

\subsubsection{Land modification gradients across the landscape}

Classifying spatially explicit gradients of land modification in our study sites based on landscape configuration and distances from forests was difficult. Our study sites are mosaic configurations of fragmented forests, agroforestry parklands and open savannah. Forest areas under preservation and management by CAF are dotted across the landscape equally (see Figure 8.6). Cropping is carried out in heterogeneous pockets based on household food and income needs, and available resources. Clustering into land modification gradients at this level is hence unconvincing. Intensification at household level is determined by access to agricultural inputs and available labor (and/ or ability to hire labor). An alternative to the formation of zones using spatial and proximity information is to cluster land modification based on household assets and land management practices. The latter is based on the hypothesis that wealthier farmers are able to manage their fields intensively and can sustain a larger area of farmland. Access to information about the assets of farmers will enable us to group farmers into different resources endowment classes to create farm typologies.

Farm typologies have been used earlier by a number of authors for similar purposes in agronomic research (Chavez et al. 2010; Tittonell et al. 2010). For this scoping study, we have classified land modification gradients using the available demographic data. The clusters shown here should be seen as a preliminary attempt to understand land use in a multipurpose mosaic landscape. The activities described in each zone are not exclusive to that particular classification but reflect the major land uses of villages in the zone. Figure 8.6 illustrates the zones and study villages that fall within each classification.

\subsubsection{Zone of low land modification (Zone 1)}

Zone 1 includes typical cereal-based systems of sorghum, maize and millet, and small farm sizes of 2 ha on average. The main commercial activities are collection of forests products and processing and sale at local markets. Fuelwood is harvested from CAF forests for domestic use. The sale of agricultural crops is limited to cereal surpluses. Household income comes from the sale of poultry and small ruminants, and is used to cover household cash needs, for example for school fees, health care and other ceremonies (e.g. funerals, births, weddings, etc.). Villages that fall into this zone are 


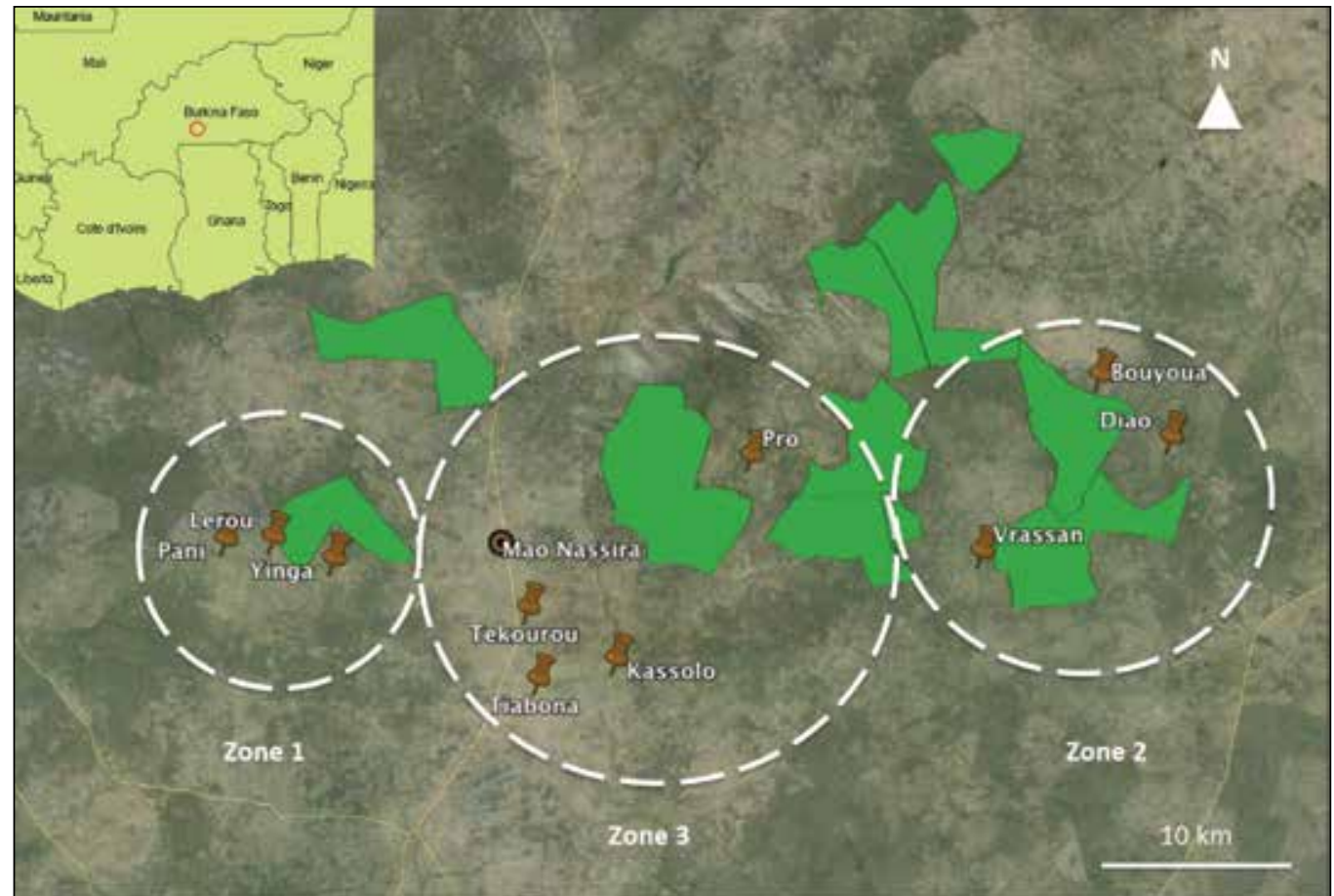

\section{Figure 8.6 Land modification gradients in Cassou, Bakata and Gao districts classified} into zones.

Note: Zone 1, 2 and 3 represent low, semi-intensive and intensive land modification clusters, respectively. Villages shown are the sites for the Agrarian Change Project data collection.

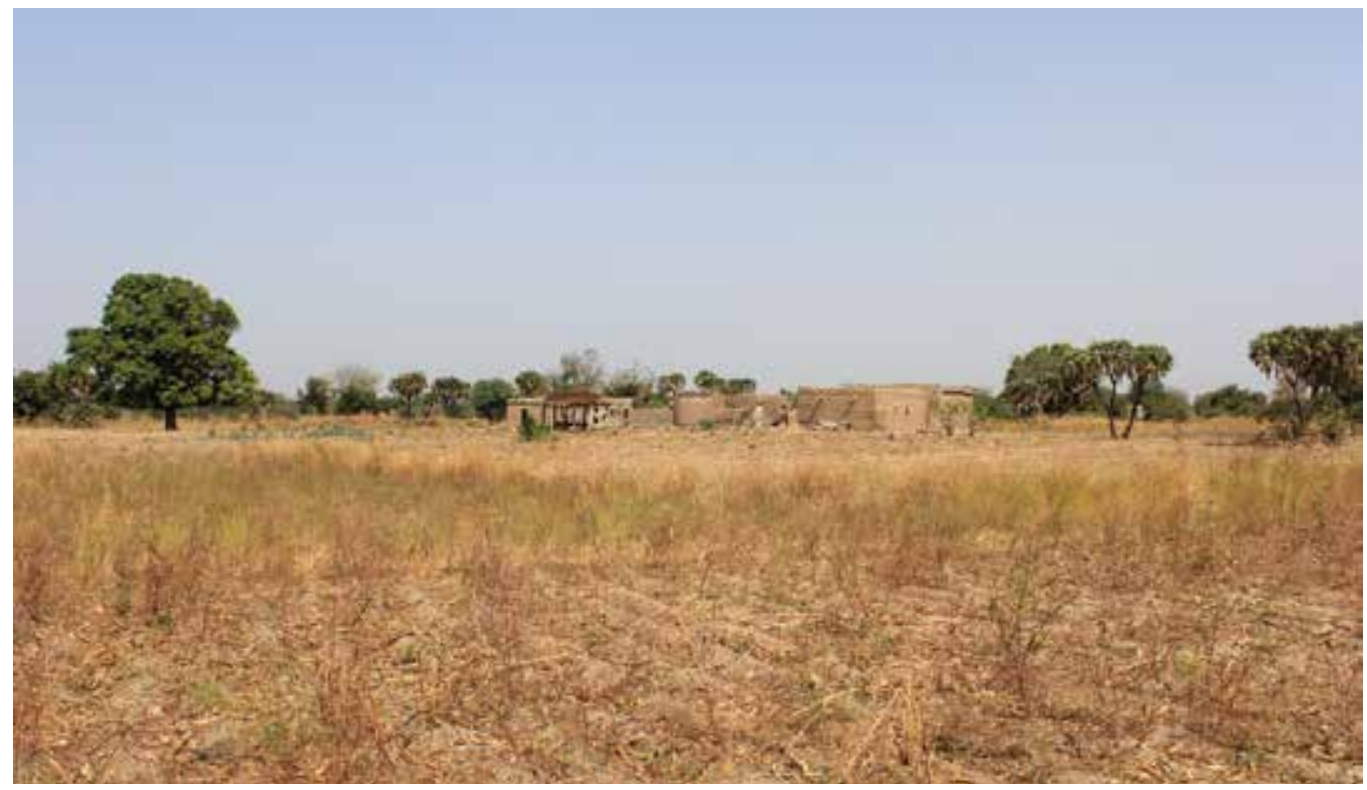

Example of Zone 1 scattered settlement with adjacent home garden fields. (Samson Foli/CIFOR) 
Yinga, Pani and Lerou in Gao district (see map in Figure 8.6). The average population is 1315 per village. There are public primary schools in these communities but no high schools. Pupils travel to Mao-Nassira (between 13 and $21 \mathrm{~km}$ away from Yinga and Pani respectively) to the nearest high school. The same holds for local health services; the nearest health center is a 25-minute bicycle trip to Mao-Nassira. The ethnic groups in this village are predominantly migrant Fulani and Mossi. Mossi are crop farmers and Fulani are semi-sedentary pastoralists. In the dry season, the Fulani move their herds further away from the communities in search of scarce fodder. Such households and their communities are less involved in market-oriented cash crop farming of cotton and sesame. Their remoteness from towns, market centers and good road connections limits market integration. Roads linking these three communities to the nearest secondary road and market center of Mao-Nassira are impassable for most of the wet season.

\subsubsection{Semi-intensive land modification (Zone 2)}

Villages that fall in the zone of medium land modification include the cluster of Vrassan, Bouyoua and Diao (see Figure 8.6) with an average population of about 2591 inhabitants per village. Vrassan is located in Cassou whilst Bouyoua and Diao are in Bakata districts. These communities are located on road networks that connect them to district centers such as Cassou and Bakata. There are public primary schools and no health care services. The nearest rural clinics are in Cassou or in Bakata towns. These villages are also major cotton producing centers and production of maize is on a commercial scale. The main forest products are processed and sold at local and district markets. All three communities are also involved in commercial trade of fuelwood to urban Ouagadougou and Sapouy urban markets. Villages in Zone 2 are involved

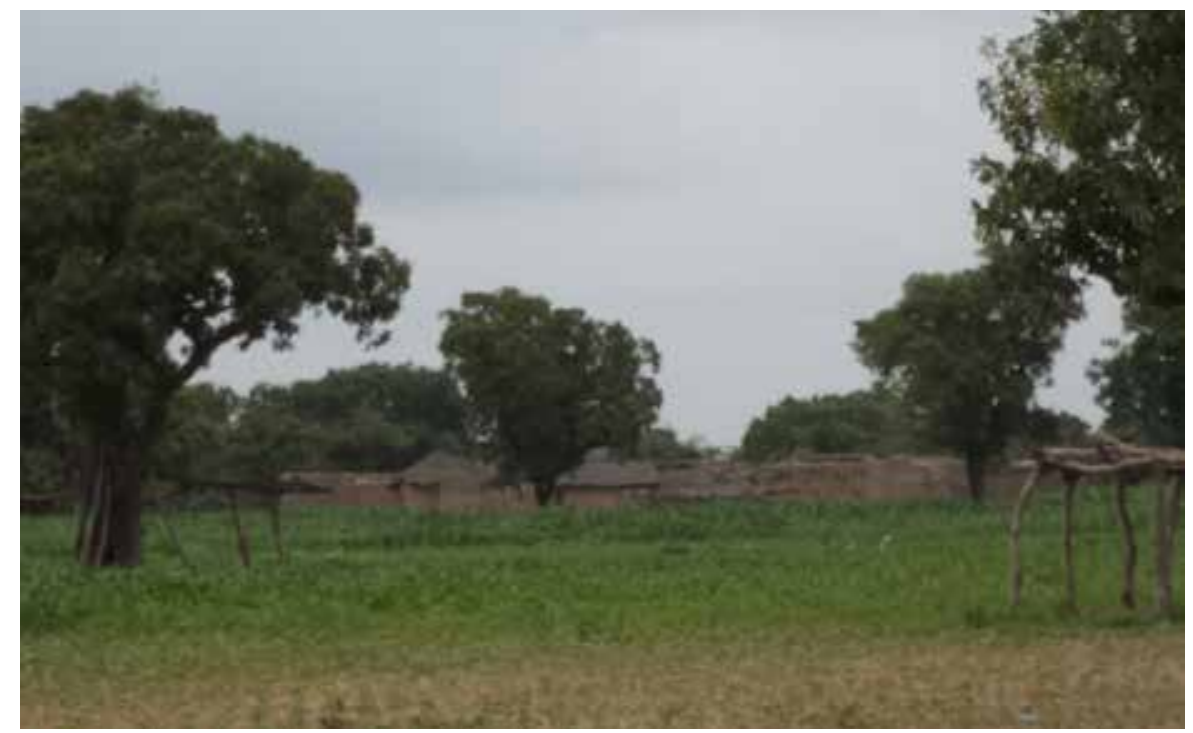

Cluster of extended family households with surrounding maize fields in a Zone 2 village. (Rabdo Abdoulaye/CIFOR) 
in mixed farming and carry out a number of livelihood activities that rely on forest products, mainly fuelwood. Cropping includes subsistence cereals and cotton for sale within the subsidy system of SOFITEX. Agricultural inputs and mechanization is reserved for cash crops.

\subsubsection{Intensive land modification (Zone 3)}

The communities in this zone are towns and bigger villages along secondary road networks. They include Cassou and Mao-Nassira, which are the two big market centers in Ziro Province, as well as Pro, Kassolo, Tiabona and Tekourou, which are linked by good roads to these markets centers (see Figure 8.6). These towns each have an average population of 3512 inhabitants. Mao-Nassira is linked by a secondary road network and Cassou is linked via a road network that is passable all year round. The road networks connect Cassou and Mao-Nassira to national roads that go through Sapouy and Sabou to the national capital. Primary and high schools and rural health care services are located in these communities or adjacent villages. In Zone 3 villages, people are involved in commercial activities or official government employment (in rural education, clinics and local administration). Crop production is intensified with comparatively easy access to inputs from markets. Farmers have access to fertilizers, herbicides and other external inputs outside of the cotton subsidy system of SOFITEX. These inputs are also used in intensifying cereal production such as maize, which is cultivated more as a cash crop than for subsistence. There is direct access to information from extension technicians.

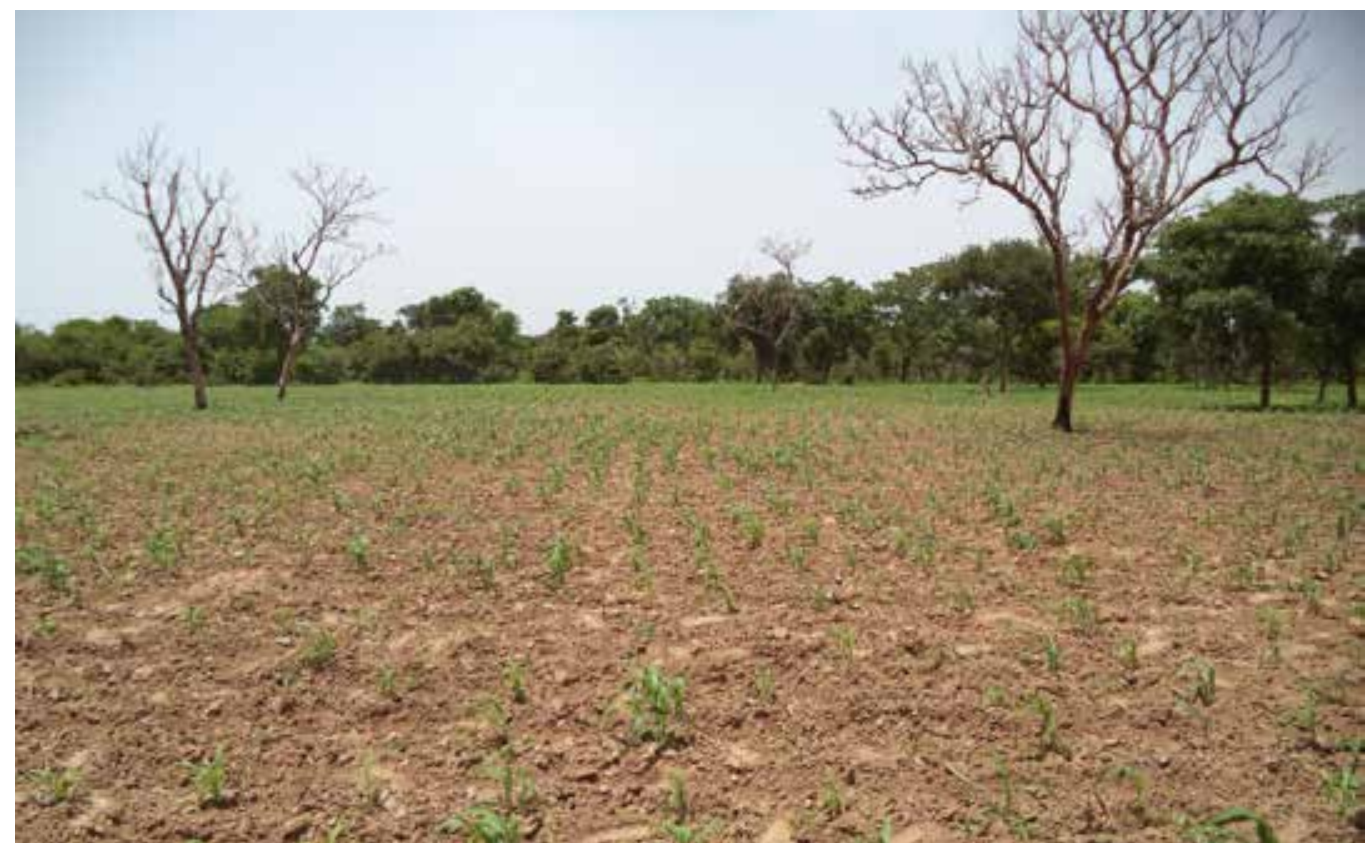

Maize fields like this, with little tree cover retained, represent intensive management with high use of agro-chemicals. (Rabdo Abdoulaye/CIFOR) 


\subsubsection{Land tenure}

Landownership and tenure falls under Gourounsi customary law in Ziro Province. Land tenure, i.e. the acquisition, use, ownership and transfer of land rights, are under Gourounsi customs despite this group only making up under $20 \%$ of the current total population of the province (see Figure 8.7). The remainder of the population is migrant Mossi, Fulani and Walla settlers who acquire and use land belonging to their Gourounsi host communities under a "borrowed" status. Gourounsi extended families own land, both farmland and forestland. Landownership is not controlled under a chieftaincy but under extended family lines; the current head of the family holds rites of transfer of the land. Households that were first to settle on a piece of land took ownership of it. If a household needed additional land to expand cropping, grazing or settlement, they could clear a vacant, virgin tract of forest. A household or family head usually divides his total area of land among his sons to set up their homesteads and farms.

During the establishment of forest management under CAF in 1990-1993, relevant villages "donated" areas of forestland that were mostly unfarmed at the time. These lands were consolidated into management units and cooperatives were formed to oversee their use and conservation. With the ongoing migration from north to south, Mossi, Fulani and Walla families mainly acquired land for settlement and farming by borrowing land from indigenous families. The indigenous population allocated virgin land to migrants for settlement and agricultural activities. As the number of immigrants has risen, the pressure on land has resulted in fragmentation of already occupied areas. The finite area of productive land outside the CAF means the pressure on agricultural land will continue to rise concurrent with the growing population.

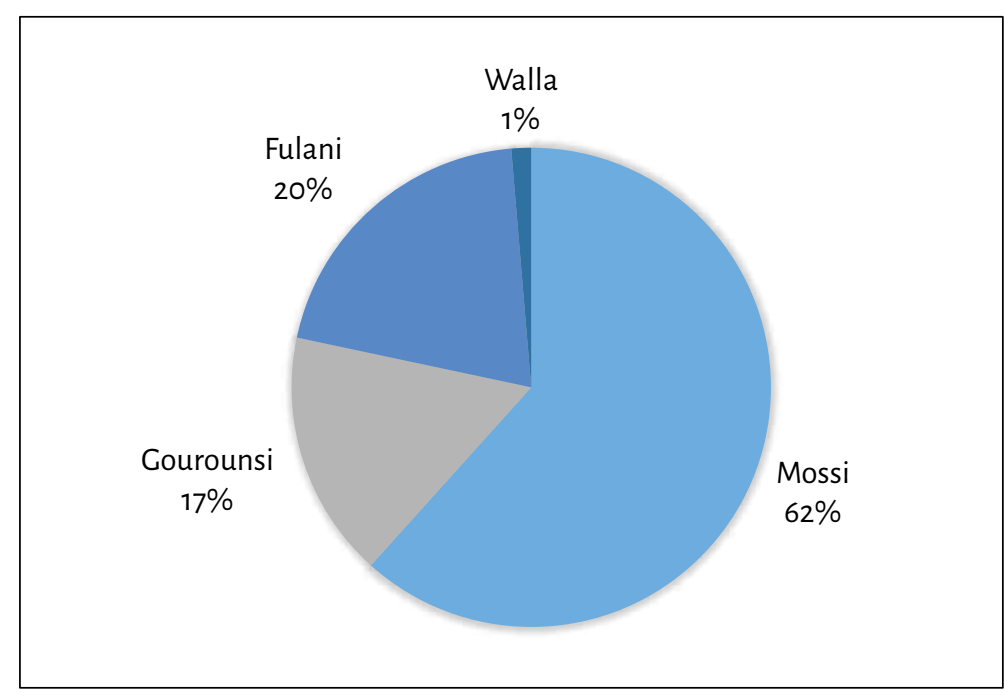

Figure 8.7 Proportion of Mossi, Gourounsi, Fulani and Walla in the local population in Ziro Province. 


\subsubsection{Food security, nutrition and livelihoods in the context of land-use change}

At the national level, a number of factors contribute to the prevailing food insecurity in Burkina Faso, which ranks 183 of 186 in the United Nations' Development Index (Von Grebmer et al. 2014). Approximately $45 \%$ of the population lives below the poverty threshold of USD 1.25 per day (Malik 2013). As a landlocked country, Burkina Faso is vulnerable to market prices of food crops while at the same time commanding little buying power regionally (Wodon et al. 2008).

The scoping study data indicated that $61 \%$ of the total volume of household food is sourced from farms, $23 \%$ comes from forest sources and the remaining $16 \%$ is purchased from local markets (see Figure 8.8). Male-headed households $(n=15)$ said their household sourced $62 \%$ of food from farms, $22 \%$ from forests and $16 \%$ from markets. Female-headed households $(n=13)$ said $61 \%$ of household food was from their own fields (farms), 23\% from forests and 16\% from markets. Information gathered in the FGDs, indicated that in the past 25 years, more food is being sourced from farms and less from forests. The share of food provisioning from markets has been approximately stable during this time. Increased crop productivity in the last two and a half decades can partly account for the increasing availability of food from farms; this has replaced the need to source wild foods from forests. Researchers would like to further explore the relative importance of farms, forests and markets to local food provisioning.

Maize, sorghum and millet constitute the staple base of local diets. Groundnuts and cowpea are the grain legumes and important sources of plant protein consumed in local dishes. Okra (Abelmoschus esculentus) and oseille (Rumex acetosa) are the locally produced and consumed vegetables. A number of wild leaves and fruits are consumed throughout the year depending on the season (see Table 8.2). Participants in our FGDs reported that they are food secure for a minimum of 9 months in a year. The most vulnerable months are between June and August - at the start of the rainy season when cropping season commences. To cope with reduced food availability, households generally reduce their daily rations from three to two meals a day. At this time of the year, there is an

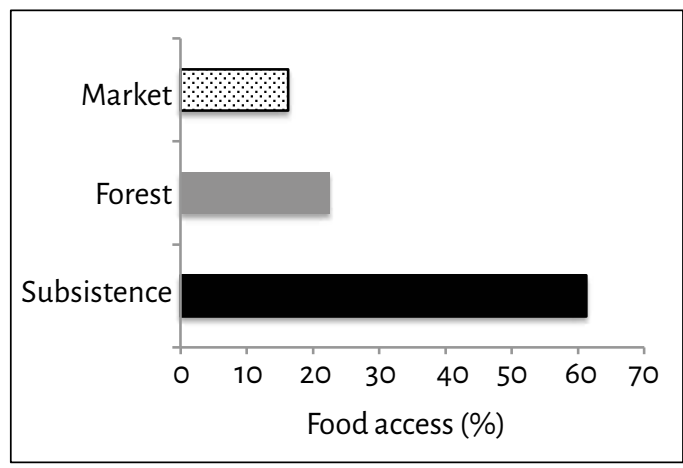

Figure 8.8 Average seasonal percentage of food sourced from markets, forests and own farms in Ziro Province. 


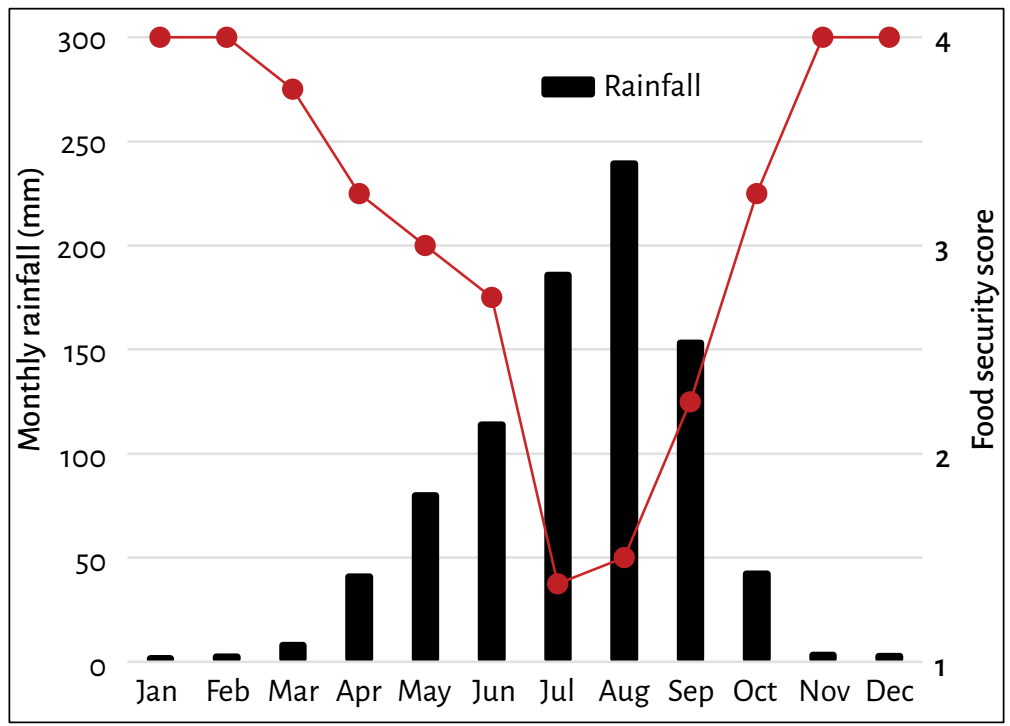

Figure 8.9 Seasonal food availability in Ziro Province overlaid with average annual rainfall.

Note: Food security score (secondary axis) assesses monthly food self-sufficiency for 12 months of the year. A score of 4 represents enough for the household with surplus food to sell at local markets. A score of 1 means household are experiencing food deficit.

abundance of leafy vegetables such as oseille in home gardens and other edible plants from forests. This enables households to supplement their diets. Bombax costatum, baobab (Adansonia digitata) and saba (Saba senegalensis) are widely used to supplement diets during the dry season. Figure 8.9 shows the food availability throughout the year against average annual rainfall.

\subsection{Discussion}

Findings from this study indicate the importance of forests for rural livelihoods (food and income) in the research area. Past studies highlighted the seasonal fluctuation in food availability and varying reliance on forests for food in different months of the year (Orr 1995; Somorin 2010). This scoping study showed that farm, forests and markets are linked in terms of supplying sufficient food for household consumption throughout the year. The Agrarian Change Project in the latter stages of analysis, aims to further investigate the relative contributions of farms, forests and markets to food security and dietary diversity during both wet and dry seasons in our study landscape. This will help understand the importance of forests, in particular in addressing food shortages, and their role as a buffer during lean periods. As stressed by Ickowitz et al. (2014), in-depth analysis is needed to understand seasonal contribution of forests to food security in sub-Saharan African countries such as Burkina Faso. One way to conduct such a study would be to hold FGDs at the village level to investigate changes over time in the proportion of food sourced from farms, forests and markets 
(classifying by monthly/seasonal variations) in the backdrop of ongoing land intensification. At the household level, this information could be accessed using food calendars, which have been designed by the Agrarian Change Project, during household and farm surveys.

Land modification gradients are not spatially clear at the landscape level in our study sites. We were able to cluster land modification patterns into zones (see Figure 8.6) across our landscape using a set of criteria (see Table 8.1). Zone 1 represents villages with predominantly low land modification and extensive cropping systems. This zone has a large pastoralist community settled in remote sections of the landscape with limited road and market access. Farming systems are largely sorghum- and millet-based for domestic use and sale of surpluses. Livestock rearing is dependent on communal pasture and fodder from forests. Zone 2 is a heterogeneous mix of both extensive and intensive land modification and management. Land modification differs by crop management practices. Cotton cultivation for example is intensively managed using agricultural inputs accessed through the national cotton input subsidy of SOFITEX. Cereal cultivation takes place in fields with little use of fertilizers and agro-chemicals. A large proportion of households in this zone are involved in commercial wood-cutting for sale as timber and fuelwood. Zone 3 is the most intensively modified cluster of communities in our landscape. The villages in this zone are rural market centers and district administration capitals (e.g. Gao and Cassou villages) with road access presenting opportunities for off-farm employment. Cropping of both subsistence and cash crops are relatively intensive compared to Zone 1 and 2. Farmers in Zone 3 cultivate maize on a commercial scale using fertilizer and agro-chemical inputs. This is a practice that is uncommon in the other two zones.

We see that farmers' ability to modify and manage their fields extensively or intensively is dependent on combinations of crop type, available agricultural input, labor and inherent soil fertility (Tittonell et al. 2010; Zorom et al. 2013). Different levels of intensification can be identified at farm level. Different crop fields within the same farm are managed differently using varying intensities of agricultural in put and labor. Farming commercial crops like cotton and maize can be classified under intensive land modification and cultivation of cereals such as millet and sorghum can be classified under extensive land modification. The reality of the landscape, partly due to climate vulnerability and seasonal rainfall variability dictates that farmers use a variety of management practices on the extensive-intensive spectrum. Such practices are inherent in traditional coping strategies against crop failure (Wardell et al. 2003; Bayala et al. 2011; Sultan et al. 2013). The zones described in this report represent areas in which certain intensities of land modification are dominant but not exclusive. These zones again are not sufficient to describe the heterogeneous nature of farming systems and farmers' access to modification of land in Ziro Province. We recommend creation of farmer typologies, taking into consideration, landownership, resource endowments (e.g. farmland and number of livestock) and farm management practices to better understand heterogeneity in land uses and change processes in the modification of the landscape in mosaic configurations in our study area. This would better reflect the reality of land use, and the drivers and outcomes for livelihoods on the ground. 


\section{Acknowledgments}

The researchers wish to thank CIFOR's Burkina Faso office for hosting field operations for the Agrarian Change project and providing background information that facilitated selection of potential study sites. We would also like to thank all of the field assistants and translators for their input during the field visits throughout the duration of the project. 


\section{References}

Arbonnier M. 2004. Trees, Shrubs and Lianas of West African Dry Zones. Centre de Coopération Internationale en Recherche Agronomique pour le Développement (CIRAD) and Museum National d'Histoire Naturelle (MNHN). Weikersheim, Germany: Margraf Publisher GMBH.

Bayala J, Kindt R, Belem M and Kalinganire A. 2011. Factors affecting the dynamics of tree diversity in agroforestry parklands of cereal and cotton farming systems in Burkina Faso. New Forests 41(3):281-96. doi:10.1007/s11056-010-9222-Z

Belem B, Nacoulma BMI, Gbangou R, Kambou S, Hansen HH, Gausset Q Lund S, Raebild A, Lompo D and Ouedraogo M. 2007. Use of non-wood forest products by local people bordering the Parc National Kaboré Tambi, Burkina Faso. Journal for Transdisciplinary Environmental Studies 6(1):1-21.

Boffa J-M. 1999. Agroforestry parklands in sub-Saharan Africa. Vol. 34. Rome: Food and Agriculture Organization of the United Nations.

Carsky R, Berner D, Oyewole B, Dashiell K and Schulz S. 2000. Reduction of Striga hermonthica parasitism on maize using soybean rotation. International Journal of Pest Management 46(2):115-20.

Carsky R, Vanlauwe B and Lyasse O. 2002. Cowpea rotation as a resource management technology for cereal-based systems in the savannas of West Africa. In Fatokun CA, Tarawali SA, Singh BB, Kormawa PM and Tamò, eds. Challenges and Opportunities for Enhancing Sustainable Cowpea Production. Ibadan, Nigeria: International Institute of Tropical Agriculture. 252-66.

Chavez M, Berentsen P and Lansink AO. 2010. Creating a typology of tobacco farms according to determinants of diversification in Valle de Lerma (Salta-Argentina). Spanish Journal of Agricultural Research 8(2):460-71.

Coulibaly-Lingani P, Tigabu M, Savadogo P, Oden P-C and Ouadba J-M. 2009.

Determinants of access to forest products in southern Burkina Faso. Forest Policy and Economics 11(7):516-24.

Djoudi H, Brockhaus M and Locatelli B. 2013. Once there was a lake: Vulnerability to environmental changes in northern Mali. Regional Environmental Change 13(3):493-508.

Foli S. 2012. Farm characterisations in the southern and northern guinea savannah zones of Nigeria [Master's thesis]. Wageningen, the Netherlands: Wageningen University.

Grimm M and Günther I. 2004. How to achieve pro-poor growth in a poor economy. The case of Burkina Faso. Document prepared for the project "Operationalizing Pro-PoorGrowth", GTZ, Eschborn.

Harris F. 1998. Farm-level assessment of the nutrient balance in northern Nigeria. Agriculture, Ecosystems \& Environment 71(1):201-14.

Henry S, Boyle P and Lambin EF. 2003. Modelling inter-provincial migration in Burkina Faso, West Africa: The role of socio-demographic and environmental factors. Applied Geography 23(2-3):115-36. 
Henry S, Schoumaker B and Beauchemin C. 2004. The impact of rainfall on the first out-migration: A multi-level event-history analysis in Burkina Faso. Population and Environment 25(5):423-60. doi:10.1023/B:POEN.0000036928.17696.e8.

Hoffmann I, Gerling D, Kyiogwom UB and Mané-Bielfeldt A. 2001. Farmers' management strategies to maintain soil fertility in a remote area in northwest Nigeria. Agriculture, Ecosystems \& Environment 86(3):263-75.

Howorth C and O'Keefe P. 1999. Farmers do it better: Local management of change in southern Burkina Faso. Land Degradation \& Development 10(2):93-109.

Ickowitz A, Powell B, Salim MA and Sunderland TCH. 2014. Dietary quality and tree cover in Africa. Global Environmental Change 24(0):287-94.

[INSD] L'Institut national de la statistique et de la démographie. 2007. Résultats préliminaires du recensement général de la population et de l'habitat de 2006. Ouagadougou: Direction de la Demographie.

[INSD] L'Institut national de la statistique et de la démographie and [MEF] Ministère de l'Economie et des Finances (MEF) du Burkina Faso. 2009. Recensement general de la population et de l'habitat, 2006 (general population census, 2006). Ouagadougou: Direction de la Demographie.

Kaminski J. 2011. Cotton dependence in Burkina Faso: Constraints and opportunities for balanced growth. In Chuhan-Pole P and Angwafo M, eds. Yes Africa can: Success stories from a dynamic continent. Washington DC: The World Bank. 107-24.

Kerr JT and Ostrovsky M. 2003. From space to species: Ecological applications for remote sensing. Trends in Ecology \& Evolution 18(6):299-305.

Kevane M and Gray LC. 1999. A woman's field is made at night: Gendered land rights and norms in Burkina Faso. Feminist Economics 5(3):1-26.

Kramer P. 2010. The fuelwood crisis in Burkina Faso: Solar cookers as an alternative. The Solar Cooking Archive. Accessed June 2015. http://solarcooking. org/Crisis.htm

Kuchinda N, Kureh I, Tarfa B, Shinggu C and Omolehin R. 2003. On-farm evaluation of improved maize varieties intercropped with some legumes in the control of striga in the northern Guinea savanna of Nigeria. Crop Protection 22(3):533-8.

Kumar S. 2002. Methods for Community Participation: A Complete Guide for Practitioners. Rugby, UK: Practical Action Publishing.

Ky-Dembele C, Tigabu M, Bayala J, Ouédraogo SJ and Odén PC. 2007. The relative importance of different regeneration mechanisms in a selectively cut savannawoodland in Burkina Faso, West Africa. Forest Ecology and Management 243(1):28-38.

Lamien N and Vognan G. 2001. Importance of non-wood forest products as source of rural women's income in western Burkina Faso. In Pasternak D and Schlissel A, eds. Combating Desertification with Plants. Springer. 69-79.

Malik K. 2013. Human development report 2013. The rise of the south: Human progress in a diverse world. United Nations Development Program-Human Development Reports Office.

Olson DM, Dinerstein E, Wikramanayake ED, Burgess ND, Powell GVN, Underwood EC, D'amico JA, Itoua I, Strand HE, Morrison JC, et al. 2001. Terrestrial ecoregions 
of the world: A new map of life on earth: A new global map of terrestrial ecoregions provides an innovative tool for conserving biodiversity. BioScience 51(11):933-8.

Orr B. 1995. Natural forest management in sahelian ecosystems of southern Niger. Journal of Arid Environments 30(2):129-42.

Ouédraogo B. 2009. Aménagement forestier et lutte contre la pauvreté au Burkina Faso. Développement durable et territoires. doi: 10.4000/developpementdurable.8215

Ouédraogo I. 2006. Land use dynamics in Bieha district, Sissili Province, southern Burkina Faso, West Africa. Umoja: Bulletin of the African and African American Studies $1(2): 18-34$.

Ouédraogo I, Savadogo P, Tigabu M, Cole R, Odén P and Ouadba JM. 2009. Is rural migration a threat to environmental sustainability in southern Burkina Faso? Land Degradation \& Development 20(2):217-30.

Paré S, Söderberg U, Sandewall M and Ouadba JM. 2008. Land use analysis from spatial and field data capture in southern Burkina Faso, West Africa. Agriculture, Ecosystems \& Environment 127(3-4):277-85.

Roose E, Kabore V and Guenat C. 1999. Zaï practice: A West African traditional rehabilitation system for semiarid degraded lands, a case study in Burkina Faso. Arid Soil Research and Rehabilitation 13(4):343-55.

Sanginga N, Dashiell K, Diels J, Vanlauwe B, Lyasse O, Carsky R, Tarawali S, AsafoAdjei B, Menkir A and Schulz S. 2003. Sustainable resource management coupled to resilient germplasm to provide new intensive cereal-grain-legume-livestock systems in the dry savanna. Agriculture, Ecosystems \& Environment 100(2):305-14.

Sawadogo L, Tiveau D and Nygård R. 2005. Influence of selective tree cutting, livestock and prescribed fire on herbaceous biomass in the savannah woodlands of Burkina Faso, West Africa. Agriculture, Ecosystems \& Environment 105(1):335-45.

Söderström B, Kiema S and Reid RS. 2003. Intensified agricultural land-use and bird conservation in Burkina Faso. Agriculture, Ecosystems \& Environment 99(1-3):113-24.

Somorin OA. 2010. Climate impacts, forest-dependent rural livelihoods and adaptation strategies in Africa: A review. African Journal of Environmental Science and Technology 4(13):903-12.

Sultan B, Roudier P, Quirion P, Alhassane A, Muller B, Dingkuhn M, Ciais P, Guimberteau M, Traore S and Baron C. 2013. Assessing climate change impacts on sorghum and millet yields in the Sudanian and Sahelian savannas of West Africa. Environmental Research Letters 8. Article ID: 014040. http://dx.doi.org/10.1088/17489326/8/1/014040

Tittonell P, Muriuki A, Shepherd KD, Mugendi D, Kaizzi K, Okeyo J, Verchot L, Coe $\mathrm{R}$ and Vanlauwe B. 2010. The diversity of rural livelihoods and their influence on soil fertility in agricultural systems of East Africa-a typology of smallholder farms. Agricultural Systems 103(2):83-97.

Tittonell P, Vanlauwe B, Leffelaar P, Rowe EC and Giller KE. 2005. Exploring diversity in soil fertility management of smallholder farms in western Kenya: I. Heterogeneity at region and farm scale. Agriculture, Ecosystems \& Environment 110(3):149-65. 
Townshend J, Hansen M, Carroll M, Dimiceli C, Sohlberg R and Huang C. 2006. User guide for the MODIS vegetation continuous field product collection 5 version 1. College Park, Maryland: University of Maryland.

Traoré S, Nygård R, Guinko S and Lepage M. 2008. Impact of Macrotermes termitaria as a source of heterogeneity on tree diversity and structure in a Sudanian savannah under controlled grazing and annual prescribed fire (Burkina Faso). Forest Ecology and Management 255(7):2337-46.

Von Grebmer K, Saltzman A, Birol E, Wiesmann D, Prasai N, Yin S, Yohannes Y, Menon P, Thompson J and Sonntag A. 2014. Global hunger index: The challenge of hidden hunger. Bonn, Washington, DC; Dublin: Welthungerhilfe, IFPRI and Concern Worldwide.

Wardell A, Reenberg A and Tøttrup C. 2003. Historical footprints in contemporary land use systems: Forest cover changes in savannah woodlands in the Sudano-Sahelian zone. Global Environmental Change 13(4):235-54.

Wodon QT, Tsimpo C, Backiny-Yetna P, Joseph G, Adoho F and Coulombe H. 2008. Potential impact of higher food prices on poverty: Summary estimates for a dozen West and Central African countries. World Bank Policy Research Working Paper Series. Washington, DC: World Bank.

Zorom M, Barbier B, Mertz O and Servat E. 2013. Diversification and adaptation strategies to climate variability: A farm typology for the Sahel. Agricultural Systems 116:7-15. 


\section{Appendices}

\section{Appendix 8A Villages and demographic data used for the scoping study}

Table 8A.1 Villages in Ziro Province and demographic information.

\begin{tabular}{|l|l|l|c|c|}
\hline District & Department/commune & Village & Population $^{\text {a }}$ & No. of households \\
\hline Cassou & Cassou & Pro & 794 & 130 \\
\hline Cassou & Cassou & Cassou & 3,867 & 662 \\
\hline Gao & Gao & Gao & 2,389 & 344 \\
\hline Gao & Gao & Tekourou & 2,439 & 344 \\
\hline Gao & Gao & Dao & 1,982 & 258 \\
\hline Cassou & Cassou & Kassolo & 424 \\
\hline Cassou & Cassou & Tiabona & - & - \\
\hline Bakata & Bakata & Kou & 1,923 & 269 \\
\hline Cassou & Gao & Mao-Nassira & 4,617 & 630 \\
\hline Cassou & Gao & Lerou & 1,119 & 180 \\
\hline Cassou & Gao & Yinga & 2,048 & 2,048 \\
\hline Cassou & Gao & Pani & 710 & 124 \\
\hline Bakata & Bakata & Diao & 2,172 & 320 \\
\hline Cassou & Cassou & Vrassan & 697 & - \\
\hline
\end{tabular}

Note: Highlighted rows indicated the selected villages that were visited during the scoping study.

a Based on population census (2006) by the state statistical office and confirmed by the West Africa Sentinel Landscapes project data. Average population rise per annum is $3.6 \%$ compared to $3.2 \%$ nationwide.

b Kassolo and Tiabona were considered as one village in the census of 2006 and also during our scoping surveys. 


\section{Appendix 8B Normalized difference vegetation index (NDVI) forest-cover change in Ziro Province}

\section{Explaining forest cover change in our study sites}

The satellite imagery from 1999 to 2013 - the timeframe presented in this study - was the most consistent for our site and so allowed for year-to-year comparisons over that timeframe. Due to extreme seasonal variation in vegetation density, i.e. pronounced greening in the rainy season, June-September, and subsequent absence of vegetation in the dry season, the window for conducting a vegetation density change is slim. In previous attempts to retrieve images, we acquired good images but they were off-season between one image and the other. This rendered the images incomparable since each covered different months of the year. This was true for the images retrieved from the 1990-99 period, which could not be used, although we anticipate substantial forest cover change occurred during this time period.

Figure 8B.1 shows reference of high-resolution imagery from Google Earth that was used to analyze degrees of vegetation density change. Small changes in vegetation density were -0.125 to -0.199 while large changes in vegetation density were -0.2 and above according to NDVI classifications (Wilson and Sader 2002; Kerr and Ostrovsky 2003).
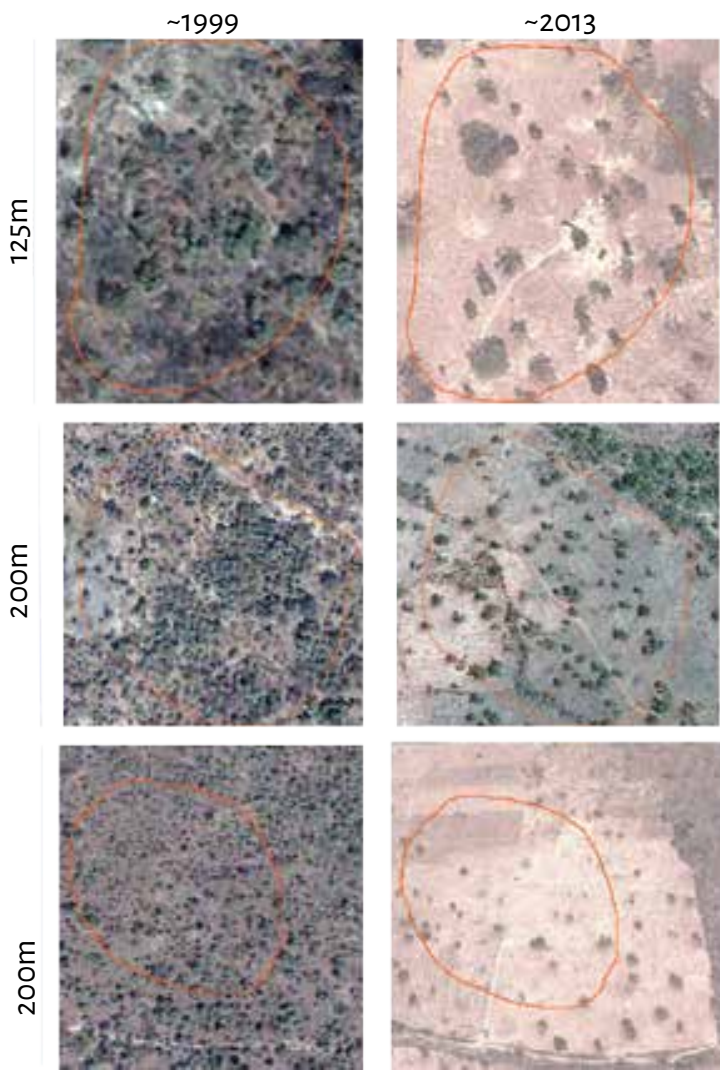

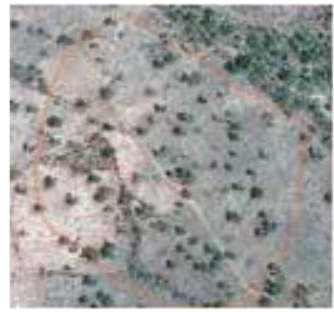

This was recorded as a single pixel of "small decrease" near the bottom A pixel $=30 \times 30 \mathrm{~m}$

No change was recorded here, although the surrounding areas had some large decreases

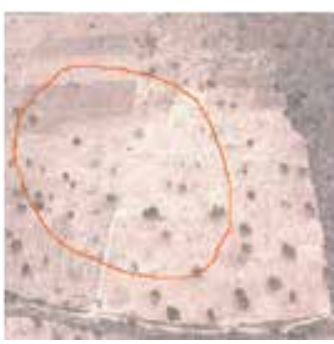

This was recorded as alrge decrease on the left of the image, small decrease on the right (due to the edge of the forest not changing) 


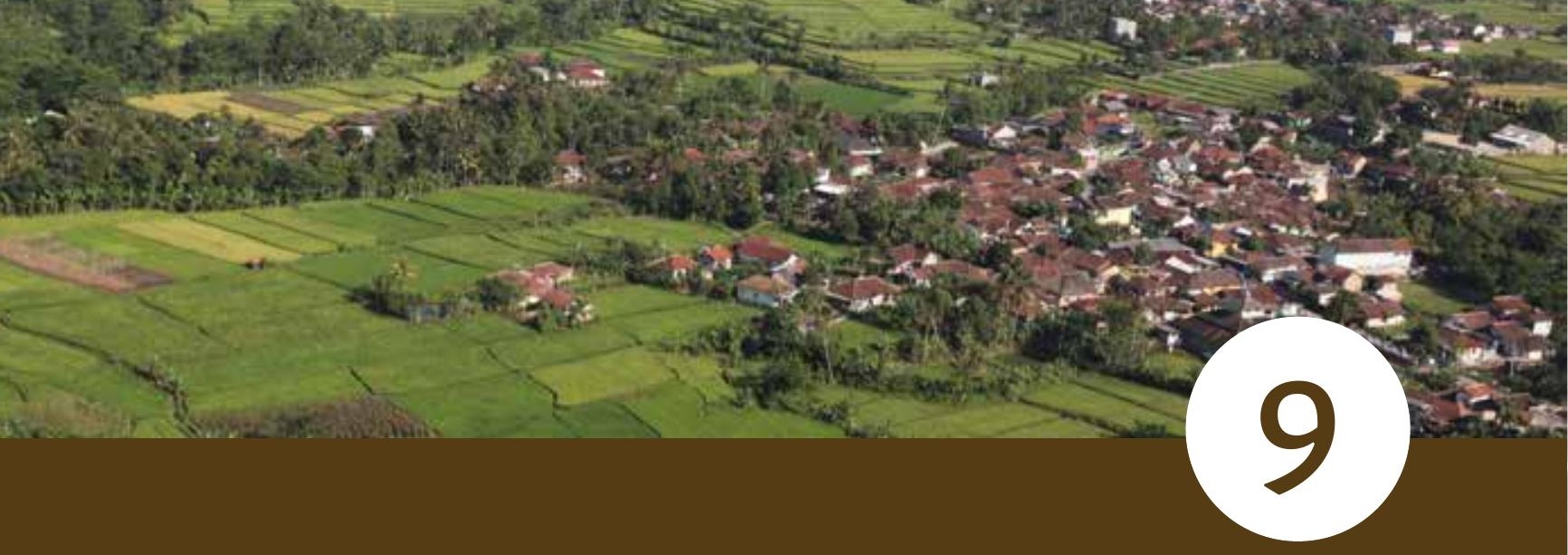

\section{Conclusion: Agrarian change}

\section{A change for the better?}

Terry Sunderland, Liz Deakin and Mrigesh Kshatriya

Perceived wisdom suggests that rural communities with better access to markets, transportation and intensive agricultural systems are better fed and fiscally better off than those in the proximity of more isolated, forested landscapes (cf. Levang et al. 2005). But is this really the case?

Historical evidence suggests the transition away from a forest-based economy leads to overwhelmingly better outcomes for poverty and human well-being (e.g. Sunderlin et al. 2007). From the early 1960s, pervasive growth-based theories of agricultural development based on technological change were promoted as a solution to persistent rural poverty (Mellor 1967). Yet local observers and village field researchers noted that rural development wasn't working as intended - the number of poor grew and some non-poor smallholders, fishermen and pastoralists subsequently became poor through loss of assets or common property resources. Overall health and nutrition benefits remained elusive. Larger farmers appropriated the land of smaller farmers, rural laborers were displaced by mechanization, and intensive farming depleted scarce water resources and affected soils. In short, as agricultural transformation takes place, there are inevitable winners and losers.

The results of the segregation of agriculture from forestry and other land uses has led to critical reflection as to how these seemingly conflicting land uses can be better integrated for improved outcomes (Sayer et al. 2013). As this book illustrates, 
agricultural production in most tropical landscapes does not come from vast swathes of monoculture crops, but from complex landscape mosaics that are managed for multiple benefits and a broad suite of goods and ecosystem services (Padoch and Sunderland 2014). Although greatly under-estimated, the presence of forests and trees in these landscapes provides a framework for the integration of diverse cropping systems. They are also immensely valuable to the livelihoods and well-being of those that live in such environments.

Agrawal et al. (2013) estimate that over 1.3 billion people utilize forests and trees in some way and that forested landscapes generate significant income for those that reside in and around them. The findings of the tropics-wide Poverty and Environment Network (PEN), also suggest that rural households rely far more on income and other services from their immediate natural environment than previously thought. The PEN project found that over $25 \%$ of household income is sourced from natural resources; this represents a greater annual household income than that of agricultural production (Angelsen et al. 2014). Ickowitz et al. (2014), in a continent-wide study in Africa, found a correlation between the presence of forests and trees and dietary diversity. Thus, the synergies between agriculture and the wider environment are gradually being understood, and it is those synergies that this project is attempting to articulate. The development lexicon has certainly changed in recent years to reflect a broader systems (or landscape) approach to food production in the context of the wider environmental benefits (Foli et al. 2014). Yet systematic and empirically-focused research to enable us to actually implement this has been largely absent from the discourse (Reed et al. 2015).

At the end of 2015, the launch of the Sustainable Development Goals provided a unique opportunity to begin that process of integrating previously isolated disciplines into a more cogent development agenda, with a strong focus on landscapes as the convening factor (van Vlanen et al. 2015). In addition, the preamble of the historic COP 21 agreement also mentions food security from a broader perspective by referring to "safeguarding food security and ending hunger, and the particular vulnerabilities of food production systems to the adverse impacts of climate change" (UNFCCC 2015: 21). The agreement also refers to human rights, gender, ecosystems and biodiversity, all issues that are central to agriculture. Thus the policy environment has become far more conducive to a more environmentally sensitive agriculture, with broader development aspirations such as improved nutrition and the alleviation of poverty.

Although this book presents some preliminary assessments of the agrarian drivers of change in seven diverse tropical landscapes, some patterns and trends are clearly emerging, even at this nascent stage.

The Ethiopian site is focused on the Munessa Forest region along corresponding agricultural intensification and forest cover gradients. While overall food security has increased over time, particularly where agricultural intensification is at its greatest, there has been a significant decrease in the contribution of forest resources (notably fuelwood) to household income and the ownership of cattle, given the removal of appropriate grazing land. The long-term implications of this transition are yet to be fully understood, but it is likely that in the more simplified production systems, overall poverty has actually increased as a proportion of the population. The role of the State 
has also had significant impact on this landscape with uncertain property rights and land annexation playing significant roles in driving rapid deforestation.

In Southwest Cameroon there remains a strong reliance on forest products for rural income and consumption, yet annexation of forestland by conservation actors and removal of the forest itself through conversion to oil palm plantations has affected basic access to NTFPs and other wild resources. So while there is plenty of forest remaining, much of it is off limits to local customary use, for agriculture or any other land use. Given that Cameroon is the breadbasket of the region, producing large quantities of foodstuffs that supply the neighboring oil rich countries of Nigeria, Equatorial Guinea and Gabon, this could have a major ripple effect for the food security of the region.

In Kupuas Hulu, Indonesia, the agrarian trajectory from diverse smallholder agricultural production toward more intensive agribusiness is having a major impact on the livelihoods of local people. The persistent argument that commercial agriculture benefits all is clearly not the case in this instance; the benefits may be accrued nationally, and in the hands of a very few, but the transformation of the landscape into oil palm monocultures has had major impacts in terms of environmental impoverishment and displacement. In terms of diets, the fact that a clear 'nutrient transition' has occurred, whereby previously diverse foodstuffs have been replaced by cheap and available consumables such as instant noodles, is having a major impact on the long-term health and nutrition of the local populace.

The parklands of southern Burkina Faso show an interesting and much more historically rooted integration of forest, farm and markets. Earlier studies from the region have highlighted the seasonal fluctuation in food availability throughout the year and a corresponding varying reliance on wild foods. Thus the forests clearly play a significant role in buffering dietary diversity during lean agricultural months. As this landscape shows the synergies between these three elements, obvious trajectories of intensification are more difficult to identify than for the other sites, with the landscape showing 'clusters' of intensification, rather than a linear pattern of transition. As such, these landscapes are managed to be as resilient as possible for the vicissitudes of climate and environment that affect the region.

In Siuna, Nicaragua, the defining drivers of land-use change have been as much political as economic and environmental. The drivers of deforestation in this landscape have been long rooted in historical trends and changes, and shaped by decades of conflict and political upheaval as much as by the expansion of agricultural production systems. This includes the migration of large numbers of people dispossessed by conflict and looking for affordable, or free, land on which to settle.

The miombo woodlands of Zambia, in this case Eastern Province, once converted, provide some of the best agricultural land in the country. Although $99 \%$ of the populace is engaged with agricultural activities, there remains a strong reliance on forest resources to supplement livelihood income. This is also reflected in the policy environment where agriculture is significantly more favored than the forestry sector. Ultimately this has resulted in a lack of understanding of the role of forests for rural livelihoods and resource conflict at the agricultural frontier. 
The Chittagong Hill Tracts of Bangladesh remain the only region of the country characterized by any kind of topography. With a high population density and in-migration, clearance of natural forest for agricultural production has been a characteristic driver of change. Although significant areas of forest remain, they are being rapidly lost, especially in more accessible sites. However, tree cover in home gardens and other farmland has increased in recent years and this goes some way in mitigating overall deforestation rates. Thus Bangladesh is at the 'restoration or agroforestation' point in the tree transition curve (Van Noordwijk et al. 2014). Despite the significant levels of agricultural expansion, livelihoods overall are rooted in poverty, malnutrition and poor health.

As the studies in each country continue, and data becomes available for a broader suite of cross-site comparison studies during 2016, significantly more compelling conclusions can be drawn from this project. Early indications suggest that the transformation of wildlands, notably forests, for agriculture does not have the concomitant transformational influence on rural poverty, livelihoods, nutrition and health that would be expected. As this research unfolds, we aim to further test the hypotheses and answer the questions listed in the introduction to this book. Agrarian change transitions are taking place all over the globe, but clearly not everyone benefits. Who does, and why, will be the focus of further assessment. 


\section{References}

Agrawal A, Shepherd G, Bensen C, Hardin R, Cashore B and Miller D. 2013. Economic contributions of forests. Background Paper 1 for UNFF1O. New York: United Nations Forum on Forests. http://www.un.org/esa/forests/pdf/session_documents/unffio/ EcoContrForests.pdf

Angelsen A, Jagger P, Babigumira R, Belcher B, Hogarth N, Bauch S, Borner J, Smith-Hall C and Wunder S. 2014. Environmental Income and Rural Livelihoods: A Global-Comparative Analysis. World Development 64(1):S12-S28

Foli S, Reed J, Clendenning J, Petrokofsky G, Padoch C and Sunderland T. 2014. To what extent does the presence of forests and trees contribute to food production in humid and dry forest landscapes? A systematic review protocol. Environmental Evidence 3(15): doi:10.1186/2047-2382-3-15

Ickowitz A, Powell B, Salim A and Sunderland T. 2014. Dietary quality and tree cover in Africa. Global Environmental Change 24:287-94. http://www.sciencedirect.com/science/ article/pii/S0959378013002318

Levang P, Dounias E and Sitorus S. 2005. Out of the forest, out of poverty? Forests, Trees and Livelihoods 15:211-35.

Mellor J. 1967. The Economics of Agricultural Development. Ithaca: Cornell University Press.

Padoch C and Sunderland T. 2014. Managing landscapes for food security and enhanced livelihoods: Building upon a wealth of local experience. Unasylva 241(64). http://www.fao. org/docrep/o19/i3482e/i3482eo1.pdf

Reed J, Deakin L and Sunderland T. 2015. What are 'integrated landscape approaches' and how effectively have they been implemented in the tropics: A systematic protocol. Environmental Evidence 4(2). doi:10.1186/2047-2382-4-2

Sayer J, Sunderland T, Ghazoul J, Pfund J-L, Sheil D, Meijaard E, Venter M, Boedhihartono AK, Day M, Garcia C, et al. 2013. The landscape approach: Ten principles to apply at the nexus of agriculture, conservation and other competing land-uses. Proceedings of the National Academy of Sciences $110(21): 8345-48$ http://www.pnas.org/content/110/21/8349.full.pdf

Sunderlin W, Dewi S and Atie Puntodewo. 2007. Poverty and forests: Multi-country analysis of spatial association and proposed policy solutions. Occasional Paper 47. Bogor, Indonesia: Center for International Forestry Research. http://www.cifor.org/publications/pdf_files/ OccPapers/OP-47.pdf

[UNFCCC] United Nations Framework Convention on Climate Change. 2015. Adoption of the Paris Agreement. Proposal by the President. (FCCC/CP/2015/L.9/Rev.1). 12 December 2015. http://unfccc.int/resource/docs/2015/cop21/eng/lo9.pdf

Van Noordwijk M, Bizard V, Wangpakapattanawong P, Tata H, Villamor G and Leimona B. 2014. Tree cover transitions and food security in Southeast Asia. Global Food Security 3:200-208.

Van Vlanen J, Reed J and Sunderland T. 2015. From global complexity to local reality: Aligning implementation frameworks with Sustainable Development Goals and landscape approaches. CIFOR Policy Brief No. 1. Bogor, Indonesia: Center for International Forestry Research. http://www.cifor.org/library/5864/from-global-complexity-to-local-reality-aligningimplementation-frameworks-with-sustainable-development-goals-and-landscapeapproaches/ 


\section{Terms and abbreviations}

$\begin{array}{ll}\text { CIFOR } & \text { Center for International Forestry Research } \\ \text { FGD } & \text { focus group discussion } \\ \text { GDP } & \text { gross domestic product } \\ \text { GIS } & \text { geographic information system } \\ \text { GIZ } & \text { Deutsche Gesellschaft für Internationale Zusammenarbeit; } \\ & \text { German Federal Enterprise for International Cooperation } \\ \text { ha } & \text { hectare } \\ \text { IMF } & \text { International Monetary Fund } \\ \text { kg } & \text { kilogram } \\ \text { m } & \text { meter } \\ \text { masl } & \text { meters above sea level } \\ \text { NDVI } & \text { normalized difference vegetation index } \\ \text { NGO } & \text { nongovernmental organization } \\ \text { NTFP } & \text { non-timber forest product } \\ \text { ton } & \text { metric ton (1 ton is equivalent to 10oo kg) } \\ \text { USAID } & \text { United States Agency for International Development } \\ \text { WWF } & \text { World Wildlife Fund/World Wide Fund for Nature }\end{array}$

Note: all currencies are referred to using ISO4217:2008 currency codes. 
Agricultural expansion has transformed and fragmented forest habitats at alarming rates across the globe, but particularly so in tropical landscapes. The resulting land-use configurations encompass varying mosaics of tree cover, human settlements and agricultural land units. Meanwhile, global demand for agricultural commodities is at unprecedented levels. The need to feed nine billion people by 2050 in a world of changing food demands is causing increasing agricultural intensification. As such, market-orientated production systems are now increasingly replacing traditional farming practices, but at what cost?

The Agrarian Change project, coordinated by the Center for International Forestry Research, explores the conservation, livelihood and food security implications of land-use and agrarian change processes at the landscape scale. This book provides detailed background information on seven multi-functional landscapes in Ethiopia, Cameroon, Indonesia, Nicaragua, Bangladesh, Zambia and Burkina Faso. The focal landscapes were selected as they exhibit various scenarios of changing forest cover, agricultural modification and integration with local and global commodity markets. A standardized research protocol will allow for future comparative analyses between these sites.

Each case study chapter provides a comprehensive description of the physical and socioeconomic context of each focal landscape and a structured account of the historical and political drivers of land-use change occurring in the area. Each case study also draws on contemporary information obtained from key informant interviews, focus group discussions and preliminary data collection regarding key topics of interest including: changes in forest cover and dependency on forest products, farming practices, tenure institutions, the role and presence of conservation initiatives, and major economic activities.

The follow-on empirical study is already underway in the landscapes described in this book. It examines responses to agrarian change processes at household, farm, village and landscape levels with a focus on poverty levels, food security, dietary diversity and nutrition, agricultural yields, biodiversity, migration and land tenure. This research intends to provide much needed insights into how landscape-scale land-use trajectories manifest in local communities and advance understanding of multi-functional landscapes as socioecological systems.

\begin{tabular}{|c|c|c|}
\hline$\underset{\text { CGIAR }}{\text { boj }}$ & \begin{tabular}{|l} 
RESEARCH \\
PRoGRAM ON \\
Forests, Trees and \\
Agroforestry
\end{tabular} & $\begin{array}{l}\text { This research was carried out by CIFOR as part of the CGIAR Research Program } \\
\text { on Forests, Trees and Agroforestry (CRP-FTA). This collaborative program aims } \\
\text { to enhance the management and use of forests, agroforestry and tree genetic } \\
\text { resources across the landscape from forests to farms. CIFOR leads CRP-FTA } \\
\text { in partnership with Bioversity International, CATIE, CIRAD, the International } \\
\text { Center for Tropical Agriculture and the World Agroforestry Centre. }\end{array}$ \\
\hline
\end{tabular}

cifor.org | blog.cifor.org
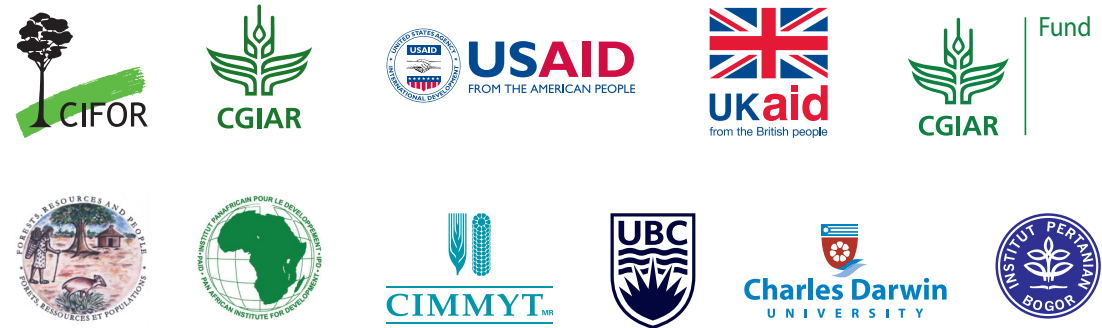